\title{
GEOQUÍMICA E GEOCRONOLOGIA DO PLUTONISMO GRANITICO MESOPROTEROZÓICO DO SW DO ESTADO DE MATO GROSSO (SW DO CRÁTON AMAZÔNICO)
}

MAURO CESAR GERALDES

Orientador: Prof. Dr. Wilson Teixeira

TESE DE DOUTORAMENTO

COMISSÃO JULGADORA

\begin{abstract}
Nome
Presidente: Prof. Dr. Wilson Teixeira

Examinadores: Prof. Dr. Jorge Silva Bettencourt

Prof. Dr. Lauro Valentim Stoll Nardi

Prof. Dr. Márcio Martins Pimentel

Prof. Dr. Roberto Dall'Agnol
\end{abstract}

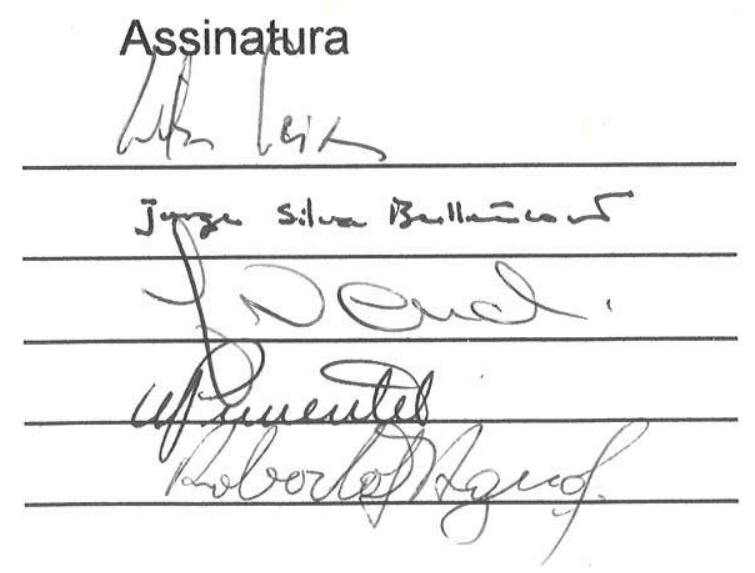

$$
\begin{aligned}
& \text { SÃO PAULO } \\
& 2000
\end{aligned}
$$


UNIVERSIDADE DE SÃO PAULO

INSTITUTO DE GEOCIÊNCIAS

\section{GEOQUÍMICA E GEOCRONOLOGIA DO PLUTONISMO GRANÍTICO MESOPROTEROZÓICO DO SW DO ESTADO DE MATO GROSSO (SW DO CRÁTON AMAZÔNICO)}

Mauro Cesar Geraldes

Orientador: Prof. Dr. Wilson Teixeira

TESE DE DOUTORAMENTO

PROGRAMA DE GEOQUÍMICA E GEOTECTÔNICA

SÃO PAULO

2000 


\section{RESUMO}

O objetivo deste trabalho é o estudo geocronológico e da composição química dos granitóides da porção SW do estado do Mato Grosso. A abordagem deste projeto tem relevância para o entendimento da evolução geológica através da identificação, na área de estudo, de eventos de acresção crustal durante o Paleo e Mesoproterozóico que vieram a compor significativa fração do SW Cráton Amazônico.

$\mathrm{Na}$ região do Terreno Jauru, tonalitos, vulcânicas ácidas e gnaisses analisados pelo método $\mathrm{U} / \mathrm{Pb}$ em zircões apresentam idades de 1790 a $1750 \mathrm{Ma}$. Análises químicas de rocha total indicam características calcioalcalinas para as rochas intrusivas, o que, adicionado a dados de quimismo de rochas vulcânicas disponíveis na literatura sugerem um ambiente de arco vulcânico para suas origens. Dados isotópicos $\mathrm{Sm} / \mathrm{Nd}\left(\mathrm{T}_{\mathrm{DM}}\right.$ entre 2.000 a $1800 \mathrm{Ma}$ e $\varepsilon_{\mathrm{Nd}(t)}$ entre +3 e +2$)$ reforçam as características juvenis para estas unidades.

Nesta mesma região, outras rochas intrusivas (com composição entre granito e tonalito) apresentam idades $\mathrm{U} / \mathrm{Pb}$ em zircões entre 1550 e $1530 \mathrm{Ma}$. O estudo químico indica trend calcioalcalino e resultados isotópicos $\mathrm{Sm} / \mathrm{Nd}\left(\mathrm{T}_{\mathrm{DM}}\right.$ ente 2047 e $1743 \mathrm{Ma}$. e $\varepsilon_{\mathrm{Nd}(\mathrm{t})}$ entre $+3,7$ e 1,3 ) e de isótopos de $\mathrm{O}$ (valores de $\delta \mathrm{O}$ entre $+9,0 \%$ e $+6,3 \%$ ) sugerem ainda que a formação destas rochas ocorreu em arco magmático desenvolvido na margem continental pré-existente, com significativo retrabalhamento desta crosta durante a geração destes corpos plutônicos. Nesta área ainda ocorrem granitos de idade U/Pb entre $1470 \mathrm{Ma}$ e $1390 \mathrm{Ma}$.

A Suíte Santa Helena apresenta idades U/Pb em zircões entre $1460 \mathrm{Ma}$ a $1420 \mathrm{Ma}$ e $\mathrm{T}_{\mathrm{DM}}$ entre $1700 \mathrm{Ma}$ a $1500 \mathrm{Ma}\left(\mathrm{com} \varepsilon_{\mathrm{Nd}(t)}\right.$ entre $\left.+4,1 \mathrm{e}+2,6\right)$ e valores de $\delta \mathrm{O}$ entre $+10,4 \%$ o e $+8,3 \%$. São rochas de composição granitica a tonalítica, com quimismo calcioalcalino, sugerindo formação em ambiente de arco magmático distal à margem continental pré-existente (Terreno Jauru) a qual teve participação subordinada na geração do plutonismo.

Rochas vulcânicas toleíticas e intrusivas básica-ultrabásicas da Sequência Vulcanossedimentar Rio Alegre foram datadas $(\mathrm{U} / \mathrm{Pb})$ entre 1508 e $1494 \mathrm{Ma}\left(\mathrm{T}_{\mathrm{DM}}\right.$ entre 1,67 e $1,54 \mathrm{Ga}$ e $\varepsilon_{\mathrm{N} d(t)}$ entre 4,8 e 2,5). Estas rochas constituem o Terreno Rio Alegre representada por rochas geradas em cadeia meso-oceânica e que possivelmente foram acreciobanadas ao protocráton Amazônico após a formação da Suíte Santa Helena. Na porção oeste do Terreno Rio Alegre ocorre ainda o Domínio Fazenda Reunidas, englobando rochas tonaliticas, granodioríticas e graníticas com idades $\mathrm{U} / \mathrm{Pb}$ entre $1600 \mathrm{Ma}$ e $1360 \mathrm{Ma}$. Estas rochas apresentam, de forma geral, zircões herdados, sugerindo processos de rehomogeneização isotópica (eventos policíclicos) na história geológica destas rochas.

A Suíte Rio Branco representa parte de uma associação AMCG (anortosito, mangerito, charnockito e granito) na região de Jauru-Araputanga com idades U/Pb entre $1460 \mathrm{Ma}$ e 1420 Ma. Rochas de composição básica a félsica, com estrutura rapakivi, indicam mistura de magmas, o que é também sugerido pela composição bimodal identificada nos estudos litoquímicos desta unidade. Dados de isótopos de $\mathrm{Sm} / \mathrm{Nd}$ e de $\mathrm{O}$ para as unidades básicas $\left(\mathrm{T}_{\mathrm{DM}}\right.$ entre 1800 e 1700 Ma e $\varepsilon_{\mathrm{Nd}(t)}$ entre $+1,9+1,2$ e $\delta \mathrm{O}$ entre $+8,4 \%$ e $+5,4 \%$ ) e para as unidades félsicas ( $\mathrm{T}_{\mathrm{DM}}$ entre 1700 e $1600 \mathrm{Ma} ; \varepsilon_{\mathrm{Nd}(t)}$ entre $+0,9 \mathrm{e}-0,1$ e $\delta \mathrm{O}$ entre $+9,0 \% \mathrm{e}+7,3 \%$ ) sugerem que os protólitos desta rochas têm origem mantélica e da base da crosta, respectivamente. Os dados de elementos traços (indicando um ambiente intra-placas) e as idades $\mathrm{U} / \mathrm{Pb}$ permitem sugerir que a Suíte Rio Branco foi gerada em um ambiente extensional no antepaís durante o desenvolvimento do arco magmático Santa Helena.

Corpos graníticos intrusivos com idade $\mathrm{U} / \mathrm{Pb}$ em zircões de 930 a $920 \mathrm{Ma}$, possivelmente relacionados a magmatismo contemporâneo (idade K/Ar entre 960 e $880 \mathrm{Ma}$ ) à deformação das rochas do Grupo Aguapeí ocorrem na região de Pontes e Lacerda. Estes corpos têm composição cálcica, metaluminosa e foram gerados após a estabilização da crosta constituída pelas acresções descritas anteriormente, tratando-se provavelmente de unidades alóctones. 


\section{ABSTRACT}

This work deals with geochronological and chemical analysis on granitoids in the SW Amazon Craton, State of Mato Grosso. The results define three crustal acrecionary events correlated to Jauru Terrane (JT), Rio Alegre Terrane (RAT), and Pontes e Lacerda Terrane (PLT), of Paleo and Mesoproterozoic ages, leading to compose significant fraction of SW Amazon Cráton.

In the JT, acid volcanics, tonalite and granite gnaisses (Alto Jauru greenstone belt) present $\mathrm{U} / \mathrm{Pb}$ ages from 1790 to $1750 \mathrm{Ma}$. Whole rock chemical analyses indicate calcioalkaline affinity for the intrusive rocks, which added to the data on volcanic rocks in the literature (interpreted as having formed in volcanic arc), suggest a B-type collision for its origin. $\mathrm{Sm} / \mathrm{Nd}$ isotopic data $\left(\mathrm{T}_{\mathrm{DM}(t)}\right.$ from 1.93 to $1.77 \mathrm{Ma}$ and $\varepsilon_{\mathrm{Nd} \text { (t) }}$ from +2.6 to +2.2$)$ indicate juvenile signature for these units.

In this same area (JT), intrusive rocks present $\mathrm{U} / \mathrm{Pb}$ ages in zircon from 1580 to 1520 Ma. The chemistry indicates calcioakaline trend, with rocks varying from granites to tonalites. The $\mathrm{Sm} / \mathrm{Nd}$ results ( $\mathrm{T}_{\mathrm{DM}}$ from 2.05 to $1.74 \mathrm{Ma}$ and $\varepsilon_{\mathrm{Nd}(t)}$ from +3.7 to -1.3$)$ and $\mathrm{O}$ isotope results ( $\sigma O$ values from $+9.0 \%$ to $+6.3 \%$ ) suggest a magmatic arc (Cachoeirinha Arc) gelogical setting for the formation of these rocks developed in a continental margin. Post-orogenic granites of $\mathrm{U} / \mathrm{Pb}$ age from 1.47 and $1.39 \mathrm{Ga}$ also occur.

In PLT is observed the Santa Helena suite, which presents U/Pb ages in zircons from $1480 \mathrm{Ma}$ to $1420 \mathrm{Ma}$ and $\mathrm{T}_{\mathrm{DM}}$ from $1.70 \mathrm{Ma}$ to $1.50 \mathrm{Ma}$ (with $\varepsilon_{\mathrm{Nd}(\mathrm{t})}$ between +4.1 and +2.6 ) and $\sigma 0$ values from $+10.4 \%$ o to $+8.3 \%$. Rock composition varies from granite to tonalite, with calcialkaline trend, suggesting formation in distal magmatic arc to the older continental margin (dated in 1790-1550 Ma) described previously.

The Rio Alegre Vulcanossedimentary Sequence is located in JP and it was described in the literature as an association of ocean floor-related rocks, as tholeiitic basalts, cherts and BIIF's. Felsic rocks of this unit were dated from 1508 to $1494 \mathrm{Ma}(\mathrm{U} / \mathrm{Pb})$ and regional geology suggests its collage to the west of Santa Helena Terrane and consequently it became part of the Amazon protocraton after the Santa Helena suite formation. Westernward of Rio Alegre Terrane rocks with inherited zircons $(\mathrm{U} / \mathrm{Pb}$ ages from 1.60 to $1.36 \mathrm{Ga}$ ) also occur, suggesting isotoperesetting processes (policiclic events) in the geologic history of this region.

The Rio Branco suite comprises basic and felsics rocks that probably represents part of an AMCG association (anortite, mangerite, charnockite and granite) hosted in the JT with U/Pb ages from $1460 \mathrm{Ma}$ to $1420 \mathrm{Ma}$. Rapakivi texture indicates magma mixture, what is corroborated by bimodal composition identified in the chemical studies on this unit. $\mathrm{Sm} / \mathrm{Nd}$ and $\mathrm{O}$ isotope data for the basic unit $\left(\mathrm{T}_{\mathrm{DM}}\right.$ from 1.80 to $1.70 \mathrm{Ma} ; \varepsilon_{\mathrm{Nd}(t)}$ from $+1.9+1.2$ and $\sigma 0$ from $+8.4 \%$ and $+5.4 \%$ ) and for felsic unit ( $\mathrm{T}_{\mathrm{DM}}$ from 1.70 to $1.60 \mathrm{Ma} ; \varepsilon_{\mathrm{Nd}(t)}$ from +0.9 to -0.1 and $\sigma \mathrm{O}$ from + $9.0 \%$ to $+7.3 \%$ ) suggest mantle-derived and inferior crust origin, respectively. Trace elements data (indicating intra-plates ambient) and $\mathrm{U} / \mathrm{Pb}$ ages allow suggesting Rio Branco suite was generated in an extensional event during the development of the magmatic arc responsible for the Santa Helena suite genesis.

Granitic intrusive bodies in Santa Helena suite yielded $\mathrm{U} / \mathrm{Pb}$ age in zircons from 930 to $920 \mathrm{Ma}$ possibly related to coeval (K/Ar age from 960 to $880 \mathrm{Ma}$ ) Aguapei deformational event. These bodies have calcic and metaluminous composition, and they were generated after the stabilization of the crust constituted by the acrecionary events described previously, being probably alloctones units. 
Aos meus pais 
Esta tese fez parte de um projeto de colaboração que envolveu professores de diversas instituições: Universidade de São Paulo, Universidade Federal de Mato Grosso, Universidade Federal de Ouro Preto, University of Kansas (EUA) e New Mexico Tech (EUA), Como não poderia deixar de acontecer, pessoas destas instituições foram de grande importância para o desenvolvimento desta tese.

Agradecimento especial é devido ao Prof. Dr. Wilson Teixeira, pelo companherismo e dedicação, que concordou em orientar este estudo no Cráton Amazônico, apesar de hoje centrar seus estudos no Cráton do São Francisco.

Ao Prof. Dr. Randy Van Schmus, que através de um projeto no NSF (EUA) concordou em iniciar estudos geocronológicos no Cráton Amazônico, apesar dos seus trabalhos centrarem na Província Borborema.

Ao Prof. Dr. Jorge Bettencourt, Prof Dr. Bley Brito Neves e Prof. Dr. Kent Condie, (os maiores tectonistas que eu conheço) que ao longo deste projeto e durante os trabalhos de campo muito contribuíram para as interpretações aqui postuladas.

Ao Prof. Dr. Colombo Tassinari, Prof. Dra. Marly Babinski, Prof. Dr. Romalino Fragoso-Cesar, Prof. Dr. Miguel Basei e Prof. Ian McReath (da USP) e ao Prof. Dr. Mauricio Carneiro (UFOP) pelas valiosas discussões.

Aos Prof. Dr. Francisco Pinho, Prof. Dr. Jaime Leite e Prof. Dr. Gerson Saes e aos Professores João Matos, Amarildo Ruiz e Marcia Pinho (UFMT), pelas importante contribuições, tanto de material como de idéias e de informações sobre a área.

Aos colegas da pós-graduação da USP, Paulo Boggiani, Miguel Tupinambá, José Pinese, pelos incentivos dados no início deste trabalho. Aos colegas Francisco, Marcelo, Veridiana, Marcelus, Heloisa, Cristina, João, Kika, Weber, Ossama, Glorinha, Renata, Jerônimo, Kau e Elcio, pelo companherismo.

Aos colegas de convívio no Geochemistry Isotope Laboratory (Universidade de Kansas): Prof. Dr. Elson de Oliveira, Prof. Dr. Valdecir Janasi, Prof. Dr. Doug Walker, aos geólogos Allen Fetter, Mariane Kozuch, Kefa Wang e Renata Schmith.

Aos amigos novos e antigos da paulistanidad, sem os quais a sobrevivência nesta metrópole não seria possível: Meirinha, Carlão e Tania, Pio, Zeza, Roque e Nidia, Jair e Eliane, Tanque e Sandra, Ines, Aurora, Henrique, Julio, Ricardinho, Rodrigo, Edson e Tania, Mamá, Gilsão, Tiozinho, Paulinho, e a mãe da turma, a Joana, que nos deixou orfãos.

Aos amigos de Pontes e Lacerda, cujo convívio durante os quatro anos no oeste do Mato Grosso me fizeram aprender a gostar desta remota região do país e que muitas facilidades me trouxeram durante a execução deste trabalho.

Este trabalho teve o financiamento de diversas instituições durante o seu desenvolvimento: FAPESP (bolsa de doutorado proc. 1996/9022-0), CAPES (bolsa sandwich, proc. BEX 0022/98-5). O custeio das análises foi através da FAPESP (proc. 1996/12627-0) e National Science Fundation (EUA). 


\section{ÍNDICE}

Resumo. i

Abstract. ii

Dedicatória

Agradecimentos

Relação de Figuras

Relação de Fotografias

Relação de Tabelas.

CAPÍTULO 1 Aspectos Gerais.............................................................................. 01

1.1 Introdução

1.2 Objetivos.

1.3 Localização da Área Estudada ..................................................... 02

1.4 Apresentação....................................................................... 04

1.50 Contexto Geológico-Geotectônico.......................................... 05

1.6 Compilação da Estratigrafia Regional .......................................... 08

1.6.1 O Substrato Metamórfico..........................................

1.6.1.1 Rochas Vulcanossedimentares.........................

1.6.1.2 Rochas Gnáissicas e Migmatíticas..................... 12

1.6.2 Intrusivas Básicas e Ultrabásicas................................... 14

1.6.3 Intrusivas Ácidas a Intermediárias.............................. 16

1.6.4 O Grupo Rio Branco............................................... 17

1.6.5 O Grupo Aguapeí..................................................... 18

1.6.6 As Suites Graníticas Guapé e São Domingos.................... 19

1.7 Limites dos Terrenos Proterozóicos do SW do Mato Grosso.............. 20

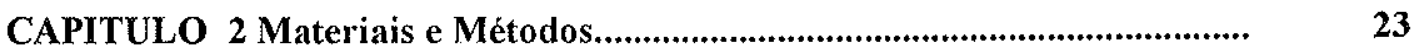

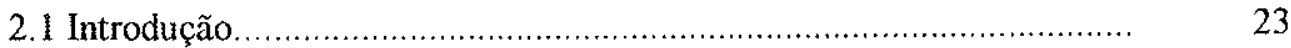

2.2 Estudos Prévios e Revisão Bibliográfica ............................................ 23

2.3 Trabalhos de Campo e Amostragem........................................ 23

2.4 Análises Petrográficas....................................................... 24

2.5 Estudos Litogeoquimicos.................................................. 25

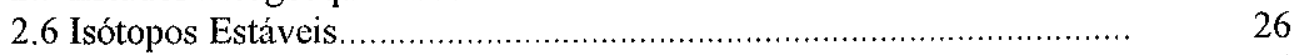

2.7 Isótopos Radiogênicos, ....................................................... 26

O Método K/Ar........................................................ 26

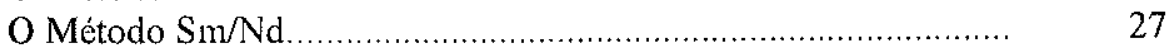

O Método U/Pb ....................................................... 29

CAPITULO 30 Terreno Jauru.....................................................................

3.1 O Embasamento do Terreno Jauru............................................... 31

Gnàisse Rosa ................................................... $\quad 34$

Gnaisse Aliança.................................................. 34

Rochas Vulcânicas............................................... $\quad 35$

3.1.1 Geoquímica ...................................................... 39

3.1.2 Discussão......................................................... 42

3.2 Os Granitóides Intrusivos do Terreno Jauru................................. 47

Rochas Tonalíticas.............................................. 47

Gnaisse São Domingos......................................... 49

Suíte Intrusiva Santa Cruz....................................... 51

Suíte Intrusiva Alvorada........................................ 51

Granodiorito Agua Clara......................................... 52 
3.2.1 Geoquímica....................................................... 63

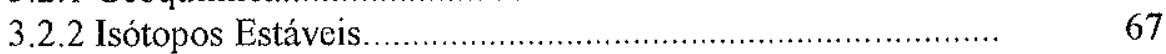

3.2 .3 Discussão........................................................ 69

CAPITULO 40 Terreno Pontes e Lacerda ……...............................................

4.1 Localização e Distribuição...................................................... 73

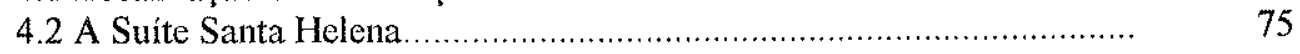

Rochas Tonaliticas. ..................................................... 75

Rochas Granodioríticas................................................ $\quad 77$

Rochas Graníticas...................................................... 85

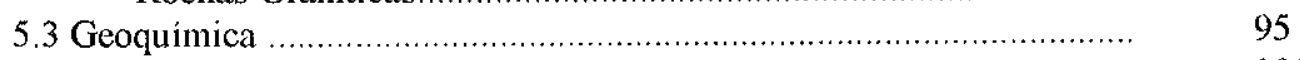

5.4 Isótopos de Oxigênio........................................................ 101

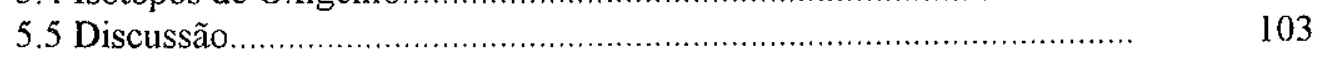

CAPITULO 50 Terreno Rio Alegre........................................................ 107

5.1 Introdução ....................................................................... 107

5.2 Rochas Vulcanossedimentares do Vale do Rio Alegre..................... 107

Metadacito Rio Alegre .................................................. $\quad 110$

Metadiorito Rio Alegre ................................................. $\quad 110$

Metabásica Santa Bárbara ............................................. $\quad 110$

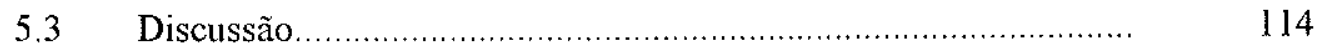

5.4 Rochas da Fazenda Reunidas.............................................. $\quad 117$

Gnaisse Tonalítico Rio Aguapeí ...................................... $\quad 117$

Granito Lajes........................................................... 118

Microgranito Carrapato................................................. 118

Granodiorito Rio Alegre ................................................ $\quad 119$

5.5 Discussão........................................................... 124

CAPÍTULO 6 A Suíte Intrusiva Rio Branco................................................. 125

6.1 Localização e Distruição das Litologias...................................... 125

6.2 Relações de Contato entre as Litologias.................................... $\quad 125$

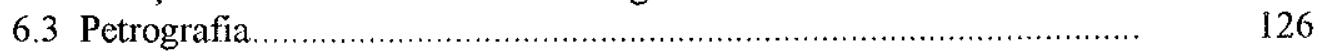

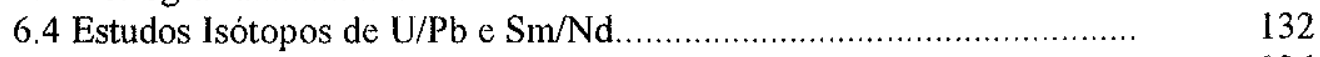

6.5 Geoquímica................................................................. $\quad 136$

6.6 Isótopos Estáveis........................................................... $\quad 143$

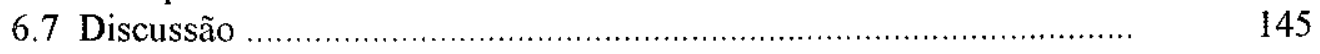

CAPÍTULO 7 As Suítes Intrusivas Guapé e São Domingos.............................. 147

7.10 Grupo Aguapeí................................................................ 147

7.2 As Suítes lntrusivas Guapé e São Domingos................................. $\quad 150$

Suíte Intrusiva Guapé................................................... 152

Granito São Domingos............................................ $\quad 152$

7.2 Geoquímica................................................................. 155

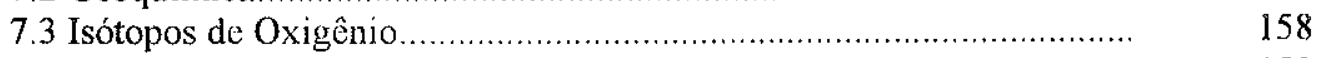

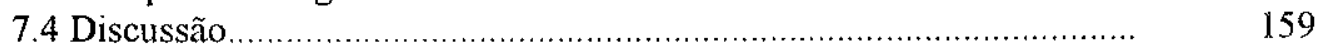

CAPITULO 8 Súmula da Evolução Tectônica............................................... 161

O greenstone belt Alto Jauru........................................... 161

$\mathrm{O}$ arco magmático Cachoeiirnha do Terreno Jauru.................... $16 \mathrm{l}$

A Suíte Santa Helena do Terreno Pontes e Lacerda................... 162

A Suíte Rio Branco do Terreno Jauru..................................... 163

A Sequência Vulcanossedimentar Rio Alegre............................ 163

As Suítes Intrusivas Guapé e São Domingos............................ 164 
CAPÍTULO 9 Correlações Tectônicas.

9.1 Correlações Regionais.

8.2 Implicações Tectônicas

CAPÍTULO X Referências Bibliográficas................................................................ 181

ANEXOS 


\section{RELAÇÃO DE FIGURAS}

CAPÍTULO 1

página

Figura 1.1. Localização e acesso da região SW do Estado do Mato Grosso.....................03

Figura 1.2. Mapa com as Províncias Tectônicas do Cráton Amazônico..........................07

Figura I.3. Mapa geológico regional, mostrando as principais unidades....................13

Figura 1.4. Disposição dos terrenos geológicos do SW do Cráton Amazônico

no Estado do Mato Grosso.

\section{CAPÍTULO 2}

Figura 3.1. Localização das amostras das rochas graníticas do Terreno Jauru. 33

Figura 3.2. Diagrama da concórdia para 4 zircões da amostra 97-133 36

Figura 3.3. Diagrama da concórdia para 4 zircões da amostra 97-149. 37

Figura 3.4. Diagrama da concórdia para 4 zircões da amostra 97 131. 38

Figura 3.5. Diagrama QAP (Streickeisen, 1976) obtido a partir de dados químicos para as rochas paleoproterozóicas do Terreno Jauru..... 40

Figura 3.6. Indice de Shand (A/CNK) versus índice de saturação em alumina para as rochas paleoproterozóicas do Terreno Jauru.

Figura 3.7. Diagramas discriminantes de trends de diferenciação (Peacock, 1931).

Figura 3.8. Diagramas e discriminação de ambientes tectônicos (Pearce et al, 1984).

Figuras 3.9. Padrões de terras raras para as rochas paleoproterozóicas do Terreno Jauru.

Figura 3.10. Diagrama de evolução de isótopo de Nd para as rochas paleoproterozóicas do Terreno Jauru.

Figura 3.11. Modelo de ambientes geológicos para a formação das rochas vulcânicas da região de Jauru-Araputanga segundo Pinho et. al., (1997).....

Figura 3.12. Modelo segundo Tassinari et. al., (1997), onde as rochas do Cinturão Rio Negro-Juruena foram gerados arcos magmáticos de idades 1,8-1,7 Ga e 1,6-1,5 Ga. 
Figura 3.13. Perfil com os ambientes geológicos segundo Saes e Fragoso Cesar (1996)

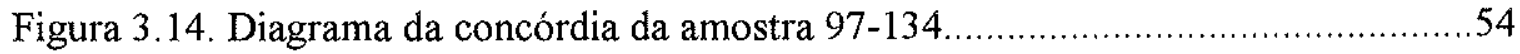

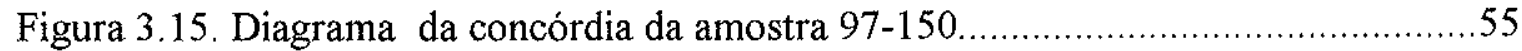

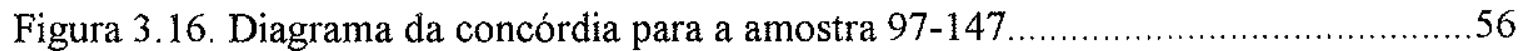

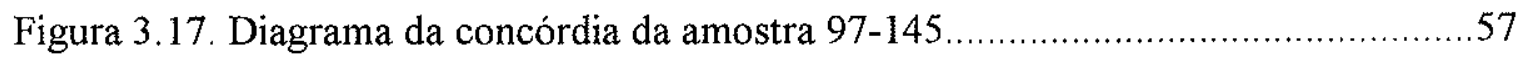

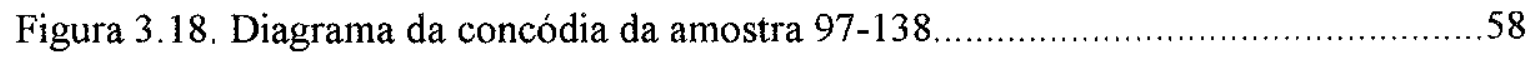

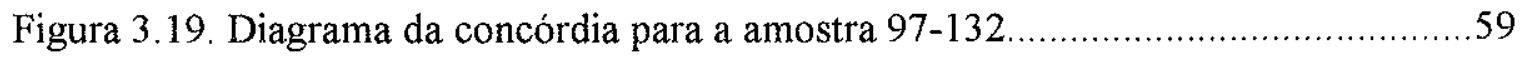

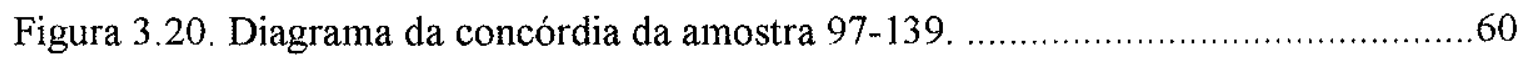

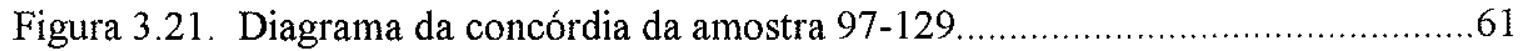

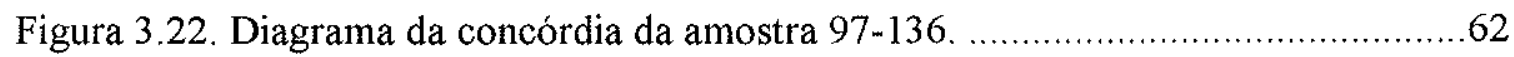

Figura 3.23. Diagrama QAP (Streckeisen, 1976) para as rochas intrusivas do Terreno

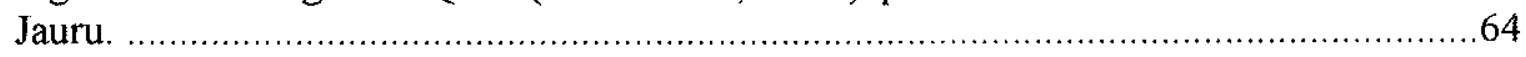

Figura 3.24. - Indice de Shand (A/CNK) versus índice de saturação em alumina para as rochas paleoproterozóicas do Terreno Jauru

Figura 3.2.5. Diagramas discriminantes de trends de diferenciação (Peacock, 1931) para as rochas graníticas do Terreno Jauru ....

Figura 3.26. Diagramas e discriminação de ambientes tectônicos (Pearce et al., 1984) para as rochas intrusivas do Terreno Jauru.

Figura 3.27. Padrões de ETR para as amostras do Terreno Jauru, normalizados pelo condrito. Círculos=granitos; quadrados $=$ granodioritos; e triângulos=tonalitos.

Figura 3.28. Valores de $\delta \mathrm{O}$ para as rochas intrusivas mesoproterozóicas do Terreno Jauru.

Figura 3.29. Valores de $\delta \mathrm{O}$ para os diversos tipos litológicos e de diferentes idades. Compilação de Taylor (1974) adicionada de dados de Agronier et. al., (1985) e Sial (1990).

Figura 3,30. Diagrama de evolução de isótopos de Nd para as rochas meosoproterozóicas do Terreno Jauru. 


\section{CAPÍTULO 4}

Figura 4.1. Localização das amostras da Suíte Santa Helena..................................... 76

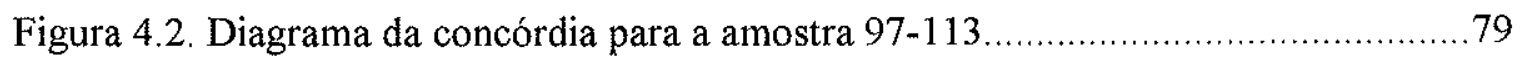

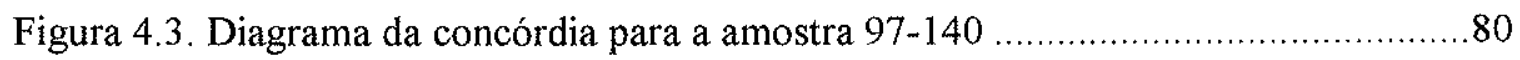

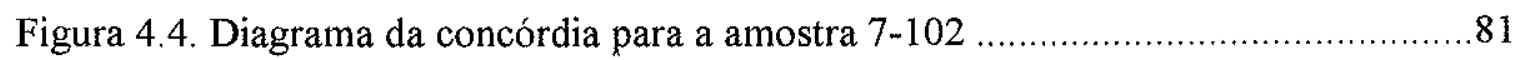

Figura 4.5. Diagrama da concórdia par a amostra 97-105, .............................. 82

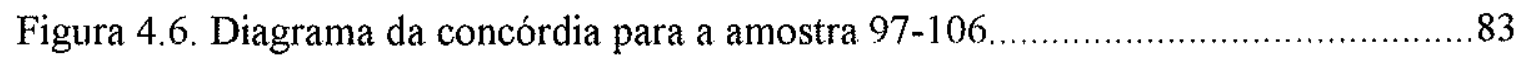

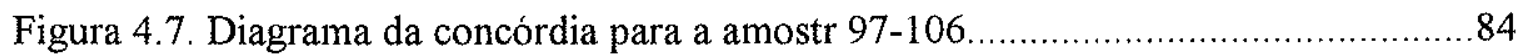

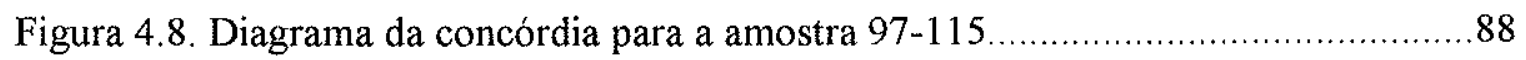

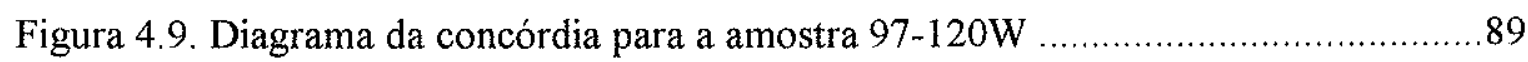

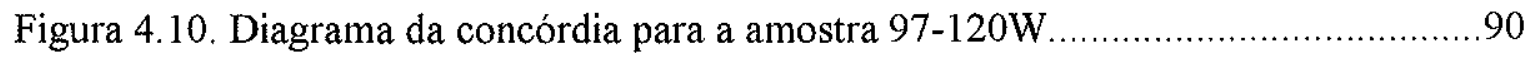

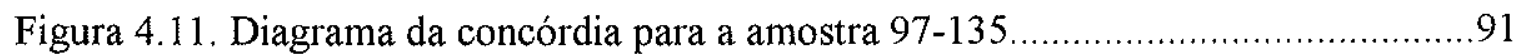

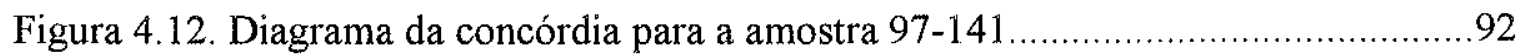

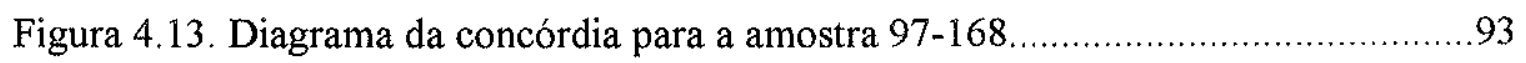

Figura 4.14. Diagrama da concórdia para a amostra $97-169 \ldots \ldots \ldots \ldots \ldots \ldots \ldots \ldots \ldots \ldots \ldots \ldots . . \ldots 4$

Figura 4.15. Diagrama QAP (Streckeisen, 1976) para as rochas da SSH...................95

Figura 4.16. Indice de Shand (A/CNK) versus índice de saturação em alumina para as amostras da Suíte Santa Helena.

Figura 4.17. Diagramas discriminantes de trends de diferenciação (Peacock, 1931). .97

Figura 4.18. Diagramas de discriminação de ambientes tectônicos (Pearce et al., 1984). 98

Figura 4.19. Padrões de elementos terras raras da $\mathrm{SSH}$, normalizados pelo condrito......98

Figura 4.20. Diagrama de Harker para as amostras da Suíte Santa Helena. Elementos e óxidos que apresentam enriquecimento com aumento de $\mathrm{SiO}_{2}$.

Figura 4.21. Diagramas de Harker para amostras da Suíte Santa Helena. Elementos e óxidos que apresentam empobrecimento com a diminuição de $\mathrm{SiO}_{2}$. 100

Figura 4.22. Resultados de isótopos de O para as rochas da Suíte Santa Helena. 102 


\section{CAPÍTULO 5}

Figura 5.1. Diagrama da discórdia para a amostra metadacito do Rio Alegre (97-122). 111 Figura 5.2. Diagrama da concórdia para o Metadiorito Rio Alegre (amostra 97-124) ..112 Figura 5.3. Diagrama da concórdia para a Metabásica Santa Bárbara (amostra 97137).

Figura 5.4. Diagrama de evolução isotópica de Nd para as rochas do Terreno Rio Alegre

Figura 5.5. Diagrama da concórdia para amostra 97-121 (Tonalito Aguapeí). 120

Figura 5.6. Diagrana da concórdia para a amosra 97-141 (Granito Lajes). 121

Figura 5.7. Diagrama da concódia par a amostra 97-12 (Microgranito Carrapato). 122

Figura 5.8. Diagrama da concódia par a amostra 97-142 (Granodiorito Rio Alegre). 123

\section{CAPÍTULO 6}

Figura 6.1. Diagrama da concórdia para o Granófiro da SIRB (amostra Rb-10)...... 134

Figura 6.2. Diagrama da concórdia para o Gabro da SIRB (amostra Rb-04) 135

Figura 6.3. Diagrama de evolução isotópico de Nd para as rochas da SIRB 136

Figura 6.4. Diagrama QAP (Streickeisen, 1976) obtido a partir de dados químicos para as rochas da SIRB

Figura 6.5. Indice de Shand $(\mathrm{A} / \mathrm{CNK})$ versus índice de saturação em alumina para as rochas da SIRB). 138

Figura 6.6. Diagramas discriminantes de trends de diferenciação (Peacock, 1931) para a SIRB. 139

Figura 6.7.. Diagramas e discriminação de ambientes tectônicos (Pearce et al, 1984).

Figuras 6.8. Padrões de terras raras para a associação leucocrática da SRB 140

Figuras 6.9. Padrões de terras raras para as rochas básicas da SRB 140 
Figura 6.10. Diagramas binários de Harker para elementos maiores e traços para o SRB

Figura 6.11. Diagramas binários de elementos traços para o SIRB.........................142

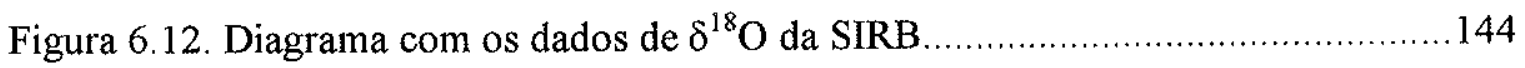

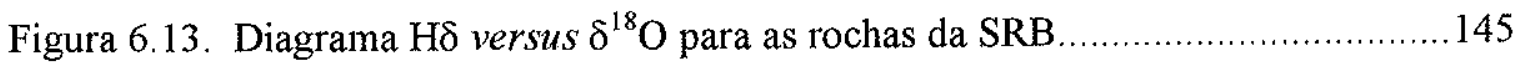

\section{CAPÍTULO 7}

Figura 7.1. Diagrama da concórdia par a amostra 97-118a ....................................153

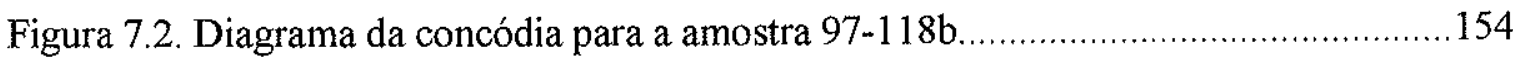

Figura 7.3: : Diagrama QAP (Streickeisen, 1976) obtido a partir de dados químicos para as rochas da SIG e GSD 155

Figura 7.4 Indice de Shand (A/CNK) versus índice de saturação em alumina para as rochas do SIG e GSD. 155

Figura 7.5. Diagramas discriminantes de trends de diferenciação (Peacock, 1931) para as amostras da SIG e do GSD 156

Figura 7.6. Diagramas e discriminação de ambientes tectônicos (Pearce et al., 1984). 156

Figura 7.7. Padrões terras raras para as rochas da SIG e duas amostras do GSD. 158

Figura 7.8. Valores de $\delta$ O para os Granitóides da SIG e da GSD. 159

Figura.7.9. Evolução isotópica do Nd par as rochas da SIG e da GSD. 160

\section{CAPÍTULO 8}

Figura 8.1. Perfil com os ambientes geológicos aqui propostos para a formação do greenstone belt Alto Jauru. Neste modelo o evento de idade 1,79-1,75 Ga representa um arco de ilhas. 165

Figura 8.2. Modelo de ambientes geológicos para a formação do Arco Cachoeirinha (entre 1,55 e 1,53 Ga). As rochas calcioalcalinas geradas são intrusivas nos cinturões vulcanossedimentares da greenstone belt Alto Jauru.. 165

Figura 8.3 Perfil esquemático sugerindo o ambiente de arco magmático para a geração das rochas da Suíte Santa Helena pelos resultados U/Pb, Sm/Nd e de geoquímica.......166

Figura 8.4. O modelo sugere que durante o processo de subducção da crosta oceânica que deu origem ao arco de Santa Helena (1450-1420 Ma) houve um processo extensional intracratônico que possibilitou a geração da Suite Intrusiva Rio Branco (1423 Ma)....166 
Figura 8.5. As rochas do Terreno Rio Alegre se formaram através de um processo de geração de crosta oceânica a oeste (atual) da crosta continental representada pelo protocráton Amazônico. 167

Figura 8.6 Perfil geológico atual para a região SW do Cráton Amazônico (estado de Mato Grosso). A deformação do Grupo Aguapeí é marcada pelas idades K/Ar em (sericita) entre 970 e $840 \mathrm{Ma}$.

\section{CAPÍTULO 9}

Figura 9.1. Mapa com localização dos granitóides Mesoproterozóicos das regiões de Rondônia, Bolívia e Mato Grosso. Na Bolívia os dados são de Litherland et. al., (1989) e em Rondônia os dados são de Bettencourt et. al., (1999). As idades apresentadas na área na Bolívia foram obtidas pelo método $\mathrm{Rb} / \mathrm{Sr}$. 


\section{RELAÇÃO DE FOTOGRAFIAS}

Prancha 1

(1) Rocha de composição granítica do embasamento do Terreno Jauru.

(2) Rocha vulcânica de composição basáltica com xenólito de rocha de composição félsica do greenstone beolt do Alato Jauru.

(3) Pillow lava aflorante no Cinturão Jauru do greenstone belt Alto Jauru .

(4) Formação ferrífera bandada do greenstone belt Alto Jauru.

Fotomicrografia 3.1. Amostra de Gnaisse Rosa (97-133). Os zircões separados desta amostra são mostrados em detalhe.

Fotomicrografia 3.2. Amostra 97-149. Gnaisse Aliança. Os zircões separados desta amostra são mostrados em detalhe.

Fotomicrografia 3.3. Amostra 97-131. Rocha tufácea milonitizada do Complexo Vulcanossedientar Alto Jauru. Os zircões separados desta amostra são mostrados em detalhe.

Prancha 2. 48

(1) Rocha de composição granítica aflorante nas margens do rio São Domingos, próximo a Cachoeirinha (97-137).

(2) Em baixo: Intrusões do Granodiorito Água Clara em gnaisse do Complexo Brigadirinho.

(3) Rochas graníticas intrusivas em gnaisse cinzento nas margens do Rio Vermelho ao norte de Nortelândia.

(4) Detalhe das rochas graníticas aflorantes na Fazenda Alvorada (97-129).

Fotomicrografia 3.4 Tonalito Quatro Marcos (amostra 97-134). Em detalhe os zircões analisados. 54

Fotomicrografia 3.5 Amostra 97-150 (Tonalito Cachoeirinha) mostrando detalhe dos zircões analisados. 55

Fotomicrografia 3.6 Amostra 97-147 (Gnaisse São Domingos) Os zircões (uma única população homogênea) são mostrados em detalhe.

Fotomicrografia 3.7 Granito Santa Cruz (amostra 97-145) Os zircões analisados estão em detalhe.

Fotomicrografia 3.8 Amostra do Granito Cachoeirinha (97-138). Os zircões analisados são mostrados em detalhe. 58

Fotomicrografia 3.9. Amostra do Granito Alvorada coletada na região de São José dos Quatro Marcos (97-132). Os zircões são mostrados em detalhe. 59

Fotomicrografia 3.10. Granito Alvorada coletado em Cachoeirinha (amostra 97-139). Os zircões apresentam duas populações e são mostrados em detalhe. 
Fotomicrografia 3.11 Granito Alvorada (amostra 97-129), coletada na fazenda Alvorada.

Fotomicrografia 3.12. Amostra 97-136 (Granodiorito Água Clara). Os zircões são mostrados em detalhe.

\section{CAPÍTULO 4}

Prancha 3.

(1) Tonalito Pau-a-Pique da Suíte Santa Helena.

(2) Granito foliado da Suíte Santa Helena.

(3) Rochas gnáissicas granodioríticas da Suíte Santa Helena.

(4) Rochas granodioríticas envolvendo corpo de rochas de composição tonalítica da Suíte Santa Helena.

Fotomicrografia 4.1. Amostra 97-113 (Tonalito Lavrinha). Os zircões analisados são mostrados em detalhe. 79

Fotomicrografia 4.2. Amostra 97-140 (Tonalito Pau-a-Pique). Os zircões analisados são mostrados em detalhe. 80

Fotomicrografia 4.3. Amostra 97-102 (Granodiorito Guapé). Os zircões analisados são mostrados em detalhe.

Fotomicrografia 4.4. Amostra 97-105 (Granodiorito Guapé). Os zircões analisados são mostrados em detalhe.

Fotomicrografia 4.5. Amostra 97-106 (Granodiorito Guapé). Os zircões são mostrados em detalhe.

Fotomicrografia 4.6. Amostra 97-108 (Granodiorito Guaporé). Os zircões são mostrados em detalhe. 84

Fotomicrografia 4.7. Amostra 97-115 Granito-gnaisse Santa Helena. Os zircões analisados são mostrados em detalhe.

Fotomicrografia 4.8. Amostra 97-120W Magnetita Granito Cardoso. Os zircões analisados são mostrados em detalhe.

Fotografia 4.9. Amostra 97-120 E Augen-Gnaisse Cardoso com veio quartzo-feldspático subconcordante com a foliação. Os zircões analisados da encaixante e do veio são mostrados em detalhe. 90

Fotomicrografia 4.10. Amostra 97-135 (Granito Santa Elina). Os zircões analisados são mostrados em detalhe. .91

Fotomicrografia 4.11. Amostra 97-141 (Granito Maraboa). Os zircões analisados são mostrados em detalhe. 
Fotomicrografia.4.12. Amostra 97-168 Granito fazenda Ellus. Os zircões analisados são mostrados em detalhe.

Fotomicrografia 4.13. Amostra 97-169 Granito Garimpo Ellus. Os zircões analisados são mostrados em detalhe.

\section{CAPÍTULO 5}

Prancha 4.

(1) Rocha de composição básica do Terreno Rio Alegre.

(2) Pillow lava aflorante no Cinturão Jauru do greenstone belt Alto Jauru .

(3) Xenólito rocha de composição anfibolítica na Suíte Santa Helena.

(4) Basaltos toléticos nas margens do Rio Aguapeí (Terreno Rio Alegre).

Fotomicrografia 5.1. Metadacito Rio Alegre com aglomerado de epitodo. Cerca de $30 \mathrm{~kg}$ de amostra foi beneficiada para a separação de zircões euédricos de coloração amarela e translúcidos.

Fotomicrografia 5.2. Metadiorito Rio Alegre com grandes cristais de anfibólio numa matriz de plagioclásio, anfibólio e opacos. $30 \mathrm{~kg}$ de amostras foram processados por gravimetria e forneceram zircões euédricos amarelos a vermelhos

Fotomicrografia 5.3. A Metabásica Santa Bárbara apresenta anfibólio, biotita, plagoclásio, opacos e granada. Os zircões obtidos nesta amostra são subédricos com as bipirâmides subarredondadas e coloração marrom

Fotomicrografia 5.4. Amostra 97-121 Tonalito Rio Aguapeí. Os zircões analisados são mostrados em detalhe.

Fotomicrografia 5.5. Amostra 97-141 Granito Lajes. Os zircões analisados são mostrados em detalhe.

Fotomicrografia 5.6. Amostra 97-123 Microgranito Carrapato. Os zircões analisados são mostrados em detalhe.

Fotomicrografia 5.7. Amostra 97-142 (Granodiorito Rio Alegre). Os zircões analisados são mostrados em detalhe.

\section{CAPÍTULO 6}

Prancha 5

(1) Rochas graníticas granofiricas da SIRB.

(2) Rochas basálticas da SIRB.

(3) Detalhe da mistura entre rochas graníticas e basálticas da SIRB.

(4) Paisagem do local de ocorrência das rochas félsicas (litotipo predominante) da SIRB.

Prancha 6.

Rb-02 Basalto (plagioclásio, piroxênio e anfibólio). 
Rb-03 Gabro (plagioclásio, piroxênio e anfibólio).

Rb-04 Gabro Pórfiro (plagioclásio, augita, pigeonita e anfibólio). Os zircões obtidos são mostrados em detalhe.

Prancha 7

Rb-05 Basalto (plagioclásio, piroxênio e anfibólio).

Rb-06 Granito (K-feldspato, plagioclásio, quartzo e anfibólio). Observar o zoneamento do k-feldspato.

Rb-07 Granito (K-feldspato, plagioclásio, quartzo e anfibólio).

Rb-08 Granito (K-feldspato, plagioclásio, quartzo e anfibólio). Observar o zoneamento do k-feldspato.

Prancha 8.

Rb-09 Granito (K-feldspato, plagioclásio, quartzo e anfibólio).

$\mathrm{Rb}-10$ Granito (K-feldspato, plagioclásio, quartzo e anfibólio). Observar o zoneamento do k-feldspato. Zircões obtidos são mostrados em detalhe.

Rb-11 Granito granofírico (K-feldspato, plagioclásio, quartzo e anfibólio). Observar o zoneamento do k-feldspato.

Rb-12 Granito granofifico (K-feldspato, plagioclásio, quartzo e anfibólio) Observar o zoneamento do k-feldspato.

\section{CAPÍTULO 7}

Prancha 9 148

(1) Sedimentos do Grupo Aguapeí. Observa-se o contato entre Fm. Vale da Promissão e a Fm. Morro Cristalina.

(2) Rocha milonitizada da Fm Fortuna. A lineação é ortogonal ao plano da foliação milonítica, caracterizando o cavalgamento.

(3) Em baixo: Fotomicrografia dos sedimentos do Grupo Aguapeí sem a deformação.

(4) Fotomicrografia de sedimento deformado (plano da foliação milonítica, clivagem de crenulação e plano axial da crenulação).

Prancha 10 151

(1) Afloramento do Granito São Domingos na Fazenda Flor das Serra (97-118a).

(2) Detalhe do afloramento $97.118 \mathrm{a}$, com xenólito de gnaisse cinza, provavelmente do Suíte Santa Helena.

(3) Pegmatito intrusivo nos arenitos da Fm. Aguapeí.

(4) Detalhe da Suíte Guapé (afloramento na Folha Jauru).

Fotomicrografia 7.1. Amostra 97-118a (Granito São Domingos na Fazenda Flor da Serra)

Os zircões analisados são mostrados em detalhe. 153

Fomicrografia 7.3. Amostra 97-118b Granito São Domingos na Fazenda das Rosas. Os zircões analisados são mostrados em detalhe. 


\section{RELAÇÃO DAS TABELAS}

\section{CAPÍTULO 1}

Tabela 1.1 Síntese cronoestratigráfica da região região SW do Cráton Amazônico no estado de Mato Grosso a partir dos dados disponíveis na literatura.

\section{CAPÍTULO 3}

Tabela 3.1. Dados $\mathrm{U} / \mathrm{Pb}$ e $\mathrm{Sm} / \mathrm{Nd}$ para as rochas Paleoproterozóicas do Terreno Jauru.

Tabela 3.2 Idades $\mathrm{U} / \mathrm{Pb}$ e $\mathrm{Sm} / \mathrm{Nd}$ das rochas intrusivas do Terreno Jauru.

Tabela 3.3 Valores de $\delta \mathrm{O}$ para as rochas granitóides do terreno Jauru. As razões ${ }^{18} \mathrm{O} /{ }^{16} \mathrm{O}$ foram normalizados pelo standart SMOW (standart mean ocean water)

\section{CAPÍTULO 4}

Tabela 4.1 Idades U/Pb (em zircão) e $\mathrm{Sm} / \mathrm{Nd}$ em rocha total para as rochas da Suíte Santa Helena. 75

Tabela 4.2 Valores de $\delta$ O para as rochas granitóides da Suíte Santa Helena 101

\section{CAPÍtULO 5}

Tabela 5.1 Resultados U/Pb e Sm/Nd da CMVSRA 109

Tabela 5.2. Dados $\mathrm{U} / \mathrm{Pb}$ e $\mathrm{Sm} / \mathrm{Nd}$ para as policíclicas do vale do Rio Alegre

\section{CAPÍTULO 6}

Tabela 6.1 Resultados U/Pb e Sm/Nd para as rochas da Suíte Rio Branco 143

Tabela 6.2. Dados de isótopos de $\mathrm{O}, \mathrm{H}$ e $\mathrm{S}$ para as rochas da SIRB 150

\section{CAPÍTULO 7}

Tabela 7.1. Resultados $\mathrm{K} / \mathrm{Ar}$ em rochas atingidas pelo evento térmico Sunsás/Aguapeí. 149

Tabela 7.2. Dados $\mathrm{U} / \mathrm{Pb}$ e $\mathrm{Sm} / \mathrm{Nd}$ para as rochas neoproterozóicas do Terreno Pontes e Lacerda. 158

Tabela 7.3 Resultados de $\delta \mathrm{O}$ para as rochas graníticas da Suíte São Domingos. 130 


\section{CAPÍTULO 1 Aspectos Gerais}

\subsection{Introdução}

A evolução tectônica da região $\mathrm{SW}$ do Cráton Amazônico tem sido foco de estudos tanto no Brasil como nos países vizinhos. Muitos destes trabalhos baseiam-se em estudos de associações magmáticas, metamórficas e sedimentares, com o apoio de datações radiométricas, análises isotópicas e geoquímicas objetivando a identificação de fontes e processos de geração das diferentes unidades geológicas encontradas na região SW do estado de Mato Grosso.

O Proterozóico nesta parte da Plataforma Sulamericana é caracterizado, segundo vários autores, pela acresção de cinturões móveis que se anexaram ao núcleo arqueano do protocráton Amazônico. Desta forma foram descritos o Cinturão Maroni-Itacaiunas (2,2 a 2,0 Ga), Cinturão Venturi-Tapajós (2,1 e 1,9 Ga), Província Rio Negro-Juruena (1,7 e 1,6 Ga), Província Rondoniana (de idade entre 1,5 e 1,3 Ga) e o Cinturão Sunsas/Aguapeí (1,1 e 1,0 Ga).

Este trabalho enfoca a área compreendida no limite entre as províncias Rio NegromJuruena e Rondoniana, abrangendo ambas, e pretende contribuir para a melhor definição dos limites temporais e ambientes geológicos para a origem das rochas destas ali presentes. 


\subsection{Objetivos}

O objetivo principal deste trabalho é obter dados geocronológicos de precisão, isotópicos e geoquímicos dos corpos graníticos do SW do Estado do Mato Grosso, marcos da evolução tectônica regional, de forma a contribuir para o conhecimento da evolução geológica do SW do Cráton Amazônico. Para atingir este objetivo pretende-se:

1) Definir as épocas de formação dos corpos graníticos através de estudos radiocronológicos.

2) Definir as fontes destes corpos plutônicos através de suas composições geoquímicas e assinaturas isotópicas.

3) Definir o ambiente geológico durante a geração destas rochas através da modelagem geoquímica e isotópica.

\subsection{Localização da área estudada}

A região está localizada no SW do Estado de Mato Grosso (Figura 1.1), abrangendo 7 folhas topográficas de escala 1:100.000, próxima da divisa com a Bolívia e Estado de Rondônia. Regionalmente a ocupação humana é recente, e como consequência apresenta tanto áreas de fácil acesso com mapeamento geológico sistemático disponível na literatura, e também áreas praticamente desconhecidas geologicamente.

O principal acesso à região de Pontes e Lacerda se dá pela BR 364 (CuiabáPorto Velho) a $440 \mathrm{~km}$ de Cuiabá. Outra rodovia asfaltada acessa Mirassol d'Oeste, São José dos Quatro Marcos, Araputanga, Rio Branco e Jauru. Estradas vicinais de terra batida permitem atingir praticamente todos os locais e são razoavelmente conservadas durante o período de estiagem (maio a setembro). Todas estas cidades apresentam facilidades de energia, telefone, agências bancárias e transporte de pessoas e carga diários. 

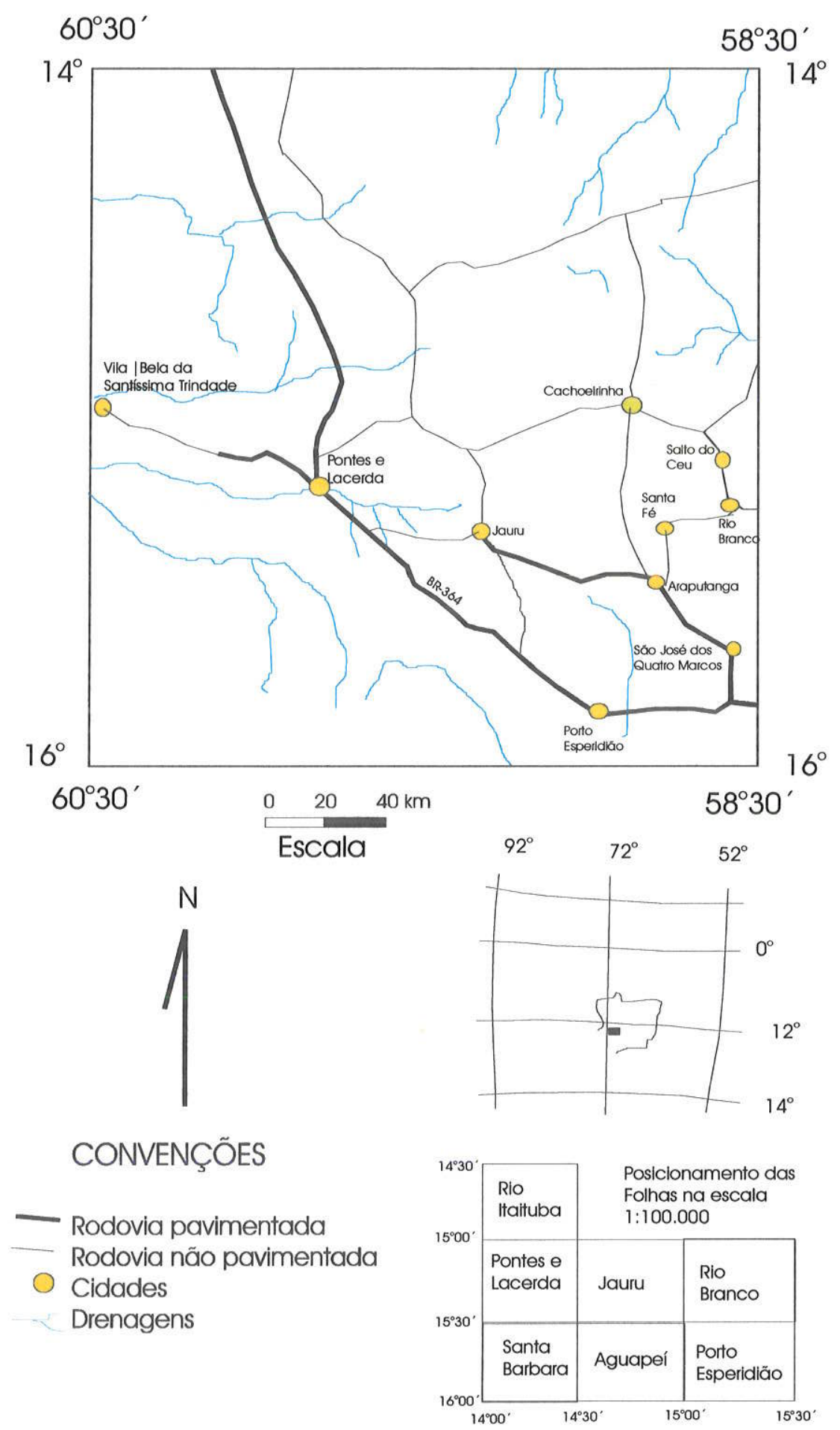

Figura 1.1 Localização e acesso da região SW do Estado do Mato Grosso. A área de estudo envolve as Folhas Pontes e Lacerda, Jauru, Rio Branco, Santa Barbara, Porto Esperidião e Rio Itaituba. 


\subsection{Apresentação}

Esta tese acha-se estruturada em 10 Capítulos. No Capítulo Introdutório são destacados trabalhos geológicos da região onde são apresentados os modelos de compartimentação tectônica e descrição de unidades litoestratigráficas na forma com que foram propostos pelos respectivos autores. O Capítulo de Materiais e Métodos descreve as metodologias e os procedimentos analíticos utilizados neste trabalho.

Nos Capítulos subsequentes a caracterização das unidades litológicas estudadas tem por base uma apresentação sequencial dos resultados petrológicos, geoquímicos e geocronológicos obtidos, seguidos de uma discussão integrada dos dados. As datações $\mathrm{U} / \mathrm{Pb}$ e $\mathrm{Sm} / \mathrm{Nd}$ foram o parâmetro principal das interpretações, além de relações de campo, no agrupamento ou subdivisão das unidades. Uma súmula da evolução geológica é apresentada no Capítulo 8. No Capítulo 9 são discutidas correlações regionais e globais.

$\mathrm{Na}$ apresentação e discussão dos dados geoquímicos foram utilizados 5 diagramas: de nomenclatura (Streckeisen, 1976), de grau de aluminosidade (Manniar e Piccoli, 1984); de tendência de diferenciação (Peacock, 1931); de discriminação de ambientes tectônicos (Pearce et al., 1984); e de elementos terras raras normalizado pelo condrito. Em adição, as unidades Suíte Santa Helena e Suíte Intrusiva Rio Branco foram avaliadas por diagramas de Harker, uma vez que a amostragem obtida foi mais representativa em termos de variação faciológica. As análises de rochas do embasamento do Terreno Jauru foram lançados nos diagramas geoquímicos conjuntamente com dados disponíveis na literatura. Para os diagramas geoquímicos das Suítes Guapé e São Domingos em função das poucas amostras analisadas, preferiu-se o lançamento dos resultados nos diagramas acima, adicionados dos resultados das rochas presentes no contexto local (encaixantes) para efeito de comparação.

Os anexos compreendem: (1) resultados $\mathrm{U} / \mathrm{Pb}$; (2) Resultados $\mathrm{Sm} / \mathrm{Nd}$; (3)

Resultados químicos rocha total; (4) Publicações vinculadas ao tema da Tese; e (5) Mapa geológico regional. 


\subsection{O Contexto Geológico-Geotectônico}

O progresso no conhecimento geológico do SW do Cráton Amazônico tem permitido a proposição de várias compartimentações tectônicas, conforme sugerido abaixo.

Cordani et al. (1978) e Cordani e Brito Neves (1982) discutiram a evolução do Craton Amazônico dividindo-o em Província Amazônica Central (núcleo cratônico Arqueano); Cinturão Móvel Maroni-Itacaiunas (bordejando a primeira unidade de leste até o norte); Cinturão Rio Negro-Juruena (com direção N/NW, bordejando a parte SW da Província Central); e Cinturão Móvel Rondoniano (de caráter ensiálico).

Tassinari (1981), definiu a Província Rio Negro-Juruena, caracterizando sua evolução geocronologica no intervalo de 1,7 a 1,4 Ga, interpretando-a como um Arco Magmático de derivação mantélica.

Teixeira e Tassinari (1984) propõem uma compartimentação do Craton Amazônico compatível com a divisão de Cordani et al. (1979), porém complementando com o Cinturão Sunsás como uma acresção mais jovem ao SW do cráton.

Litherland et al. (1996) apresentou uma grande gama de resultados através de seus estudos no pré-Cambriano na Bolívia. Os autores descrevem os eventos San Ignácio e Sunsás como orogenias completas, iniciando pelas suas unidades sedimentares, magmatismo e eventos tectono-termais que as metamorfisaram.

Teixeira et al. (1989) em revisão da geocronologia do Cráton Amazônico ratificaram essa compartimentação interpondo a sul do Cinturão Móvel Rondoniano o Cinturão Móvel Sunsás, caracterizado por embasamento ensiálico e eventos termomagmáticos importantes no intervalo de 1,45-1,25 Ga e registros de retrabalhamento tectônico em 1,1 a 0,9 Ga.

Através de mapeamentos sistemáticos no Estado de Rondônia, Bettencourt et al. (1989) caracterizaram os granitos correlacionados ao Cinturão Móvel Rondoniano nos aspectos geocronológicos $(1,4$ a 0,97 Ga), petrográficos, geoquímicos e metalogenético, ao passo que Priem et al. (1989) subdividiram os granitos do Cinturão Móvel Rondoniense em (i) granitos e embasamento gnáissico, (ii) granitos antigos, (iii) granitos intermediários e (iv) granitos jovens. 
Basu et al. (1990) estudaram os sedimentos atuais da Bacia Madre de Dios no Peru e Bolívia pelo método $\mathrm{Sm} / \mathrm{Nd}$ e identificaram a mixtura de duas fontes, uma do arco magmático Andino e outra mais antiga (Proterozóica) derivada do Escudo Brasileiro. Tosdal (1996) apresenta dados de $\mathrm{U} / \mathrm{Pb}$ (em zircão) e $\mathrm{Pb} / \mathrm{Pb}$ (rocha total) no intervalo de 1170 a $1080 \mathrm{Ma}$ no norte do Chile, norte da Argentina e sul do Peru. As assinaturas isotópicas de $\mathrm{Pb}$ são interpretadas em termos da existência de um cráton denominado Arequipa-Antofalla, exposto de forma descontínua na região andina e correlacionável em parte (norte da Argentina e Chile) ao Laurentia e outra parte (sul do Peru) ao SW do Cráton Amazônico.

Bettencourt et al. (1996) apresentaram datações ${ }^{40} \mathrm{Ar} /{ }^{39} \mathrm{Ar}$ e paleomagnetismo para corpos graníticos aflorantes no estado de Rondônia e sugerem o prolongamento do Cinturão Grenvilliano da América do Norte com o protocráton Amazônico durante o Mesoproterozóico (1080 Ma a $980 \mathrm{Ma}$ ). Um segundo trabalho de paleomagnetismo publicado na região (D'Agrella et al., 2000) apresenta resultados compatíveis com esse modelo de reconstituição paleogeográfica no qual o Craton Amazônico estaria justaposto ao Laurentia no final do Mesoproterozóico.

Sadowsky e Bettencourt (1996) em estudo a respeito da evolução tectônica regional correlacionaram o evento Ketilidiano ao evento Transamazônico (2,2-2,0 Ga); o evento Paleohelikiano (ou Elsoniano) ao evento Rondoniano (1,5-1,3 Ga); e o evento Grenvilliano (ou Neohelikiano) ao evento Sunsás (1,08-1,06 Ga). Os autores sugerem que o Laurentia e a Amazonia apresentam evoluções geológicas correlacionáveis durante o Mesoproterozóico.

Tassinari et al. (1997) apresentam um conjunto de resultados $\mathrm{U} / \mathrm{Pb}, \mathrm{Pb} / \mathrm{Pb}$ e $\mathrm{Rb} / \mathrm{Sr}$ para a parte $\mathrm{SW}$ do Cráton Amazônico e concluem pela existência de dois eventos de geração e acresção de crosta nesta parte do cráton. O primeiro ocorreu entre 1,8 a 1,6 Ga e constituiu-se de arco magmático de tipo andino. O segundo ocorreu entre 1,6 e 1,5 Ga e constituiu-se de arco magmático desenvolvido na margem continental formada durante o evento anterior. Os autores apresentam também uma proposta de divisão de Províncias Tectônicas sumarizada no mapa reproduzido na Figura 1.2.

Os trabalhos de Saes et al. (1992), e Saes (1999) sobre os ambientes deposicionais do Grupo Aguapeí dão subsídios para a formulação de um abiente de rift 
Rizzoto (1999) apresenta detalhadas descrições geológicas e geocronológicas no estado de Rondônia, concluindo por eventos de sedimentação marinha acompanhado por intrusões máficas e metamorfismo de fácies anfibolito, cujos produtos anatéxicos foram datados $(\mathrm{U} / \mathrm{Pb})$ em 1,1 Ga e correlacioinados pelos autor ao evento Sunsás.

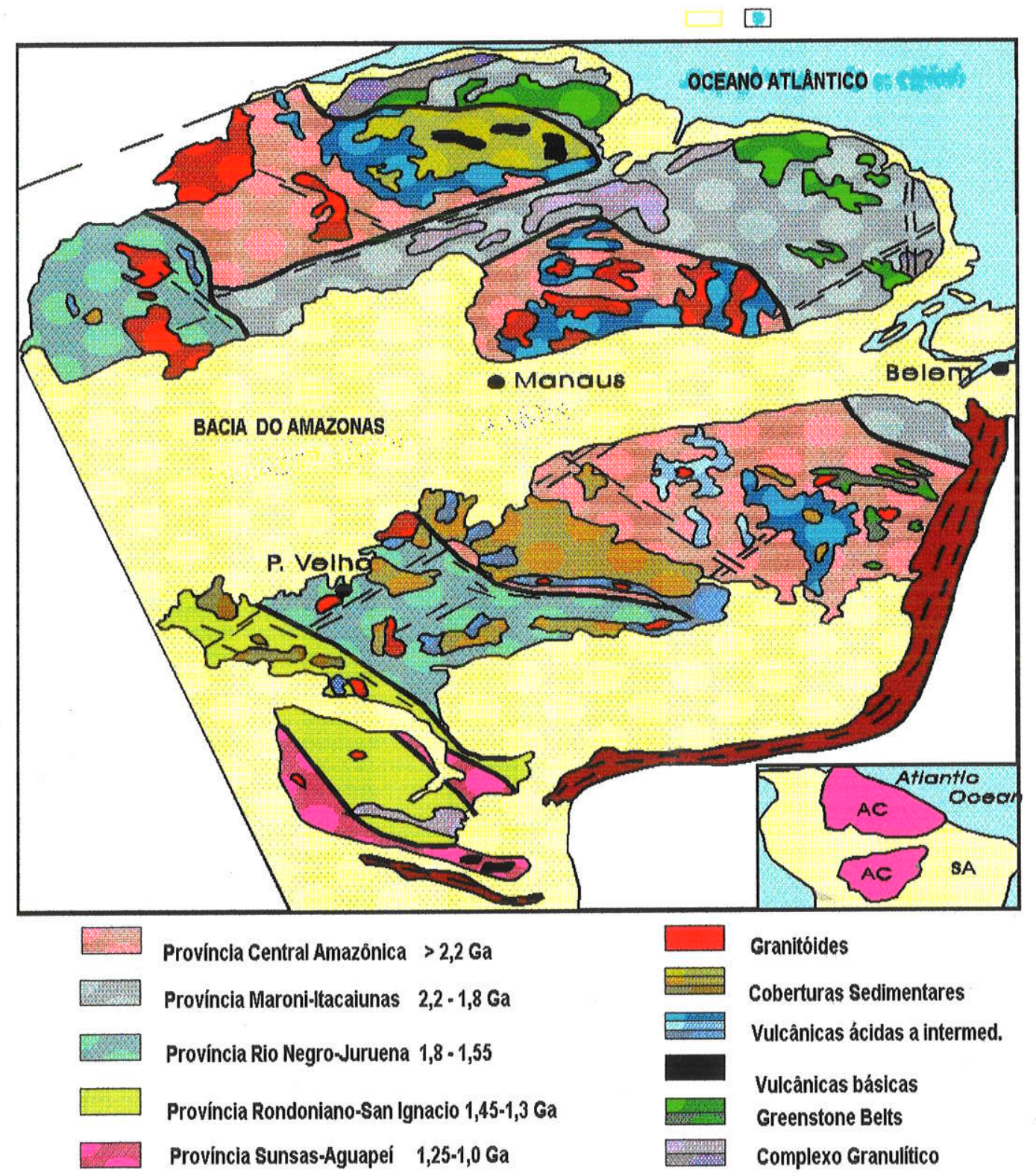

Figura 1.2 Mapa com as Províncias Tectônicas do Cráton Amazônico, segundo Tassinari et al. (1997).

O trabalho mais recente sobre a evolução tectônica regional é de Bettencourt et al. (1999), onde sete diferentes episódios de magmatismo geradores de granitos rapakivi 
O trabalho mais recente sobre a evolução tectônica regional é de Bettencourt et al. (1999), onde sete diferentes episódios de magmatismo geradores de granitos rapakivi foram identificados na província estanífera de Rondônia, com base em mapeamento geológico e detalhado estudo geocronológico $(\mathrm{U} / \mathrm{Pb})$ : (1) Suíte Intrusiva Serra da Providência (1606 \pm 24 a $1532 \pm 4.5 \mathrm{Ma}$ ); (2) Suíte Intrusiva Santo Antônio (1406 \pm 32 Ma); (3) Suíte Intrusiva Teotônio (1387 $\pm 16 \mathrm{Ma})$; (4) Suíte Intrusiva Alto Candeias $(1347 \pm 4.7 \mathrm{Ma})$; (5) Suíte Intrusiva São Lourenço-Caripunas (1314 $\pm 13 \mathrm{Ma}$ to $1309 \pm$ $24 \mathrm{Ma}$ ); (6) Suíte Intrusiva Santa Clara (1082 $\pm 4 \mathrm{Ma})$; e (7) Granitos Jovens de Rondônia $(998 \pm 5 \mathrm{Ma}$ a $991 \pm 14 \mathrm{Ma})$. Este trabalho, em adição aos trabalhos previamente descritos, apresentam bases geocronológicas e tectônicas para importantes comparações com o objeto desta tese, apresentadas nos próximos Capítulos.

\subsection{Compilação da Estratigrafia Regional}

A compilação da estratigrafia regional foi realizada tomando por base os trabalhos publicados na região SW do Estado do Mato Grosso, onde afloram rochas paleoproterozóicas do substrato metamórfico (granulitos, gnaisses e migmatitos), sequências metavulcanossedimentares, rochas intrusivas máficas, intermediárias e ácidas, metamorfizadas ou não, rochas sedimentares clásticas mesoproterozóicas do Grupo Aguapeí e intrusivas intermediárias e ácidas meso e neoproterozóicas .

As principais unidades estratigráficas definidas na região estão na Tabela 1.1. Esta compilação resultou na elaboração de um mapa na escala 1:100.000 a partir dos trabalhos anteriores, cuja redução está apresentada na Figura 1.3, e cuja legenda segue as denominações dos subítens a seguir apresentados.

\subsubsection{Substrato Metamórfico}

O embasamento regional foi originalmente descrito como composto por rochas metavulcanossedimentares intrudidas por rochas gnáissicas migmatíticas, descritas a seguir separadamente. 
Tabela 1.1 Síntese cronoestratigráfica da região SW do Cráton Amazônico no estado de Mato Grosso a partir dos dados disponíveis na literatura.

\begin{tabular}{|c|c|c|c|}
\hline Idade $(\mathrm{Rb} / \mathrm{Sr})$ & Unidade & Descrição & Observações \\
\hline Palcozóica & $\begin{array}{c}\text { Grupo Parecis } \\
\text { Formação Pantanal }\end{array}$ & Sedimentos & Cobertura \\
\hline 1,1 a 0,9 Ga & Granitos Jovens & $\begin{array}{c}\text { Granitóides de } \\
\text { composições variadas }\end{array}$ & $\begin{array}{c}\text { Suíte Guapé } \\
\text { Granito São Domingos } \\
\text { Suíte Intrusiva Rio } \\
\text { Branco } \\
\end{array}$ \\
\hline 1,3 a $0,95 \mathrm{Ga}$ & Grupo Aguapeí & Sedimentos & $\begin{array}{c}\text { Fm Fortuna } \\
\text { Fm Vale da Promissão } \\
\text { Fm Morro Cristalino }\end{array}$ \\
\hline $1,35 \mathrm{Ga}$ & Intrusivas Ácidas & Gnaisses Graníticos & $\begin{array}{c}\text { Granito-Gnaisses } \\
\text { (Suíte Santa Helena) }\end{array}$ \\
\hline 1,6 a $1,7 \mathrm{Ga}$ & Intrusivas Básicas & Gabros e Peridotitos & Figueira Branca \\
\hline 1,7 a $1,4 \mathrm{Ga}$ & $\begin{array}{c}\text { Granitos Alvorads e } \\
\text { Água Clara }\end{array}$ & $\begin{array}{c}\text { Tonalitos, Granodioritos e } \\
\text { Granitos }\end{array}$ & $\begin{array}{l}\text { Granitóides intrusivos } \\
\text { nas sequências meta- } \\
\text { vulcanossedimentares }\end{array}$ \\
\hline$?$ & $\begin{array}{c}\text { Sequência } \\
\text { Metavulcanossedimen- } \\
\text { tar Pontes e Lacerda }\end{array}$ & $\begin{array}{l}\text { Basaltos Toleíticos e } \\
\text { Andesitos, Sedimentos } \\
\text { Clásticos e Químicos }\end{array}$ & $\begin{array}{c}\text { Faixas de rochas } \\
\text { metamorfizadas na } \\
\text { região de Pontes e } \\
\text { Lacerda } \\
\end{array}$ \\
\hline$?$ & $\begin{array}{c}\text { Sequência } \\
\text { Metavulcanossedimen- } \\
\text { tar Quatro Meninas }\end{array}$ & $\begin{array}{l}\text { Basaltos Toleíticos e } \\
\text { Andesitos, Sedimentos } \\
\text { Clásticos e Químicos }\end{array}$ & $\begin{array}{l}\text { Faixas de rochas } \\
\text { metamorfizadas na } \\
\text { região Jauru- } \\
\text { Araputanga } \\
\end{array}$ \\
\hline$?$ & $\begin{array}{c}\text { Complexo Gnáissico } \\
\text { Migmatítico } \\
\text { Brigadeirinho }\end{array}$ & $\begin{array}{c}\text { Gnaisses, Anfibolitos e } \\
\text { Xistos }\end{array}$ & Embasamento \\
\hline $\begin{array}{l}1,97 \mathbf{G a} \\
(\mathbf{R b} / \mathrm{Sr})\end{array}$ & $\begin{array}{c}\text { Complexo } \\
\text { Metamórfico Jauru }\end{array}$ & $\begin{array}{c}\text { Gnaisse cinza, tonalito e } \\
\text { gnaisse rosa }\end{array}$ & Embasamento \\
\hline$\stackrel{?}{(2,8 \mathrm{Ga})}$ & $\begin{array}{l}\text { Greenstone Belt } \\
\text { Alto Jauru }\end{array}$ & $\begin{array}{l}\text { Rochas vulcânivas e } \\
\text { inrusivas plutônicas } \\
\text { (metamorfismo facies } \\
\text { xisto verde) }\end{array}$ & Embasamento \\
\hline$?$ & $\begin{array}{c}\text { Complexo Anfibolítico } \\
\text { Granulítico } \\
\text { Santa Barbara } \\
\end{array}$ & Granulitos e Anfibolitos & Embasamento \\
\hline
\end{tabular}

\subsubsection{Rochas Vulcanossedimentares}

Estas unidades compreendem rochas metavulcânicas de composições variadas e rochas metassedimentares associadas, que ocorrem na região leste da área estudada (região de Jauru-Araputanga) e na área oeste, na região de Pontes e Lacerda, nas proximidades do vale do Rio Alegre. As rochas de ambas regiões foram inicialmente 
correlacionadas geneticamente e temporalmente por diversos autores e objeto de estudo deste trabalho.

Rochas vulcanossediemntares da região de Jauru-Araputanga

A Sequência Vulcanossedimentar Quatro Meninas, proposta por Saes et al. (1984), compreende um conjunto de rochas básicas, ultrabásicas, vulcânicas e plutônicas metamorfizadas na fácies xisto verde, associada a metassedimentos terrígenos $\mathrm{e}$ químicos, de coloração variando de verde a preto e granulometria afanítica a fanerítica. As estruturas são maciças nos corpos plutônicos e maciças ou bandadas nos vulcânicos. Observam-se ainda estruturas de almofadas, e textura porfíróide a amigdaloidal em lavas basálticas komatíticas. Os litotipos mais freqüentes são metagabros, metanortositos, metabasaltos e xistos magnesianos.

O Greenstone Belt Alto Jauru (termo adotado neste trabalho) foi proposto por Monteiro et al. (1986) como resultado do mapeamento regional executado na região entre Jauru e Araputanga. Compreende uma sequência vulcano-sedimentar arqueana constituida de três faixas de trend N-NW/S-SE separadas pelo embasamento graníticognáissico. Denominadas de leste para oeste de Cabaçal, Araputanga e Jauru (esta última corresponde a Sequência Vulcanossedimentar Quatro Meninas de Saes et al. 1984), estas três faixas têm composição variável de rochas ultrabásicas, lavas ácidas a intermediárias, rochas básicas com estruturas almofadadas e tufáceas, vulcanoclásticas, sedimentos químicos e clásticos intercalados. Monteiro et al. (1986) dividiram ainda o Greenstone Belt Alto Jauru em três unidades: Formação Mata Preta (unidade basal com basaltos toleíticos), Formação Manuel Leme (lavas e tufos dacíticos e riodacíticos) e Formação Rancho Grande (metassedimentar). Toledo (1997) apresenta uma errócrona $\mathrm{Sm} / \mathrm{Nd}$ (rocha total) com a idade de $1988 \pm 45 \mathrm{Ma}$ para os metabasaltos da unidade basal, porém o autor não avança nas interpretações deste resultado em função da existência de alterações (carbonatação e epidotização) que possivelmente fracionaram o $\mathrm{Sm}$ em relação ao $\mathrm{Nd}$.

Ruiz (1992), em trabalhos geológicos de detalhe próximo ao Rio Cabaçal e na Faixa Cabaçal do greenstone belt Alto Jauru, denominou uma faixa de rochas vulcânicas 
como Grupo Alto Jauru, caracterizando-a como um cinturão estreito e alongado de direção aproximada de $\mathrm{N} 20^{\circ} \mathrm{W}$. Os litotipos observados são: biotitamusovita-granadagnaisse, tremolita-clorita-xisto, tremolitamactinolita-anfibolito, muscovita-quartzo-xisto e granada-muscovita-silimanita-biotita-xisto. Apresentam ainda três fases superpostas de deformação com base na geração de novas texturas e estruturas.

Leite et al. (1986) e Pinho e Fyfe (1994) estudaram as rochas vulcânicas básicas da Faixa Quatro Meninas do Greenstone Belt Alto Jauru, identificando basaltos tholeiíticos de alto ferro e sugerindo opela afinidade geoquímica que o ambiente tectônico de formação para estas rochas é do tipo arco de ilha. Pinho (1994) apresenta uma datação U/Pb (SHRIMP) em zircão de ca. $1800 \mathrm{Ma}$, interpretanda como idade de formação.para rochas vulcânicas do greenstone belt Alto Jauru,

Rochas vulcanossedimentares da região de Pontes e Lacerda

A Sequência Metavulcanossedimentar Pontes e Lacerda foi proposta por Menezes et al. (1993) no mapeamento da Folha Pontes e Lacerda (1:100.000), e compreende rochas vulcânicas e sedimentares químicas e clásticas, fortemente transpostas e metamorfizadas no intervalo das fácies xisto verde alta a anfibolito baixa. A Sequência Metavulcanossedimentar Pontes e Lacerda é dividida nas formações São José do Rio Branco (composta por espessos pacotes de anfibolitos e metassedimentos químico exalativos), Paumar (rochas vulcânicas) e Triângulo (unidades essencialmente clásticas, psamo-pelíticas com caráter vulcânico subordinado). Através de correlações estratigráficas com o Granito Gnaisse Santa Helena, os proponentes desta unidade sugerem a idade de $1.350 \mathrm{Ma}(\mathrm{Rb} / \mathrm{Sr}$ em rocha total).

$\mathrm{Na}$ Folha Santa Barbara Matos (1994) denominou o conjunto de litotipos vulcânicos de Sequência Vulcanossedimentar Rio Alegre (termo adotado neste trablho). Estas rochas variam de basaltos até tufos ácidos, associados a rochas sedimentares químicas, e têm continuidade física com a Sequência Metavulcanossedimentar Pontes e Lacerda. Matos (1994) propõem a divisão desta unidade em Formação Minouro (metabasaltos de granulação fina associados a metassedimentos químicos como cherts e formação ferrífera bandada), Formação Santa Isabel (metavulcânicas e metapirocláticas 
de natureza riodacítica) e Formação São Fabiano (intercalações de sedimentos clásticos, metacherts, BIF e metavulcanoclásticas). Estas rochas apresentam foliação principal com direção N20W subvertical e duas secundárias (foliação de transposição e clivagem de crenulação) (Matos e Ruiz, 1991).

\subsubsection{Rochas Gnáissicas e Migmatíticas (Embasamento Metamórfico).}

A unidade regional originalmente denominada de Complexo Xingu por Silva (1974) e Barros et al. (1982) referia-se a rochas polideformadas arqueanas na porção leste do Cráton Amazônico. Trabalhos subsequentes sugeriram a subdividisão desse complexo metamórfico.

O Complexo Gnáissico-Migmatítico Brigadeirinho foi definido por Saes et al. (1984) na região de Jauru. Os tipos petrográficos registrados nesta unidade correspondem a gnaisses leucocráticos a mesocráticos, anfibolitos e subordinadamente migmatitos, granada muscovita-xistos e muscovita quartzitos. As paragêneses enquadram-se na fácies anfibolito, localmente observado retrometamorfismo em fácies epidoto-anfibolito.

Ferreira Filho e Bizzi (1985) descreveram o Complexo Granulítico Anfibolítico Santa Bárbara na área a leste de Pontes e Lacerda, constituído por gabros noríticos, olivina-noritos, leucogabros e anortositos com reações metamórficas nas fácies anfibolito a granulito. Figueiredo et al. (1974) já haviam identificado as rochas anfibolíticas na região da Serra de Santa Bárbara, as quais Barros et al. (1982) incluíram na Suíte Intrusiva Rio Alegre. O padrão de terras raras horizontalizado destes anfibolitos reportados por Menezes et al. (1993) sugere a origem a partir de toleiítos arqueanos. Os granulitos do Complexo Granulítico Lomas Maneches, exposto em território boliviano, são provavelmente correlacionáveis a esta unidade, com idade de 1961 Ma (segundo Litherland et al. 1989).

O Complexo Metamórfico Jauru foi proposto por Carneiro et al. (1992), agrupando o Gnaisse São José dos Quatro Marcos e o Gnaisse Santa Fé. O primeiro ocorre próximo da cidade homônina e é representado por gnaisses cinza, leucocráticos, 
Leite et al. (1986) individualizaram uma unidade ao norte de Jauru, denominada como Complexo Gnáissico Rio Vermelho, reunindo gnaisses e migmatitos polideformados anteriormente incluídos no Complexo Gnáissico Migmatitico Brigadeirinho por Saes et al. (1984). Dados estruturais obtidos pelos autores nesta unidade indicam a ação de quatro episódios de deformação dúctil, com dobramentos e figuras de interferência tipo domo e bacia e bumerangues.

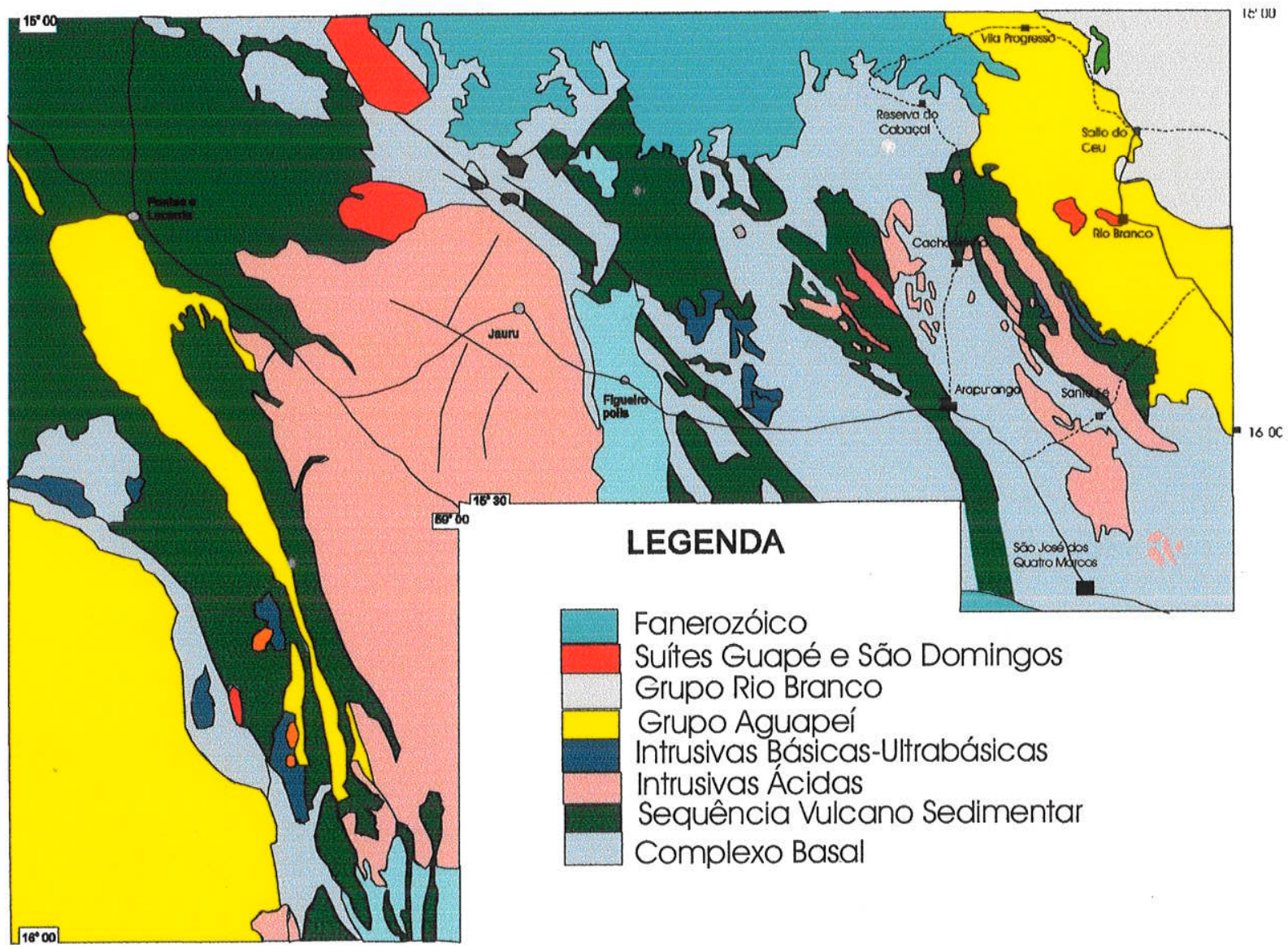

Figura 1.3. Mapa geológico regional, mostrando as principais unidades. Mapa compilado com base nos trabalhos de Saes et al. (1984); Monteiro et al. (1986); Leite et al. (1986); Carneiro et al. (1989); Leite (1989); Pinho (1990); Matos e Ruiz (1991); Menezes et al. (1993); e Matos (1994).

O Complexo Metamórfico Alto Guaporé foi proposto por Menezes et al. (1993) reunindo rochas gnáissicas e metavulcânicas possivelmente, segundo os autores, correlacionável ao Complexo Brigadeirinho descrito por Saes et al. (1984). Nesta 
O Complexo Metamórfico Alto Guaporé foi proposto por Menezes et al. (1993) reunindo rochas gnáissicas e metavulcânicas possivelmente, segundo os autores, correlacionável ao Complexo Brigadeirinho descrito por Saes et al. (1984). Nesta unidade foram descritos ortognaisses e paragnaisses com anfibolitos e metabásicas e ortognaises com composição granodiorítica. Na região de São José dos Quatro Marcos, Carneiro et al. (1992) obtiveram a idade isocrônica $\mathrm{Rb} / \mathrm{Sr}$ em rocha total de $1971 \pm 70$ Ma $(\mathrm{RI}=0,702)$ para gnaisses correlacionáveis, segundo Menezes et al. (1993), ao Complexo Metamórfico Alto Guaporé.

$\mathrm{Na}$ região do vale do Rio Alegre, Pinho (1990) cita termos tonalíticotrondhjemíticos predominantes que passam para granodioríticos, monzoníticos e quartzo dioríticos. Mais ao sul da Folha Santa Barbara, Matos e Ruiz (1991) reportam a ocorrência de gnaisses e migmatitos pertencentes a esta unidade. Matos (1994) correlacionou o Complexo Metamórfico Alto Guaporé as rochas observadas nas margens do Rio Aguapeí, compostas por biotita-gnaisses e migmatitos, além de rochas cataclásticas com composição modal predominante de tonalitos e granodioritos.

Ruiz (1992) propôs a divisão do Complexo Metamórfico Jauru (de Carneiro et al. 1992), em três unidades litoestatigráficas distintas: Gnaisses São Domingos e Aliança (ortoderivados) e Suite Intrusiva Santa Cruz, sendo que a relação de contato entre as rochas vulcano-sedimentares e o Complexo Gnáissico Migmatítico Brigadeirinho evidencia a precocidade das supracrustais. Os inúmeros enclaves centimétricos, métricos e quilométricos de anfibolitos finos, homogêneos ou bandados e metagabros no interior dos gnaisses ortoderivados e dos granitos parecem corroborar com esta hipótese.

O termo greenstone belt Alto Jauru utilizado nos Capítulos seguintes, envolverá as rochas vulcânicas e plutônicas associadas em função dos resultados obtidos no presente trabalho

\subsubsection{Intrusivas Básicas e Ultrabásicas}

As rochas intrusivas básicas e ultrabásicas descritas pelos diversos autores são de ampla distribuição geográfica e apresentam características distintas que dificultam 
correlações, de forma que preferiu-se apresentar essas unidades na sequência temporal em que foram publicadas.

Intrusivas Básico-Ultrabásicas. Esta unidade foi inicialmente estudada no Projeto Alto Guaporé por Figueiredo et al. (1974), incluindo gabros, metagabros, biotita-uralita-gabros, microgabros anfibolitizados e serpentinitos.

Suíte Intrusiva Figueira Branca. Saes et al. (1984) utilizaram este termo para designar a sequência de rochas básico-ultrabásicas não metamórficas, caracterizada por uma associação de litotipos tais como dunitos, anortositos, troctolitos e noritos, correlacionáveis a uma sucessão ígnea básico-ultrabásica diferenciada de natureza tholeiítica. Datações K/Ar (rocha total) em gabro forneceram idades aparentes de 2,8-2,2 Ga (Monteiro et al. 1986), sem valor geológico. A idade isocrônica $\mathrm{Sm} / \mathrm{Nd}$ desta suíte é de $1688 \pm 45 \mathrm{Ma}$ (Toledo, 1997).

Complexo Ígneo Rio Cágado. Menezes et al. (1993) definiram este complexo como rochas efusivo-plutônicas de composição básica a intermediária, com discretas intercalações ácidas cujas relações de campo, aliadas aos aspectos petrotectônicos que sugerem afinidades comagmáticas. São basaltos, andesitos, tonalitos e granodioritos com evidências de metamorfismo na fácies xisto-verde. As principais ocorrências desta unidade estão próximas do Rio Alegre. Uma amostra de quartzo-diorito possui uma datação K/Ar em muscovita em $1142 \pm 44$ Ma. Esta unidade em função de uma datação pelo método $\mathrm{U} / \mathrm{Pb}$ em zircão, teve sua posição cronoestratigráfica modificada no presente trabalho.

Intrusivas Máfico-Ultramáficas Metamorfizadas. São corpos intrusivos máficos e ultramáficos metamorfizados representados por serpentinitos, gabros e tonalitos próximo ao vale do Rio Alegre (Matos, 1994). A granulação grosseira atesta seu caráter plutônico, sendo que os gabros e serpentinitos apresentam textura cumulática, caracterizando diferenciação. Os termos constituintes de gabros variam de peridotito-harzburgíticos até gabros e leuco-gabros. Os termos serpentinitos variam de peridotitos e dunitos a harzburgitos.

As rochas básicas e ultrabásicas não foram abordadas no presente trabalho, de forma que as relações temporais entre estas unidades ainda carecem de estudos químicos e isotópicos detalhados. 


\subsubsection{Intrusivas Ácidas a Intermediárias}

Foram agrupadas neste ítem as unidades de composição ácida a intermediária e que foram individualizadas do Complexo Basal pelos autores que estudaram a região. As denominações aqui apresentadas foram seguidas nos trabalhos de campo e de coleta de amostras de forma que esta nomenclatura é utilizada nos Capítulos seguintes.

Tonalito Cabaçal. Esta unidade foi descrita originalmente por Monteiro et al. (1986). Ocorre na porção leste da Figura 1.3, apresentando composição tonalíticatrondhjemítica, coloração rosa acizentada, textura equigranular e granulação fina, geralmente foliado com alinhamento dos minerais máficos, textura hipidiomórfica a xenomórfica. Enclaves de gnaisses e anfibolitos, além de veios de granito rosa são frequentes. A idade proposta para esta unidade é de $1710 \pm 70 \mathrm{M}$ a, obtida a partir de uma isócrona $\mathrm{Rb} / \mathrm{Sr}$ (Carneiro et al. 1992) que foi interpretada como final de uma diferenciação magmática, iniciada com tonalitos e representada por litotipos mais diferenciados como os granitos.

Granodiorito Água Clara. Esta denominação foi proposta por Saes et al. (1984) para individualizar um maciço de dimensões batolíticas aflorante ao sul da Folha Jauru. Em 1986, Monteiro et al. prolongaram esta unidade para o sul da área inicial, o que foi confirmado por Leite (1989). Acha-se intrudido pelos gabros e noritos da Suíte Figueira Branca e mostra relações de intrusão com o Complexo Gnáissico-Migmatítico Brigadeirinho. Essa unidade não apresenta posição estratigráfica definida, tendo sido apenas indicado por Saes et al. (1984) seu caráter intrusivo no Complexo Basal.

Granito Alvorada. São vários corpos graníticos, subordinadamente granodioríticos, alongados, homogêneos, granulação média a grossa, localmente porfiríticos, rosados a cinza claros, fracamente foliados nas bordas (Monteiro et al. 1986). Foi obtida uma isócrona de referência $(\mathrm{Rb} / \mathrm{Sr})$ com idade de $1505 \pm 20 \mathrm{M}$.a com ${ }^{87} \mathrm{Sr}^{86} \mathrm{Sr}_{\text {iniocial }}=0,7037$, segundo Carneiro et al. (1992). Toledo (1997) obteve uma idade isocrônica $\mathrm{Rb} / \mathrm{Sr}$ para esta unidade de $1523 \pm 278 \mathrm{Ma} \mathrm{com}{ }^{87} \mathrm{Sr} /{ }^{86} \mathrm{Sr}_{\text {iniocial }}=0,703$.

Granito-Gnaisse Santa Helena. A designação Granito Santa Helena foi introduzida por Saes et al. (1984) na Folha Jauru. Durante o mapeamento da Folha Pontes e Lacerda, Menezes et al. (1993) renomearam-no como Granito-Gnaise Santa 
Helena. Estas rochas são ricas em $\mathrm{SiO}_{2}$, pobres em $\mathrm{Al}_{2} \mathrm{O}_{3}$ e $\mathrm{CaO}$ e podem ser caracterizadas como granitos do tipo A. As idades obtidas por isócronas $\mathrm{Rb} / \mathrm{Sr}$ é de $1308 \pm 12 \mathrm{Ma}$ (Menezes et al. 1993) e $1318 \pm 24 \mathrm{Ma}$ (Geraldes, 1996). Com ${ }^{87} \mathrm{Sr}^{86}{ }^{8 \mathrm{Sr}_{\text {iniocial }}}$ de 0,711 e 0,734 , respectivamente.

Granito Maraboa . Esta unidade foi separada do granito-gnaisse Santa Helena, no qual é intrusivo, por Geraldes (1996). O granito Maraboa é isótropo, de granulação grosseira e coloração cinza-avermelhada, e apresenta-se também intrudindo as rochas da SMVS Pontes e Lacerda. Sua idade isocrônica $\mathrm{Rb} / \mathrm{Sr}$ é de $1257 \pm 125 \mathrm{Ma}$, com razão inicial ${ }^{87} \mathrm{Sr} /{ }^{86} \mathrm{Sr}_{(\mathrm{i})}$ de 0,711 .

Granito Lages. Rochas de composição granítica (s.s.) com coloração variando de rosa a cinza, granulação média a grossa (esta última predominante) segundo Matos e Ruiz (1991). O seu caráter intrusivo é demonstrado pela presença de enclaves de anfibolito, augen-gnaisses e biotita-gnaisses em seu corpo de dimensões batolíticas. Há uma incipiente foliação metamórfica, orientada na direção N/S (direção local do Cinturão Aguapeí). Não há dados geocronológicos para esta unidade.

\subsubsection{O Grupo Rio Branco}

As rochas desta unidade foram inicialmente descritas por Oliva (1974), denominada de Complexo Serra de Rio Branco. Barros et al. (1982) denominaram o Grupo Rio Branco como caracterizado por uma seqüência plutono-vulcânica, composta por rochas básicas (diabásios e gabros) na porção basal e ácidas (riodacitos, granitos pórfiros, andesitos e dacitos) na parte superior desta sequência. Neste trabalho os autores sugerem que os sedimentos do Grupo Aguapeí são cortados pelos basaltos do Grupo Rio Branco. Uma isócrona $\mathrm{Rb} / \mathrm{Sr}$ indica a idade de $1130 \pm 72 \mathrm{Ma}$ e $\mathrm{RI}$ de 0,708. Dados isotópicos $\mathrm{K} / \mathrm{Ar}$ entretanto indicam idades entre $1450 \pm 20 \mathrm{Ma}$ a $875 \pm 21 \mathrm{Ma}$, sugerindo que esta suíte ter sido perturbada isotópicamente.

Leite et al. (1986) caracterizaram o Grupo Rio Branco composto por duas unidades, originadas a partir de um magma basáltico toleítico geradas por processo de diferenciação e estratificação, com termos como gabros (base), quartzo-monzonitos (intermediário) e granófiros (topo). Em oposição à proposta de Barros et al. (1982), Leite et al. (1986), 
preconizam que as rochas do Grupo Rio Branco são recobertas pelos sedimentos do Grupo Aguapeí.

\subsubsection{O Grupo Aguapeí}

Figueiredo et al. (1974), descreveram o espesso pacote de metassedimentos proterozóicos existentes na parte SW do Cráton Amazônico inicialmente como Unidade Aguapeí. Souza e Hildred (1980) propuseram sua elevação ao status de Grupo Aguapeí e dividiram-no em Formação Fortuna (correspondente ao pacote basal constituído de metarenitos ortoquartzíticos intercalados com metaconglomerados oligomíticos); Formação Vale da Promissão (formada por uma sequência pelítica, constituída de metassiltitos, filitos, ardósias e metapsamitos finos) e Formação Morro Cristalino (formada por metarenitos, intercalações de metaconglomerados e finos leitos de metassiltitos). Saes et al. (1992) e Saes (1999) propuseram, a partir de estudos faciológicos, que a bacia de deposição do Grupo Aguapeí passou por três estágios: Estágio Rift; Estágio Marinho com subsidência; e Estágio de Inversão com retrabalhamento e correspondem, respectivamente, às Formações Fortuna, Vale da Promissão e Morro Cristalino. Segundo estes autores o aulacógeno Aguapeí no Brasil e o Cinturão Sunsás na Bolívia são correlacionáveis cronologicamente (idades $\mathrm{K} / \mathrm{Ar}$ e $\mathrm{Rb} / \mathrm{Sr}$ ao redor de 1,0 $\mathrm{Ga}$ ) e estão separados pelo Maciço de Paraguá. A SW do Grupo Sunsás foi proposta uma zona de subducção (Saes et al. 1994; Saes, 1999), com as consequentes associações de sedimentação, magmatismo, mineralizações, deformação e metamorfismo, com idades do Proterozóico Médio, segundo Litherland et al. (1989). Estes autores propuseram o início de deposição do Grupo Sunsás em $1300 \mathrm{Ma}$ e final em $950 \mathrm{Ma}$.

Após a deposição e deformação dos sedimentos do Grupo Sunsás ocorreram atividades magmáticas representadas pelo Complexo Rincon Del Tigre constituído de sills (dunitos, gabros e granófiros de idade isocrônica $\mathrm{Rb} / \mathrm{Sr}$ de $993 \mathrm{Ma}$ ) intrudidos nos sedimentos do Grupo Sunsás e pelo Granito Casa de Piedra (idade isocrônica $\mathrm{Rb} / \mathrm{Sr}$ de $1006 \mathrm{Ma}$ ), além de outros granitos mapeados, mas não datados, correlacionáveis ao evento Sunsás. Estes granitos apresentam variação composicional de monzogranitos e granodioritos a granitos. 
Estas unidades ocorrem intrusivas nas rochas graníticas do batólito Santa Helena, apresentando xenólitos da encaixante. Ambas localizam-se na porção NE da Folha Pontes e Lacerda na forma de corpos alongado (Guapé) e arredondado (São Domingos).

Suíte Intrusiva Guapé. O termo Suíte Guapé foi empregado por Barros et al. (1982) e reune maciços ácidos compostos por biotita-hornblenda-granitos e microgranitos porfiríticos segundo Saes et al. (1984). Mapeado por Menezes et al. (1993), a Suíte Intrusiva Guapé foi dividida em duas associações principais, uma de composição sieno e monzogranítica a alaskítica e outra, subordinada quartzomonzonítica. Compreendem tipos microgranulares, eventualmente subvulcânicos. Esta rochas são mesocráticas, cinza escuras, apresentam cristais arredondados de quartzo e feldspatos manteados por finas películas de plagioclásio (textura rapakivi). A isocrona $\mathrm{Rb} / \mathrm{Sr}$ em rocha total da Suíte Guapé indica uma idade de $950 \pm 40 \mathrm{Ma} \mathrm{e}{ }^{87} \mathrm{Sr}^{86} \mathrm{Sr}_{\mathrm{i}}=$ 0.703 (Menezes et al. 1993).

Granito São Domingos. Esta denominação é utilizada para definir um conjunto de granitos granadíferos, associado a um pequeno corpo de aproximadamente $50 \mathrm{~km}^{2}$, na Folha Pontes e Lacerda, segundo Menezes et al. (1993). Nas zonas de contato observam-se xenólitos das rochas vulcânicas encaixantes. Ainda segundo estes autores, o caráter hololeucocrático da rocha aliado a sua peculiar paragênese mineral, permite concluir sobre sua composição córindon-normativa, peraluminosa e por conseguinte, sua caracterização como granito tipo $S$, derivado de fusão crustal de rochas metassedimentares, sob condições hidratadas na fácies anfibolito. Não se dispõem até o momento de estudos geocronológicos, mas considerando sua natureza intrusiva no Granito Gnaisse Santa Helena e composição (granito tipo S) correlacionável ao período colisional, sugere-se (Menezes et al. 1993) para esta unidade, posição estratigráfica mais antiga do que o Grupo Aguapeí. 
1.7 Os Limites dos Terrenos Proterozóicos do SW do estado de Mato Grosso.

Neste trabalho o conceito de terreno será aplicado a associações de rochas limitadas por falhas, zonas de falhas ou zonas de cisalhamentos com estratigrafia própria e que possuam uma história geológica coerente e distinta das unidades adjacentes (Howell, 1995).

A integração das informações disponíveis na literatura permitiu delinear três terrenos com características distintas considerando a associação litológica, dados litogeoquímicos, dados isotópicos, dados de campo e arranjo estrutural. Estes terrenos (Figura 1.4), têm seus limites definidos por grandes lineamentos estruturais e confirmados por dados geofísicos, descritos a seguir.

O Terreno Jauru agrupa as unidades que ocorrem no lado leste do lineamento Taquaruçu-Lucialva (Monteiro et al. 1986) recobertas ao norte por sedimentos do Grupo Parecis (Saes et al. 1984). O termo é emprestado do principal rio que corta de norte a sul os limites do terreno e utilizado nos trabalhos de cunho regional (Saes et al., 1984; Monteiro et al., 1986). As rochas observadas neste terreno são polideformadas de origem vulcanossedimentar e plutônicas e com idades paleo e mesoproterozóicas. Estão incluídas neste terreno a Suíte Intrusiva Rio Branco e a cobertura sedimentares do Grupo Aguapeí, ambas não deformadas.

O Terreno Pontes e Lacerda localiza-se a oeste do lineamento TaquaruçuLucialva, sendo limitado a oeste pela faixa de sedimentos deformados do Grupo Aguapeí (Souza e Hildred, 1980). Esta faixa coincide com as anomalias gravimétricas identificadas por Bezerra (1993) e interpretadas por este autor como zona de sutura. Este terreno é composto por rochas graníticas a tonalíticas foliadas ou não, além de granitos anorogênicos não foliados, como o Guapé e São Domingos (Menezes et al., 1993).

A principal distinção entre os Terrenos Pontes e Lacerda e Jauru são as idades radiométricas. O Terreno Jauru tem idades mais antigas (1,90 a 1,40 Ga), obtidas principalmente pelo método Rb/Sr (Carneiro et al. 1992; Ruiz, 1992; e Toledo, 1997 e dados inéditos do Centro de Pesquisas Geocronológicas, Instituto de Geociências-USP). As médias das idades K/Ar (em micas e anfibólios) obtidas em rochas deformadas 
também indicam uma idade mais antiga (1,40 a 1,00 Ga) para o Terreno Jauru (Carneiro et al. 1989; Carneiro et al. 1992).

$\mathrm{O}$ Terreno Pontes e Lacerda apresenta idades radiométricas $\mathrm{Rb} / \mathrm{Sr}$ mais jovens $(1,30$ a $0,95 \mathrm{Ga}$ ). As idades $\mathrm{K} / \mathrm{Ar}$ (em sericitas) são mais recentes em relação ao Terreno Jauru, com média próxima de 1,00 Ga, análises estas realizadas em sedimentos deformados pelo evento Sunsás e no seu embasamento. Ambos os Terrenos são recobertos pelos sedimentos do Grupo Aguapeí.

O Terreno Rio Alegre foi separado do Terreno Pontes e Lacerda em função das diferenças nas associações litológicas limitadas pelo Lineamento definido pela zona de cisalhamento geradas pelo Evento Aguapeí, onde anomalias detectadas em levantamentos geofísicos (gravimetria e cintilometria) sugerem uma zona de sutura (Menezes et al. 1993) reativada e representando o depocentro da bacia Aguapeí (Saes, 1999). O Terreno Rio Alegre é constituído por rochas vulcanossedimentares metamorfisadas na fácies xisto-verde, com características distintas dos granitos típicos do Granito Gnaisse Santa Helena, que predominam no Terreno Pontes e Lacerda. As rochas deformadas do Grupo Aguapeí (evento Sunsas/Aguapeí segundo Litherland et al. 1989) estão presentes tanto no Terreno Pontes e Lacerda como no Terreno Rio Alegre. Não pode ser descartada a hipótese da continuidade do Cráton Parágua (Litherland et al. 1989) em território brasileiro, que poderia estar representado a oeste do Lineamento Rio Alegre, onde ocorrem rochas granulíticas (Complexo Anfibolítico-Granulítico Santa Bárbara), o Granito Lages e outras rochas gnáissicas de alto grau nas margens do rio Aguapeí. 


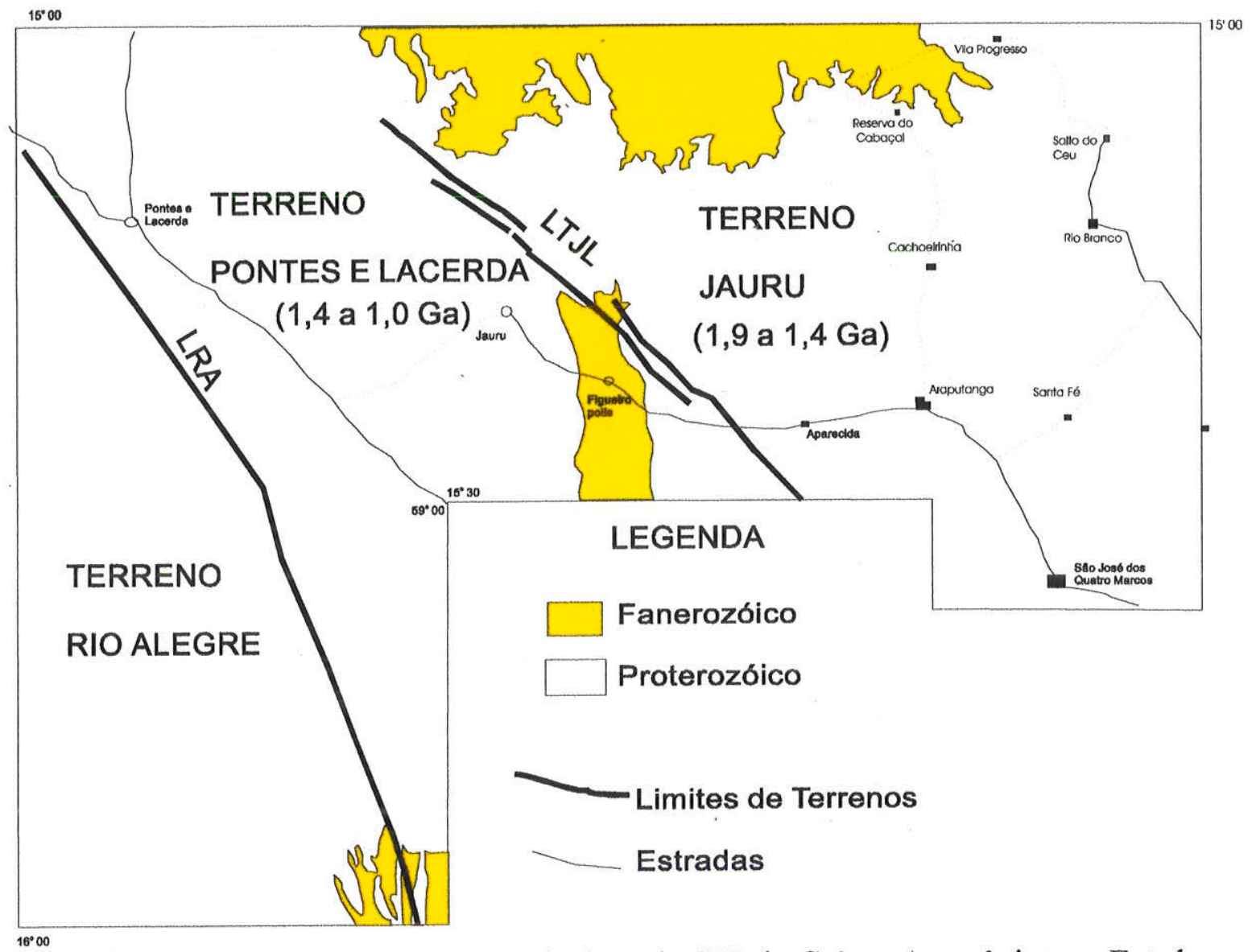

Figura 1.4 Disposição dos terrenos geológicos do SW do Cráton Amazônico no Estado do Mato Grosso. LRA = Lineamento Rio Alegre. LTJL = Lineamento TaxaquaraJundiuvira-Lucialva. LDA = Lineamento e Depocentro Aguapeí.

As idades indicadas são datações $\mathrm{Rb} / \mathrm{Sr}$ disponíveis na literatura.

As unidades geológicas pré-Cambrianas estão apresentadas na Figura 1.3. 


\section{CAPÍTULO 2 \\ Materiais e Métodos}

2.1 Introdução

Para atingir os objetivos propostos neste trabalho foram programados vários estudos. A seguir são descritos os materiais e métodos utilizados em cada um destes estudos.

\subsection{Estudos Prévios e Revisão Bibliográfica}

Esta etapa compreendeu a compilação dos trabalhos realizados durante levantamentos geológicos da região SW do cráton Amazônico e uma atualização quanto a literatura internacional tratando de terrenos Mesoproterozóicos da América do Sul, Central e do Norte, com enfoque na geocronologia, modelamento geoquímico de corpos plutônicos e modelagem de processos magmáticos.

\subsection{Trabalhos de Campo e Amostragem}

Os trabalhos de campo foram programados com os objetivos de identificação e melhor caracterização das unidades litológicas plutônicas descritas nos trabalhos já realizados na região e execução da amostragem necessária para os tratamentos laboratoriais. Os trabalhos de campo foram concentrados nas Folhas 1:100.000 citadas no ítem introdução. 
A primeira etapa de campo foi realizada em janeiro se 1997, com o Prof. Romalino Fragoso-Cesar (IG-USP) e o Prof. Gerson Saes (UFMT). A segunda foi realizada em agosto de 1997 com o Prof. Van Schmus (Universidade de Kansas) Profa. Marly Babinsky (IG-USP). Através destas duas etapas de campo coletou-se amostras das unidades representativas da região e iniciaram-se os tratamentos laboratoriais, cujos resultados estão apresentados e discutidos nos capítulos seguintes. Neste trabalho de campo houve a oportunidade de se fazer também um reconhecimento geológico no Estado de Rondônia com com professores da USP e UNESP e geólogos da CPRM de Porto Velho, com o objetivo de estabelecer correlações com as unidades observadas na área de estudo.

A terceira etapa de campo ocoreu em dezembro de 1997 com o Prof. Wilson Teixeira (IG-USP), Prof. Jorge Bettencourt (IG-USP), Prof. Igor Pacca (IAG-USP) e Dr. Manuel D'Agrella (IAG-USP). Este campo teve o objetivo de coleta de amostras e de definir uma estratégia de trabalho com vistas a um projeto em andamento que tem por objetivo estudos paleomagnéticos no SW do Cráton Amazônico. A última etapa de campo foi realizada em julho de 1999 com o Prof. Van Schmus (Universidade de Kansas), o Prof. Kent Condie (Universidade do Novo México) e Prof. Dr. Wilson Teixeira (IG-USP), Prof. Dr. B.B. Brito Neves e geólogos da CPRM de Porto Velho e da UFMT (Cuiabá).visando a visita dos locais amostrados e discussão a luz dos resultados obtidos.

\subsection{Análises Petrográficas}

As amostras representativas das unidades geológicas identificadas e coletadas nas etapas de campo foram analisadas inicialmente ao microscópio ótico com a finalidade de se observar texturas, estruturas e associações minerais diagnósticas dos eventos ígneos e metamórficos regionais. Este trabalho realizado em 70 lâminas foi de suma importância visto que as ferramentas utilizadas posteriormente (geoquímica e geocronologia) dependem fundamentalmente dos resultados das análises petrográficas, tanto para a interpretação petrogenética conjunta dos resultados isotópicos e de geoquímica de rocha 
total como para a escolha dos métodos radiocronológicos e consequente interpretações dos resultados obtidos.

\subsection{Estudo Litogeoquímicos}

Foram selecionadas quatro conjuntos de amostras para análises químicas em rocha total. O primeiro conjunto compreendeu amostras da Suíte Intrusiva Rio Branco, com variações de gabros a quartzo sienitos, totalizando 12 análises. $\mathrm{O}$ segundo conjunto compreendeu amostras de litotipos correlacionados ao Granito Gnaisse Santa Helena e totalizou 15 amostras. $\mathrm{O}$ terceiro conjunto realizado compreendeu os granitos jovens (três amostras) e rochas do Terreno Jauru (treze amostras).

Frações de rocha foram cominuídas em britador de aço $(<5 \mathrm{~mm})$ e moídas em moinho de ágata. Uma alíquota de $20 \mathrm{~g}$ foi encaminhada ao Laborátório de Geoquímica do IG-USP para análise de elementos maiores e uma alíquota de $20 \mathrm{~g}$ foi encaminhada ao ACTALAB para análises de elementos traços e terras raras.

Os elementos maiores analisados (em óxidos) foram: $\mathrm{SiO}_{2}, \mathrm{Al}_{2} \mathrm{O}_{3}, \mathrm{Fe}_{2} \mathrm{O}_{3}, \mathrm{FeO}, \mathrm{CaO}$, $\mathrm{Na}_{2} \mathrm{O}, \mathrm{MgO}, \mathrm{K}_{2} \mathrm{O}, \mathrm{TiO}_{2}, \mathrm{MnO}$ e $\mathrm{P}_{2} \mathrm{O}_{5}$. Os elementos traços foram: $\mathrm{Cr}, \mathrm{NiO}, \mathrm{Rb}, \mathrm{Sr}, \mathrm{Ba}, \mathrm{Zr}$, $\mathrm{Y}, \mathrm{Nb}, \mathrm{Hf}$, Th e U. Os elementos terras raras analizados foram: La, Ce, Nd, Sm, Eu, Gd, Dy, $\mathrm{Ho}, \mathrm{Er}, \mathrm{Yb}, \mathrm{Lu}$.

As técnicas analíticas empregadas incluíram ICP-AS para os elementos maiores. Detalhes da sistemática utilizada estão descritos em Janasi et. al., (1989). No laboratório ACTLABS os elementos traços $\mathrm{P}, \mathrm{S}, \mathrm{Cl}, \mathrm{Rb}, \mathrm{Sr}, \mathrm{Ba}$ e $\mathrm{Zr}$ foram analisados por fluorescência de raio $\mathrm{X}$ (em pastilhas fundidas); espectrometria de absorção absorção atômica para $\mathrm{Mn}$, $\mathrm{Mg}, \mathrm{Na}, \mathrm{K}, \mathrm{Cu}, \mathrm{Mo}$, Sn e $\mathrm{Pb}$; espectrometria óptica para $\mathrm{Nb}, \mathrm{Y}, \mathrm{Ni}$ e $\mathrm{V}$; espectrometria de emissão com plasma induzido (ICP) para terras raras e titulação com $\mathrm{KMnO}_{4}$ e para $\mathrm{Fe}^{2+}$.

Os erros esperados para as principais metodologias situam-se em torno de $2 \%$ (ICPES), e entre 5\% e 10\% (FRX e Absorção Atômica e titulação). 


\subsection{Isótopos Estáveis}

Os isótopos estáveis analisados objetivando uma modelagem para rochas silicatadas foram o oxigênio $\left({ }^{18} \mathrm{O}\right.$ e ${ }^{16} \mathrm{O}$ ), o hidrogênio (deutério e ${ }^{1} \mathrm{H}$ ) e o enxofre $\left({ }^{18} \mathrm{~S} /\right.$ ${ }^{16} \mathrm{~S}$ ). Para estas análises isotópicas foram utilizadas amostras de rocha total. Neste sentido realizaram-se aproximadamente 13 análises para isótopos de $\mathrm{O}$ para as unidades graníticas do Terreno Jauru e do Terreno Santa Helena. Na Suíte Intrusiva Rio Branco foram realizadas 8 análises de isótopos de $\mathrm{O}$, seis análises de isótopos de $\mathrm{H}$ e 6 análises de S. Para cada corpo amostrado iniciou-se esta abordagem com uma coleção de amostras já estudada pelos métodos anteriores (geoquímica, rocha total, química mineral e geocronologia).

\subsection{Isótopos Radiogênicos}

As preparações das amostras foram realizadas no Centro de Pesquisas Geocronológicas (CPGeo) do Instituto de Geociências da USP e as análises isotópicas foram realizadas no Isotope Geochemistry Laboratories na Universidade de Kansas (EUA). As unidades de maior importância estratigráfica na região foram selecionadas após as etapas de campo, análises petrográficas e litogeoquímica.

\subsubsection{Método $\mathrm{K} / \mathrm{Ar}$}

No presente estudo este método foi utilizado em sericitas de xistos coletados na Sequência Metavulcanossedimentar Pontes e Lacerda e em sedimentos arquimetamórficos do Grupo Aguapeí.

As amostras foram britadas em pilão manual e cominuídas até atingir a granulometria entre 60 e 80 meshs. Em sequência lavou-se o material em água e secouse em lâmpadas por duas vezes. As amostras passaram posteriormente pelo separador isomagnético Frantz em duas etapas com ângulos de 10 e 15 graus. Obtida assim uma amostra de alta pureza em sericita, foi separada uma alíquota para a coleta de argônio e outra alíquota para a análise de concentração de potássio. 
As análises radiométricas foram efetuadas conforme as técnicas descritas por Amaral et. al. (1966), com modificações. As dosagens de potássio foram feitas por fotometria de chama em aparelho Micronal modelo B262, utilizando-se o lítio como padrão. $\mathrm{O}$ argônio foi extraído da amostra em unidades de ultra-vácuo, com pressões inferiores a $2 \times 10^{-7} \mathrm{mmHg}$ e purificado em fornos de $\mathrm{Cu}-\mathrm{CuO}$ e titânio. Para as análises espectrométricas utilizou-se o espectrômetro de massa Reynolds, tipo Nuclide, de fonte gasosa do CPGeo. Os resultados finais foram tratados em microcomputador, utilizandose o programa ISOPLOT (Ludwig, 1990). As constantes utilizadas no cálculo das idades $\mathrm{K} / \mathrm{Ar}$ foram as recomendadas por Steiger e Jaeger (1978) sendo $\lambda_{\beta}$ o decaimento da partícula $\beta$ e $\lambda_{\text {tot }}$ o decaimento total:

$$
\begin{aligned}
& \lambda_{\beta}=4,962 \times 10^{-10} \mathrm{a}^{-1} \\
& \lambda_{\text {tol }}=5,543 \times 10^{-10} \mathrm{a}^{-1} \\
& \% \text { atom. de } \mathrm{K}^{40} \mathrm{em} \mathrm{K}^{\mathrm{tol}}=0,01167 \\
& \mathrm{Ar}^{40} / \mathrm{Ar}^{36}=295,5
\end{aligned}
$$

O branco para o potássio foi de $0,0037 \mu$ g obtido em recipiente analisado simultaneamente à bateria de amostras.

\subsubsection{Método $\mathrm{Sm} / \mathrm{Nd}$}

Para as análises de $\mathrm{Sm} / \mathrm{Nd}$ foram utilizadas rochas pulverizadas (granulometria $>200 \mathrm{mesh}$ ). As amostras foram dissolvidas em HF e os traçadores ${ }^{145} \mathrm{Nd}$ e ${ }^{144} \mathrm{Sm}$ foram adicionados às soluções. A separação dos elementos terras raras foi feita por colunas de troca catiônica com resina AGW-50. Nova separação por colunas de troca cationica foram realizadas para a concentração do $\mathrm{Sm}$ e do $\mathrm{Nd}$, segundo-se os procedimentos descritos em Patchet e Ruiz (1987). As concentrações isotópicas destes elementos foram medidos no espectrômetro VG Sector multicoletor do Isotope Geochemistry Laboratory da Universidade de Kansas (EUA). O Sm foi depositado com $\mathrm{H}_{3} \mathrm{PO}_{4}$ em filamento de $\mathrm{Ta}$ e analizado como $\mathrm{Sm}^{+}$em coletor estático. $\mathrm{O} \mathrm{Nd}$ foi depositado com $\mathrm{H}_{3} \mathrm{PO}_{4}$ (além de uma fina camada de resina $\mathrm{AGW}-50$ ) em filamento simples de Re e analisado como $\mathrm{Nd}^{*}$. 
Para se obter dados estatisticamente confiáveis foram coletadas normalmente entre $30 \mathrm{e}$ 50 razões com um feixe de ${ }^{144} \mathrm{Nd}$ de $1 \mathrm{~V}$ ou de 50 a 100 razões com feixe de ${ }^{144} \mathrm{Nd}$ a 500 $\mathrm{mV}$. Este procedimento assegura precisão interna entre 10 e $20 \mathrm{ppm}$. A precisão externa de $\pm 30 \mathrm{ppm}(1 \sigma)$ foi obtida através de análises de padrões periódicas. Nestes termos, as análises do padrão La Jolla $\mathrm{Nd}$ resultou em uma média de 0,511860 $\pm 0,000010$. Oito análises do padrão $\mathrm{BCR}-1$ resultou em valores médios de $\mathrm{Nd}=29,44 \pm 0,70 \mathrm{ppm}, \mathrm{Sm}=$ $6,77 \pm 0,21 \mathrm{ppm},{ }^{147} \mathrm{Sm} /{ }^{144} \mathrm{Nd}=0,13931 \pm 0,00071$ e ${ }^{143} \mathrm{Nd} /{ }^{144} \mathrm{Nd}=0,512641 \pm$ 0,000007 , resultando em valores de $\varepsilon_{\mathrm{Nd}}=0,07 \pm 0,12($ todos com $1 \sigma)$. Durante o curso das análises os brancos de Nd estiveram entre 500 e 150 pg, com valores de branco de $\mathrm{Sm}$ correspondentes de 100 a $50 \mathrm{pg}$. Correções para o branco de $\mathrm{Nd}$ foram insignificantes e geralmente insignificantes para as razões $\mathrm{Sm} / \mathrm{Nd}$. Amostras com baixos valores de $\mathrm{Nd}$ tiveram erros ao redor de $0,6 \%$. Razões de $\mathrm{Sm} / \mathrm{Nd}$ tiveram erros inferiores a $0,5 \%$, baseados nas incertezas analíticas.

Obedeceu-se ainda a uma seleção dos dados com base no parâmetro do fracionamento $(f)$ do sistema $\mathrm{Sm} / \mathrm{Nd}$ para rochas crustais (e.g. DePaolo, 1988b), utilizando-se o modelo de simples estágio para o cálculo das idades modelo $\mathrm{T}_{\mathrm{DM}}$. Para os cálculos de razões isotópicas, do parâmetro $\varepsilon_{\mathrm{Nd}}$ e de idade modelo $\mathrm{T}_{\mathrm{DM}}$ foram utilizadas as seguintes constantes (DePaolo, 1988; Faure, 1987):

$$
\begin{array}{ll}
{ }^{146} \mathrm{Nd} /{ }^{144} \mathrm{Nd} & =0,7219 \\
\lambda_{\text {Sin }} & =0,654 \times 10^{-11} \mathrm{ano}^{-1} \\
\left({ }^{143} \mathrm{Nd} /{ }^{144} \mathrm{Nd}\right)_{\text {CHUR }(0)} & =0,512638 \\
\left({ }^{147} \mathrm{Sm} /{ }^{144} \mathrm{Nd}\right)_{\text {CHUR }(0)} & =0,1967 \\
\left({ }^{143} / \mathrm{Nd} /{ }^{144} \mathrm{Nd}\right)_{\text {DM }(0)} & =0,513114 \\
\left({ }^{147} \mathrm{Sm} /{ }^{144} \mathrm{Nd}\right)_{\text {DM }(0)} & =0,222
\end{array}
$$

\subsubsection{Método $\mathrm{U} / \mathrm{Pb}$}

Este método foi realizado no Isotope Geochemistry Laboratory da Universidade de Kansas em 40 amostras, resultando 189 análises, o que representa uma média superior a 4 análises de zircão por amostra. O critério utilizado para a definição do número de 
frações de zircão por amostra foi a obtenção de resultados com o menor erro possível. Desta forma quando os dados analíticos de 3 frações de zircão resultavam em uma idade com erro próximo de $1 \%$ da idade, as análises desta amostra eram encerradas. Por outro lado houve casos de onze análises de zircão de uma amostra que não resultaram em idade com erro aceitável.

Neste laboratório da Universidade de Kansas foi possível a realização de análises $\mathrm{U} / \mathrm{Pb}$ em monocristal de zircão por diluição isotópica, o que permite resultados precisos (com menores erros) e identificação de populações de zircões de diferentes idades, proporcionando uma melhor interpretação da evolução das rochas e das associações de rochas estudadas.

A sistemática envolveu a coleta de 10 a $20 \mathrm{~kg}$ de amostras separadamente nos trabalhos de campo. No Laboratório de Preparação de Amostras do CPGeo-USP, estas amostras foram cominuídas em britador e moídas em moinho de disco com controle de granulometria mínimo de 100 mesh, obtida por peneiramento. A concentração gravimétrica foi realizada por mesa vibratória e do concentrado obtido foi separado os minerais magnéticos utilizando-se o Franzt. A fração não magnética foi então processada em líquidos densos (bromofórmio e iodeto de metileno) da onde resultou o concentrado com zircões transportado para a Universidade de Kansas (EUA).

Os zircões foram separados em função da susceptibilidade magnética, gerando frações que variaram entre $M(6)$ (fração mais magnética) a M(-2) (fração menos magnética). A fração menos magnética teve entre 10 a 20 grãos selecionados e abradados em abradador a ar comprimido (utilizando-se pirita) segundo a sistemática desenvolvida por Krough (1982a e b). Os grãos foram dissolvidos individualmente com $\mathrm{HF}$ e adicionado o traçador misto ${ }^{205} \mathrm{~Pb}$ ${ }^{235} \mathrm{U}$. Os zircões pesavam entre 0,001 e $0,025 \mathrm{mg}$. Após a dissolução completa (3 a 5 dias a $\left.200^{\circ} \mathrm{C}\right) \mathrm{Pb}$ e $\mathrm{U}$ foram separados em colunas de troca catiônica, segundo os procedimentos descritos por Krough, (1973) e Parrish (1987). As razões isotópicas foram medidas usando um espectrômetro de massa VG sector com multicoletor usando-se o detector Daly. As composições isotópicas do $\mathrm{Pb}$ foram analisadas em filamento simples de $\mathrm{Re}$ utilizando-se sílica gel e ácido fosfórico, sendo estas análises corrigidas pela discriminação de massa média de $0,12 \pm 0,05 \%$ de massa por unidade, o qual foi determinado pela análise do padrão NBS 
SEM-982 e valores de $\mathrm{Pb}$ radiogênico foi monitorado periodicamente pelo padrão NBS SEM-983.

Para o $U$, as amostras foram depositadas no mesmo filamento (Re) e analisadas como $\mathrm{UO}_{2}{ }^{+}$. O fracionamento de U foi monitorado pela análise do padrão NBS SEM U-500. Incertezas na razão $\mathrm{U} / \mathrm{Pb}$ resultantes do fracionamento e da espectrometria de massa para as análises são ao redor de $\pm 0,5 \%$. As composições isotópicas de ${ }^{208} \mathrm{~Pb},{ }^{207} \mathrm{~Pb}$ e ${ }^{206} \mathrm{~Pb}$ radiogênicos foram calculadas levando em conta correções para o branco de $\mathrm{Pb}$ atual e para as composições não radiogênicas destes isótopos foram afetuadas correções utilizando-se o modelo de Stacer e Krammers (1975). Incertezas no Pb radiogênico são da ordem de $\pm 0,1 \%$ com exceção das amostras com baixa razão ${ }^{206} \mathrm{~Pb} /{ }^{204} \mathrm{~Pb}$, nas quais incertezas na composição de $\mathrm{Pb}$ comum original podem provocar erros maiores.

Os brancos laboratoriais situaram-se entre 5 e $24 \mathrm{pg}$ de $\mathrm{Pb}$ total durante as análises. Os cálculos das idades foram efetuados utilizando-se o programa ISOPLOT de Ludwig (1998). Os erros gerados pela incerteza na regressão das discórdias foram calculados para $2 \sigma$, ou $1 \sigma$ quando indicado. Os resultados são apresentados em diagrama ${ }^{206} \mathrm{~Pb} /{ }^{238} \mathrm{U}$ versus ${ }^{207} \mathrm{~Pb} /{ }^{235} \mathrm{U}$ com elípses cujas dimensões são representativas dos erros analíticos obtidos.

As constantes de decaimento utilizadas foram as recomendadas por Steiger e Jäger (1977) :

$$
\begin{aligned}
& \lambda\left({ }^{238} \mathrm{U}\right)=1,55125 \times 10^{-10} \mathrm{ano}^{-1} \\
& \lambda\left({ }^{235} \mathrm{U}\right)=9,8485 \times 10^{-10} \mathrm{ano}^{-1}
\end{aligned}
$$




\section{CAPÍTULO 3 \\ O Terreno Jauru}

Neste terreno ocorrem rochas vulcânicas, plutônicas e sedimentares que representam o substrato mais antigo da região em estudo uma vez que é intrudido por rochas granitóides de composição variada e rochas máfico-ultramáficas. As rochas do embasamento regional ocorrem em três subparalelas denominadas (de oeste para leste) de Faixa Jauru, Faixa Araputanga e Faixa Cabaçal. Estes cinturões foram denominado por Monteiro et al., (1986) de Grenstone Belt Alto Jauru. As rochas do embasamento e as rochas intrusivas são descritas separadamente a seguir.

\subsection{O Embasamento do Terreno Jauru}

Neste item são apresentados os resultados de unidades compostas por rochas graníticas e por rochas vulcânicas que representam o substrato do Terreno Jauru. Foram coletadas amostras de rochas plutônicas aflorantes na região de Araputanga e São José dos Quatro Marcos e Cachoeirinha, e uma amostra de rocha vulcânica da Faixa Araputanga, nas proximidades da Mina de Ouro Cabaçal. (Figura 3.1).

Os dados isotópicos $\mathrm{Sm} / \mathrm{Nd}$ e $\mathrm{U} / \mathrm{Pb}$ para estas rochas estão na Tabela 3.1 e a descrição das amostras analisadas é apresentada a seguir. Aspectos gerais dos afloramentos destas unidades são apresentadas na Prancha 1. 

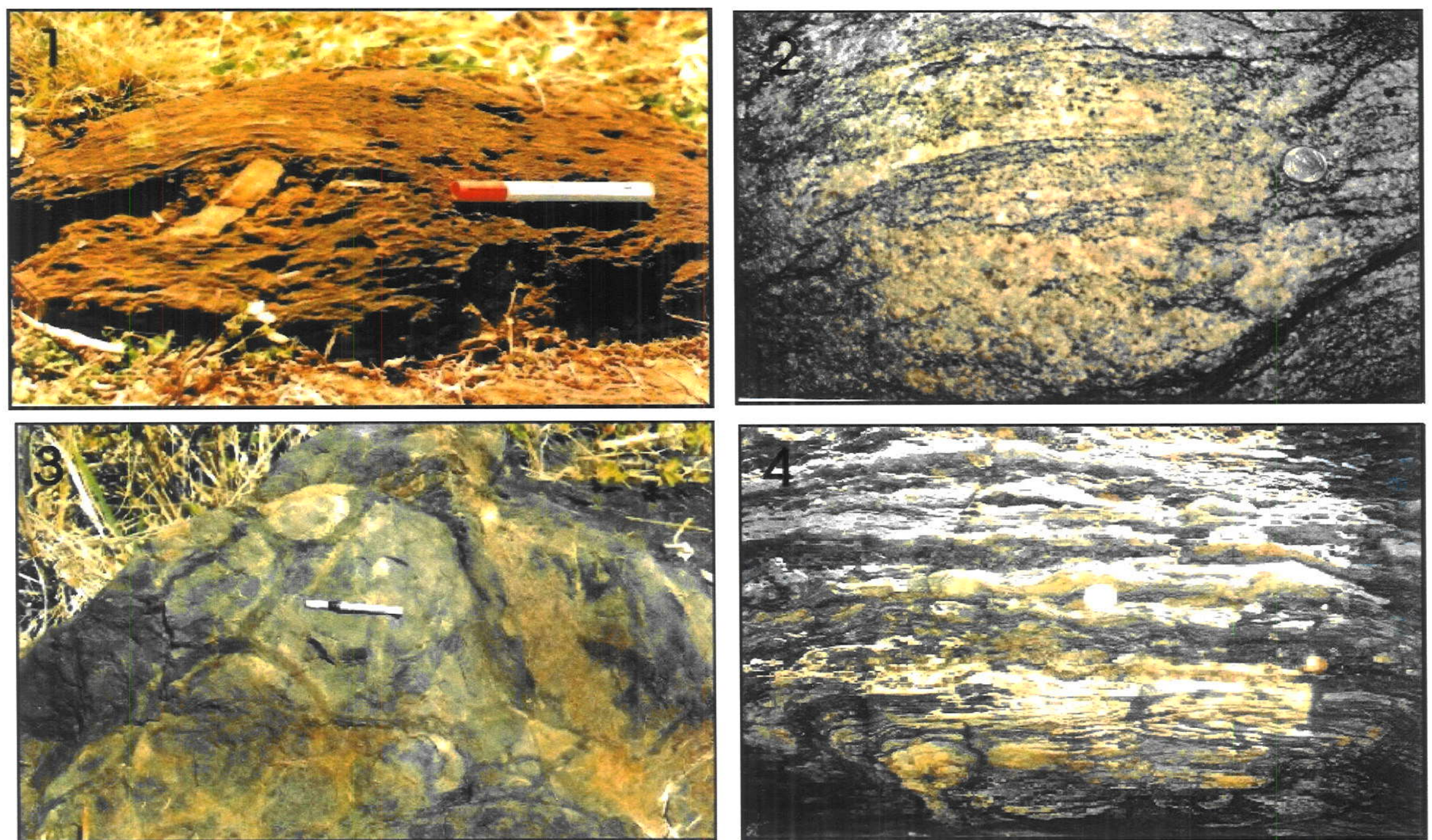

Prancha 1 (1) Rocha vulcânica de composição basáltica com xenólito de rocha de composição félsica do greenstone belt Alto Jauru.

(2) Rocha de composição granítica do embasamento do Terreno Jauru.

(3) Pillow lava aflorante no greenstone belt Alto Jauru .

(4) Formação ferrífera bandada do greenstone belt Alto Jauru. 

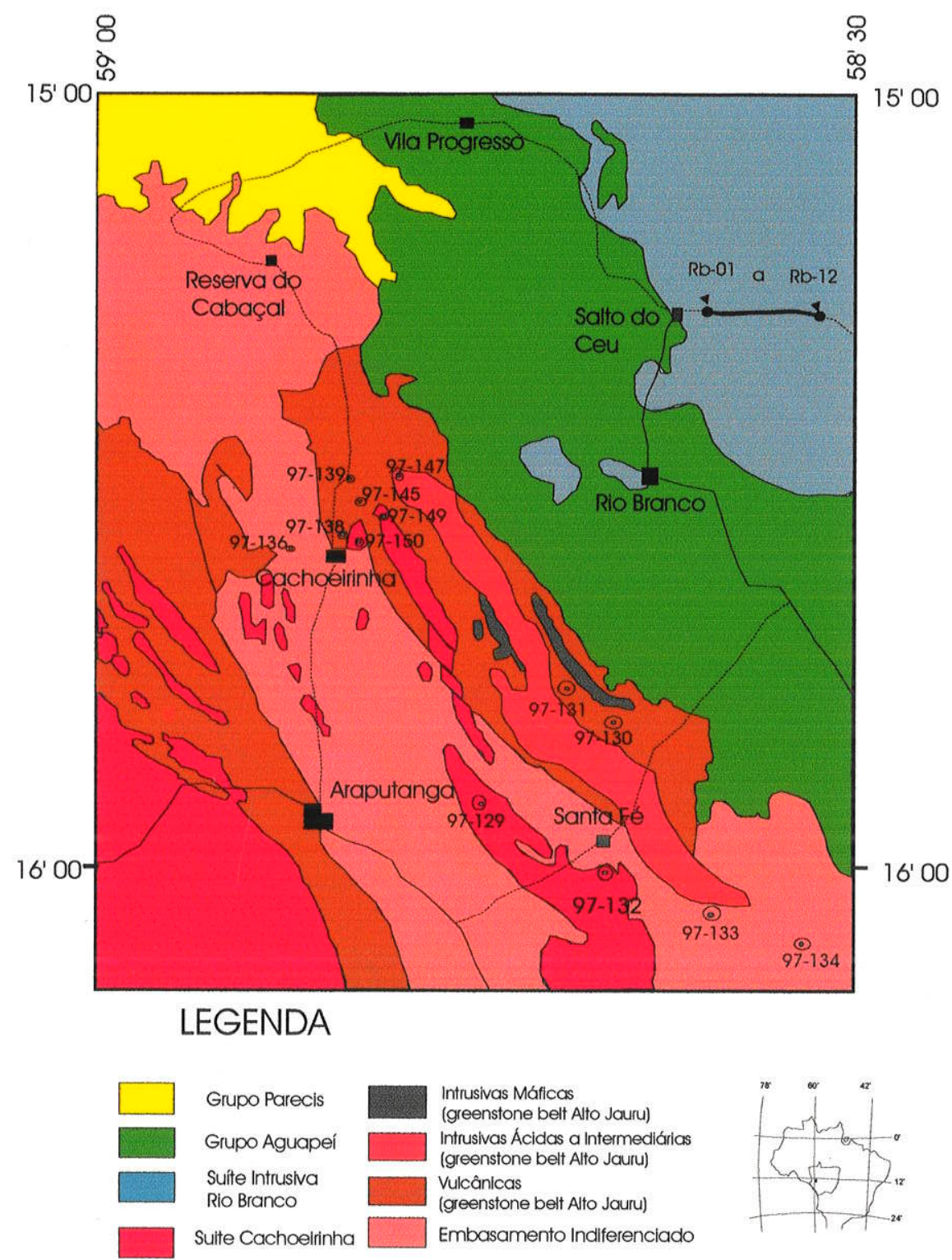

Figura 3.1 Localização das amostras das rochas graníticas do Terreno Jauru. Algumas unidades de pequenas dimensões em área não são mostradas. Neste mapa estão lançadas as amostras de idades paleo e mesoproterozóicas.

Tabela 3.1. Dados U/Pb e Sm/Nd para as rochas Paleoproterozóicas do Terreno Jauru.

\begin{tabular}{lllllll} 
Amostras & Litologia & $\mathrm{U} / \mathrm{Pb}(\mathrm{Ma}) *$ & $\varepsilon_{\mathrm{Nd}}(0)$ & $\varepsilon_{\mathrm{Nd}(\mathrm{t})}$ & $\mathrm{T}_{\mathrm{DM}}$ & $f$ \\
$==$ & $==========$ \\
$97-133$ & Gnaisse Rosa & $1795 \pm 10$ & -18.1 & 2,2 & 1,93 & $-0,44$ \\
$97-149$ & Gnaisse Aliança & $1746 \pm 20$ & -18.1 & 2,4 & 1,77 & $-0,36$ \\
$97-131$ & Vulcânica Cabaçal & $1767 \pm 24$ & -17.7 & 2,6 & 1,85 & $-0,48$ \\
\hline$=$
\end{tabular}

* Datação U/Pb por diluição isotópica com monocristais de zircão.

$\varepsilon_{\mathrm{Nd}(t)}$ calculado para a idade U/Pb. $\mathrm{T}_{\mathrm{DM}} \mathrm{em} \mathrm{Ga}$. 
Gnaisse Rosa

Trata-se de corpos de composição granítica com trend N $20^{\circ} / 40^{\circ}$ W-NW que ocorrem na parte leste do Terreno Jauru e apresentam relações de contato interpretadas como intrusivas nas rochas vulcânicas deste terreno (Monteiro et al., 1986). O Gnaisse Rosa (denominação de Carneiro et al., 1992), expõe-se na região de Araputanga e Santa Fé. São rochas predominantemente mesocráticas com composições variando de granitos a granodioritos e complexa deformação. Apresentam granulação média a grossa e bandamento definido pela alternância de bandas félsicas e mesocráticas (enriquecidas por biotita e/ou hornblenda) irregulares e descontínuas, caracterizando gnaisses nebulíticos. A microtextura destas rochas é granoblástica. O quartzo configura mosaicos enquanto o plagioclásio (oligoclásio e menos freqüentemente andesina) é subédrico a anédrico, ao passo que os cristais de biotita e hornblenda são euédricos (Fotomicrografia 3.1). Os minerais acessórios são apatita, zircão, titanita, alanita e opacos (principalmente magnetita).

Gnaisses rosa-acinzentados são descritos por Carneiro et al., (1992) como intrusivos no gnaisse cinza. Estas rochas são inequigranulares, grossas com textura protomilonítica. $O$ bandamento é definido pela alternância irregular de bandas quartzo-feldspáticas (com feldspato potássico rosa) inserido em fina matriz. As bandas máficas contêm biotita, hornblenda e quartzo como mineral principal. A amostra de Gnaisse Rosa coletada teve quatro frações de zircão analisados que indicaram a idade de $1795 \pm 21 \mathrm{Ma}$ (Figura 3.2), interpretada como idade de cristalização da rocha.

\section{Gnaisse Aliança}

Esta unidade proposta por Ruiz (1992) refere-se a um conjunto de gnaisses ortoderivados expostos ao sul da cidade de Cachoeirinha, também anteriormente mapeadas como Complexo Xingu (Barros et al., 1982, e Monteiro et al., 1986) e como Associação Gnáissico Migmatítica Brigadeirinho (Saes et al., 1984). Segundo Ruiz (1992), apresenta um formato aproximadamente alongado segundo a direção $\mathrm{N} 20^{\circ} \mathrm{W}$, com os limites oeste e sul marcados pela penetração de diques de pegmatitos e aplitos pertencentes à Suíte Santa Cruz e do Granito Alvorada. Os contatos ao norte e a leste com o Tonalito Cabaçal, segundo Ruiz (op.cit.) são por falhamentos.

As rochas desta unidade exibem cor cinza clara, granulação média a raramente 
grossa e são equigranulares. A foliação é caracterizada pela orientação planar preferencial tanto dos minerais placóides como prismáticos e pela alternância de níveis ou bandas descontínuas enriquecidas em componentes máficos e félsicos, bandamento este utilizado por Ruiz (1992) para a caracterização como gnaisse. Basicamente compõem-se por plagioclásio cinza esbranquiçado e quartzo e, em menor proporção, por feldspato potássico cinza, biotita e hornblenda (Fotomicrografia 3.2). Ao microscópio petrográfico verificou-se que as rochas mostram textura lepidoblástica e nematoblástica. Estudos isotópicos $\mathrm{Rb} / \mathrm{Sr}$ (Carneiro, 1985) resultaram em uma isócrona $\mathrm{Rb} / \mathrm{Sr}$ que indicou a idade de $1734 \pm 226 \mathrm{Ma}$ com $\mathrm{RI}=0,7019$. Nove frações de zircão desta unidade foram analisados e indicaram a idade de $1744 \pm 38 \mathrm{Ma}$ (Figura 3.3), interpretada como idade de cristalização da rocha.

Rochas vulcânicas

O Cinturão Araputanga ocorre na porção leste da Figura 1.1, na região compreendida entre as cidades de Jauru e Araputanga, onde rochas vulcânicas de composições basálticas, andesíticas e riolíticas expõem-se em meio as rochas intrusivas tonalíticas e gabróicas. Na área da Mina de Ouro do Cabaçal, a encaixante do minério corresponde a rochas vulcânicas félsicas cisalhadas. A amostra coletada apresenta bandamento sugestivo de deposição em ambiente vulcanogênico, porém fortemente foliada. A composição mineral original está mascarada por uma intensa sericitização (Fotomicrografia 3.3). Os zircões analisados para esta amostra tufácea de composição riolítica indicaram a idade de $1747 \pm 17 \mathrm{Ma}$ (Figura 3.4), confirmando as idades das duas amostras anteriores, sugerindo um evento formador de rochas plutônicas e vilcânicas no intervalo de tempo entre 1795-1745 Ma. 


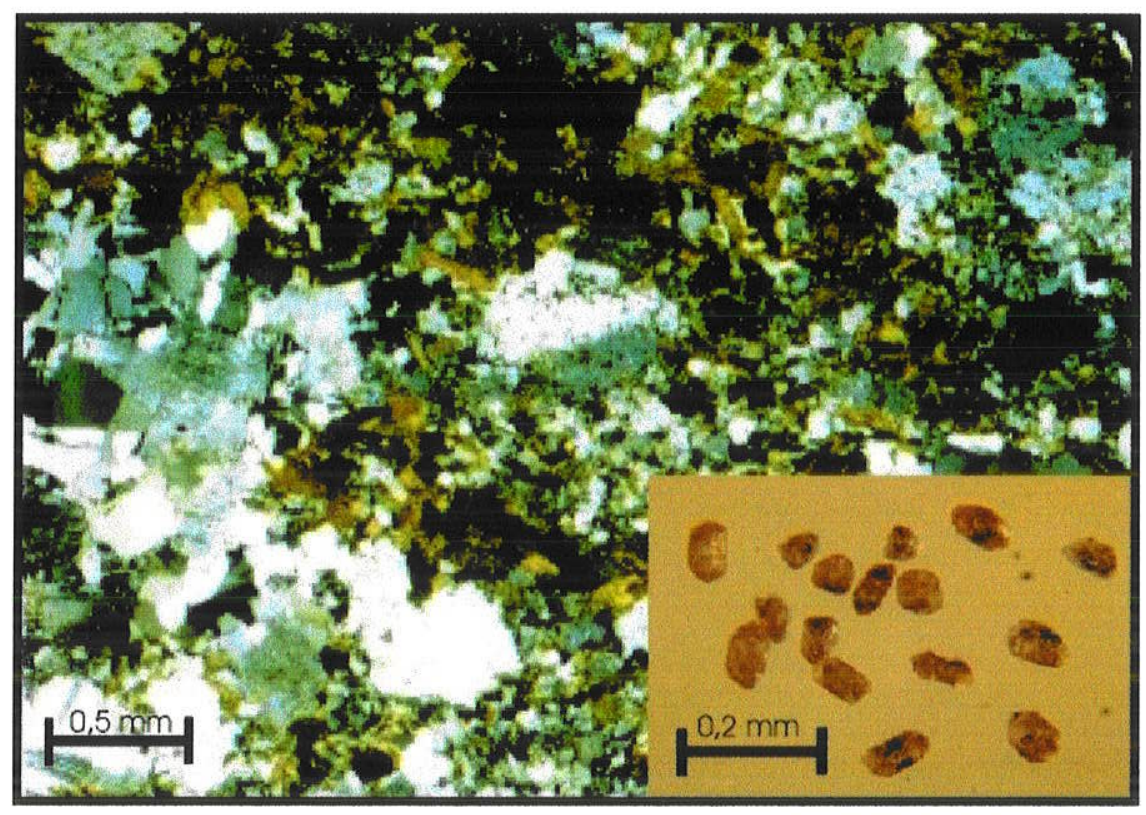

Fotomicrografia 3.1. Detalhe em lâmina da amostra Gnaisse Rosa (97-133). Os zircões separados desta amostra são translúcidos a levemente leitosos, com coloração caramelo a marrom e forma subarredondada ou pouco alongada (2:1).

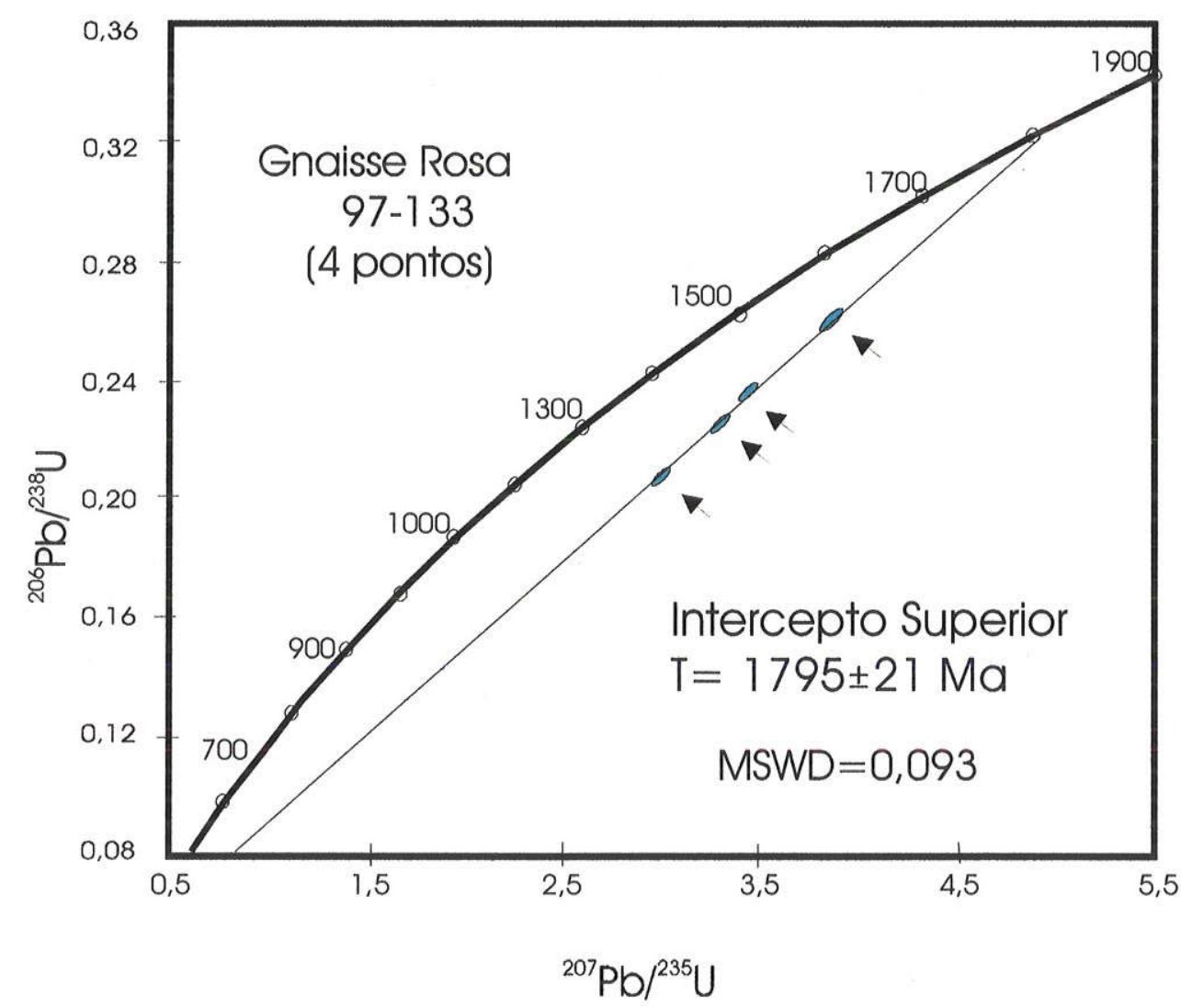

Figura 3.2 Diagrama da concórdia para 4 zircões da amostra 97-133 (Gnaisse Rosa). O intercepto superior indica uma idade de $1795 \pm 21 \mathrm{Ma}$. Intercepto inferior forçado a 0 . 


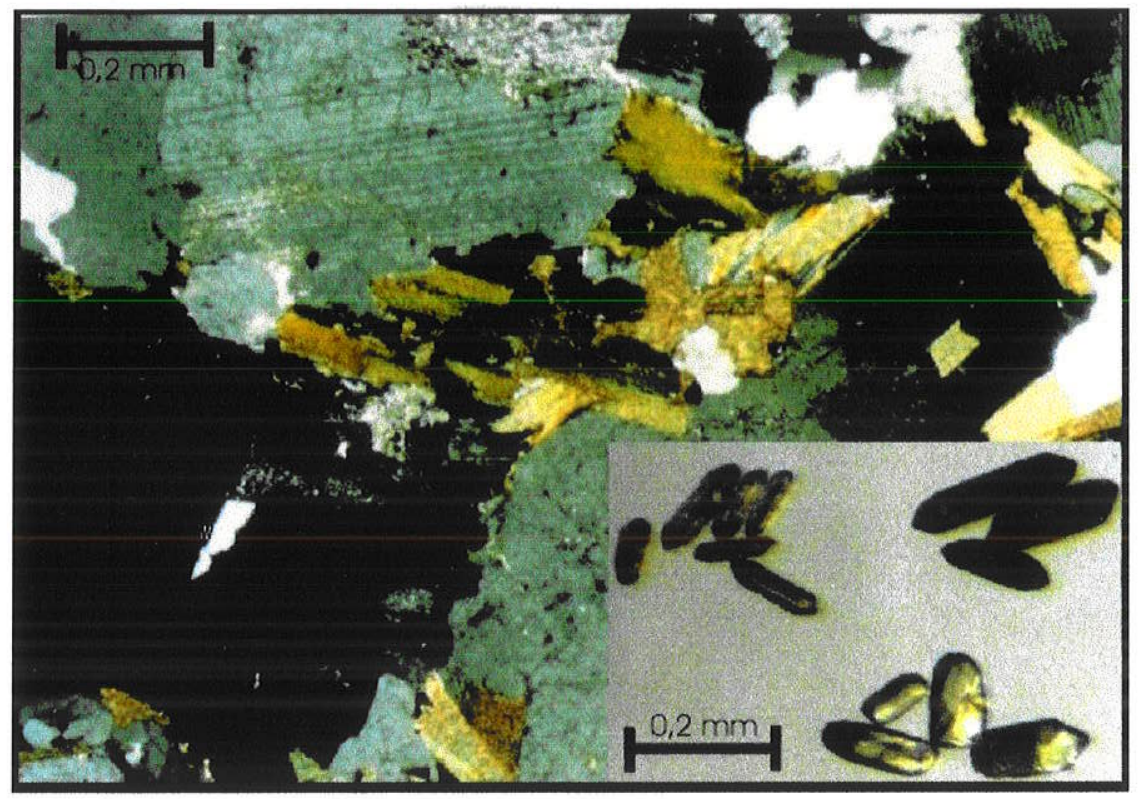

Fotomicrografia 3.2. Detalhe em lâmina da amostra Gnaisse Aliança (97-149). Os zircões separados desta amostra podem ser divididos em três populações: zircões caramelados 4:1; zircões marrom escuro 5:1; e zircões translúcidos 3:1.

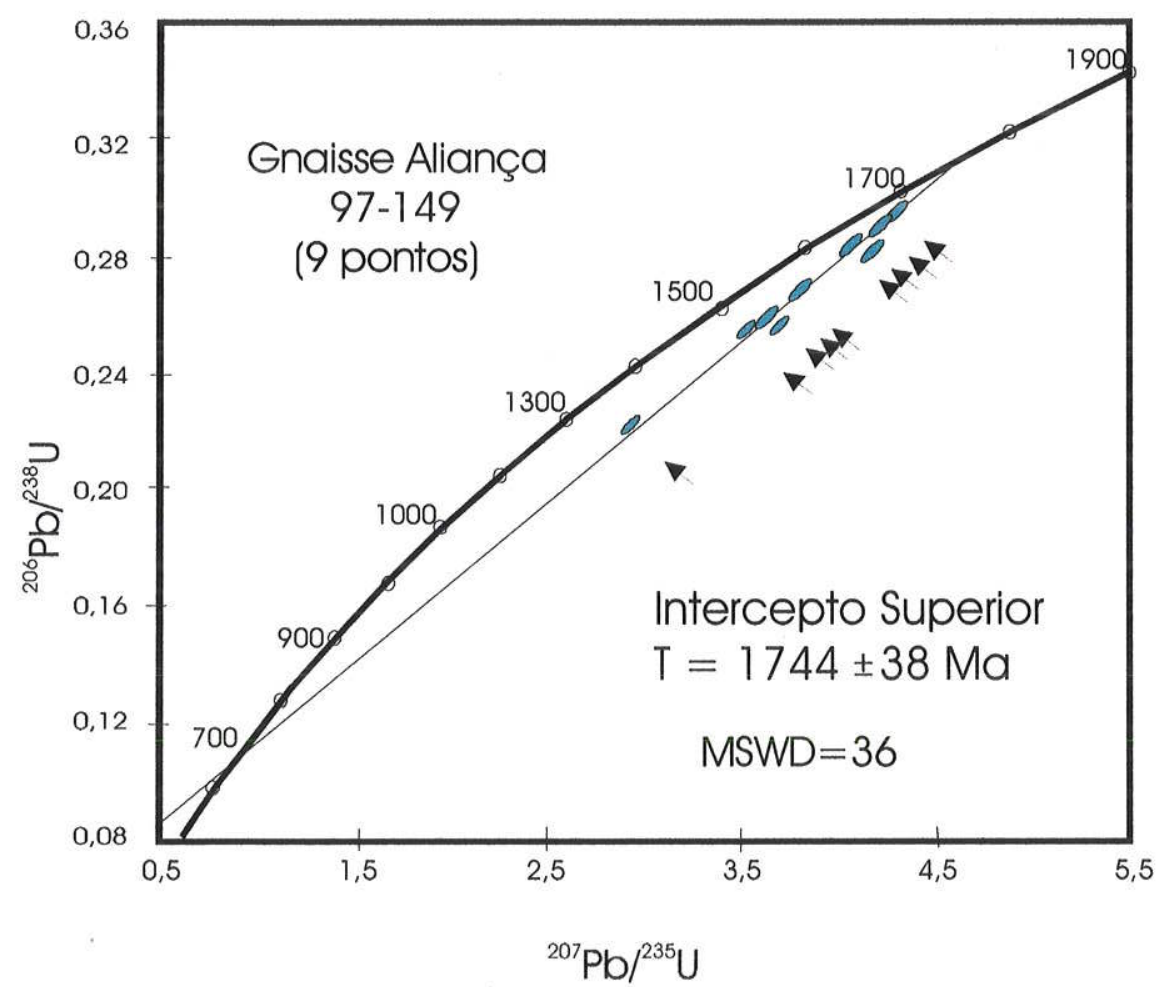

Figura 3.3 Diagrama da concórdia para 9 zircões da amostra 97-149 (Gnaisse Aliança). O intercepto superior indica uma idade de $1744 \pm 38 \mathrm{Ma}$. Não foi identificada diferença de idade entre as populações de zircões. $\mathrm{O}$ intercepto inferior não apresenta significado geológico. 


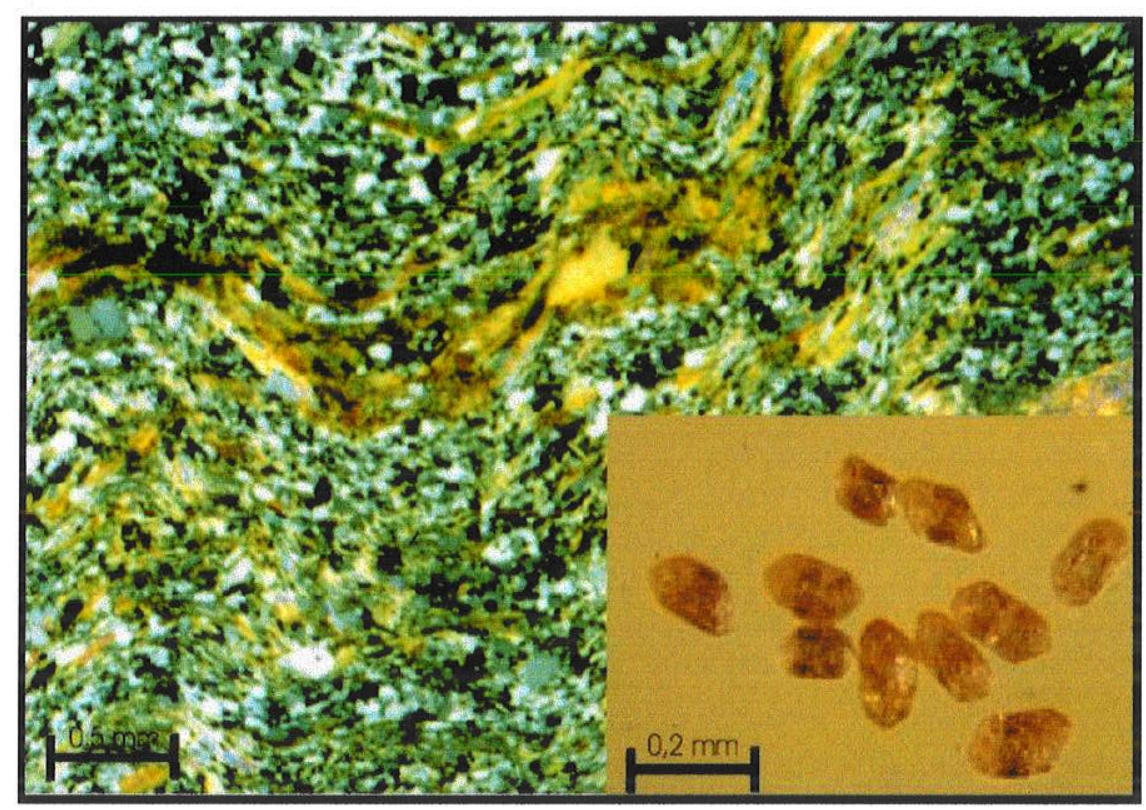

Fotomicrografia 3.3. Detalhe em lâmina da amostra 97-131, rocha tufácea milonitizada do Complexo Vulcanossedientar Alto Jauru. Os zircões separados desta amostra compõem uma população homogênea, são translúcidos, amarelados e pouco alongados (2:1).

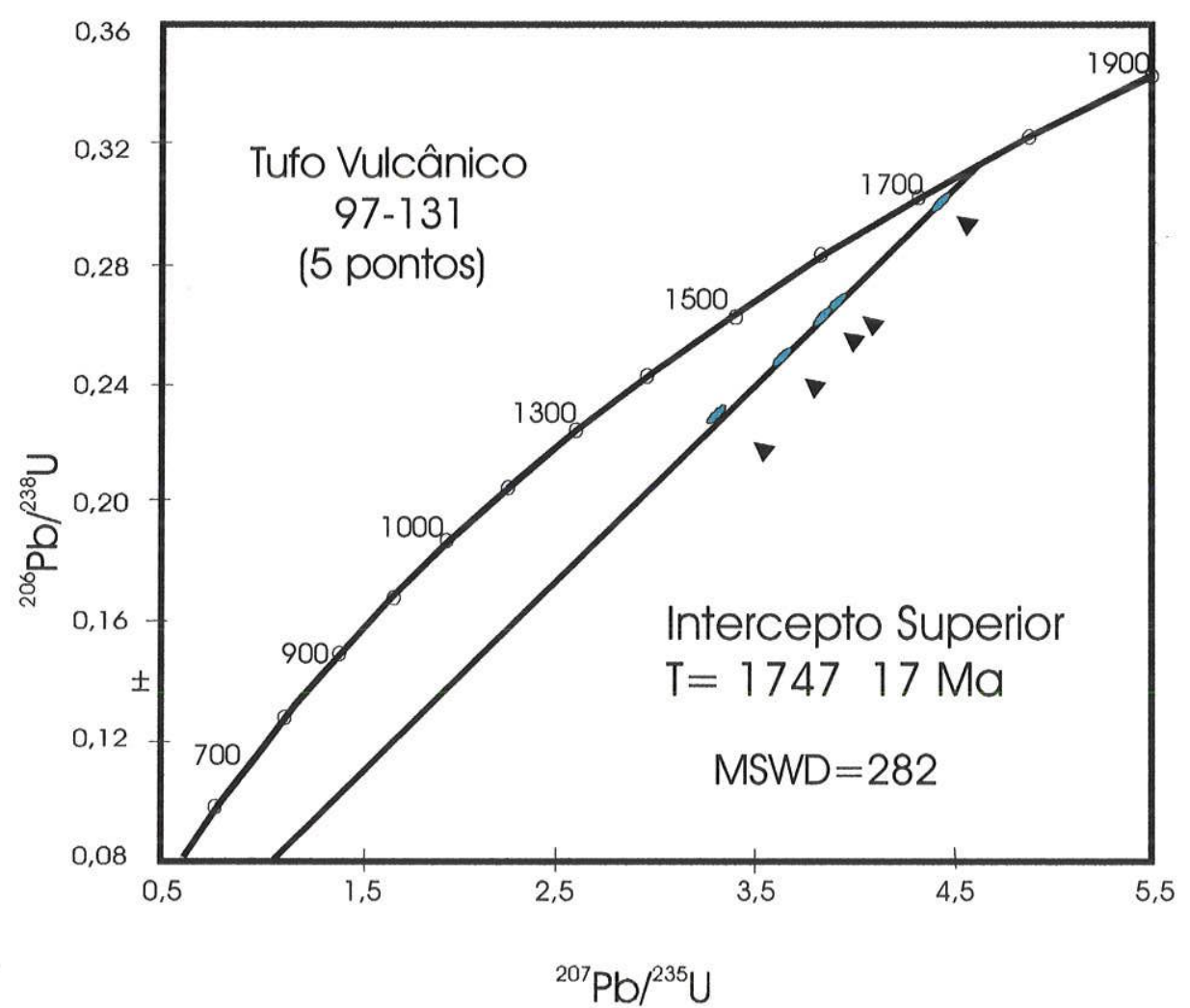

Figura 3.4 Diagrama da concórdia para 5 zircões da amostra 97-131 (rocha tufácea do greenstone belt Alto Jauru). O intercepto superior indica uma idade de $1747 \pm 17 \mathrm{Ma}$. Intercepto Inferior forçado a 0. 


\subsubsection{Geoquímica}

Os resultados das análises químicas das duas amostras plutônicas (Gnaisse Rosa e Aliança) intrusivas do Terreno Jauru são apresentados, para efeito de comparação, juntamente com os resultados da literatura (Toledo, 1997).

Os resultados químicos indicam uma composição granítica (97-133) e granodiorítica (97-147), segundo a Figura 3.5, sendo que os resultados reportados por Toledo (1998) indicam uma variação entre granodioritos e gabros. Os resultados obtidos também indicam que as rochas analisadas exibem uma composição levemente peraluminosa (Figura 3.6) com as proporções moleculares de $\mathrm{Al}_{2} \mathrm{O}_{3}$ maiores do que a soma de $\mathrm{CaO}, \mathrm{Na}_{2} \mathrm{O}$ e $\mathrm{K}_{2} \mathrm{O}$. Embora os dados da literatura indicam composição metaluminosa para estes gnaisses, as duas análises sugerem um trend, indicando uma variação composicional desde metaluminosa (para rochas básicas) a peraluminosa (para granitos). Os dados, quando lançados em diagramas de tendências de diferenciação sugerem pertencerem a uma única suíte calcioalcalina (Figura 3.7) com tendência cálcica. Os valores de $\mathrm{Nb}(8,3 \mathrm{ppm}$ e 7,0 ppm, respectivamente) e Y (27 e 35 , respectivamente) indicam ambiente de arco vulcânico para a formação destas rochas (Figura 3.8), coerentemente aos dados de rochas plutônicas de Toledo (1997) e de rochas vulcânicas reportadas por Pinho (1996).

Os padrões de terras raras das duas amostras são quase equivalentes (Figura 3.9): a amostra granodiorítica (97-147 com idade de $1746 \mathrm{Ma}$ ) mostra um enriquecimento em ETR leves, uma leve anomalia de Eu e um padrão subhorizontalizado para os ETR pesados. Este padrão sugere a presença de fases feldspáticas sendo cristalizadas precocemente no líquido magmático durante um processo de cristalização fracionada. A amostra granítica (97-133 com idade de $1795 \mathrm{Ma}$ ) apresenta padrão mais horizontalizado, com enriquecimento de terras raras leves, mas não tão acentuado como na rocha granodiorítica. Os dados disponíveis na literatura (Pinho et al., 1997) para rochas vulcânicas básicas (geradas no mesmo ambiente de arco vulcânico) indicam um padrão menos fracionado, sugerindo processos de diferenciação magmática menos intensos nas rochas vulcânicas em relação as rochas plutônicas. 


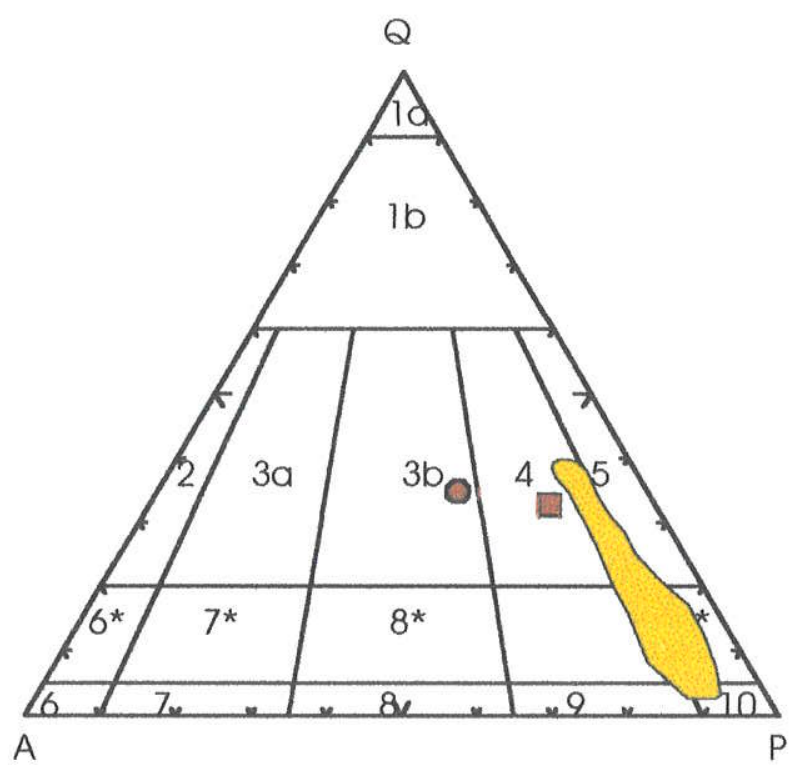

Figura 3.5 Diagrama QAP (Streickeisen, 1976) obtido a partir de dados químicos para as rochas paleoproterozóicas do Terreno Jauru, indicando composição entre monzogranito e granodiorito. (1a) quartzolito; (1) granitóide rico em Qz; (3) granito alcalifeldspático; (3a) sienogranito; (3b) monzogranito; (4) granodiorito; (5) tonalito; (6*) quartzo sienito alcalifeldspático; (6) sienito alcalifeldspático; $\left(7^{*}\right)$ quartzo sienito; $\left(8^{*}\right)$ quartzo monzonito; (8) monzonito; (9*) quartzo monzogabro; (9) monzogabro; (10) quartzo gabro; e (10*) diorito, gabro, anortosito. Em amarelo dados de Toledo (1997).

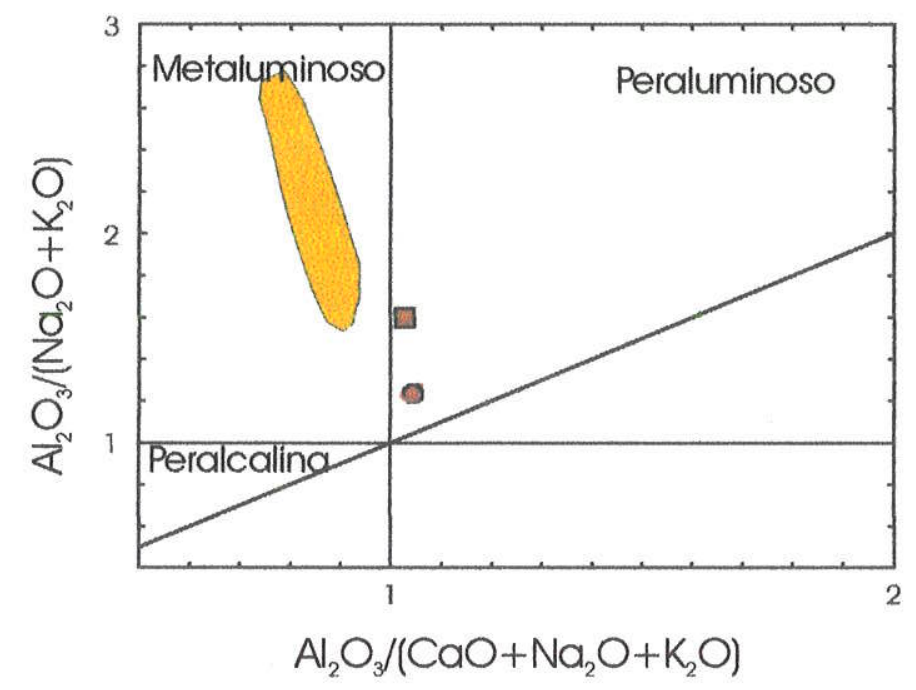

Figura 3.6 - Indice de Shand (A/CNK) versus índice de saturação em alumina para as rochas paleoproterozóicas do Terreno Jauru. Os resultados sugerem composição peraluminosa. Também estão representadas as áreas correspondentes aos resultados químicos de Toledo (1997). 


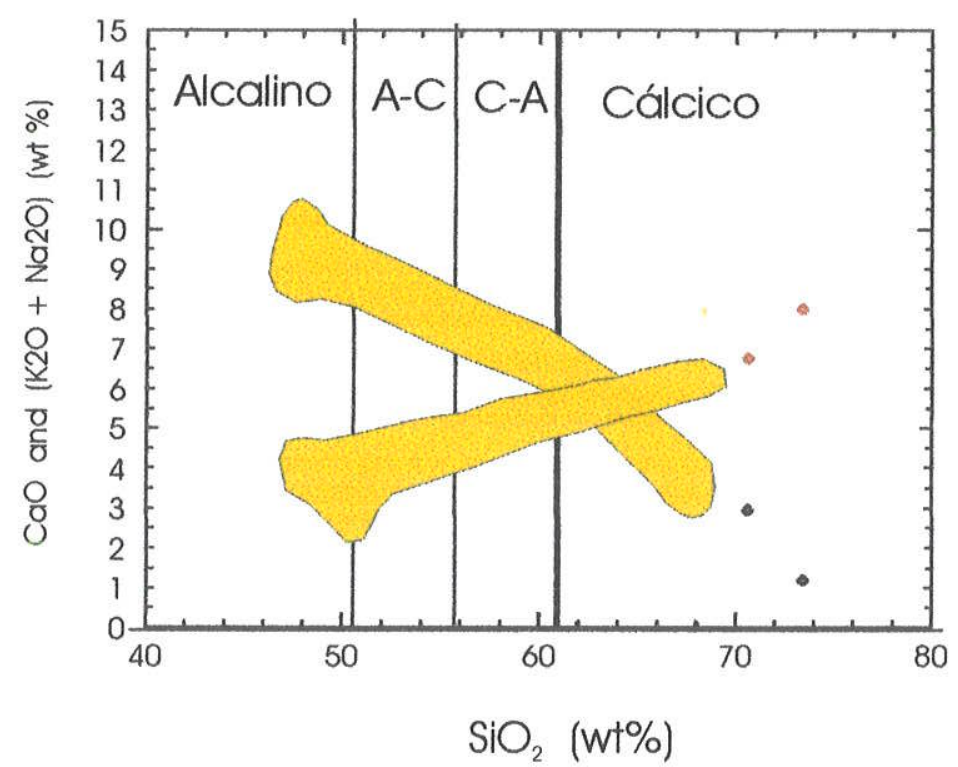

Figura 3.7 Diagramas discriminantes de trends de diferenciação (Peacock, 1931). As duas amostras de gnaisse do terreno Jauru analisados indicam participar de uma suite calcioalcalina, porém sugerem uma composição mais cálcica (cruzamento dos trends). Também estão representadas as áreas correspondentes aos resultados químicos de Toledo (1997).

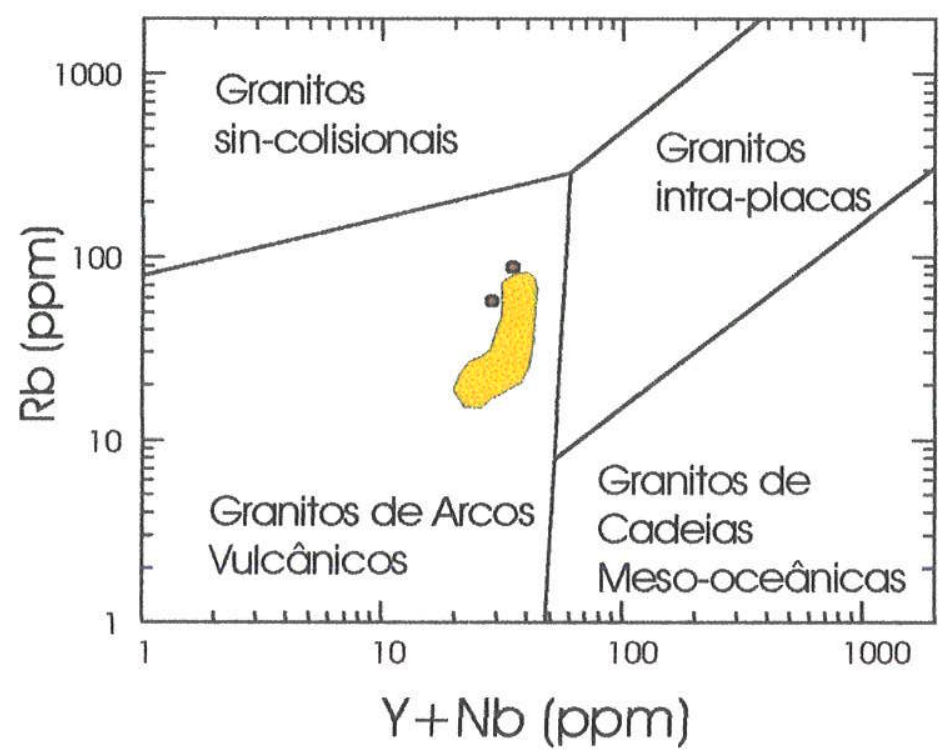

Figura 3.8 Diagramas e discriminação de ambientes tectônicos (Pearce et al., 1984). Os resultados das análises químicas indicam que estas rochas graníticas paleoproterozóicas do Terreno Jauru podem ter sido geradas em ambiente de arco magmático. Em amarelo dados de Toledo (1997). 


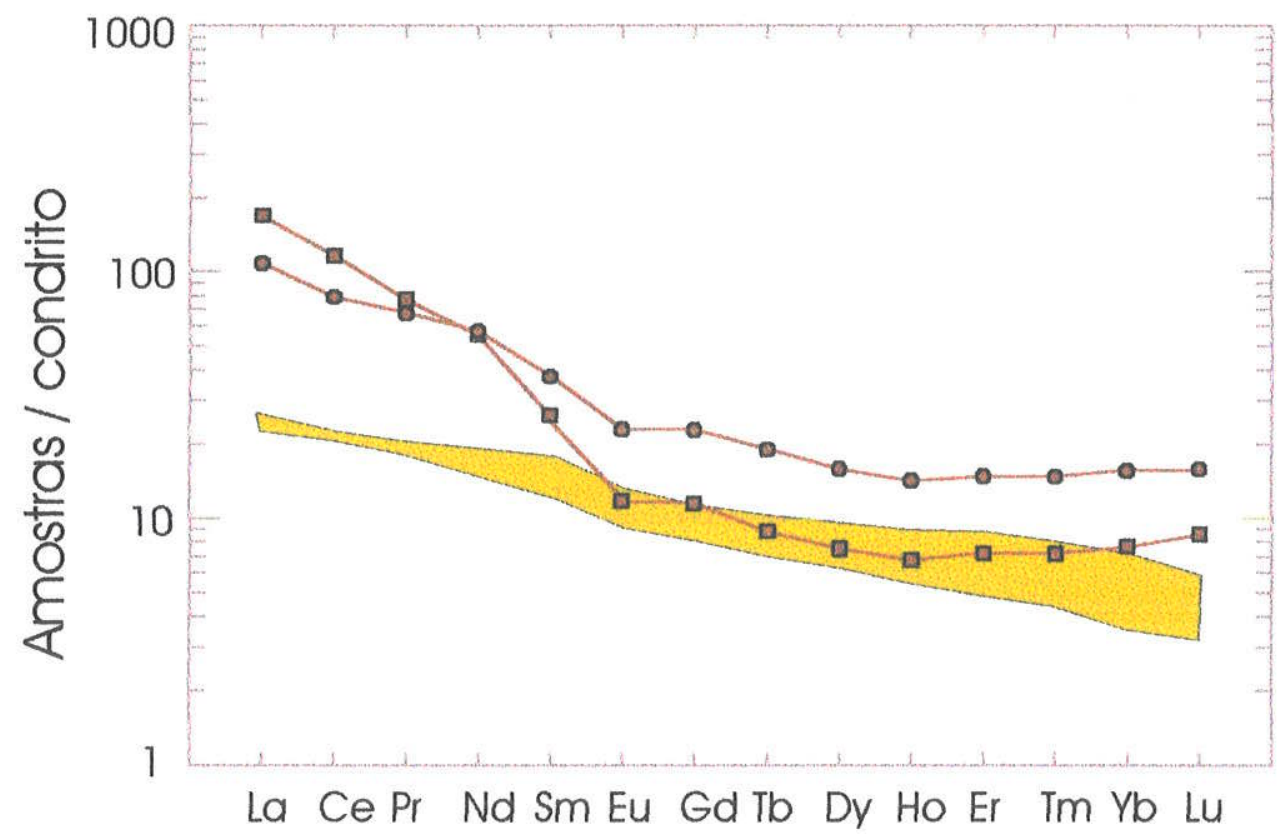

Figuras 3.9 Padrões de terras raras para as rochas paleoproterozóicas do Terreno Jauru. Em amarelo dados de Pinho et al., (1997) para as rochas vulcânicas. Os valores de terras raras foram normalizados segundo Sun e McDonough (1989).

\subsubsection{Discussão}

As duas amostras graníticas somadas a amostra de rocha vulcânica, através de suas assinaturas geoquímicas e isotópicas, trazem importantes contribuições para o entendimento do quadro geológico paleoproterozóico do Terreno Uma importante questão a ser levantada é sobre como as rochas plutônicas aqui estudadas se relacionam com as rochas vulcânicas da associação vulcanossedimentar do Terreno Jauru. Segundo Monteiro et al., (1986) as relações de campo entre as rochas vulcanossedimentares do Greenstone Belt Alto Jauru indicam a precocidade do pacote supracrustal em relação aos corpos plutônicos. Porém os resultados de datação U/Pb ora obtidos indicam idades para as rochas plutônicas e vulcânicas entre 1795 e 1746 Ma, sugerindo sua formação em curto espaço de tempo e provavelmente no mesmo ambiente geológico. Dados U/Pb em SHRIMP em rocha vulcânica do Cinturão Cabaçal reportados por Pinho (1996) indicam duas populações de zircões, uma ( 8 pontos) apresentando a idade de $1769 \pm 29$ Ma e a segunda (4 pontos) de idade $1724 \pm 30 \mathrm{Ma}$, coerentemente com os resultados 
obtidos.

Consequentemente a formação conjunta de rochas plutônicas de composição tonalítica a granítica a rochas vulcânicas de composição basáltica (toleítica) a riolítica envolve a existência de um ambiente de arco intraoceânico. Apesar do limitado número de amostras analisadas destas unidades, a composição química das rochas plutônicas também indica sua formação em ambiente de arco de ilha (indicada pelos valores de $\mathrm{Y}$, $\mathrm{Nb}$ e $\mathrm{Rb}$ ). Pinho (1996) obteve resultados equivalentes em 15 analises químicas do tonalito Cabaçal, não analisado no presente trabalho.

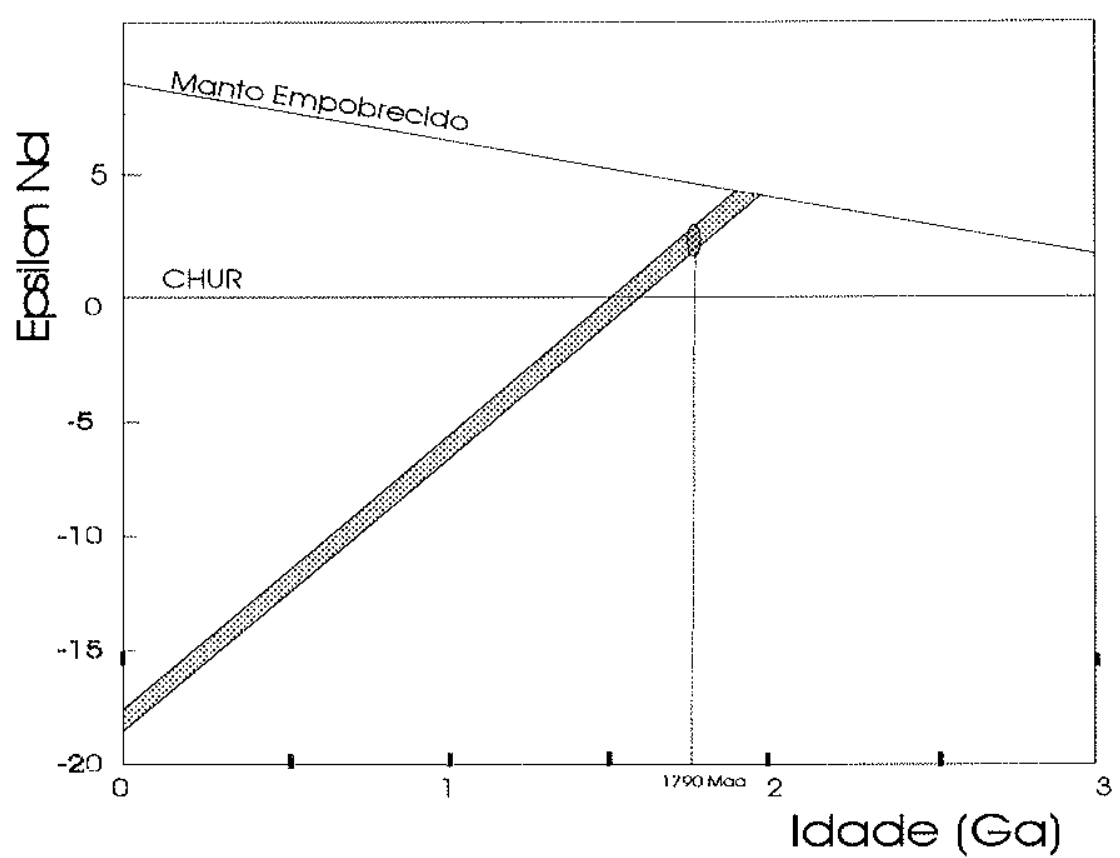

Figura 3.10 Diagrama de evolução de isótopos de $\mathrm{Nd}$ para as rochas paleoproterozóicas do Terreno Jauru. Os valores de $\varepsilon_{\mathrm{Nd}}$ calculado para as idades U/Pb são positivos, indicando origem mantélica para os respectivos protólitos.

Exemplos de rochas plutonicas e consangüíneas e contemporâneos são descrios por Dickinson (1970), representando níveis estruturais diferentes em um mesmo complexo vulcanoplutônico. Similarmente, as rochas aqui estudadas podem ser correlacionadas a componentes de edificio vulcanoplutônico gerado em ambiente de arco vulcânico, estando agora exposto, pela erosão, a raiz deste arco. Os valores de $\varepsilon_{\mathrm{Nd}(t)}$ para as rochas do Terreno Jauru estão entre $+2,6$ e $+2,2$, sugerindo derivação mantélica para os protólitos destas rochas (Figura 3.10). 
Tassinari (1981) apresenta idades $\mathrm{Rb} / \mathrm{Sr}$ (rocha total) de $1732 \pm 32 \mathrm{Ma}(\mathrm{RI}$ de 0.7020) de rochas da Província Rio Negro/Juruena correlacionável ao evento de 1,791,75 $\mathrm{Ga}$ aqui definido. Estas idades foram confirmadas por Tassinari et al., (1996) com análises U/Pb (SHRIMP) de rochas dioríticas de $1703 \pm 7 \mathrm{Ma}$ e $1750 \mathrm{Ma} \pm 24 \mathrm{Ma}$, interpretadas como idades de cristalização. Segundo estes autores, este evento de geração de granitóides ocorreu em ambiente de arco magmático, o qual foi seguido da geração dos vulcanismos félsicos Iriri e Teles Pires $(1,7$ a $1,6 \mathrm{Ga})$ na Província Central Amazônica e a geração dos granitos rapakivi de Rondônia, na Serra da Providência (1,6 a 1,57 Ga).

Carneiro et al., (1992) apresentam a idade isocrônica $\mathrm{Rb} / \mathrm{Sr}$ mais antiga na região $(1971 \pm 70 \mathrm{Ma})$, com uma razão inicial $(\mathrm{RI}=0,7017)$, característica de granitos mantoderivados e sugere a existência de uma crosta siálica anterior à formação das rochas vulcânicas. Um tonalito intrusivo nos vulcanossedimentos da Faixa Jauru na Fazenda Quatro Meninas indicou uma idade isocrônica $\mathrm{Rb} / \mathrm{Sr}$ (rocha total de 4 pontos) de $1852 \pm 75$ Ma e uma $\mathrm{RI}=0,70208 \pm 0,00022$, corroborando a hipótese da existência de um magmatismo tonalítico mais antigo do que as rochas vulcânicas no Greenstone Belt Alto Jauru, hipótese não comprovada através dasd análises isotopicas nas amostras descritas no presente trabalho.

Nas Figuras 3.11, 3.12 e 3.13 são mostrados três modelos especulativos sobre a evolução geológica do SW do Cráton Amazônico durante o limite PaleoMesoproterozóico. Os resultados aqui apresentados são coerentes com estes modelos de propostos para a formação do greenstone belt Alto Jauru. Na Figura 3.11 (segundo Pinho et al., 1997) as rochas desta unidade são caracterizadas, segundo a composição química, por terem sido geradas em ambiente de cadeia meso-oceânica (Cinturão Jauru), basaltos de fundo oceânico (MORB) (Cinturão Araputanga) e arco magmático associado com bacia back-arc (Cinturão Cabaçal).

Uma proposta alternativa é apresentada na Figura 3.12, onde o Terreno Jauru é constituído por complexo vulcanoplutônico paleoproterozóico cujas associações de rochas sugerem geração por aglutinação de antigos arcos de ilhas intra-oceânicas (Saes e Fragoso Cesar, 1996). A acreş̧ão destes arcos de ilhas à paleoplaca Amazônia Central teria ocorrido antes de 1,55 Ga, considerando os dados geocronológicos $\mathrm{Rb} / \mathrm{Sr}$ obtidos nos granitóides calci-alcalinos (1,55-1,53 Ga) que o intrudem. Neste modelo, porém, as 
subducções ocorreram para oeste (atual), discordantemente das conclusões aqui apresentadas.

Na Figura 3.13 é reproduzido o modelo proposto por Tassinari et al., (1997). Neste modelo no período de tempo entre 1,8 e 1,7 Ga na margem SW (atual) do Cráton Amazônico havia um processo de subducção e formação de arco magmático, onde foram geradas rochas plutônicas simultaneamente ao vulcanismo e a sedimentação cratônica a leste, na Província Amazônia Central. Este modelo difere do modelo de Pinho et al., (1997), que propõem um ambiente de arco de ilhas e não de margem continental, isto é, sem o envolvimento de crosta siálica pré-existente para a geração das rochas paleoproterozóicas do Terreno Jauru.

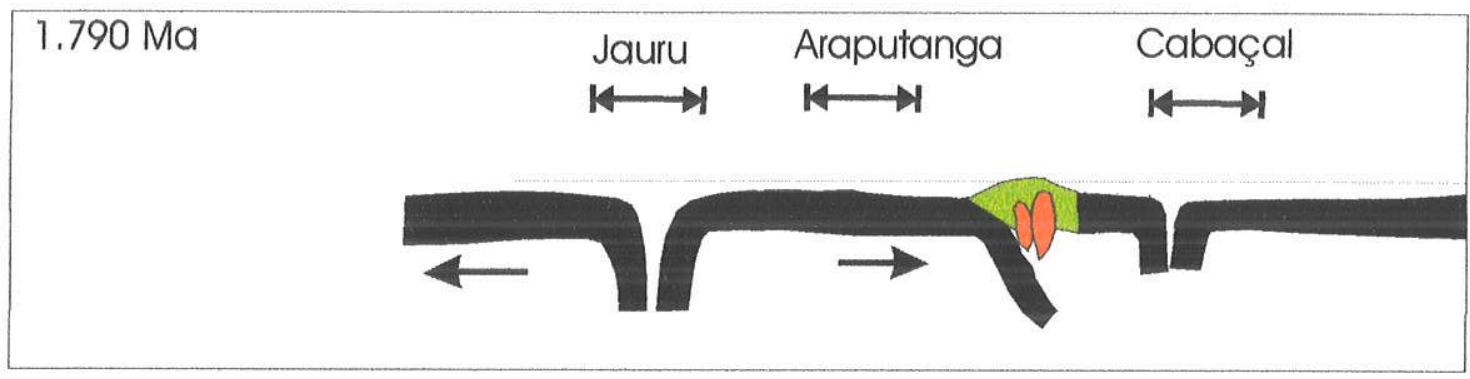

Figura 3.11 Modelo de ambientes geológicos para a formação das rochas vulcânicas da região de Jauru-Araputanga segundo Pinho et al., (1997).

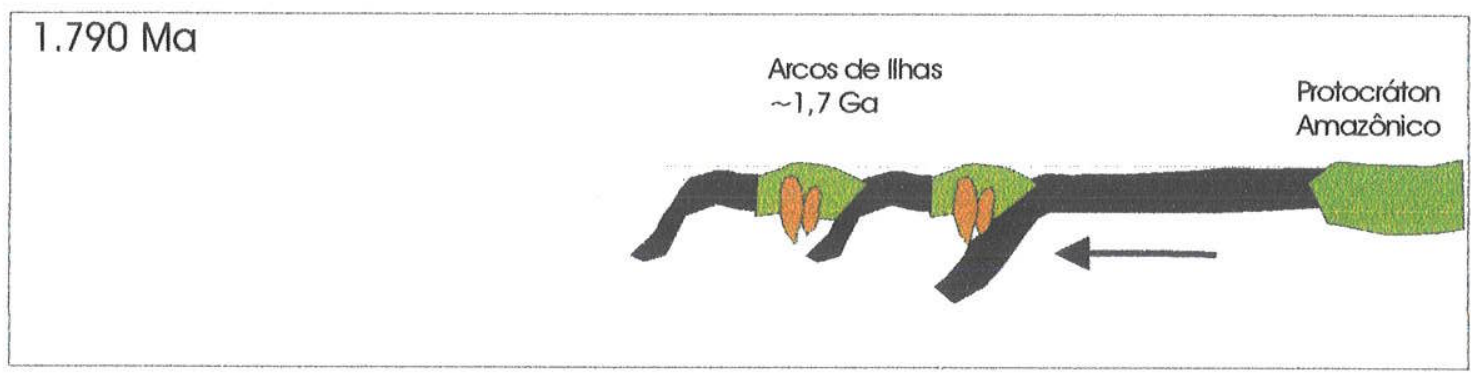

Figura 3.12 Perfil com os ambientes geológicos segundo Saes e Fragoso Cesar (1996). 


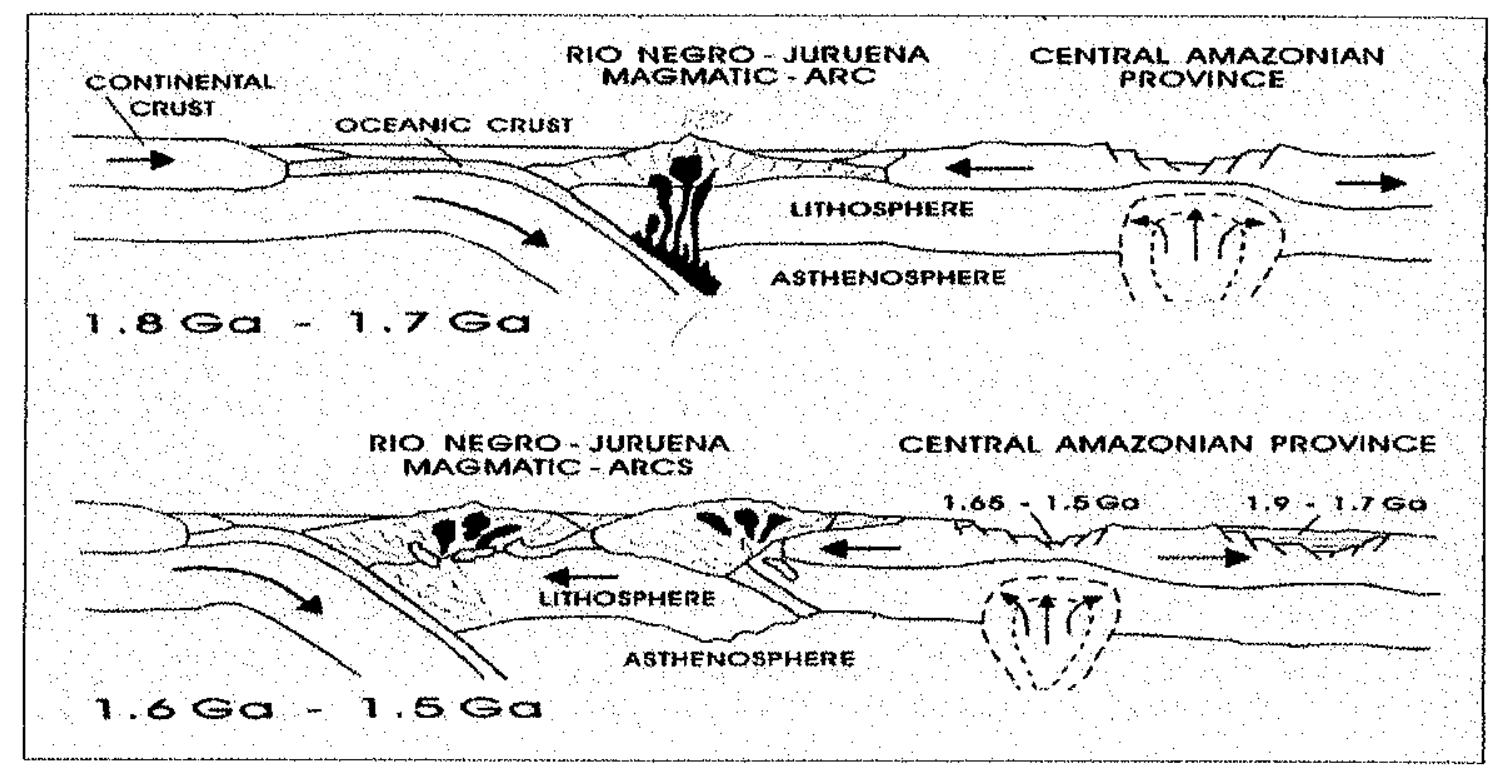

Figura 3.13. Modelo segundo Tassinari et al., (1997). As rochas do Cinturão Rio Negrow Juruena foram geradas durante arcos magmáticos de idades 1,8-1,7 Ga e 1,6-1,5 Ga. Observar que o arco magmático de idade 1,8-1,7 Ga desenvolveu-se na margem continental representada pela Província Amazônica Central. 


\subsection{Os Granitóides Intrusivos do Terreno Jauru}

Rochas intrusivas de composição variada são descritas no Terreno Jauru por diversos autores (Saes et. al., 1984; Monteiro et. al., 1986; Leite et. al., 1986; Ruiz 1992). Os trabalhos publicados com datações radiométricas, até o momento, se concentraram nas metodologias $\mathrm{K} / \mathrm{Ar}$ e $\mathrm{Rb} / \mathrm{Sr}$, indicando variações em idade entre 1,4 a 1,0 Ga e 1,6 e 1,4 Ga, respectivamente.

Neste trabalho foi identificado um importante evento gerador de rochas plutônicas com idades U/Pb entre 1,59 e 1,52 Ga (Tabela 3.2). Foram observadas ainda rochas graníticas intrusivas mais jovens (1485-1389 Ma) e apresentadas a seguir Aspectos gerais dos afloramentos destas unidades são mostrados na Prancha 2.

Tabela 3.2 Idades $\mathrm{U} / \mathrm{Pb}$ e $\mathrm{Sm} / \mathrm{Nd}$ das rochas intrusivas do Terreno Jauru.

\begin{tabular}{|c|c|c|c|c|c|c|}
\hline $\mathrm{N}^{\circ}$ amostra & Descrição & $\mathrm{U} / \mathrm{Pb}(\mathrm{Ma})^{*}$ & $\varepsilon_{\mathrm{Nd}}(0)$ & $\varepsilon_{\mathrm{Nd}}$ & TDM & $f$ \\
\hline \multicolumn{2}{|c|}{ 97-134 Tonalito Quatro Marcos } & $1536 \pm 11$ & $-14,2$ & $+0,5$ & 1,77 & $-0,38$ \\
\hline \multicolumn{2}{|c|}{ 97-150 Tonalito Cachoeirinha } & $1549 \pm 10$ & $-14,7$ & $+1,0$ & 1,83 & $-0,40$ \\
\hline \multicolumn{2}{|c|}{ 97-147 Granito Santa Cruz } & $8<1587 \pm 04$ & $-15,0$ & $-0,8$ & 2,05 & $-0,36$ \\
\hline \multicolumn{2}{|c|}{ 97-145 Gnaisse São Domingos } & $81562 \pm 36$ & $-20,2$ & +0.9 & 1,79 & $-0,53$ \\
\hline \multicolumn{2}{|c|}{ 97-138 Granito Cachoeirinha } & $1536 \pm 06$ & $-22,2$ & $+0,5$ & 1,75 & $-0,60$ \\
\hline \multicolumn{2}{|c|}{ 97-132 Granito Alvorada (2) } & $1522 \pm 12$ & $-19,6$ & $+0,9$ & 1,78 & $-0,54$ \\
\hline \multicolumn{2}{|c|}{ 97-136 Granodiorito Água Clara } & $1485 \pm 04$ & -5 & $+1,7$ & 1,77 & $-0,50$ \\
\hline \multirow{2}{*}{\multicolumn{2}{|c|}{ 97-139 Granito Alvorada (3) }} & $1440 \pm 06$ & $-20,2$ & $-0,2$ & 1,74 & $-0,56$ \\
\hline & 97-129 Granito Alvorada (1) & $1389 \pm 03$ & $-20,3$ & $-1,3$ & 1,77 & $-0,54$ \\
\hline
\end{tabular}

Idade $\mathrm{U} / \mathrm{Pb}$ em zircão obtida por diluição isotópica de monocristal em zircão.

nd=não determinado;

$\varepsilon \mathrm{Nd}$ calculado para a idade $\mathrm{U} / \mathrm{Pb}$;

$\mathrm{T}_{\mathrm{DM}} \mathrm{em} \mathrm{Ga}$.

\section{Rochas Tonalíticas}

Foram descritos na literatura vários corpos tonalíticos no Terreno Jauru, porém em função da imprecisão das respectivas idades, estes foram correlacionados ao greenstone Alto Jauru (descritos anteriormente). Neste trabalho foi possivel distinguir a ocorrência de um grupo de rochas tonalíticas intrusivas naquela unidade, descritas a seguir. 

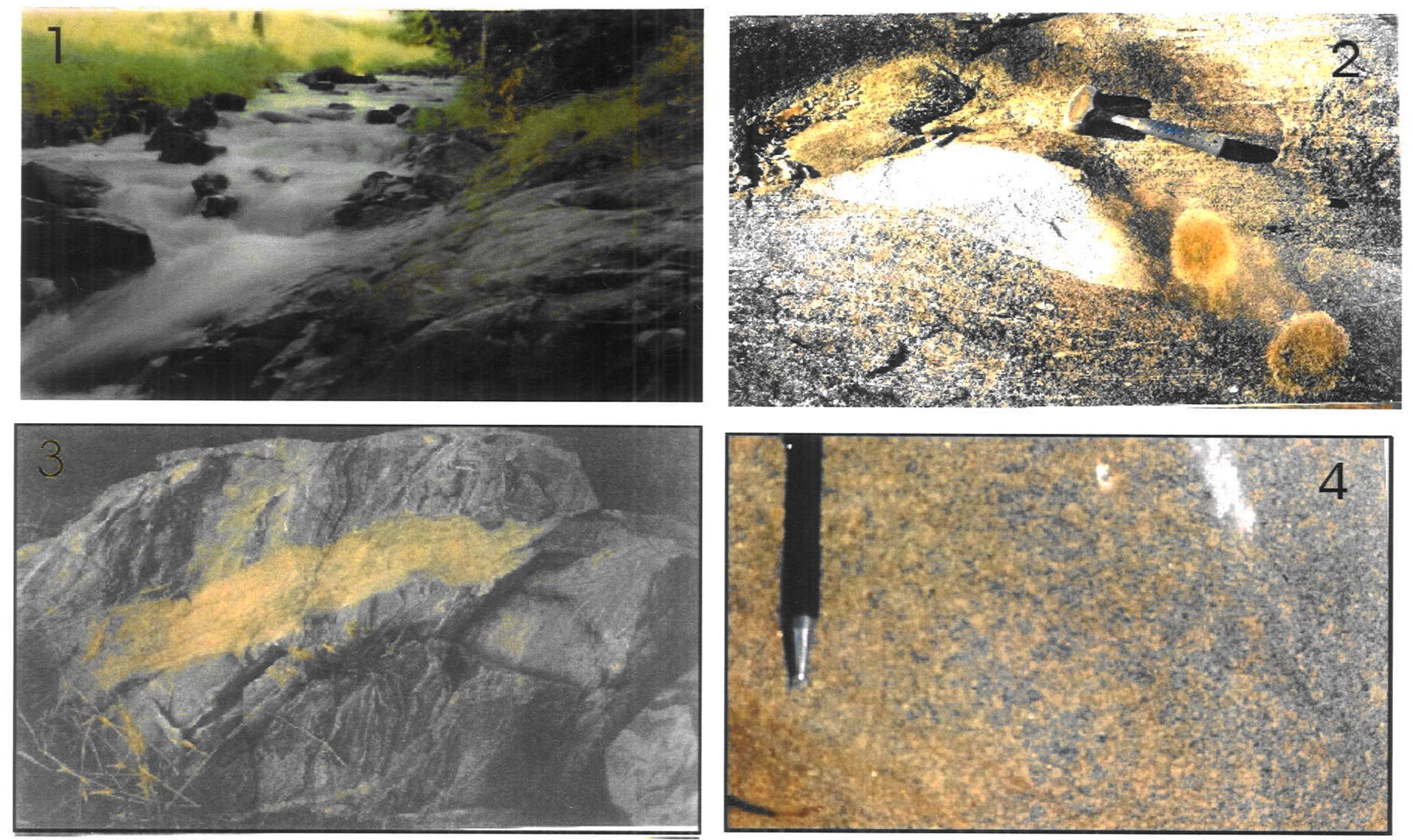

Prancha 2. (1) Gnaisse de composição granítica aflorante nas margens do rio São Domingos, próximo a Cachoeirinha (97-137).

(2) Intrusões do Granodiorito Água Clara em gnaisse do Complexo Brigadeirinho.

(3) Rochas graníticas intrusivas em gnaisse cinza nas margens do Rio Vermelho ao norte de Nortelândia.

(4) Detalhe das rochas graníticas aflorantes na Fazenda Alvorada (97-129). 
O Tonalito Cachoeirinha trata-se de um corpo intrusivo alongado com direção preferencial $\mathrm{N} 40^{\circ} / 50^{\circ} \mathrm{W}$ que corta os gnaisses do greenstone Alto Jauru, representado por gnaisses denominados localmente por Gnaisse Cachoeirinha (Ruiz, 1992), sendo por sua vez cortado pelo Granito Santa Cruz (descritos a seguir).

São rochas mesocráticas, cinza escuras, de granulação média a grossa e dominantemente equigranulares. É marcante o desenvolvimento de uma xistosidade definida pela orientação de minerais placóides e prismáticos e localmente, de bandamento caracterizado por alternância de níveis ricos em máficos (hornblenda e biotita) e félsicos. As bandas mostram com frequência ocelos (fenocristais de ortoclásio) visíveis, principalmente nos níveis leucocráticos. A observação microscópica mostrou cristais de hornblenda e biotita alternados com níveis ricos em plagioclásio e quartzo (Fotomicrografias 3.4 e 3.5), normalmente engrenados em mosaico. Onde ocorre foliação milonítica observa-se textura porfiroblásica, definida por cristais de plagioclásio ou de agregado minerais circundados por uma matriz de granulação mais fina a base de quartzo, plagioclásio, hornblenda e biotita. O Tonalito Cabaçal (Toledo, 1997) forneceu uma errócrona $\mathrm{Rb} / \mathrm{Sr}$ de 4 pontos (rocha total) com idade de $1556 \pm 250$ Ma, com RI=0,70444 $\pm 0,00511$.

Duas amostras tonalíticas foram analisadas para datação $\mathrm{U} / \mathrm{Pb}$. A primeira foi coletada na região de São José dos Quatro Marcos e os quatro zircões analisados indicaram a idade de $1536 \pm 10 \mathrm{Ma}$ (Figura 3.14). A segunda amostra, coletada próximo à Cachoeirinha, teve quatro zircões analisados e indicou a idade de $1550 \pm 10 \mathrm{Ma}$ (Figura 3.15). As idades são interpretadas como de cristalização das rochas e indicam, portanto, que o Tonalito Cachoeirinha é mais jvem do que o Tonalito Cabaçal.

\section{Gnaisse São Domingos}

Esta unidade foi definida por Ruiz (1992) como um conjunto de rochas gnáissicas ortoderivadas aflorante no curso do rio homônimo, previamente cartografadas como Complexo Xingu (Barros et. al., 1982, e Monteiro et. al., 1986) e como Associação Gnáissico Migmatítica Brigadeirinho (Saes et. al., 1984). As rochas mapeadas por Ruiz (1992) localizam-se entre as Faixas Araputanga e Cabaçal e apresentam-se na forma de matacões e mais raramente da forma de pequenos lajeados. Uma das ocorrências mais expressivas é observada sob a ponte do Rio São Domingos na cidade de Cachoeirinha 
(local amostrado). Esta unidade gnáissica é intrudida pelos Granitos Alvorada e Santa Cruz. Tais contatos são materializados por diques centimétricos a decimétricos de material pegmatítico ou aplítico injetados, discordantemente da estrutura gnáissica. Na região de São José dos Quatro Marcos, Carneiro et. al. (1992) efetuaram estudos petrográficos e isotópicos em litotipos caracterizados como Gnaisses Rosa (idade U/Pb de 1,79 Ga) descrito no início deste Capítulo, os quais correlacionou ao Gnaisse São Domingos, correlação esta também sugerida por Ruiz (1992).

Os ortognaisses são cinza escuros a cinza rosados, principalmente equigranulares, de granulação grossa a média, mostram bandamento definido pela alternância de leitos claros compostos a base de quartzo e feldspatos e leitos mais ricos em biotitas (Fotomicrografia 3.6). O bandamento, normalmente descontínuo e com espessura variável, mostra dobramento complexo, resultando em dobras irregulares. Ao microscópio os cristais de quartzo e feldspato apresenta-se em contatos irregulares e raramente textura em mosaico. A biotita aparece em ripas orientadas paralelamente ao bandamento.

Dados K/Ar (em biotita) de Ruiz (1992) para o Gnaisse São Domingos na Folha Jauru apresentam idades variando de $1553 \pm 34 \mathrm{Ma}$ a $1140 \pm 80 \mathrm{Ma}$. O Complexo Rio Vermelho (Leite, 1989) cartografado separadamente do Complexo Metamórfico Brigadeirinho, correlacionável a esta unidade forneceu uma isócrona $\mathrm{Rb} / \mathrm{Sr}$ (rocha total de seis pontos) para paleossoma do gnaisse com idade de $1513 \pm 30 \mathrm{Ma}$ com a $\mathrm{RI}=0,7020$. Três idades $\mathrm{K} / \mathrm{Ar}$ indicam uma variação de $1615 \pm 32 \mathrm{Ma}$ a $985 \pm 13 \mathrm{Ma}$.

Os resultados $\mathrm{U} / \mathrm{Pb}$ para a amostra indicou uma variação de idade entre $1587 \mathrm{Ma}$ e $1489 \mathrm{Ma}$. As cinco frações de zircões analisados (que compõem uma única população homogênea) indicam eventos superimpostos, resultando na dispersão dos pontos analíticos que geram um "envelope" com idades variando em $100 \mathrm{Ma}$ (Figura 3.16). Os resultados isotópicos $\mathrm{U} / \mathrm{Pb}$ para a amostra estudada fornece, por sua vez, a idade ao redor de 1,74 Ga quando levado em conta apenas quatro zircões analizados. A partir deste resultado é possível sugerir que a correlação desta rocha com o Gnaisse Rosa, já descrito e datado em 1,79 Ga, correlação esta proposta por Carneiro et al., (1992) e Ruiz, (1992). Ademais, os resultados indicam um processo de rehomogeneização dos sistemas $\mathrm{U} / \mathrm{Pb}$, resultado da gnaissificação e recristalização mineral (observada a nível microscópico) ocorrido ao redor de $1587 \mathrm{Ma}$, durante a geração das rochas granitóides 
em discussão. Este processo de rehomogeneização isotópica também seria o responsável pala dispersão das idade obtidas pelos sistemas $\mathrm{K} / \mathrm{Ar}$ e $\mathrm{Rb} / \mathrm{Sr}$ descritos na literatura.

\section{Suite Intrusiva Santa Cruz}

A Suíte Intrusiva Santa Cruz foi proposta por Ruiz (1992) para um batólito alongado segundo NS, localizado a Leste e Norte da cidade de Cachoeirinha. É intrusiva nas rochas do Gnaisse São Domingos, Gnaisse Aliança e no Tonalito Cabaçal. Apresenta ainda xenólitos de rochas vulcânicas do Greenstone Belt Alto Jauru. Na região de São José dos Quatro Marcos foram descritas por Carneiro et. al., (1992) rochas graníticas intrusivas nos tonalitos, possivelmente correlacionáveis a esta unidade.

Esta Suíte é composta por duas fácies petrográficas, uma constituída por rochas róseas (Fotomicrografias 3.7 e 3.8), principalmente grossas, orientadas, de composição monzogranítica e subordinadamente sienogranítica e outra, mais restrita a afloramentos isolados, compõe-se exclusivamente de rochas cinza escuras, grossas, orientadas e de composição granodiorítica. A Suíte Santa Cruz (Ruiz, 1992) apresenta uma isócrona $\mathrm{Rb} / \mathrm{Sr}$ (rocha total com 4 pontos) de idade $1448 \pm 30 \mathrm{Ma}$ e $\mathrm{RI}=0,7032 \pm 0,0004$ (Ruiz, 1992).

Duas amostras desta unidade foram analisadas para o método $\mathrm{U} / \mathrm{Pb}$. A primeira amostra coletada próximo a fazenda Santa Cruz, teve três zircões analisados que indicaram a idade de $1562 \pm 36 \mathrm{Ma}$ (Figura 3.17). A segunda amostra (denominada Granito Cachoeirinha) teve três zircões analisados e indicou a idade de $1521 \pm 84 \mathrm{Ma}$ (Figura 3.18). No entanto a fração de zircão menos magnética indicou a idade concordante de $1536 \pm 06$ que pode ser interpretada como a idade mais precisa para a cristalização desta rocha.

Suíte Intrusiva Alvorada

Esta unidade foi descrita inicialmente por Saes et. al., (1984), sendo ainda descrita nos trabalhos de Monteiro et. al., (1986), Ruiz (1992), Carneiro et. al., (1992) e em Toledo (1997). Segundo a literatura, esta unidade é representada por um conjunto de rochas graníticas, ocorrendo sob a forma de intrusões nas unidades descritas anteriormente no Terreno Jauru ou na forma de batólitos alongados segundo o trend NS. Exemplo desta última forma de exposição observa-se na fazenda Alvorada, local tipo da unidade e estudado por Toledo (1997). Na região de Cachoerinha foi identificada nos 
estudos de Ruiz (1992) e a sul de Santa Fé foi estudada por Carneiro et. al., (1992). Xenólitos do Gnaisse São Domingos e da Suíte Intrusiva Santa Cruz são observados nesta unidade. Todas as ocorrências descritas na literatura foram checadas e coletadas no atual trabalho para estudos isotópicos e geoquímicos.

As rochas estudadas apresentam cor cinza claro a rosa acinzentado, são maciças a levemente foliadas, principalmente equigranulares, de granulação fina a média. Nas rochas de coloração rosa domina o feldspato potássico de cor rosa carne, com plagioclásios cinza, enquanto nos exemplares cinza predomina o plagioclásio cinza esbranquiçado. As amostras inequigranulares apresentam pórfiros de feldspato potássico, com quartzo intersticial e biotita como máfico principal. Ao microscópio observa-se o domínio da textura hipidiomórfica equigranular e raramente inequigranular. $O$ plagioclásio e $o$ feldspato potássico são subidiomórficos, sendo comum o primeiro apresentar zonação. $\mathrm{O}$ quartzo é xenomórfico e intersticial e a biotita apresenta-se em pequenas lamelas, distribuindo-se homogeneamente e aleatoriamente, exceto nos exemplares levemente foliados. Detalhes de lâminas delgadas das 3 amostras da Suíte Intrusiva Alvorada são apresentadas nas Fotomicrografias 3.9, 3.10 e 3.11.

Na região de São José dos Quatro Marcos, Carneiro et. al., (1992), reportam a idade $\mathrm{Rb} / \mathrm{Sr}$ (rocha total) de $1472 \pm 19 \mathrm{Ma}$ e $\mathrm{RI}=0,7027 \pm 0,0003$, porém três frações de zircões analisados em rocha da mesma ocorrência indicaram a idade U/Pb de $1546 \pm 47$ Ma (Figura 3.19). A ocorrência do Granito Alvorada em Cachoeirinha (Ruiz, 1992) apresenta uma isócrona $\mathrm{Rb} / \mathrm{Sr}$ (rocha total de 6 pontos) de idade de $1440 \pm 80 \mathrm{Ma}$ e $\mathrm{RI}=0,705$. Novamente os resultados analíticos $\mathrm{U} / \mathrm{Pb}$ em zircões obtidos em rocha da mesma ocorrência indicaram a idade U/Pb entre 1483 e 1440 Ma (Figura 3.20). Outra idade $\mathrm{Rb} / \mathrm{Sr}$, porém com alto erro, foi obtida por Toledo (1997) a partir de 5 pontos (agora na fazenda Alvorada) indicou a idade de $1523 \pm 278$ Ma para a cristalização do granito Alvorada e razão inicial ${ }^{87} \mathrm{Sr} /{ }^{86} \mathrm{Sr}$ de 0,7033 . Três frações de zircões analisados em rocha da mesma ocorrência indicaram a idade U/Pb de $1394 \pm 37 \mathrm{Ma}$ (Figura 3.21). Estes resultados indicam que as ocorrências de granitos isotrópicos de ocorrência generalizada no Terreno Jauru não podem ser agrupados na unidade Alvorada, pois foram formados em diferrentes pulsos magmáticos. 
Granodiorito Água Clara

O Granodiorito Água Clara foi inicialmente descrito por Saes et. al., (1984), e apresenta uma grande extensão em área, compreendendo a maior parte da região entre a Faixa Jauru e a Faixa Araputanga do Greenstone Belt Alto Jauru. No trabalho de Monteiro et. al., (1986), esta unidade foi prolongada para a área ao sul da inicial, o que foi confirmado no mapa apresentado por Leite (1989). Segundo Saes et. al., (1984) esta unidade ocorre na forma de um maciço de dimensões batolíticas e é intrusiva nos gnaisses da Associação Brigadeirinho, além de apresentar xenólitos de anfibolitos e migmatitos próximo a suas bordas. Matos et. al., (1996) apresenta estudos petrográficos desta unidade, caracterizando-a como de variada composição (granito 3a, 3b, granodiorito e tonalito). É sugerido na literatura que esta unidade é mais antiga do que o Granito Alvorada em função de sua estrutura mais foliada, contrariamente o que indica a idade $\mathrm{Rb} / \mathrm{Sr}$.

Em campo esta unidade apresenta coloração cinza, granulometria média a fina, ocasionalmente porfírítica, com fenocristais de oligoclásio. O aspecto maciço é predominante apesar da existência de uma incipiente foliação junto aos contatos com as encaixantes. Petrograficamente as amostras coletadas apresentam composição granodiorítica, sendo seus constituintes essenciais o quartzo e o oligoclásio, com ortoclásio e pertita subordinados. Os máficos são a biotita e a hornblenda, além de titanita e zircão como acessórios (Fotomicrografia 3.12).

O Granodiorito Água Clara apresenta idade isocrônica $\mathrm{Rb} / \mathrm{Sr}$ (rocha total com 4 pontos) de $1400 \pm 63 \mathrm{Ma}(\mathrm{RI}=0,70326 \pm 0,00049)$ e dados $\mathrm{K} / \mathrm{Ar}$ (em biotita) indicam a idade de $1266 \pm 21$, A amostra coletada a oeste de Cachoeirinha teve quatro frações de zircões analisados e indicaram a idade $\mathrm{U} / \mathrm{Pb}$ de $1468 \pm 35$ Ma (Figura 3.22), confirmando ser esta unidade uma das mais novas do Terreno Jauru, hipótese corroborada com os dados de campo que indicam características isotrópicas. 


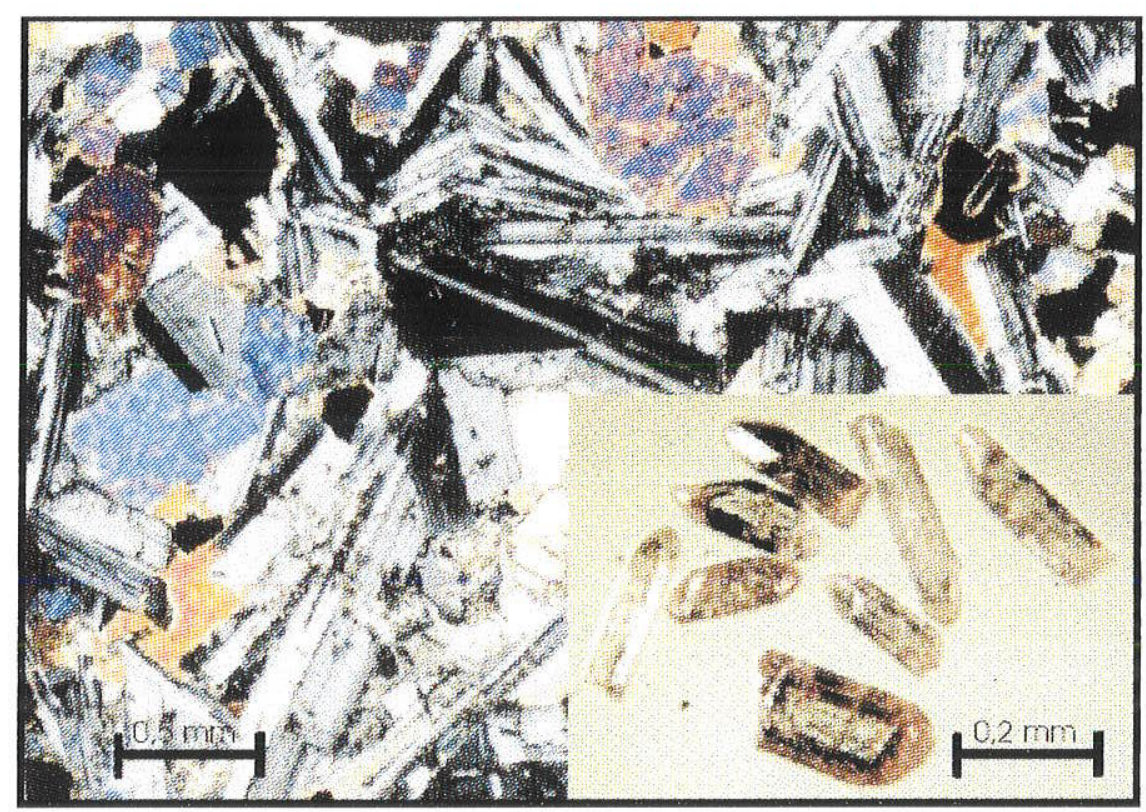

Microfotografia 3.4 Detalhe em lâmina do Tonalito Quatro Marcos (amostra 97-134). Os zircões analisados são translúcidos, com pirâmides e faces laterais bem desenvolvidas (3:1 a $5: 1)$.

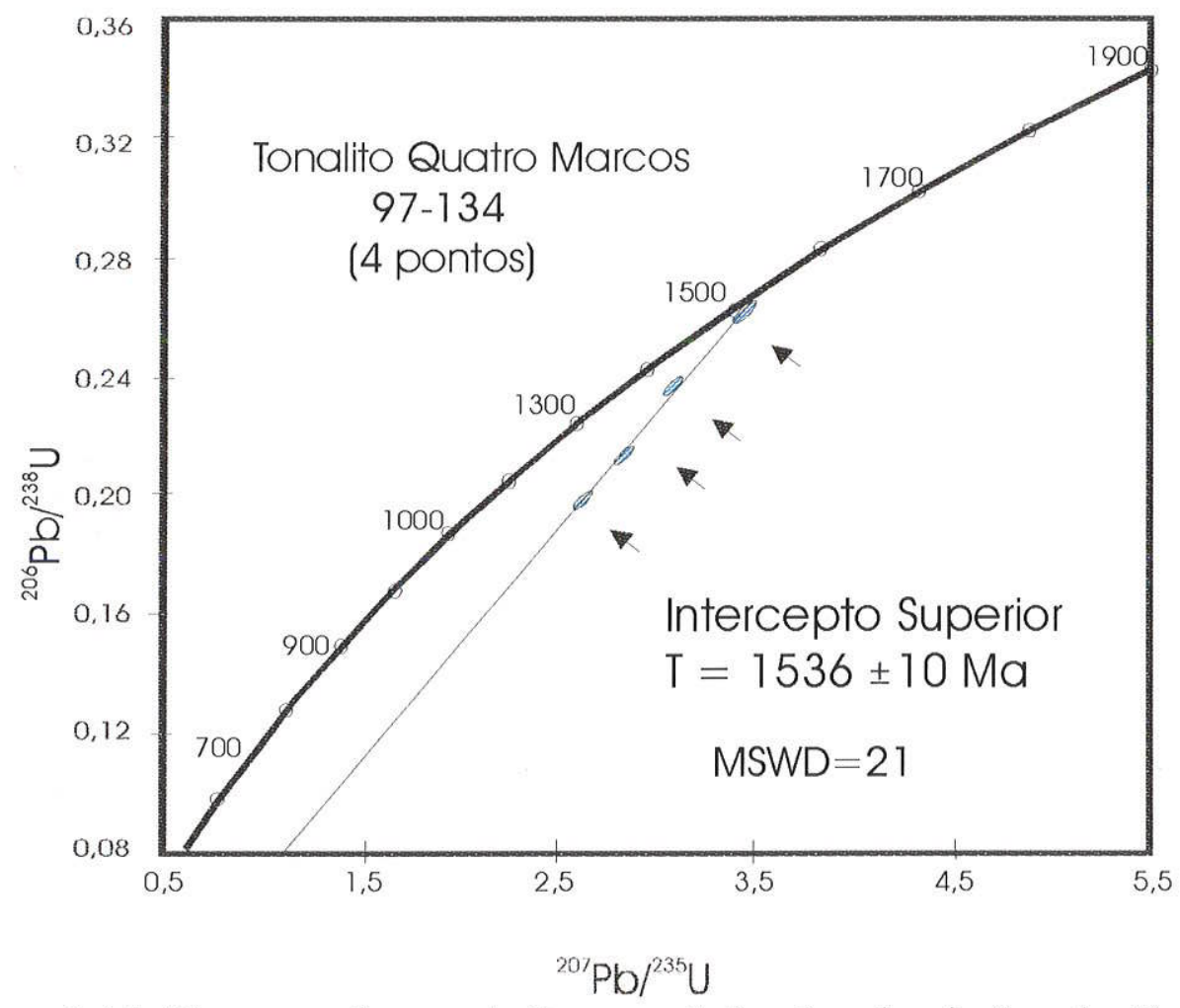

Figura 3.14 Diagrama da concórdia para 4 frações de zircões do Tonalito Quatro Marcos (amostra 97-134). Os resultados indicaram uma idade de cristalização de $1536 \pm$ $10 \mathrm{Ma}$. Intercepto inferior forçado a 0. 


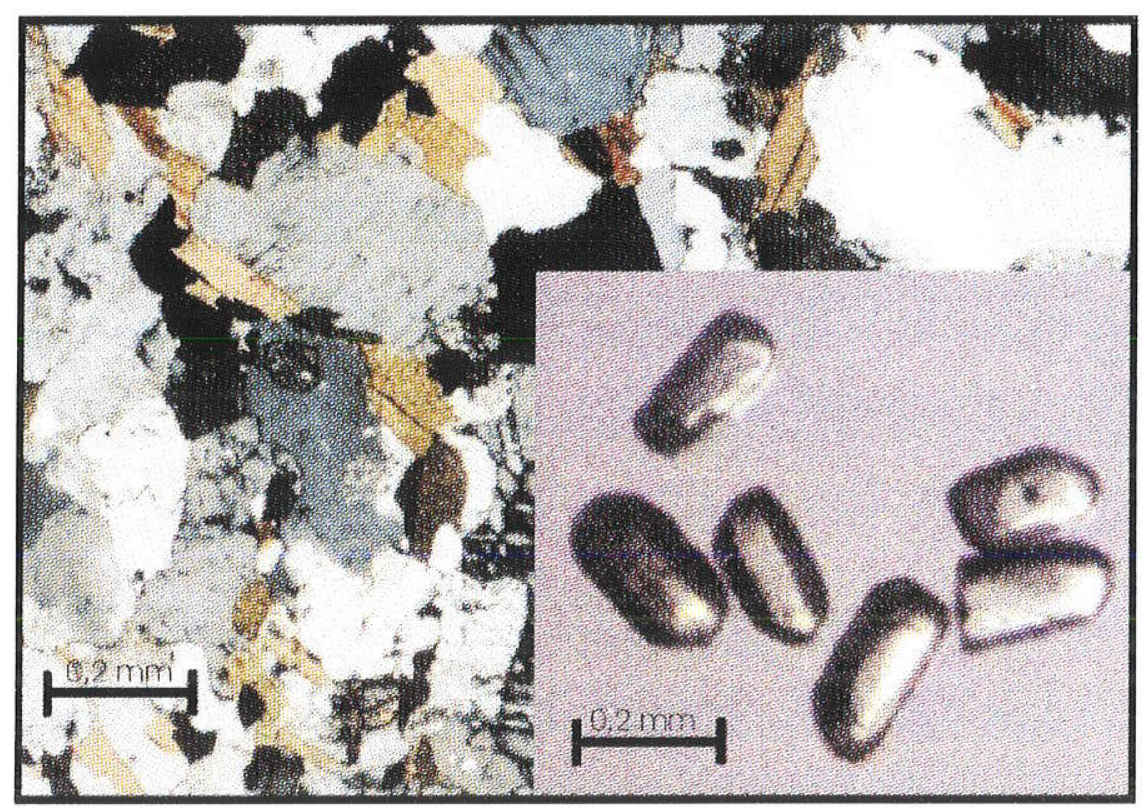

Fotomicrografia 3.5 Detalhe em lâmina do Tonalito Cachoeirinha (Amostra 97-150). Os zircões analisados compõem uma população homogênea, com terminações arredondadas e faces laterais parcialmente desenvolvidas e translúcidos.

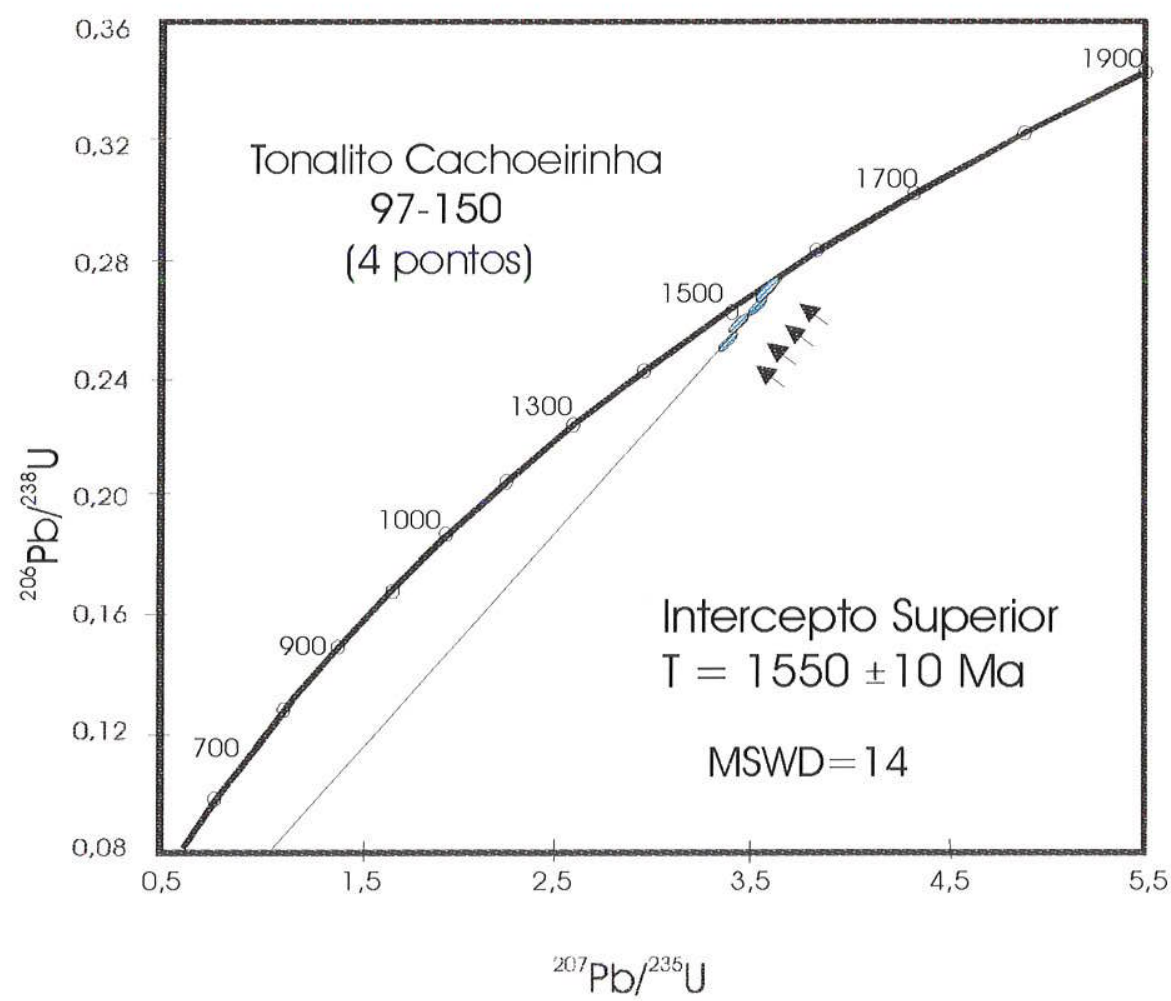

Figura 3.15 Diagrama da concórdia para 4 cristais de zircões do Tonalito Cachoeirinha (amostra 97-150). A idade obtida é de $1550 \pm 10$ Ma com o intercepto inferior forçado a 0 . 


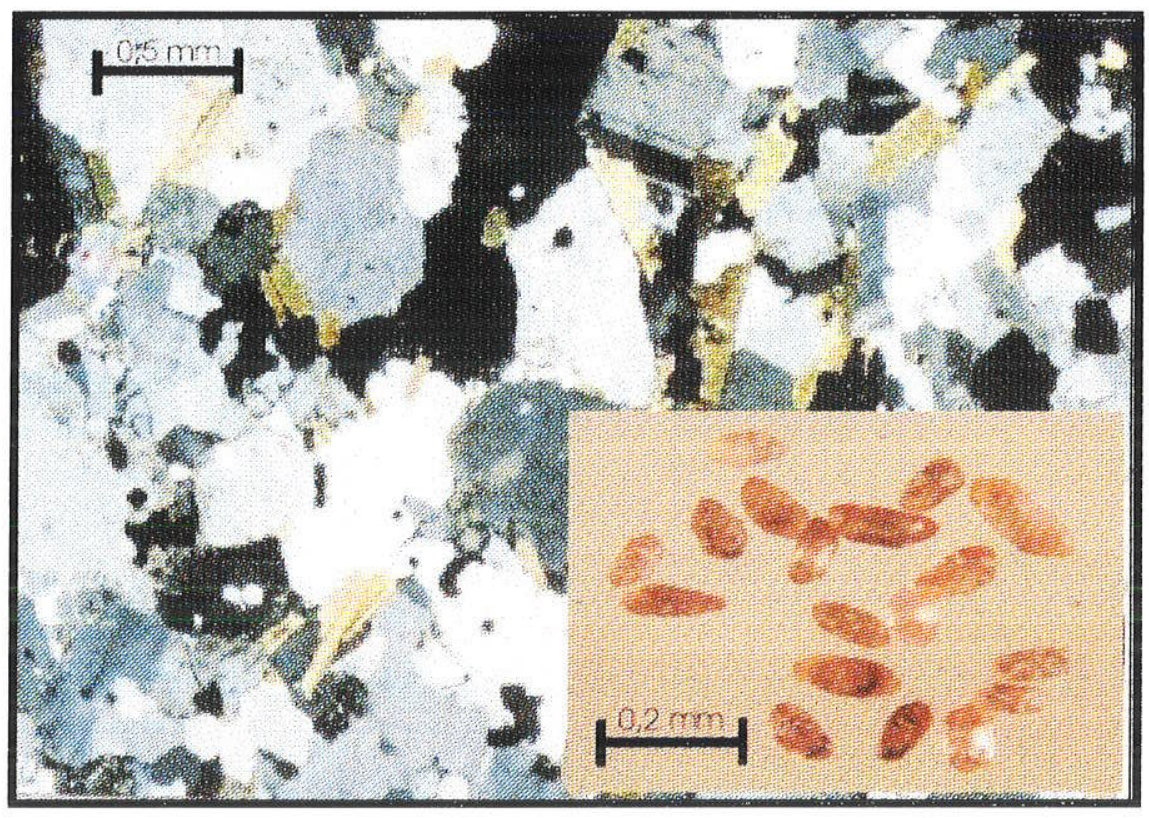

Fotomicrografia 3.6 Detalhe em lâmina do Gnaisse São Domingos (amostra 97-147) Os zircões (uma única população homogênea, translúcida e de coloração caramelada) são mostrados em detalhe.

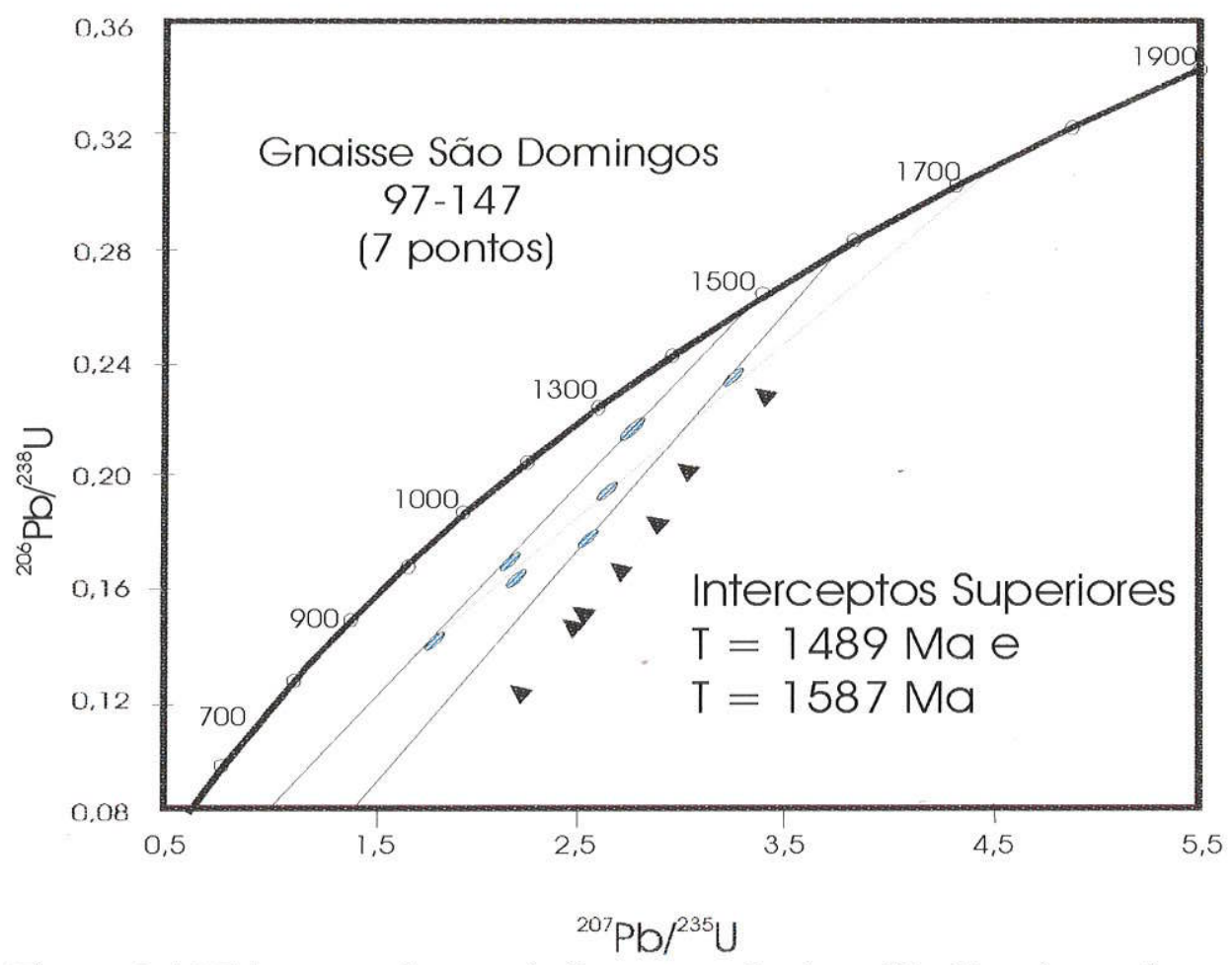

Figura 3.16 Diagrama da concórdia para o Gnaisse São Domingos (amostra 97-147). A idade obtida pelo envelope está entre 1489 e 1557 Ma. A discórdia mais inclinada apresenta a idade ao redor de $1,74 \mathrm{Ga}$. 


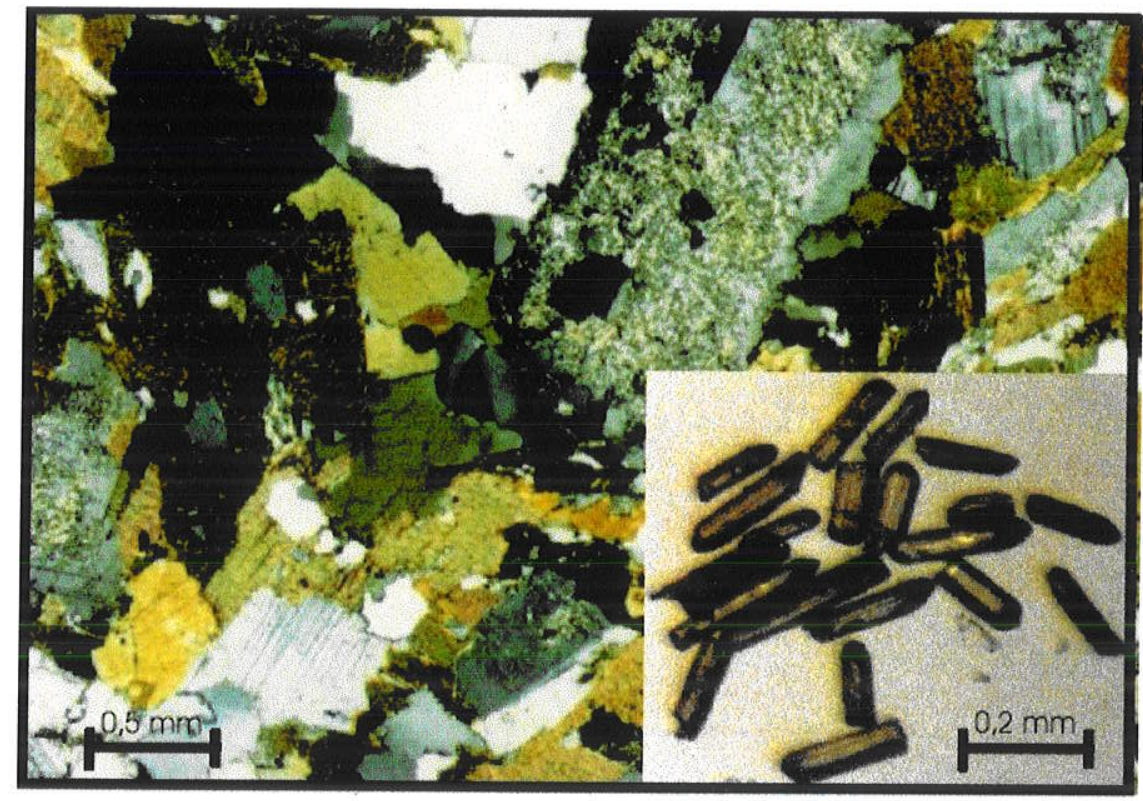

Fotomicrografia 3.7 Detalhe em lâmina do Granito Santa Cruz (amostra 97-145). Os zircões analisados são translúcidos e alongados (4:1 a 6:1).

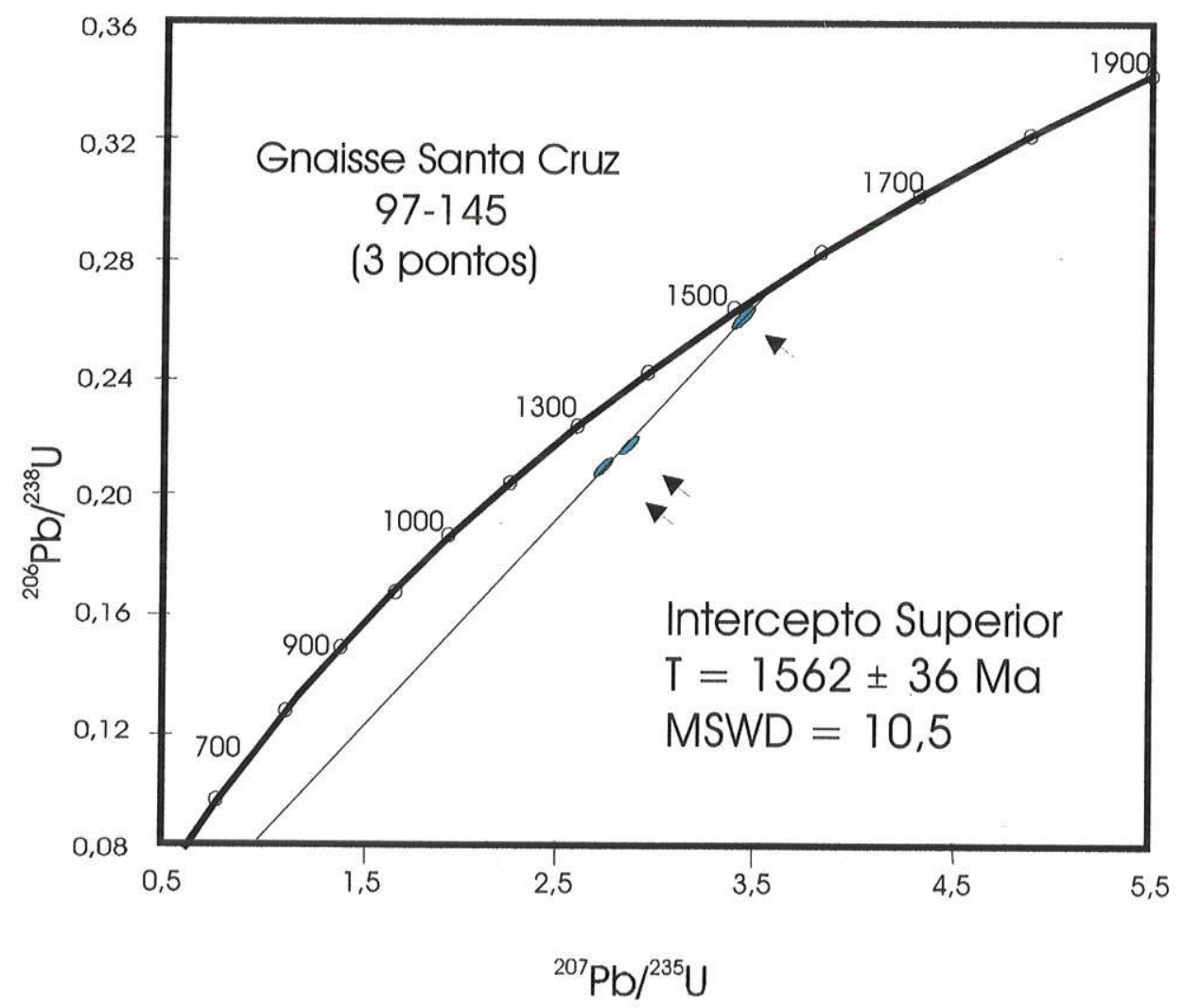

Figura 3.17 Diagrama da concórdia para a 4 zircões do Gnaisse Santa Cruz (amostra 97-145). A idade obtida é $1562 \pm 36 \mathrm{Ma}$ com o intercepto inferior forçado a 0 . 


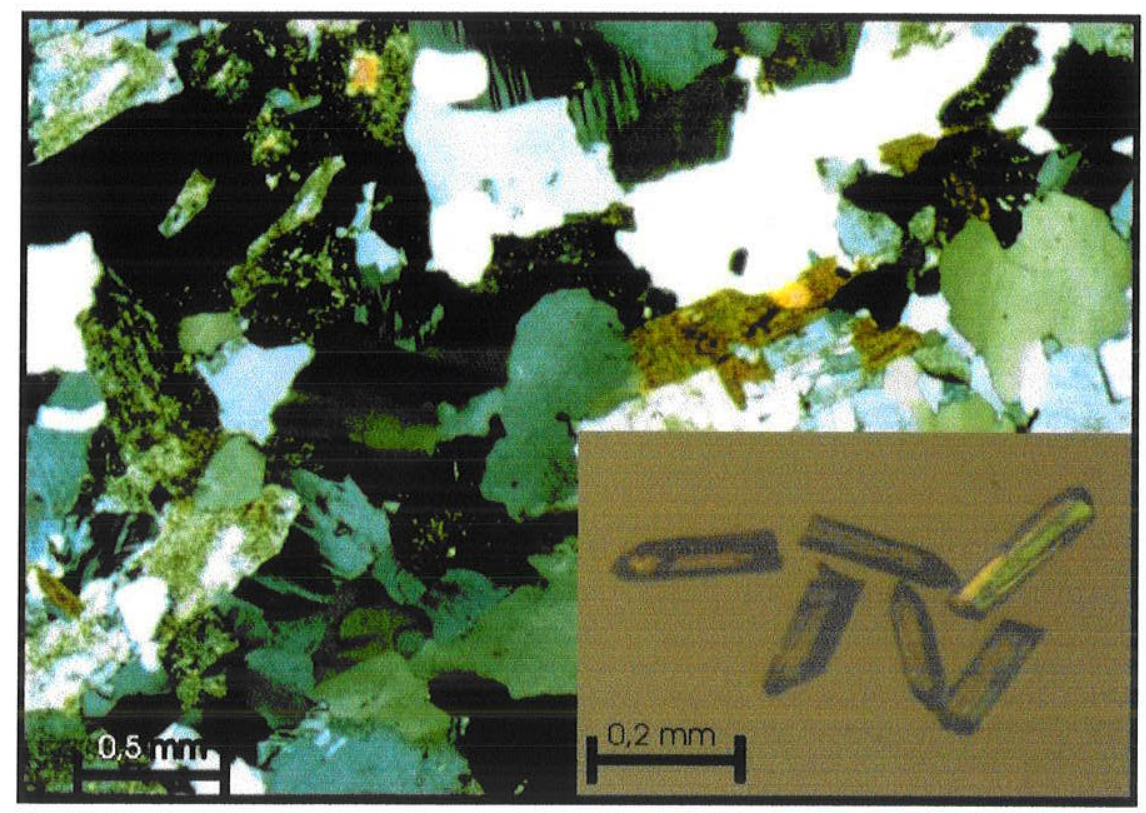

Fotomicrografia 3.8 Detalhe em lâmina da amostra do Granito Cachoeirinha (97-138). Os zircões analisados são translúcidos e alongados (4:1 a 5:1).

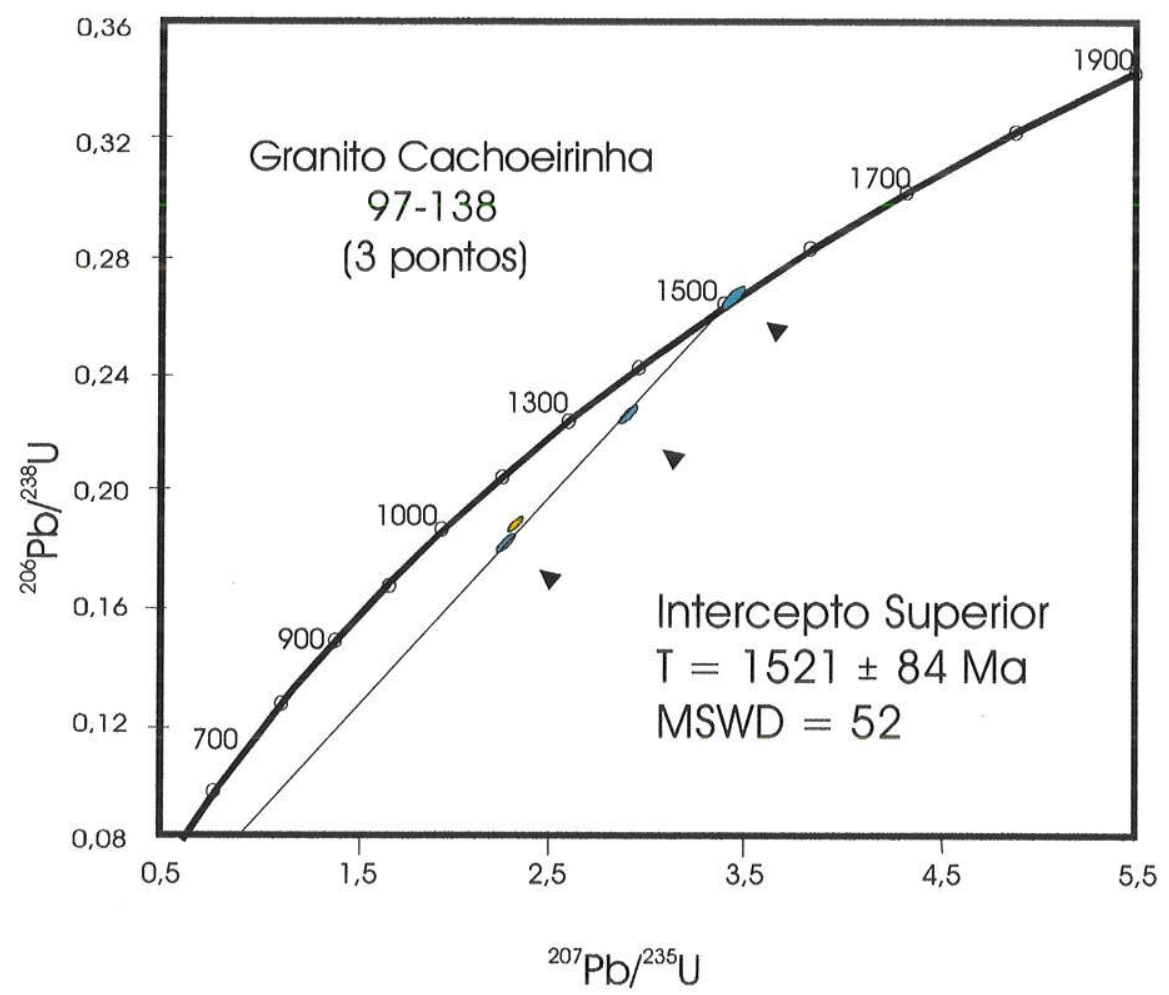

Figura 3.18 Diagrama da concódia para 4 cristais de zircões analisados do Granito Cachoeirinha (amostra 97-138). A idade obtida através da regressão dos 3 pontos (a elipse em amarelo não foi utilizada para o cálculo da idade por ser discordante e não colinear com os outros pontos) foi $1521 \pm 84 \mathrm{Ma}$. A idade de uma fração concordante $(1536 \pm 06 \mathrm{Ma})$ pode ser interpretada como a melhor para a cristalização desta rocha. 


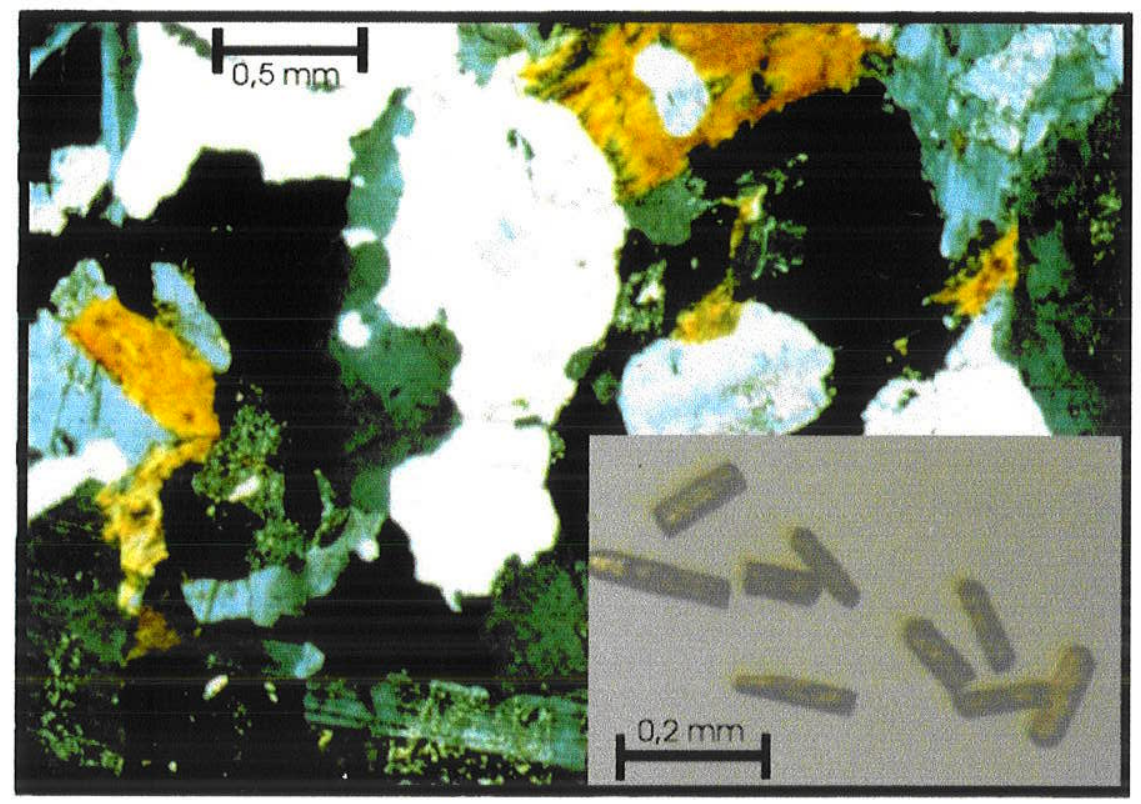

Fotomicrografia 3.9. Detalhe em lâmina da amostra do Granito Alvorada coletada na região de São José dos Quatro Marcos (97-132). Os zircões analisados são translúcidos e alongados (3:1 a 4:1).

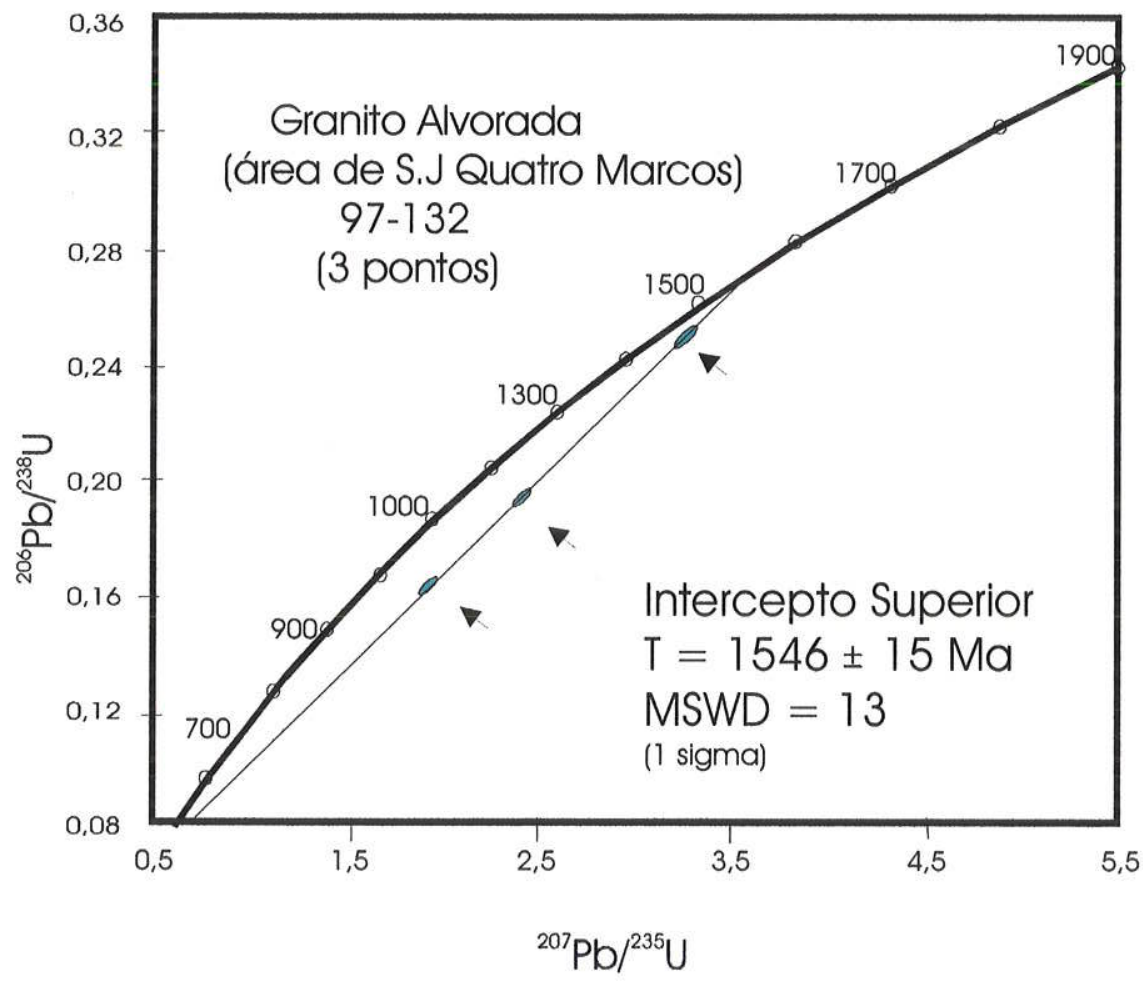

Figura 3.19. Diagrama da concórdia para 3 cristais de zircão do Granito Alvorada coletado em São José dos Quatro Marcos (amostra 97-132). A idade obtida foi de 1546 $\pm 15 \mathrm{Ma}$. O intercepto inferior não tem significado geológico. 


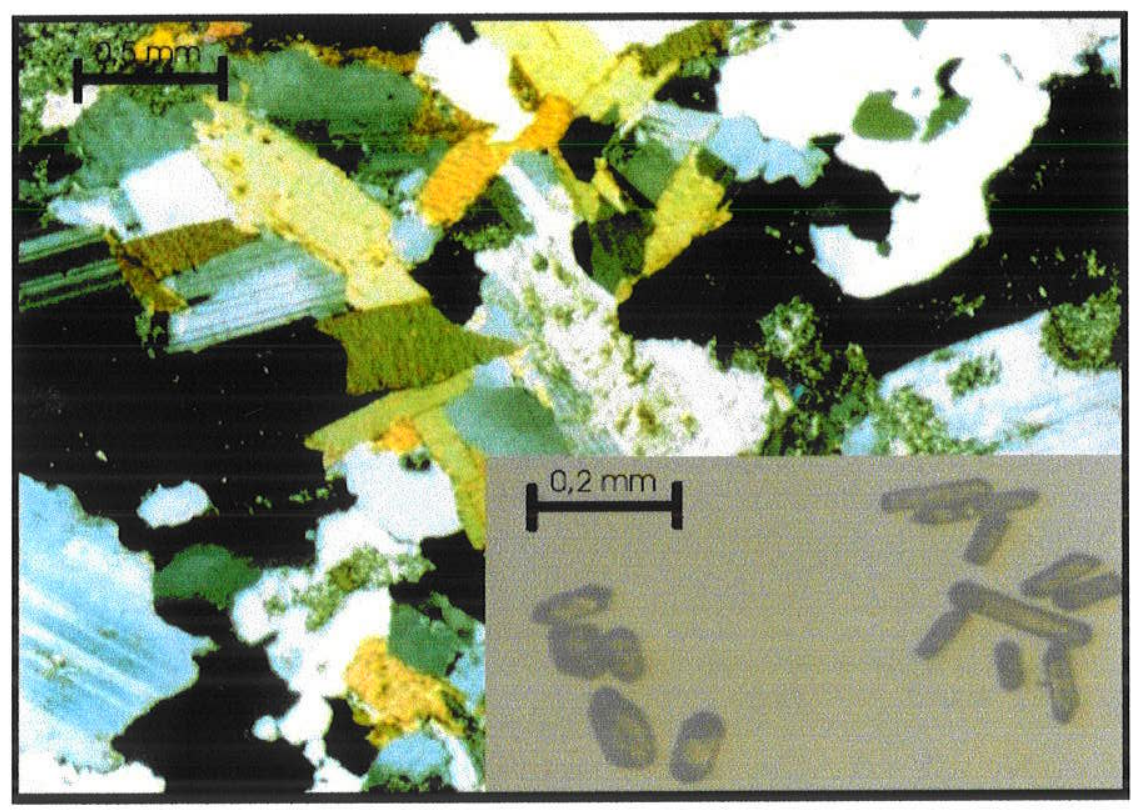

Fotomicrografia 3.10. Detalhe em lâmina do Granito Alvorada coletado em Cachoeirinha (amostra 97-139). Os zircões apresentam duas populações: translúcidos arredondados e translúcidos alongados.

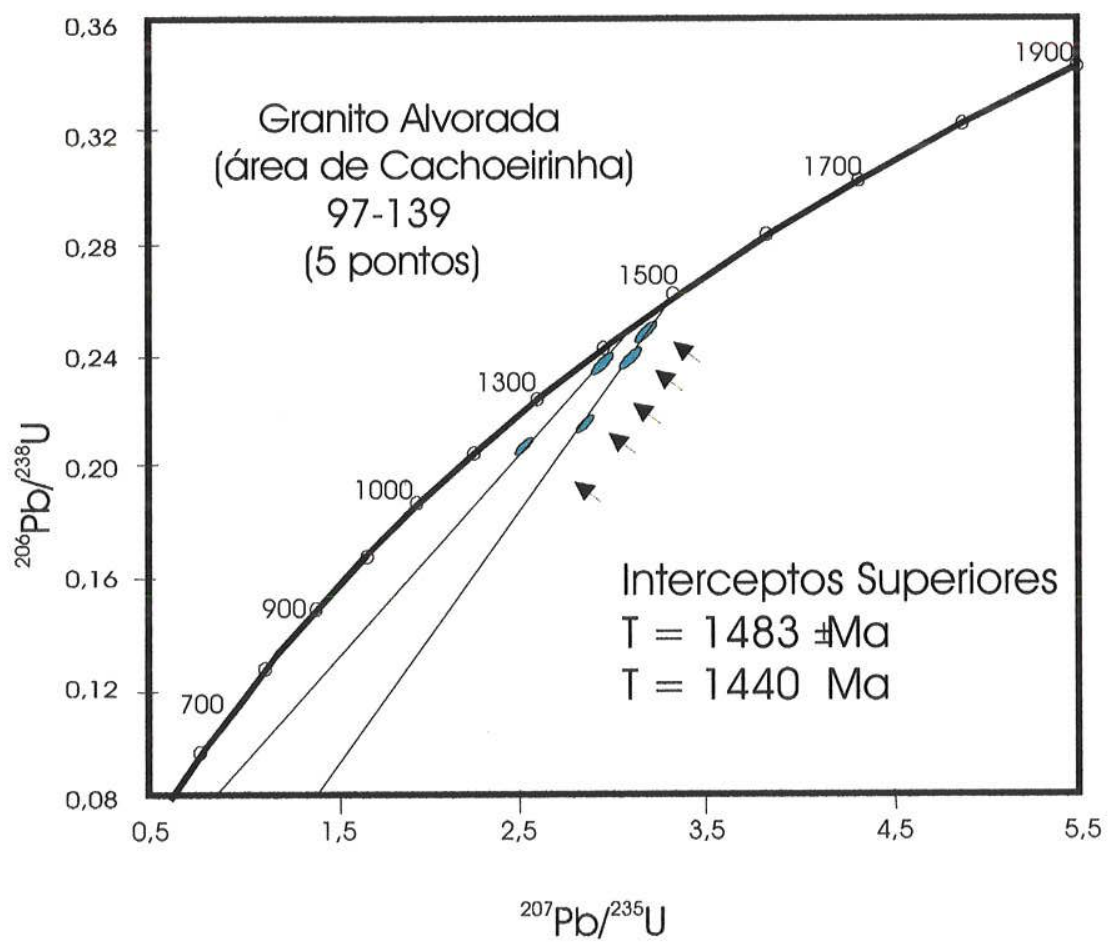

Figura 3.20. Diagrama da concórdia para o Granito Alvorada da área de Cachoeirinha (amostra 97-139). Uma população de zircão indica a idade 1469 e outra população indica a idade $1440 \mathrm{Ma}$. A população de zircões arredondada é a mais antiga. 


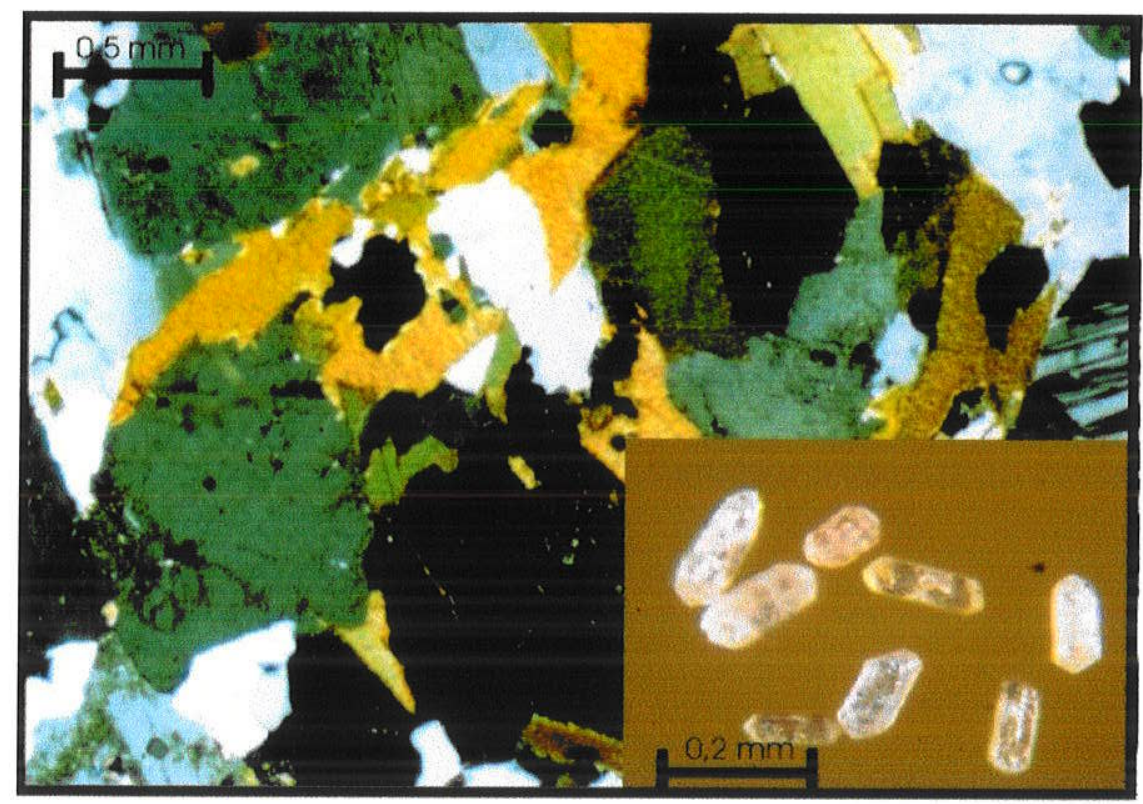

Fotomicrografia 3.11. Detalhe em lâmina do Granito Alvorada (amostra 97-129), coletada na fazenda Alvorada. Os zircões analisados são translúcidos e alongados (3:1).

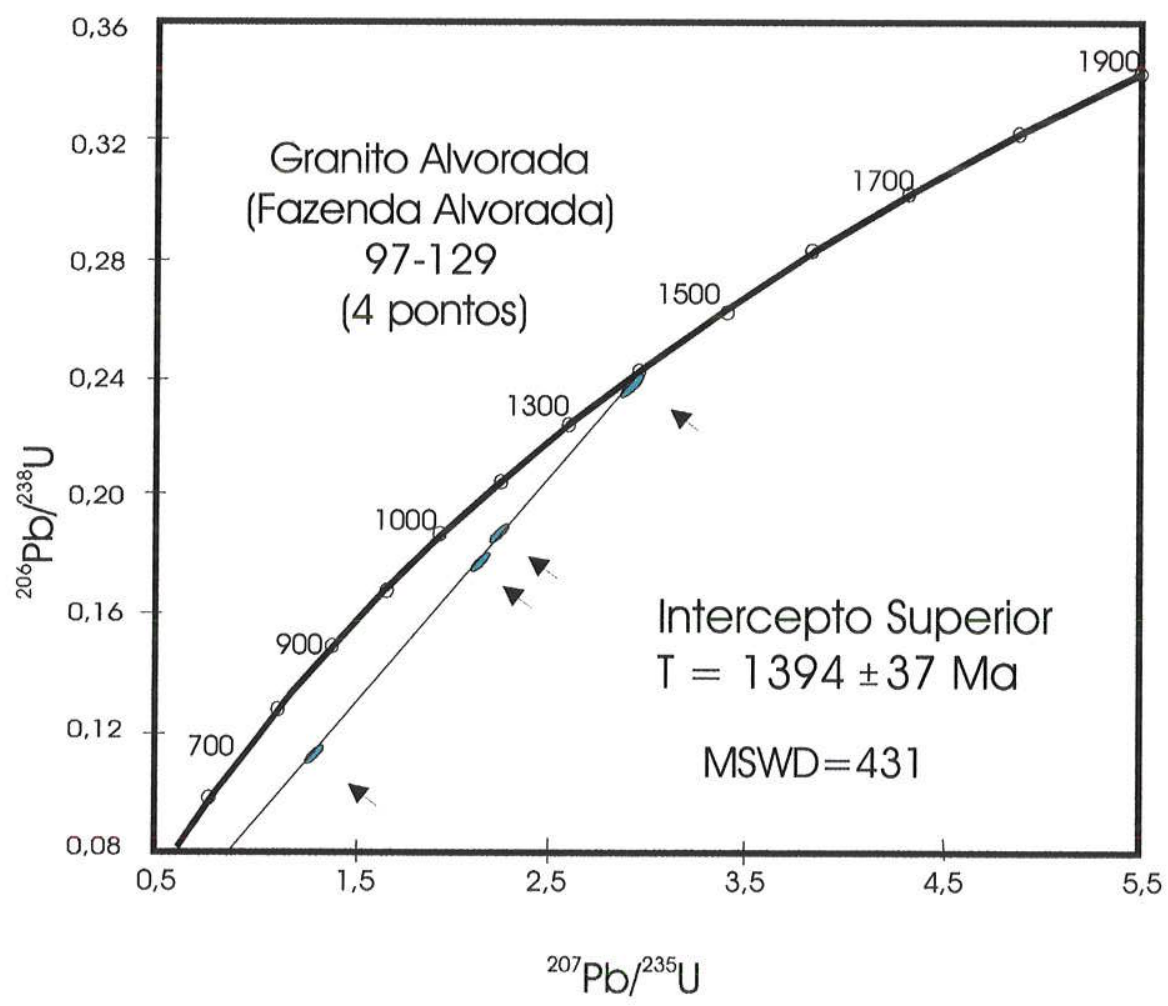

Figura 3.21. Diagrama da concórdia da amostra do Granito Alvorada (amostra 97-129), coletada na fazenda Alvorada. A idade obtida foi de $1394 \pm 37 \mathrm{Ma}$. Intercepto inferior forçado a 0 . 


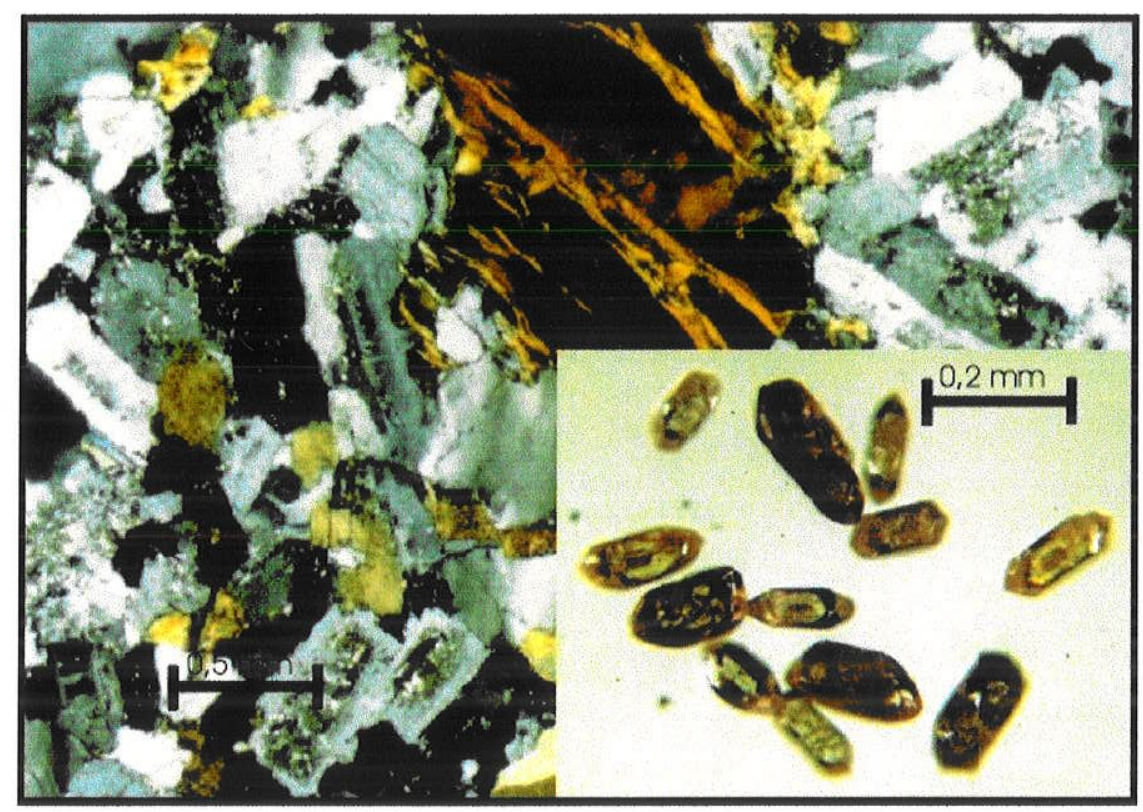

Fotomicrografia 3.12. Detalhe em lâmina do Granodiorito Água Clara (amostra 97136). Os zircões obtidos nesta amostra são translúcidos a pouco translúcidos, com cores entre caramelo e marrom. Podem apresentar pirâmides bem desenvolvidas ou serem arredondados (3:1 a 4:1).

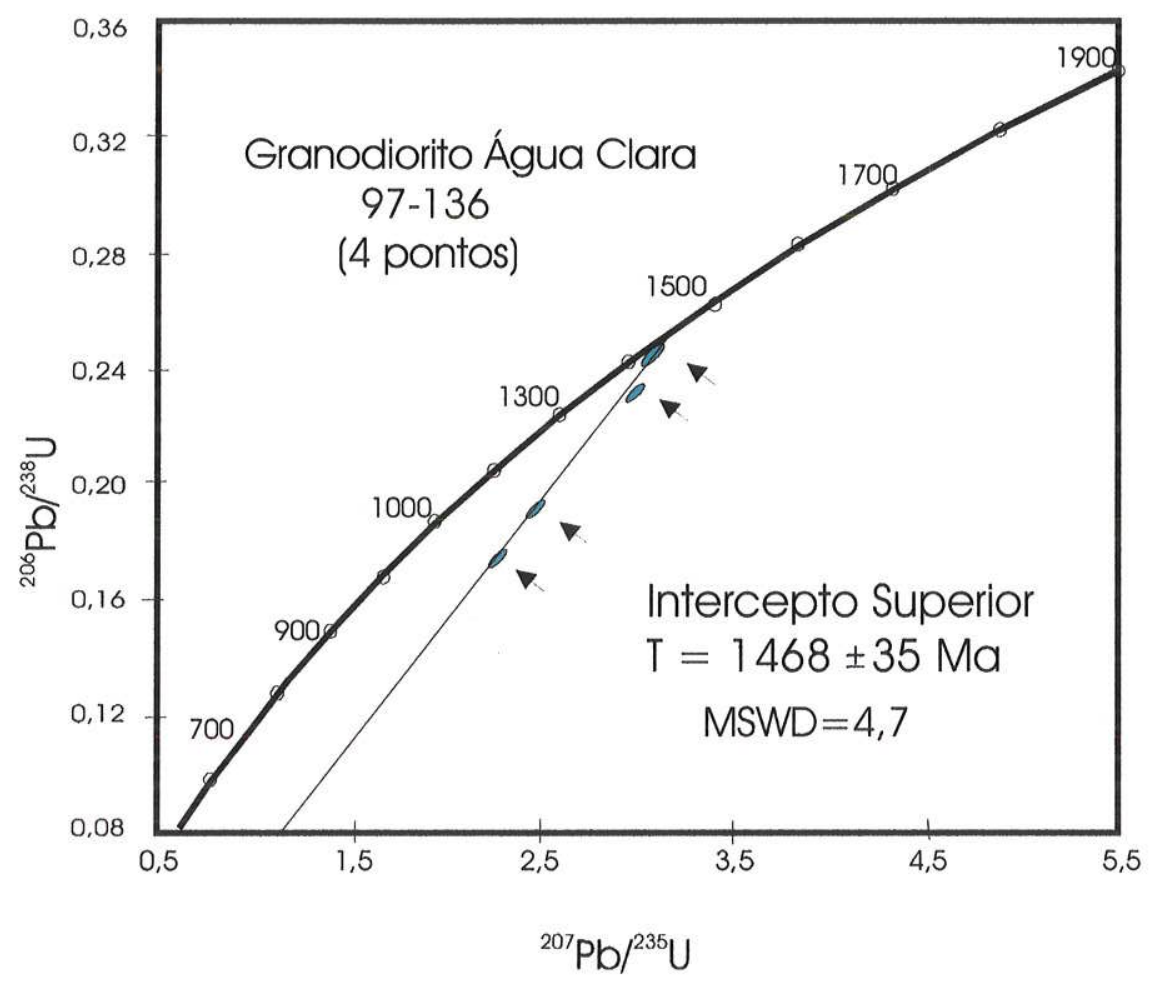

Figura 3.22. Diagrama da concórdia para 4 frações de zircões analisados da amostra 97136. A idade obtida é de $1468 \pm 35 \mathrm{Ma}$. Intercepto inferior forçado a 0 . 


\subsubsection{Geoquímica}

As 10 amostras coletadas dos granitóides intrusivos do Terreno Jauru foram analisadas quimicamente para elementos maiores, traços e terras raras e os resultados são discutidos a seguir.

O conjunto destas amostras envolve granitos, granodioritos e tonalitos de diferentes características deformacionais e idades $\mathrm{U} / \mathrm{Pb}$ entre 1,56 e 1,39 $\mathrm{Ga}$. No entanto, os estudos geocronológicos $\mathrm{Sm} / \mathrm{Nd}$ em rocha total indicaram que elas foram geradas em um evento entre $2,0 \mathrm{Ga}$ e 1,74 Ga (idades $\mathrm{T}_{\mathrm{DM}}$ ), intervalo de tempo de geração da crosta do Terreno Jauru, que pode representar participação de crosta mais antiga na geração desteas unidades.

Neste trabalho tentoumse um tratamento conjunto destas rochas com o objetivo de se delinear os enquadramentos tectônicos de tais litotipos, bem como outras características como calcioalcalinidade, aluminosidade e padrões de terras raras. Verificou-se, no entanto, que a amostra 97-129 (de idade $1394 \pm 37 \mathrm{Ma}$ ) do Granito Alvorada apresenta características mais evoluídas, possivelmente por se tratar de magmatismo pós-orogênico resultado de fusão crustal (o que não alterou sua assinatura isotópica de $\mathrm{Nd}$ ), coerentemente com a interpretação de Pinho, (1996). As outras duas amostras (97-139 e 97-136) apresentam resultados químicos coerentes com o conjunto de amostras graníticas intrusivas do Terreno Jauru.

Os resultados químicos foram convertidos e a proporção de minerais obtidos lançado no diagrama de Streikceisen (1976), definindo a existência de um grupo de rochas graníticas sensu lato composto pelas 3 amostras do Granito Alvorada, o Gnaisse Rosa descrito por Carneiro et. al., (1992), os Granito Cachoeirinha e Gnaisse Santa Cruz. Apresentam composição granodiorítica os Gnaisses Quatro Meninas e Água Clara. O Tonalito Quatro Marcos e o Tonalito Cachoeirinha formam na verdade o terceiro grupo representado por quartzo gabro e quartzo monzogabro (Figura 3.23). Este diagrama foi utilizado para definir os símbolos para cada amostra, de forma que, para os granitos foi escolhido o círculo, para os granodioritos o quadrado e, para tonalitos o triângulo. A mesma simbologia passou a ser utilizada para os demais diagramas.

No diagrama indicador de índice de Shand e de saturação em alumina todas as amostras graníticas e granodioríticas indicaram ser peraluminosas, de forma que o excesso de alumina possivelmente foi incorporado pela biotita, sendo que as amostras 
tonalíticas são metaluminosas, onde se observa os minerais moderadamente aluminosos como hornblenda (Figura 3.24). A Figura 3.25 o diagrama de trend de diferenciação sugere que os litotipos amostrados apresentam variações composicionais características de suítes calcioalcalinas. E na Figura 3.26 o diagrama de discriminação de ambientes tectônicos sugere que as amostras analisadas pertencem a unidades geradas em ambiente de arco magmático.

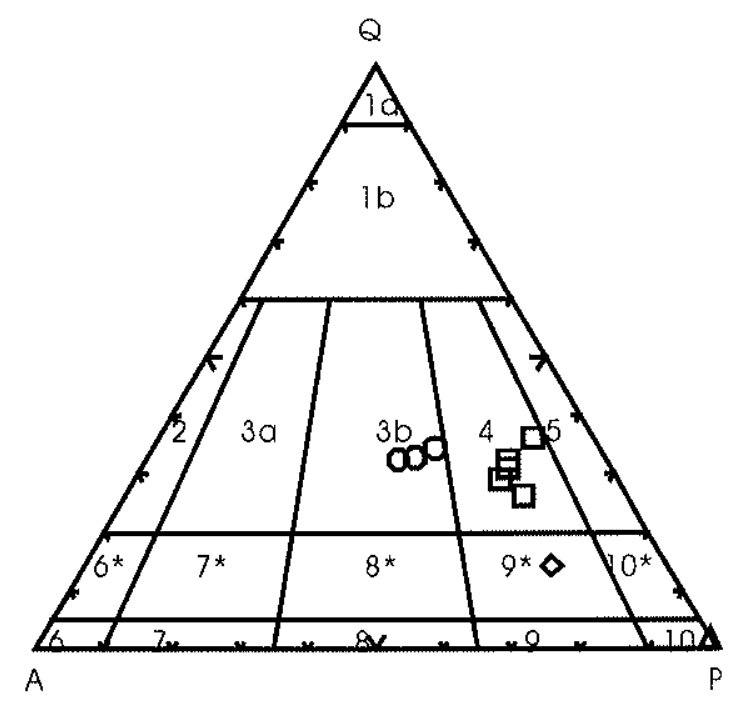

Figura 3.23 Diagrama QAP (Streckeisen, 1976) para as rochas intrusivas do Terreno Jauru obtido através da conversão dos resultados químicos. Os resultados analíticos das 10 amostras graníticas podem ser agrupadas em rochas monzograníticas (as 3 amostras do Granito Alvorada, o Granito Cachoeirinha e o Gnaisse Santa Cruz em círculos); rochas granodioríticas (o Gnaisse Quatro Meninas, o Granodiorito Agua Clara e o Gnaisse Aliança em quadrados); rocha tonalítica (Tonalito Cabaçal em triângulo); rocha quratzo-monzogábrica (Tonalito Cachoeirinha em diamante). (1a) quartzolito; (1) granitóide rico em Qz; (3) granito alcalifeldspático; (3a) sienogranito; (3b) monzogranito; (4) granodiorito; (5) tonalito; (6*) quartzo sienito álcalifeldspático; (6) sienito álcalifeldspático; $\left(7^{*}\right)$ quartzo sienito; $\left(8^{*}\right)$ quartzo monzonito; (8) monzonito; (9*) quartzo monzogabro; (9) monzogabro; (10) quartzo gabro; e (10*) diorito, gabro, anortosito. 


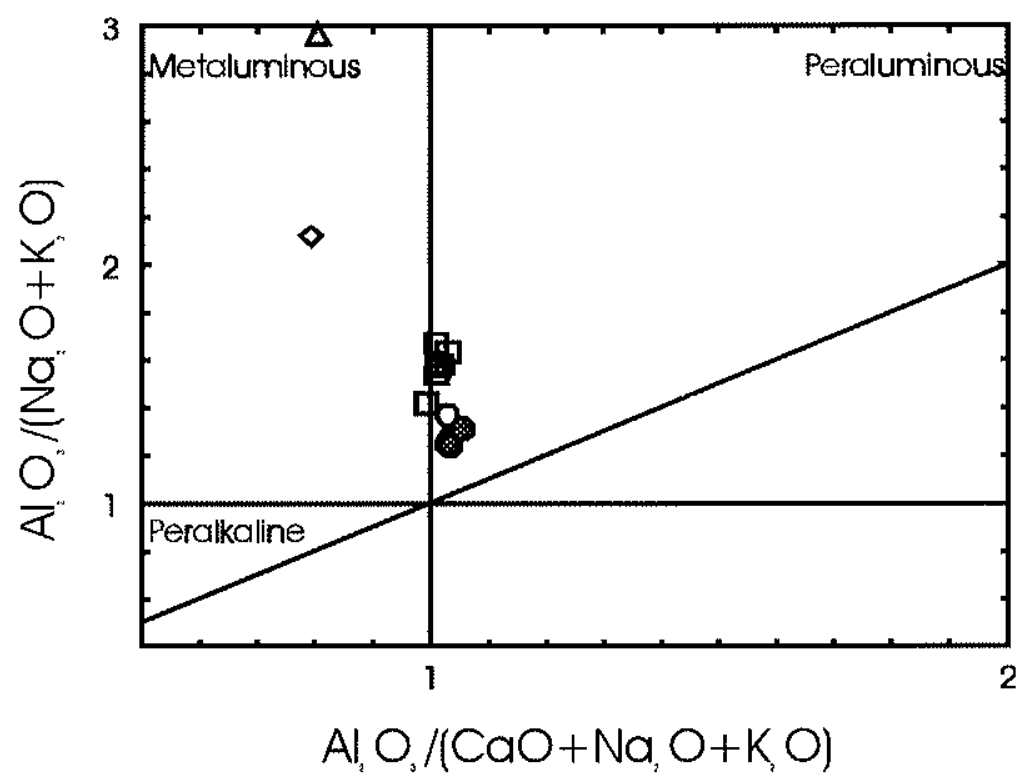

Figura 3.24- Indice de Shand (A/CNK) versus índice de saturação em alumina para as rochas paleoproterozóicas do Terreno Jauru. As dez rochas analisadas apresentam composição peraluminosa (com exceção do tonalito e do quartzo-monzogabro).

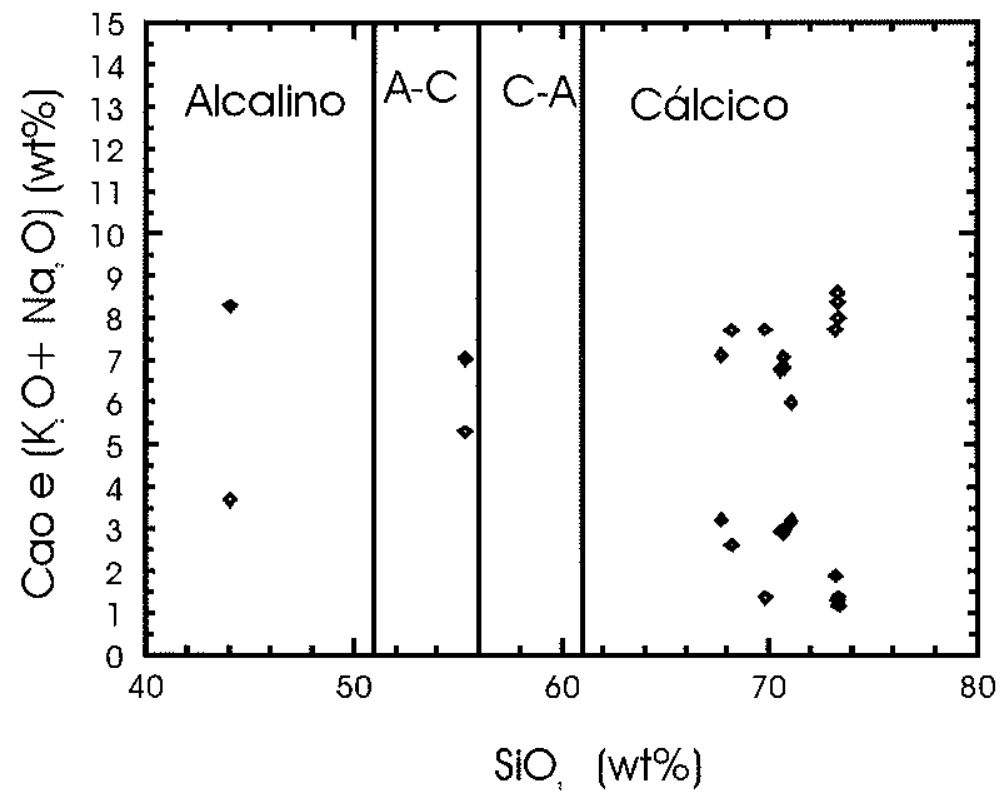

Figura 3.25 Diagramas discriminantes de trends de diferenciação (Peacock, 1931). As rochas graníticas do Terreno Jauru apresentam composição química que se enquadram em suítes calcioalcalinas. 


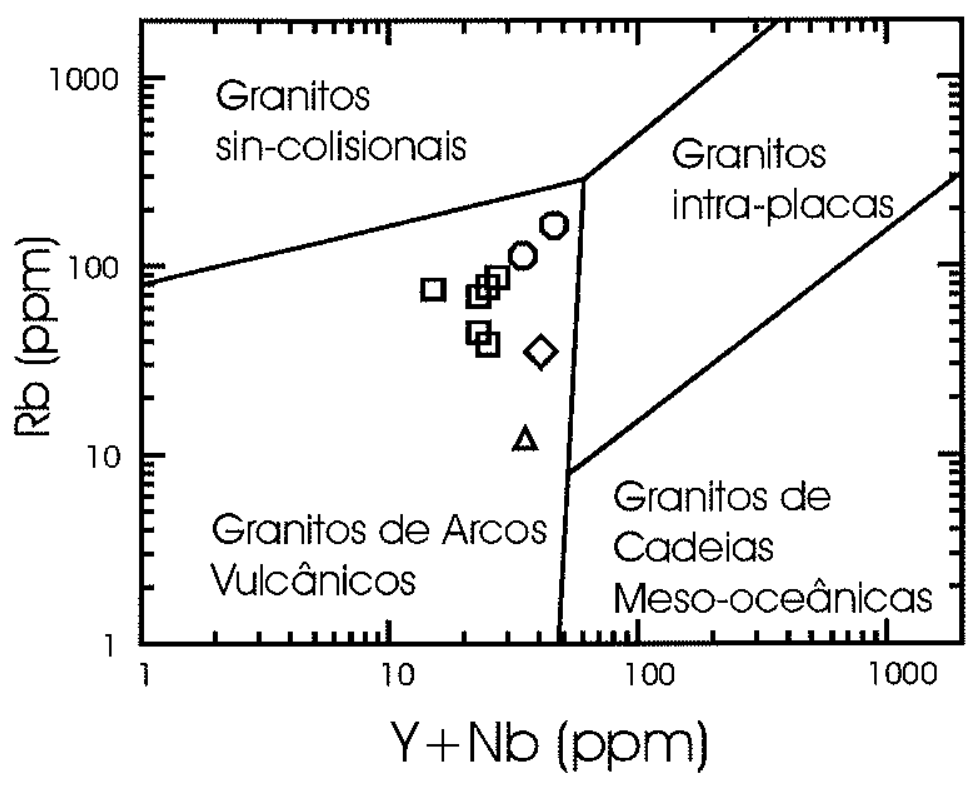

Figura 3.26 Diagramas e discriminação de ambientes tectônicos (Pearce et al., 1984) para as rochas intrusivas do Terreno Jauru. Os diagramas de discriminação de ambientes tectônicos sugerem que as amostras analisadas pertencem a unidades geradas em ambiente de arco magmático.

Na Figura 3.27 foram lançados os resultados analíticos de terras raras das amostras normatizado pelo condrito, de forma que pode-se sugerir que todo o conjunto de amostras apresenta um enriquecimento de terras raras pesados variando de 80 a 140 vezes o condrito. Quanto aos terras raras leves há um enriquecimento de no máxino 10 vezes o condrito, caracterizando um padrão horizontalizado. Observa-se também a existência de leves anomalias positivas de Eu nas amostras tonalíticas e granodioríticas e uma pequena anomalia negativa deste elemento nas amostras mais graníticas indicando, em ambos os casos, um fracionamento de Eu como resultado da cristalização de plagioclásios nos líquidos magmáticos precoces. $O$ padrão mais fracionado observado corresponde a amostra 7-129, reforçando o seu caráter pós-orogênico, resultado da fusão parcial da crosta pré-formada. 


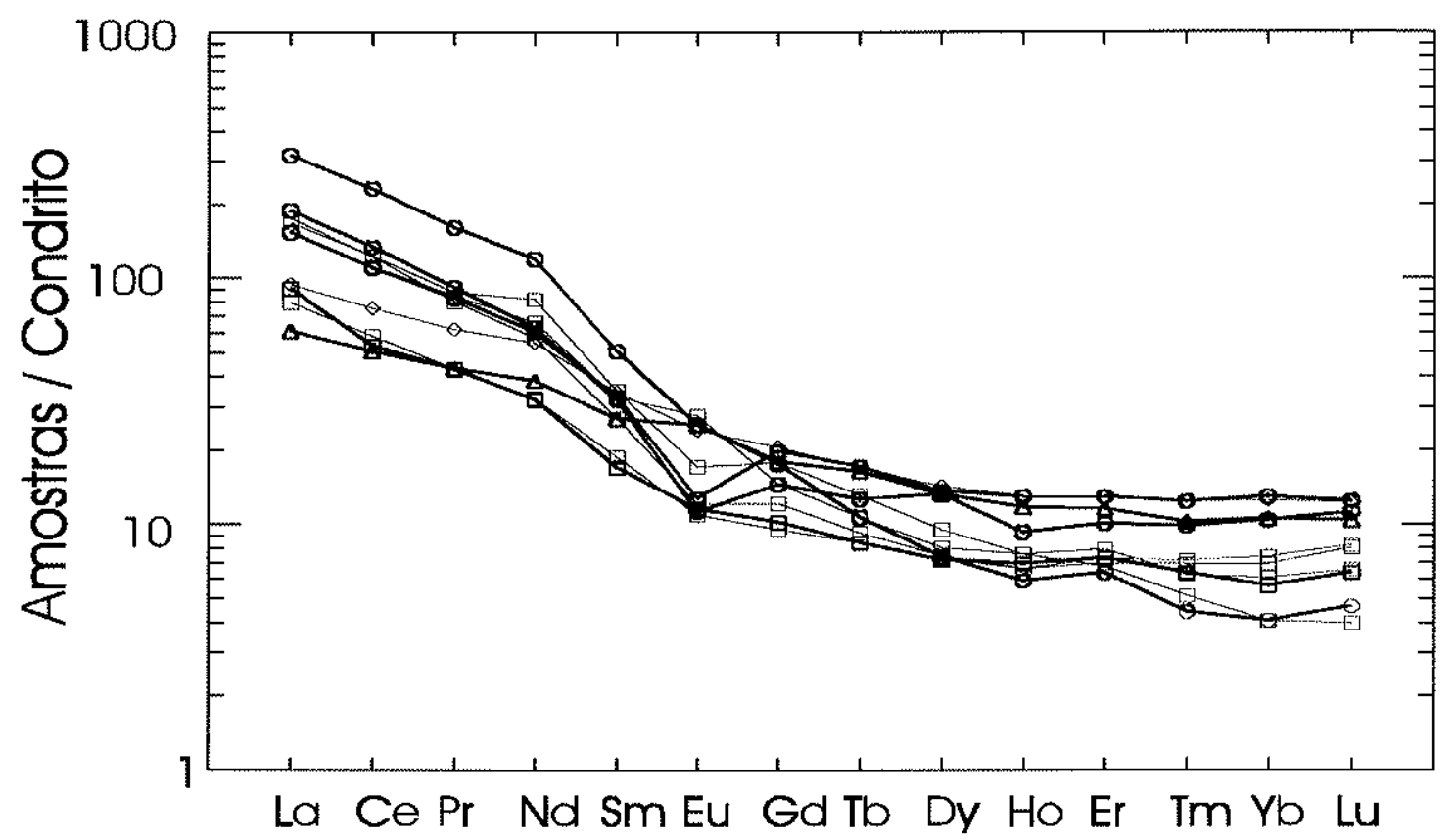

Figura 3.27 Padrões de ETR para as amostras do Terreno Jauru, normalizados pelo condrito. Círculos=granitos; quadrados=granodioritos; e triângulos=tonalitos. Os valores de terras raras foram normalizados segundo Sun e McDonough (1989).

\subsubsection{Isótopos Estáveis}

Seis amostras de rochas granitóides intrusivos do Terreno Jauru foram analisadas para isótopos de oxigênio, (Gnaisse Aliança, Tonalito Cabaçal, Gnaisse Quatro Meninas, Granito Cachoeirinha, Granodiorito Agua Clara e Granito Alvorada). Os resultados de ${ }^{16} \mathrm{O} /{ }^{18} \mathrm{O}$ foram normalizados pelo standart SMOW e são apresentados na Tabela 3.3 .

\begin{tabular}{|c|c|c|}
\hline Amostra & Descrição & $\delta \mathrm{O}^{18}$ \\
\hline $97-129$ & Granito Alvorada & $+6,3$ \\
\hline $97-136$ & Granodiorito Agua Clara & $+9,0$ \\
\hline $97-138$ & Granito Cachoeirinha & $+7,2$ \\
\hline $97-130$ & Tonalito Cabaçal & $+6,6$ \\
\hline $97-149$ & Gnaisse Aliança & $+6,3$ \\
\hline $97-134$ & Gnaisse Cinza & $+6,3$ \\
\hline
\end{tabular}

Tabela 3.3 Valores de $\delta \mathrm{O}^{18}$ para as rochas granitóides do terreno Jauru. As razões ${ }^{18} \mathrm{O} /{ }^{16} \mathrm{O}$ foram normalizados pelo standart SMOW (standart mean ocean water).

Estes dados isotópicos lançados no diagrama da Figura 3.28 indicam uma variação de valores de $\delta \mathrm{O}$ entre $+6,3$ e $+9,0 \%$ coerentemente com valores de $\delta \mathrm{O}$ característicos de 
suítes calcioalcalinas geradas em arcos magmáticos (Figura 3.29), corroborando a interpretação do diagrama $\mathrm{Rb}$ versus $(\mathrm{Nb}+\mathrm{Y})$ de ambiência tectônica. Estes valores de $\delta \mathrm{O}$ indicam também, com exceção do granodiorito Água Clara, que estas rochas foram derivadas de magmas cujos protólitos não apresentam indícios de processos de baixas temperaturas de ambientes sub-superficiais (Taylor, 1974), isto é, o comportamento é típico de protólitos que não apresentam um componente sedimentar importante. $\mathrm{O}$ alto valor de $\delta O$ para a amostra 97-136 (Granodiorito Água Clara) não deve ser resultado de importante participação de material crustal na geração desta unidade uma vez que o valor de $\varepsilon_{\mathrm{Nd}(\mathfrak{t})}=+1,77$ indica uma origem juvenil. Os estudos petrográficos e geoquímicos não apontaram características que explicassem o alto valor de $\delta$ O para esta amostra.

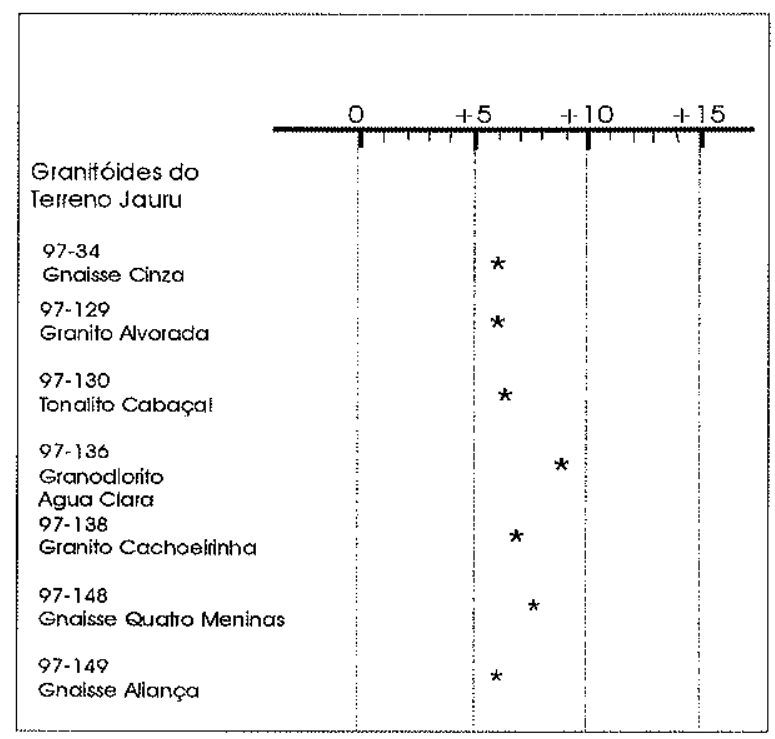

Figura 3.28 Valores de $\delta \mathrm{O}$ para as rochas intrusivas mesoproterozóicas do Terreno Jauru. 


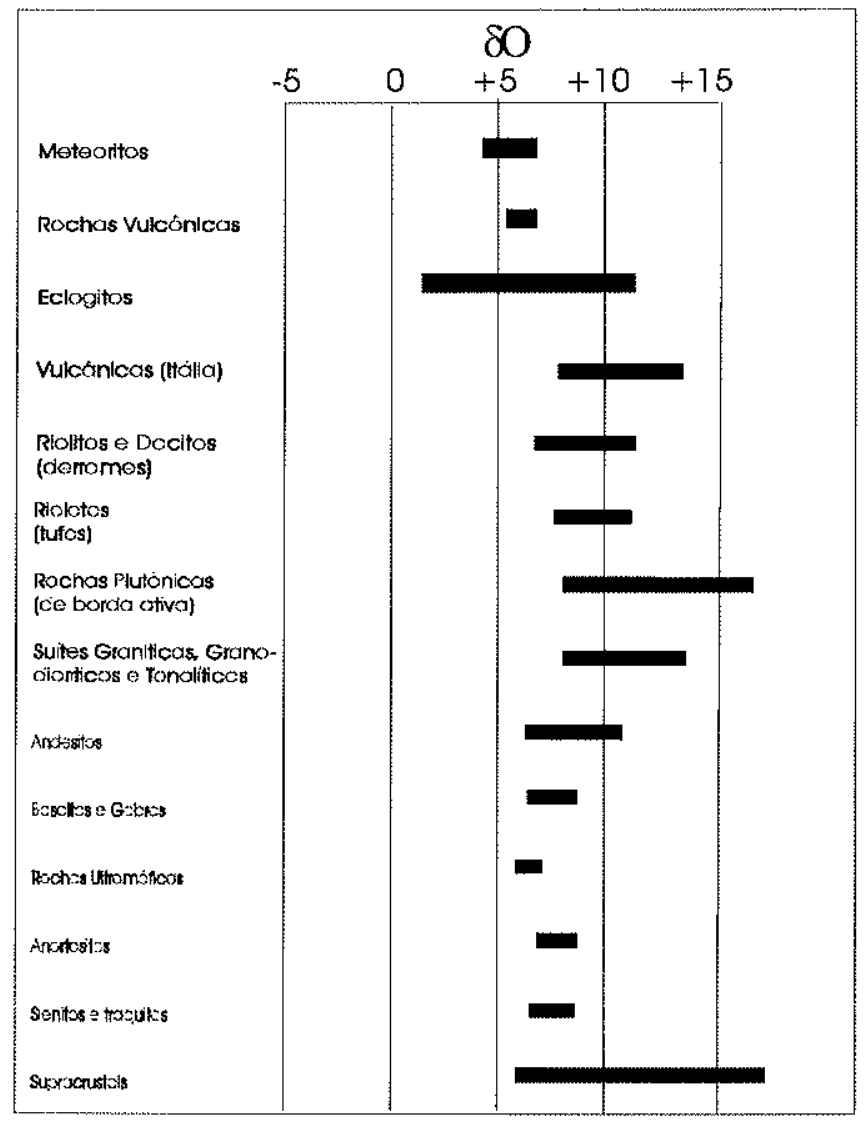

Figura 3.29. Valores de $\delta 0$ para os diversos tipos litológicos e de diferentes idades. Compilação de Taylor (1988) adicionada de dados de Agrinier et. al., (1985) e Sial (1990)

\subsubsection{Discussão}

Nos ítens anteriores foi apresentado um conjunto de dados geocronológicos e geoquímicos das rochas granitóides intrusivas do Terreno Jauru que possibilita definir características dos eventos formadores de crosta bem como ambientes de formação destes corpos plutônicos.

Um importante evento gerador de plútons graníticos ocorreu entre 1550 e 1530 Ma (idades $\mathrm{U} / \mathrm{Pb}$ em zircões) no Terreno Jauru a partir de magmas com participação subordinada de material crustal. Este evento gerou rochas com o quimismo compatível com uma suíte calcioalcalina, com variedades entre granitos e tonalitos. Estes resultados sugerem o desenvolvimento de um arco magmático para a formação destas rochas que, em função do local tipo das rochas deste evento terem sido inicialmente descritas nos arredores de Cachoeirinha (Ruiz, 1992), sugere-se a denominação de Arco 
Cachoeirinha. Segundo Miyashiro (1975) rochas calcioalcalinas são praticamente restritas a arcos magmáticos, constituindo característica distintiva deste ambiente, desde que apresentem sequências expressivas em volume. Este arco magmático, representado pelas rochas intrusivas do Terreno Jauru, provavelmente se formou na margem continental pré-existente de idade paleoproterozóica. Isto é sugerido pela ocorrência de corpos intrusivos granitóides mesoproterozóicos (1,55 e 1,53 Ga) numa mesma área geográfica dos três cinturões vulcano-sedimentares paleoproterozóicos (Jauru, Araputanga e Cabaçal) com rochas graníticas e vulcânicas de idades entre 1,79 a 1,75 Ga. Estes corpos graníticos mesoproterozóicos apresentam também valores de $\mathrm{T}_{\mathrm{DM}}$ (2047 e $1743 \mathrm{Ma}$ ), semelhantes aos TDM dos corpos graníticos paleoproterozóicos (1926 a $1853 \mathrm{Ma}$ ) sugerindo o envolvimento subordinado de crosta durante o desenvolvimento do arco magmático gerador das rochas mais jovens, hipótese corroborada pelos valores de $\varepsilon_{\mathrm{Nd}}$ entre $+1,7 \mathrm{e}-1,3$.

As amostras coletadas denominadas na literatura como Granito Alvorada na verdade representam rochas de diferentes idades e não devem ser agrupadas em uma única unidade. A amostra 97-129, coletada na fazenda Alvorada (afloramento este que representa o local tipo do Granito Alvorada), apresenta idade U/Pb $1394 \pm 37 \mathrm{Ma}$ e deve ter prioridade para a utilização desta nomenclatura. A amostra 97-132 (coletada na região de São José dos Quatro Marcos) apresenta a idade U/Pb de $1546 \pm 47 \mathrm{Ma}$, idade

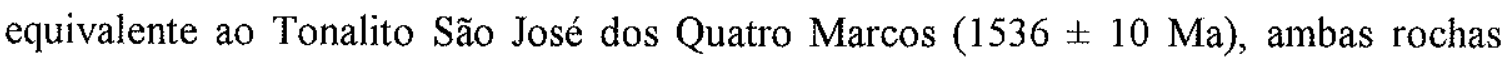
representantes do arco Cachoeirinha. A terceirra amostra regionalmente identificada como pertencente ao Granito Alvorada (Ruiz, 1992), na verdade apresenta idade U/Pb (1483-1440) equivalente ao Granodiorito Agua Clara, e deve representar variação faciológica lateral desta unidade, concordantemente com a descrição de Matos et. al., (1996), que sugere variações de granito, granodiorito e tonalito para a unidade Água Clara.

Tassinari (1981) e Tassinari et. al., (1996) apresentam um grande número de datações no Cinturão Rio Negro-Juruena com resultados $\mathrm{Rb} / \mathrm{Sr}$ (em rocha total) entre 1,8 e 1,5 Ga, e idades K/Ar estão entre 1,4 e 1,1 Ga. Dados U/Pb (SHRIMP) em granito gnáissico apresenta a idade de $1570 \pm 17$ Ma. Sato e Tassinari (1997) reportam resultados $\mathrm{Sm} / \mathrm{Nd}$ equivalentes aos aqui apresentados, com $\mathrm{T}_{\mathrm{DM}}$ entre 2,1 e 1,7 Ga e $\varepsilon_{\mathrm{Nd}(t)}$ entre $+5,1$ e $-3,0$. Segundo os autores acima, no período de tempo entre 1,8 e 1,5 
Ga houve a geração de grande volume de crosta juvenil acrescionado ao protocráton Amazônico. Segundo ainda Tassinari et. al., (op. cit.), a geração desta crosta juvenil ocorreu em dois períodos de tempo: o primeiro entre 1,8 e 1,7 Ga e o segundo entre 1,6 e $1,5 \mathrm{Ga}$. Este último evento envolveria a formação de arco magmático e o retrabalhamento da crosta mais antiga, interpretações estas plenamente confirmadas com os resultados obtidos no presente trabalho. A exposição de rochas plutônicas intrusivas e a não identificação de seus equivalentes vulcânicos de idade 1,55-1,53 Ga sugere que as rochas aqui estudadas contituem uma raiz de arco magmático construído em margem continental com crosta siálica mais antiga cujo edifício foi erodido, expondo a sua estrutura interna.

A variação das características geoquímicas das rochas geradas em arco magmático são correlacionáveis a protólitos originados de magmas de diferentes fusões fracionadas da litosfera descendente e do manto superior, ao longo da zona de subducção (Haterton e Dickinsosn, 1969). Segundo Miyashiro (1975) o zoneamento geoquímico de rochas geradas em arco é caracterizado pelo aumento das taxas de $\mathrm{K}_{2} \mathrm{O}$, $\mathrm{Na}_{2} \mathrm{O}+\mathrm{K}_{2} \mathrm{O}$ e $\mathrm{Na}_{2} \mathrm{O}+\mathrm{K}_{2} \mathrm{O} / \mathrm{Al}_{2} \mathrm{O}_{3}$ em rochas posicionadas a distâncias crescentes em relação ao lado interno (lado da fossa) para o lado externo do arco. Nas rochas em estudo ocorre variação em termos de elementos maiores, onde são observadas rochas de composição mais cálcicas (tonalitos) a calcioalcalinas (granitos e granodioritos). O mesmo ocorre com os indices de saturação em alumina, gerando variedades metaluminosas (tonalitos) a peraluminosas (granitos e granodioritos). Estas variações provocam a existência de rochas mais evoluídas (graníticas de alto $\mathrm{SiO}_{2}$ ) com composições equivalentes de rochas graníticas geradas em ambiente intra-placas, como pode ser observado no diagram Rb versus $\mathrm{Y}+\mathrm{Nb}$. Não se obteve indícios, entretanto, sobre o sentido da subducção a partir dos dados geoquímicos, sendo apenas sugestivo o sentido oeste para leste (atual) pelo motivo da crosta mais antiga do Cráton Amazônico estar posicionada a leste (atual) do Terreno Jauru.

Os dados isotópicos de $\mathrm{O}$ mostram-se úteis na determinação de fontes de rochas graníticas, em combinação com as inferências dos isótopos de $\mathrm{Nd}, \mathrm{Sr}$ e $\mathrm{Pb}$. Os dados isotópicos de $\mathrm{O}$ das rochas aqui estudadas apresentam valores de $\delta \mathrm{O}$ entre $+6,3$ e $+9,0$ \%o. As rochas calcioalcalinas geradas em ambiente de arco magmático usualmente apresentam valores de $\delta \mathrm{O}$ entre $+6,5 \mathrm{e}+8,0 \%$, ao passo que rochas supracrustais 
usualmente apresentam valores de $\delta \mathrm{O}$ entre $+6,0 \mathrm{e}+18,0 \%$. Rochas cujas fontes magmáticas apresentam valores de $\delta \mathrm{O}$ maiores do que +8 requerem o envolvimento de algum material que em certo período de tempo no passado tenha residido próximo da superficie como rochas sedimentares, rochas alteradas meteoricamente ou hidrotermalmente (Taylor, 1988).

Como as rochas aqui estudadas provavelmente foram geradas como resultado de uma crosta oceânica em subducção que provocou a hidratação e fusão parcial do manto, pode-se sugerir a participação de sedimentos oriundos da placa em subducção na geração dos protólitos destas rochas, como nos casos de rochas com valores de $\delta \mathrm{O}$ de +8 e $+9 \%$ e $\mathrm{T}_{\mathrm{DM}}$ de $\sim 2,0$ Ga e $\varepsilon_{\mathrm{Nd}}$ entre $+1,7$ e $-1,3$ (Figura 3.30 ), resultando em variações composicionais (peraluminosidade) e isotópicas ( $\varepsilon_{\mathrm{Nd}(\mathrm{t})}$ negativos) nos magmas que deram origem a suíte calcioalcalina de idade mesoproterozóica do Terreno Jauru.

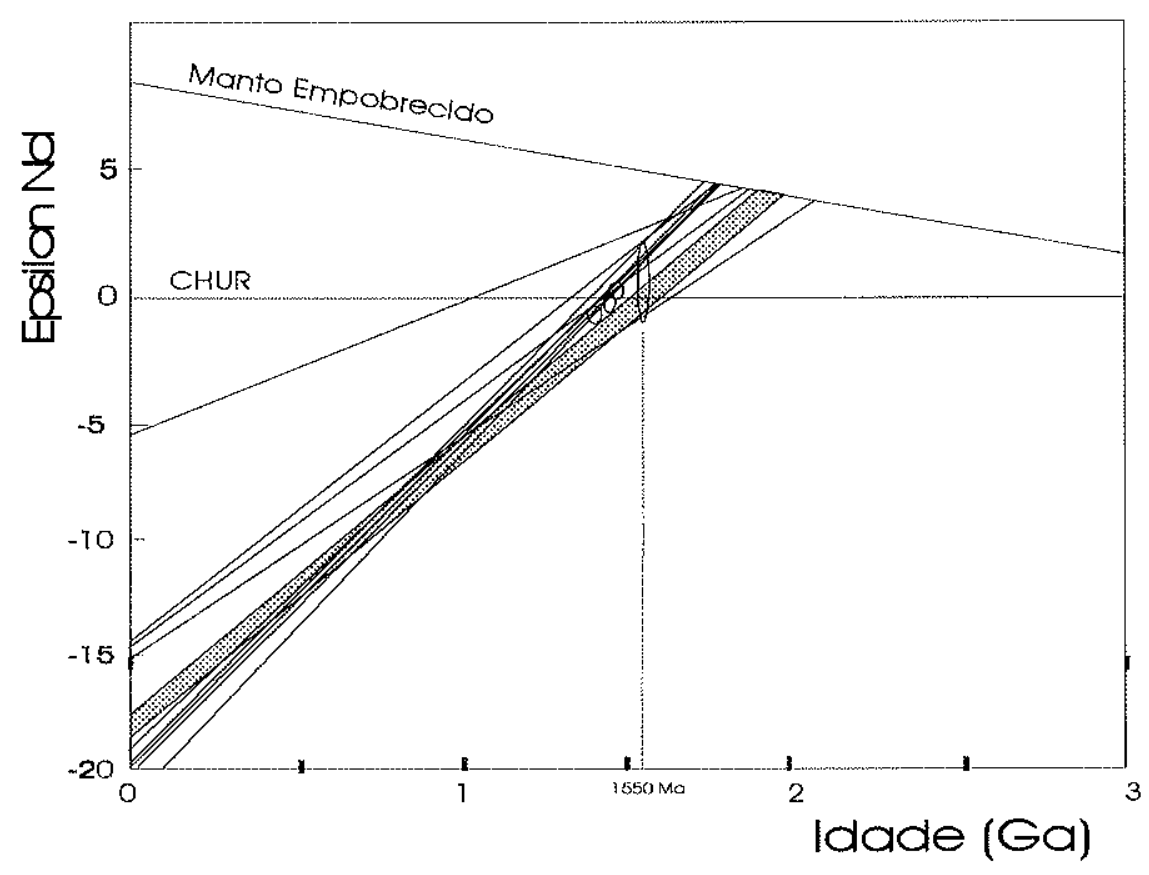

Figura 3.30 Diagrama de evolução isotópica de Nd para as rochas mesoproterozóicas do Terreno Jauru. As rochas de idade de cristalização 1,55 Ga apresentam valores de $\varepsilon_{\mathrm{Nd}}$ positivos e pouco negativos. Em cinza são apresentados os resultados de isótopos de $\mathrm{Nd}$ das rochas do embasamento. Os círculos representam rochas de idade $\mathrm{U} / \mathrm{Pb}$ mais jovens que 1,55-1,53 $\mathrm{Ga}$, mas que apresentam evolução de isótopos de $\mathrm{Nd}$ coerentes com o restantes das amostras. 


\section{CAPÍTULO 4 \\ O Terreno Pontes e Lacerda}

\subsection{Localização e Distribuição}

O Terreno Pontes e Lacerda é representado pelas rochas da Suíte Santa Helena (SSH). Esta unidade apresenta dimensões batolíticas, com limite a leste com o Lineamento Taxaquara-Jundiuvira-Lucialva; a oeste o limite são as falhas, empurrões e zonas de cisalhamento com as rochas do Grupo Aguapeí; a sul a unidade é coberta pelos sedimentos da Formação Pantanal; e a norte o limite não é conhecido (Figura 4.1).

A ocorrência da SSH no extremo leste da Folha Pontes e Lacerda, onde a unidade foi descrita por Menezes et al., (1993), apresenta composição preponderantemente granítica. Rochas de composição tonalítica a quartzo-dioríticas descritas como pertencentes ao Complexo Ígneo Rio Cágado (Menezes et al., op. cit.) foram aqui incluídas na SSH a partir dos novos resultados $\mathrm{U} / \mathrm{Pb}$ (idades equivalentes as das rochas da $\mathrm{SSH}$ ). A área de ocorrência da SSH atinge ainda as Folhas Jauru (a leste, onde foi definida a unidade), Santa Bárbara e Aguapeí. As amostras para este estudo foram coletadas em diferentes porções do batólito, sendo que as unidades amostradas receberam denominações informais em função do local de coleta.

As rochas da SSH apresentam idades U/Pb em zircões entre 1481 e $1423 \mathrm{Ma}$ com concentração de idades (11 amostras) entre 1445 e $1423 \mathrm{Ma}$. As idades $\mathrm{T}_{\mathrm{DM}}$ variam entre 1698 a $1491 \mathrm{Ma}$, com valores de $\varepsilon_{\mathrm{Nd}(\mathrm{t})}$ entre $+4,1 \mathrm{e}+2,7$ (Tabela 4.1). A seguir são apresentados os resultados de cada amostra individualmente. Aspectos gerais dos afloramento desta unidade são apresentados na Prancha 5. 

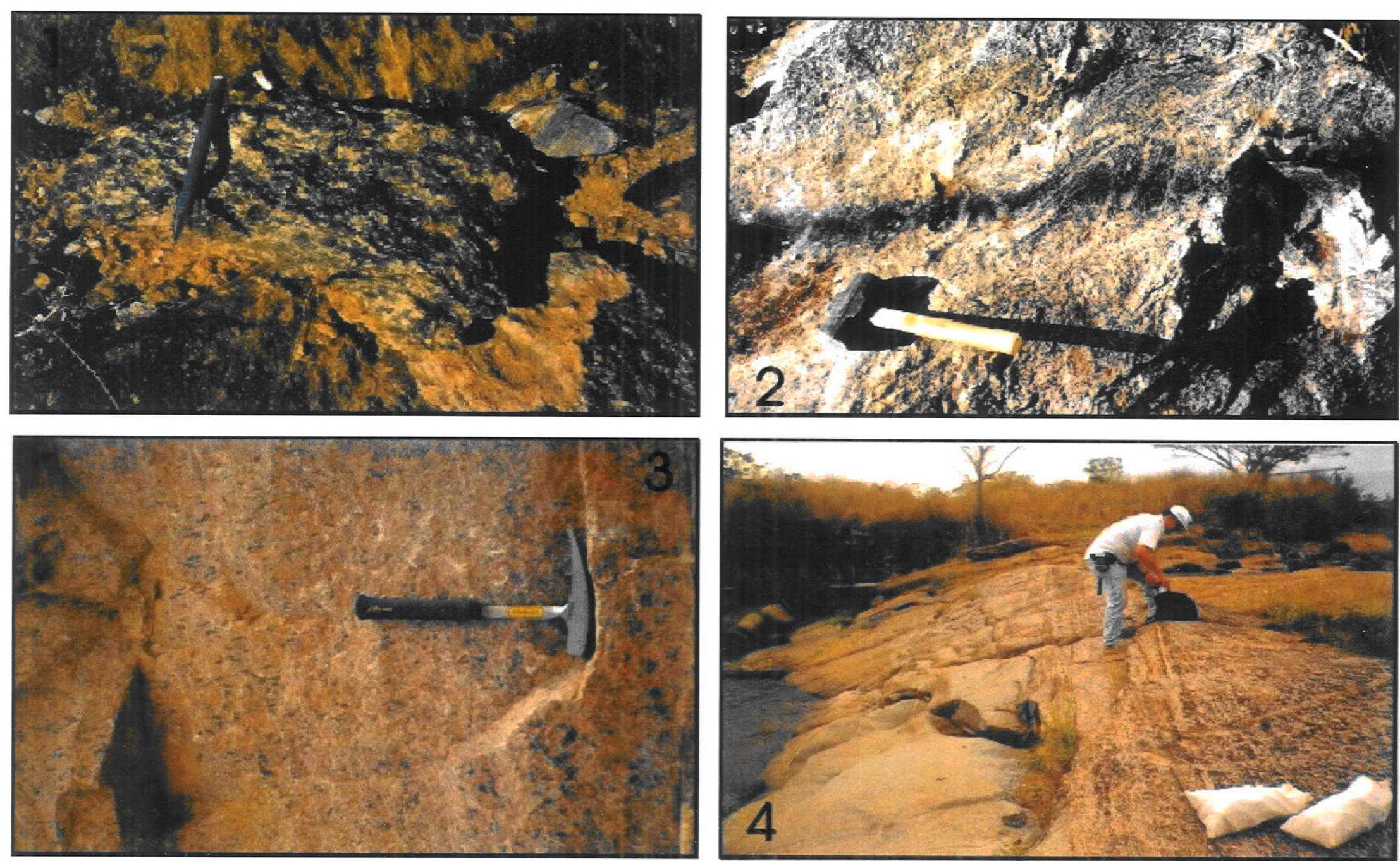

Prancha 3. (1) Tonalito Pau-a-Pique da SSH (amostra 97-140).

(2) Rochas gnáissicas granodioríticas da SSH (amostra 97-102).

(3) Granito foliado da SSH (amostra 97-115).

(4) Rochas granodioríticas envolvendo corpo de rochas de composição tonalítica da SSH (amostras 97-105 e 97-106). 
Tabela 4.1 Idades U/Pb (em zircão) e $\mathrm{Sm} / \mathrm{Nd}$ em rocha total para as rochas da Suíte Santa Helena.

\begin{tabular}{|c|c|c|c|c|c|c|}
\hline Amostra & Litologias & $\mathrm{U} / \mathrm{Pb}(\mathrm{Ma})^{*}$ & $\varepsilon_{\mathrm{Nd}(0)}$ & $\varepsilon_{\mathrm{Nd}(t)}$ & $\mathrm{T}_{\mathrm{DM}}$ & $f$ \\
\hline $97-102$ & Gnaisse Alto Guaporé & $1445 \pm 04$ & $-15,4$ & $+2,9$ & 1,56 & $-0,51$ \\
\hline $97-105$ & Gnaisse Alto Guaporé & $1424 \pm 11$ & $-12,8$ & $+2,8$ & 1,57 & $-0,44$ \\
\hline $97-106$ & Gnaisse Alto Guaporé & $1424 \pm 15$ & $-8,6$ & $+4,0$ & 1,49 & $-0,35$ \\
\hline $97-108$ & Granodiorito Guaporé & $1435 \pm 22$ & $-11,8$ & $+3,4$ & 1,54 & $-0,42$ \\
\hline $97-113$ & Tonalito Lavrinha & $1464 \pm 25$ & $-13,1$ & $+3,8$ & 1,53 & $-0,45$ \\
\hline $97-115$ & Granito Santa Helena & $1433 \pm 06$ & $-8,9$ & $+3,1$ & 1,62 & $-0,32$ \\
\hline $97-120 \mathrm{E}$ & Magnet. Granito Cardoso & $1423 \pm 15$ & $-11,7$ & $+3,6$ & 1,52 & $-0,33$ \\
\hline $97-120 \mathrm{~W}$ & Augen-gneiss Cardoso & $1436 \pm 06$ & $-13,4$ & $+3,9$ & 1,48 & $-0,42$ \\
\hline $97-135$ & Granito Santa Elina & $1437 \pm 12$ & $-10,2$ & $+2,7$ & 1,55 & $-0,38$ \\
\hline $97-140$ & Tonalito Pau-a-Pique & $1481 \pm 47$ & $-4,9$ & $+4,1$ & 1,50 & $-0,25$ \\
\hline $97-141$ & Granito Maraboa & $1449 \pm 07$ & $-7,1$ & $+2,6$ & 1,70 & $-0,26$ \\
\hline $97-168$ & Granito Fazenda Ellus & $1437 \pm 12$ & $-11,1$ & $+3,7$ & 1,52 & $-0,40$ \\
\hline $97-169$ & Granito Garimpo Ellus & $1444 \pm 21$ & $-10,8$ & $+3,6$ & 1,51 & $-0,39$ \\
\hline
\end{tabular}

* Resultado das análises U/Pb por diluição isotópica em monocristais de zircão.

$\varepsilon_{\mathrm{Nd}(\mathrm{t})}$ calculado para a idade $\mathrm{U} / \mathrm{Pb} ; \mathrm{T}_{\mathrm{DM}} \mathrm{em} \mathrm{Ma}$.

\subsection{A Suíte Santa Helena}

Rochas Tonalíticas

As rochas da SSH apresentam variações composicionais entre tonalitos, granodioritos e granitos, sendo que os tonalitos ocorrem preferencialmente na porção $\mathrm{W}$ do batólito, nas localidades do Garimpo Lavrinha e Garimpo Pau-a-Pique (amostras 97 113 e 97-140, respectivamente). São rochas leucocráticas, cinza a verde acinzentado, de granulação grossa a porfiróide, isótropas a levemente foliadas. A mineralogia essencial inclui feldspatos (principalmente plagioclásio) anfibólio, biotita e pouco quartzo.

Em lâmina delgada os tonalitos exibem texturas equigranulares médias a grossas e, mais raramente, textura porfiróide. O plagioclásio ocorre como cristais hipidiomórficos, em prismas curtos ou alongados. Normalmente estão saussuritizados, permitindo ainda a determinação de sua composição entre oligoclásio e andesina. $\mathrm{O}$ quartzo é anédrico, com contatos interlobados e deformações intracristalinas como extinção ondulante e subgranulação. $O$ anfibólio e a biotita acham-se parcialmente substituídos por clorita e actinolita, respectivamente. Zircão, apatita, allanita e opacos são os acessórios mais comuns. 


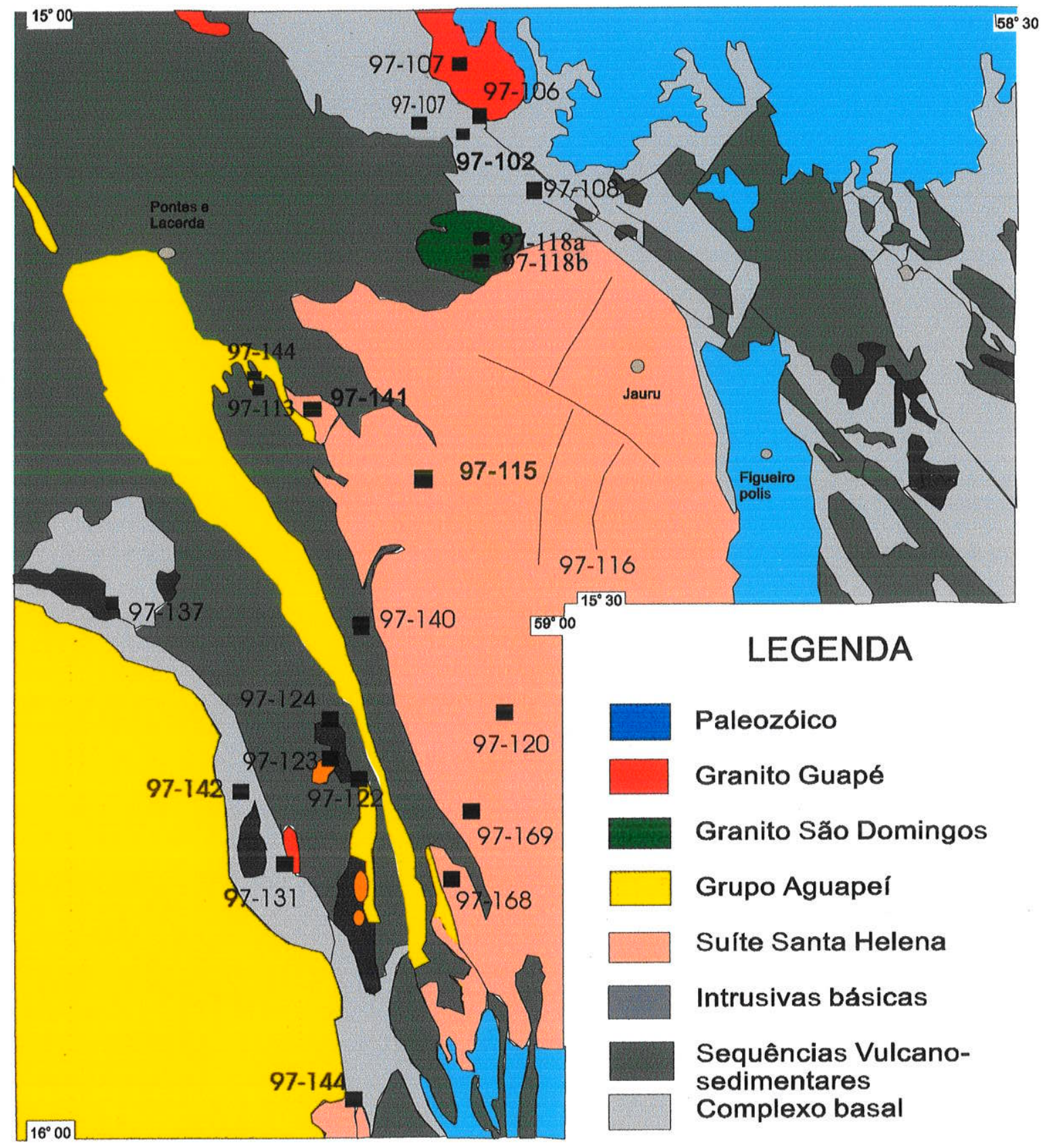

Figura 4.1 Localização das amostras da Suíte Santa Helena. A escala do mapa não permite a apresentação de todas as unidades aflorantes. Neste mapa as amostras 97-102, 97-107 e 97-108 estão localizadas no Complexo Basal a NW de Pontes e Lacerda, indicando que parte do que compunha o embasamento (nos trabalhos anteriores) constitui rochas pertencentes a SSH. Estão lançadas neste mapa rochas do Terreno Rio Alegre (97-122, 97-124 e 97-137), as rochas da Fazenda Reunidas (Complexo Basal) (97-123, 97-131, 97-142 e 97-144) e rochas do Granito Guapé (97-107) e São Domingos (97-118a e 97-118b), descritas nos capítulos seguintes. 
97-113-Tonalito Lavrinha. Esta amostra foi coletada na área de garimpo denominada Lavrinha, cujo nome do lugarejo é emprestado. A rocha é isotrópica, com anfibólio e biotita (distribuídos proporcionalmente), além de plagioclásio e quartzo, constituindo uma textura em mosaico. A rocha tem coloração cinza a verde com granulometria grossa, sendo que a presença de sericita, clorita e epidoto indicam uma alteração hidrotermal pós cristalização (Fotomicrografia 4.1). Cinco frações desta amostra foram analisadas e os resultados, quando lançados no diagrama da concórdia, indicam uma idade no intercepto superior de $1464 \pm 25 \mathrm{Ma}$ (Figura 4.2).

97-140 Tonalito Pau-a-Pique. Esta rocha é exposta no garimpo denominado Pau-aPique, onde está tectonicamente justaposta a metassedimentos do Grupo Aguapeí através de um contato por zona de cisalhamento mineralizada a ouro. A cinco metros deste contato a rocha apresenta início de milonitização, sendo que a poucos centímetros do contato a textura fina resultado da milonitização não permite mais o reconhecimento dos minerais. A amostra coletada tem granulometria grosseira, com cristais subcentimétricos de plagioclásios que em lâmina delgada se mostram totalmente sericitizados. Anfibólio e biotita completam os minerais principais (Fotomicrografia 4.2). Quatro zircões concentrados desta amostra indicaram uma idade de (intercepto superior) $1481 \pm 47 \mathrm{Ma}$ (Figura 4.3).

\section{Rochas Granodioríticas}

As variedades granodioríticas da SSH foram observadas nas localidades da Fazenda Triângulo (amostra 97-102), Fazenda Guapé (amostra 97-106), e na antiga rodovia Cuiabá-Porto Velho (amostra 97-108). Estas rochas são acinzentadas, homogêneas ou bandadas, localmente descritas no campo como gnássicas (granitognaisses, biotita-gnaisses e magnetita-gnaisses). Na ocorrência da Fazenda Triângulo observam-se variações laterais para rochas de composição anfibolítica, com contatos graduais. No ponto 97-102 ocorrem porções com bandas bem definidas por leitos com mais biotita e enfibólio e leitos mais quartzo-feldspáticas e apresentam-se dobradas isoclinalmente. Microscopicamente estas rochas apresentam feldspato alcalino (ortoclásio), plagioclásio, anfibólio e biotita com textura de intercrescimento. Os acessórios são titanita, zircão e opacos. 
97-102- Granodiorito Guapé (GG) Esta foi a amostra coletada na porção setentrional do mapa da Figura 4.1, área definida no mapeamento de CPRM como constituídas do embasamento representado pelo Complexo Pontes e Lacerda. A amostra de composição granodiorítica apresenta contatos difusos com rochas de composição anfibolítica e também é cortado por diques quatzo-feldspáticos com biotita e muscovita decimétricos. Esta rocha é composta por quartzo, ortoclásio, plagioclásio, biotita e hornblenda (Fotomicrografia 4.3). Cinco zircões concentrados desta amostra apresentam resultados, que, quando lançados no diagrama da concórdia, indicam um intercepto superior de $1445 \pm 9 \mathrm{Ma}$ (Figura 4.4)

97-105- Granodiorito Gnáissico Guapé. Esta é outra amostra coletada na área mapeada por Menezes et al., (1993) como pertencente ao embasamento da região. O afloramento é composto por duas rochas de composição e estruturas diferentes (amostras 97-105 e 97-106). A amostra 97-105 tem composição granodiorítica com quartzo, ortoclásio e plagioclásio em proporção equivalente, além de biotita e anfibólio, o que define uma cor cinza escuro para a rocha. A composição mineralógica formada por quartzo, ortoclásio, plagiocásio, biotita, anfibólio e opacos (Fotomicrografia 4.4). Quatro zircões desta amostra indicam uma idade de cristalização de $1424 \pm 12 \mathrm{Ma}$ (Figura 4.5).

97-106 Granodiorito Gnáissico Guapé. Esta rocha foi coletada no mesmo afloramento da amostra 97-105, de forma que a amostra 97-106 esta englobada pela encaixante (97-105) sendo que as duas apresentam contato difuso: irregular onde o contato é ortogonal a foliação gnáissica e contato retilíneo onde a foliação é paralela. As duas rochas apresentam foliação concordante, textura com matriz fina e fenocristais de ortoclásio. Em lâmina fenocristais de ortoclásio são bordejados por uma matriz composta por quartzo, ortoclásio, plagioclásio, biotita e anfibólio (Fotomicrografia 4.5). Quatro frações desta amostra apresentam uma idade U/Pb (intercepto superior) de 1425 $\pm 12 \mathrm{Ma}$ (Figura 4.6). 


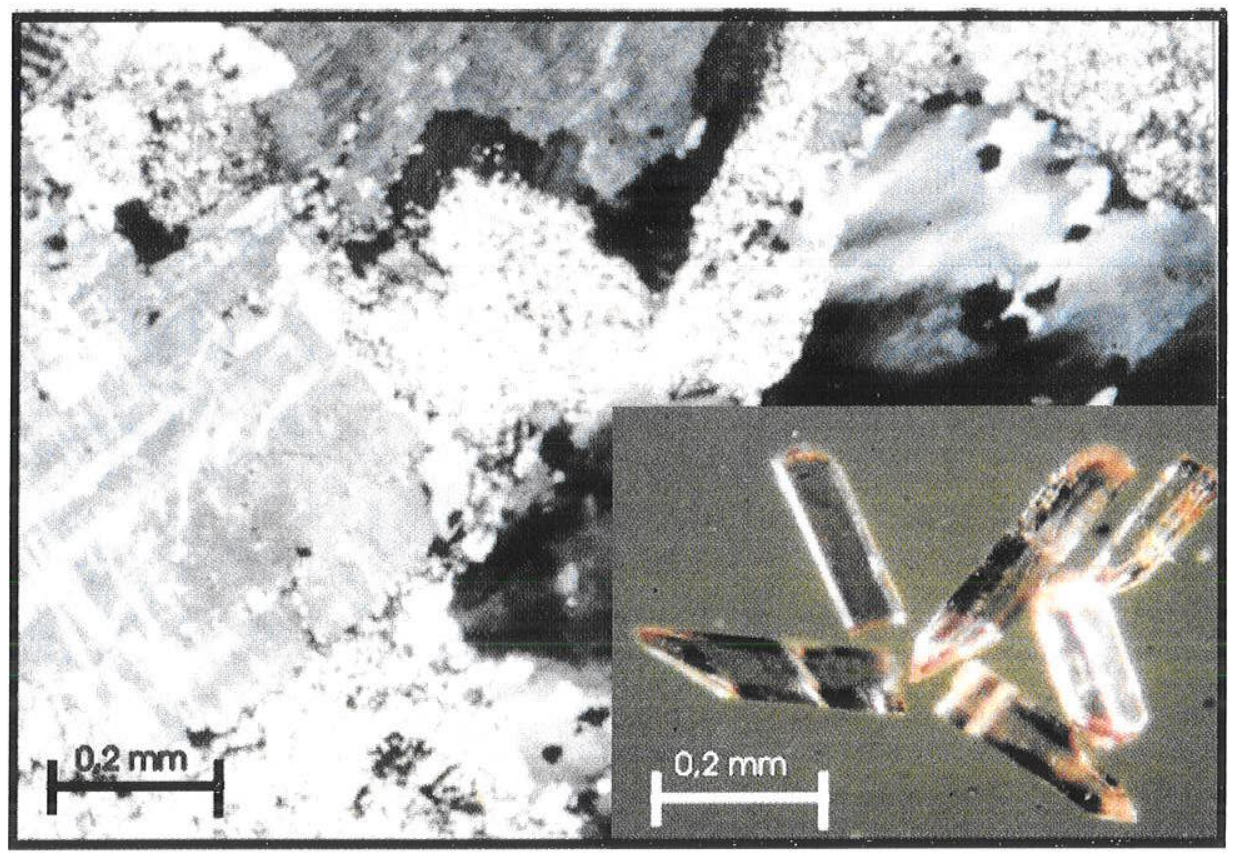

Fotomicrografia 4.1. Detalhe em lâmina do Tonalito Lavrinha (amostra 97-113). Os zircões analisados são translúcidos, caramelados e alongados (5:1).

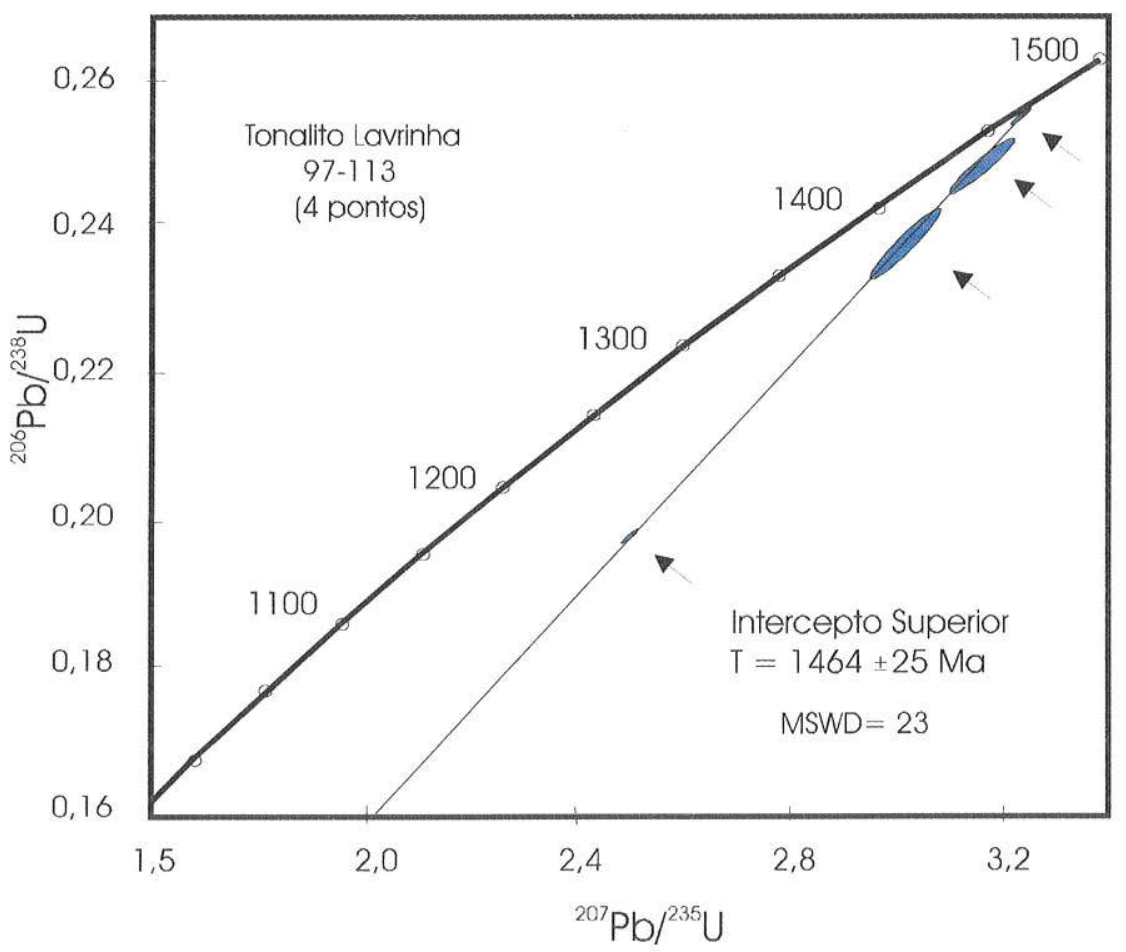

Figura 4.2. Diagrama da concórdia para o Tonalito Lavrinha (amostra 97-113). Quatro frações desta amostra foram analisadas e indicam uma idade concordante no intercepto superior de $1464 \pm 25 \mathrm{Ma}$. Intercepto inferior forçado a 0 . 


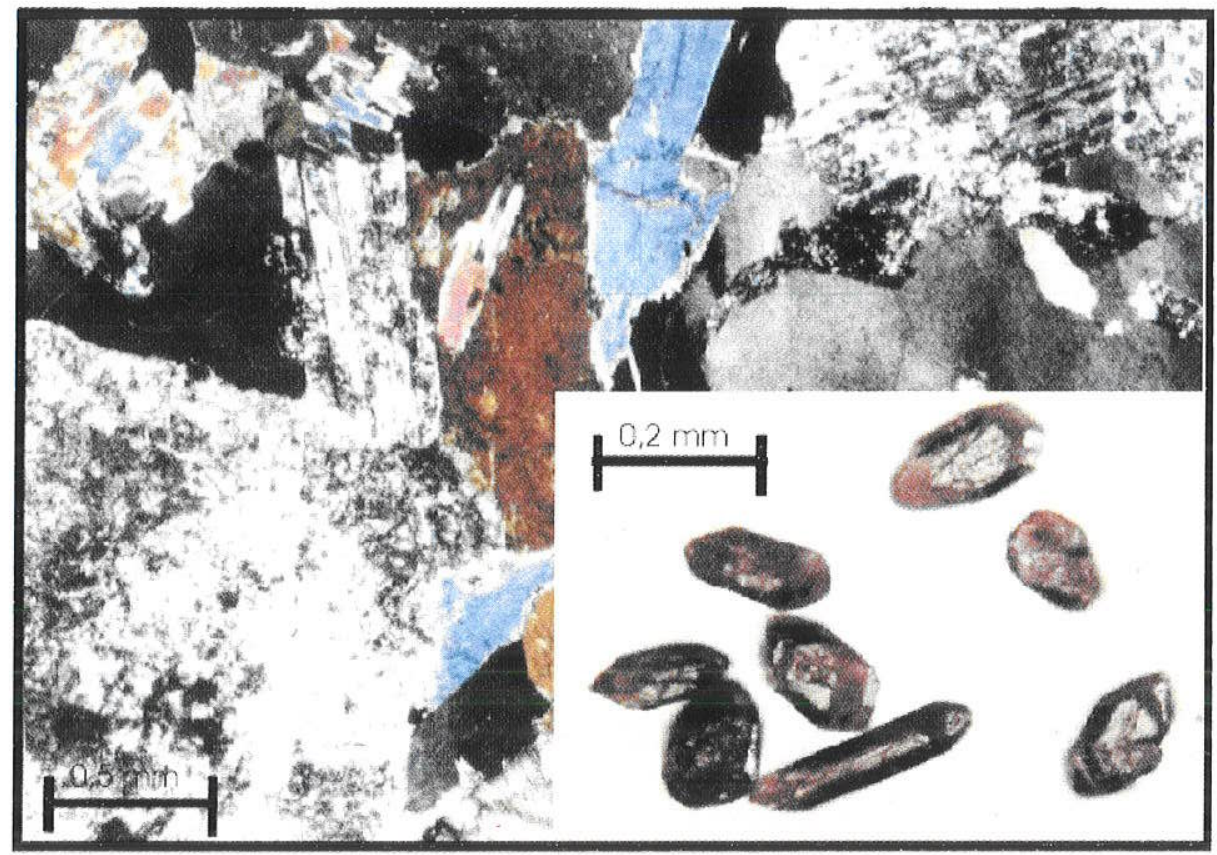

Fotomicrografia 4.2. Detalhe em lâmina do Tonalito Pau-a-Pique (amostra 97-140). Os zircões analisados são pouco translúcidos, podendo ter pirâmides bem formadas ou serem arredondados $(2: 1)$ ou pouco alongados $(4: 1)$.

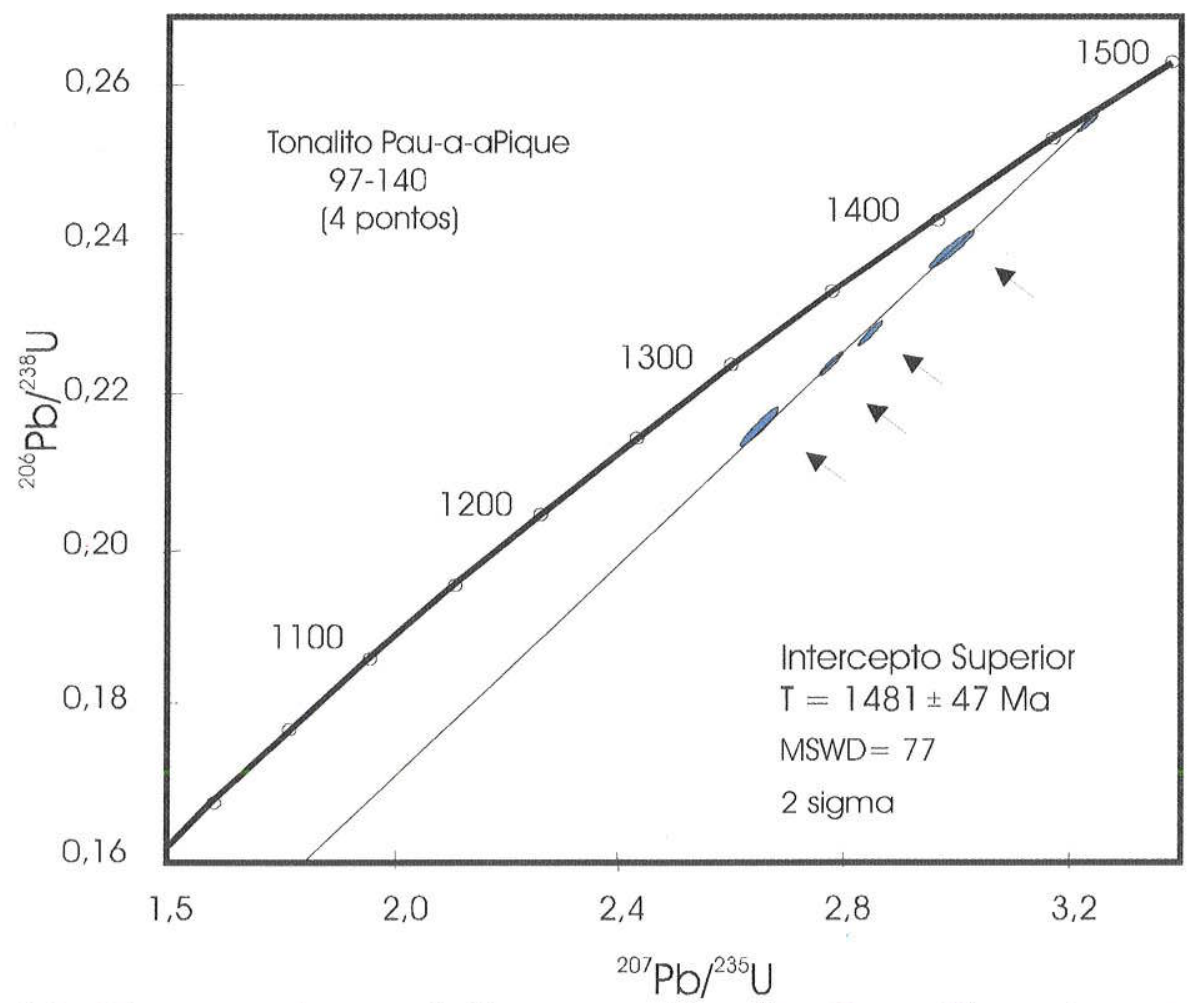

Figura 4.3. Diagrama da concórdia para o Tonalito Pau-a-Pique (amostra 97-140). Quatro zircões concentrados desta amostra indicaram uma idade de (intercepto superior) $1481 \pm 47 \mathrm{Ma}$. Intercepto inferior forçado a 0 . 


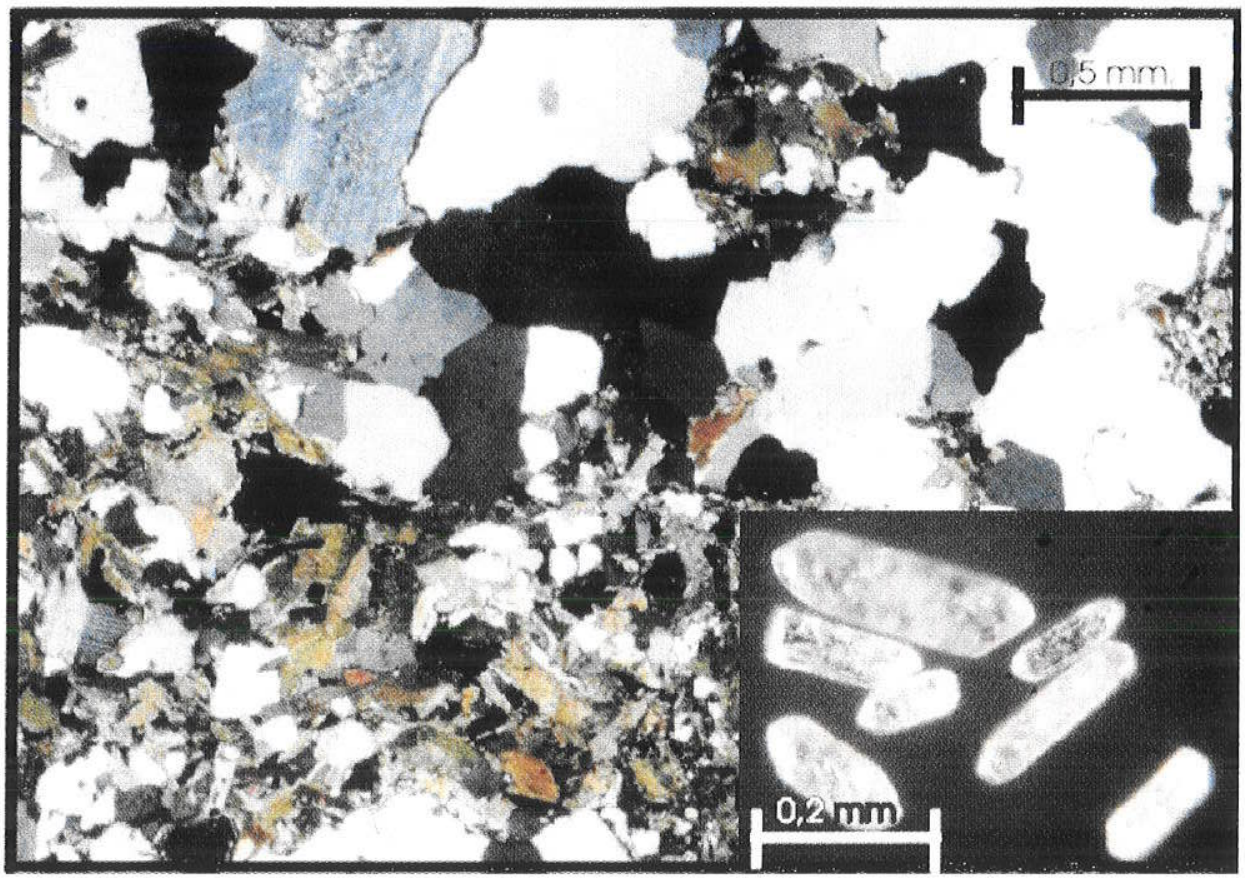

Fotomicrografia 4.3. Detalhe em lâmina do Granodiorito Guapé (amostra 97-102). Os zircões analisados são leitosos a translúcidos, variando os tamanhos mas mantendo as proporções (3:1 a 4:1).

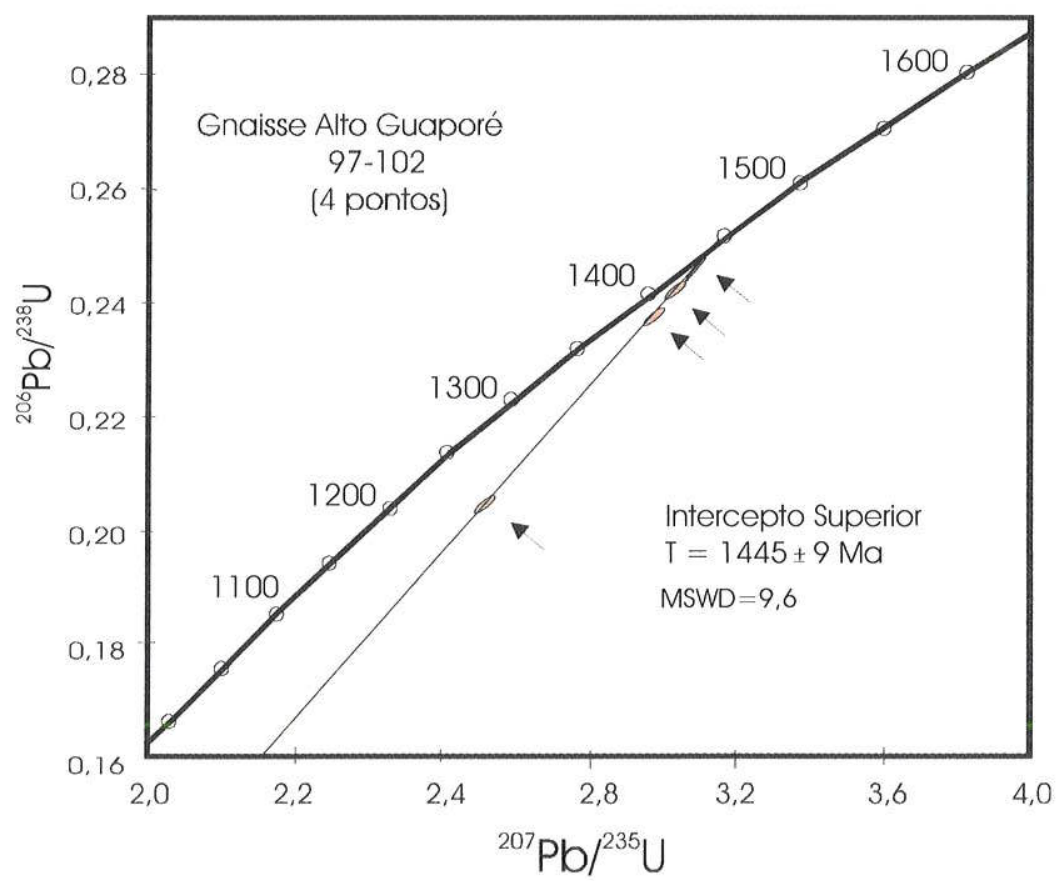

Figura 4.4. Diagrama da concórdia para o Granodiorito Guapé (amostra 7-102). Cinco zircões concentrados desta amostra apresentam resultados que indicam um intercepto superior de $1445 \pm 9 \mathrm{Ma}$. Intercepto inferior forçado a 0 . 


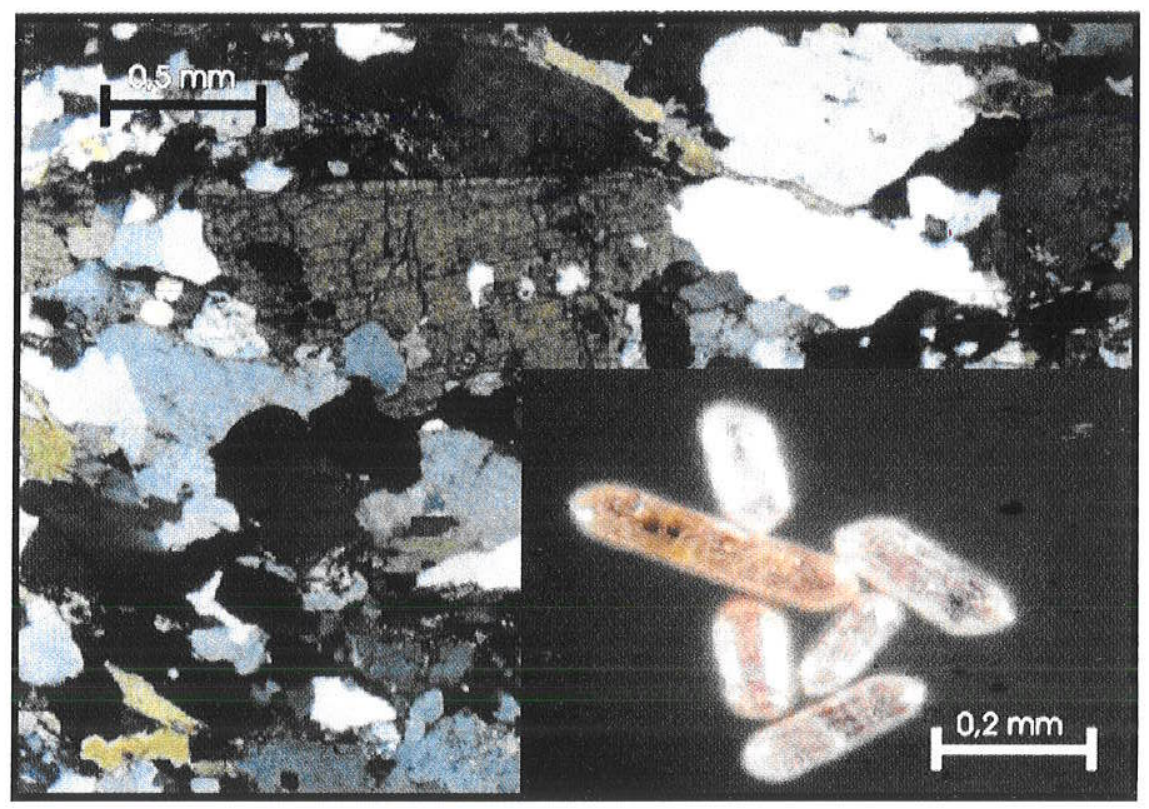

Fotomicrografia 4.4. Detalhe em lâmina do Granodiorito Guapé (amostra 97-105). Os zircões analisados são translúcidos, com cores variando de levemente amarelado a caramelo. As proporções variam entre 2:1 (mais claros) a 5:1 (mais coloridos).

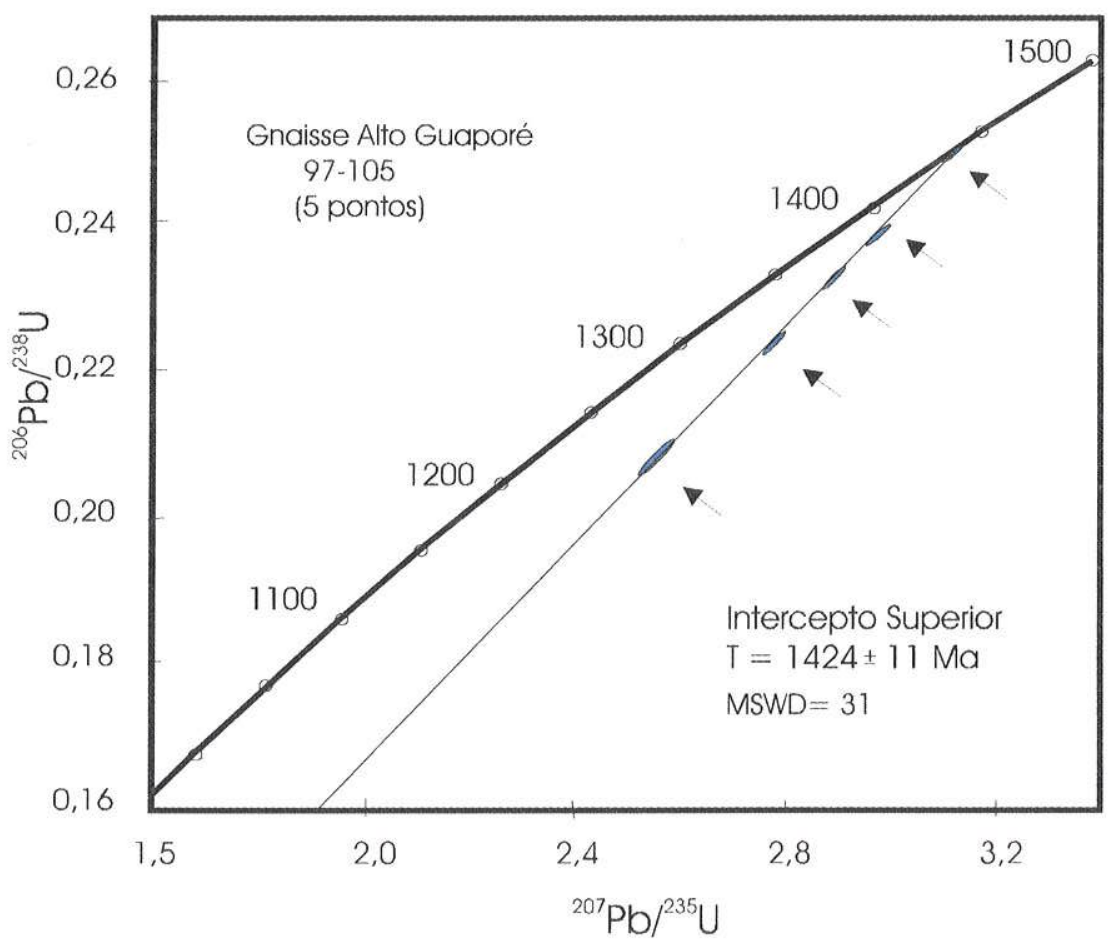

Figura 4.5 . Diagrama da concórdia para o Granodiorito Guapé (amostra 97-105). Quatro zircões desta amostra indicam uma idade de cristalização de $1424 \pm 11 \mathrm{Ma}$. Intercepto inferior forçado a 0 . 


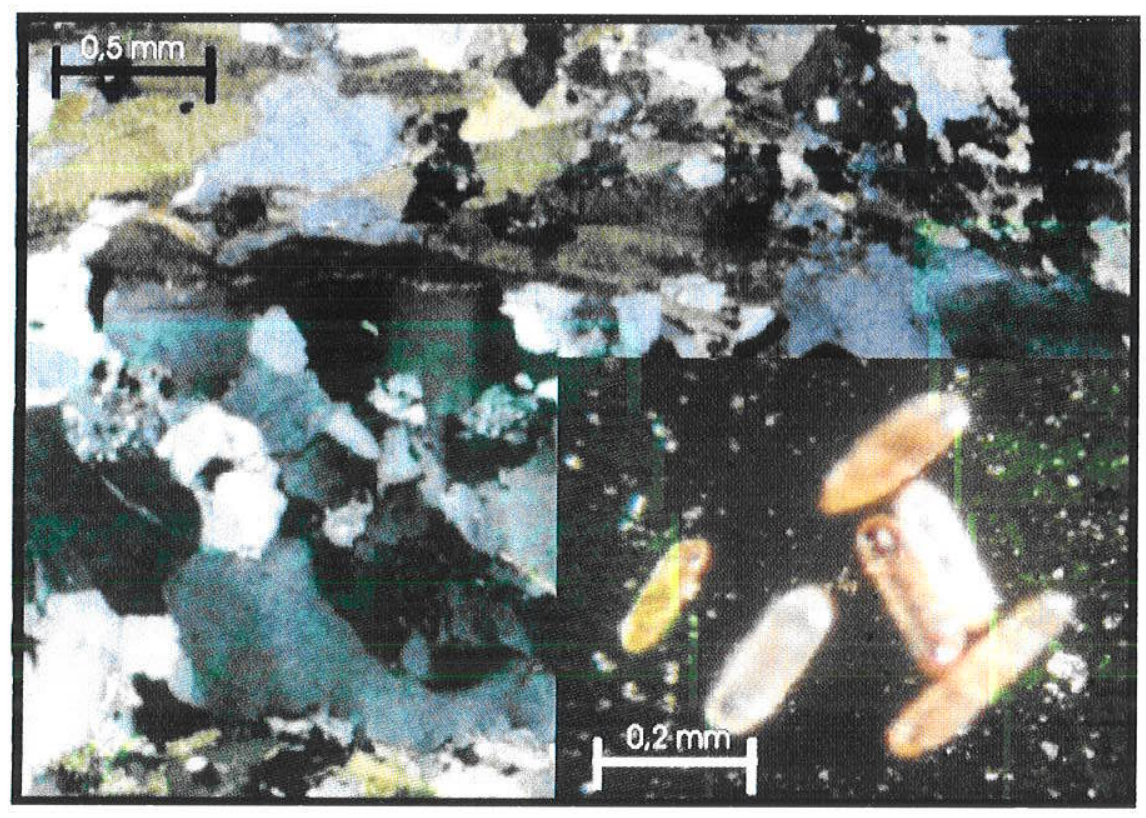

Fotomicrografia 4.5. Detalhe em lâmina do Granodiorito Guapé (amostra 97-106). Os zircões são analisados compreendem uma população homogênea formada por grãos translúcidos, claros a amarelados, com proporcão média 3:1.

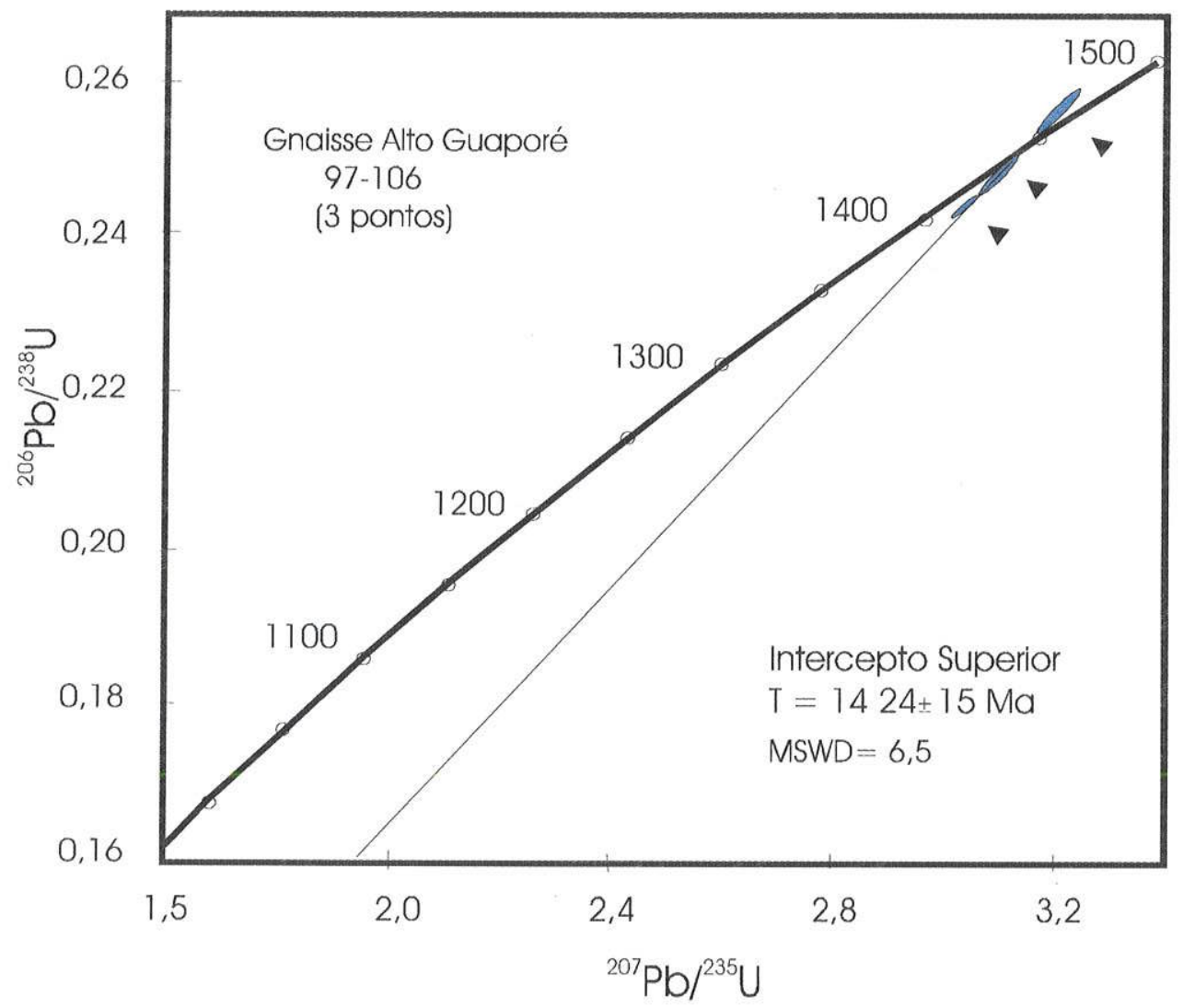

Figura 4.6. Diagrama da concórdia para a amostra Granodiorito Guapé (97-106). A idade indicada é de $1424 \pm 15$ Ma. Intercepto inferior forçado a 0. 


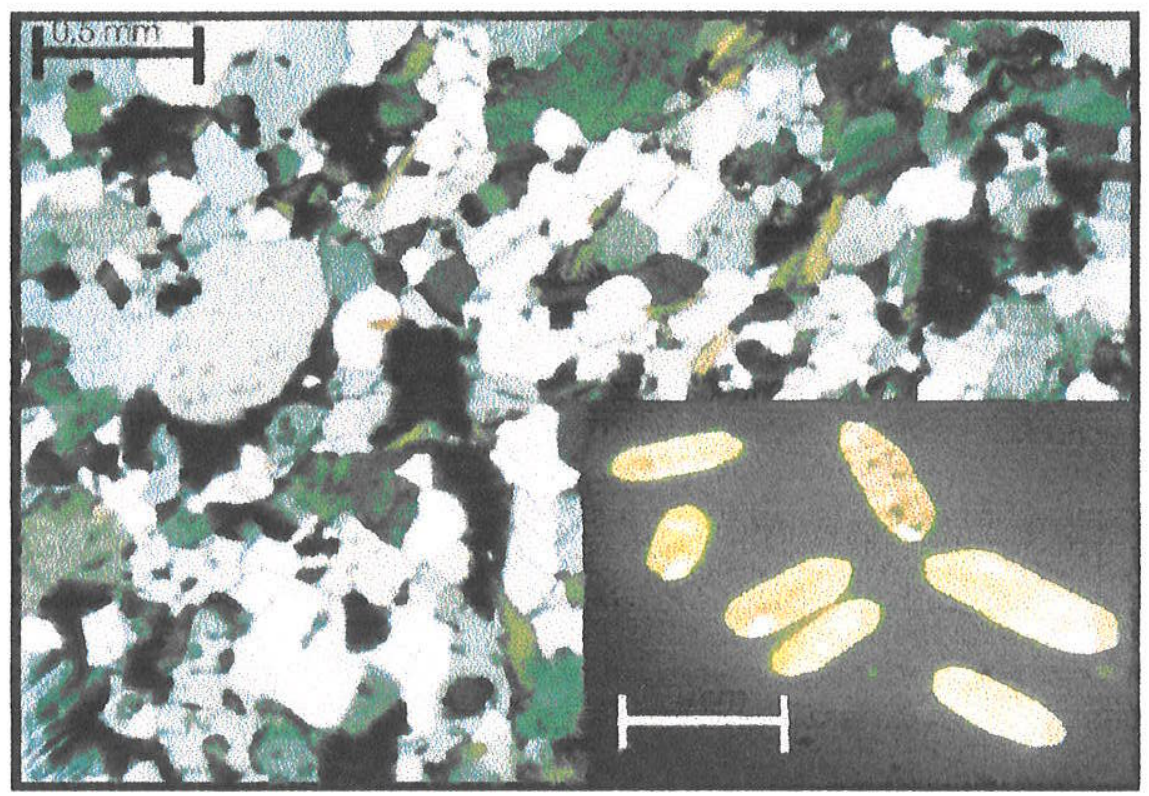

Fotomicrografia 4.6. Detalhe em lâmina do Granodiorito Guaporé (amostra 97-108). Os zircões analisados são leitosos, amarelados, arredondados (2:1) a alongados (4:1).

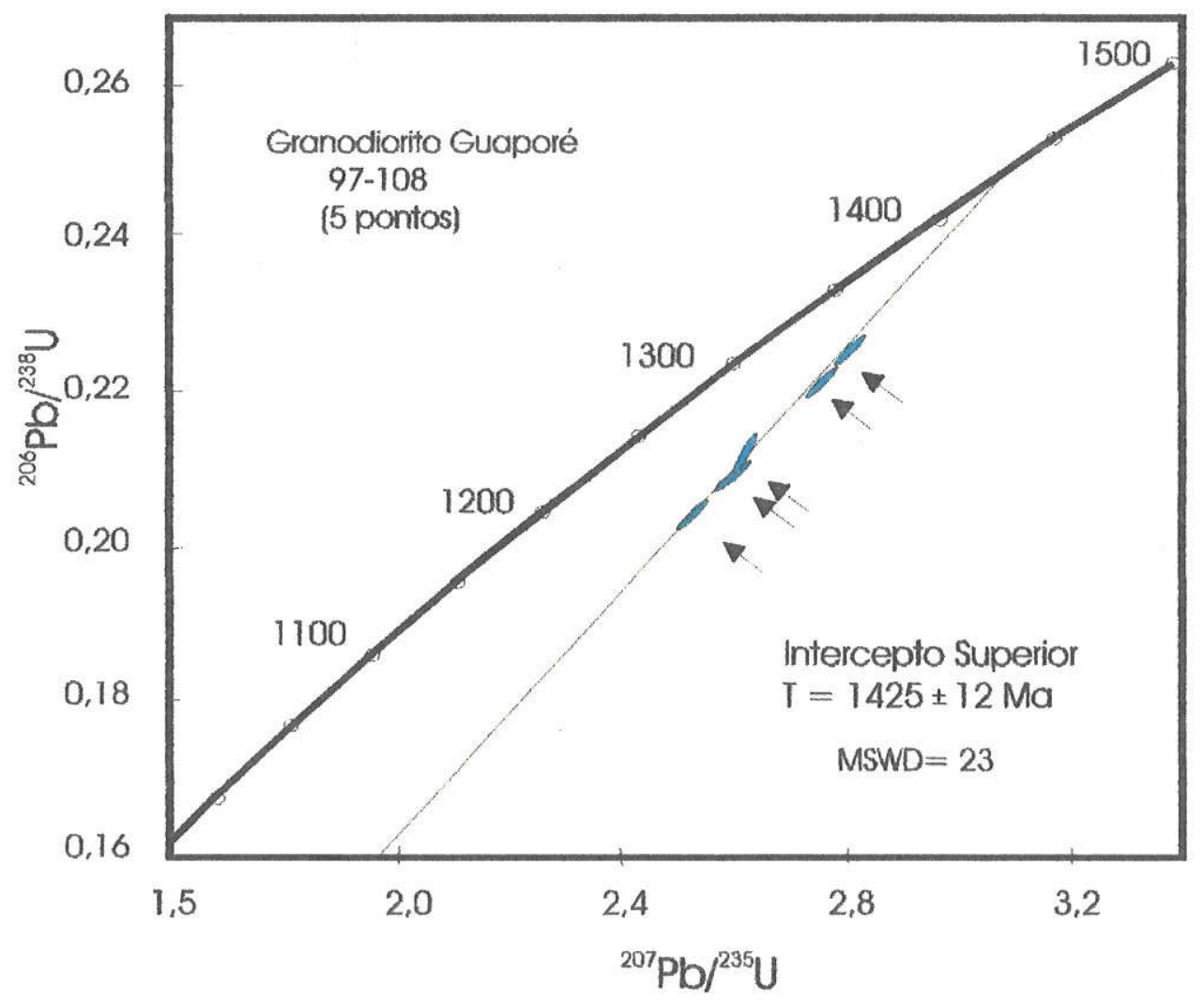

Figura 4.7. Diagrama da concórdia para a amostra Granodiorito Guapé (97-108). A idade indicada é de $1425 \pm 12 \mathrm{Ma}$. Intercepto inferior forçado a 0 . 
Rochas Graníticas

As rochas graníticas têm uma distribuição homogênea no batólito (Figura 4.1). As amostras foram coletadas em cortes de estrada da BR 364 (amostras 97-115 e 97-101), no Garimpo Maraboa (97-141), na Vila de Cardoso (97-120W, 97-120E e 97-120P), e ao sul na Fazenda Ellus (amostras 97-168 e 97-169).

97-115-Granito-Gnaisse Santa Helena. Esta denominação foi mantida para esta amostra em função dela ter sido coletada na área de mapeamento de Menezes et al., (1993). Na Folha Pontes e Lacerda esta unidade apresenta pouca variação e está representada por granitos foliados cinza-avermelhados a róseos, com granulometria média a grossa. Compreendem granito-gnaisses, biotita-gnaisses e magnetita-gnaisses. Esta amostra tem composição granítica (Fotomicrografia 4.7), com cor cinza a rosa e intensa foliação. A mineralogia principal é quartzo, k-feldspato, plagioclásio, biotita e anfíbólio. Uma isócrona $\mathrm{Rb} / \mathrm{Sr}$ (rocha total) para rochas do mesmo afloramento indicou a idade de 1318 $\pm 24 \mathrm{Ma}$ (Geraldes, 1996). Quatro frações desta amostra indicam a idade U/Pb de $1433 \pm$ $06 \mathrm{Ma}$ (Figura 4.8).

97-120W-Magnetita-Granito Cardoso. Esta rocha aflora a $4 \mathrm{~km}$ a oeste de Cardoso, mas tem ampla distribuição na área de coleta em blocos e lajedos e faz contato intrusivo com o augen-gnaisse descrito a seguir (amostra 97-120W). Cristais de magnetita podem ser vistos a olho nu, entre cristais de quartzo e ortoclásio e plagioclásio (Fotomicrografia 4.8). Não é observada foliação em amostra de mão, porém em lâmina observa-se orientação de grão de biotita e anfibólio. Os resultados $\mathrm{U} / \mathrm{Pb}$ de cinco zircões, quando lançados no diagrama da concórdia apresentam a idade de $1425 \pm 15$ Ma (Figura 4.9).

97-120E Augen Gnaisse Cardoso. Em continuidade a oeste do afloramento anterior (97-120W) ocorrem lajes decamétricas de augen gnaisse de composição granodiorítica (quartzo, plagioclásio, feldspato alcalino, anfibólio e biotita). Veios subcentimétricos de composição quartzo-feldspática (amostra 97-120P) apresentam trama concordante a subconcordante com a foliação do augen gnaisse encaixante (Fotografia 4.9). O contato 
com o magnetita granito (97-120W) ocorre em por zona de shear, indicando cinemática em condições altamente plásticas. A insipiente foliação do magnetita granito sugere a precocidade deste em relação ao augen gnaisse. $O$ diagrama da concórdia para a amostra 97-120E (Augen-gnaisse Cardoso) indica a idade de $1425 \pm 15$ Ma e para a amostra $97-$ $120 \mathrm{P}$ (veio quartzo-feldspático subconcardante) indica a idade em torno de $1425 \mathrm{Ma}$. Porém uma fração da amostra 97-120P indica a idade de 1389 Ma. Os resultados estão lançados em um mesmo diagrama para efeito de comparação (Figura 4.10).

Curiosamente, a distribuição dos pontos analíticos no diagrama da concórdia para a amostra 97-120E indicou que os zircões mais concordantes são os grãos maiores (e mais pesados). Isto sugere que, no caso desta rocha, quanto menor o tamanho do grão, maior a perda de chumbo ocorrida através da estrutura cristalina, provocando o distanciamento dos pontos analíticos em relação a concórdia. A variação de tamanho dos grãos de zircão pode ser observada na Fotomicrografia 4.9.

97-135 Granito Santa Elina. A exposição desta rocha pode ser observada na estrada entre Nova Aliança e a Mina Santa Elina e em cortes da rodovia 364. Estas rochas apresentam as características comuns de serem isotrópicas, com cor rosa acinzentada e a presença de duas micas (biotita e muscovita) na sua paragênese mineral. Ortoclásio e plagioclásio estão sericitizados e quartzo e anfibólio completam mineralogia (Fotomicrografia 4.10). Quatro frações de zircões quando lançados no diagrama da concódia apresenta a idade no intercepto superior 1436 $\pm 6 \mathrm{Ma}$ (Figura 4.11).

97-141 Granito Maraboa. Esta unidade corresponde a uma área mapeada como Granito Gnaisse Santa Helena por Menezes et al., (1993) É representado por um corpo alongado situado no limite SE da Folha Pontes e Lacerda. Diferentemente dos outros corpos graníticos desta unidade, não apresenta foliação, o que lhe confere um caráter póscinemático. Esta unidade compreende granitos róseo-avermelhados, porfiróides, de granulação grossa (com cristais de qurtzo e feldspato de até $5 \mathrm{~cm}$ ) isótropos, inequigranulares. A composição mineralógica é quartzo, ortoclásio, palgioclásio, biotita e anfibólio (Fotomicrografia 4.11).

A idade disponível para esta unidade é de uma isócrona preliminar $\mathrm{Rb} / \mathrm{Sr}$ (rocha total) de $1275 \pm 125 \mathrm{Ma}$ com razão inicial de 0,711 , resultado este interpretado como 
indicativo de origem crustal (Geraldes, 1996). Os resultados U/Pb para 5 frações de zircões desta amostra quando lançados no diagrama da concórdia, apresentam a idade (intercepto superior) $1449 \pm 7 \mathrm{Ma}$ (Figura 4.12).

97-168 Granito Fazenda Ellus. Esta rocha aflora na fazendo homônima, entre Cardoso e a sede da fazenda na forma de grandes matacões e lajedos nas laterais da estrada de terra. Estes afloramentos são observados nas áreas topograficamente mais baixas em relação às cristas de serras constituídas de sediementos do Grupo Aguapeí deformadas, sendo que as rochas graníticas são o embasamento destes sedimentos na região. A rocha apresenta orientação definida pelos cristais de biotita e anfibólio além de quartzo, ortoclásio e plagioclásio (Fotomicrografia 4.12). Resultados $\mathrm{U} / \mathrm{Pb}$ para cinco frações de zircões desta amostra indicam a idade no intercepto superior de $1437 \pm 12$ Ma (Figura 4.13).

97-169 Granito Garimpo Ellus. Esta rocha aflora na fazendo homônima, na porção sul do batólito Santa Helena. A amostra apresenta-se fraturada, sericitizada, sulfetada, e mineralizada a ouro. O local de coleta é constituído por open pit (permitindo uma exposição das rochas por mais de duas centenas de metros) onde o granito é lavrado e transportado para as plantas de beneficiamento para concentração de ouro. A mineralogia principal é constituída por quartzo, anfibólio e biotita. Em lầmina o feldspato encontra-se totalmente sericitizado (Fotomicrografia 4.13). Quatro frações de zircões desta amostra foram analisadas para datação $\mathrm{U} / \mathrm{Pb}$ e os resultados quando lançados no diagrama da concórdia indicam a idade de cristalização de $1444 \pm 21$ Ma (Figura 4.14), indicando que o processo hidrotermal responsável pela mineralização a ouro não atingiu atemperatura de homogeneização isotópica dos sistemas $\mathrm{U} / \mathrm{Pb}$. 


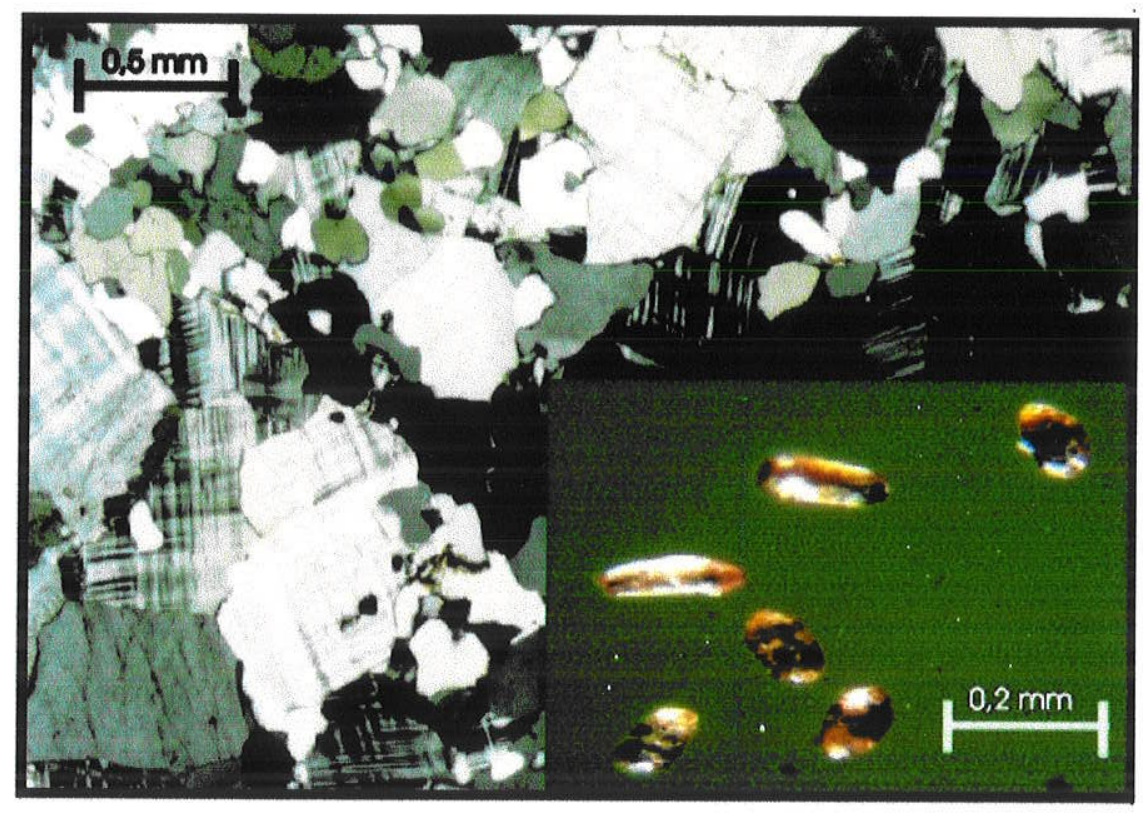

Fotomicrografia 4.7. Detalhe em lâmina do Granito-Gnaisse Santa Helena (amostra 97115). Os zircões analisados são translúcidos, caramelados, com forma variando entre arredondados (2:1) a alongados (3:1).

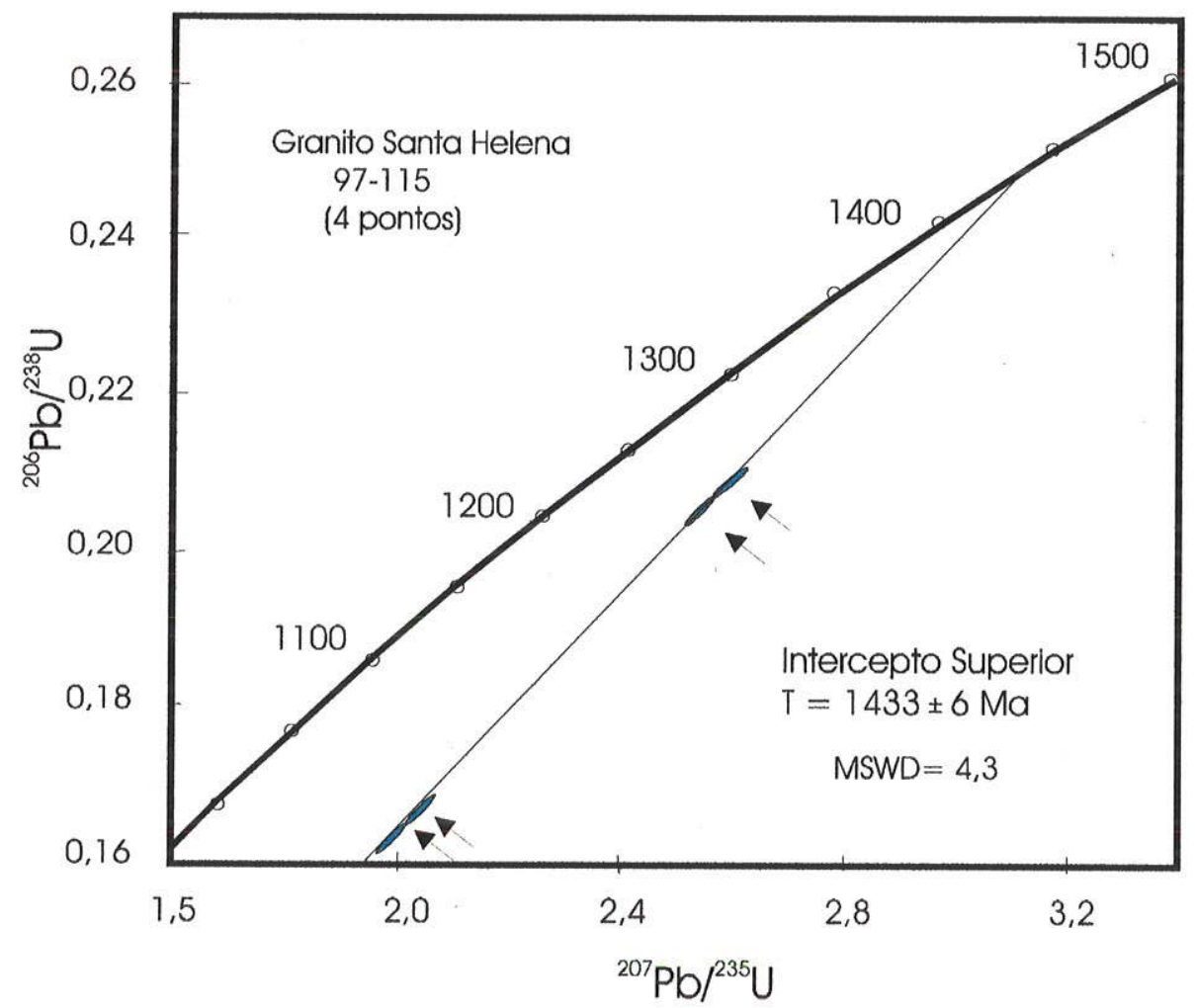

Figura 4.8. Diagrama da concórdia para o Granito-Gnaisse Santa Helena (amostra 97115). Quatro frações desta amostra indicam a idade de $1433 \pm 06$ Ma. Intercepto inferior forçado a 0 . 


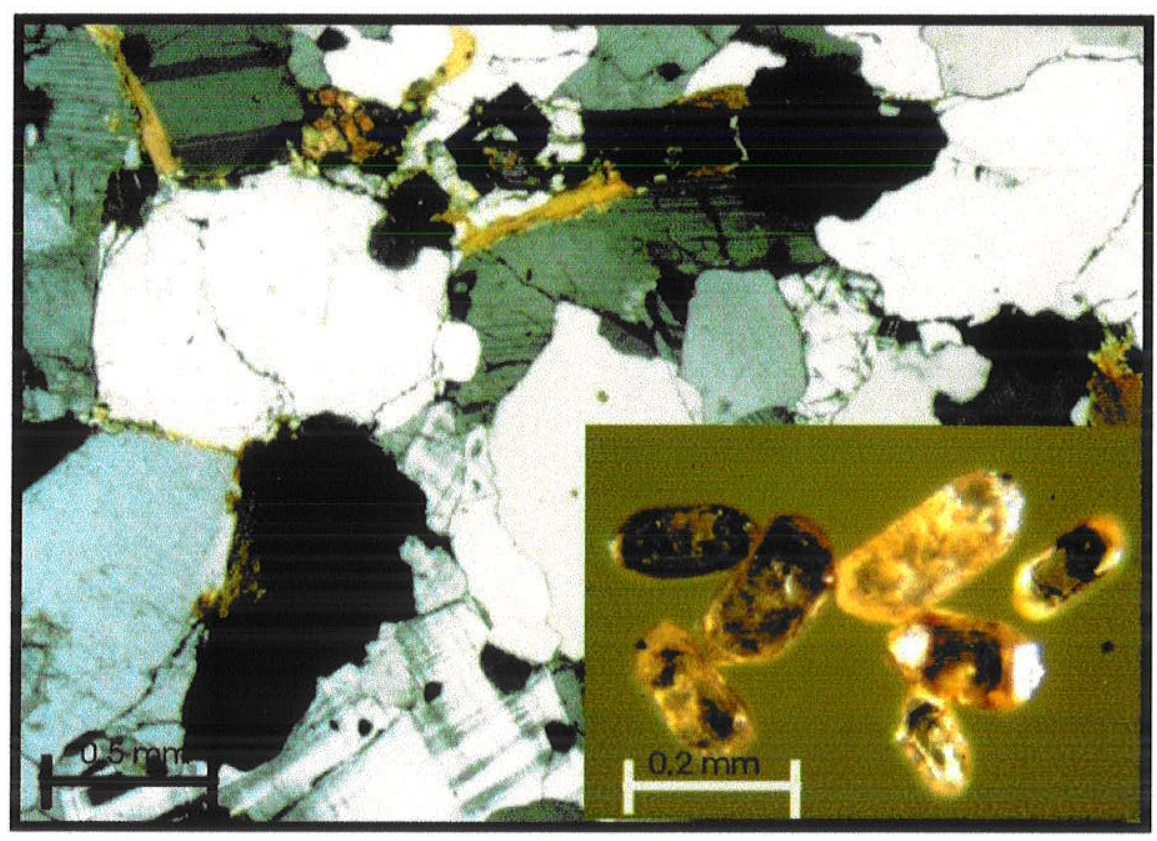

Fotomicrografia 4.8. Dealhe em lâmina do magnetita Granito Cardoso (amostra 97$120 \mathrm{~W})$. Os zircões analisados são translúcidos a levemente leitosos. Apresentam cores carameladas e terminações arredondadas (2:1 a $3: 1)$..

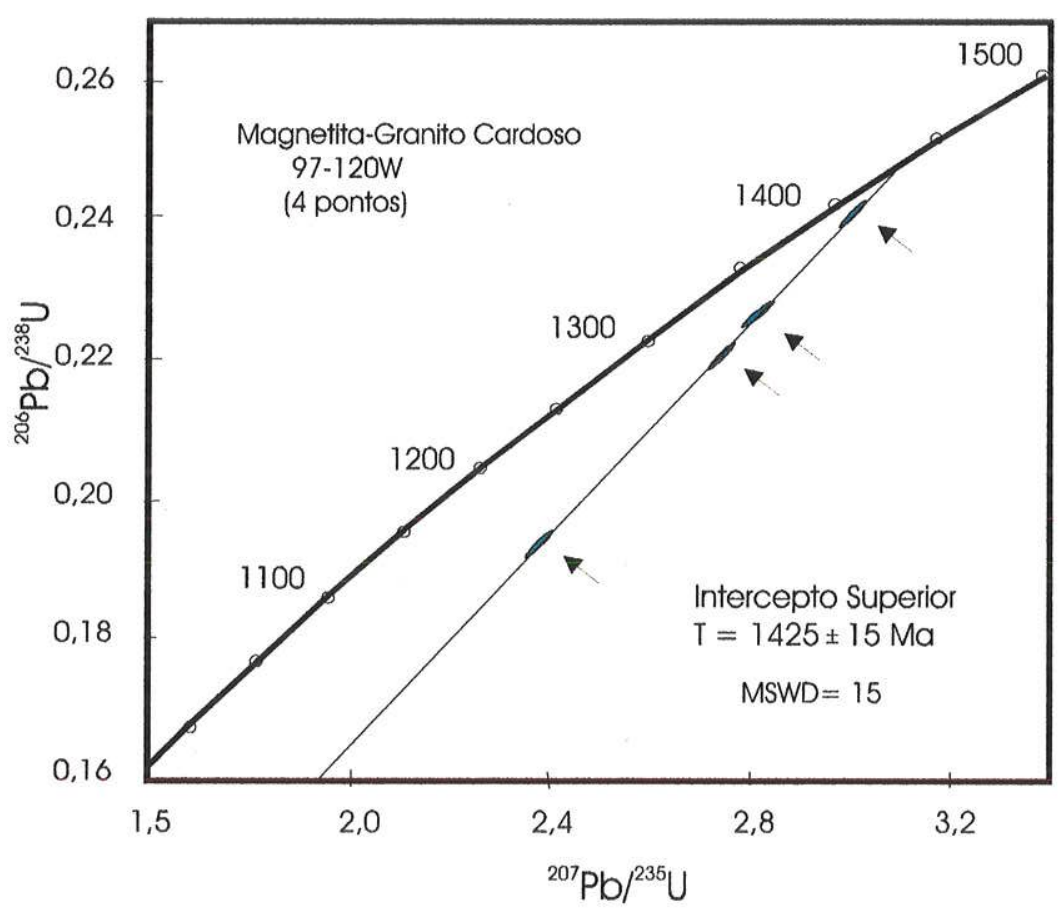

Figura 4.9. Diagrama da concórdia para a amostra 97-120W (Magnetita Granito Cardoso). Os resultados $\mathrm{U} / \mathrm{Pb}$ de cinco zircões desta amostra quando lançados no diagrama da concórdia apresentam a idade de $1425 \pm 15$ Ma. Intercepto inferior forçado a 0 . 


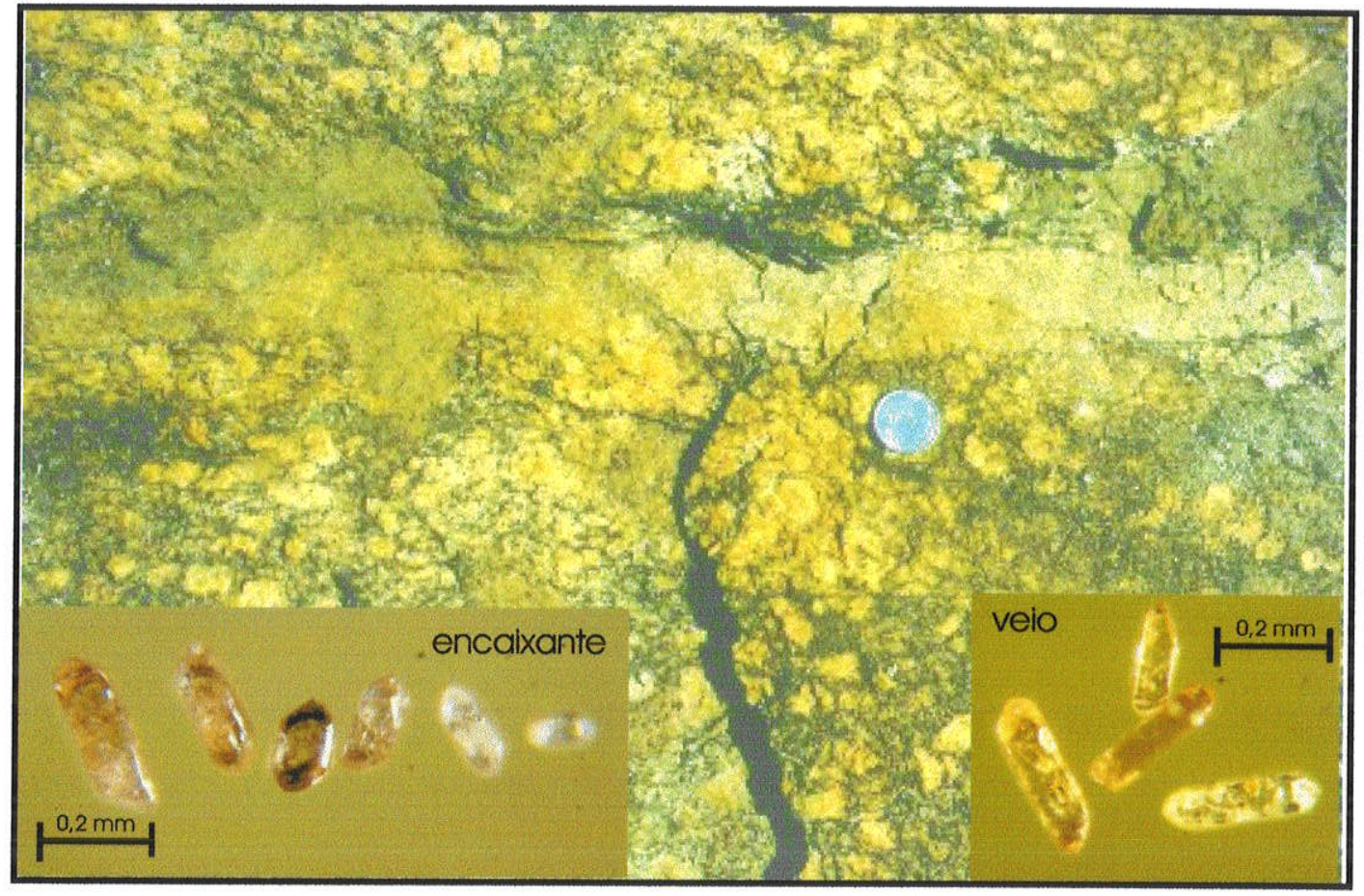

Fotografia 4.9. Detalhe do afloramento da amostra 97-120E (Augen-Gnaisse Cardoso) com veio quartzo-feldspático (amostra 97-120P) subconcordante com a foliação. Os zircões analisados da encaixante e do veio são mostrados em detalhe.

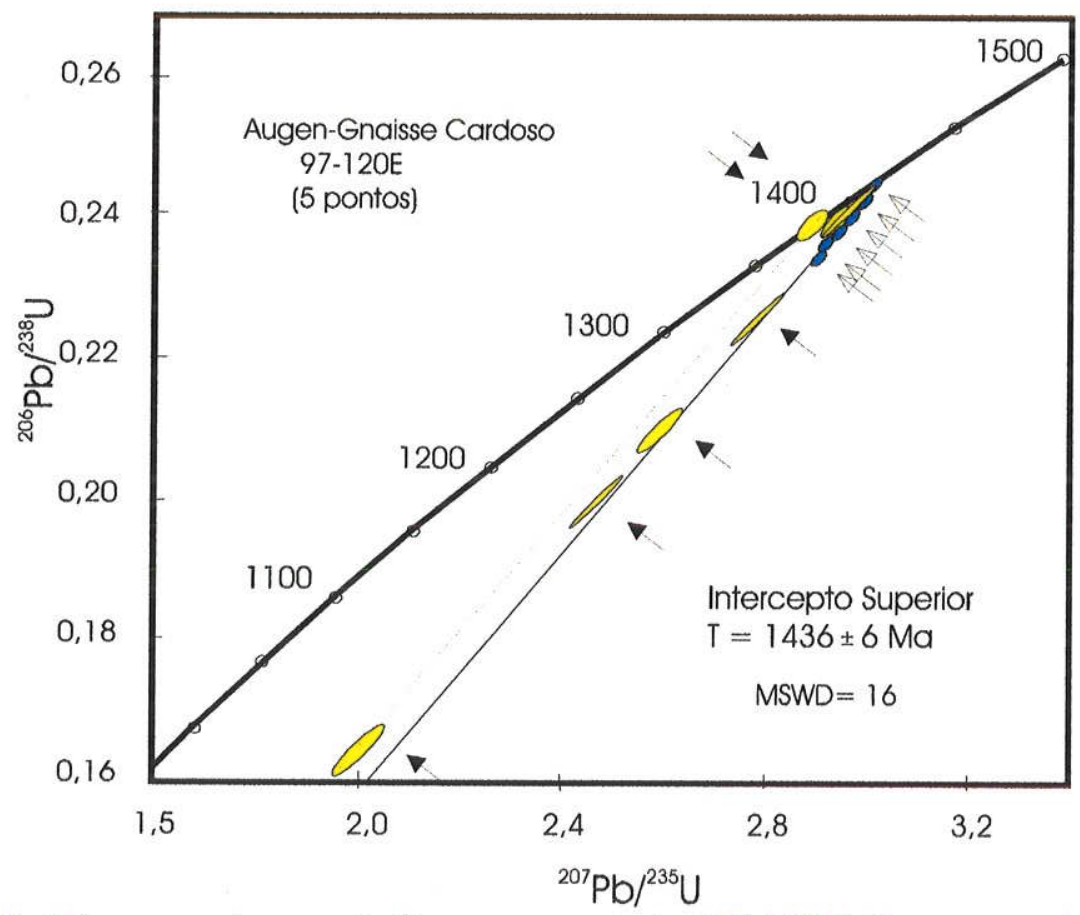

Figura 4.10. Diagrama da concórdia para a amostra 97-120E (Augen-gnaisse Cardoso) e da amostra 97-120P (veio qartzo-feldspático subconcordante). Os resultados $\mathrm{U} / \mathrm{Pb} \mathrm{da}$ amostra 97-120E (elípses azuis) apresentam a idade de $1436 \pm 15 \mathrm{Ma}$. Seis frações (elípses amarelas) obtidas no veio Qz-feldspático indica a idade em torno de $1425 \mathrm{Ma}$, e a fração concordante indica a idade de 1389 Ma. Intercepto inferior forçado a 0. 


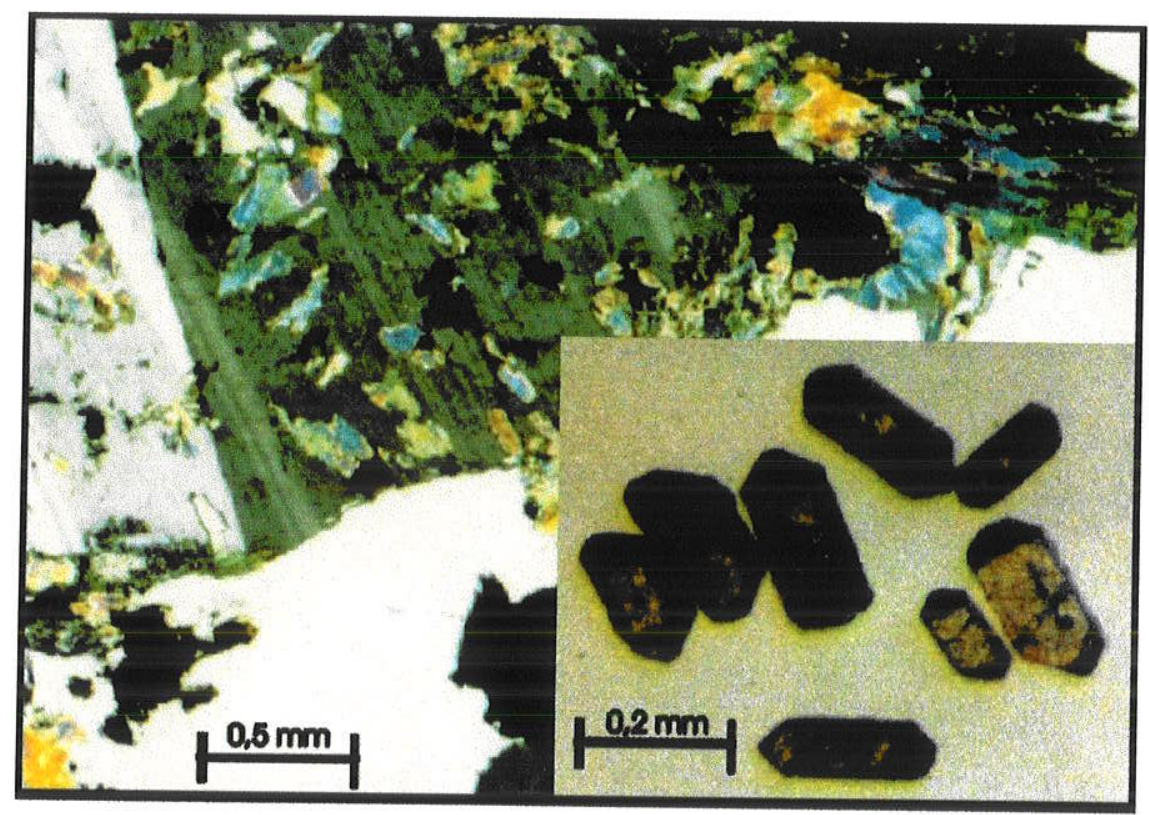

Fotomicrografia 4.10 Detalhe em lâmina do Granito Santa Elina (amostra 97-135). Os zircões analisados são pouco translúcidos, com coloração marrom a marrom escuro. Os grãos apresentam bipirâmides bem formadas e são pouco alongados (3:1).

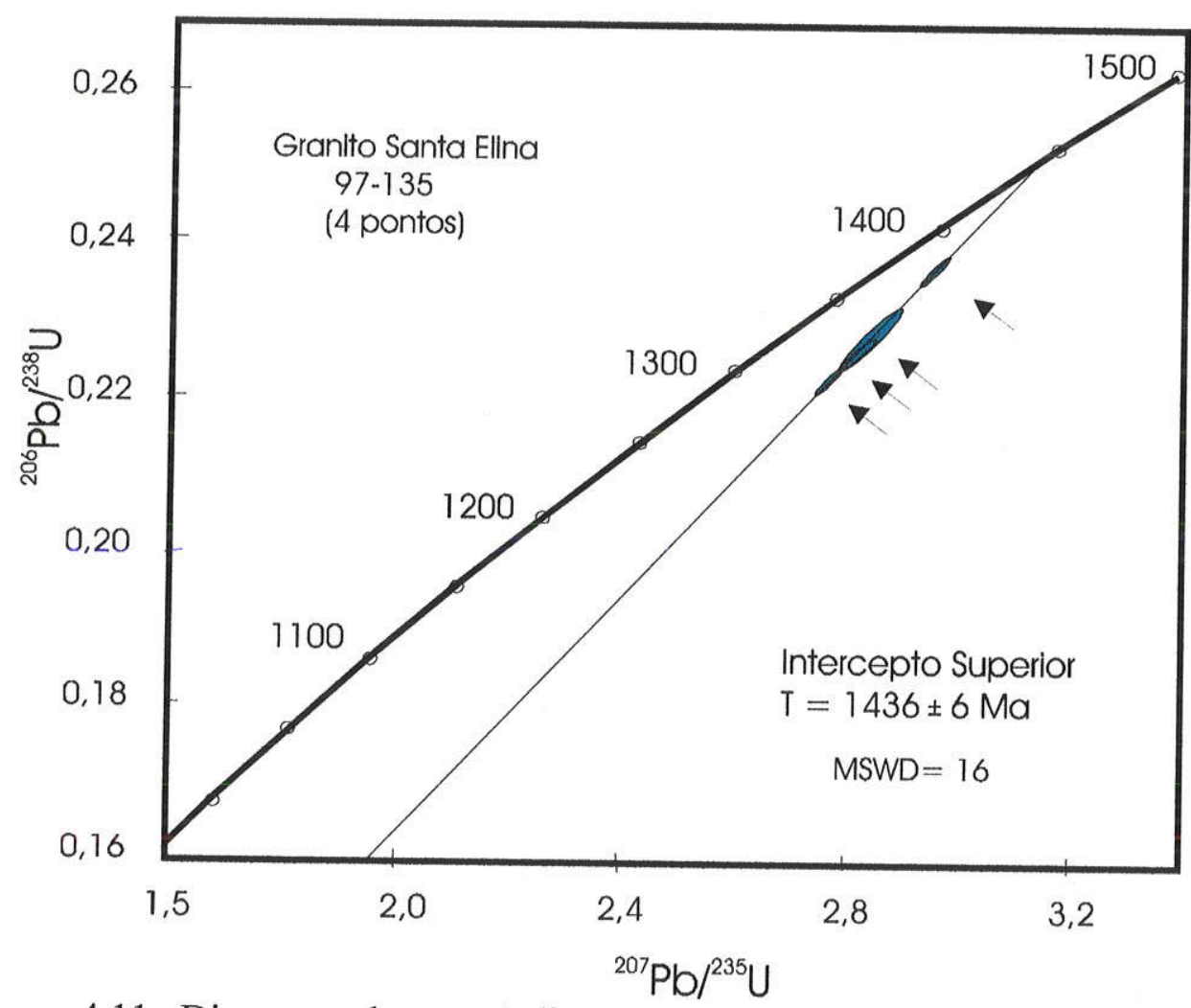

Figura 4.11. Diagrama da concórdia para o Granito Santa Elina (amostra 97-135). Quatro frações desta amostra quando lançados no diagrama da concódia apresenta a idade no intercepto superior de $1436 \pm 6 \mathrm{Ma}$. Intercepto inferior forçado a 0 . 


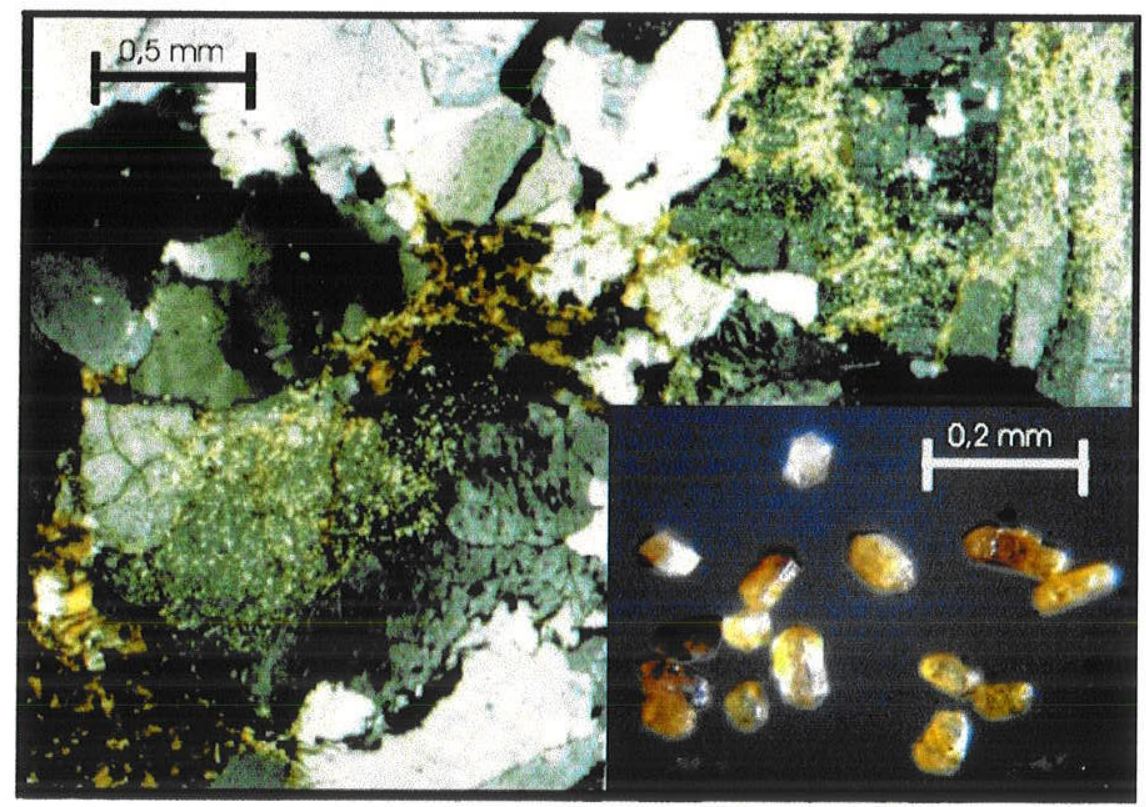

Fotomicrografia 4.11. Detalhe em lâmina do Granito Maraboa (amostra 97-141). Os zircões analisados são pouco translúcidos, de coloração caramelada e pouco alongados $(2: 1$ a $1: 1)$.

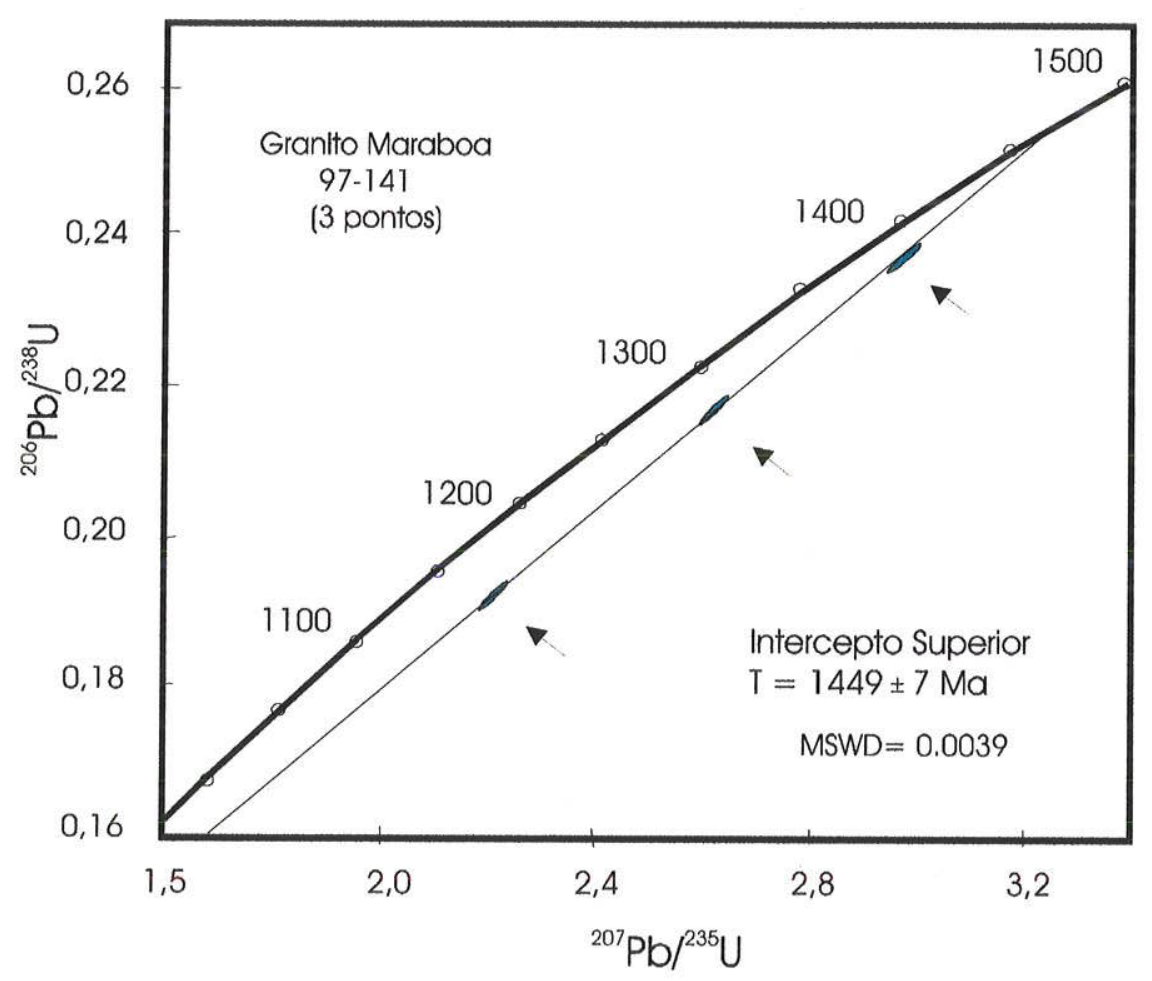

Figura 4.12. Diagrama da concórdia para o Granito Maraboa (amostra 97-141). Os resultados $\mathrm{U} / \mathrm{Pb}$ para 3 frações de zircões desta amostra quando lançados no diagrama da concórdia, apresentam a idade (intercepto superior) de 1449 $\pm 7 \mathrm{Ma}$. 


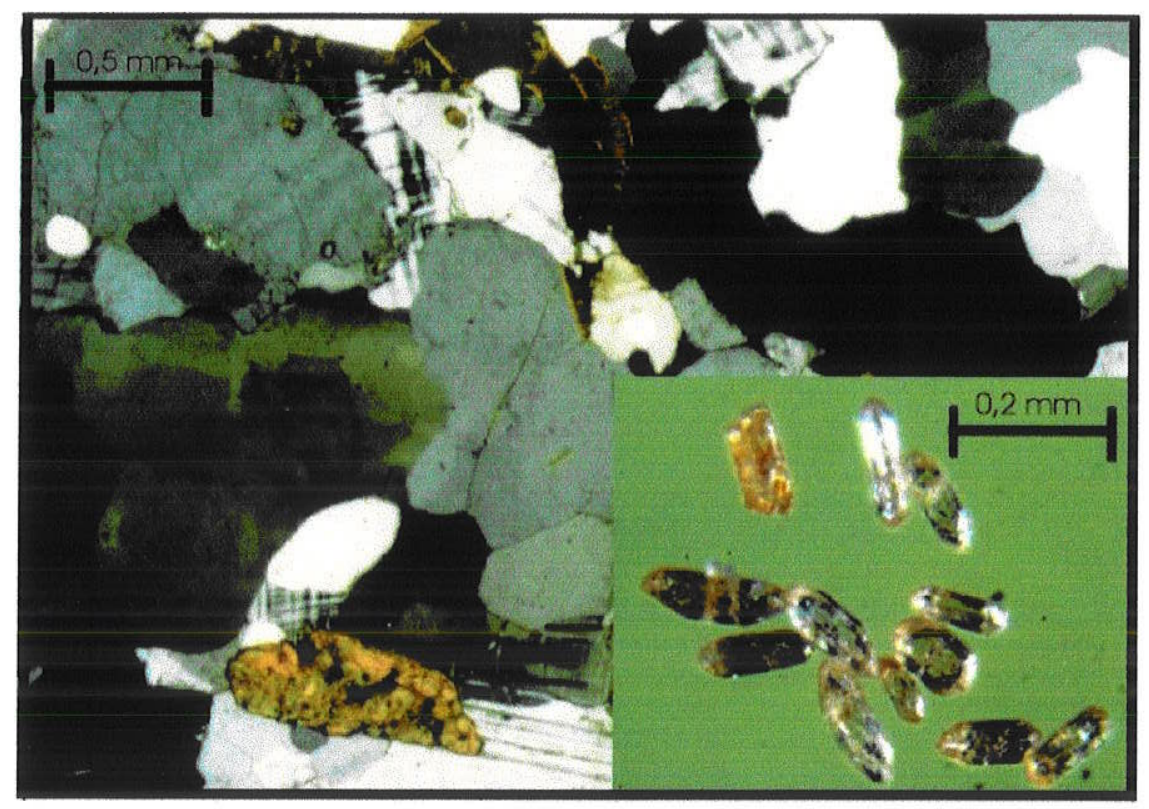

Fotomicrografia.4.12 Detalhe em lâmina do Granito Fazenda Ellus (amostra 97-168). Os zircões analisados são translúcidos com cores entre claro a caramelo, além de alongados (3:1 a 4:1).

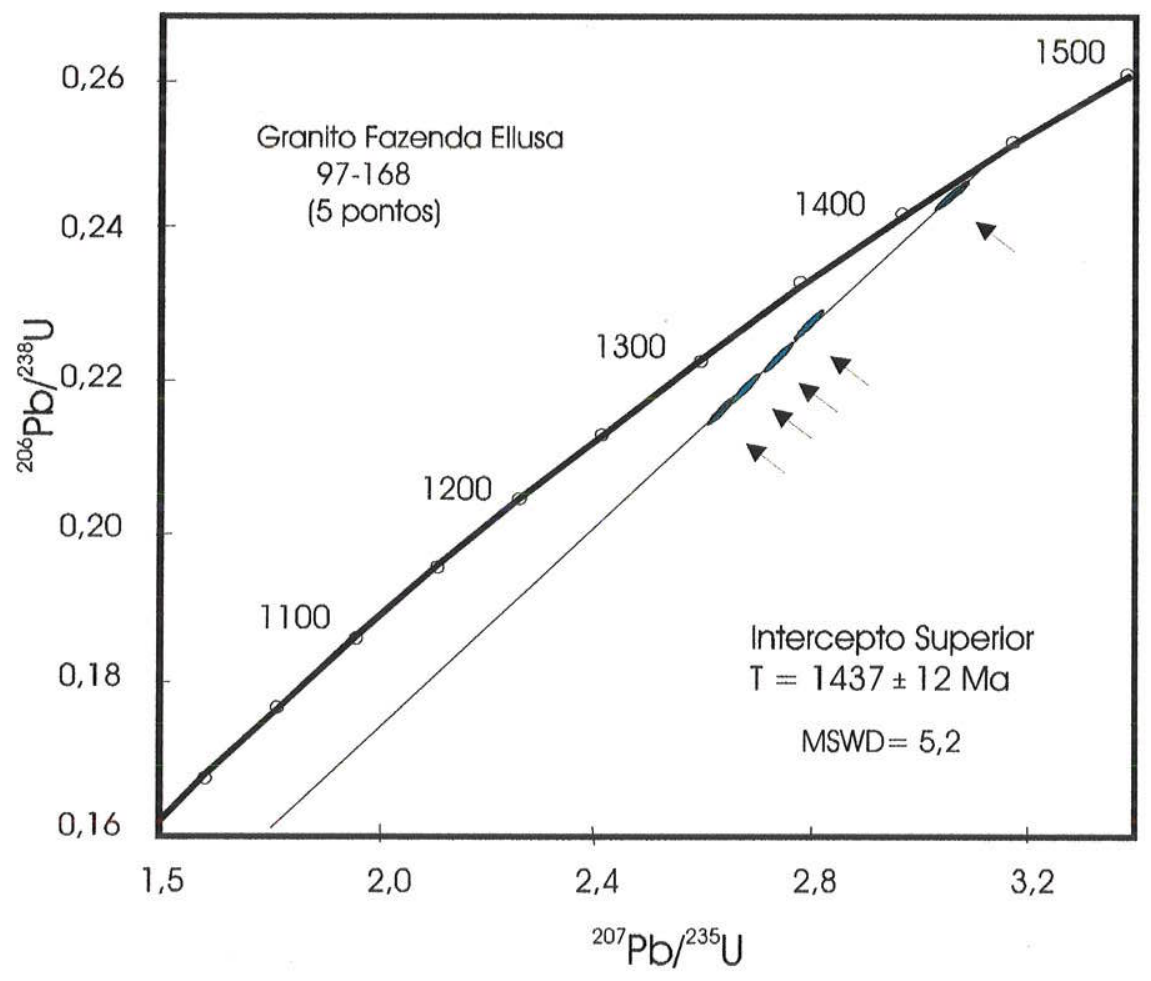

Figura 4.13. Diagrama da concórdia para o Granito Fazenda Ellus (amostra 97-168). Cinco frações de zircões desta amostra foram analisados e os resultados indicam a idade no intercepto superior de $1437 \pm 12 \mathrm{Ma}$. Intercepto inferior forçado a 0. 


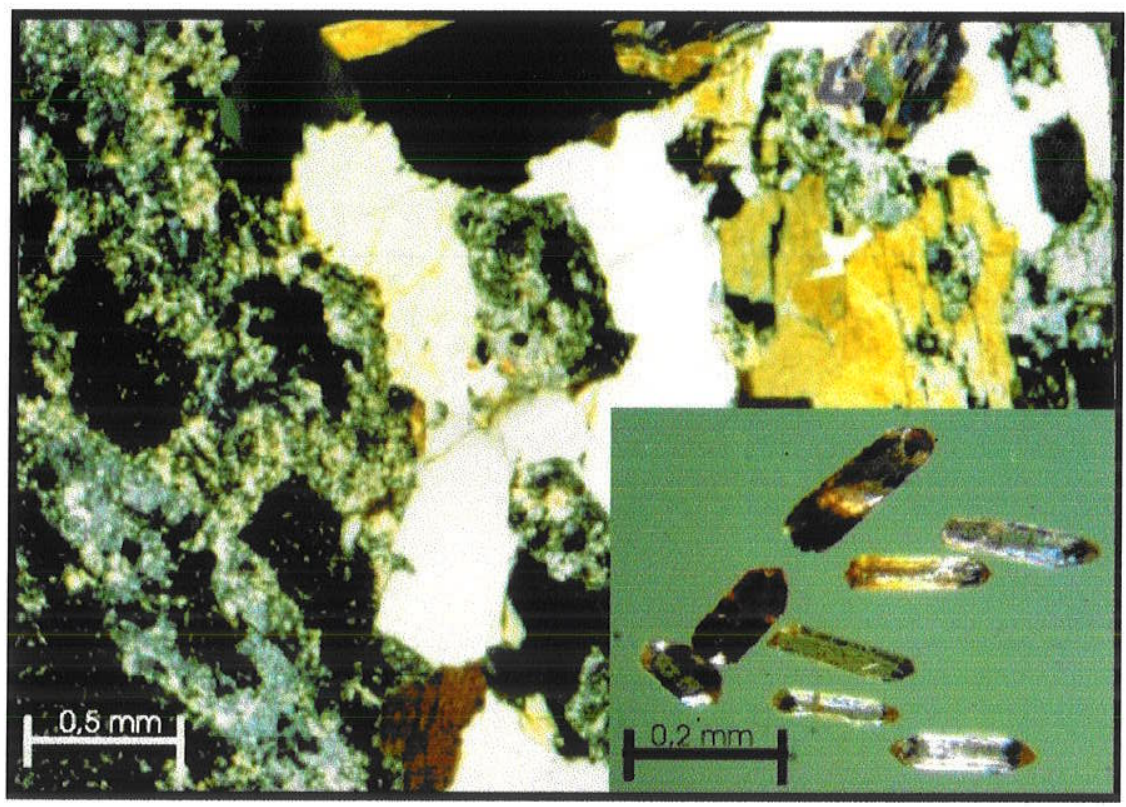

Fotomicrografia 4.13. Detalhe em lâmina do Granito Garimpo Ellus (amostra 97-169). Os zircões analisados são translúcidos com cores entre claro a caramelo, além de alongados (4:1 a 5:1).

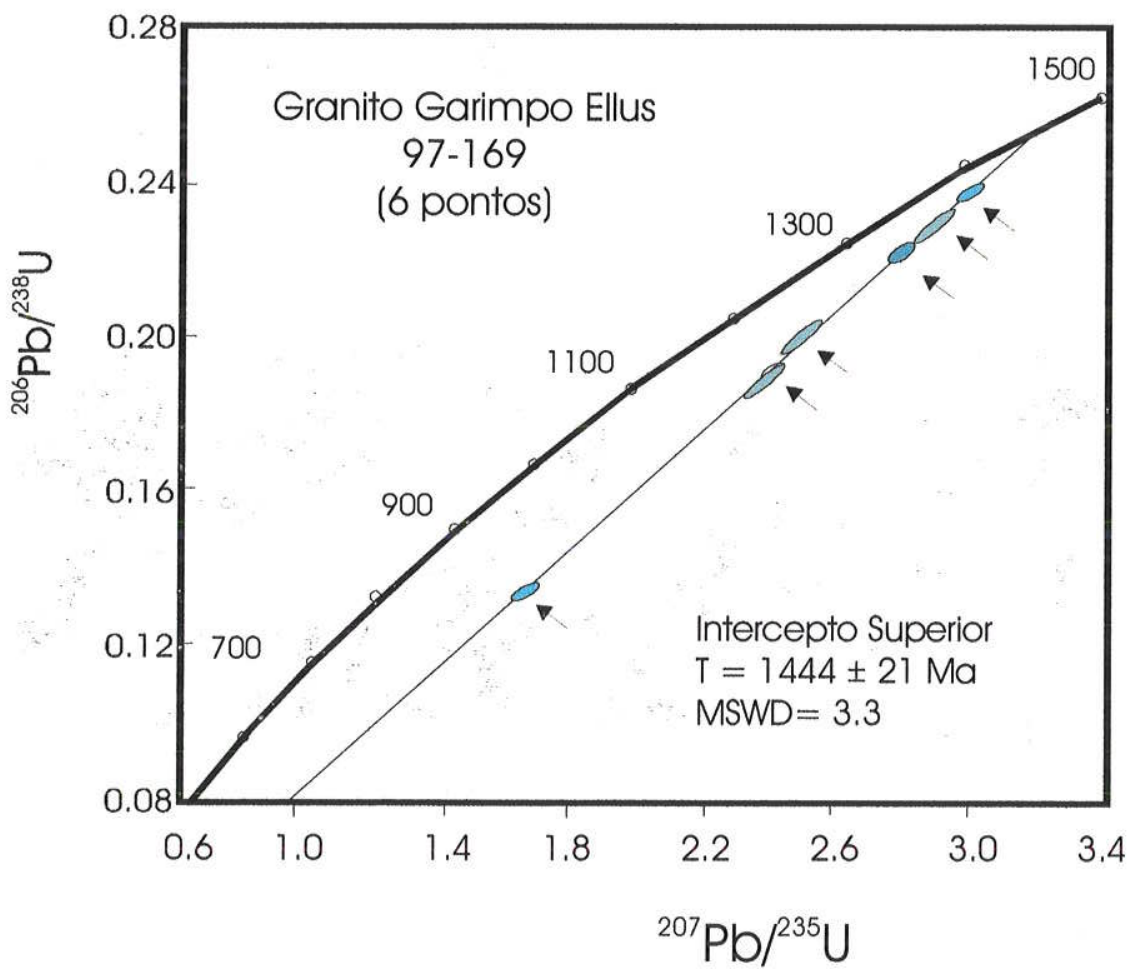

Figura 4.14 Diagrama da concórdia para o Granito do Garimpo Ellus (amostra 97-169). Seis frações de zircões desta amostra foram analisadas para datação $U / P b$ e os resultados quando lançados no diagrama da concórdia indicam a idade de cristalização de $1444 \pm 21 \mathrm{Ma}$. Intercepto inferior forçado a 0. 


\subsection{Geoquímica}

Os estudos químicos desta unidade permitem caracterizar uma variação composicional de rochas entre tonalitos a granitos. A SSH apresenta ainda características químicas que podem ser relacionadas a um processo orogenético compatível a um arco magmático, configurando corpos sin, tardi a pós cinemáticos. Conseqüentemente podem ser caracterizados como granitos tipo I, diferentemente ao proposto por Menezes et al., (1993) e Lopes et al., (1992) que, em função de uma menor abrangência em área de amostragem, caracterizou esta unidade como granito tipo A.

No diagrama da Figura 4.15 as rochas analisadas podem ser enquadradas nos termos graníticos (amostras 97-116fi, 97-116co, 97-141, 97-115, 97-120, 97-168 e 97169); granodioríticos (amostras 97-102a, 97-102b e 97-108); tonalítico (amostra 97113) e quartzo monzogabro (97-140).

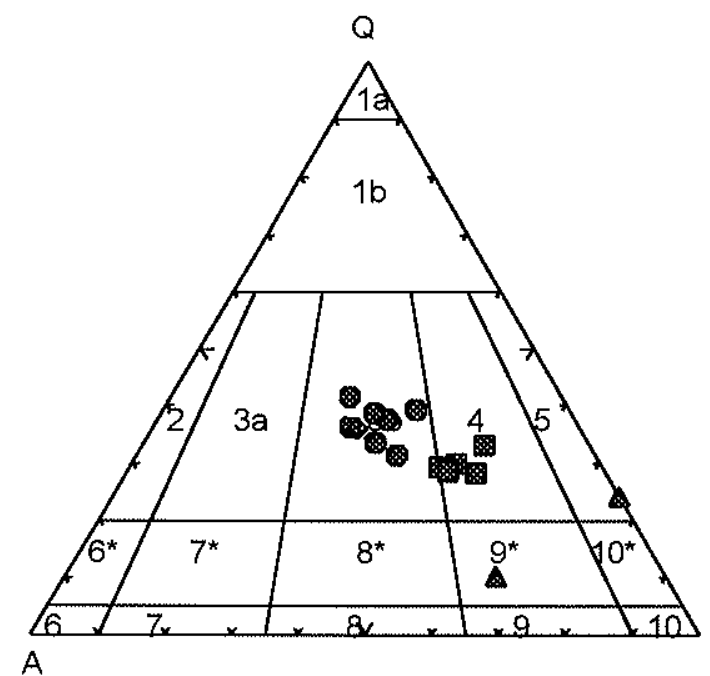

Figura 4.15 Diagrama QAP (Streckeisen, 1976) para as rochas da SSH obtido através da conversão dos resultados químicos. As rochas podem ser denominadas de graníticas (ćrculos), granodioríticas (quadrados), diorítica e tonalítica (triângulo).

Campos cmposicionais: (1a) quartzolito; (1) granitóide rico em Qz; (3) granito alcalifeldspático; (3a) sienogranito; (3b) monzogranito; (4) granodiorito; (5) tonalito; $\left(6^{*}\right)$ quartzo sienito álcalifeldspático; (6) sienito álcalifeldspático; $\left(7^{*}\right)$ quartzo sienito; $\left(8^{*}\right)$ quartzo monzonito; (8) monzonito; $\left(9^{*}\right)$ quartzo monzogabro; (9) monzogabro; (10) quartzo gabro; e (10*) diorito, gabro, anortosito. 
Na Figura 4.16, observa-se uma composição peraluminosa para os granitos, porém algumas amostras de composição granodiorítica e tonalítica indicam composição metaluminosa, características estas também marcadas pela presença de micas ferromagnesianas nos primeiros e grande proporção de anfibólios no segundo grupo. Além disso as rochas aqui pesquisadas apresentam um caráter evolutivo característico de suítes cálcioalcalinas (Figura 4.17). O diagrama da Figura 4.18 sugere que a geração das rochas tonalíticas a granodioríticas pode ter ocorrido em ambiente de arco magmático e as rochas graníticas em ambiente intermédiário entre arco magmático e ambiente intraplaca.

$\mathrm{Na}$ distribuição de elementos terras raras (Figura 4.19) observa-se um padrão caracterizado pelo enriquecimento em terras raras pesados (de 10 a 120 vezes) e terras raras leves (de 2 a 80 vezes) em relação ao condrito. As amostras graníticas apresentam forte anomalia negativa de Eu. Provavelmente durante a diferenciação o plagioclásio cristalizado se concentrou nas rochas menos evoluídas como os tonalitos (com anomalias positivas por ter incorporando $\mathrm{Eu}) \mathrm{e}$ as rochas graníticas tornaram-se empobrecidas neste elemento. Este resultado pode indicar a origem deste granito a partir de um magma que sofreu diferenciação segundo a evolução de uma suíte calcioalcalina (Clark, 1984; Burt, 1989).

Os resultados analíticos da $\mathrm{SSH}$ quando lançados nos diagramas de Harker indicam um fracionamento de forma a promover um enriquecimento nos valores de $\mathrm{Na}_{2} \mathrm{O}, \mathrm{K}_{2} \mathrm{O}, \mathrm{Rb}, \mathrm{Hf}, \mathrm{Pb}, \mathrm{Th}, \mathrm{Ta}$ e Nd (Figura 4.20) e um empobrecimento nos valores de $\mathrm{MgO}, \mathrm{MnO}, \mathrm{CaO}, \mathrm{TiO}_{2}, \mathrm{Co}, \mathrm{Cr}, \mathrm{Zr}$ e $\mathrm{Sr}$ (Figura 4.21) em relação à sílica, coerentemente a um processo de diferenciação magmática, onde elementos compatíveis são incorporados nos minerais cristalizados no início da solidificação do magma, inversamente aos elementos incompatíveis, que permanecem na fase líquida no início da solidificação e são incorporados pelos minerais apenas nas fases finais da cristalização fracionada.

No diagrama silica versus potássio observa-se a maior concentração de resultados na área do diagrama com valores de $\mathrm{K}_{2} \mathrm{O}>5 \mathrm{ppm}$, sugerindo que as rochas da SSH apresentam, em sua maioria, alto $\mathrm{K}$, em acordo com os resultados por Menezes et al., (1993). 


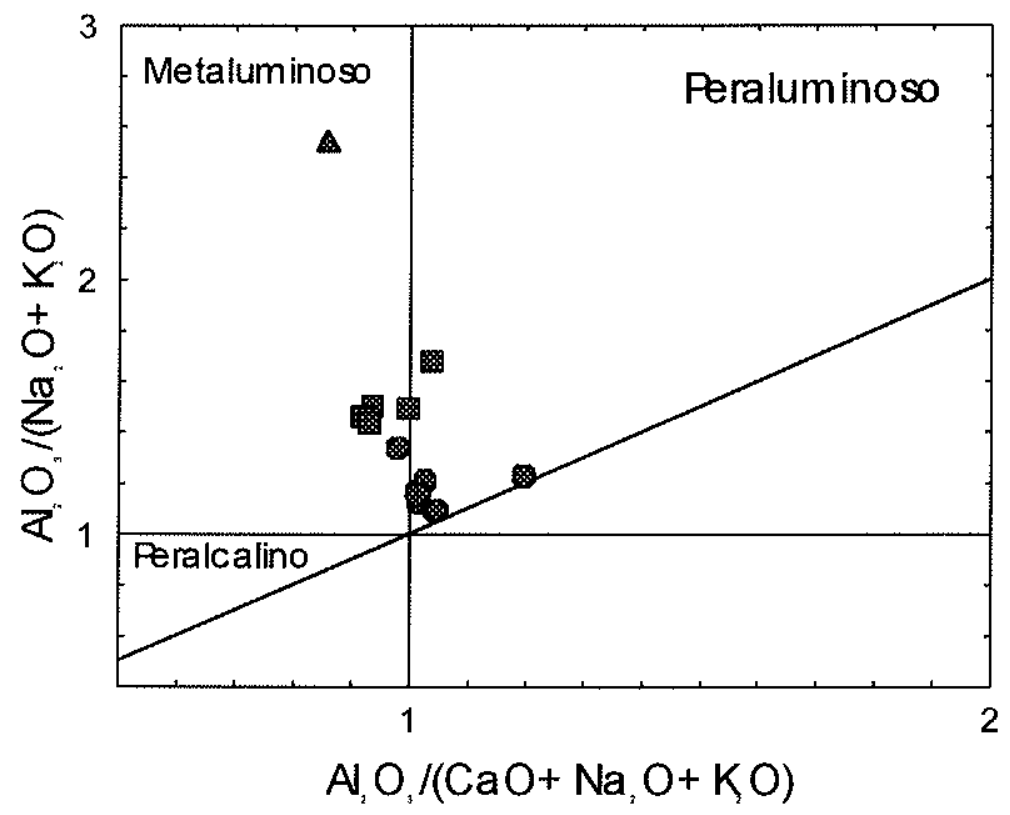

Figura 4.16 - Indice de Shand (A/CNK) versus índice de saturação em alumina para as amostras da Suíte Santa Helena variam entre peraluminosas e peraluminosas a metaluminosas.

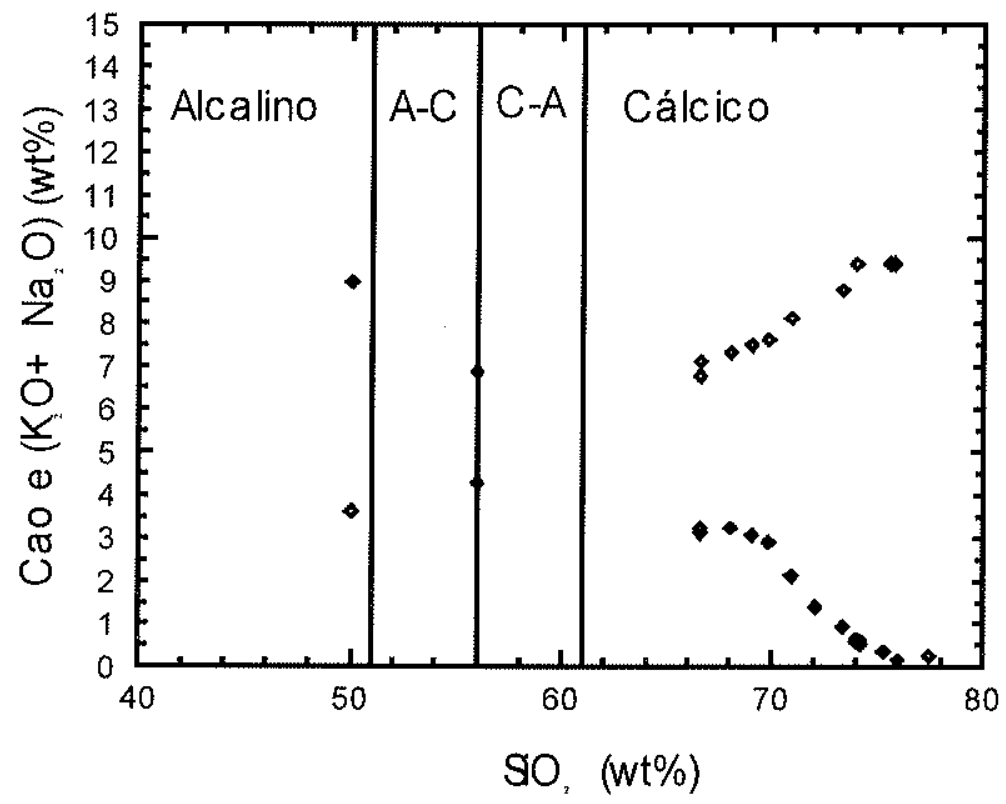

Figura 4.17 Diagramas discriminantes de trends de diferenciação (Peacock, 1931). A SSH apresenta rochas que se distribuem desde fácies alcalinas a cálcicas, com cruzamento dos trends no campo das calcio-alcalinas. 


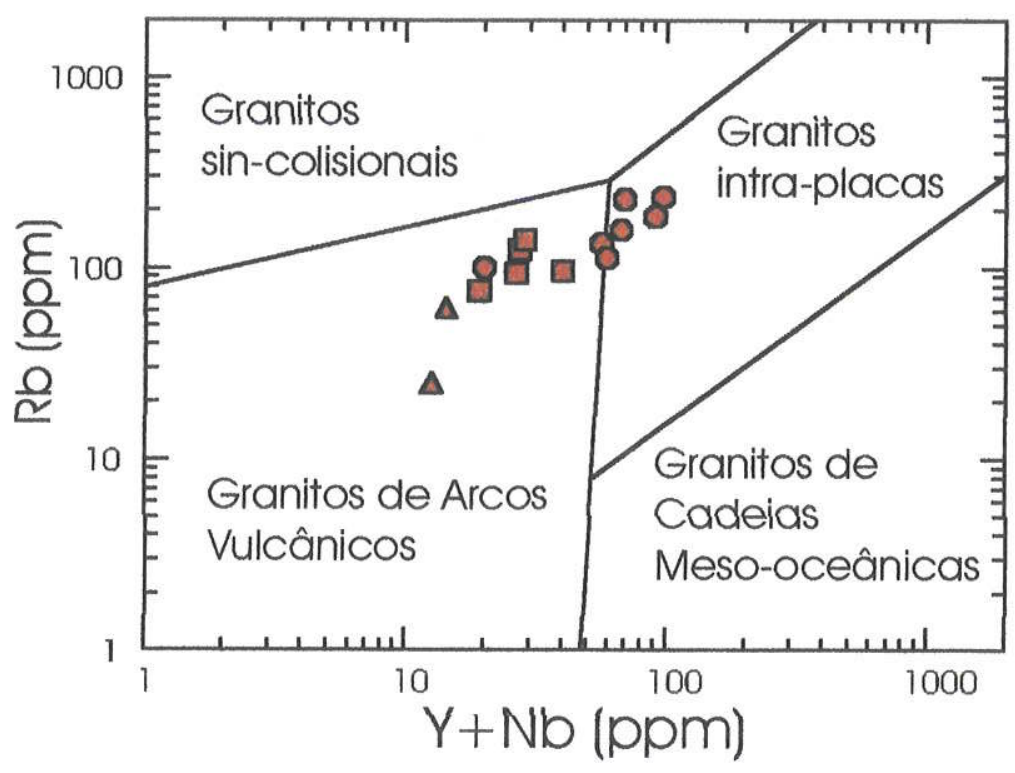

Figura 4.18 Diagramas de discriminação de ambientes tectônicos (Pearce et al., 1984). Os resultados das análises químicas indicam que as rochas do $\mathrm{SSH}$ podem ter sido geradas em ambiente de arco magmático (tonalitos e granodioritos) e intraplaca (granitos).

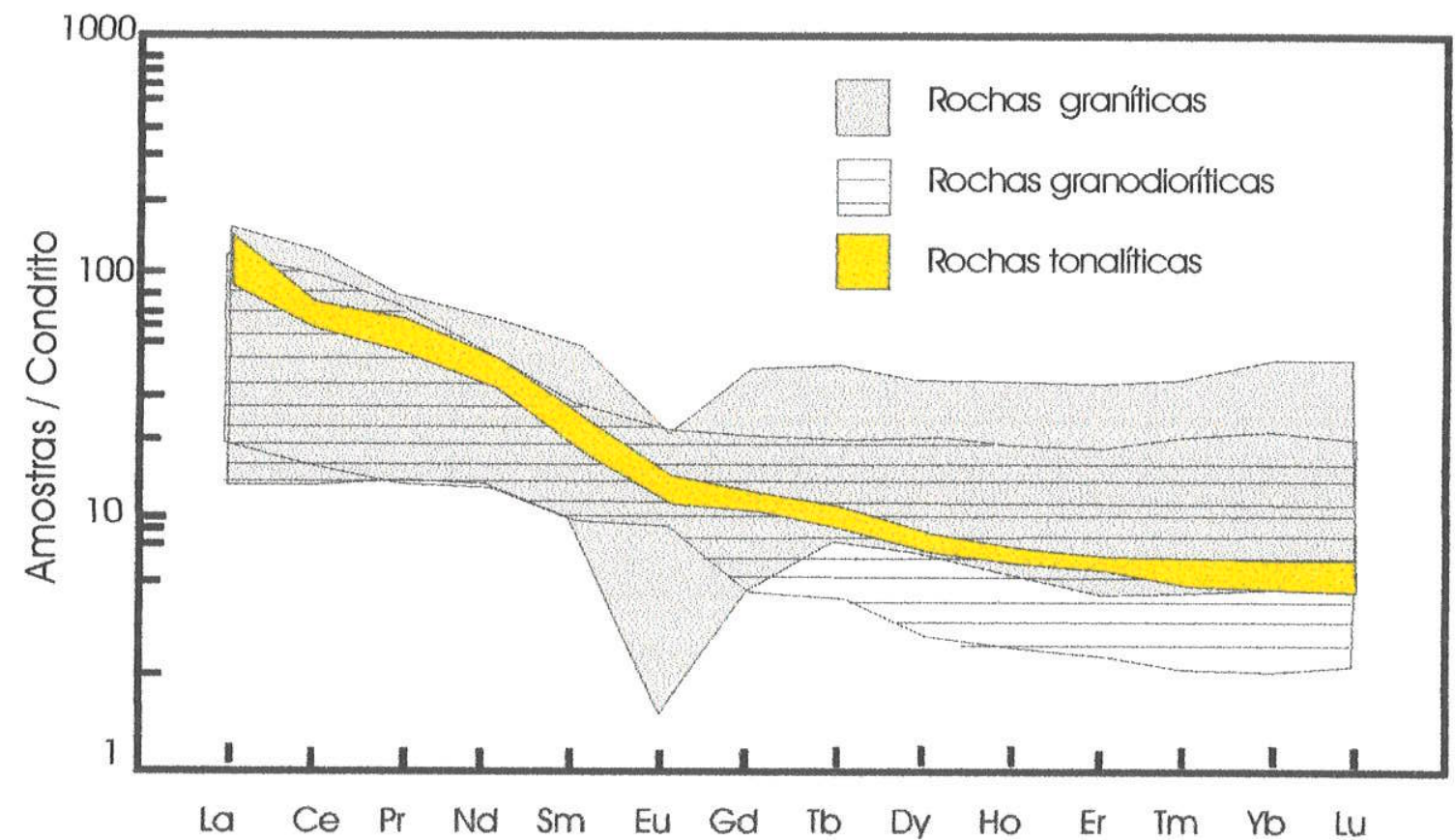

Figura 4.19 Padrões de elementos terras raras da SSH, normalizados pelo condrito. As rochas mais primitivas (tonalitos) apresentam um padrão com enriquecimento de ETR leves e os ETR pesados horizontalizados. O mesmo padrão tem as rochas granodioríticas, porém com uma maior variação de concentração. As rochas graníticas apresentam um padrão de ETR similar aos das rochas tonalíticas e granodioríticas, porém com uma acentuada anomalia negativa de Eu. Os valores de terras raras foram normalizados segundo Sun e McDonough (1989). 

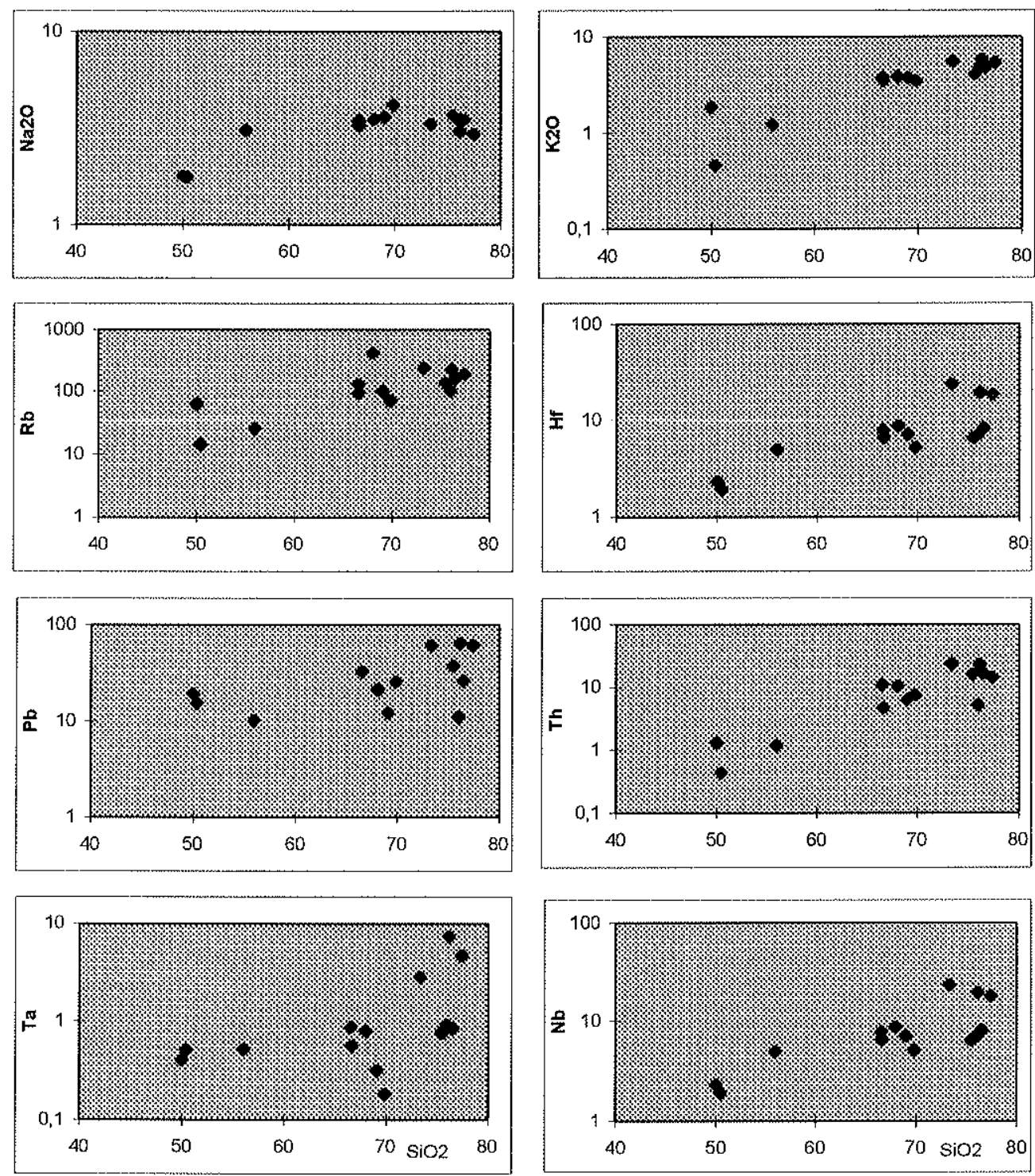

Figura 4.20 Diagrama de Harker para as amostras da Suíte Santa Helena. Elementos e óxidos que apresentam enriquecimento com aumento de $\mathrm{SiO}_{2}$. O enriquecimento destes elementos é coerente com um processo de diferenciação magmática, onde elementos incompatíveis se concentram no líquido residual durante a cristalização do magma. 

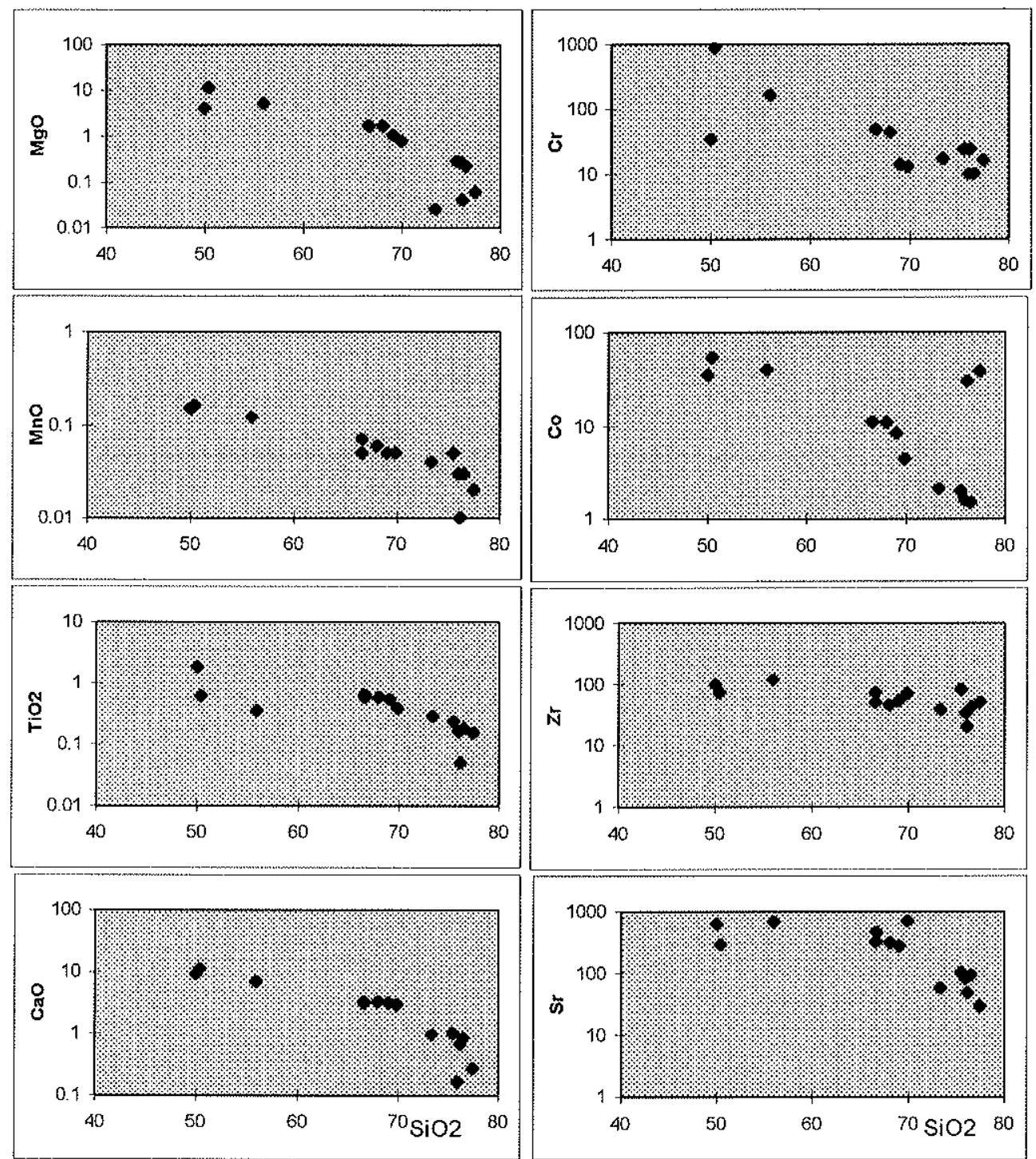

Figura 4.21 Diagramas de Harker para amostras da Suíte Santa Helena. Elementos e óxidos que apresentam empobrecimento com a diminuição de $\mathrm{SiO}_{2}$. O empobrecimento destes elementos é coerente com um processo de diferenciação magmática, onde elementos compatíveis tendem a ser incorporados pelos minerais no período inicial da cristalização do magma. 


\subsection{Isótopos de Oxigênio}

Seis amostras de rochas granitóides do SSH foram analisadas para isótopos estáveis de oxigênio. As amostras selecionadas foram o Tonalito Lavrinha (97-113), Gnaisse granodirítico (97-108), Gnaisse Santa Helena (97-115), Granito Maraboa (97141), Granito Serrana (97-116) e Granodiorito Comodoro (97-127). Os resultados de ${ }^{16} \mathrm{O} /{ }^{18} \mathrm{O}$ foram normalizados pelo standart SMOW e são apresentados na Tabela 5.2 e Figura 4.22 .

Tabela 5.2 Valores de $\delta$ O para as rochas granitóides da Suíte Santa Helena.

\begin{tabular}{|l|l|l|}
\hline Amostra & Descrição & $\delta \mathrm{O}(\% \mathrm{o})$ \\
\hline $97-113$ & Tonalito Lavrinha & $+4,4$ \\
\hline $97-108$ & Gnaisse Granodiorítico & $+8,9$ \\
\hline $97-115$ & Gnaisse Santa Helena & $+4,4$ \\
\hline $97-140$ & Granito Maraboa & $+10,4$ \\
\hline $97-116$ & Granito Serrana & $+4,4$ \\
\hline $97-117$ & Granodiorito Comodoro & $+8,3$ \\
\hline
\end{tabular}

Os resultados da Tabela 5.2 indicam uma variação entre $+4,4 \%$ e $+10,4 \%$ para as rochas da $\mathrm{SSH}$. Destes resultados podemse dividir as rochas em dois grupos com valores de $\delta \mathrm{O}$ distintos: o primeiro grupo com valores de $\delta \mathrm{O}=+4,4 \%$ (amostras 97 $113,97-115$ e 97-116) e o segundo grupo (amostras 97-108, 97-140 e 97-117) com $\delta \mathrm{O}$ entre $+8,3 \%$ e $10,4 \%$.

Os estudos petrográficos do primeiro grupo não apresentaram indícios de alteração que promovessem a diminuição dos valores de $\delta 0$. Porém a interação destas rochas com soluções hidrotermais com baixos valores de $\delta$ o pode ter-se dado ainda na fase subsolidus da cristalização destas rochas. Taylor (1988) explica desta forma batólitos de rochas graníticas nas Ilhas Seychelles com valores de $\delta \mathrm{O}$ de até $-5,0 \%$. $\mathrm{O}$ autor ressalta ainda que no exemplo estudado não teria ocorrido modificação dos valores de $\varepsilon_{\mathrm{Nd}}$.

Dentre as amostras do segundo grupo, apenas a amostra 97-141 apresenta paragênese mineral resultante de alteração hidrotermal, principalmente sinalizada pela 
sericitização de feldspatos. Neste caso, no entanto, o hidrotermalismo comum pode ter provocado um aumento no valor de $\delta \mathrm{O}$ em função de altos valores de $\delta \mathrm{O}$ presentes em águas meteóricas. Os resultados das amostras restantes são coerentes com valores de $\delta 0$ característicos de suítes calcioalcalinas ao passo que os valores de $\delta 0$ pouco superiores aos valores do manto $(+5,0 \%$ a $+6,0 \%$, ver Figura 3.30$)$ sugerem uma derivação de protólitos mantélicos.

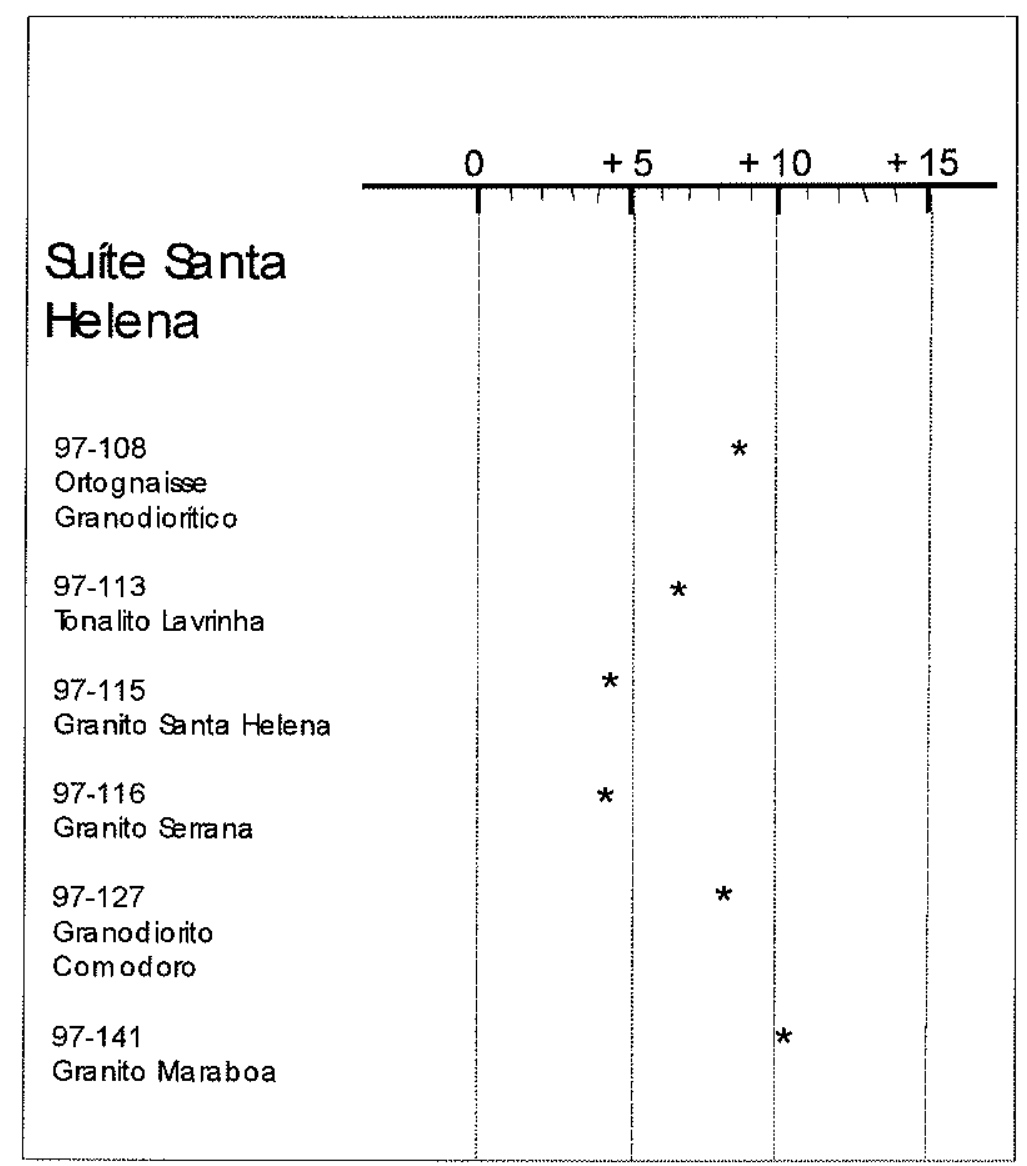

Figura 4.22 Resultados de isótopos de O para as rochas da Suíte Santa Helena. 


\subsection{Discussão}

Os dados geoquímicos, de isótopos estáveis e geocronológicos das rochas da $\mathrm{SSH}$ permitem sugerir tipos de fontes e ambientes de formação para este grupo de rochas, característicos dos eventos formadores de crosta na região para o Mesoproterozóico.

A contemporaneidade de um grande número de corpos graníticos resultou de um importante evento granitogênico (indicado pelas idades U/Pb entre 1481 e $1423 \mathrm{Ma}$ ) e geração da crosta siálica (sugerido pelas idades modelo $\mathrm{Sm} / \mathrm{Nd}$ entre 1,70 e 1,48 $\mathrm{Ma}$ ), incluindo, possivelmente, retrabalhamento de crosta pré-existente. $O$ metamorfismo (representado pela gnaissificação) sugere uma fase de estabilização desta crosta, com amalgamação e acresção possivelmente ao protocráton Amazônico estabilizado ao início do Mesoproterozóico, o qual constituiu o antepaís para o estabelecimento de um arco magmático aqui denominado de Santa Helena.

A isócrona $\mathrm{Rb} / \mathrm{Sr}$ (Geraldes, 1996) para o Gnaisse Santa Helena com idade $1318 \pm$ $24 \mathrm{Ma}(1 \sigma)$ e razão inicial de $0,711 \pm 0,008$ deve corresponder a época de fechamento do sistema $\mathrm{Rb} / \mathrm{Sr}$ ocorrido posteriormente 'a cristalização da rocha, uma vez que o diagrama ${ }^{206} \mathrm{~Pb} /{ }^{238} \mathrm{U} x{ }^{207} \mathrm{~Pb} /{ }^{235} \mathrm{U}$ da mesma amostra apresenta o intercepto superior em $1433 \pm 6$ $\mathrm{Ma}$ interpretada como de formação (ou intrusão) da rocha. A idade $\mathrm{T}_{\mathrm{DM}}$ (para a mesma amostra) é de 1,62 Ma e sugere que a formação do protólito a partir do manto em um período de tempo relativamente curto antes da sua cristalização, indicando o caráter juvenil para esta unidade.

A idade errócrona $\mathrm{Rb} / \mathrm{Sr}$ preliminar (rocha total) para a amostra do Granito Maraboa (Geraldes, 1996) indicou $1275 \pm 125 \mathrm{Ma}$, com razão inicial de 0,711 $\pm 0,035$, sinalizando origem crustal. $\mathrm{O}$ alto erro deve-se ao espalhamento restrito dos pontos analíticos e da grande distância entre os pontos e o eixo da razão ${ }^{86} \mathrm{Sr} /{ }^{87} \mathrm{Sr}$ do diagrama isocrônico. Os resultados $\mathrm{U} / \mathrm{Pb}$ do Granito Maraboa quando lançados no diagrama ${ }^{206} \mathrm{~Pb} /{ }^{238} \mathrm{U} \times{ }^{207} \mathrm{~Pb} /{ }^{235} \mathrm{U}$ apresentam o intercepto superior em $1449 \pm 7 \mathrm{Ma}$ e pode ser interpretada como a idade de cristalização dos zircões (formação da rocha) e portanto a idade $\mathrm{Rb} / \mathrm{Sr}$ pode ser interpretada como de um evento metamórfico que tenha provocado a abertura do sistema $\mathrm{Rb} / \mathrm{Sr}$. Esta amostra apresenta ainda a idade $\mathrm{T}_{\mathrm{DM}}$ de 1,70 Ma, indicativa da época de diferenciação do seu protólito. 
O resultado U/Pb para os zircões do veio subconcordante (amostra 97-102 P) com a foliação da rocha encaixante $(97-120 \mathrm{E})$ apresentados na Figura 5.10 indica que o veio pode ter cristalizado até 30 Ma após a cristalização do augen gnaisse encaixante (com idades de $1384 \pm 10 \mathrm{Ma}$ e $1436 \pm 6 \mathrm{Ma}$, respectivamente). A idade do zircão mais jovem do veio pode indicar a idade mínima para o evento gerador da foliação, o que sugere uma idade entre cristalização da rocha e seu metamorfismo dentro de um período relativamente curto de tempo. Seguindo este raciocínio, as idades $\mathrm{Rb} / \mathrm{Sr}$ podem indicar idades de resfriamento ou de reabertura do sistema isotópico $(\mathrm{Rb} / \mathrm{Sr})$, possivelmente por eventos posteriores, como o Evento Aguapeí, descrito no Capítulo 8.

Os resultados $\mathrm{U} / \mathrm{Pb}$ das amostras estudadas permitem uma avaliação do quadro evolutivo do Terreno Santa Helena. Inicialmente os resultados U/Pb concordantes das 14 amostras revelam a geração desta rochas em um intervalo curto de tempo, certamente relacionado a um importante evento regional responsável por uma granitogênese de extensão batolítica e composição variada representado pela SSH. As idades $\mathrm{T}_{(\mathrm{DM})}$ calculadas a partir dos dados isotópicos $\mathrm{Sm} / \mathrm{Nd}$ sugerem que o(s) protólito(s) destas rochas se fracionaram do manto no período de tempo entre 1,70-1,50 Ga e tiveram um estágio crustal máximo de $250 \mathrm{Ma}$, antes de se cristalizarem (idade U/Pb em zircões). Esta hipótese é apoiada pelos valores de $\varepsilon_{\mathrm{Nd}(t)}$ calculados para as rochas para as respectivas idades de cristalização $(\mathrm{U} / \mathrm{Pb})$ e que variam entre $+2,6$ e $+4,0$ reforçando a origem mantélica para os protólitos.

Os resultados $\mathrm{U} / \mathrm{Pb}$ sugerem ainda que as rochas estudadas foram formadas durante um evento gerador de granitóides cujos protólitos apresentam idades $\mathrm{T}_{(\mathrm{DM})}$ intermediárias entre as idades de cristalização das rochas da SSH e do Terreno Jauru cujas rochas apresentam idades $\mathrm{U} / \mathrm{Pb}$ (em zircões) entre 1,8 a 1,55 Ga, como pode ser visualizado na Figura 4.23. Tal fato pode sugerir a participação desta crosta mais antiga na geração dos protólitos do $\mathrm{SSH}$, de forma que a mistura em várias proporções da crosta mais antiga com material mantoderivado teria como resultado rochas com idades $\mathrm{T}_{\mathrm{DM}}$ intermediárias entre os dois tipos de fontes.

As rochas $\mathrm{SSH}$ apresentam variações nos valores de elementos maiores de forma que as rochas de composição mais cálcicas (tonalitos) limitadas à borda oeste do batólito e as calcioalcalinas (granitos e granodioritos) distribuídas uniformemente pelo batólito, sugerindo que a subducção ocorreu no sentido de oeste para leste (atual). Além 
do mais, as composições químicas das rochas mais evoluídas (graníticas de alto $\mathrm{SiO}_{2}$ ) apresentam características equivalentes de rochas graníticas geradas em ambiente intraplacas, como altos valores de $\mathrm{Rb}$ e $\mathrm{Y}+\mathrm{Nb}$.

Os dados isotópicos de $\mathrm{O}$ das rochas da SSH mostram uma maior complexidade de resultados e interpretações em relação aos resultados de isótopos estáveis obtidos em parte das rochas graníticas da região de Jauru-Araputanga. Os dados isotópicos de $\mathrm{O}$ das rochas aqui estudadas apresentam valores de $\delta \mathrm{O}$ menores de $+6,0 \%$ (o valor mínimo de $\delta O$ para rochas mantoderivadas), que podem ser explicados pela reação da rocha com soluções hidrotermais com baixos valores de $\delta \mathrm{O}$ em condições subsolidus na cristalização destas rochas. Os valores de $\delta \mathrm{O}$ para o restante das amostras são coerentes com material mantoderivado.

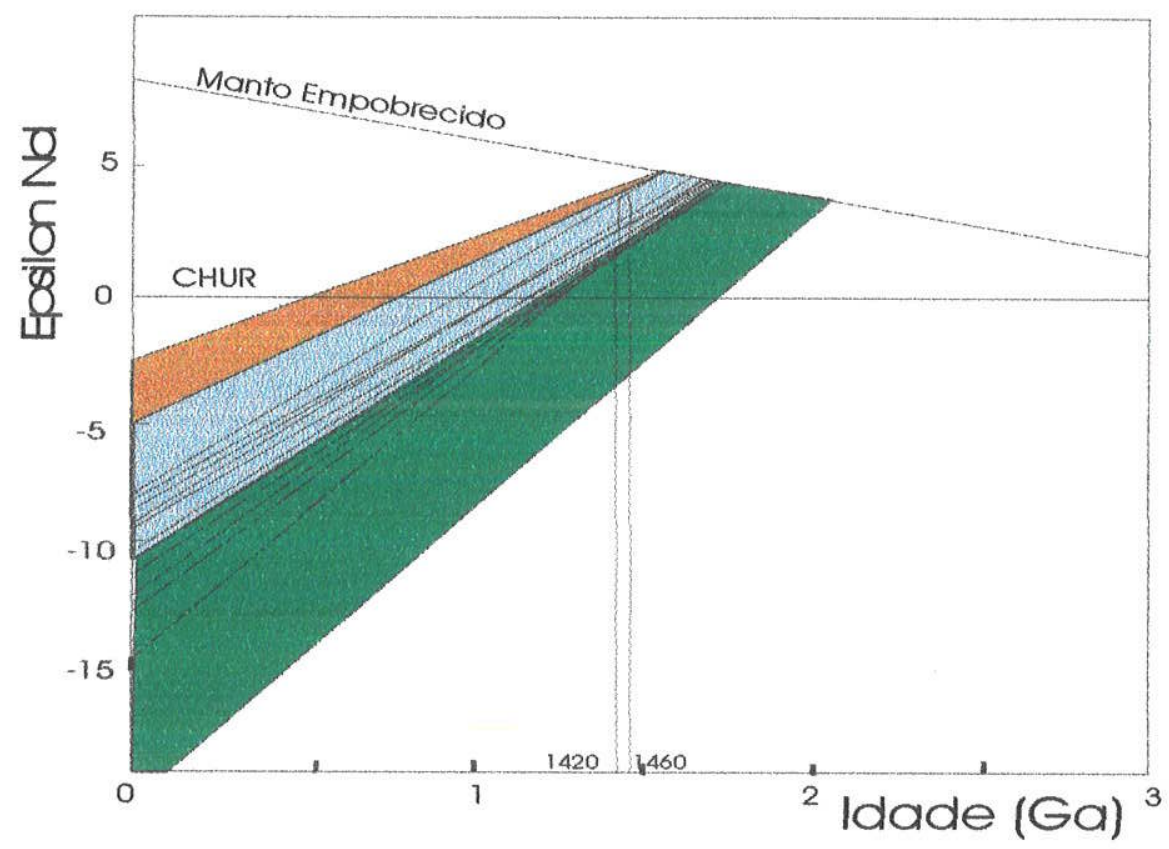

Figura 4.23 Diagrama de evolução isotópica de Nd para as rochas da SSH. Os valores de $\mathrm{T}_{\mathrm{DM}}$ estão entre 1,70 e $1,43 \mathrm{Ga}$ e de $\varepsilon_{\mathrm{Nd}}$ entre $+4,1$ e $+2,6$ (calculados para as respectivas idades $\mathrm{U} / \mathrm{Pb}$ ), sugerindo a fonte mantélica para a origem dos respectivos protólitos. Em vermelho estão lançados os resultados $\mathrm{Sm} / \mathrm{Nd}$ para as rochas do Terreno Rio Alegre; em verde do Terreno Jauru; em azul a área de sobreposição de dados $\mathrm{Sm} / \mathrm{Nd}$ dos terrenos Rio Alegre e Jauru.

Cumpre ressaltar que a idade U/Pb obtida para o Granodiorito Água Clara (1468 \pm $35 \mathrm{Ma})$ no Terreno Jauru (descritas no Capítulo anterior) é equivalente aos valores das idades $\mathrm{U} / \mathrm{Pb}$ aqui reportadas para rochas do arco Santa Helena. Os resultados isotópicos de 
Nd para o Granodiorito Água Clara também são comparáveis aos valores encontrados para as rochas do arco Santa Helena $\left(\mathrm{T}_{\mathrm{DM}}=1,77 \mathrm{Ga}\right.$ e $\left.\varepsilon_{\mathrm{Nd}(\mathrm{t})}=+1,7\right)$. Esta equivalência de idades pode sugerir que o Granodiorito Água Clara representa parte do magmatismo gerado pelo arco Santa Helena, porém intrudido na crosta mais antiga, representada pelo Terreno Jauru, daí sua idade $\mathrm{T}_{\mathrm{DM}}$ compatível com aquele terreno. Ocorrências de outras rochas que podem ser correlacionadas a este magmatismo no Terreno Jauru é sugerida por outros pesquisadores (Francisco Pinho e Jaime Leite, comunicação verbal). 


\section{CAPÍTULO 5 \\ O TERRENO RIO ALEGRE}

\subsection{Introdução}

O Terreno Rio Alegre ocorre ao longo do rio homônimo, tendo como limite leste e norte a faixa de sedimentos dobrados do Grupo Aguapei; ao sul é recoberto pelos sedimentos da Formação Pantanal e a oeste pelos sedimentos (subhorizontais) do Grupo Aguapeí.

Neste terreno ocorrem rochas vulcanossedimentares (xistos, BIF's, metariodacitos e metabasaltos), granulitos básicos a félsicos, granitos foliados, tonalitos gnáissicos segundo a descrição de Matos e Schorscher, (1997a e b) e pequenos stocks de microgranitos isotrópicos. Este conjunto litológico é distinto das litologias observadas no Terreno Santa Helena com o qual apresenta um limite definido pelas rochas (deformadas) do Grupo Aguapeí e anomalias gravimétricas que indicam uma zona de sutura (Bezerra, 1993) Rochas policíclicas (com herança isotópica U/Pb) são observadas no setor oeste do Terreno Rio Alegre, representados por rochas granitóides de diversas composições. Estes resultados permitem sugerir um domínio a oeste com evolução geológica distinta da Sequência Vulcanossedimentar Rio Alegre. A localização das amostras pode ser observada na Figura 4.1.

\subsection{Rochas Vulcanossedimentares do Vale do Rio Alegre}

As rochas vulcanossedimentares do Terreno Rio Alegre ocorrem ao longo do vale do rio Alegre, na região de Porto Esperidião (parte SE) e a vila do Matão (parte NW), na estrada entre Pontes e Lacerda e Ponta do Aterro, na divisa de Brasil e Bolívia. 

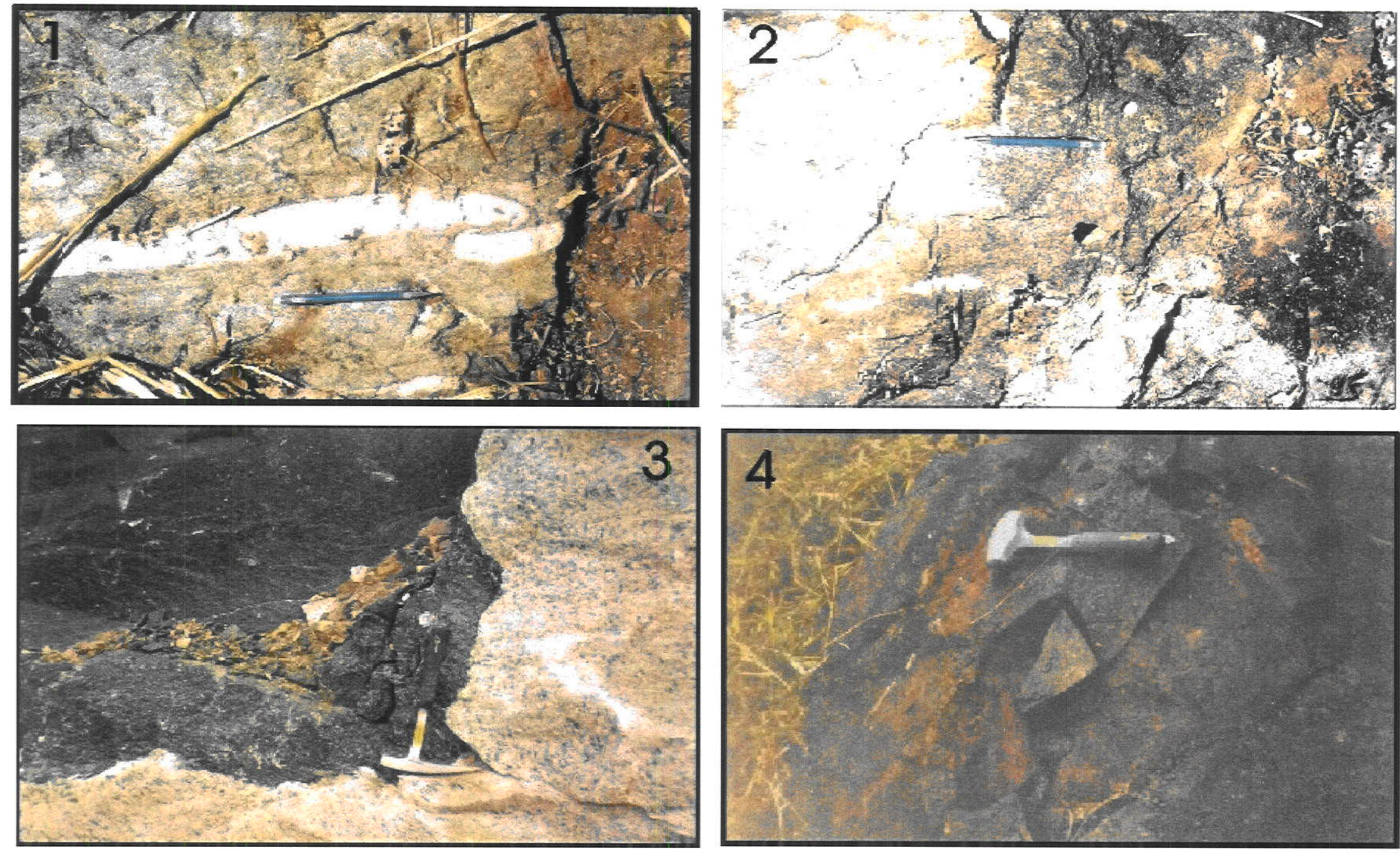

Prancha 4. (1) Rocha de composição básica do Terreno Rio Alegre (97-137).

(2) Rocha de composição básica do Terreno Rio Alegre (97-137).

(3) Xenólito rocha de composição anfibolítica na Suíte Santa Helena (97-116).

(4) Basaltos toleíticos nas margens do Rio Aguapeí (Terreno Rio Alegre). 
A oeste deste domínio observa-se a Serra Santa Barbara e a leste as cristas das serras Azul e Ricardo Franco, constituídas pelo Grupo Aguapeí (zona de maior deformação desta unidade). Aspectos gerais dos afloramentos desta unidade são mostrados na Prancha 3.

Matos (1994) denominou o conjunto de litotipos vulcânicos mapeados na região de Sequência Metavulcanossedimentar Rio Alegre (SMVSRA), denominada por Menezes et al., (1993) como Sequência Metavulcanossedimentar Pontes e Lacerda (SMVSPL). Estas rochas têm composição que varia de basaltos até tufos ácidos, associados a rochas sedimentares químicas. Matos (1994) dividiu a SMVSRA em Formação Minouro (metabasaltos de granulação fina associados a metassedimentos químicos como cherts e formações ferríferas bandadas), Formação Santa Isabel (metavulcânicas e metapirocláticas de natureza riodacítica) e Formação São Fabiano (intercalações de sedimentos clásticos e químicos metamorfizados como metacherts, formações ferríferas bandadas e metavulcanoclásticas). As rochas intrusivas constituem complexos diferenciados básicos (gabros e serpentinitos) com texturas cumuláticas, metamorfisadas na fácies xisto-verde. Matos e Schorscher (1997a) interpretam as tendências geoquímicas das rochas vulcânicas e intrusivas máficas desta região como componentes de um greenstone belt originado em ambiente de back arc. Estas rochas apresentam, segundo Matos e Ruiz (1991), foliação principal com direção N20W subvertical e duas secundárias (foliação de transposição e clivagem de crenulação).

As amostras analisadas compreendem rochas metamórficas (metadacito e metadiorito) com idades U/Pb entre 1509 e 1497 Ma (Tabela 5.1), interpretadas como época de formação desta unidade. $\mathrm{O}$ caráter juvenil é definido pelos valores de $\mathcal{E}_{\mathrm{Nd}(\mathrm{t})}$ entre $+3,6 \mathrm{e}+2,5$. As unidades estudadas são apresentadas a seguir.

Tabela 5.1 Resultados U/Pb e Sm/Nd da CMVSRA.

\begin{tabular}{|c|c|c|c|c|c|c|}
\hline Número & Descrição & $\mathrm{U} / \mathrm{Pb}(\mathrm{t})$ & $\varepsilon_{\mathrm{Nd}(0)}$ & $\varepsilon_{\mathrm{Nd}(\mathrm{t})}$ & $\mathrm{T}_{\mathrm{DM}}$ & $f$ \\
\hline $97-122$ & Metadiorito Rio Alegre & $1509 \pm 10$ & $-2,7$ & 4,3 & 1,54 & $-0,19$ \\
\hline $97-124$ & Metadacito Rio Alegre & $1503 \pm 14$ & $-2,4$ & 4,8 & 1,48 & $-0,19$ \\
\hline $97-137$ & Metadiorito Santa Barbara & $1494 \pm 11$ & $-11,3$ & 2,5 & 1,67 & $-0,36$ \\
\hline
\end{tabular}

$\mathrm{U} / \mathrm{Pb}(\mathrm{t})$ em Ma e $\mathrm{T}_{\mathrm{DM}}$ em Ga. 
Metadacito Rio Alegre (amostra 97-122)

Esta amostra foi coletada nas margens da estrada entre o Salto do Aguapeí e a fazenda Minouro, a menos de $500 \mathrm{~m}$ do afloramento onde são observados formação ferrífera bandada e metachert. Apresenta coloração verde escura, com minerais de fina granulometria. Microscopicamente apresenta plagioclásio parcial ou totalmente alterado para sericita e minerais máficos (principalmente anfibólio) cloritizados. Epidotos são observados dispersos pela lâmina delgada ou em aglomerados minerais (Fotomicrografia 5.1). Quatro frações de zircão desta amostra foram analisados e indicaram a idade (intercepto superior) de $1503 \pm 14 \mathrm{Ma}$ (Figura 5.1).

Metadiorito Rio Alegre (97-124).

Esta amostra foi coletada na mesma estrada da amostra 97-122, aproximadamente $4 \mathrm{~km}$ a norte. Apresenta uma composição equivalente a da amostra 97-124 porém uma granulometria maior, além da presença de fenocristais de anfibólio total ou parcialmente cloritizado. A matriz é composta por plagioclásio sericitizado, anfibólio e opacos (Fotomicrografia 5.2). Três frações de zircões desta amostra foram analisados e indicaram a idade (intercepto superior) de $1509 \pm 10 \mathrm{Ma}$ (Figura 5.2).

Metabásica Santa Bárbara (amostra 97-137)

A amostra metabásica Santa Barbara foi coletada entre o Rio Alegre e a Serra Santa Bárbara. A rocha apresenta coloração verde escuro, com uma foliação de transposição caracterizada pelo estiramento mineral e com vênulas de quartzo orientados concordantemente a foliação e também com pequenas dobras cabo-deguarda-chuva. Microscopicamente a rocha é um anfibolito que apresenta anfibólio, biotita, plagioclásio e granada (Fotomicrografia 5.3). Estes minerais estão fortemente orientados sendo a granada parcialmente substituída por quartzo. Quatro frações de zircão analisados indicaram a idade (intercepto superior) de $1494 \pm 11 \mathrm{Ma}$ (Figura 5.3). 


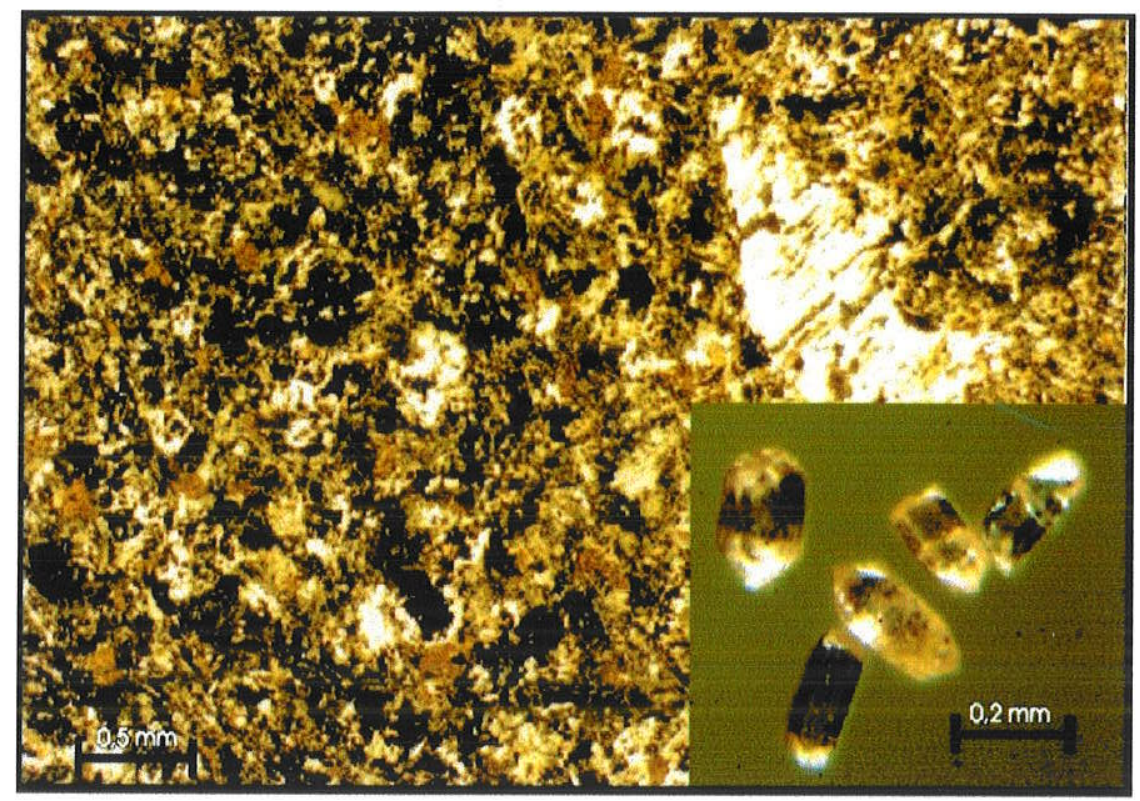

Fotomicrografia 5.1. Detalhe em lâmina do Metadacito Rio Alegre com aglomerado de epitodo. Cerca de $30 \mathrm{~kg}$ de amostra foi processada para a separação de zircões euédricos de coloração amarela e translúcidos.

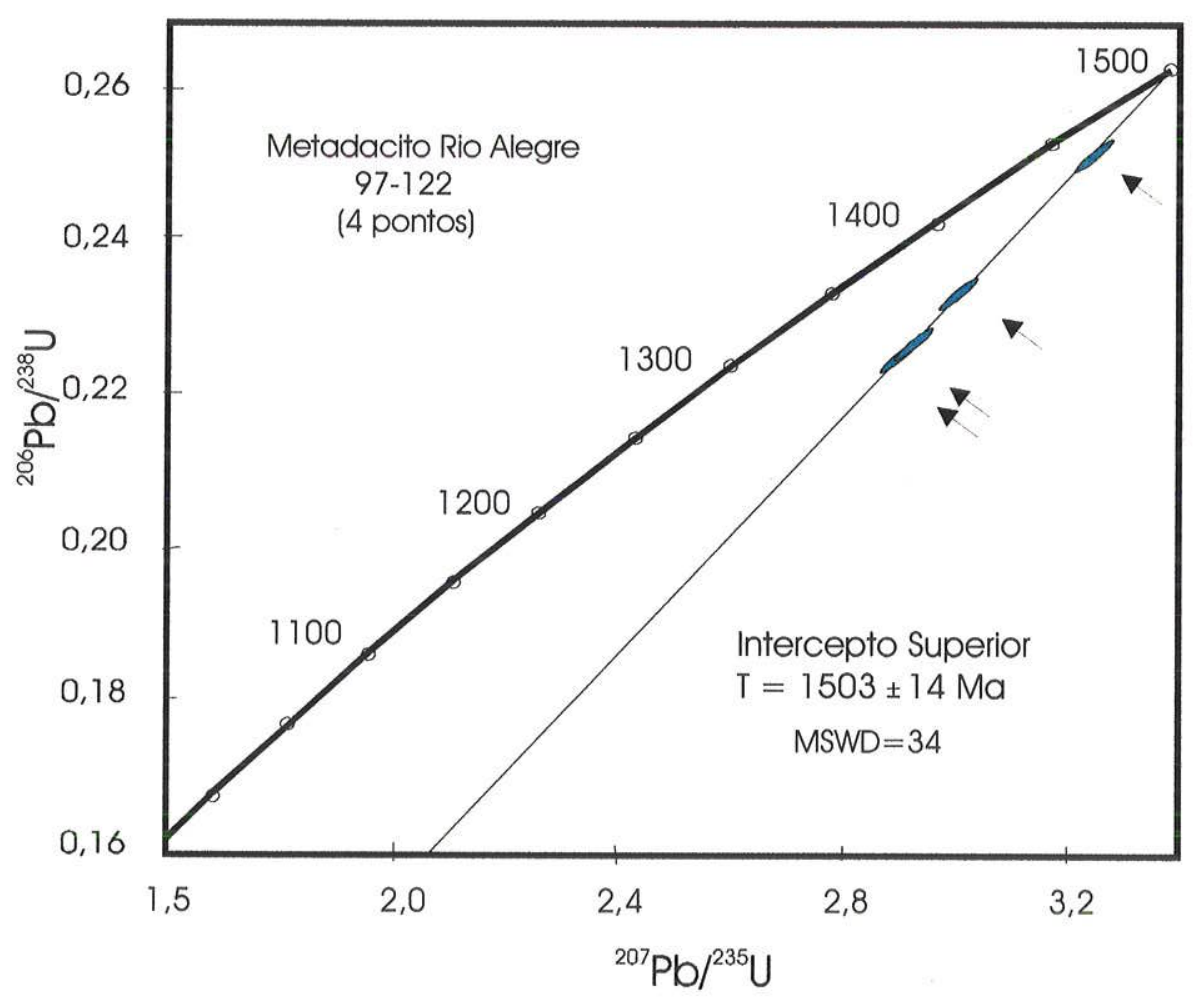

Figura 5.1. Diagrama da discórdia para a amostra metadacito do Rio Alegre (97-122). As 4 frações (monocristal de zircão) analisadas apresentam uma idade (intercepto superior) de $1503 \pm 14 \mathrm{Ma}$. Intercepto inferior forçado a 0 . 


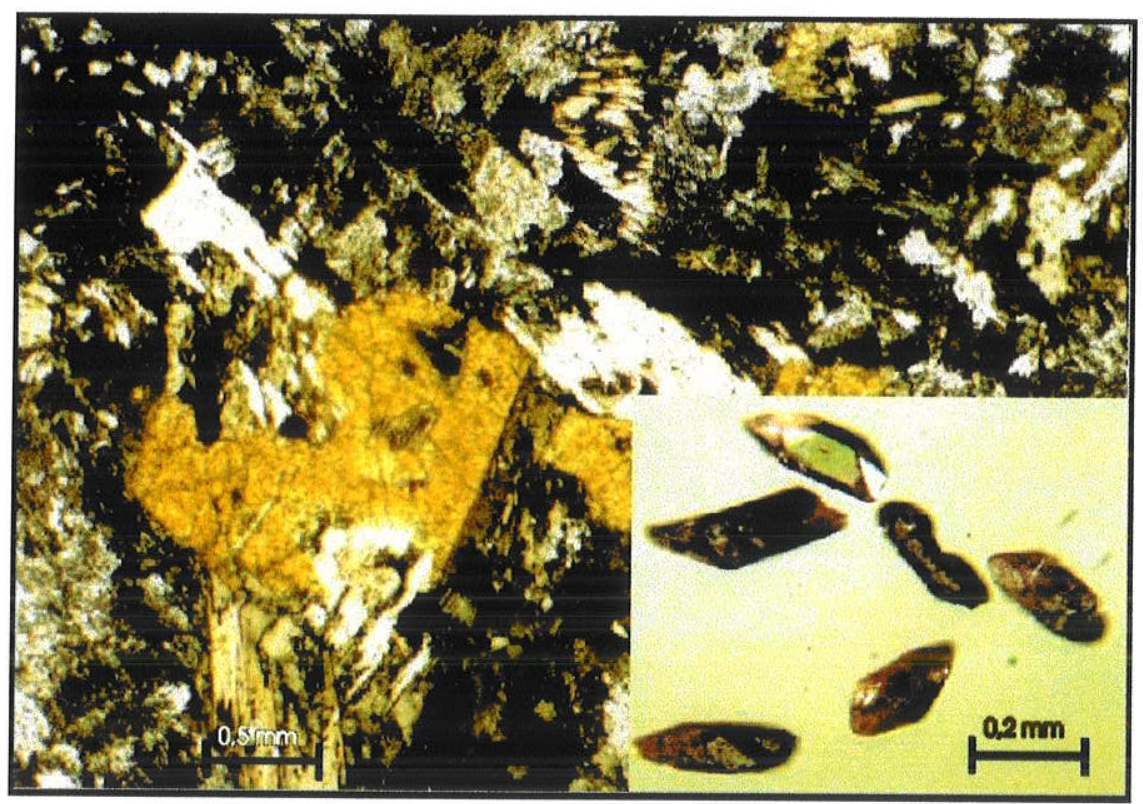

Fotomicrografia 5.2. Detalhe em lâmina do Metadiorito Rio Alegre com grandes cristais de anfibólio numa matriz de plagioclásio, anfibólio e opacos. $30 \mathrm{~kg}$ de amostras foram processados por gravimetria e forneceram zircões euédricos amarelos a vermelhos.

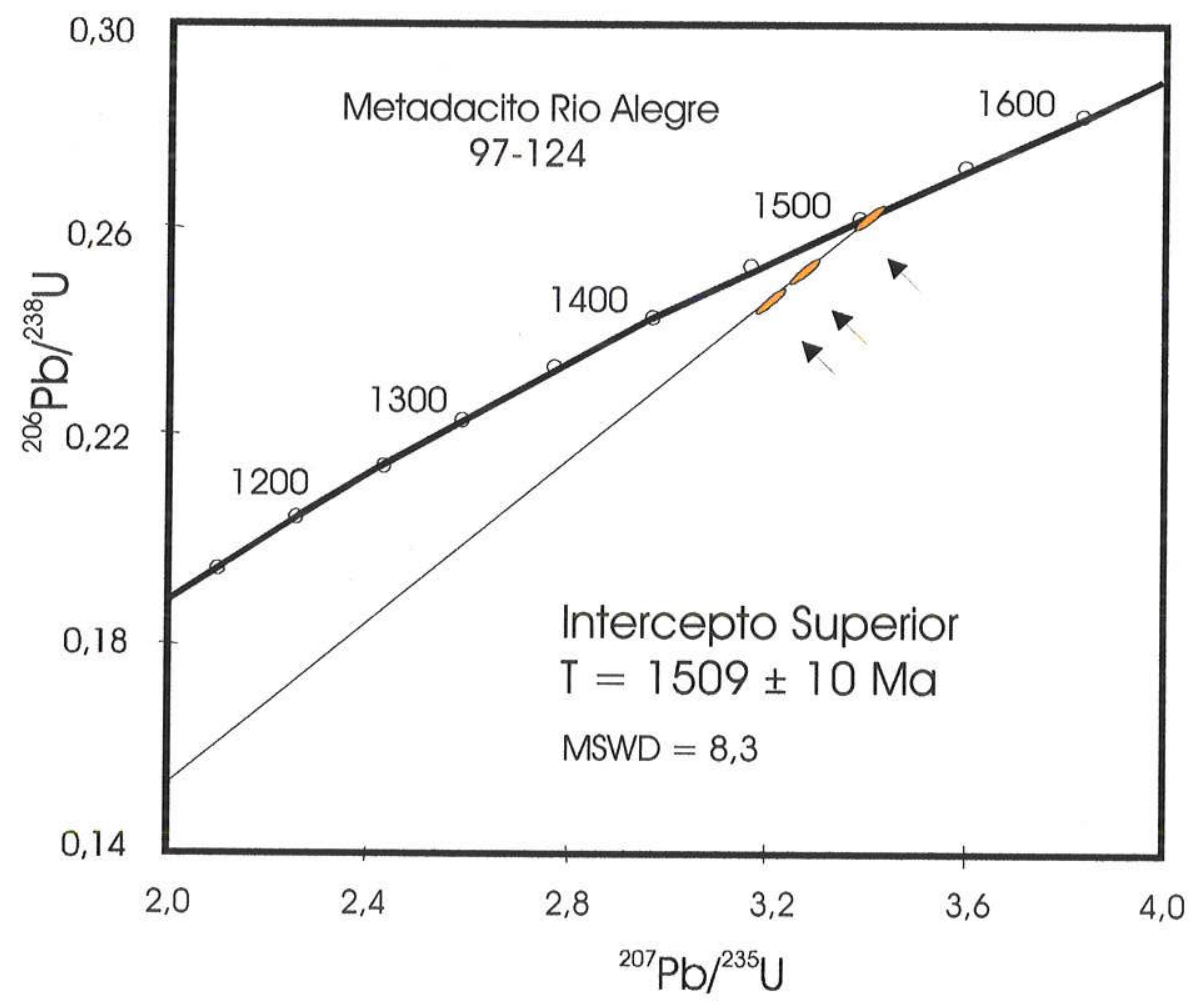

Figura 5.2. Diagrama da concórdia para o Metadiorito Rio Alegre (amostra 97-124) com 3 frações (monocristal de zircão) analisados indicando uma idade (intercepto superior) de $1509 \pm 10 \mathrm{Ma}$. Intercepto inferior forçado a 0 . 


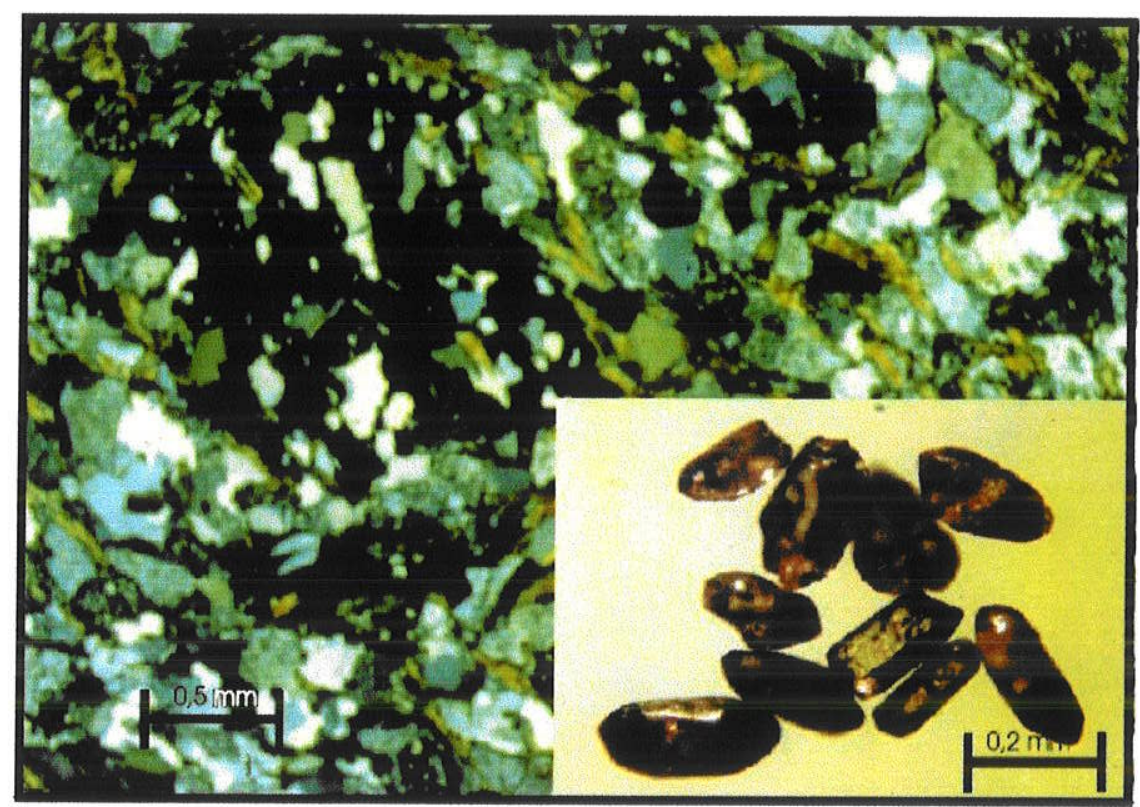

Fotomicrografia 5.3. Detalhe em lâmina da amostra metabásica Santa Bárbara. Os zircões obtidos nesta amostra são subédricos com as bipirâmides subarredondadas e coloração marrom.

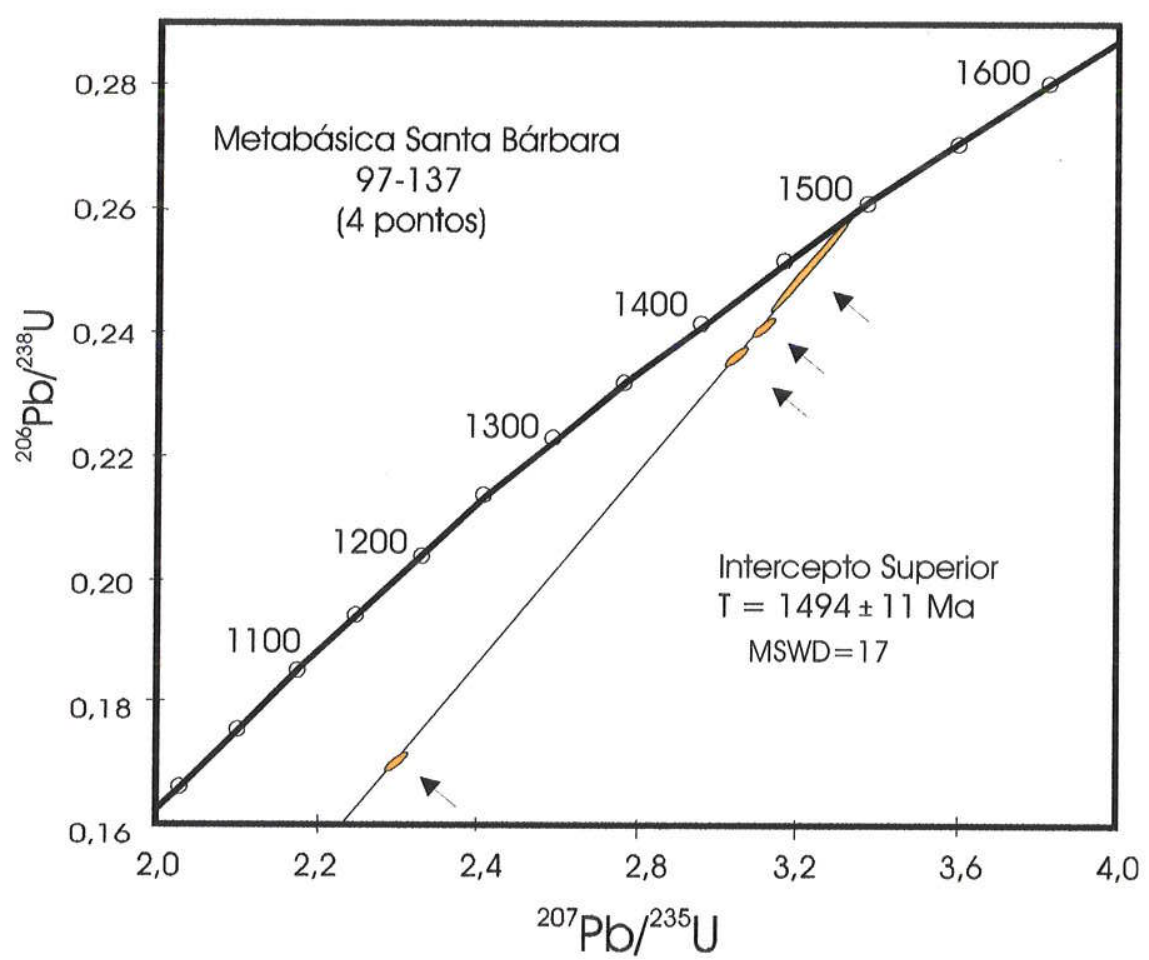

Figura 5.3. Diagrama da concórdia para a Metabásica Santa Bárbara (amostra 97-137). As 4 frações (monocristal de zircão) analisadas indicam uma idade (intercepto superior) de $1494 \pm 11 \mathrm{Ma}$. Intercepto inferior forçado a 0 . 


\subsection{Discussão}

O Terreno Rio Alegre observam-se rochas vulcânicas de composição variada (basaltos toleíticos a dacitos) intercaladas com rochas intrusivas máficas (peridotitos) e rochas sedimentares clásticas (arenitos e pelitos) e químicas (formação ferrífera bandada e chert) metamorfisados na fáciés xisto-verde.

Matos (1994) apresenta estudos geoquímicos das rochas vulcânicas e intrusivas associadas, indicando que as rochas básicas a intermediárias possuem características subalcalinas, sendo que os termos efusivos representam litotipos formados em assoalho oceânico gerados em bacia de retro arco (Matos e Schorscher, 1997a e b), com as rochas máfico-ultramáficas intrusivas exibindo evolução e diferenciação de tendência toleítica. As rochas efusivas apresentam alterações mineralógicas típicas de processos metassomáticos do tipo epidotização, carbonatação e sericitização, interpretadas como alterações de fundo oceânico.

A Sequência Metavulcanossedimentar Pontes e Lacerda foi correlacionada por Menezes et al., (1993) com a sequência vulcanossedimentar do Terreno Jauru. Segundo estes autores ambas as unidades seriam correlacionáveis por suas associações de rochas similares e contemporâneas. Esta correlação não é suportada pelos resultados aqui apresentados, uma vez que as rochas vulcânicas do Terreno Jauru apresentam idades entre 1795-1747 Ma e as rochas da Sequência Metavulcanossedimentar Rio Alegre apresentam idades entre 1509-1497 Ma. As unidades também apresentam descrições litológicas cuja mineralogia resultado de recristalização metamórfica compreende a associação clorita-granada-cianita, indicando a facies anfibolito baixo, segundo os autores.

As propostas de modelagem ambiental para a geração das rochas da $\mathrm{SSH}$ e da Sequência Vulcanossedimentar Rio Alegre devem levar em conta, ainda, uma hipótese em que o arco magmático da primeira pode ter sido formado da subducção da crosta oceânica representado pela segunda. Neste modelo especulativo, após a acresções representada pelo Terreno Jauru $(1,79$ a $1,55 \mathrm{Ga})$, haveria a formação do assoalho oceânico representado pelas rochas do Terreno Rio Alegre (1,50 Ga) e de sua subduç̧ão, gerando as rochas da Suíte Santa Helena (1,45 a 1,42 Ga) através de fusão parcial da crosta em subducção e a hidratação do manto superior. Corrobora com este 
modelo as assinaturas isotópicas de $\mathrm{Sm} / \mathrm{Nd}$ de ambos os terrenos, que apresentam mesmas idades de diferenciação mantélica ( $\mathrm{T}_{\mathrm{DM}}$ entre 1,70 e 1,50 Ga). Neste sentido, havendo fusão parcial das rochas do Terreno Rio Alegre para a formação das rochas da Suíte Santa Helena, não seria possível distinguir a assinatura isotópica de $\mathrm{Nd}$, uma vez que o método apresenta erros absolutos maiores que a diferença de idade entre ambas unidades. Outro aspecto que corrobora que este modelo são as idades $\mathrm{U} / \mathrm{Pb}$, uma vez que as rochas mais primitivas da SSH são exatamente as que apresentam idades de cristalização mais antigas (Tonalito Lavrinha, $1464 \pm 25 \mathrm{Ma}$, e Tonalito Pau-a-Pique, $1481 \pm 47 \mathrm{Ma}$ ), idades muitos próximas das idades de cristalização das rochas do Terreno Rio Alegre (1508 a $1494 \mathrm{Ma}$ ).

Os resultados geoquímicos descritos na literatura adicionados aos resultados isotópicos $\mathrm{U} / \mathrm{Pb}$ e $\mathrm{Sm} / \mathrm{Nd}$ aqui apresentados permitem que se façam as seguintes sugestões sobre o conjunto de rochas estudadas:

1. As rochas vulcânicas e plutônicas observadas no vale do Rio Alegre representam atividades magmáticas que ocorreram entre 1509 e $1494 \mathrm{Ma}$. O conjunto de rochas magmáticas observado indica ainda um ambiente de cadeia mesoceânica e a sua associação com metassedimentos clásticos e químicos sugere a deposição, dos últimos, em assoalho oceânico.

2. Os resultados $\mathrm{Sm} / \mathrm{Nd}$ (Figura 5.4) destas rochas sugerem que este complexo representa uma crosta juvenil (valores de $\varepsilon_{\mathrm{Nd}(t)}$ positivos) que veio a ser amalgamado ao longo da margem ocidental mesoproterozóica do protocráton Amazônico provavelmente decorrente de um processo de obducção.

3. As rochas do Terreno Rio Alegre possivelmente se formaram durante um evento extensional em placa(s) oceânica(s) localizada(s) a oeste (atual) da crosta continental que compunha, na época, o protocráton Amazônico no Mesoproteroz6ico conforme é sugerido pelo perfil dos terrenos mesoproteroz6icos apresentado na Figura 5.5.

4. Trabalhos futuros devem levar em conta a possibilidade das rochas do Terreno Rio Alegre representarem um complexo ofiolítico. 


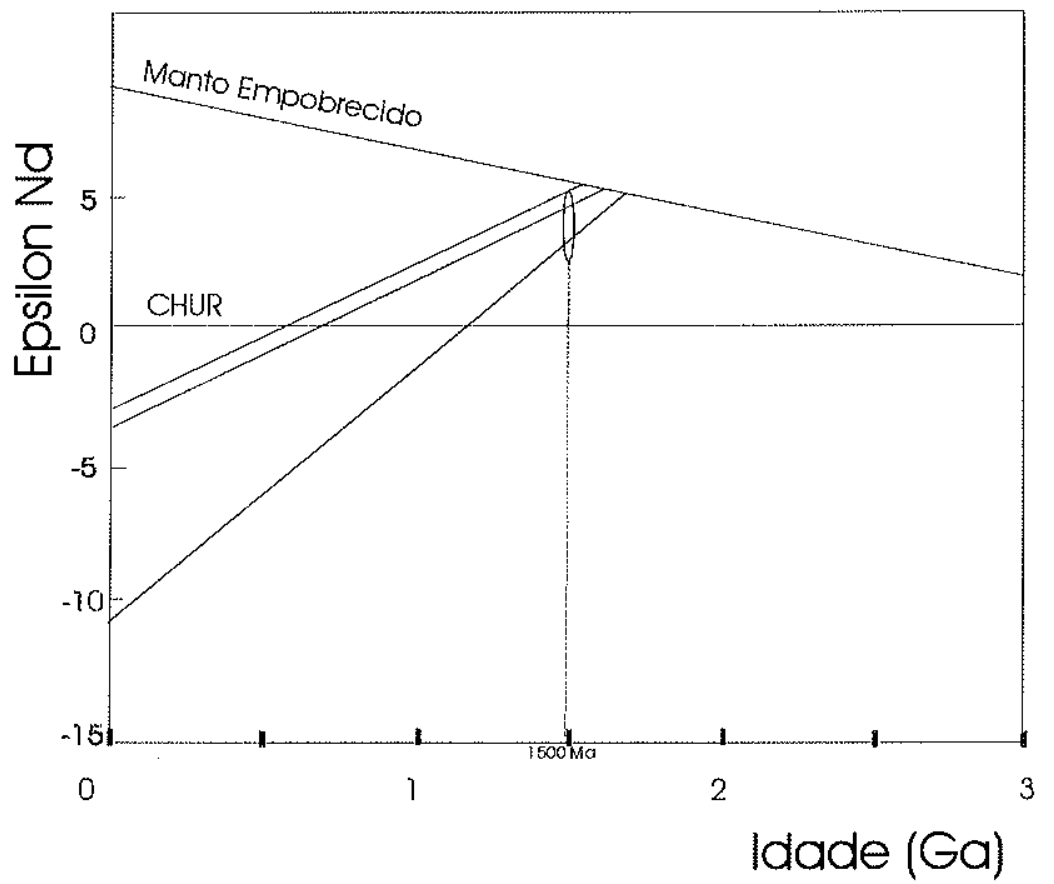

Figura 5.4 Diagrama de evolução isotópica de Nd para as rochas do Terreno Rio Alegre. Os valores positivos de $\varepsilon_{\mathrm{Nd}}$ sugerem a origem mantélica para os protólito destas rochas. 


\subsection{Rochas da Fazenda Reunidas}

Estas rochas ocorrem a oeste do vale do Rio Alegre (com exceção do microgranito Carrapato, descrito a seguir) e poderia ser continuidade do Cráton Parágua em território Brasileiro. Matos e Schorscher (1997a) identificam zonas de falhas ou cisalhamentos que podem indicar a separação entre o Terreno Rio Alegre e esta unidade descrita em território Boliviano. Este domínio localiza-se a oeste do Terreno Rio Alegre e é representada por rochas de composição tonalítica (Gnaisse Tonalítico Aguapeí), granodioritica (Granodiorito Rio Alegre) e granítica (Granito Lajes e Microgranito Carrapato). Ocorrem ainda rochas granulíticas do Complexo Anfibolítico-Granulítico Santa Bárbara, mas que não foram estudadas no presente trabalho.

As rochas estudadas são descritas a seguir e aspectos gerais dos afloramentos destas unidades são mostrados na Prancha 5.

Tabela 5.2. Dados U/Pb e Sm/Nd para as rochas da Fazenda Reunidas.

\begin{tabular}{lllllll}
\hline Numero & Descrição & $\mathrm{U} / \mathrm{Pb}(\mathrm{Ma})^{*}$ & $\varepsilon_{\mathrm{Nd}(0)}$ & $\varepsilon_{\mathrm{Nd}(\mathrm{T})}$ & $\mathrm{T}_{\mathrm{DM}}$ & $f$ \\
\hline$=-121$ & Gnaisse Tonalítico & $1384 \pm 40$ & $-4,7$ & 3,6 & 1,52 & $-0,24$ \\
$97-121$ & Microgranito Carrapato & $1400 \pm 24$ & $-11,2$ & 4.2 & 1,49 & $-0,42$ \\
$97-123$ & Granodionito Rio Alegre & $1412 \pm 21$ & $-5,1$ & 3,6 & 1,58 & $-0,24$ \\
$97-142$ & Granito Lajes*** & 1360 & $-14,8$ & 0,0 & 1,69 & $-0,44$ \\
$97-144$ & Granito Lajes*** & 1606 & $-14,8$ & 3,4 & 1,69 & $-0,44$ \\
$97-144$ &
\end{tabular}

* Idades $\mathrm{U} / \mathrm{Pb}$ obtida por diluição isotópica em monocristais de zircão.

** $\varepsilon_{\mathrm{Nd}(\mathrm{t})}$ calculado para a idade U/Pb. $\mathrm{T}_{\mathrm{DM}} \mathrm{em} \mathrm{Ga}$.

***A amostra 97-144 teve o $\varepsilon_{\mathrm{Nd}(\mathrm{t})}$ calculado para as duas idades U/Pb obtidas.

\section{Gnaisse Tonalítico Rio Aguapeí}

Esta unidade foi observada nas margens do Rio Aguapeí, na área de dissertação de mestrado de Pinho (1992). São rochas gnáissicas de composição tonalítica, de coloração rósea, com granulometria grosseira a média (Fotomicrografia 5.6), cuja composição varia de tonalitos a trondjemitos.

A relação de contato entre as rochas desta área (Pinho, 1992) apresenta grande complexidade, uma vez que são observadas rochas de composição 
anfibolítica com alto nível de deformação em contato com rochas de composição tonalíticas e graníticas foliadas. Ocorrem também rochas de composição monzogranítica anisotrópicas prrovavelmente resultado da fusão local das rochas tonalíticas.

A amostra coletada apresenta composição tonalítica, com variações laterais com litotipos com foliação fraca a intensa. No local de coleta ainda observam-se bolsões monzograníticos com contatos graduais com o tonalito. Três frações (monocristal) de zircões do tonalito foram analisados e os resultados quando lançados no diagrama da concórdia resultaram em uma idade de $1383 \pm 40 \mathrm{Ma}$ (Figura 5.5). Todas as frações são concordantes (foi observada apenas uma população de zircões) e se distribuem por sobre a concórdia com uma variação de idade entre $1400 \mathrm{Ma}$ e $1360 \mathrm{Ma}$, sugerindo ter ocorrido o processo de fusão do tonalito (e formação do monzogranito), provocando a rehomogeneização isotótica parcial do sistema $\mathrm{U}-\mathrm{Pb}$, e a consequente distribuição dos resultados analíticos.

\section{Granito Lajes}

Esta unidade ocorre na porção Sul do Domínio Rio Alegre, ao longo da estrada de acesso para Casal Vasco, sendo recoberta parcialmente pelos sedimentos da Formação Pantanal. Foi descrita inicialmente por Matos e Ruiz (1989) e é constituída por um granito cinza foliado de granulometria fina (Fotomicrografia 5.7). Seis frações de zircões (monocristais) fora analisados e quando lançados no diagrama da concórdia resultam em duas idades distintas. A primeira é definida por duas frações que indicam uma idade imprecisa (pelo alto erro) de $1608 \pm 200 \mathrm{Ma}$. Quatro outras frações de zircões indicam a idade de $1310 \pm 34 \mathrm{Ma}$ (Figura 5.6), sugerindo que esta rocha, como o Gnaisse tonalítico Rio Aguapeí, teve o sistema U-Pb rehomogeneizado após o período de tempo correspondente a sua cristalização.

\section{Microgranito Carrapato}

O microgranito, aqui denominado informalmente de Carrapato, apresenta uma coloração cinza a rosa, textura fina, equigranular e isotrópico. Microscopicamente esta 
rocha apresenta quartzo, k-feldspato e plagioclásio e poucos opacos. Uma intensa sericitização envolve os feldspatos, não sendo observadas biotitas (Fotomicrografia 5.8).

Oito frações de zircões (monocristal) foram analisadas e indicam uma idade de $1453 \pm 51 \mathrm{Ma}$ (Figura 5.7). Ocorre uma grande distribuição dos pontos analíticos, sugerindo que esta rocha pode ter passado por processos posteriores a sua cristalização que tenham alterado o sistema $\mathrm{U}-\mathrm{Pb}$. $\mathrm{O}$ erro $( \pm 51 \mathrm{Ma})$ foi obtido através de um número acima da média de análises (oito), quando comparado com as outras amostras analisadas (3 a 5 frações analisadas).

Granodiorito Rio Alegre.

A oeste do Rio Alegre são observados lajedos e blocos de rochas de composição granodiorítica, aqui informalmente denominado Granodiorito Rio Alegre. Sua composição mineralógica principal é quartzo, plagioclásio, k-feldspato e anfibólio (Fotomicrografia 5.9). Em amostras de mão não é observada orientação mineral, sendo a rocha de coloração cinza a rosa e granulação grosseira. Na Figura 5.8 é apresentado o diagrama da concódia para esta amostra (97-142). Sete frações de zircões (monocristal) foram analisadas e indicam uma idade de $1453 \pm 51 \mathrm{Ma}$, com pontos discordantes e desalinhados que indicam composições isotópicas distintas e sugerem que a rochas possa ter passado por processos que alteraram a composição isotópica original. 


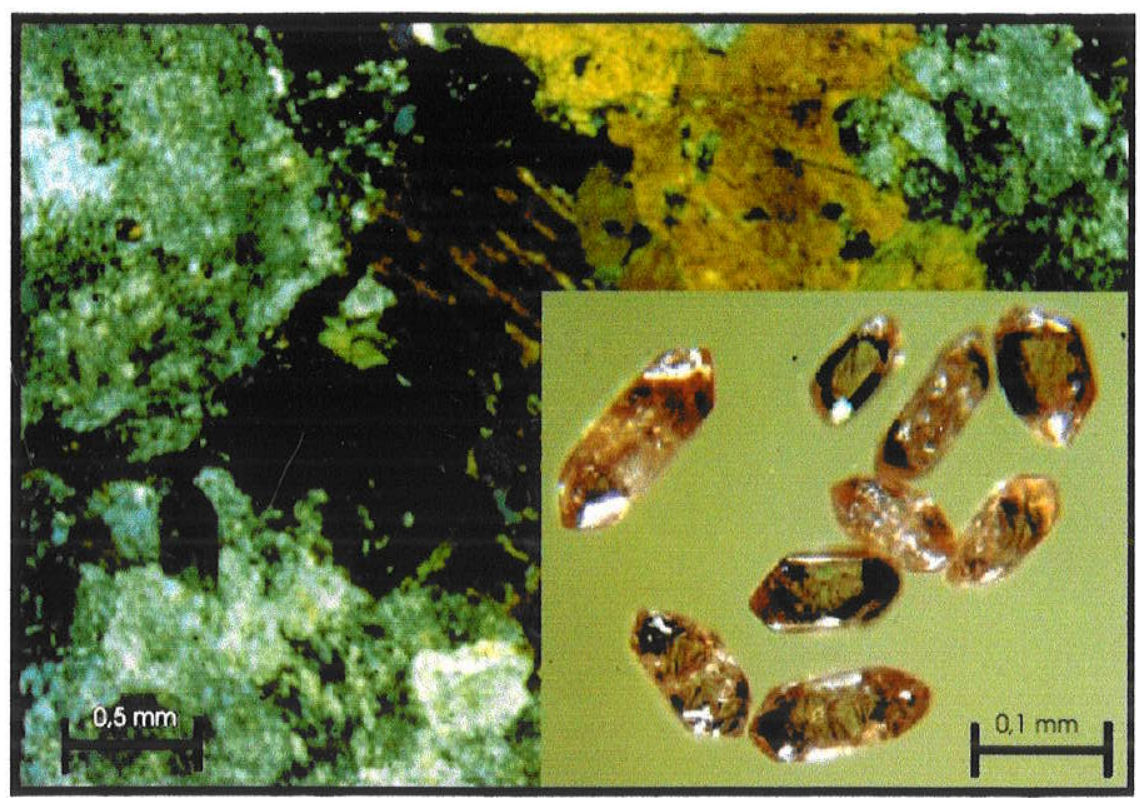

Fotomicrografia 5.6. Detalhe em lâmina do Tonalito Rio Aguapeí (amostra 97-121). Os zircões analisados são mostrados em detalhe.

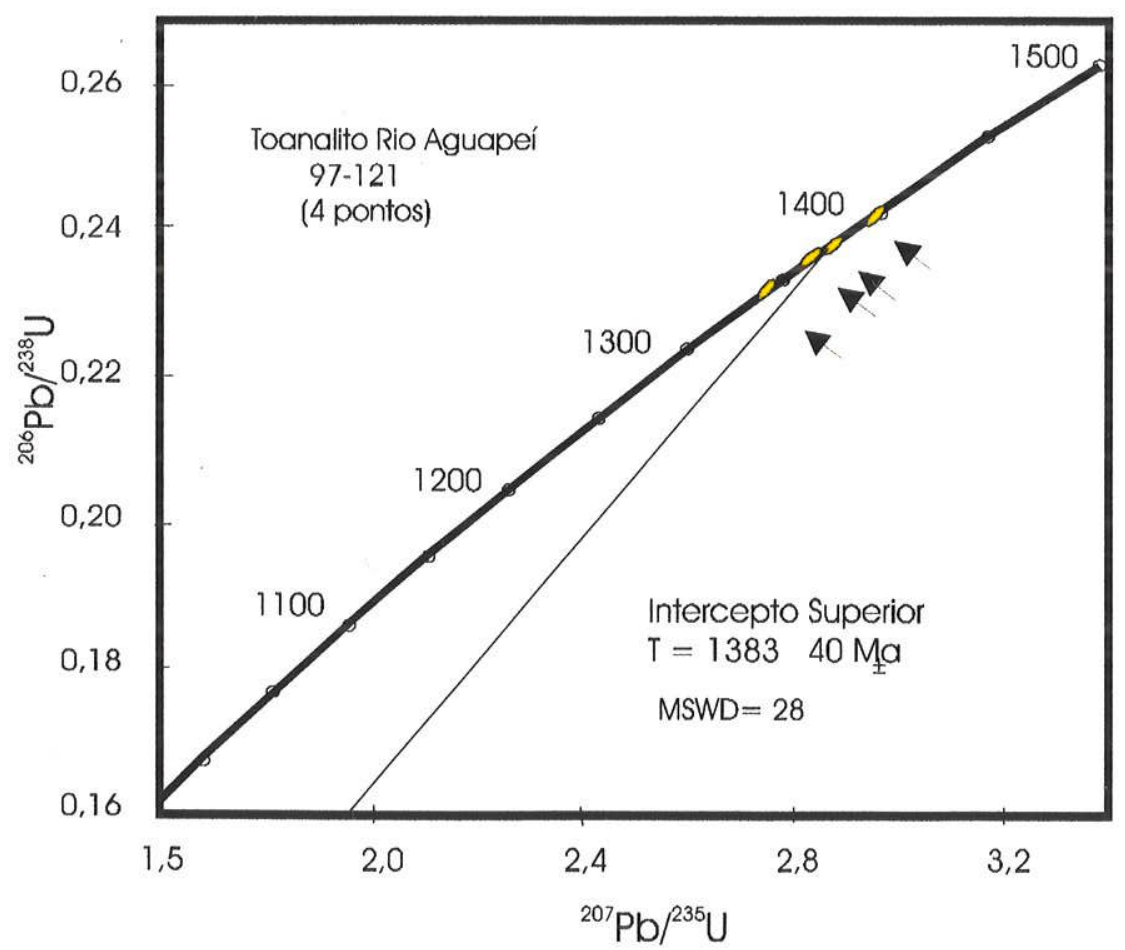

Figura 5.5. Diagrama da concórdia para o Tonalito Aguapeí (amostra 97-121). Três frações (monocristal) de zircões do tonalito foram analisados e os resultados quando lançados no diagrama da concórdia resultaram em uma idade de $1383 \pm 40 \mathrm{Ma}$. As três frações são concordantes. Intercepto inferior forçado a 0 . 


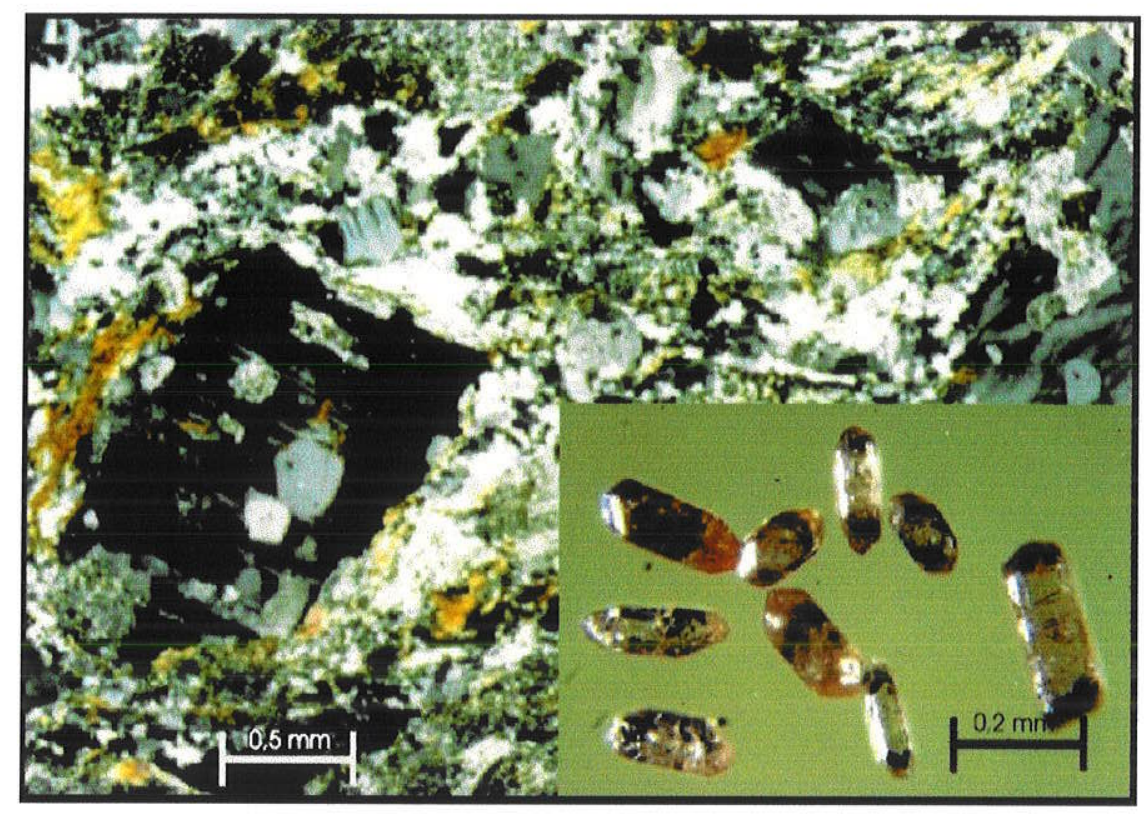

Fotomicrografia 57. Detalhe em lâmina do Granito Lajes (amostra 97-141). Os zircões analisados são mostrados em detalhe.

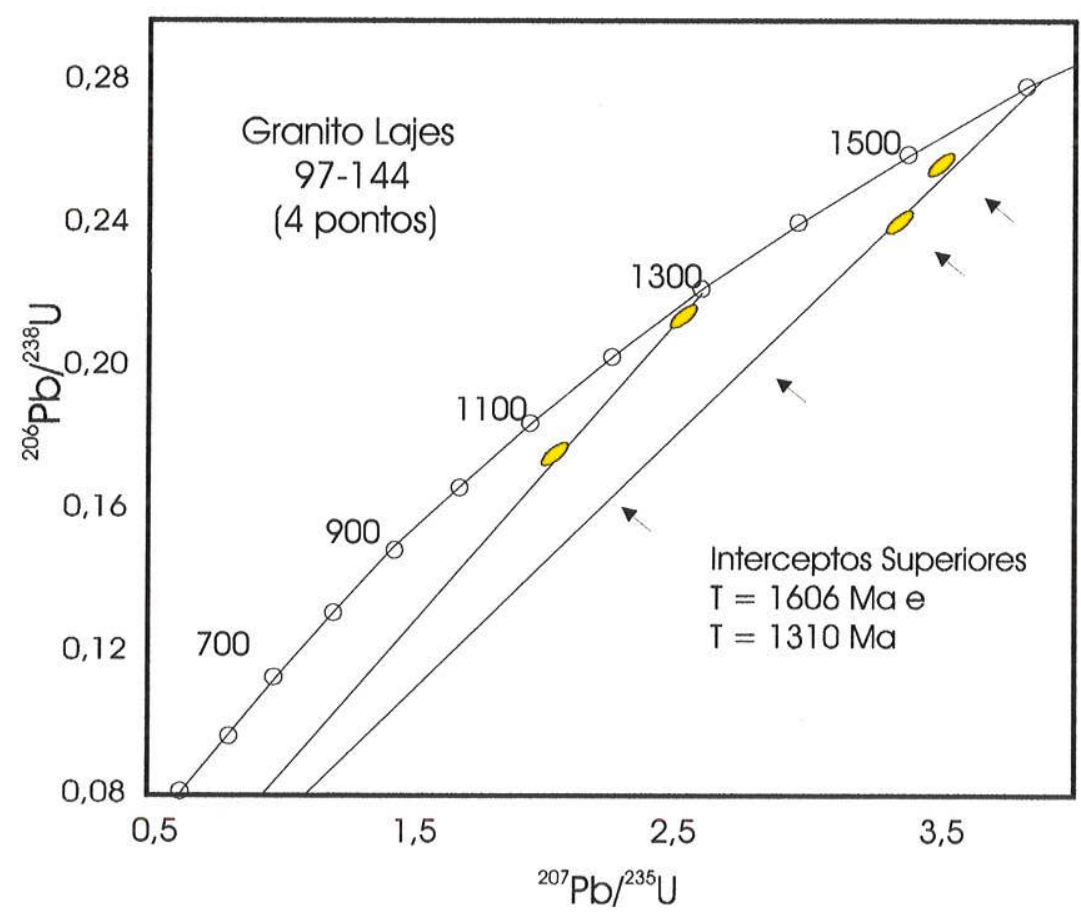

Figura 5.6. Diagrama da concórdia para a amosra 97-141 Granito Lajes. Duas frações de zircões indicam a idade de $1606 \mathrm{Ma}$ e duas outras frações indicam a idade de $1310 \mathrm{Ma}$. Interceptos inferiores forçados a 0 . 


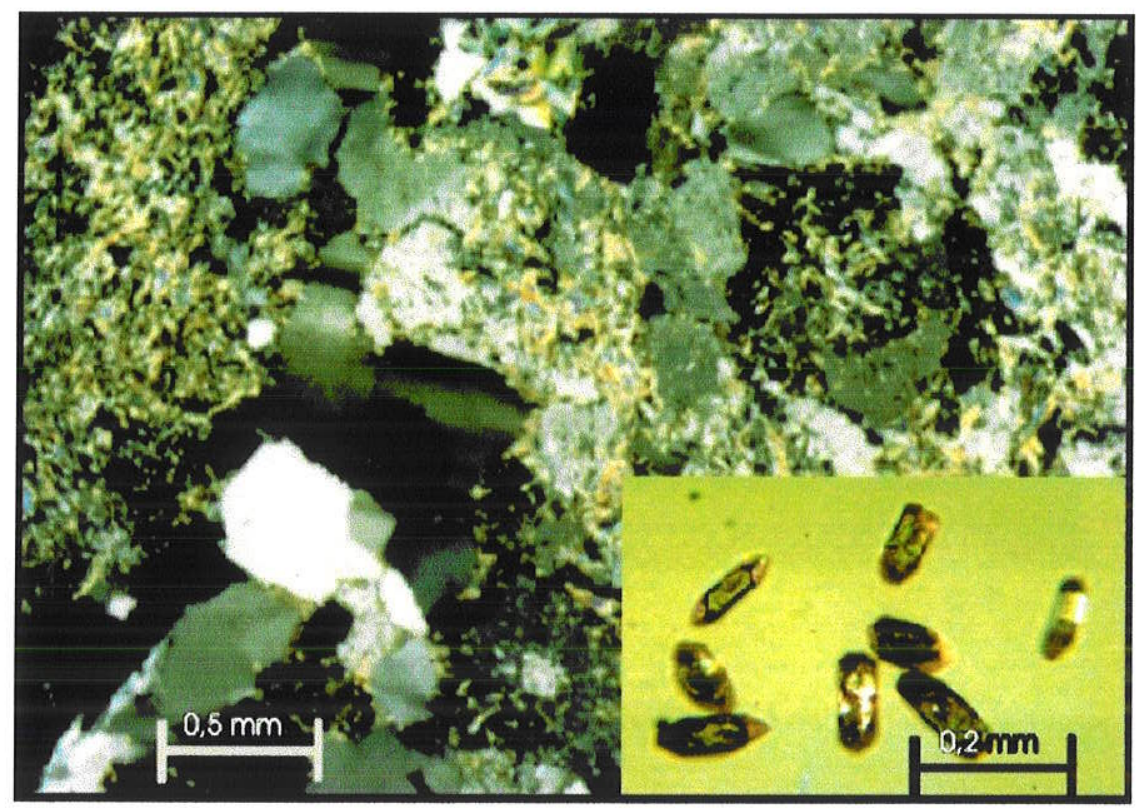

Fotomicrografia 5.8. Detalhe em lâmina do Microgranito Carrapato (amostra 97-123). Os zircões analisados são mostrados em detalhe.

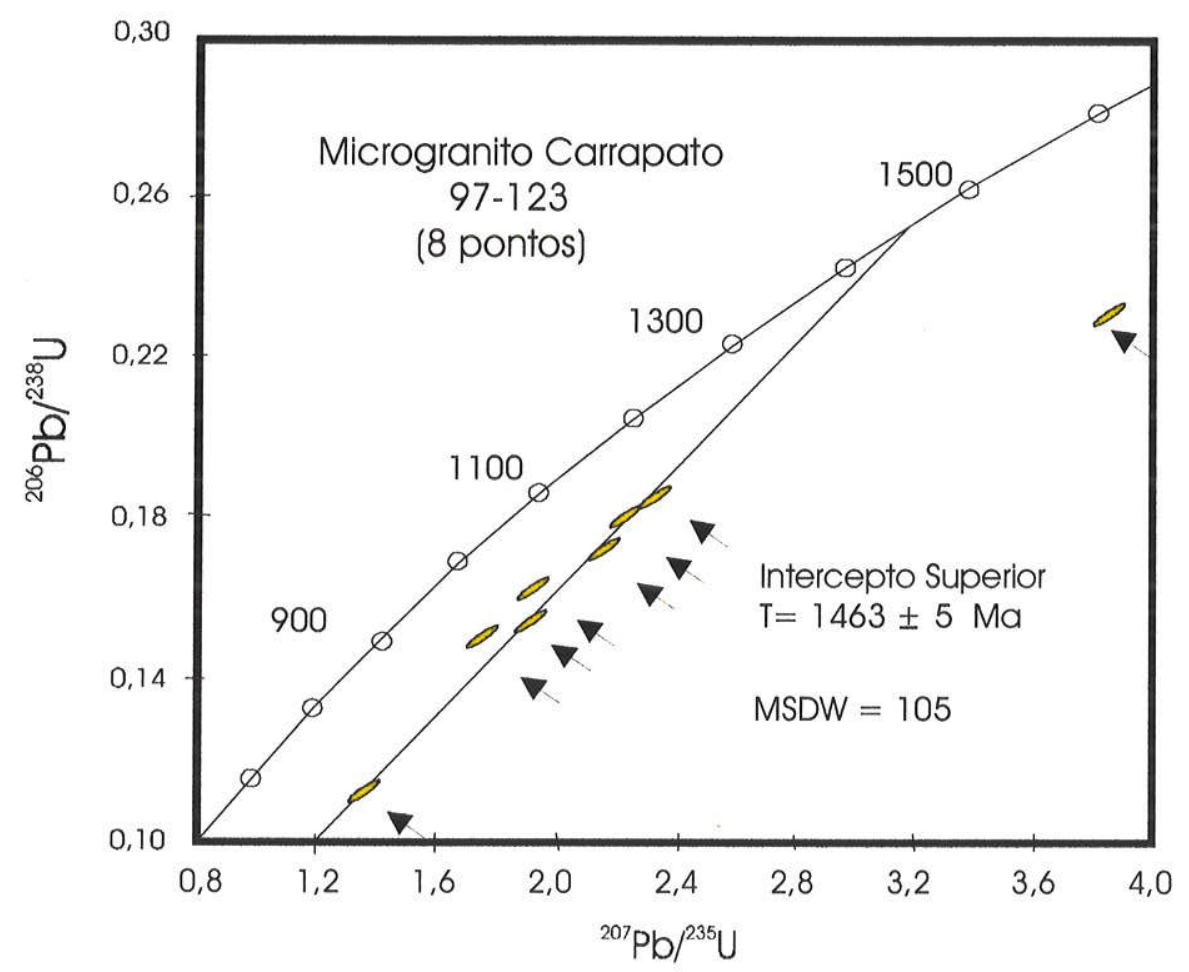

Figura 5.7 Diagrama da concódia para o Microgranito Carrapato (amostra 97-123). Oito frações de zircões (monocristal) foram analisadas e indicam uma idade de $1453 \pm 51 \mathrm{Ma}$. Intercepto inferior forçado a 0. 


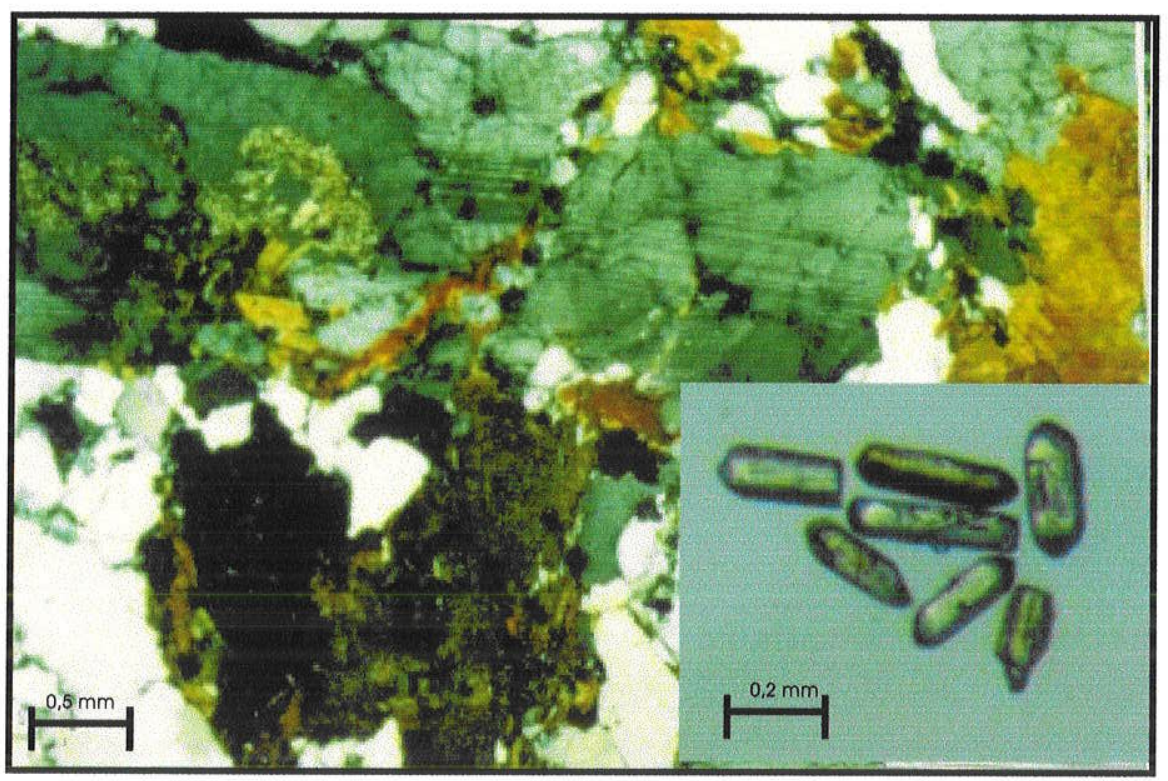

Fotomicrografia 5.9. Detalhe em lâmina do Granodiorito Rio Alegre (amostra 97-142). Os zircões analisados são mostrados em detalhe.

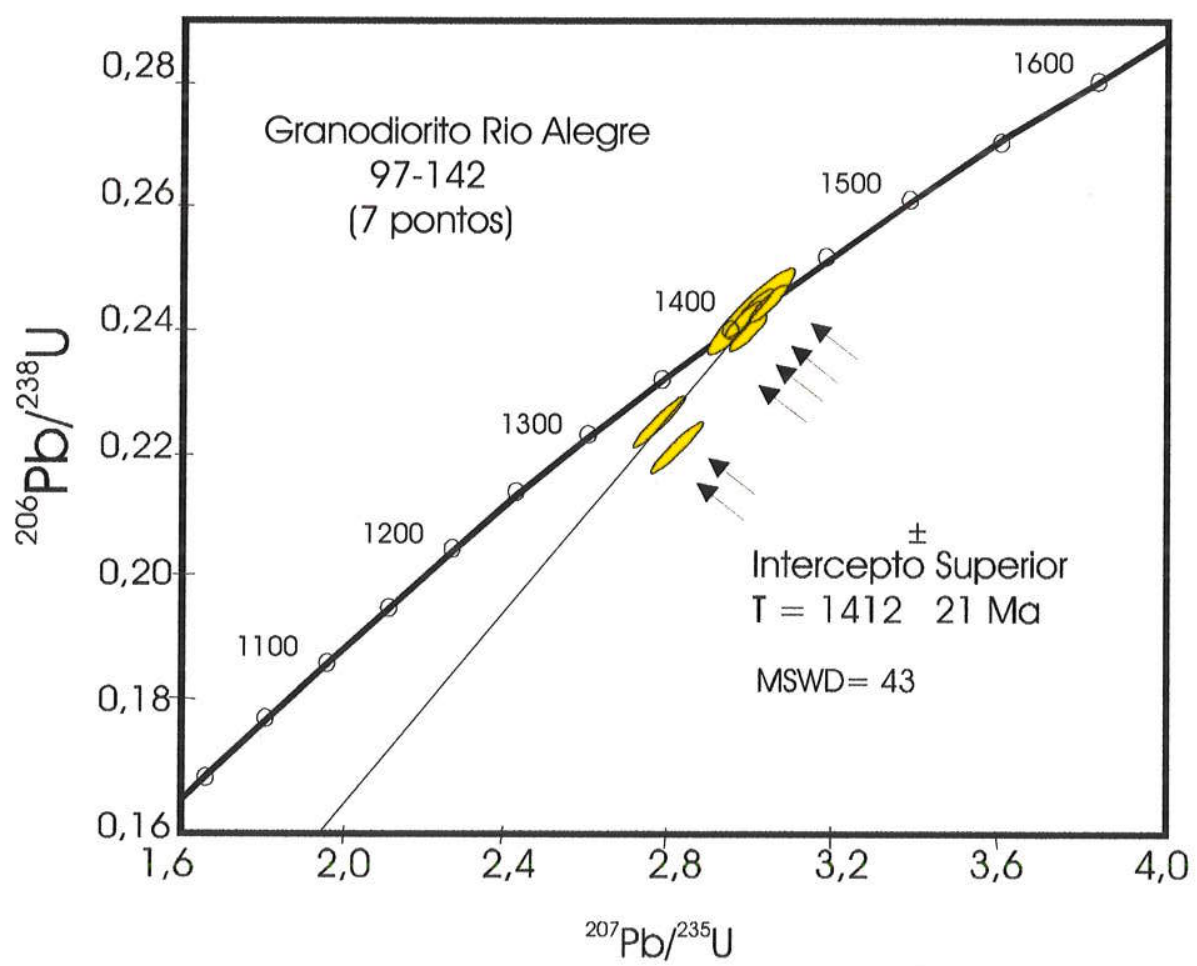

Figura 5.8. Diagrama da concódia para o Granodiorito Rio Alegre (amostra 97-142). Sete frações de zircões (monocristal) foram analisadas e indicam uma idade de $1453 \pm 51 \mathrm{Ma}$. Intercepto inferior forçado a 0 . 


\subsection{Discussão}

A hipótese da extensão do Terreno Parágua na região oeste de Mato Grosso tem por base apenas uma eventual continuidade geográfica do terreno uma vez que falta estudos geológicos de detalhe. $\mathrm{O}$ grupo de rochas observado na área em estudo no extremo oeste do Terreno Rio Alegre tem similaridades com as associações litológicas descritas na Bolivia (Litherland et. al., 1989)., porém os resultados do estudo U/Pb realizado em zircões destas amostras não permitem definir uma história geológica coerente e de continuidade entre os dois terrenos.

O Cráton Parágua foi definido englobando as rochas do Complexo Pensamiento, que compreendem granitos pré, sin e tardi-cinemáticos, gerados, segundo Liherland et. al. (1986), durante o evento San Ignácio. A estas rochas dicionado de plútons alcalinos com características anorogênicas (rapakivíticas), possivelmente ocorem nesta área na Bolívia, também descritas em Rondônia. As idades $\mathrm{Rb} / \mathrm{Sr}$ e $\mathrm{K} / \mathrm{Ar}$ das rochas do Complexo Pensamiento estão no intervalo de tempo entre 1400-1270 Ma, o que levou Teixeira e Tasinari (1984) a sugerir a Província Rondoniano/San Ignácio.

As rochas aqui estudadas não apresentam limites geocronológicos precisamente definidos porém sugerem ter uma história geológica policíclica, em função dos resultados analíticos $\mathrm{U} / \mathrm{Pb}$ em zircões indicarem idades concordantes porém variando entre 1,60 a 1,30 Ga, caracterizando o Domínio Fazenda Reunidas integrante, até que se defina com mais precisão essa associação de rochas, do Terreno Rio Alegre. É interessante notar que esta variação de idades não é uma variação entre as idades das rochas, mas corresponde a variações de idades de zircões pertencentes a cada uma das rochas analisadas, com exceção do Gnaisse Tonalítico Rio Aguapeí, que apresenta zircões com idades dentro de um intervalo de tempo menor (1400 a $1360 \mathrm{Ma}$ )

Estas rochas encontram-se cobertas pelos sedimentos do Grupo Aguapeí, cujo início e final de deposição provavelmente varia entre $1,3 \mathrm{Ga}$ a $0,95 \mathrm{Ga}$ segundo Litherland et. al., (1989), limites temporais estes de acordo com os resultados apresentados no presente trabalho. Conseqüentemente a colagem das rochas policíclicas aqui descritas na borda oeste do Terreno Rio Alegre, é anterior a 1,3 Ga, configurando o embasamento para a Bacia do Grupo Aguapeí que se estende desde o Terreno Jauru (a leste) até o Cráton Parágua (na Bolívia). 


\section{CAPÍTULO 6 \\ A Suíte Intrusiva Rio Branco}

\subsection{Localização e Distribuição das Unidades.}

As rochas desta unidade foram inicialmente descritas por Oliva et al., (1979), denominada de Complexo Serra de Rio Branco. Barros et. al., (1982) efetuaram um estudo mais detalhado, definindo o Grupo Rio Branco. Posteriormente Leite et al., (1986) integraram dados de mapeamento geológico na região de Rio e definiram a Suíte Intrusiva Rio Branco (SIRB)

As rochas desta unidade afloram no Terreno Jauru e tiveram um estudo mais detalhado através da coleta de uma maior variedade de litotipos. Isto permitiu, através de uma maior quantidade de análises e variedade de análises isotópicas, avançar no entendimento da gênese da SIRB. Os dados isótopicos de U/Pb e $\mathrm{Sm} / \mathrm{Nd}$ estão sumarizados na Tabela 6.1. A localização dos pontos amostrados pode ser vista na Figura 3.1. Aspectos gerais dos afloramentos desta unidade são apresentados na Prancha 6.

\subsection{Relações de Contato entre as litologias}

As amostras RB-01 a RB-12 foram coletadas em um perfil contínuo de direção oeste para leste com início a cerca de $2 \mathrm{Km}$ da cidade de Salto do Céu e com aproximadamente 5 $\mathrm{km}$ de extensão. As rochas apresentam contato litológico, variando de termos gábricos a granófiros de composição granítica ao longo do perfil. Nas proximidades do ponto onde foi 
coletada a amostra Rb-06 observa-se a presença de textura de mistura com porções de composição básica com porções de composição félsica e textura tipo rapakivi.

A SIRB é representada por duas associações principais, uma de composição gabróica (mais subordinada) e outra granítica. A primeira compreende tipos granulares, eventualmente subvulcânicos, com composições de tendência mais básica. Estas rochas são melanocráticas, isotrópicas, com plagioclásio, piroxênio e anfibólio. De forma mais restrita tais rochas podem apresentar caráter porfirítico, resultado da presença de cristais arredondados de piroxênio (pigeonita) subcentimétrico envolvido por uma matriz equigranular de plagioclásio, anfibólio e piroxênio.

A segunda associação ocorre como granitos leucráticos, avermelhados a róseos, Este grupo grupo é representado por rochas leucocráticas, com textura subvulcânica e composição granítica, isótropas, via de regra equigranulares e frequentemente grosseiras com quartzo, plagioclásio, feldspato alcalino, anfibólio, titanita, biotita e opacos. Esta fácies é predominante no contexto geral do pluton, sendo normal ainda a observação de variações laterais com fácies mais ou menos grossas. Relativamente às fácies leucocráticas predominantes, as relações de campo indicam claramente cristalização dos termos básicos quase que simultânea, com mistura mecânica parcial (comingling) entre as duas associações. Estas fácies gabróicas destacam-se freqüentemente como xenólitos subarredondados a fusiformes em diferentes estágios de assimilação nas massas mais ácidas. Localmente resultam rochas híbridas pela interação avançada, cujas feições mais notáveis desta mistura são feldspatos alcalinos manteados por finas películas de plagioclásio.

\subsection{Petrografia}

Os estudos petrográficos indicaram que as rochas da fácies predominante da SIRB são de composição granítica com textura subvulcânica, granulação média ou porfirítica de matriz granítica. O plagioclásio apresenta moderado a forte zoneamento, com núcleos corroídos de feldspato alcalino com freqüentes inclusões primárias e manteamento por plagioclásio. A biotita ocorre em palhetas idiomórficas, constituindo o principal acessório e encontra-se comumente alterada para clorita. Os demais acessórios incluem apatita, zircão e opacos. 
As rochas de composição básica são gabros a monzogabros, predominantemente equigranulares, porém microporfiríticos freqüentes, com matriz basáltica. Os fenocristais são compostos por piroxênio (pigeonita) alterado para clorita e sericita. $\mathrm{O}$ anfibólio verde azulado (hornblenda) ocorre em proporção equivalente ao plagioclásio e a augita, que apresenta hábitos retangulares a ripiformes, podendo apresentar bordas corroídas. Detalhes petrográficos das amostras analisadas são mostrados nas Pranchas 7,8 e 9 .

A possível interação das duas fases magmáticas contrastantes é sugerida, microscopicamente pela presença, nas variedades de composição granítica, k-feldspato zonado e corroído, manteado por plagiocásio; e nas variedades básicas por plagioclásios corroídos, relacionados a processos magma commingling. Neste contexto, a existência de termos mais ácidos com textura tipo rapakivi poderia sugerir xenocristais provenientes do magma básico, englobados e constituintes da matriz supostamente hibridizada. Neste caso, as texturas seriam geradas em um ambiente de rápido resfriamento (quenching) de um magma mais básico, com alta temperatura de fusão (indicado pela presença de pigeonita, piroxênio de alta temperatura), posto em contato com o mágma félsico, mais frio conforme sugerido pela presença de textura granofírica nas porções mais diferenciadas do magma félsico.

A análise petrográfica das rochas da SIRB também indicou um forte processo de alteração hidrotermal caracterizado pela sericitização dos feldspatos, uralitização dos piroxênios e cloritização dos opacos. Observa-se também a cloritização de anfibólio nas amostras mais ácidas. A seritização dos feldspatos é indicada pela presença de finas palhetas de sericita tanto nos plagioclásios dos termos mais básicos como nos feldspatos alcalinos nos termos mais ácidos. Nos termos mais ácidos observa-se a alterção hidrotermal ocorrendo nas bordas de cristais de ortoclásios, sendo o núcleo parcialmente preservados. Em alguns cristais observamse o núcleo intensamente alterado e a borda parcialmente alterada, resultado do zoneamento com diferentes composições. 

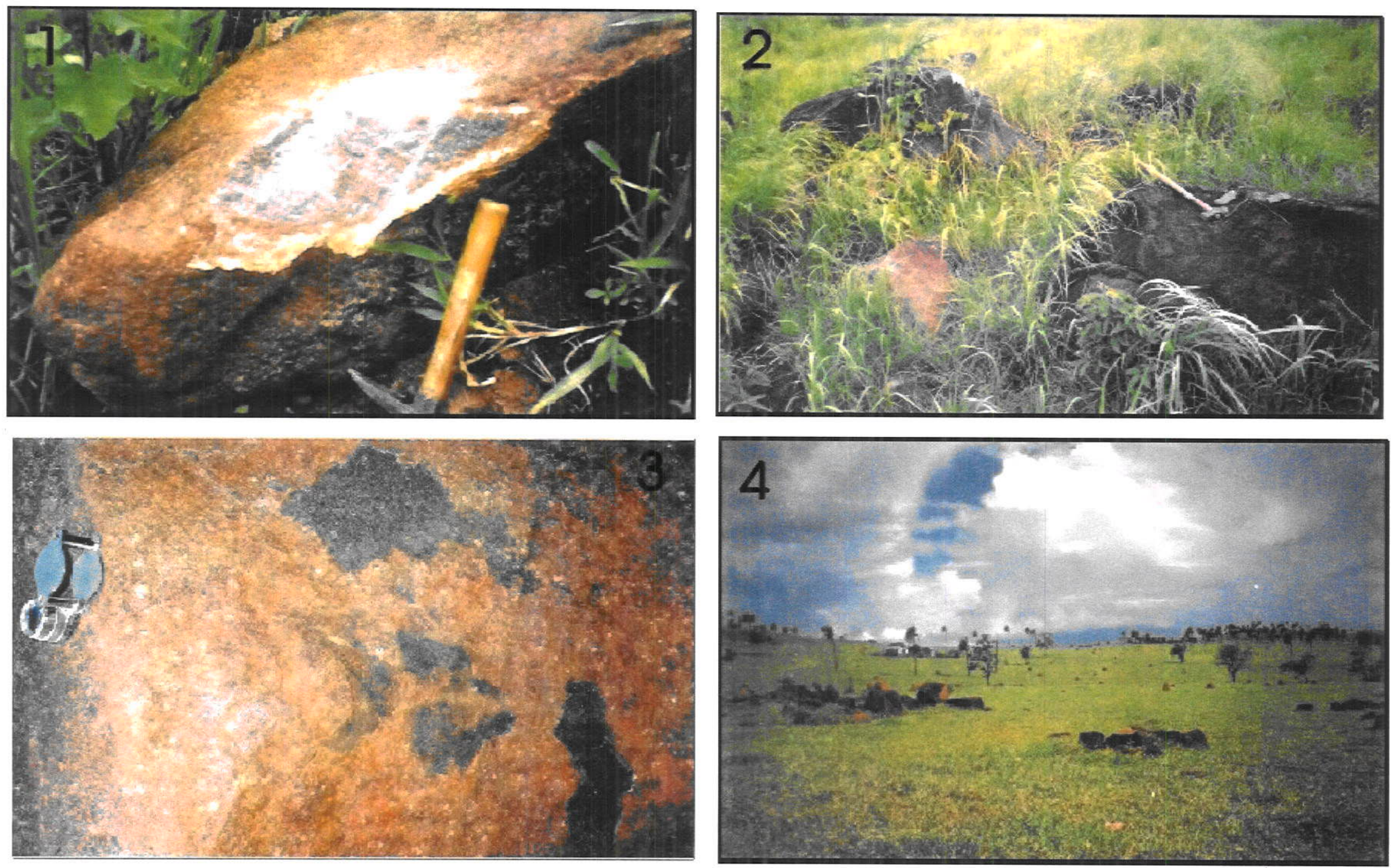

Prancha 5 (1) Rochas graníticas granofíricas da SIRB (amostra Rb-10).

(2) Rochas basálticas da SIRB (amostra Rb-01)

(3) Detalhe da mistura entre rochas graníticas da SIRB (porções de rochas básicas envolvidas por rochas de composição granítica).

(4) Afloramento de rochas félsicas (litotipo predominante) da SIRB (amostra Rb-12). 

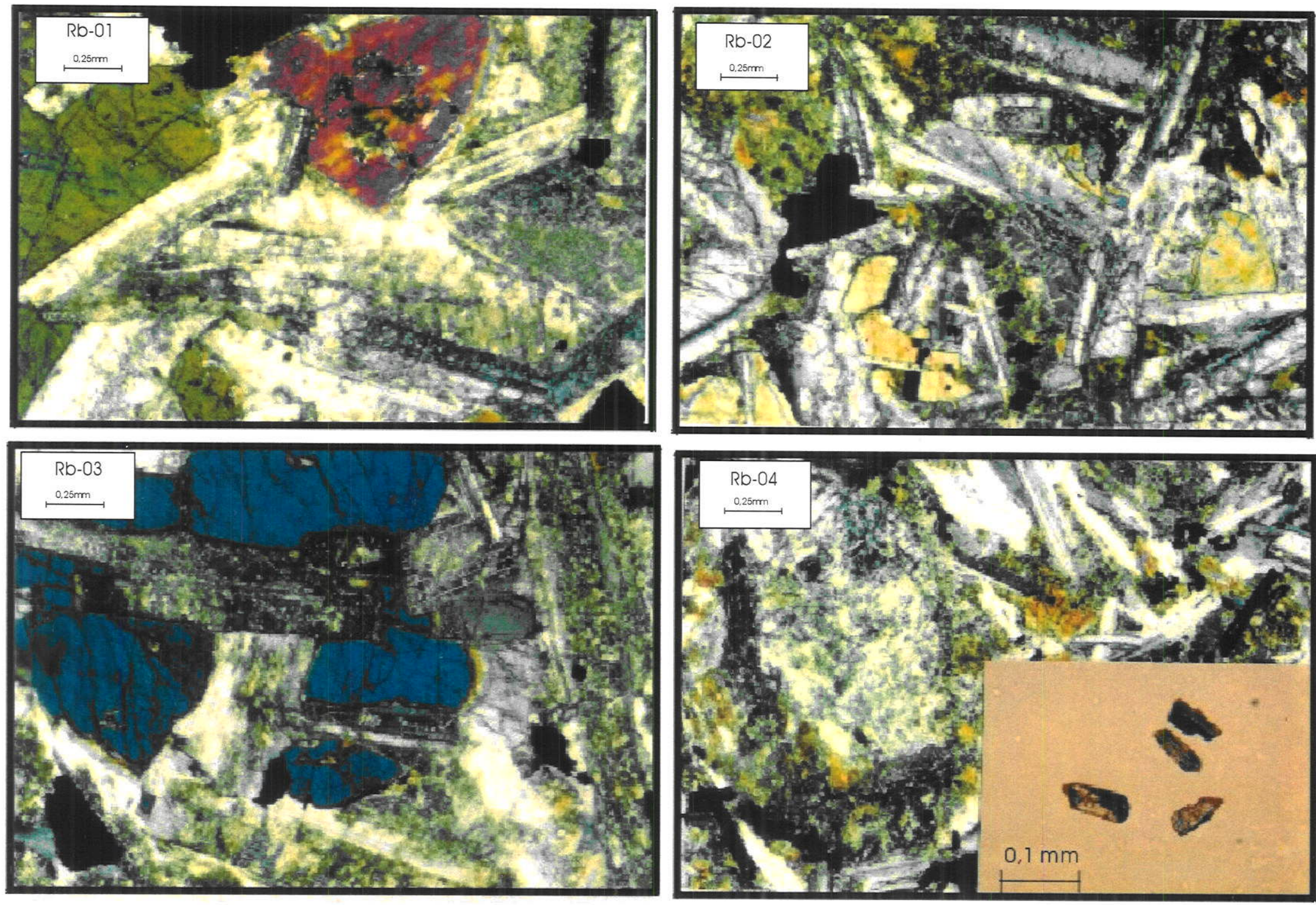

Prancha 6 Rb-01 Basalto (plagioclásio, piroxênio e anfibólio).

$\mathrm{Rb}-02$ Basalto (plagioclásio, piroxênio e anfibólio).

Rb-03 Gabro (plagioclásio, piroxênio e anfibólio).

Rb-04 Gabro Pórfiro (plagioclásio, augita, pigeonita e anfibólio). Os zircões obtidos são mostrados em detalhe. 

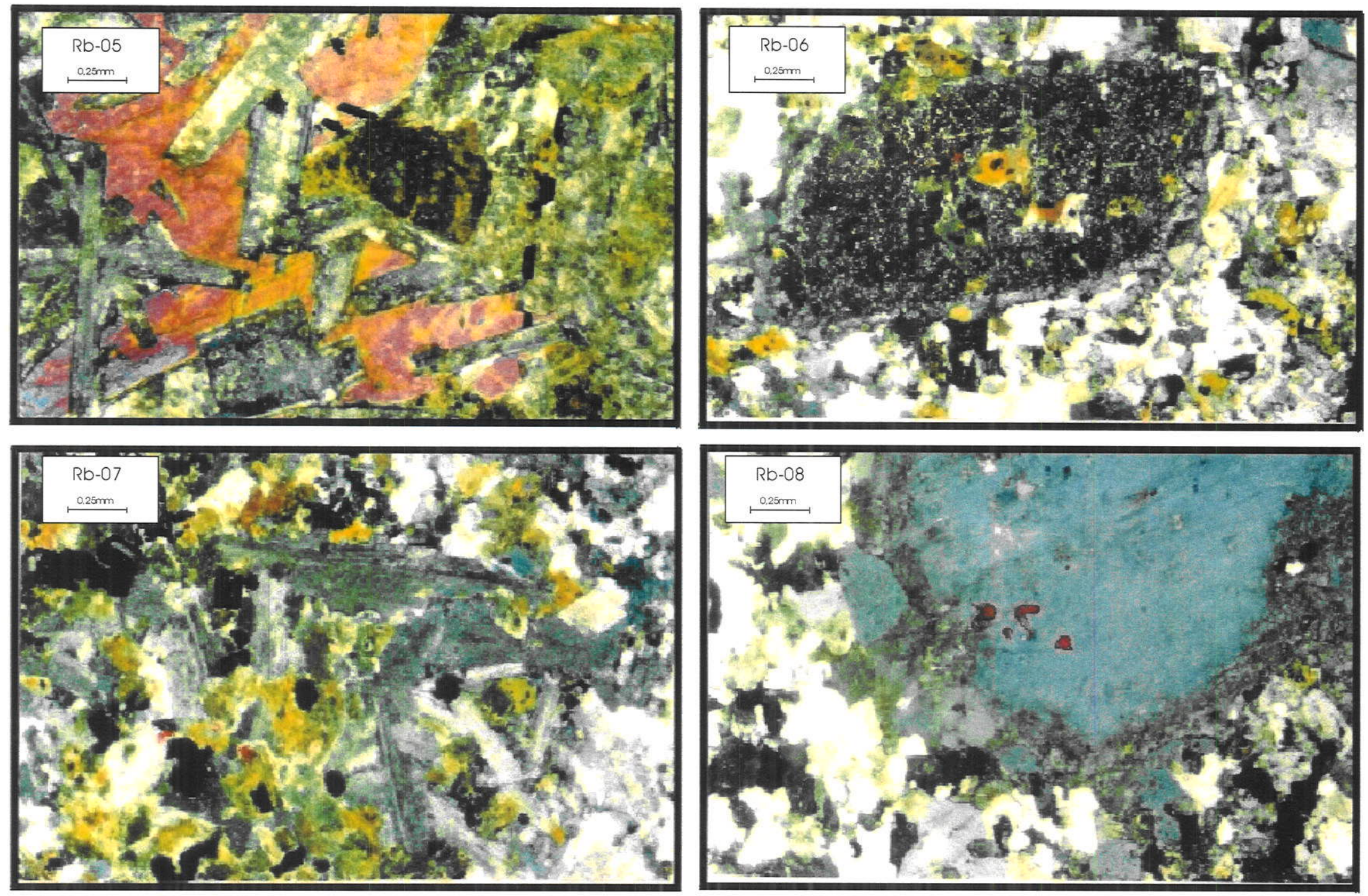

Prancha $7 \mathrm{Rb}-05$ Basalto (plagioclásio, piroxênio e anfibólio).

$\mathrm{Rb}$-06 Granito (K-feldspato, plagioclásio, quartzo e anfibólio) Observar o zoneamento do k-feldspato.

Rb-07 Granito (K-feldspato, plagioclásio, quartzo e anfibólio).

Rb-08 Granito (K-feldspato, plagioclásio, quartzo e anfibólio) Observar o zoneamento do k-feldspato. 

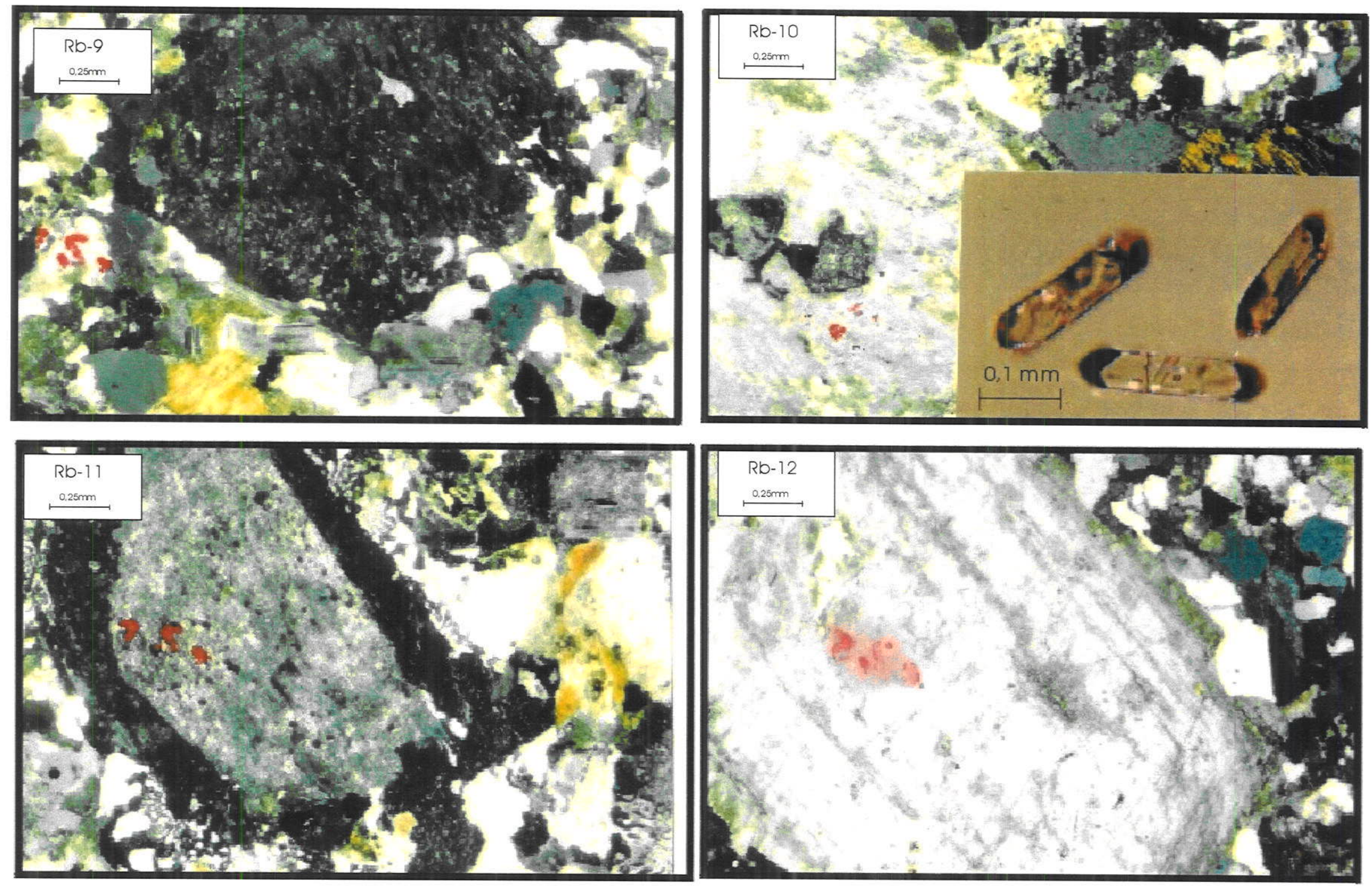

Prancha 8 Rb-09 Granito (K-feldspato, plagioclásio, quartzo e anfibólio)

Rb-10 Granito (K-feldspato, plagioclásio, quartzo e anfibólio). Observar o zoneamento do k-feldspato. Zircões obtidos são mostrados em detalhe. Rb-11 Granito granofírico (K-feldspato, plagioclásio, quartzo e anfibólio). Observar o zoneamento do k-feldspato. $\mathrm{Rb}-12$ Granito granofífico (K-feldspato, plagioclásio, quartzo e anfibólio) Observar o zoneamento do k-feldspato. 


\subsection{Estudos isotópicos $\mathrm{U} / \mathrm{Pb}$ e $\mathrm{Sm} / \mathrm{Nd}$}

Foram realizados trabalhos de datação segundo a metodologia $\mathrm{U} / \mathrm{Pb}$ em zircão para o grupo de rochas félsicas e básicas. No ponto $\mathrm{Rb}-10$ foram coletados $20 \mathrm{~kg}$ de amostra de rocha fésica para fins de concentração mineral e separação de zircões. No ponto Rb-04 foi coletada uma amostra de basalto em função da alta concentração de $U$ na rocha analisada previamente, o que poderia facilitar a concentração de minerais pesados e obtenção de grãos de zircões para fins de datação. Um amostra de $30 \mathrm{Kg}$ foi processada e foram obtidas cerca de 2 dúzias de zircões.

$\mathrm{Da}$ amostra $\mathrm{Rb}-10$ foram analisadas 4 frações de zircão (monocristal) após abrasão de duas horas. Os resultados, quando plotados no diagrama da $r$ (e forçados para zero) apresenta uma idade no intercepto superior de $1423 \pm 02 \mathrm{Ma}$, interpretada como idade de cristalização da rocha. Os pontos são concordantes e resultaram numa idade com alta precisão e pequeno erro (Figura 6.1).

$\mathrm{Da}$ amostra $\mathrm{Rb}-04$ 4cinco zircões foram escolhidos para análise U/Pb por diluição isotópica. Os resultados quando lançados no diagrama da concórdia apresenta uma idade de $1469 \pm 31 \mathrm{Ma}$ (Figura 6.2). As idades U/Pb são cerca de $300 \mathrm{Ma}$ mais antigas que as idades $\mathrm{Rb} / \mathrm{Sr}$ reportadas por Barros et al., (1982) de $1130 \pm 72 \mathrm{Ma}\left(\mathrm{Sr} / \mathrm{Sr}_{\text {inicial }}=0.708\right)$ e uma isócrona $\mathrm{Rb} / \mathrm{Sr}$ (Cepegeo, dados não publicados) de 3 pontos cujo resultado é de $1126 \pm 39 \mathrm{Ma}\left(\mathrm{Sr} / \mathrm{Sr}_{\text {inicial }}=0.716\right)$. Esta diferença de $300 \mathrm{Ma}$ provavemente é resultado da atividade hidrotermal que permeou as rochas da SIRB, uma vez que não há evidência de metamorfismo regional nesta unidade.

Alíquotas das mesma amostras pulverizadas para as análises químicas foram utilizadas para as análises isotópicas de $\mathrm{Nd}$. Os resultados estão apresentados na tabela $6.3 \mathrm{e}$ indicam diferenças entre as rochas máficas e félsicas. As concentrações de $\mathrm{Sm}$ e de $\mathrm{Nd}$ para amostra Rb-04 apresentam valores anômalos em relação às outras amostras básicas. A média de concentração nestas rochas é de $22 \mathrm{ppm}$ para o $\mathrm{Nd}$ e de 5,2 ppm para o $\mathrm{Sm}$, enquanto a amostra Rb-04 apresenta valores de 49,6 e 8,7 ppm, respectivamente. Os valores de $\varepsilon_{N d(t)}(8,9)$ e T $\mathrm{DM}(1,17 \mathrm{Ga})$ também são anômalos em relação ao grupo de rochas básicas e podem ser resultante do fracionamento relativo entre $\mathrm{Sm}$ e $\mathrm{Nd}$. Colaboram com esta hipótese as altas concentrações de minerais acessórios como monazita e apatita, o que explica os altos valores de terras raras observado nesta 
amostra. Em função do valor anômalo obtido para a amostra Rb-04, ela não foi levada em consideração na interpretações seguintes.

Tabela 6.1 Resultados $\mathrm{U} / \mathrm{Pb}$ e Sm/Nd para as rochas da Suite Rio Branco.

\begin{tabular}{|c|c|c|c|c|c|c|c|}
\hline Amostra & $\mathrm{Nd}$ & $\mathrm{Sm}$ & $\mathrm{U} / \mathrm{Pb}(\mathrm{Ma})^{*}$ & $f$ & $\varepsilon_{\mathrm{Nd}}(0)$ & $\varepsilon_{\mathrm{Nd}(t)}$ & $\mathrm{T}_{\mathrm{DM}}{ }^{* * *}$ \\
\hline $\mathrm{Rb}-0 \mathrm{l}$ & 25,02 & 5,59 & $1469 \pm 31$ & $-0,31$ & $-9,8$ & $+1,9$ & 1,75 \\
\hline $\mathrm{Rb}-02$ & 25,17 & 5,62 & $1469 \pm 31$ & $-0,31$ & $-10,4$ & $+1,2$ & 1,80 \\
\hline $\mathrm{Rb}-03$ & 21,35 & 4,72 & $1469 \pm 31$ & $-0,32$ & $-10,0$ & $+1,9$ & 1,73 \\
\hline $\mathrm{Rb}-04$ & 49,64 & 8,71 & $1469 \pm 31$ & $-0,61$ & $-8,3$ & $+8,9$ & 1,17 \\
\hline $\mathrm{Rb}-05$ & 20,62 & 4,73 & $1469 \pm 31$ & $-0,30$ & $-9,4$ & $+1,6$ & 1,79 \\
\hline $\mathrm{Rb}-06$ & 64,33 & 12,69 & $1469 \pm 31$ & $-0,39$ & $-14,1$ & 0,0 & 1,81 \\
\hline $\mathrm{Rb}-07$ & 58,59 & 12,5 & $1423 \pm 02$ & $-0,37$ & $-13,1$ & $+1,2$ & 1,82 \\
\hline $\mathrm{Rb}-08$ & 81,13 & 16,9 & $1423 \pm 02$ & $-0,39$ & $-14,3$ & $-0,3$ & 1,84 \\
\hline $\mathrm{Rb}-09$ & 74,28 & 14,49 & $1423 \pm 02$ & $-0,40$ & $-14,9$ & $-0,5$ & 1,85 \\
\hline $\mathrm{Rb}-10$ & 69,55 & 13,40 & $1423 \pm 02$ & $-0,41$ & $-14,8$ & $-0,2$ & 1,82 \\
\hline $\mathrm{Rb}-11$ & 58,09 & 11,91 & $1423 \pm 02$ & $-0,37$ & $-13,4$ & $-0,1$ & 1,84 \\
\hline$R b-12$ & 92,71 & 18,18 & $1423 \pm 02$ & $-0,40$ & $-15,2$ & $-1,0$ & 1,89 \\
\hline
\end{tabular}

* idade U/Pb (em Ma) obtida por diluição isotópica em monocristais de zircão para as amostras $\mathrm{Rb}-10$ (1423 $\pm 02 \mathrm{Ma})$ e Rb-04 (1469 $\pm 31 \mathrm{Ma})$.

$\varepsilon_{\mathrm{Nd}(\mathrm{t})}$ Calculado para a idade $\mathrm{U} / \mathrm{Pb}$.

*** Idade em Ga.

As diferenças de valores de $\mathrm{Sm}$ e $\mathrm{Nd}$ entre o grupo de rochas félsicas e o grupo de rochas básicas são esperadas em função das rochas mais evoluídas (rochas félsicas) tenderem a ter altos teores de elementos incompatíveis.

Valores atuais de $\varepsilon_{\mathrm{N} d}$ para as rochas básicas estão entre -8.3 e -10.4 e para as rochas félsicas estão entre $-13,1$ e $-15,2$, indicando que as rochas básicas tiveram uma evolução diferente desde a sua separação do manto comparado com as rochas félsicas. O protólito destas teve uma separação do manto em um período de tempo anterior, quando comparado com as rochas básicas e uma evolução diferente dos isótopos de $\mathrm{Nd}$ durante o tempo geológico (Figura 6.3). 


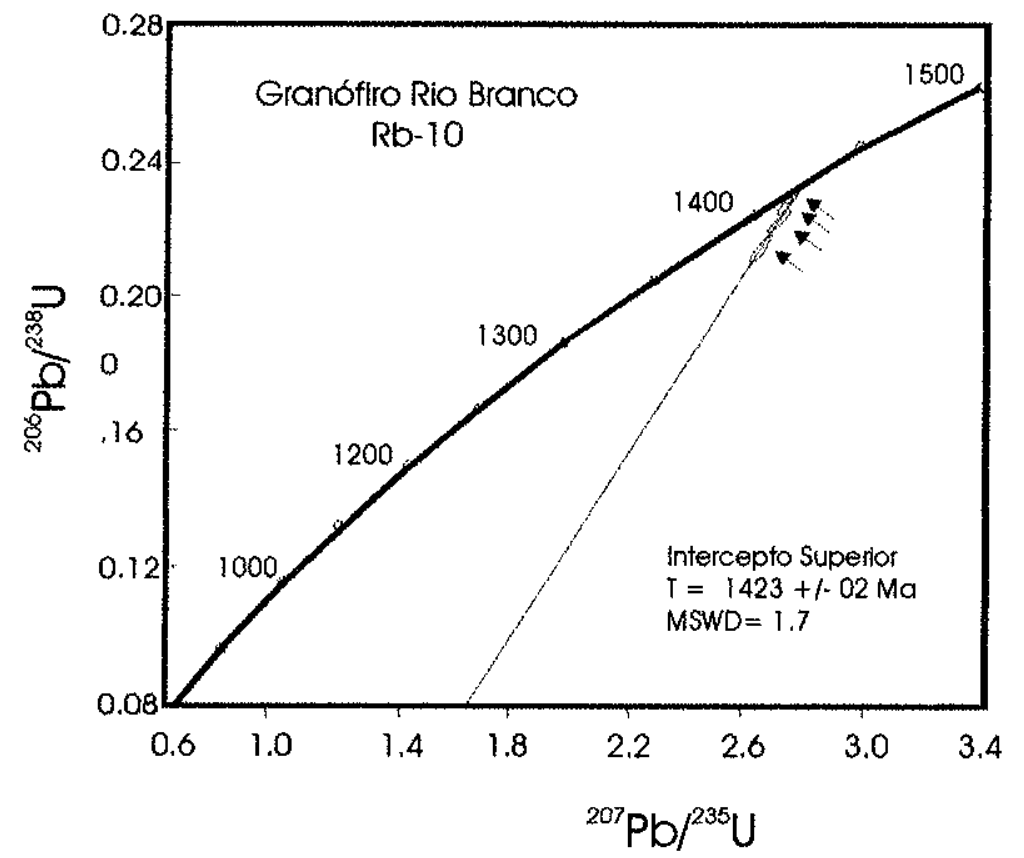

Figura 6.1 Diagrama da concórdia para o granófiro da SIRB (amostra Rb-10). As 4 frações de zircão (monocristal) indicam uma idade de $1423 \pm 2 \mathrm{Ma}$ (intercepto superior).

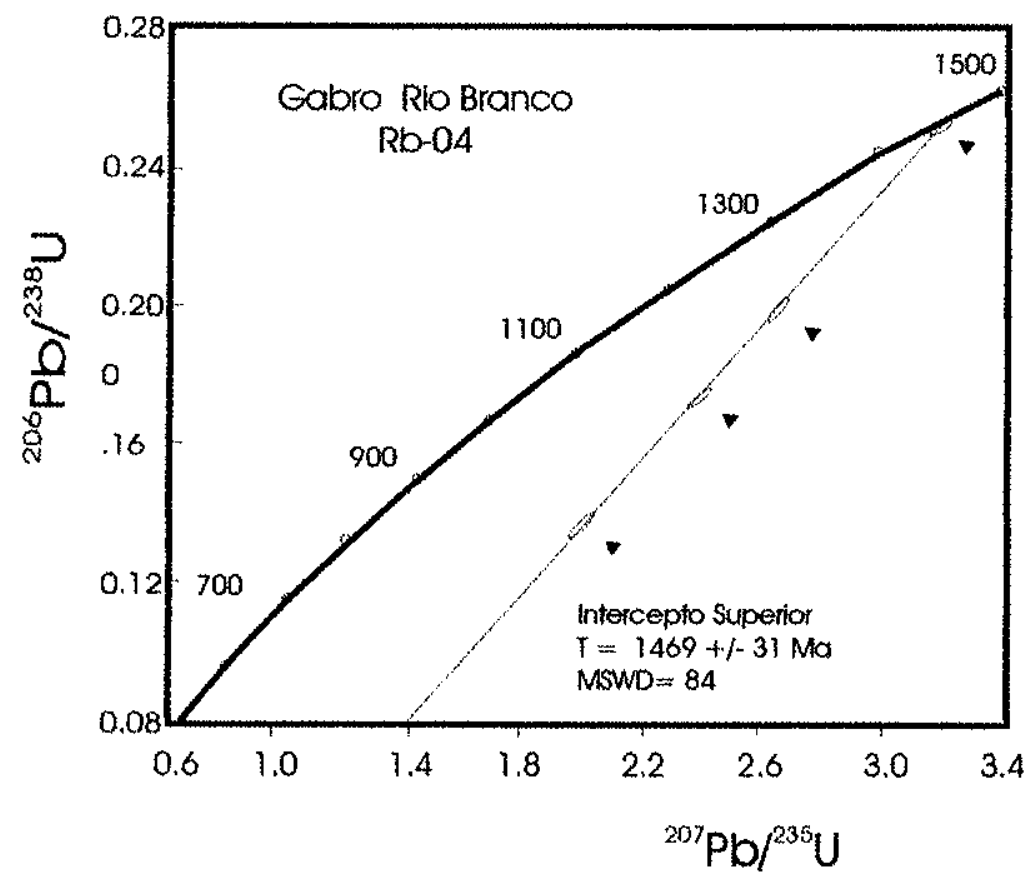

Figura 6.2 Diagrama da concórdia para o gabro da SIRB (amostra Rb-04). As 4 frações de zircão (monocristal) indicam uma idade de $1423 \pm 3 \mathrm{Ma}$ (intercepto superior). 


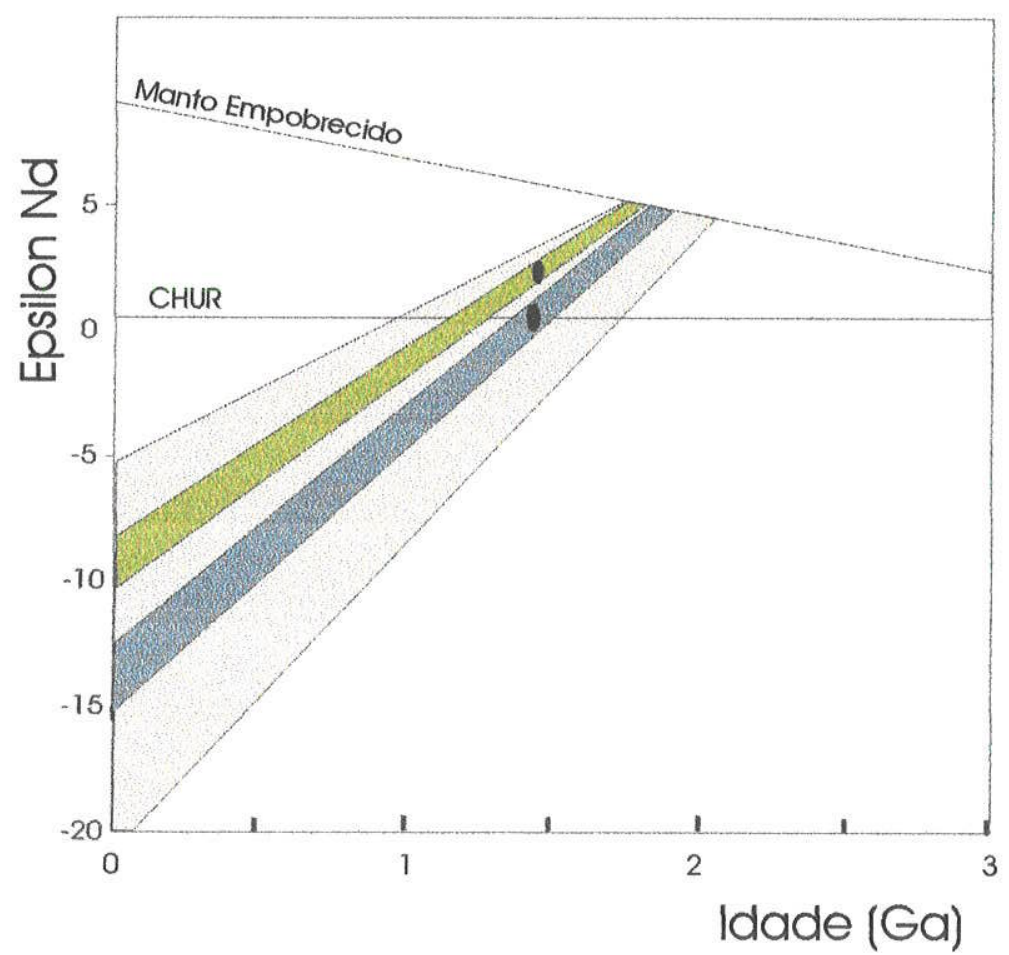

Figura 6.3 Diagrama de evolução isotópica de Nd para as rochas da SIRB. Rochas básicas em azul; rochas félsicas em verde. Em cinza estão representados os resultados $\mathrm{Sm} / \mathrm{Nd}$ das rochas do Terreno Jauru, embasamento da SIRB. 


\subsection{Geoquímica}

As doze rochas da SIRB foram analisadas para elementos maiores e traços. Quando lançados no diagrama de caracterização das rochas, a SIRB indica composição entre monzogranítica, quartzo monzogábrica e gábrica (Figura 6.4). O índice de Shand (A/CNK) versus índice de saturação em alumina indica variações entre rochas de metaluminosas (associação leucocrática, caracterizada por minerais mais enriquecidos em $\mathrm{Al}$ como a biotita) a intensamente metaluminosa (associação básica, onde o par de minerais como piroxênio e biotita é característico de suítes metaluminosas).

O diagrama discriminante de trends de diferenciação (Figura 6.6) sugere que a o grupo de rochas félsicas são alcalinas e o grupo de rochas básicas são cálcicas. Os dados sobre o quimismo das rochas da SIRB foram utilizados para construção do diagrama de discriminação de ambientes tectônicos apresentados na Figuras 6.7 e 6.8. Os resultados indicam que as rochas podem ter sido geradas em ambiente anorogênico (félsicas) e intraplacas (básicas).

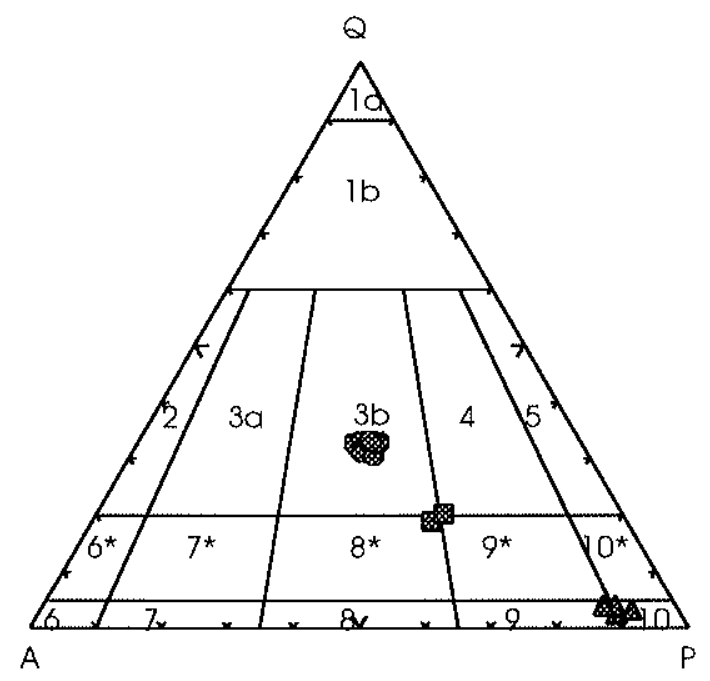

Figura 6.4 Diagrama QAP (Streickeisen, 1976) obtido a partir de dados químicos para as rochas da SIRB, indicando composição entre quartzo monzogabro a monzogranito. Campos composicionais: (1a) quartzolito; (1) granitóide rico em Qz; (3) granito alcalifeldspático; (3a) sienogranito; (3b) monzogranito; (4) granodiorito; (5) tonalito; (6*) quartzo sienito álcalifeldspático; (6) sienito álcalifeldspático; $\left(7^{*}\right)$ quartzo sienito; $\left(8^{*}\right)$ quartzo monzonito; (8) monzonito; (9*) quartzo monzogabro; (9) monzogabro; (10) quartzo gabro; e (10*) diorito, gabro, anortosito. 
Os resultados analíticos dos ETR das rochas estudadas foram normalizados pelo condrito e apresentados nas Figuras 6.9 e 6.10. Os padrões de ETR obtidos para as rochas básicas são subhorizontalizados com um leve enriquecimento em ETR leves e sem anomalia positiva de Eu. Os padrões de ETR obtidos para a associação leucocrática apresentam um enriquecimento em ETR leves e um empobrecimento em ETR pesados e anomalia negativa de Eu indicando um fracionamento de Eu como resultado da solidificação do plagioclásios no fase inicial da cristalização magmática. Observa-se também um enriquecimento nas concentrações dos ETR em direção aos termos mais evoluídos

Os resultados analíticos destas rochas quando lançados nos diagramas binários de Harker (Figura 6.11 e 6.12) sugerem, de forma geral, dois agrupamentos de rochas. O primeiro composto pelas amsotras RB-01 a Rb-04 e outro grupo composto pelas amostras Rb-08 a RB12. Os diagramas de Haker ainda sugerem uma correlação positiva entre concentração de $\mathrm{SiO}_{2} \mathrm{e}$ de $\mathrm{K}_{2} \mathrm{O}, \mathrm{Rb}, \mathrm{Zr}, \mathrm{Ba}, \mathrm{Nb}, \mathrm{Sr}, \mathrm{Hf}, \mathrm{Ta}, \mathrm{Tl}$, Th e U. E uma correlação negativa de $\mathrm{SiO}_{2}$ com $\mathrm{CaO}$, $\mathrm{Cr}, \mathrm{MgO}, \mathrm{Fe}_{2} \mathrm{O}_{3}, \mathrm{~V}, \mathrm{Ni}, \mathrm{Cu}, \mathrm{Zn}$ e $\mathrm{Sr}$.. De forma geral os diagramas de Harker sugerem duplo agrupamento das amostras, caracterizando a bimodalidade da SIRB, com um grupo de amostras com alta sílica e enriquecido em elementos incompatíveis e um grupo de amostras pobre em sílica e enriquecido em elementos compatíveis. Duas amostras (Rb-06 e Rb-07) tendem a se localizar de forma intermediária entre os dois grupos em acordo com suas características petrográficas, que indicam composição de mistura. 


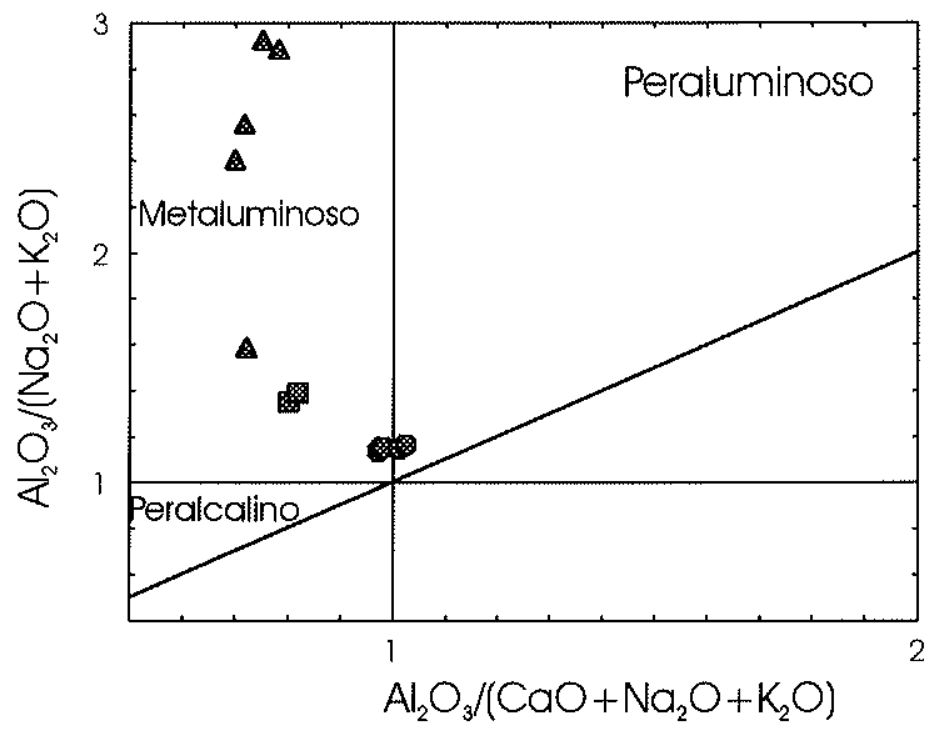

Figura 6.5 - Indice de Shand (A/CNK) versus índice de saturação em alumina para as rochas da SIRB variam entre peraluminosas (associação leucocrática) e metalumiosas (associação básica).

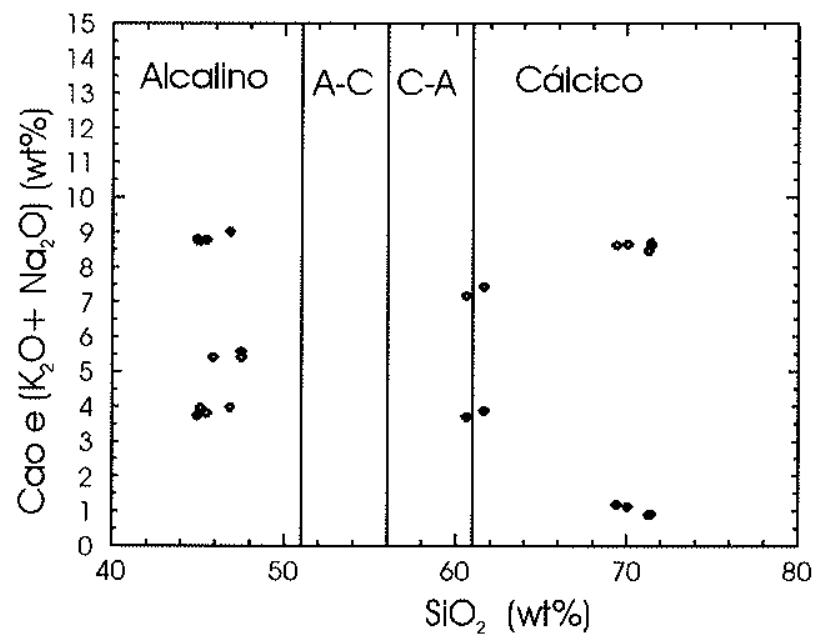

Figura 6.6 Diagramas discriminantes de trends de diferenciação (Peacock, 1931). A SIRB apresenta dois grupos de rochas que se distribuem desde fácies alcalinas (rochas félsicas) a cálcicas (rochas básicas). 


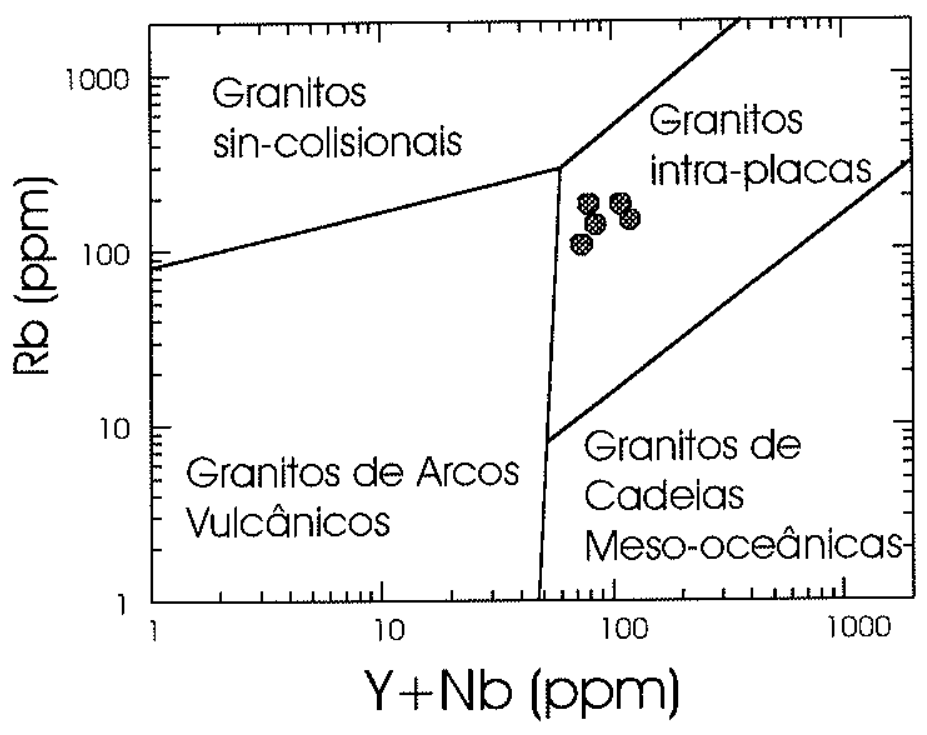

Figura 6.7 Diagramas e discriminação de ambientes tectônicos (Pearce et al., 1984). Os resultados das análises químicas das rochas graníticas da SIRB indicam ambiente anorogênico para a sua formação.

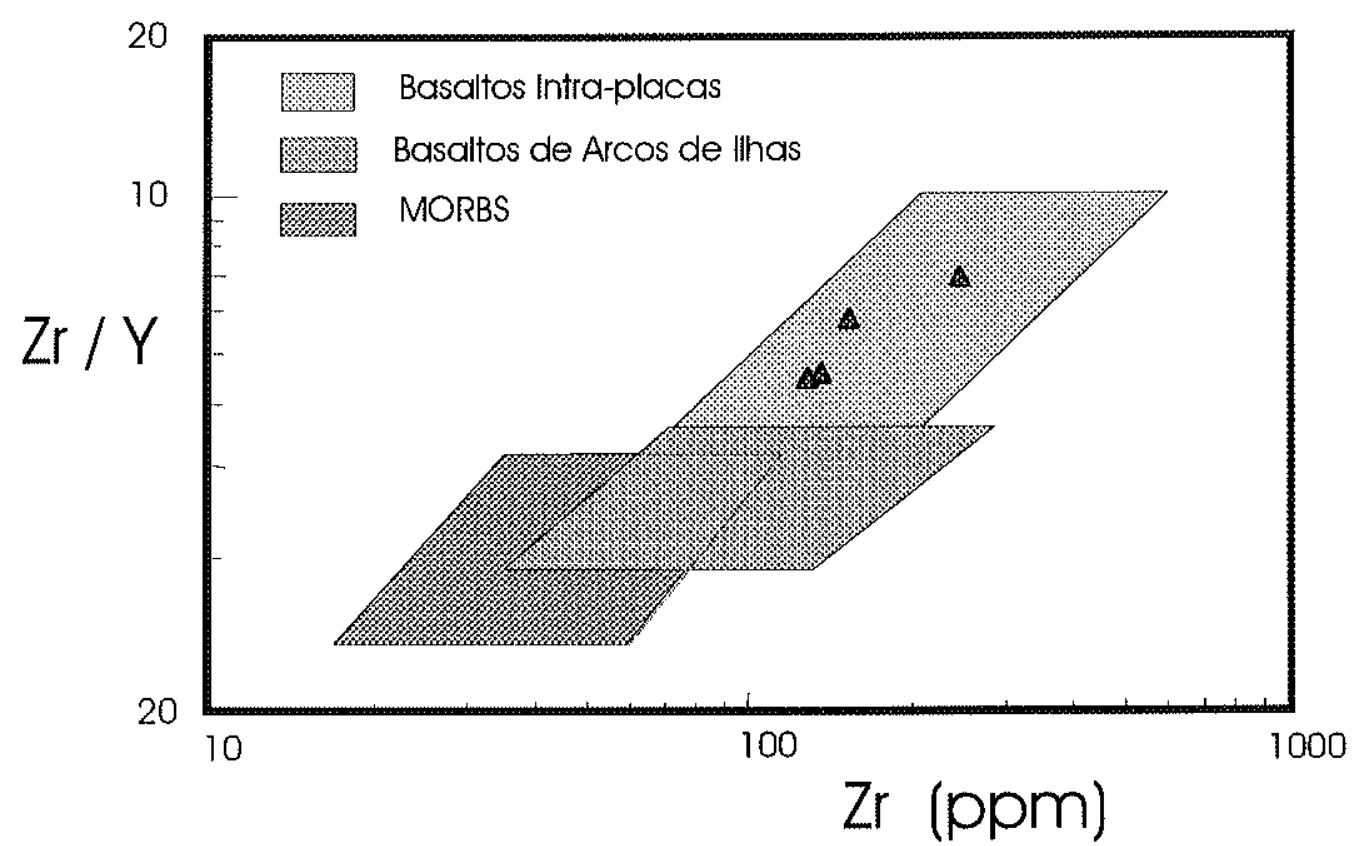

Figura 6. Diagramas e discriminação de ambientes tectônicos (Pearce e Norry., 1979). Os resultados das análises químicas das rochas básicas da SIRB indicam ambiente intraplacas para a sua formação. 


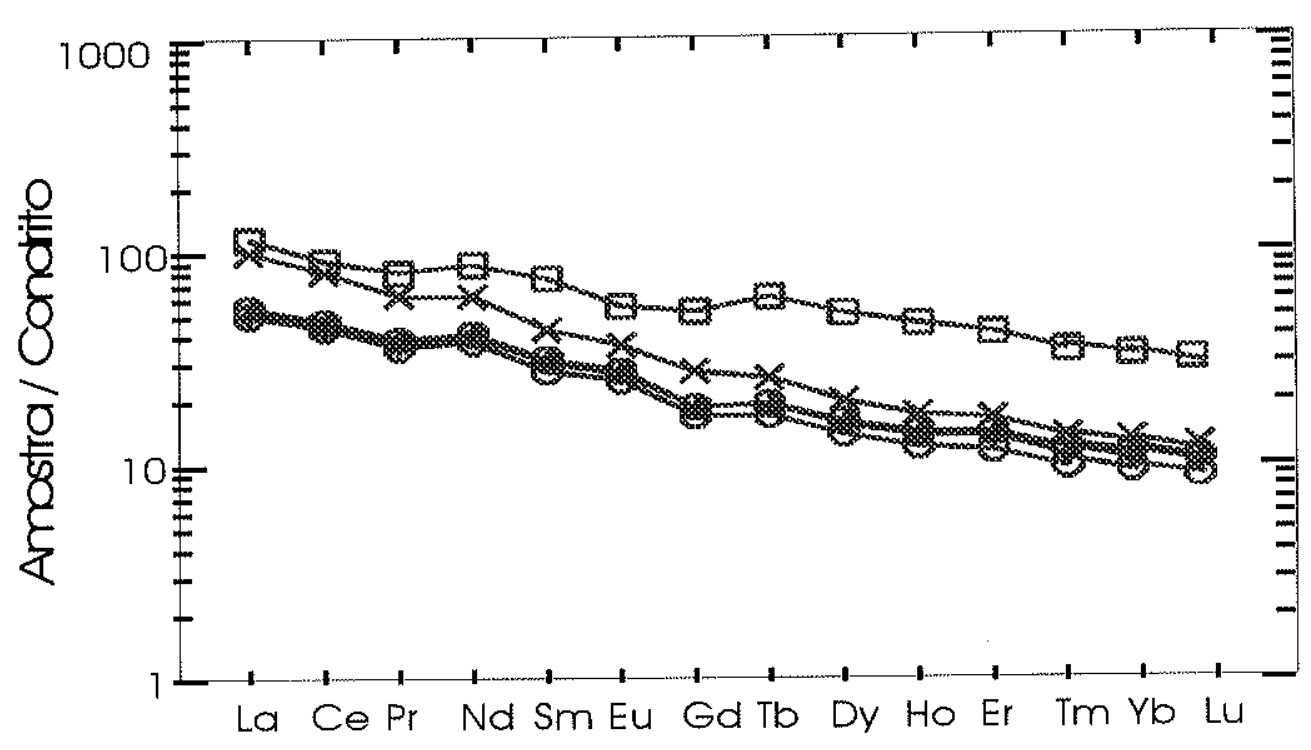

Figuras 6.9 Padrões de terras raras para as rochas básicas da SIRB. O padrão horizontalizado é característico de basaltos toleíticos continentais. Os valores de terras raras foram normalizados segundo Sun e McDonough (1989).

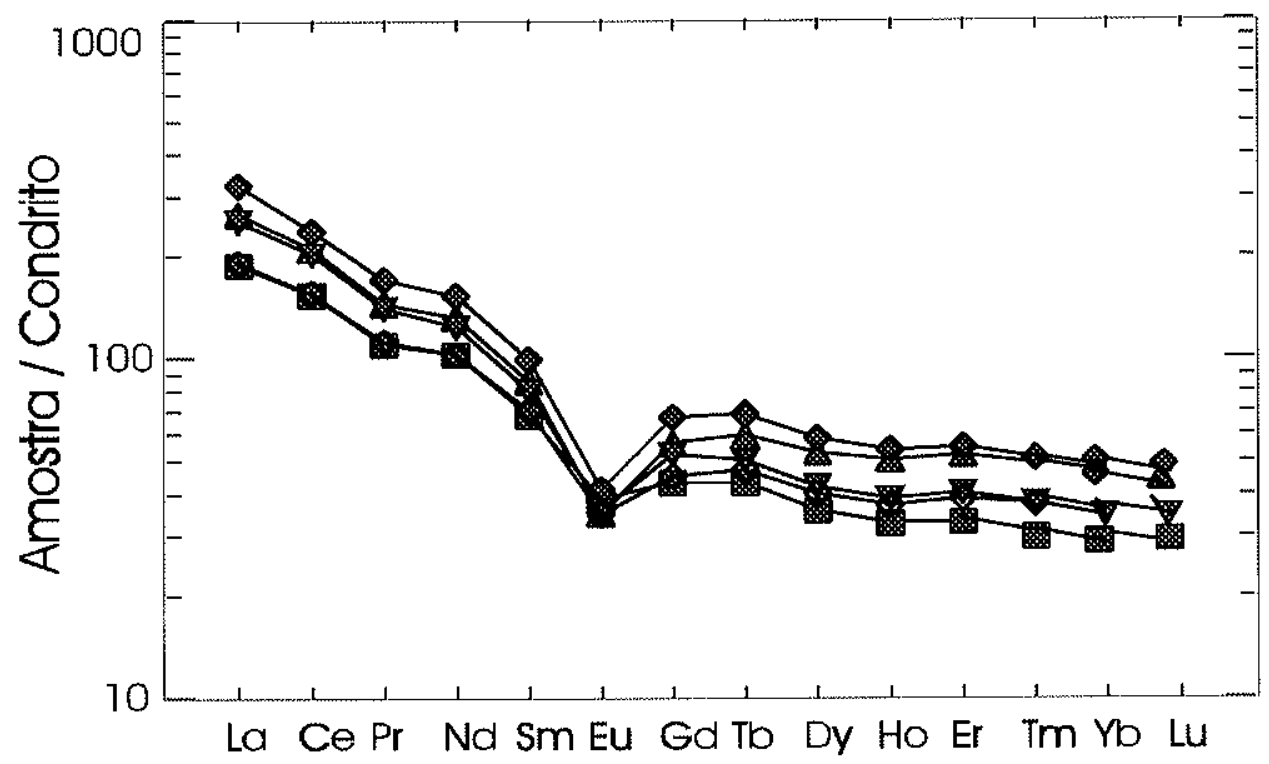

Figuras 6.10 Padrões de terras raras para as rochas félsicas da SIRB. A anomalia negativa de Eu indica que o grupo de rochas félsicas representam facies evoluídas resultante de um processo de diferenciação magmática (Humphris, 1984). Os valores de terras raras foram normalizados segundo Sun e McDonough (1989). 

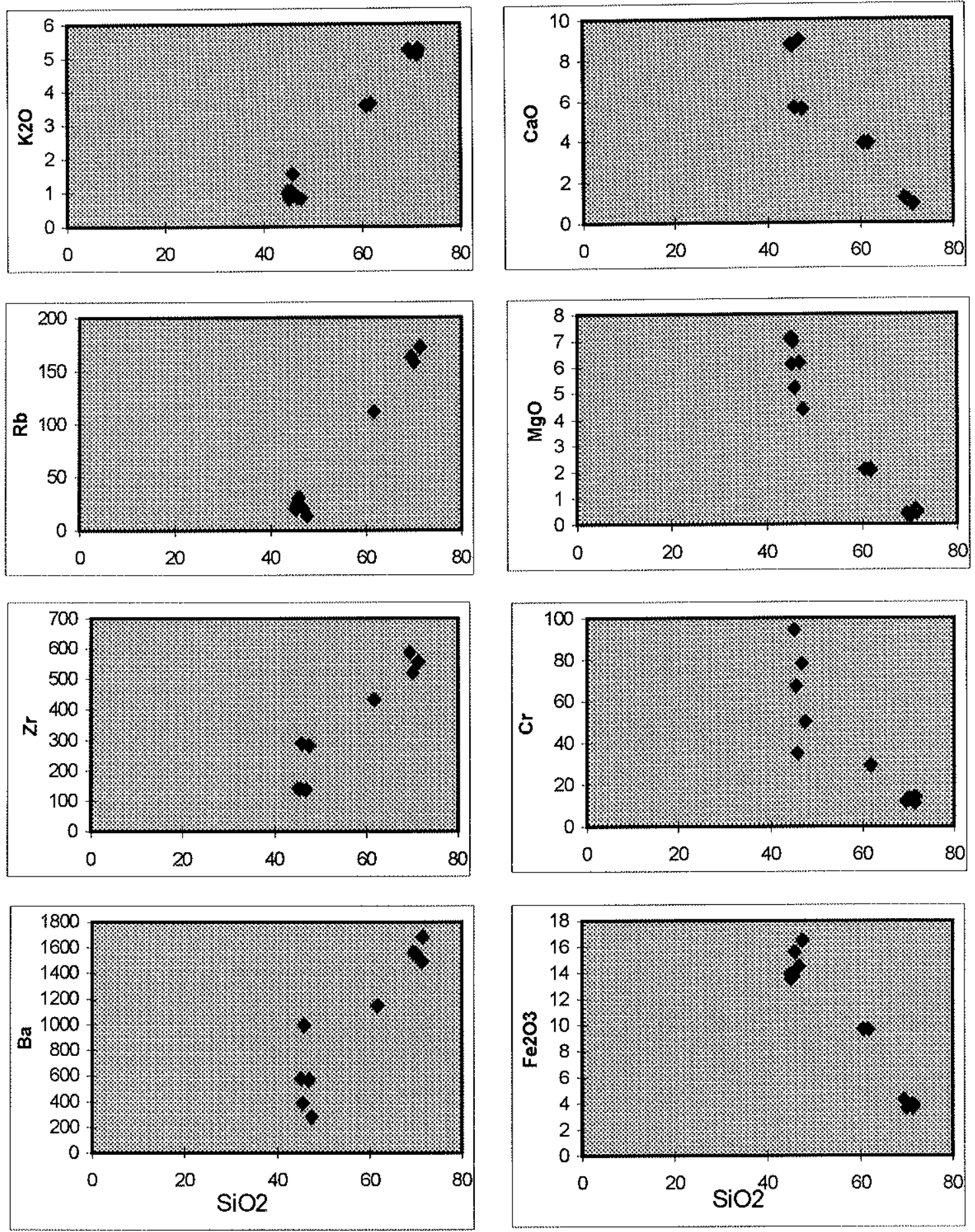

Figura 6.11 Diagramas binários de Harker para elementos maiores e traços para o SIRB. $\mathrm{O}$ grupo de rochas félsicas apresenta alto valores de sílica $(>65 \%)$ e enriquecimento em elementos incompatíveis $(\mathrm{Zr}, \mathrm{Rb}, \mathrm{K}$ e $\mathrm{Ba})$. O grupo de rochas básica apresenta baixos valores de sílica $(<50 \%)$ e enriquecimento em elementos compatíveis ( $\mathrm{Fe}, \mathrm{Cr}, \mathrm{Mg}$ e $\mathrm{Ca}$ ). 

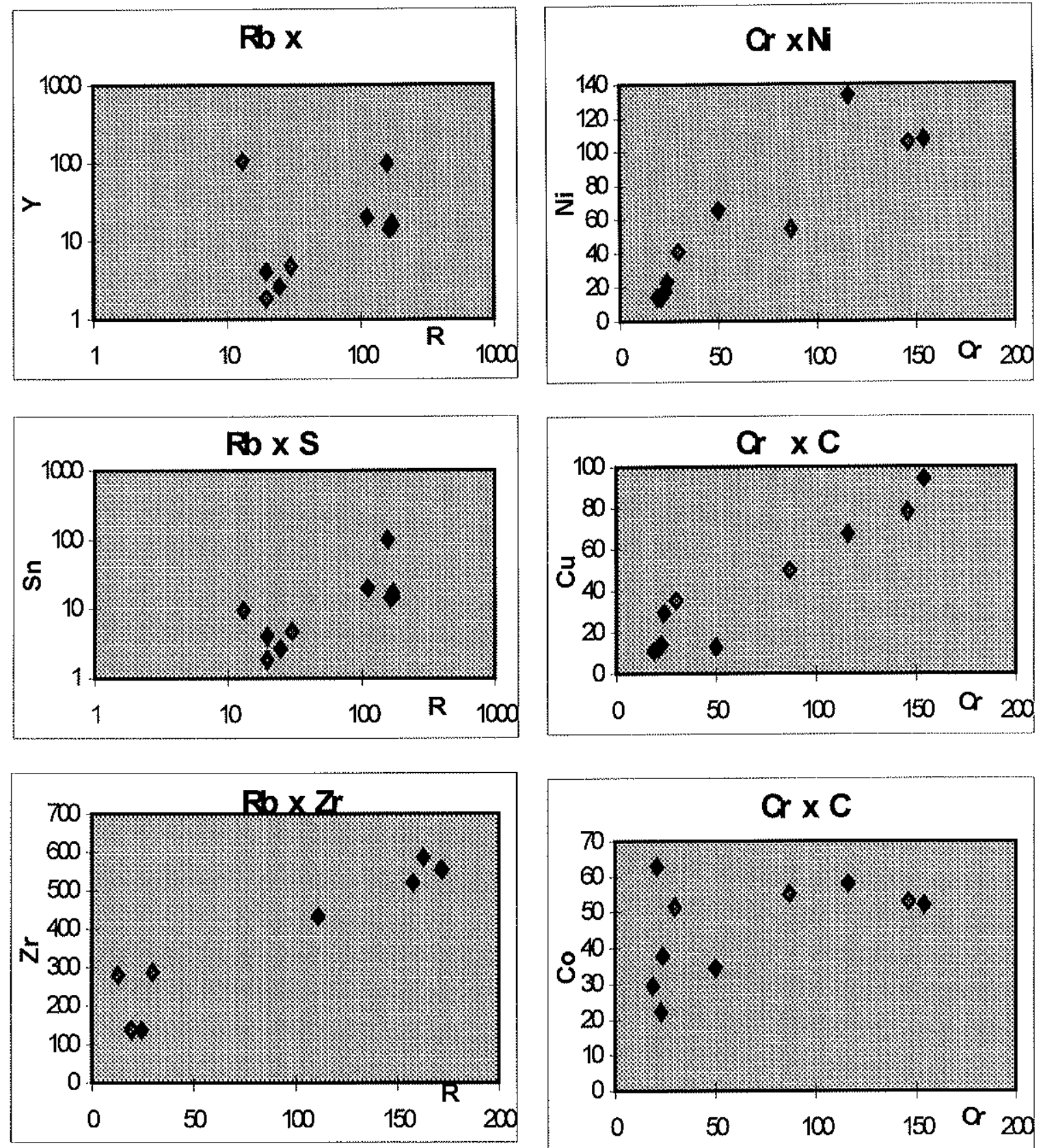

Figura 6.12. Diagramas binários de Harker de elementos traços para o SIRB. Os diagramas indicam a bimodalidade da SIRB, com um grupo de rochas félsicas e outro de rochas básicas. As amostras Rb-06 e Rb-07 tendem a se localizar entre os dois grupos, resultado de suas composições de mistura. 


\subsection{Isótopos Estáveis}

Oito amostras da SIRB (rocha total) foram analisadas para isótopos estáveis de oxigênio, cujos resultados foram normalizados pelo standart SMOW $\left({ }^{18} \mathrm{O} /{ }^{16} \mathrm{O}=\right.$ 0,0039948) (Tabela 6.2 e Figura 6.18). Desta forma os valores de $\delta^{18} \mathrm{O}$ obtidos variam de $+5,4 \%$ a $+8,4 \%$ (nas rochas mais básicas) e 7,3\% a $+9,0 \%$ (nas rochas félsicas). Portanto as rochas do primeiro grupo apresentam menor influência crustal comparado com as rochas do segundo grupo. Os resultados obtidos são compatíveis com as variações de $\delta^{18} \mathrm{O}$ para rochas básicas (gabros e basaltos) descritos por Taylor (1974) e de sienitos e traquitos descritos por Sial (1990), conforme pode ser observado na Figura 3.30. O primeiro grupo apresenta resultados equivalentes com valores de $\delta^{18} \mathrm{O}$ próximos de 5,5\%o, normais em rochas manto-derivadas (gabros e basaltos).

Tabela 6.2. Dados de isótopos de $\mathrm{O}, \mathrm{H}$ e S para as rochas da SIRB.

\begin{tabular}{|c|c|c|c|}
\hline Amostra & Oxigênio* & Hidrogênio ** & Enxofre \\
\hline $\mathrm{Rb}-01$ & $+5,8$ & nd & nd \\
\hline $\mathrm{Rb}-02$ & $+5,4$ & -88 & $+3,8$ \\
\hline $\mathrm{Rb}-04$ & $+5,6$ & nd & nd \\
\hline $\mathrm{Rb}-06$ & $+8,3$ & -83 & $+0,7$ \\
\hline $\mathrm{Rb}-07$ & $+7,3$ & -85 & $+1,2$ \\
\hline $\mathrm{Rb}-08$ & $+9,0$ & -90 & $+2,8$ \\
\hline $\mathrm{Rb}-09$ & $+8,9$ & -85 & $+6,1$ \\
\hline Rb-12 & $+8,7$ & -92 & $+5,2$ \\
\hline
\end{tabular}

* Os resultados de isótopos de O são apresentados normalizados pelo SMOW.

** Os resultados de isótopos de $\mathrm{H}$ são apresentados normalizados pelo SMOW.

*** Os resultados de isótopos de $\mathrm{S}$ são apresentados normalizados pela troilita do Canyon Diablo (CDT).

nd não determinado.

Os resultados das análises de isótopos de $\mathrm{H}$ para as rochas da SIRB indicam valores de $\delta \mathrm{H}$ entre -83 a $-93 \%$. Estes resultados, quando lançados no diagrama $\delta \mathrm{H}$ versus $\delta^{18} \mathrm{O}$ (Figura 6.13) não apoiam a participação de soluções hidrotermais com águas meteóricas nas amostras estudadas da SIRB. A normalização levando em conta a assinatura isotópica atual de águas marinhas (SMOW apresenta $\mathrm{H} \delta=0$ ) indica a ausência deste componente de sub-superfície, mesmo levando em conta a evolução da assinatura isotópica deste reservatório do decorrer dos períodos geológicos (Figura 6.14). 
O grupo de rochas básicas da SIRB apresenta valores de $\delta \mathrm{S}$ entre $+0,7 \mathrm{e}+3,8$ $\%$ sugerindo uma fonte manto-derivada para a sua origem coerentemente com os valores de $\varepsilon_{\mathrm{Nd}}$. Já o grupo de rochas félsicas apresenta valores de $\delta \mathrm{S}$ entre $+2,8 \mathrm{e}+6,1$ $\%$, sugerindo um componente crustal na gênese de seus protólitos. Isto é coerente com os valores de sulfetos em meteoritos (utilizados para a normalização e que portanto apresentam $\delta S=0$ ), cujas composições são interpretadas como equivalentes a composição da Terra anteriormente aos processos de diferenciação e formação de crosta continental.

\begin{tabular}{|l|l|l|}
\hline Suíte & \\
Río Branc0 & \\
RB-01 \\
basalto \\
Rb-02 \\
gabro \\
Rb-04 \\
gabro póffiro \\
Rb-06 \\
monzonito \\
Rb-07 \\
granito7 \\
Rb-08 \\
granitol \\
Rb-09 \\
granitol \\
Rb-12 \\
granitol
\end{tabular}

Figura 6.13 Diagrama com os dados de $\delta^{18} \mathrm{O}$ da SIRB 

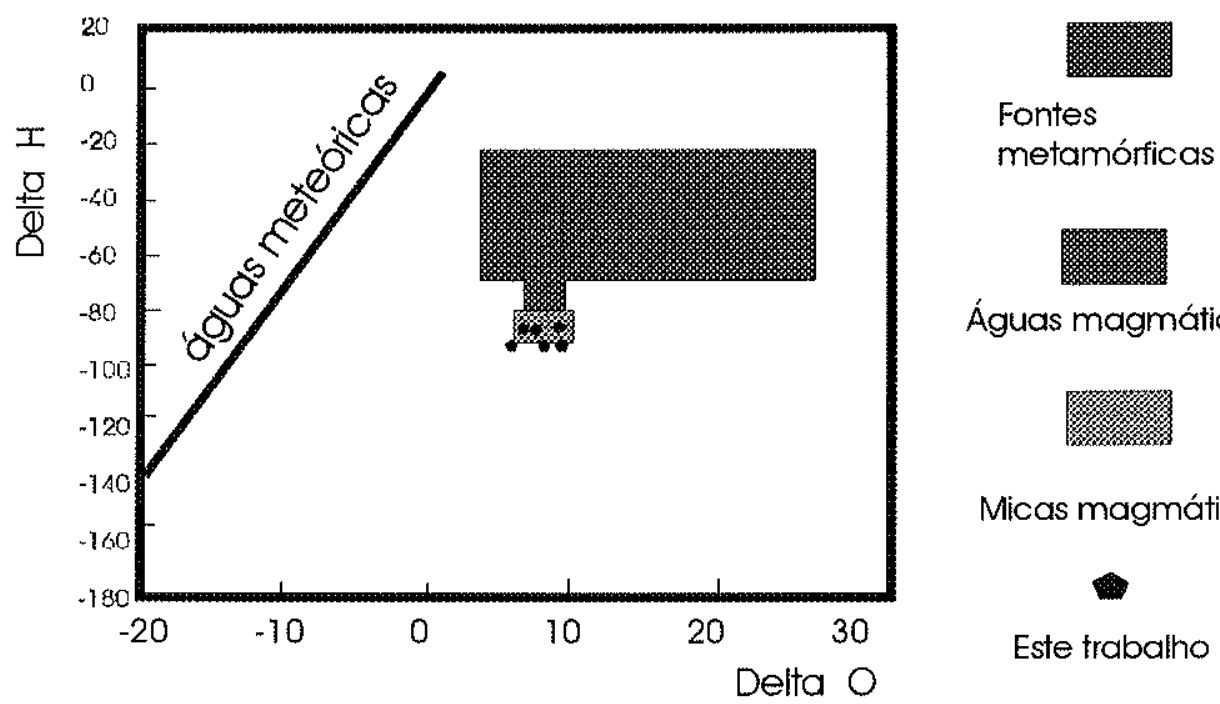

Águas magmáticas

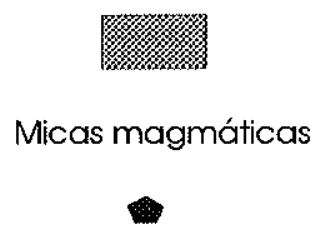

Este trabalho

Figura 6.14. Diagrama $\delta \mathrm{H}$ versus $\delta^{18} \mathrm{O}$ para as rochas da SIRB Os resultados das amostras analisadas são coerentes com assinaturas de águas de origem magmática. A dimensão dos pontos lançados no diagrama não representam erro analítico.

\subsection{Discussão}

As idades $\mathrm{U} / \mathrm{Pb}$ (em zircão) obtidas para as rochas félsicas e básicas do SIRB situam-se entre 1469 e 1423 Ma e marcam o período de tempo de cristalização das rochas da suite. As idades modelo $\mathrm{T}_{\mathrm{DM}}$, interpretadas como idades de extração mantélica, indicam que o protólito das rochas básicas foi formado entre 1,86-1,82 Ga. O protólito das rochas félsicas é aproximadamente contemporâneo conforme indicado pelas idades $\mathrm{T}_{\mathrm{DM}}$ entre $1,80-1,73 \mathrm{Ga}$ e os valores de $\varepsilon_{\mathrm{Nd}}$ variáveis entre $+0,1 \mathrm{e}-0,9$ sugerem a existência de componente crustal no processo genético do respectivo protólito (Figura 6.3).

Como as rochas básicas da SIRB tem $\varepsilon_{\mathrm{Nd}}$ positivos (o que é interpretado como derivação mantélica), é possível ainda sugerir que foram formadas a partir de um processo underplating a exemplo dos granitos rapakivi descritos na Finlândia (Rämö, 1991). Desta forma magmas de composição basáltica já diferenciados do manto e localizados na base da crosta continental teriam sido reativados no Mesoproterozóico. É provável que um processo de caráter extensional intracratônico permitiu a fusão de rochas básicas underplating e esta fusão forneceu também calor para a fusão da base da crosta gerando magma félsico e cristalização de ambos os magmas (básico e félsico) em níveis hipoabissais. $\mathrm{O}$ uso dos mesmos condutos ou o contato em níveis mais rasos da crosta permitiria que os magmas estivessem em contato, originando texturas comingling 

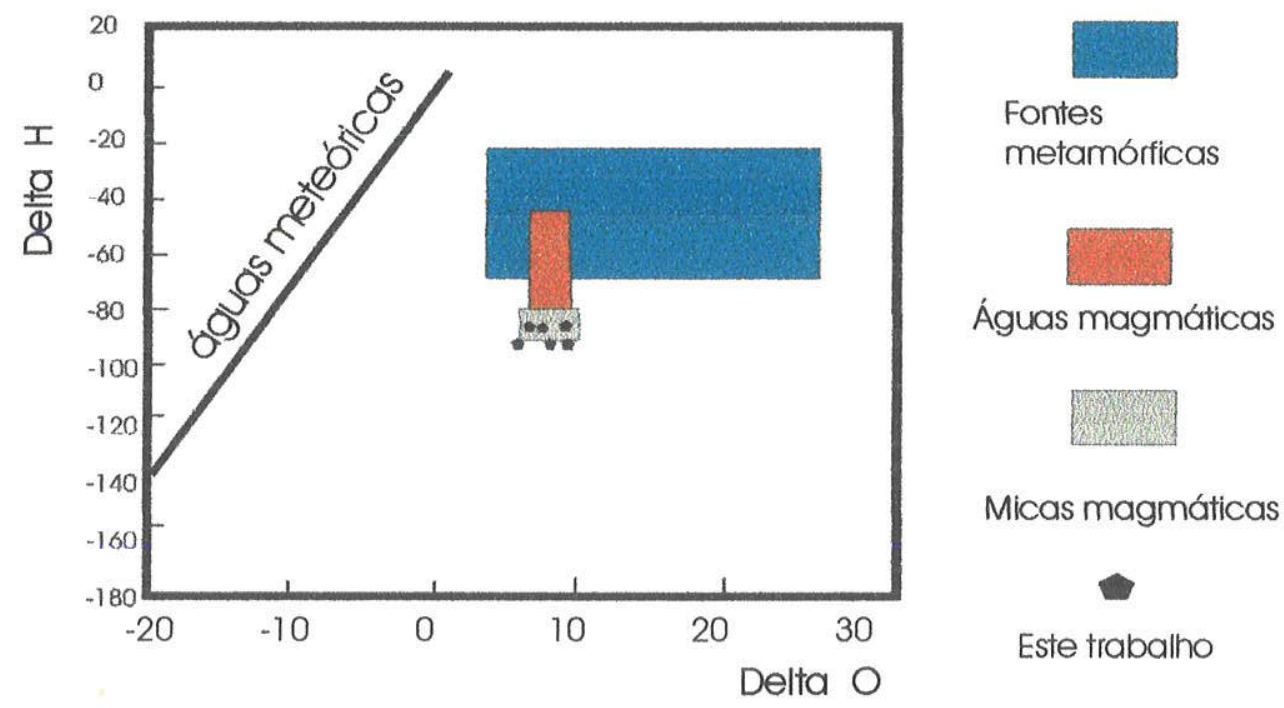

Figura 6.14. Diagrama $\delta \mathrm{H}$ versus $\delta^{18} \mathrm{O}$ para as rochas da SIRB Os resultados das amostras analisadas são coerentes com assinaturas de águas de origem magmática. A dimensão dos pontos lançados no diagrama não representam erro analítico.

\subsection{Discussão}

As idades $\mathrm{U} / \mathrm{Pb}$ (em zircão) obtidas para as rochas félsicas e básicas do SIRB situam-se entre 1469 e 1423 Ma e marcam o período de tempo de cristalização das rochas da suíte. As idades modelo $\mathrm{T}_{\mathrm{DM}}$, interpretadas como idades de extração mantélica, indicam que o protólito das rochas básicas foi formado entre 1,86-1,82 Ga. O protólito das rochas félsicas é aproximadamente contemporâneo conforme indicado pelas idades $\mathrm{T}_{\mathrm{DM}}$ entre 1,80-1,73 Ga e os valores de $\varepsilon_{\mathrm{Nd}}$ variáveis entre $+0,1 \mathrm{e}-0,9$ sugerem a existência de componente crustal no processo genético do respectivo protólito (Figura 6.3).

Como as rochas básicas da SIRB tem $\varepsilon_{\mathrm{Nd}}$ positivos (o que é interpretado como derivação mantélica), é possível ainda sugerir que foram formadas a partir de um processo underplating a exemplo dos granitos rapakivi descritos na Finlândia (Rämö, 1991). Desta forma magmas de composição basáltica já diferenciados do manto e localizados na base da crosta continental teriam sido reativados no Mesoproterozóico. É provável que um processo de caráter extensional intracratônico permitiu a fusão de rochas básicas underplating e esta fusão forneceu também calor para a fusão da base da crosta gerando magma félsico e cristalização de ambos os magmas (básico e félsico) em níveis hipoabissais. O uso dos mesmos condutos ou o contato em níveis mais rasos da crosta permitiria que os magmas estivessem em contato, originando texturas comingling 
e rochas híbridas, marcadas pela presença de textura tipo rapakivi. No entanto ainda não foram encontrados todos os membros de uma suíte AMCG na região.

As rochas félsicas estudadas apresentam composições químicas caracterizadas por alto teores de $\mathrm{SiO}_{2}, \mathrm{Na}_{2} \mathrm{O}, \mathrm{K}_{2} \mathrm{O}, \mathrm{Fe} / \mathrm{Mg}, \mathrm{F}, \mathrm{Zr}, \mathrm{Nb}, \mathrm{Ga}, \mathrm{Sn}, \mathrm{Y}$ e elementos terras raras e baixos valores de $\mathrm{Cao}, \mathrm{Ba}$ e $\mathrm{Sr}$, coerentes com as característcas químicas de granitos rapakivi descritos na literatura. Os valores de $\delta^{18} \mathrm{O}$ para as rochas básicas da $\mathrm{SIRB}(\mathrm{Rb}-01 \mathrm{a} \mathrm{Rb}-04)$ variam de $+5,4 \mathrm{a}+5,8 \%$; as rochas de misturas $(\mathrm{Rb}-05 \mathrm{e} \mathrm{Rb}-06)$ apresentam valores de $\delta^{18} \mathrm{O}$ de $+5,6$ a $+8,3 \%$ e as rochas félsicas de $+7,3$ a $+9,0 \%$ o. Os valores mais baixos de $\delta^{18} \mathrm{O}$ são compatíveis com rochas de derivação mantélica, como descrito por Taylor (1974). As rochas de mistura e félsicas apresentam valores de $\delta^{18} \mathrm{O}$ compatíveis com rochas crustais como reportado por Sial e Ferreira (1990). Todos os valores de $\delta^{18} \mathrm{O}$ das rochas da SIRB não apresentam assinatura metamórfica (Mathews, 1994). Valores de $\delta \mathrm{O}, \delta \mathrm{D}$ e $\delta \mathrm{S}$ são coerentes com uma fonte magmática, sugerindo que as soluções hidrotermais são orto-derivadas.

Os resultados referentes às sistemáticas $\mathrm{U} / \mathrm{Pb}$ e $\mathrm{Sm} / \mathrm{Nd}$ ora apresentados estão em concordância com os resultados obtidos em suítes correlatas investigadas nas Províncias Rio Negro-Juruena e Rondoniana (Sato e Tassinari, 1997). Bettencourt et al., (1999) descrevem suítes de rochas rapakivítivas anorogênicas, como por exemplo a Suíte Intrusiva Santo Antônio (1406 $\pm 32 \mathrm{Ma}$, idade U/Pb), intrușiva na crosta mista Rio Negro-Juruena e Rondoniana. As suítes anorogênicas descritas em Mato Grosso (SIRB) e Rondônia são reflexo em ambiente intracratônico do evento mesoproterozóico (1450$1420 \mathrm{Ma}$ ) gerador do Arco de Santa Helena desenvolvido na margem SW do protocráton Amazônico. Em ambas as regiões as suítes rapakivíticas são anorogênicas em relação às encaixantes, porém são orogênicas em relação ao arco em desenvolvimento na borda do cráton. 


\section{CAPÍTULO 7 \\ O Grupo Aguapeí e as Suítes Intrusivas Guapé e São Domingos}

\subsection{O Grupo Aguapeí}

A região SW do Cráton Amazônico passou por um processo de estabilização durante o final do Mesoproterozóico que proporcionou a deposição de espessos pacotes de rochas sedimentares do Grupo Aguapeí (Figueiredo et al., 1974; Souza e Hildret, 1980; Saes et al., 1992; e Menezes et al., 1993). Esta unidade foi dividida nas Formações: Fortuna (correspondente ao pacote basal constituído de metarenitos ortoquartzíticos intercalados com metaconglomerados oligomíticos); Vale da Promissão (formada por uma sequência pelítica, constituída de metassiltitos, filitos, ardósias e metapsamitos finos); e Morro Cristalina (formada por metarenitos, intercalações de metaconglomerados e finos leitos de metassiltitos) (Prancha 9).

Litherland et al. (1986 e 1989) descrevem com detalhes os ambientes de deposição do Grupo Sunsás na Bolívia e de acordo com Saes (1999) a deposição das duas unidades (Grupo Sunsás e Aguapeí) seria contemporânea. Segundo Litherland et al. (1989) o Grupo Sunsas teve o seu início de deposição há $1300 \mathrm{Ma}$ (idade K/Ar mais jovem do Complexo Pensamiento) e portanto pode-se sugerir que o início da deposição do Grupo Aguapeí tenha começado no mesmo período de tempo.

O encerramento da deposição de ambos os Grupos tem o seu registro definido tanto no Brasil como na Bolívia. Naquele país Litherland et al., (1989) apresentam idades $\mathrm{Rb} / \mathrm{Sr}$ de granitos intrusivos nos sedimentos do Grupo Sunsás de idade $\mathrm{Rb} / \mathrm{Sr}$ de $\sim 1,0 \mathrm{Ga}$. 

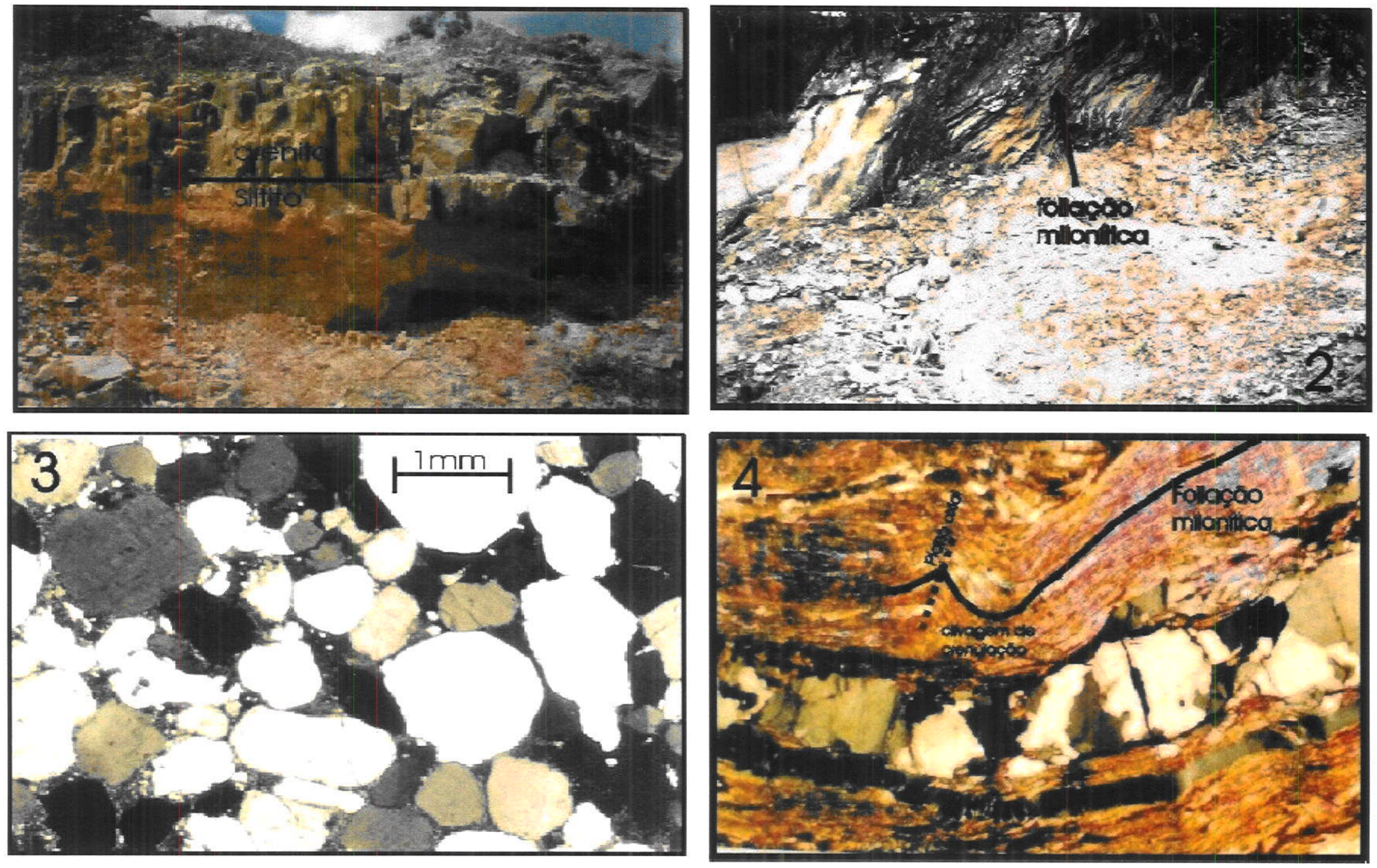

Prancha 9 (1) Sedimentos do Grupo Aguapeí. Observa-se o contato entre Fm. Vale da Promissão e a Fm. Morro Cristalina.

(2) Rocha milonitizada da Fm Fortuna. A lineação é ortogonal ao plano da foliação milonítica, caracterizando o cavalgamento.

(3) Fotomicrografia de sedimento da Fm. Fortuna (Grupo Aguapeí) sem a deformação.

(4) Fotomicrografia de sedimento deformado (observar plano da foliação milonítica, clivagem de crenulação e plano axial da crenulação). 
No Brasil o período de tempo final da deposição do Grupo Aguapeí pode ser definido através da idade $\mathrm{K} / \mathrm{Ar}$ dos minerais formados durante a milonitização que caracterizou a deformação desta unidade durante o evento denominado thrust Aguapeí. $\mathrm{O}$ conjunto de análises isotópicas $\mathrm{K} / \mathrm{Ar}$ em sericitas obtidas nestas rochas miloníticas permitiram definir um evento térmico que atingiu as unidades da região. As amostras selecionadas para o estudo foram: (7418) milonito da Formação Fortuna; (7520) metarenito da Formação Fortuna; (7419 e 7512) xistos da Seqüência Metavulcano Sedimentar Pontes e Lacerda e os resultados estão no intervalo de tempo entre $957 \mathrm{Ma}$ a $876 \mathrm{Ma}$ (Tabela 7.1). As amostras de metarenitos do Grupo Aguapeí foram selecionadas por apresentarem micas (sericitas) formadas como conseqüência do metamorfismo que atingiu esta unidade. Uma das amostras apresenta estrutura milonítica, resultado da deformação também imposta à estas rochas.

As amostras de xisto foram coletadas em afloramentos próximo da localidade de São Domingos e não evidenciam a deformação rúptil que atingiu as rochas do Grupo Aguapeí. Porém as idades $\mathrm{K} / \mathrm{Ar}$ são semelhantes às idades obtidas em sericitas do Grupo Aguapeí, indicando que o evento térmico ocorrido por volta de $900 \mathrm{Ma}$ tem uma área de influência maior do que a área atingida pela deformação nas supracrustais.

Estes resultados $\mathrm{K} / \mathrm{Ar}$ (Tabela 7.1) indicam um evento térmico cujo resfriamento ocorreu por volta de 980-880 Ma e estão em concordância com a idade $\mathrm{K} / \mathrm{Ar}$ de um basalto intrusivo no Grupo Aguapeí de $977 \pm 35 \mathrm{Ma}$. (Carneiro, comunicação escrita) e os resultados $\mathrm{K} / \mathrm{Ar}$ em veios quartzosos mineralizados a ouro intrusivos na Formação Fortuna com idades entre 925 e 817 Ma (Geraldes, 1996). Idades K/Ar em biotitas desta ordem acham-se reportados Barros et al., (1982) em plagioclásios dos basaltos e gabros do Grupo Rio Branco (idades entre 1000 e $850 \mathrm{Ma}$ ).

Tabela 7.1. Resultados $\mathrm{K} / \mathrm{Ar}$ em sericita para as unidades atingidas pelo evento témico Sunsás/Aguapeí.

\begin{tabular}{|l|l|l|l|l|l|l|l|}
\hline SPK & unidade & $\% \mathbf{K}$ & $\%$ erro & Ar (rad) & ${ }^{40} \mathbf{A r}$ (atm) & $\begin{array}{l}\text { Idade } \\
\text { (Ma) }\end{array}$ & $\begin{array}{l}\text { Erro } \\
\text { (Ma) }\end{array}$ \\
\hline 7418 & Aguapeí & 4.9836 & 1.5823 & 244.53 & 1.19 & 957 & 23 \\
\hline 7520 & Aguapeí & 4.9660 & 1.3928 & 223.39 & 0.80 & 894 & 20 \\
\hline 7419 & xisto & 7.4715 & 3.0815 & 326.97 & 1.24 & 876 & 28 \\
\hline 7521 & xisto & 3.3667 & 2.4918 & 162.79 & 0.98 & 947 & 29 \\
\hline
\end{tabular}




\subsection{As Suítes Intrusivas Guapé e São Domingos}

As unidades magmáticas tratadas neste Capítulo apresentam características anorogênicas e são intrusivos na Suíte Santa Helena e no Grupo Aguapeí (Prancha 10). Compreendem unidades com posição cronoestratigráfica das mais jovens na região, características estas observadas nos trabalhos de campo e em concordância com os trabalhos publicados. As unidades magmáticas tratadas neste Capítulo apresentam características anorogênicas e são intrusivos na Suíte Santa Helena e no Grupo Aguapeí. Compreendem unidades com posição cronoestratigráfica das mais jovens na região, características estas observadas nos trabalhos de campo e em concordância com os trabalhos publicados.

Segundo o mapeamento realizado pela CPRM (Menezes et al., 1993) a Suíte Intrusiva Guapé está representada por um único corpo rochoso (Figura 5.1), localizado no canto $\mathrm{NE}$ da Folha Pontes e Lacerda. As análises isotópicas $\mathrm{Rb} / \mathrm{Sr}$ disponíveis na literatura indicam uma isócrona rocha total (com cinco pontos) de $950 \pm 41 \mathrm{Ma}$ e RI de 0,70292 \pm 0,00136 .

O Granito São Domingos aflora ao sul do Granito Guapé (Prancha 11), sendo representado por um único corpo cujas relações de contato sugerem ser intrusivo na Suíte Santa Helena. Esta unidade apresenta idades U/Pb entre 939 e $916 \mathrm{Ma}$ e valores de $\varepsilon_{\mathrm{Nd}}(\mathrm{t})$ entre $-2,1$ e -1,6 (Tabela 7.2). Não foram obtidos dados U/Pb para o Granito Guapé. A seguir é apresentada uma descrição das amostras analisadas.

Tabela 7.2. Dados $\mathrm{U} / \mathrm{Pb}$ e $\mathrm{Sm} / \mathrm{Nd}$ para as rochas neoproterozóicas do Terreno Pontes e Lacerda

\begin{tabular}{|c|c|c|c|c|c|c|c|}
\hline Numero & Descrição & $\mathrm{U} / \mathrm{Pb}^{*}$ & $\mathrm{Rb} / \mathrm{Sr}$ & $\varepsilon_{\mathrm{Nd}(0)}$ & $\varepsilon_{\mathrm{Nd}(\mathrm{t})^{* *}}$ & $\mathrm{~T}_{\mathrm{DM}}$ & $f$ \\
\hline $97-107$ & Guapé & nd & $950 \pm 50$ & $-11,9$ & $+1,2-$ & 1,28 & $-0,57$ \\
\hline $97-118 a$ & São Domingos & $939 \pm 19$ & & $-17,7$ & $-7,1$ & 2,21 & $-0,15$ \\
\hline $97-118 b$ & São Domingos & $914 \pm 15$ & & $-18,1$ & $-7,6$ & 2,22 & 0,15 \\
\hline
\end{tabular}

* Idades $\mathrm{U} / \mathrm{Pb}$ em Ma obtida por diluição isotópica em monocristais de zircão.

$* *$ Os valores de $\varepsilon_{\mathrm{Nd}(\mathfrak{l})}$ para as amostras $97-118 \mathrm{a} 197-118 \mathrm{~b}$ foram calculados para as respectivas idades $\mathrm{U} / \mathrm{Pb}$. $\mathrm{O}$ valor de $\varepsilon_{\mathrm{Nd}(\mathrm{t})}$ para a amostra $97-107$ foi calculado para a idade $\mathrm{Rb} / \mathrm{Sr}$ de $950 \mathrm{Ma}$.

$\mathrm{T}_{\mathrm{DM}}$ em Ga. $\mathrm{nd}=$ não determinado 

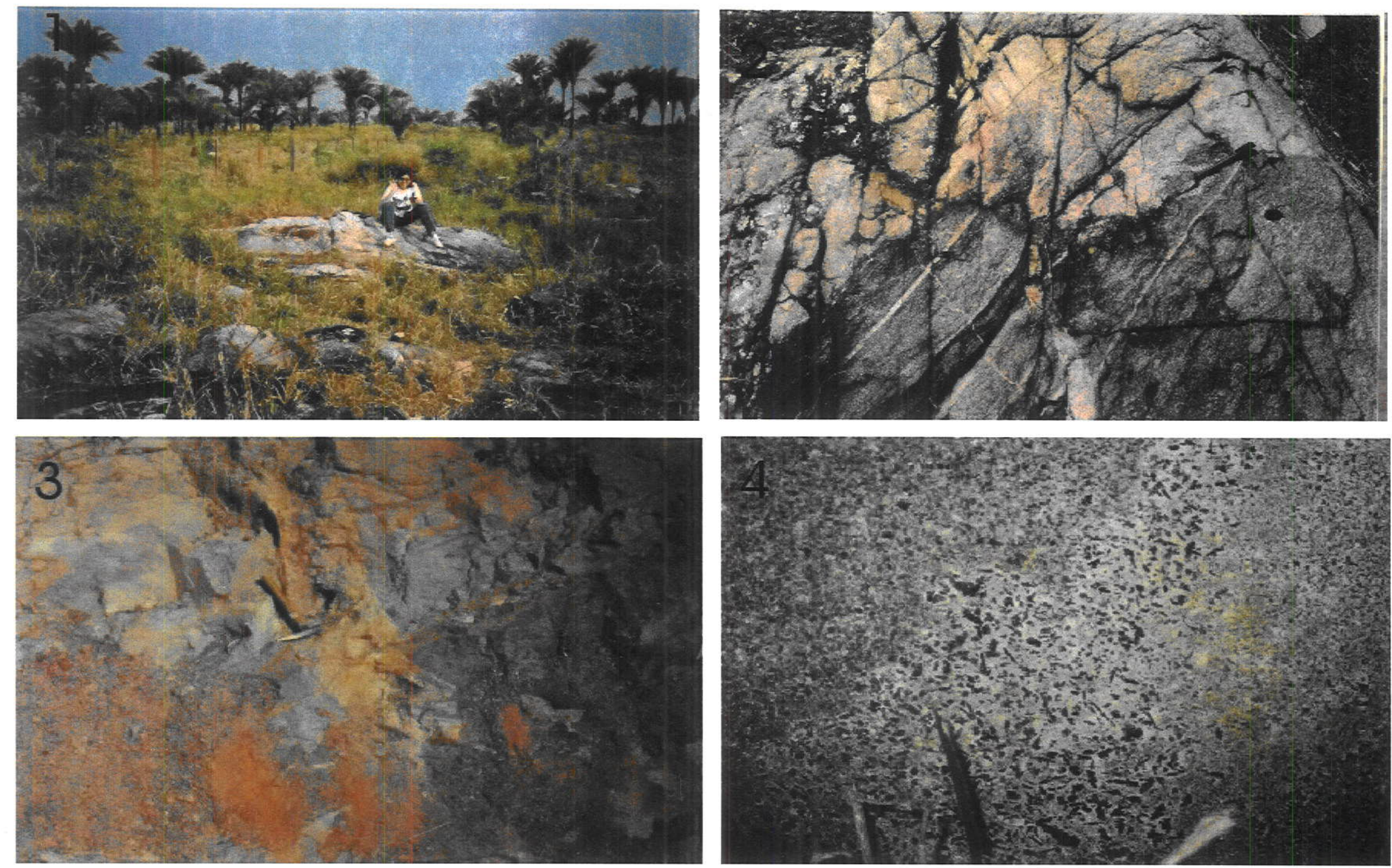

Prancha 10. (1) Afloramento do Granito São Domingos na Fazenda Flor das Serra (97-118a).

(2) Detalhe do aflorameto (97-118a), com xenólito de gnaisse cinza, provavelmente da Suíte Santa Helena.

(3) Pegmatito intrusivo nos arenitos da Fm. Fortuna (Grupo Aguapeí).

(4) Detalhe da Suíte Guapé (afloramento na Folha Jauru) 
Suíte Intrusiva Guapé (SIG)

Nos trabalhos de campo desenvolvidos no atual projeto a SIG foi identificada apenas com uma fácies de rochas graníticas grosseiras, isotrópicas, aflorante internamente nos limites do batólito da Suíte Santa Helena. Ao microscópio a amostra é definida como granito (senso stricto) com textura equigranular, constituído por quartzo e k-feldspato subcentimétricos e plagioclásio com granulação média. A biotita (marrommesverdeada) ocorre em palhetas milimétrica idiomórficas, constituindo o principal acessório e encontrase comumente alterada para clorita. Os demais minerais acessórios são zircão, apatita e opacos. Esta amostra não foi estudada pelo método $\mathrm{U} / \mathrm{Pb}$, uma vez que a variação morfológica dos poucos $(\sim 15)$ grãos de zircões não definia uma população segura para datação. Uma isócrona $\mathrm{Rb} / \mathrm{Sr}$ reportada por Menezes et al., (1993) indica uma idade de 950 $\pm 40 \mathrm{Ma}$. Sua idade $\mathrm{T}_{\mathrm{DM}}$ de $1,27 \mathrm{Ga}$ com $\varepsilon_{\mathrm{Nd}(\mathrm{t})}$ de $+1,2$ (calculado para a idade $\mathrm{Rb} / \mathrm{Sr}$ ).

O Granito São Domingos (GSD)

O litotipo mais característico do GSD (coletada a sul do rio Guaporé, na Fazenda das Rosas) é uma rocha de coloração esbranquiçada, textura isotrópica localmente orientada e granulação fina a média. Seus principais constituintes são o feldspato alcalino, quartzo e plagioclásio (Fotomicrografia 7.1), e acessoriamente biotita e muscovita (amostra 97-118b). Quatro frações de zircões desta amostra indicam intertcepto superior com idade de $939 \pm 19 \mathrm{Ma}$ (Figura 7.1).

Uma segunda amostra foi coletada na Fazenda Flor da Serra, ao norte do rio Guaporé. Esta amostra apresenta coloração cinza esbranquiçada e seus principais constituintes são microclínio secundado por quartzo e plagioclásio (Fotomicrografia 7.2). Biotita, muscovita e granada são minerais acessórios. Observam-se fases pegmatíticas que apresentam em lâmina intercrescimento gráfico de quartzo e k-feldspato, além de biotita e muscovita. As análises U/Pb em monocristais de zircões indicam a idade de $914 \pm 15 \mathrm{Ma}$ (Figura 7.2). 


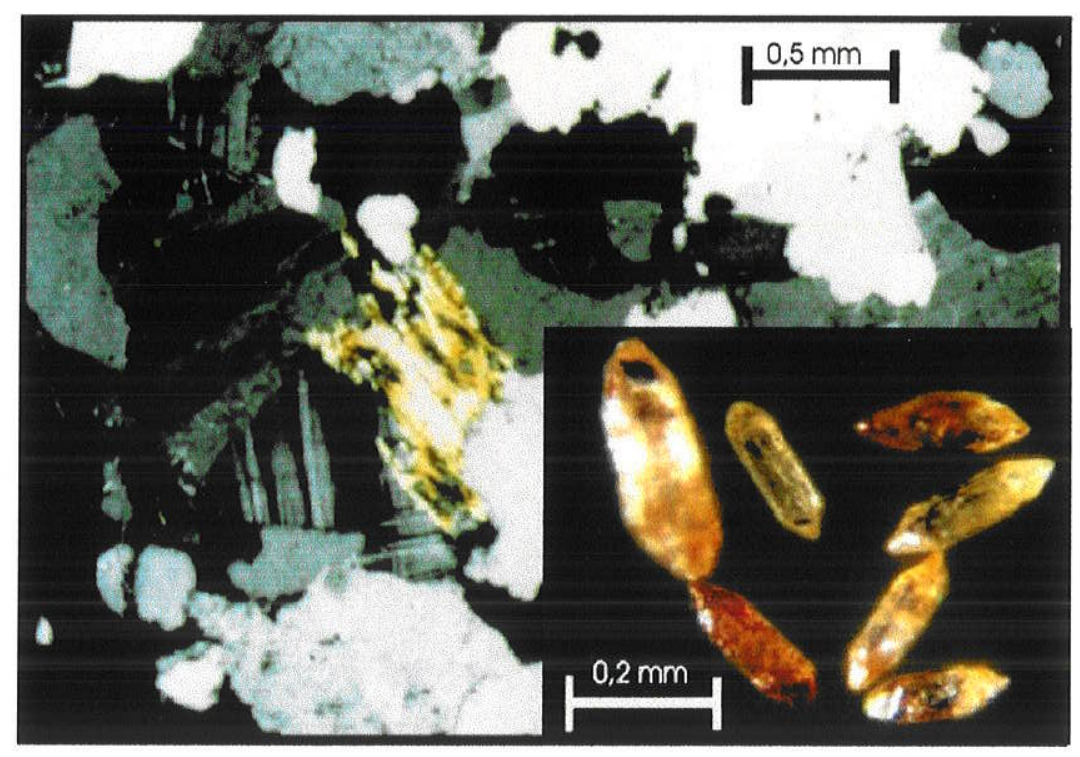

Fotomicrografia 7.1. Granito São Domingos na Fazenda Flor da Serra (amostra 97-118a). Os zircões analisados são mostrados em detalhe.

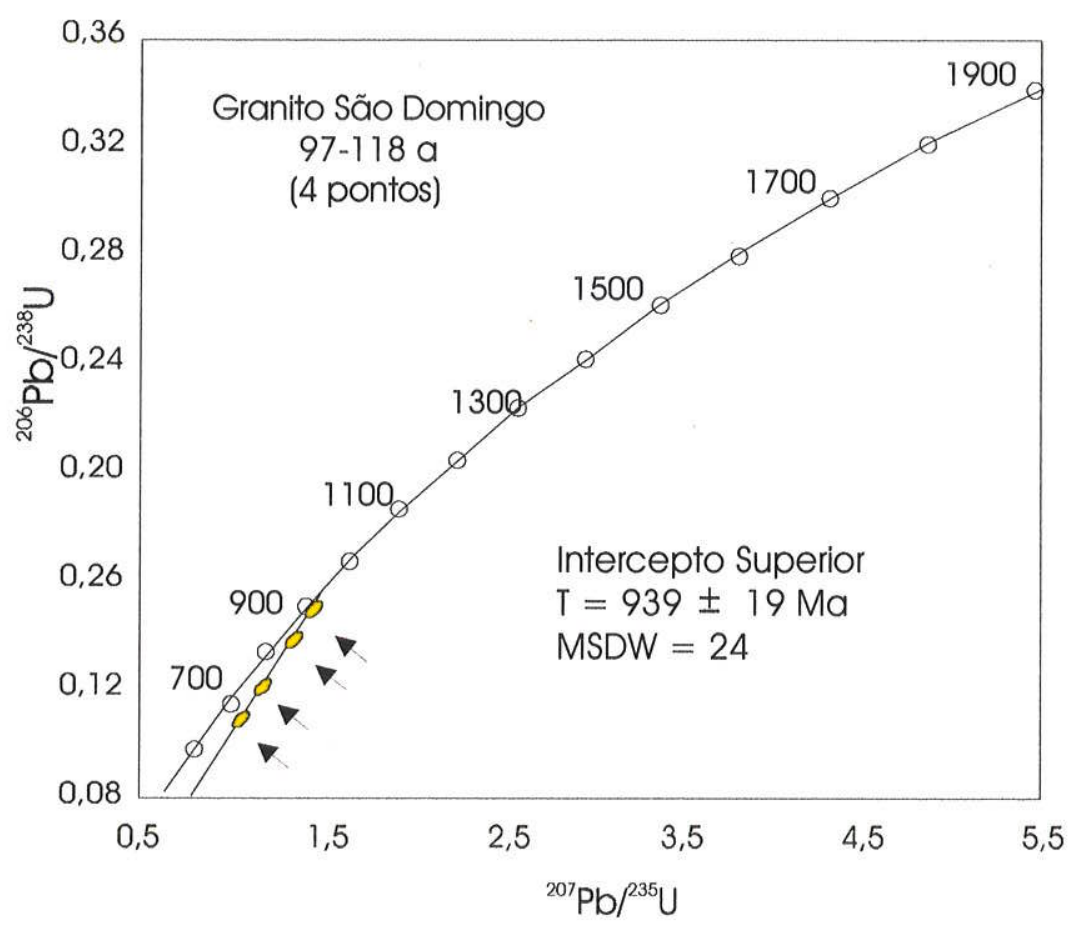

Figura 7.1. Diagrama da concórdia para o Granito São Domingos na fazenda Flor da Serra (amostra 97-118a). Quatro frações de zircões indicam a idade de 939 \pm 19 Ma. 


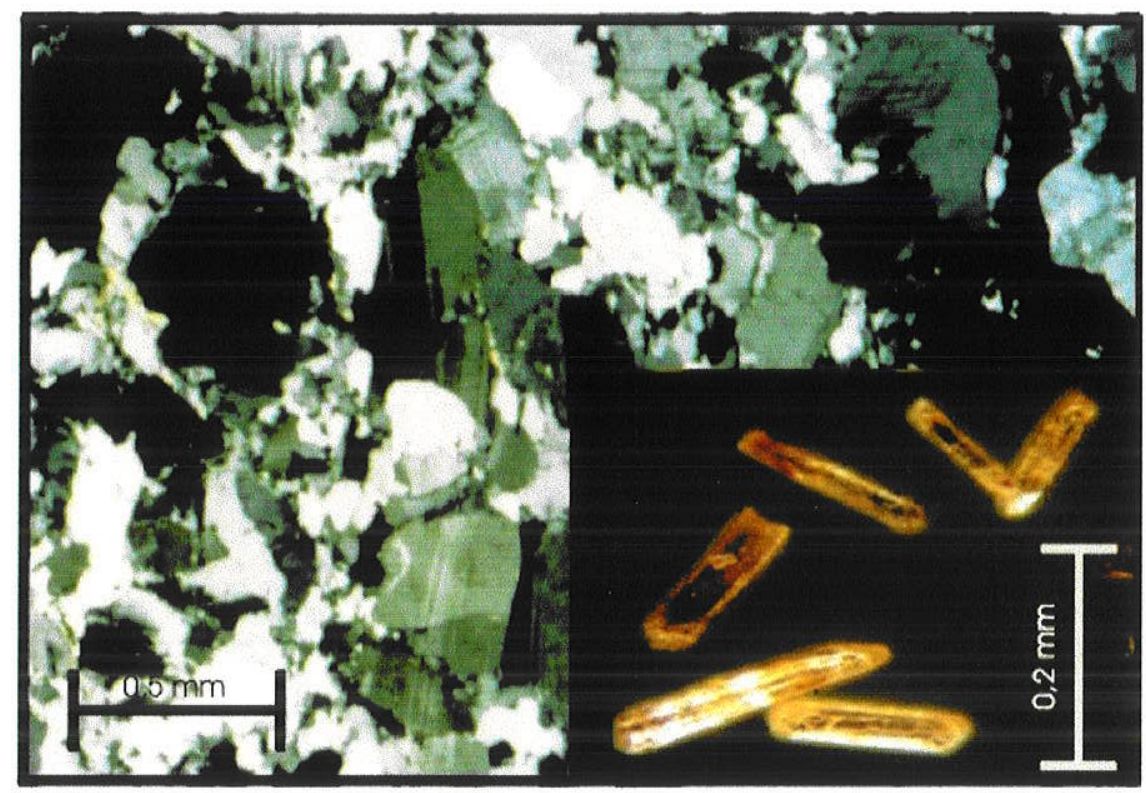

Fomicrografia 7.2. Granito São Domingos na Fazenda das Rosas (amostra 97-118b). Os zircões analisados são mostrados em detalhe.

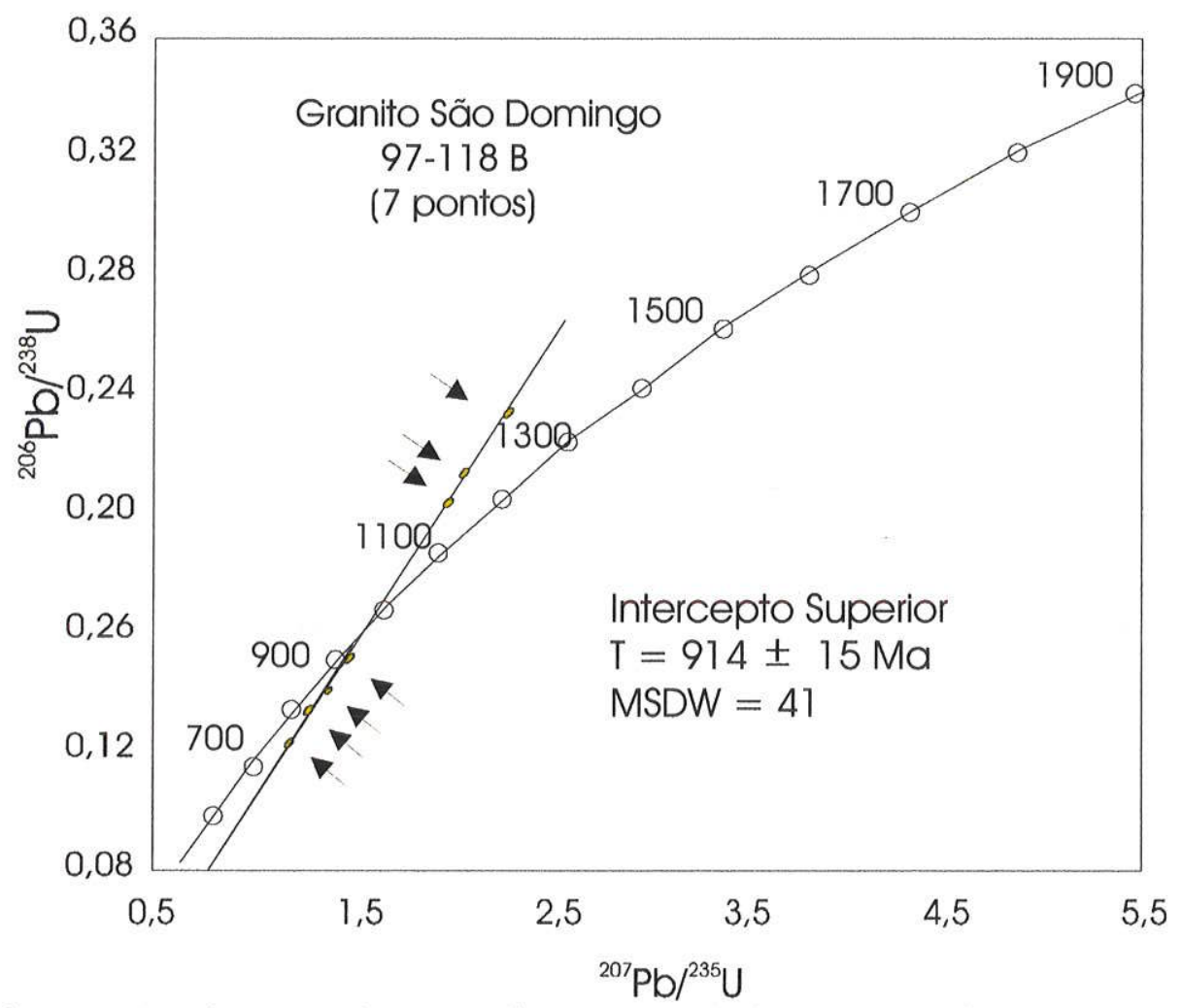

Figura 7.2. Diagrama da concódia para o Granito São Domingos na Fazenda das Rosas (amostra 97-118b). As análises U/Pb em monocristais de zircões indicaram a idade de 914 $\pm 15 \mathrm{Ma}$. Sete cristais de zircões foram analisados, porém 3 deles localizam-se acima da curva da concórdia (provavelmente por dissolução incompleta dos grãos) e não foram utilizados para o cálculo da idade. 


\subsection{Geoquímica}

Apenas três amostras coletadas (uma da SIG e duas do GSD) foram analisadas para elementos maiores, traços e ETR. O tratamento destes resultados foi realizado de forma conjunta numa tentativa de se averiguar a cogeneticidade das rochas coletadas, ficando ressaltadas, na verdade, importantes diferenças entre elas. Os dados foram lançados também nos mesmos diagramas da Suíte Santa Helena para efeito de comparação entre os granitos jovens e suas encaixantes. Desta forma o tratamento dos resultados analíticos demonstrou que a amostra coletada da SIG (97-107) e uma amostra da GSD (97-118b) apresentam composição granítica ao passo que a amostra do GSD (97-118a) indica composição granodiorítica (Figura 7.3). A Figura 7.4 indica uma composição peraluminosa para as três amostras analisadas, semelhante, portanto, a Suíte Santa Helena. Na Figura 7.5 as amostras da SIG e do GSD apresentam composição predominante cálcica, diferentemente às amostras da Suíte Santa Helena que indicam um trend calcioalcalino, ressaltando no entanto que o número restrito de análises dos granitos joves impede uma afirmação mais conclusiva. Este fato também impede uma interpretação dos dados químicos do Granitos Jovens quando lançados no diagrama de ambientes tectônicos (Figura 7.6), em função das discrepância observada.

O padrões dos elementos terras raras (Figura 7.7) indicam um comportamento diferente para cada amostra, o que confirma a heterogeneidade geoquímica das amostras analisadas. A amostra 97-107 (SIG), apresenta enriquecimento em ETR leves e empobrecimento em ETR pesados. A amostra 97-118a (rocha granodiorítica do GSD) apresenta também enriquecimento de ETR leves e empobrecimento de ETR pesados, porém com um padrão sub-horizontalizado. A amostra 97-118b (rocha granítica do GSD) apresenta empobrecimento em ETR leves, enriquecimento em ETR pesados e uma proeminente anomalia negativa de Eu. Este último padrão de ETR é coerente com o padrão da granada, o que pode ser explicado pela grande quantidade deste mineral observado na amostra em questão. 


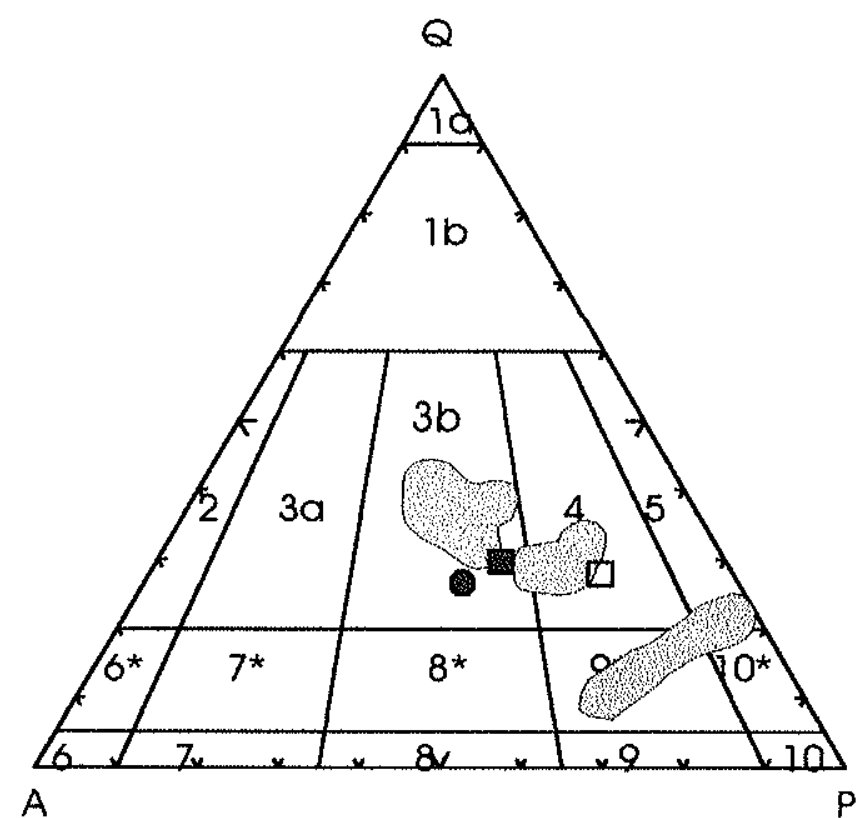

Figura 7.3: Diagrama QAP (Streickeisen, 1976) obtido a partir de dados químicos para as rochas da SIG e GSD. As rochas analisadas apresentam composição granítica (97-107 em círculo e 97-118b em quadrado preenchido) a granodiorítica (97-118a em quadrado vazio). Também estão representadas as áreas correspondentes aos resultados químicos das rochas intrusivas mesoproterozóicas da Suíte Santa Helena. Campos composicionais (1a) quartzolito; (1) granitóide rico em Qz; (3) granito alcalifeldspático; (3a) sienogranito; (3b) monzogranito; (4) granodiorito; (5) tonalito; $\left(6^{*}\right)$ quartzo sienito ácalifeldspático; (6) sienito ácalifeldspático; $\left(7^{*}\right)$ quartzo sienito; $\left(8^{*}\right)$ quartzo monzonito; (8) monzonito; $\left(9^{*}\right)$ quartzo monzogabro; (9) monzogabro; (10) quartzo gabro; e (10*) diorito, gabro, anortosito,

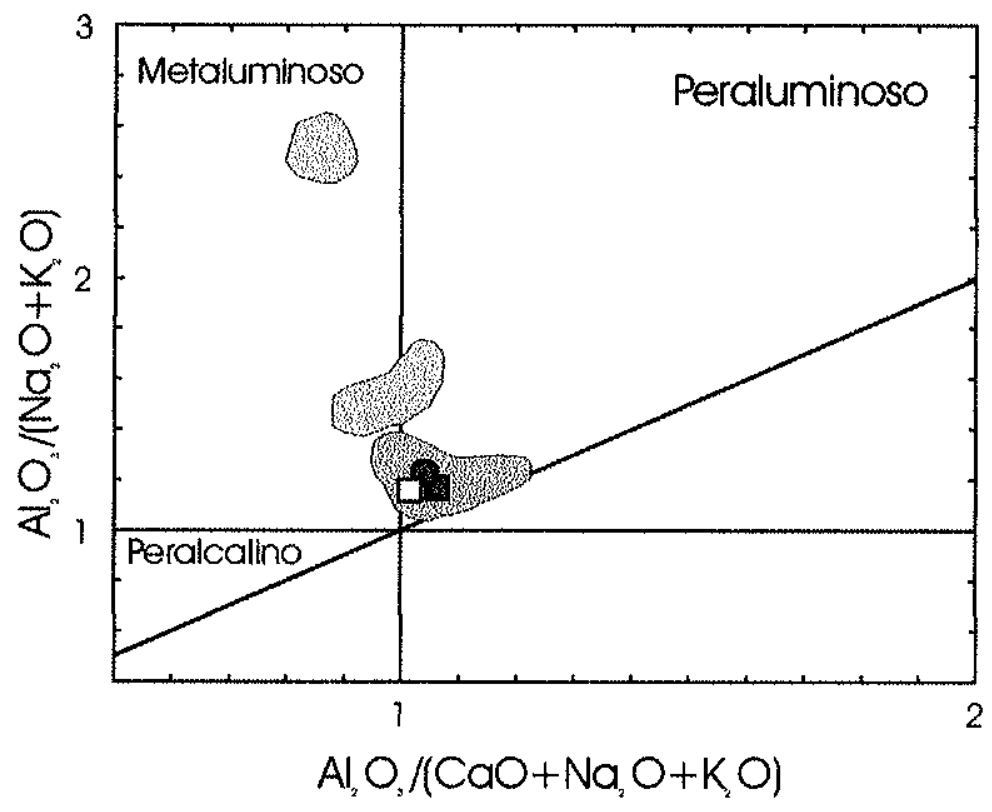

Figura 7.4 Indice de Shand (A/CNK) versus índice de saturação em alumina para as rochas do SIG e GSD. O diagrama indica que as rochas analisadas têm composição predominante cálcica. Também estão representadas as áreas correspondentes aos resultados químicos das rochas intrusivas mesoproterozóicas da Suíte Santa Helena. 


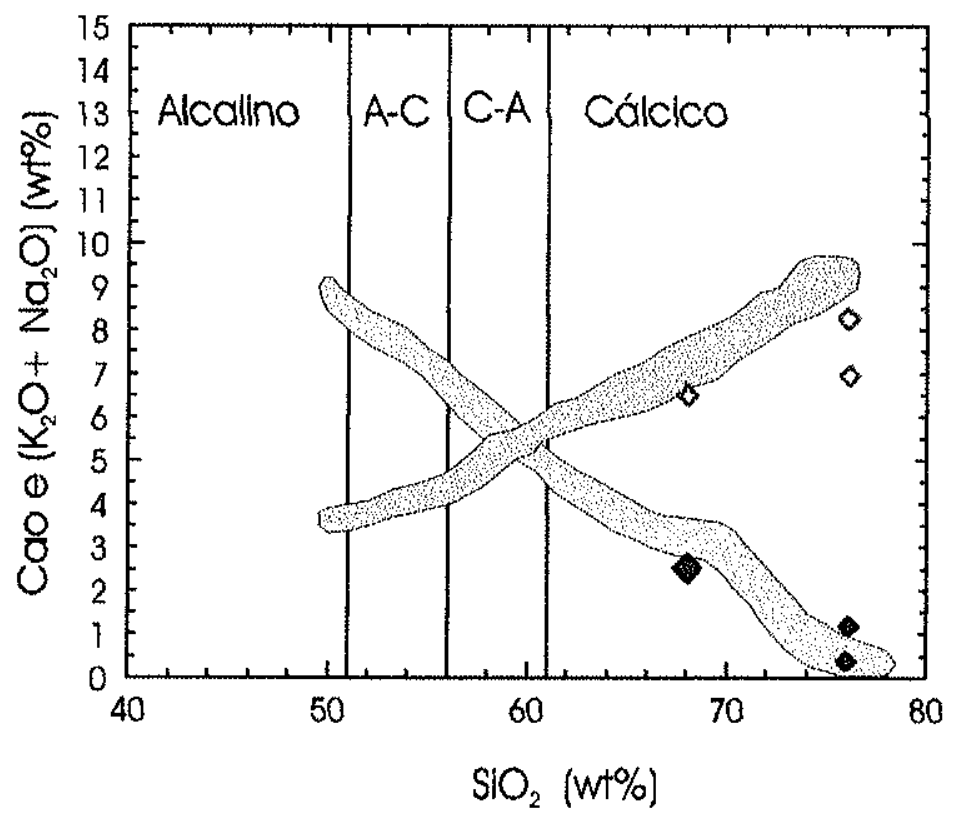

Figura 7.5 Diagramas discriminantes de trends de diferenciação (Peacock, 1931). As amostras da SIG e do GSD apresentam composição cálcica, diferentemente dos resultados da SSH. Também estão representadas as áreas correspondentes aos resultados químicos das rochas intrusivas mesoproterozóicas da Suíte Santa Helena.

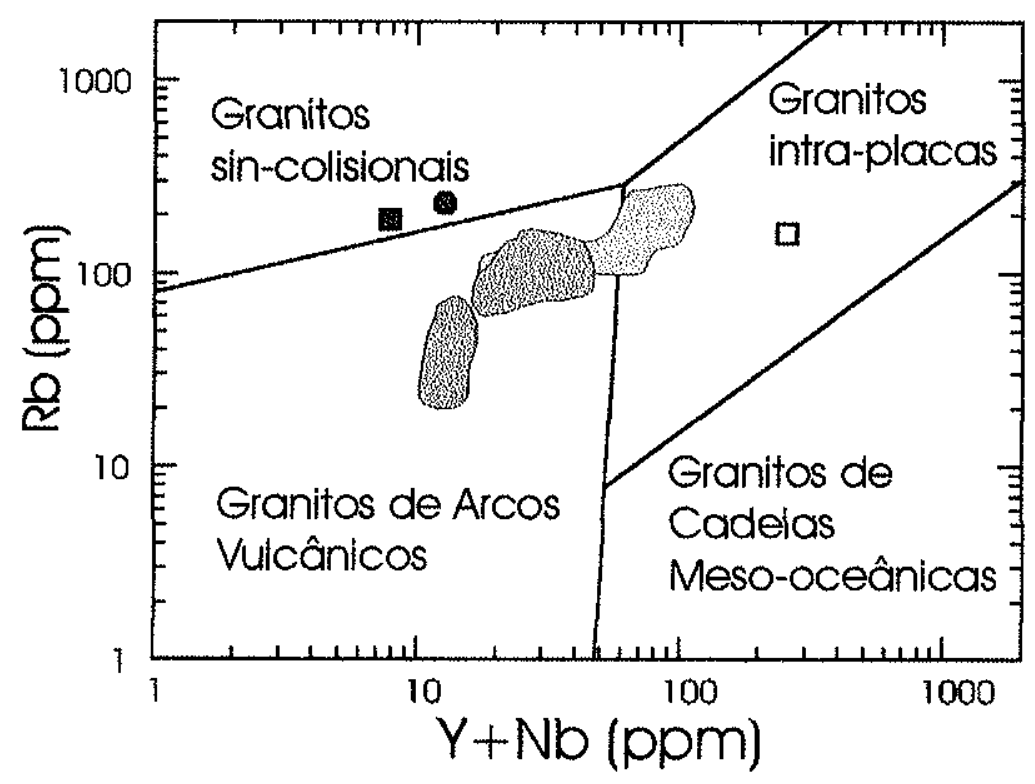

Figura 7.6 Diagramas e discriminação de ambientes tectônicos (Pearce et al., 1984). A composição das amostras 97-107, 97-118b indicam ambiente sin-colisional e da amostra 97-118 ambiente intra-placas. Também estão representadas as áreas correspondentes aos resultados químicos das rochas intrusivas mesoproterozóicas da Suíte Santa Helena. 


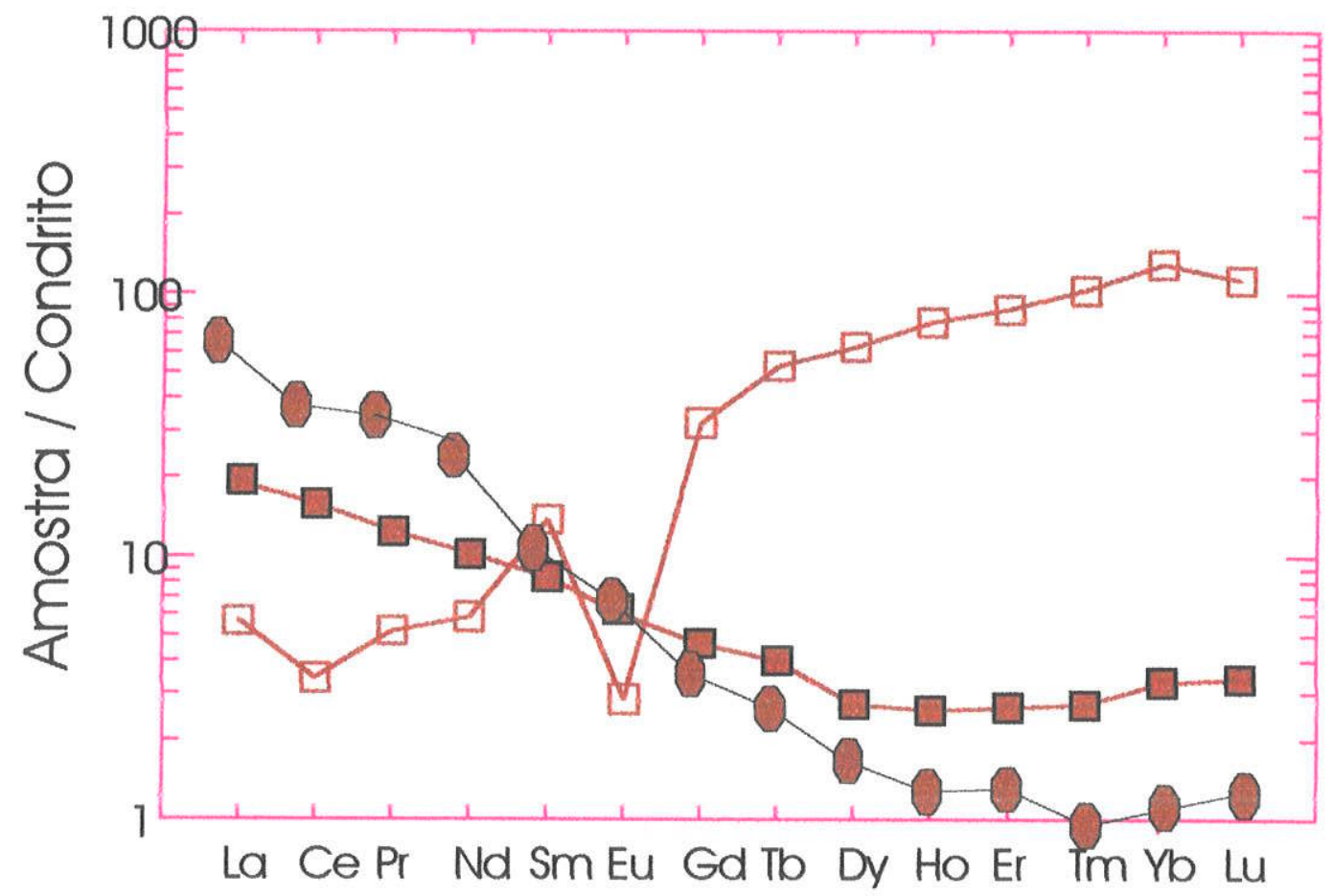

Figura 7.7 Padrões terras raras para as rochas da SIG e duas amostras do GSD. Os valores de terras raras foram normalizados segundo Sun e McDonough (1989).

\subsection{Isótopos de Oxigênio}

Três amostras foram analisadas para isótopos estáveis de oxigênio: amostras do Granito Fazenda Guapé (97-107), Granito São Domingos na Fazenda Flor da Serra (97118a), Granito São Domingos na Fazenda das Rosas (97-118b). Os resultados de ${ }^{16} \mathrm{O} /{ }^{18} \mathrm{O}$ foram normalizados pelo standart SMOW e são apresentados na Tabela 7.3.

Tabela 7.3 Resultados de $\delta \mathrm{O}$ para as rochas graníticas intrusivas na Suíte Santa Helena.

\begin{tabular}{|l|l|}
\hline Amostra & $\delta$ O \%o \\
\hline Granito Faz. Guapé & $+9,6$ \\
\hline Granito S. Domingos Faz. Flor da S. & $+8,6$ \\
\hline Granito S. Domingos Faz. das Rosas & $+9,0$ \\
\hline
\end{tabular}




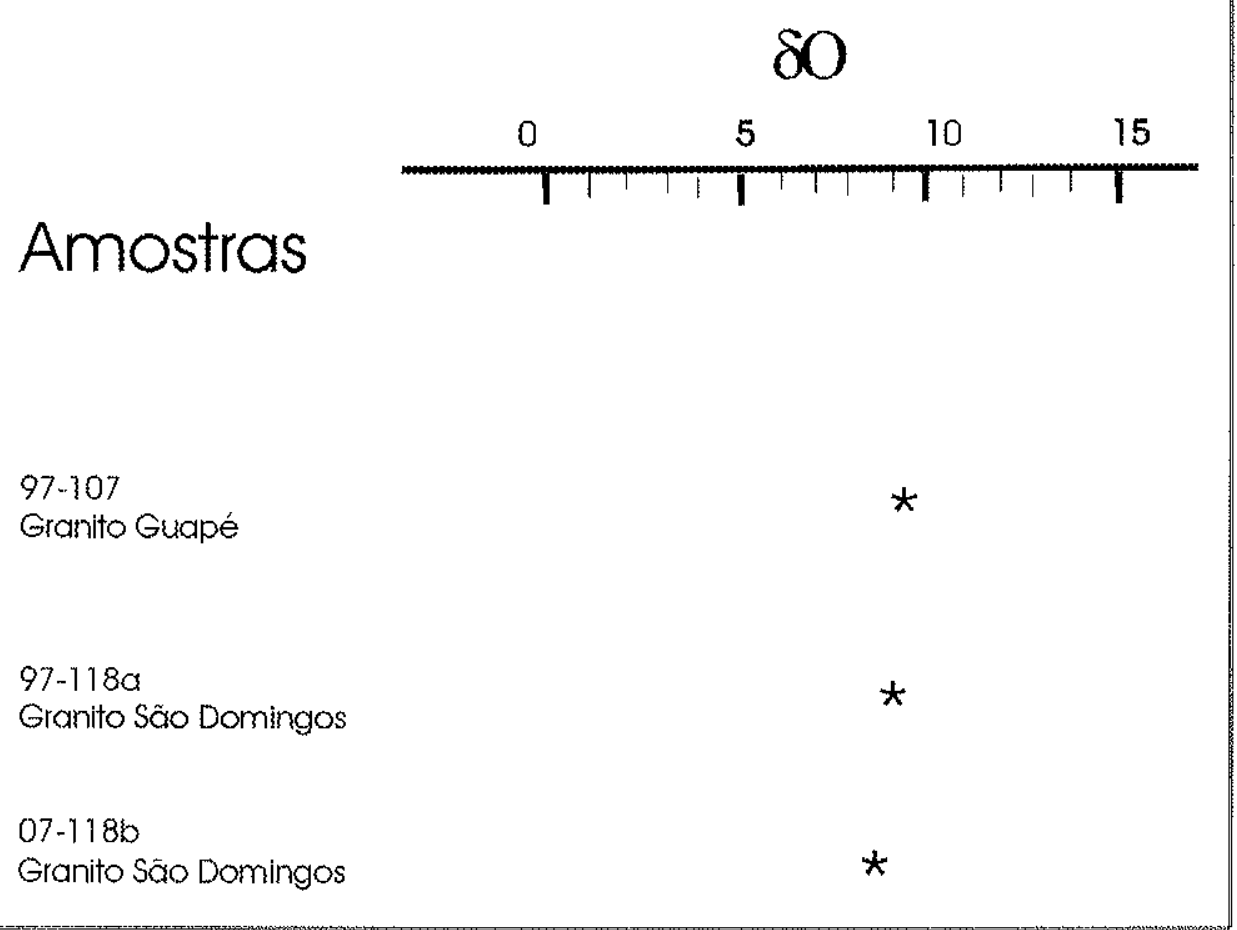

Figura 7.8 Valores de $\delta$ O para as rochas graníticas intrusivas na Suíte Santa Helena.

Os resultados da Tabela 7.2. indicam uma variação entre $+8,6 \%$ e $+9,6 \%$ (Figura 7.8) coerentemente com valores de $\delta \mathrm{O}$ característicos de rochas graníticas de bordas ativas e de supracrustais, como pode ser visto na Figura 3.30. Os resultados de isótopos de $\mathrm{O}$ sugerem a participação de rochas supracrustais na geração dos protólitos desta rochas.

\subsection{Discussão}

Os resultados químicos e isotópicos das rochas das suítes Guapé e São Domingos indicam protólitos e processos de geração distintos, muito embora o pequeno número de amostras estudadas, impossibilita obter conclusões definitivas sobre suas características genéticas. Tanto nas análises de elementos maiores (classificação) quanto nas de traços (definição de tipos de magmas e ambientes de geração) os resultados sugerem diferentes em coerência com valores de $\varepsilon_{\mathrm{Nd}}$ entre $+1,2$ e $-7,6$. Apesar disso os 
resultados isotópicos de $\mathrm{U} / \mathrm{Pb}$ definirem a época de geração contemporânea destes corpos intrusivos.

As idades aqui reportadas obtidas pelo método $\mathrm{U} / \mathrm{Pb}$ em zircões em granitos intrusivos no Grupo Aguapeí definem o limite temporal para a deposição deste grupo no Brasil por volta de $930 \mathrm{Ma}$. Neste sentido, o ambiente marinho onde foram depositados os sedimentos sofreu inversão e passou a um regime compressivo que gerou dobras em áreas localizadas (como ao longo do vale do Rio Alegre, Figura 1.3) e a intrusão de corpos graníticos aqui estudados. As idades $\mathrm{K} / \mathrm{Ar}$ entre $1.000 \mathrm{Ma}$ e $870 \mathrm{Ma}$ em sericitas de sedimentos dobrados do grupo Aguapeí estão em coerência com os dados reportados por Litherland et al., (1989), de forma que as idades dos granitos intrusivos nos sedimentos do Grupo Sunsás na Bolívia apresentam de idade $\mathrm{Rb} / \mathrm{Sr}$ ao redor de $1,0 \mathrm{Ga}$. 


\section{CAPÍTULO 8 \\ Súmula da Evolução Tectônica}

Os resultados reportados nesta tese, adicionados aos dados existentes na literatura, permitem chegar a algumas conclusões principais sobre a evolução do SW do Craton Amazônico no estado de Mato Grosso.

O greenstone belt Alto Jauru

No Terreno Jauru foi identificado um evento magmático de idade $\mathrm{U} / \mathrm{Pb}$ entre $1,79 \mathrm{Ga}$ a 1,75 responsável pela geração de rochas vulcânicas e graníticas (Figura 8.1). Estas rochas apresentam $\mathrm{T}_{\mathrm{DM}}$ entre 1,92 e 1,86 Ga e valores de $\varepsilon_{\mathrm{Nd}(t)}$ entre $+2,8$ e $+2,0$ que sugerem uma origem mantélica. Os resultados químicos indicaram uma composição graníticamgranodiorítica peraluminosa e calcioalcalina, e os elementos terras raras indicam fracionammento magmático para as rochas gnáissicas deste terreno, compatíveis com ambiente de arco vulcânico.

O Arco Magmático Cachoeirinha do Terreno Jauru

O Terreno Jauru também foi palco de um evento gerador de rochas datado entre 1,58 e 1,52 Ga. Suas rochas possuem $\mathrm{T}_{\mathrm{DM}}$ entre 2,04 a $1,74\left(\varepsilon_{\mathrm{Nd}(\mathrm{t})}\right.$ entre $-1,7$ e +3.0$)$, 
indicando uma origem híbrida com materiais juvenis e componentes de crosta mais antiga na geração dos magmas destas rochas.

Os resultados químicos das rochas intrusivas deste terreno definem a existência de grupos de rochas graníticas, granodioríticas (peraluminosas) e tonalíticas (metaluminosas) com características de suítes geradas em ambiente arco magmático (Figura 8.2). Os elementos traços e de ETR revelam um processo de fracionamento na cristalização magmática para a geração destas rochas, corroborado pelos valores de $\delta \mathrm{O}$ entre $+9 \%$ e $+6 \%$. Corpos graníticos mais jovens (idades $\mathrm{U} / \mathrm{Pb}$ entre 1,48 e $1,38 \mathrm{Ga}$ e $\varepsilon_{\mathrm{Nd}(\mathfrak{l})}$ entre $-1,3$ e $+3,7$ ) possuem uma assinatura geoquímica de materiais formados intra-placas (magmatismo pós-orogênico).

A Suíte Santa Helena do Terreno Pontes e Lacerda

Neste terreno um importante conjunto de rochas granitóides formou-se entre 1480 Ma a $1420 \mathrm{Ma}$ (idades $\mathrm{U} / \mathrm{Pb})$. Apresenta idades $\mathrm{T}_{\mathrm{DM}}$ entre $1,70 \mathrm{Ma}$ a $1,50 \mathrm{Ma}\left(\varepsilon_{\mathrm{Nd}(t)}\right.$ entre +3 e +1 e valores de $\delta \mathrm{O}$ entre $+8,3 \%$ e $+10,4 \%$ ). Os dados isotópicos sugerem formação de suas rochas em ambiente de arco distal (Figura 8.3), à margem continental pré-existente (com idades entre 1790 e $1550 \mathrm{Ma}$ ).

Suas rochas apresentam composições químicas entre termos graníticos (peraluminosa), granodioríticos, tonalíticos e dioríticos (metaluminosa). característicos de suítes calcio-alcalinas, com o padrão de distribuição de elementos terras raras compatível com processo de diferenciação magmática.. Os resultados químicos sugerem que a geração das rochas tonalíticas a granodioríticas teria ocorrido em ambiente de arco magmático em coerência com os dados isotópicos, já as rochas graníticas provavelmente em ambiente intermediário entre arco magmático e ambiente intra-placa. 


\section{A Suíte Rio Branco no Terreno Jauru}

As rochas desta unidade são intrusivas no Terreno Jauru (Figura 8.4) e foram formadas entre 1460 e $1427 \mathrm{Ma}$ (idades $\mathrm{U} / \mathrm{Pb}$ ). $\mathrm{O}$ grupo de rochas básicas apresenta $\mathrm{T}_{\mathrm{DM}}$ entre 1,88 e 1,80 , com $\varepsilon_{\mathrm{Nd}(t)}$ entre $+1,9 \mathrm{e}+1,2$ e as rochas félsicas apresentam $\mathrm{T}_{\mathrm{DM}}$ entre 1,88 e 1,74, com $\varepsilon_{\mathrm{Nd}(t)}$ entre - 0,9 e - 0,1. Tais parâmentros sugerem a derivação mantélica dos magmas das rochas básicas e participação de rochas crustais na formação dos magmas das rochas do grupo félsico. Valores de $\delta \mathrm{O}$ entre $+8,4 \% 0$ e $+5,4 \%$ para as rochas básicas e entre $+9,0$ e $+7,3$ para as rochas félsicas corroboram com esta interpretação.

Elementos maiores e traços apontam para a bimodalidade química da Suíte Intrusiva Rio Branco, o que é corroborado pelos diferentes padrões de ETR dos dois grupos de rochas. Os resultados também indicam composição gabróica para os grupo de rochas básicas (com característica peraluminosa) e composição granítica a quartzo monzonítica para o grupo de rochas félsicas (com característica metaluminosa). Dados de campo e de petrografia indicam a presença de mistura de magmas, com textura comingling, tipo rapakivi e rochas híbridas. Quimicamente as rochas da Suíte Intrusiva Rio Branco são coerentes com uma geração em ambiente intraplacas.

\section{A Sequência Metavulcanossedimentar Rio Alegre do Terreno Rio Alegre}

O Terreno Rio Alegre (Figura 8.5) apresenta rochas formadas entre 1504 Ma e 1494 $\mathrm{Ma}$, representadas por metavulcânicas (metadacitos) e metaplutônicas (metadioritos e anfibolitos), associadas a rochas intrusivas máfica-ultramáficas (peridotitos e piroxenitos) e rochas sedimentares de origem clástica (metarenitos) e química (metachert e formação ferrífera bandada). Dados químicos da literatura indicam a formação da sequência de rochas em ambiente de assoalho oceânico e ambientes deposicionais associados.

A pequena diferença de idade desta unidade em relação às rochas da Suíte Santa Helena (20-50 Ma), e o seu posicionamento a oeste indicam que provavelmente a colagem 
do Terreno Rio Alegre ocorreu posteriormente a formação do Terreno Pontes e Lacerda e conseqüentemente foi amalgamado ao protocraton Amazônico entre 1,38 Ga (idade de estabilização do Arco Santa Helena) e 1,30 Ga (provável idade de início de deposição do Grupo Aguapeí). Diante destas pressupostos é possível sugerir que as vulcânicas do Rio Alegre representariam uma crosta oceânica parte obductada e parte subductada que deu origem ao arco magmático Santa Helena.

As Suítes Intrusivas Guapé e São Domingos

No período Meso-Neoproterozóico foram geradas unidades graníticas representadas pelo Granito São Domingos (idade U/Pb entre 939 e $916 \mathrm{Ma}$ ) e pela Suíte Intrusiva Guapé (idade $\mathrm{Rb} / \mathrm{Sr}$ de $950 \mathrm{Ma}$ ) no Terreno Pontes e Lacerda (Figura 8.6). No mesmo período de tempo o Grupo Aguapeí foi deformado, conforme sinalizam as idades $\mathrm{K} / \mathrm{Ar}$ (970 a $840 \mathrm{Ma}$ ) em sericitas. Esta equivalência de idades sugere que durante o encurtamento crustal causado pelo evento Aguapeí houve fusão parcial da crosta e geração de magmas graníticos crustais.

Análises químicas destas rochas graníticas revelam ampla variação composicional, possivelmente resultado de diferentes origens. Elementos maiores indicam classificações entre granito a granodiorito, ao passo que os elementos traços apontam para magmas cálcicos e peraluminosos, originados em ambientes de colisão e intraplaca). Os dados de $\mathrm{Sm} / \mathrm{Nd}$ de modo similar indicam diferentes fontes (valores de $\varepsilon_{\mathrm{Nd}(\mathrm{t})}$ entre $-0,2$ e $-2,1$ ), não sendo excluída a possibilidade do Granito São Domingos ser uma unidade alóctone. 


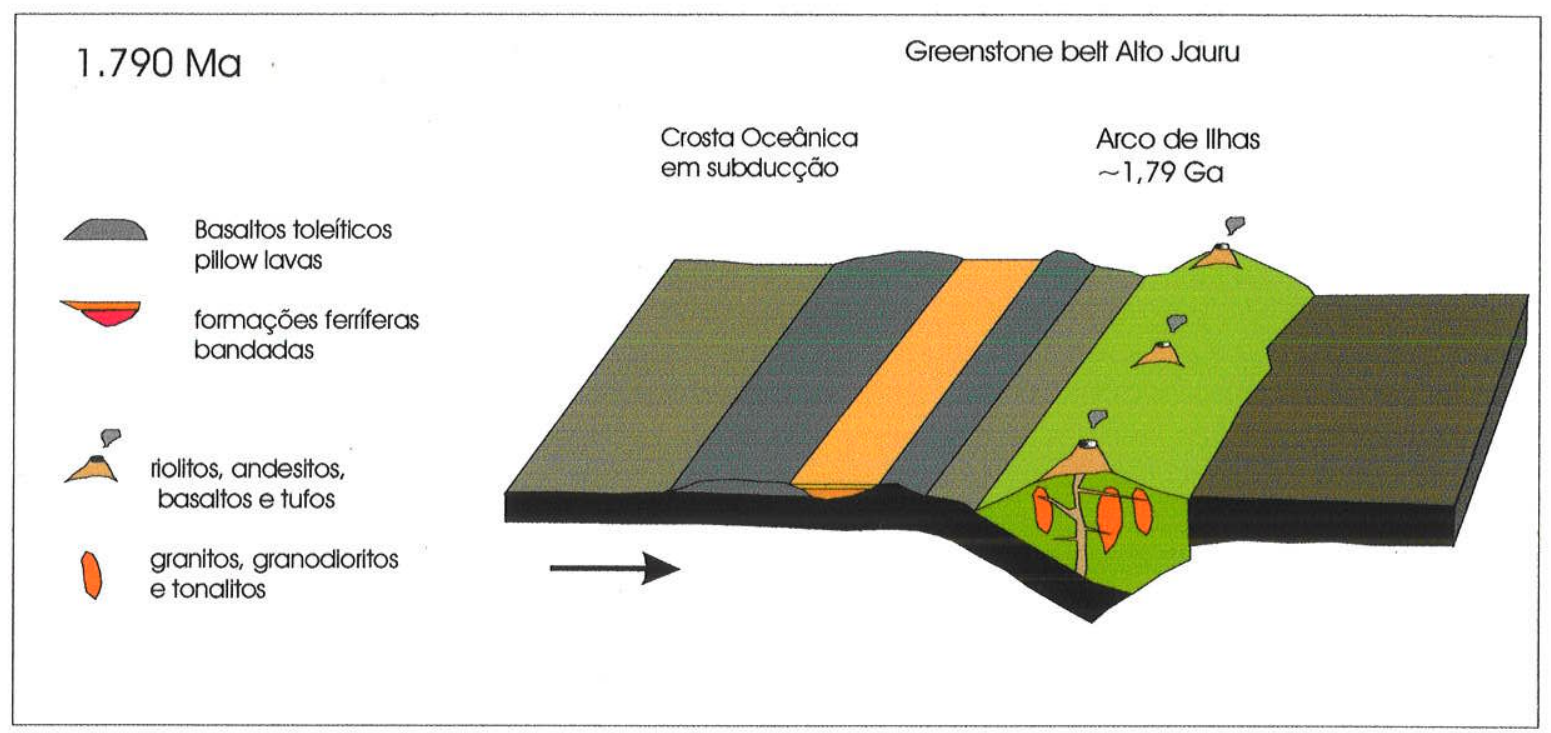

Figura 8.1 Perfil com os ambientes geológicos aqui propostos para a formação do greenstone belt Alto Jauru. Neste modelo o evento de idade 1,79-1,75 Ga representa um arco de ilhas.

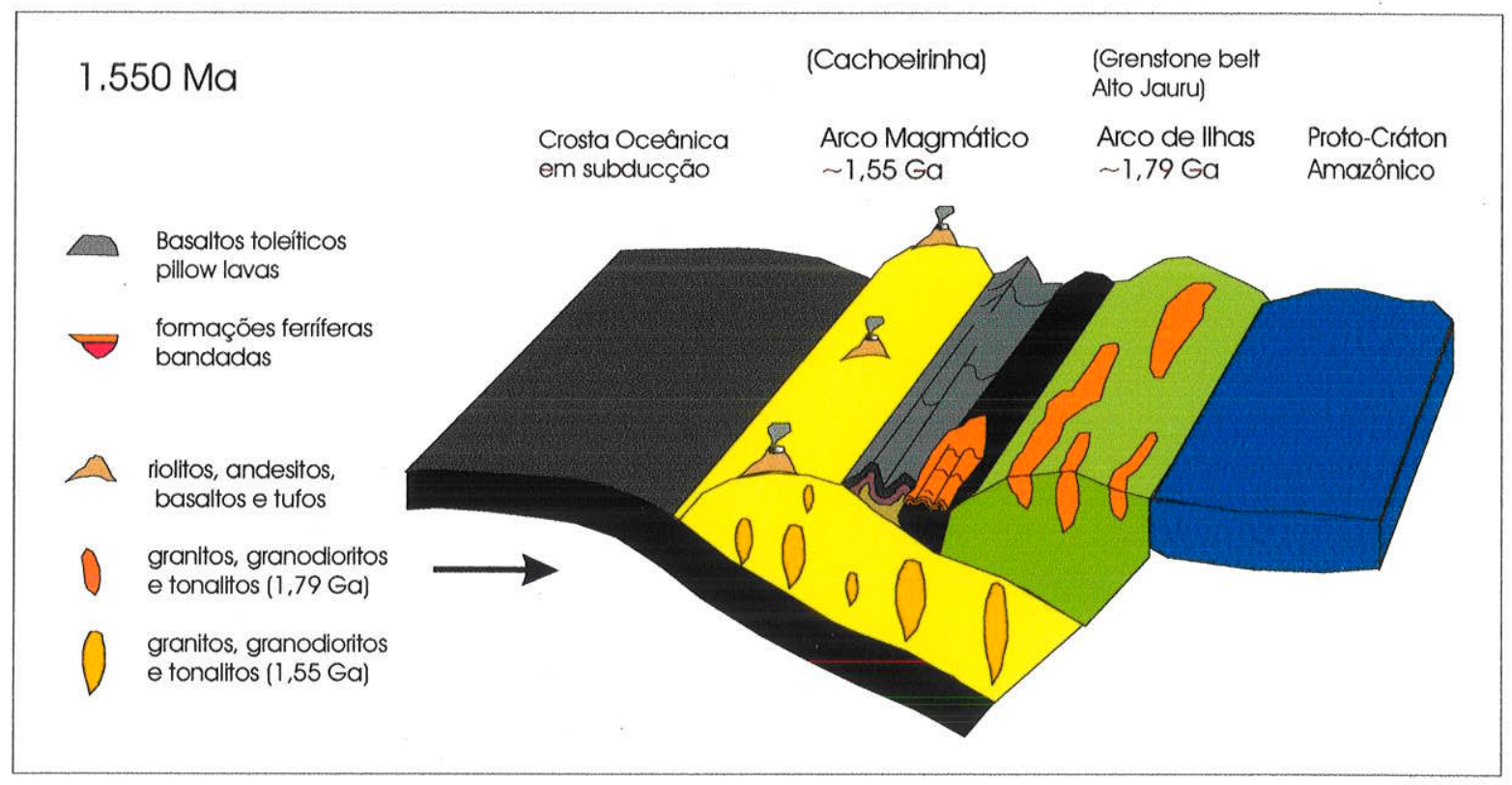

Figura 8.2 . Modelo de ambientes geológicos para a formação do Arco Cachoeirinha (entre 1,55 e 1,53 Ga). As rochas calcioalcalinas geradas são intrusivas nos cinturões vulcanossedimentares da greenstone belt Alto Jauru. 


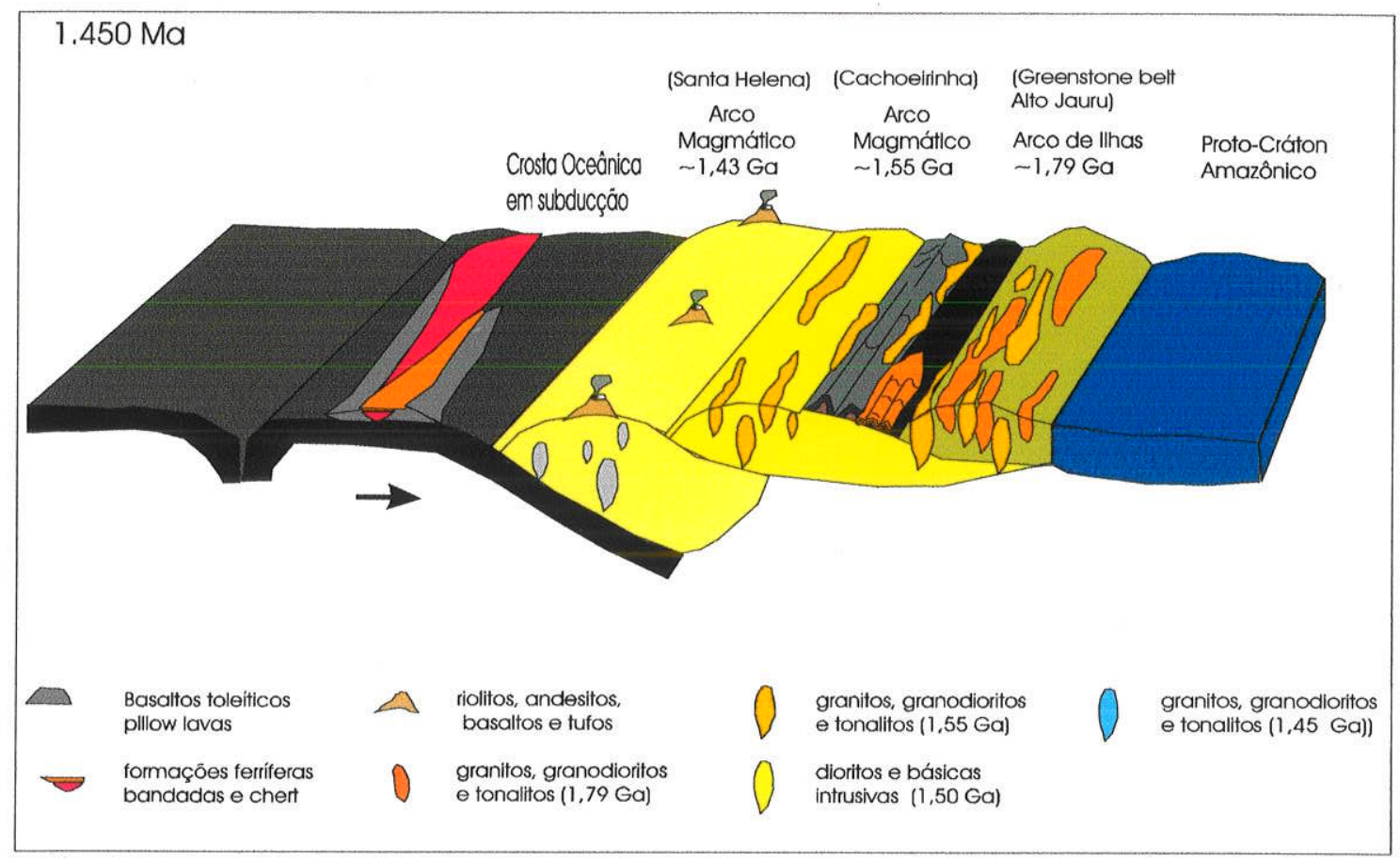

Figura 8.3 Perfil esquemático sugerindo o ambiente de arco magmático para a geração das rochas da Suíte Santa Helena pelos resultados $\mathrm{U} / \mathrm{Pb}, \mathrm{Sm} / \mathrm{Nd}$ e de geoquímica.

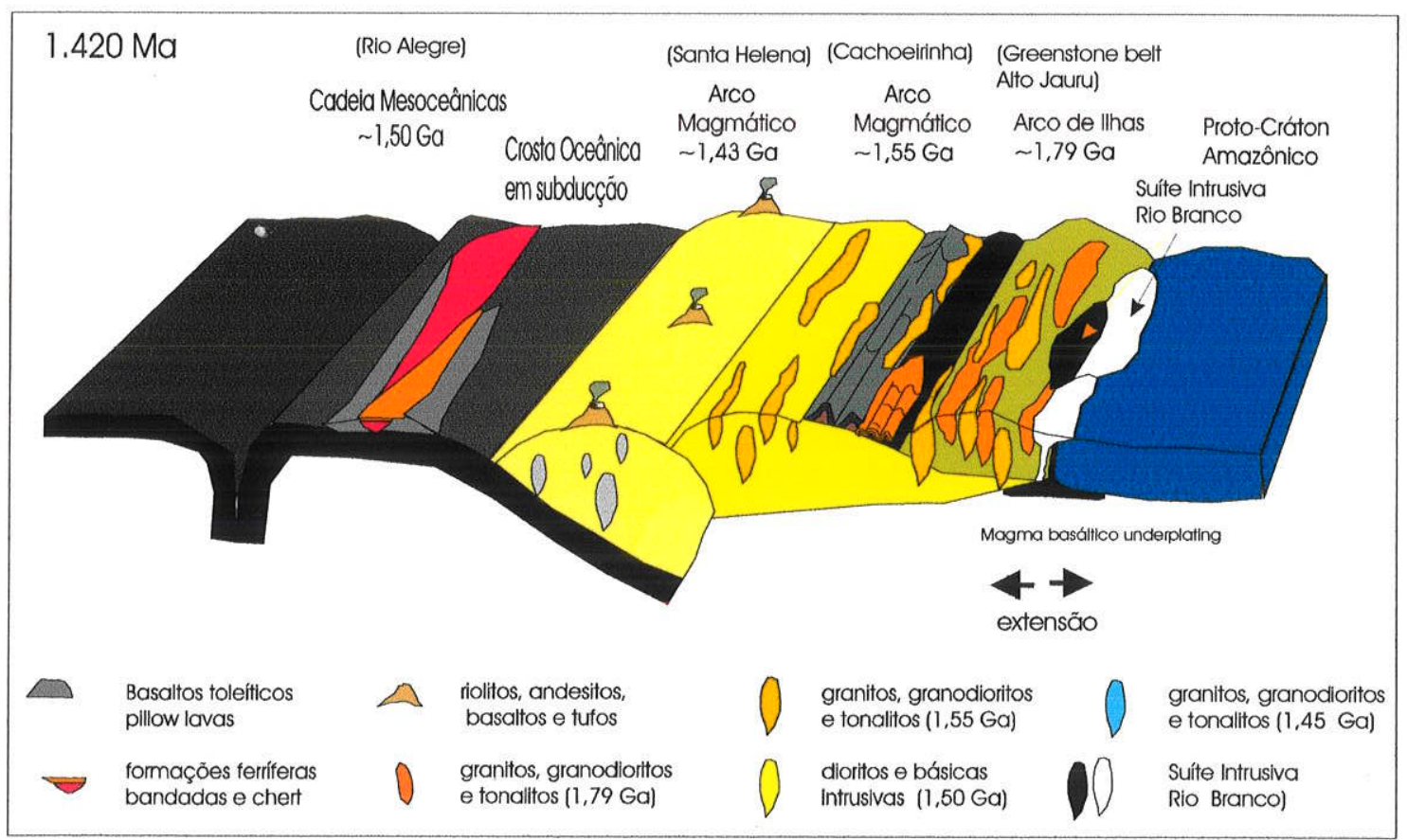

Figura 8.4. O modelo sugere que durante o processo de subducção da crosta oceânica que deu origem ao arco de Santa Helena (1450-1420 Ma) houve um processo extensional intracratônico que possibilitou a geração da Suíte Intrusiva Rio Branco (1423 Ma). 


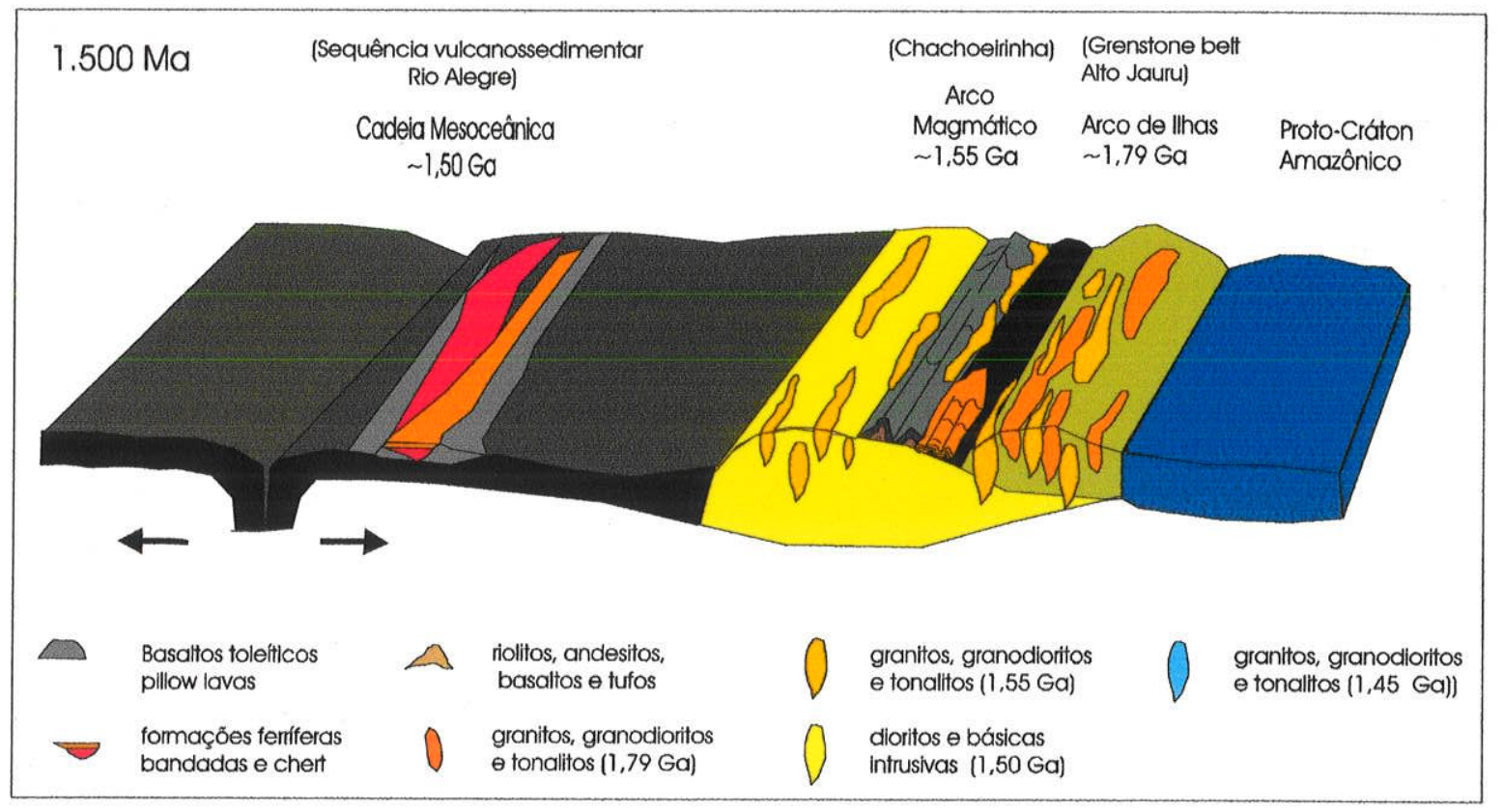

Figura 8.5. As rochas do Terreno Rio Alegre se formaram através de um processo de geração de crosta oceânica a oeste (atual) da crosta continental representada pelo protocráton Amazônico.

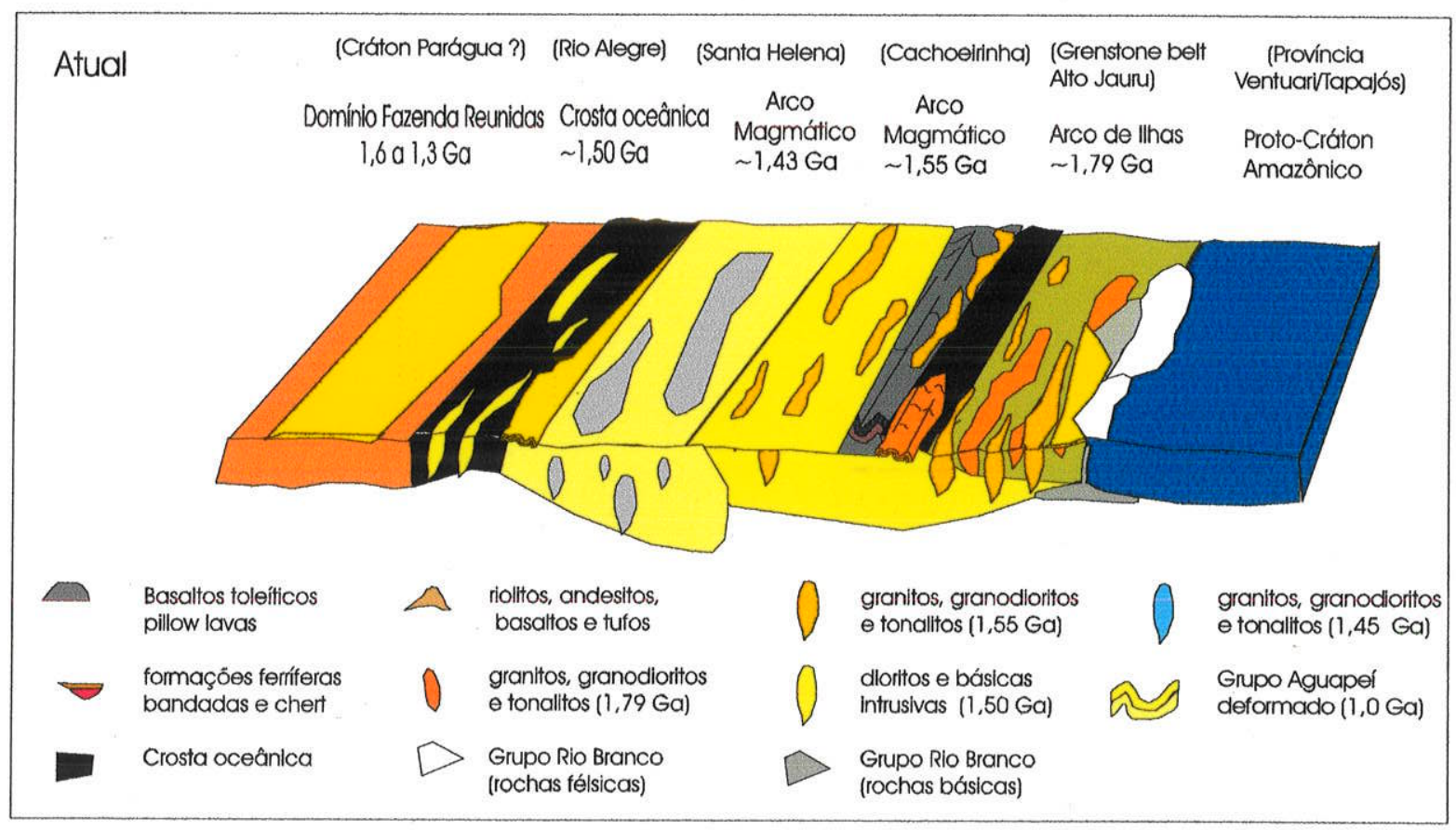

Figura 8.6 Perfil geológico atual para a região SW do Cráton Amazônico (estado de Mato Grosso). A deformação do Grupo Aguapeí é marcada pelas idades K/Ar em (sericita) entre 970 e $840 \mathrm{Ma}$. 


\section{CAPÍTULO 9 \\ CORRELAÇÕES TECTÔNICAS}

\subsection{Correlações Regionais}

As unidades observadas na região SW de Mato Grosso têm sido enquadradas em duas províncias geocronológicas. A mais antiga corresponde a Província Rio NegroJuruena, (e.g. Cordani et. al., 1979) que engloba rochas com idades entre 1,8 a 1,4 Ga. A Província ocorre em uma faixa alongada na direção N-NW desde o estado de Mato Grosso até os estados de Amazonas e Roraima. A unidade mais jovem corresponde a Província Rondoniano/San Ignacio (e.g. Teixeira et al., 1989), que engloba rochas com idades entre 1,4 Ga e 1,0 Ga, identificadas nos estados de Mato Grosso e Rondônia.

Este item tem por objetivo discutir as correlações entre unidades regionais descritas na literatura e as unidades estudadas, a partir dos resultados isotópicos e geoquímicos dos 3 terrenos aqui individualizados: o Terreno Jauru, subdividido no arco de ilhas (greenstone belt Alto Jauru) de idade 1,79-1,75 Ga e no arco magmático (Cachoeirinha) de idade 1,57$1,53 \mathrm{Ga}$; o Terreno Pontes e Lacerda representado pelo arco magmático Santa Helena $(1,45-1,42 \mathrm{Ga})$, intrudido pelas suítes Guapé e São Domingos (950 e $930 \mathrm{Ma})$; e as rochas

de idade $\sim 1,50$ Ga do Complexo Vulcanossedimentar Rio Alegre. O Terreno Jauru contém ainda a Suíte Rio Branco, de característica anorogênica, formado contemporaneamente ao Arco Santa Helena (1,42 Ga). As suítes Guapé e São Domingos, por sua vez, de idade entre 930 e $915 \mathrm{Ma}$, ocorrem no Terreno Pontes e Lacerda. 


\section{O Terreno Jauru}

As rochas do Terreno Jauru são interpretadas como integrantes da Província Rio Negro-Juruena. Os resultados obtidos permitem sugerir que, no estado de Mato Grosso, esta província é constituída por rochas pertencentes a duas unidades distintas, geradas, respectivamente há 1,79-1,75 Ga e 1,57-1,53 Ga. Cada um destes eventos formadores de rochas com características distintas representa orógenos distintos. $\mathrm{O}$ primeiro grupo de rochas gerado em arco vulcânico intraoceânico e o segundo gerado em arco magmático desenvolvido em margem continental ativa. O quimismo destas rochas é compatível com rochas geradas ambiente de back arc e MORB (Pinho et. al., 1994), sendo que as idades U/Pb (SHRIMP) reportada por Tassinari et. al., (1997) e por Pinho (1994), estão entre 1,8 e $1,72 \mathrm{Ga}$, concordantemente com as idades para estas rochas aqui propostas $(1,79$ a 1,75 $\mathrm{Ga})$.

A estruturação do greenstone belt Alto Jauru segue a orientação geológica regional, com alinhamento de corpos vulcânicos e corpos intrusivos na direção preferencial N-NW. Esta mesma geometria estrutural é observada no Estado de Rondônia nas unidades Complexo Jamari e Complexo Gnáissico-Migmatítico Juru, unificados recentemente como Complexo Jamari (Amorim et. al., 1999a e b; Scandolara e Amorim, 1999). Erste complexo é caracterizado por rochas supracrustais (Amorim et. al., 1999a e b; Scandolara et. al., 1999a, b e c; Scandolara, 1999) com paragnaisse feldspático, granada-biotita gnaisse, sillimanita gnaisse, biotititos, kinzigitos, rochas calcossilicatadas e anfibolitos. Resultados $\mathrm{U} / \mathrm{Pb}$ (SHRIMP) de $1,75 \mathrm{Ga}$ reportados preliminarmente para coberturas vulcanossedimentares em Rondônia apresentam variações de idade equivalentes $(\sim 1,75 \mathrm{Ga})$ ao greenstone belt Alto Jauru (Amorim et. al., 1999).

Estes resultados permitem sugerir que a associação de rochas paleoproterozóicas do greenstone belt Alto Jauru observadas em Mato Grosso tem continuidade para N-NW alcançando o Estado de Rondônia, sendo representado nesta região por uma associação de rochas de idade contemporânea. Entretanto, a continuidade física destas unidades em nível de afloramento é impedida devido a existência da cobertura Cretácea do Grupo Parecis. 
Os dados isotópicos $\mathrm{U} / \mathrm{Pb}$ e $\mathrm{Sm} / \mathrm{Nd}$ e composição química das rochas estudadas permitem fazer algumas especulações sobre os seus ambientes de formação e compará-los com estudos em unidades equivalentes existentes na literatura. Exemplo de associação de rochas como a observada no Terreno Jauru pode ser encontrada no Orógeno Penokeano na América do Norte. Este orógeno é interpretado como uma acresção lateral de um arco de ilha na margem SE do Cráton Superior (Sims, 1989) com subducção em direção ao cráton arqueano, e cuja estabilização deu origem ao paleocontinente Laurentia. O orógeno é dominado por uma associação de rochas vulcânicas e plutônicas (Reed et al., 1993; e Robertson et al., 1993) e as composições químicas para as rochas plutônicas geralmente sugerem trend calcioalcalino com afinidade relacionada a arco (Sims et al., 1989 e 1992). Dados isotópicos $\mathrm{U} / \mathrm{Pb}(1,88$ a $1,86 \mathrm{Ga})$ e $\mathrm{Sm} / \mathrm{Nd}\left(\mathrm{T}_{\mathrm{DM}}\right.$ entre 1,9 a $\left.1,8 \mathrm{Ga}\right)$ sugerem que a maior parte do material magmático se originou de fontes juvenis (de forma similar ao caso estudado em Mato Grosso), apesar de haver contribuição localizada de crosta mais antiga (Barovich et al., 1989; Van Wyck and Johnson, 1997).

\section{O Arco Magmático Cachoeirinha}

O Arco Cachoeirinha $(1,57$ e 1,53 Ga) não tem continuidade identificada em trabalhos publicados além da região de estudo. Isto pode decorrer da sua interrup̧̧ão sob os sedimentos do Grupo Parecis (a norte) ou por ainda não ter sido identificado através de trabalhos de datação radiométrica no Estado de Rondônia e na Bolívia. Por outro lado rochas graníticas tipo rapakivi, de característica anorogênica, ocorrem na região de Rondônia com idades equivalentes. Bettencourt et al, (1999), reportam idades U/Pb da Suíte Intrusiva Serra da Providência (1606 \pm 24 a $1532 \pm 45 \mathrm{Ma}$ ) que pode ter sido gerada por magmatismo intracratônico reflexo da subducção contemporânea na margem continental existente a W-SW (atual). Seguindo este raciocínio, rochas originadas durante este este evento $(1,57-1,53 \mathrm{Ga})$ poderiam ser encontradas a W-SW da região central e oeste do estado de Rondônia, ou até mesmo como intrusões nas rochas do Complexo Jamari. 
Exemplo de associação de rochas com as mesmas características químicas, isotópicas e de idades equivalentes as rochas do arco Cachoeirinha são descritas no Escudo Báltico, geradas durante a orogenia Svecofeniana. Ali ocorrem rochas cujas composições variam entre gabros e granitos, sendo os granodioritos tipo-I os predominantes e as rochas metassedimentares associadas são interpretadas como integrantes de um complexo acrecionário formado adjacente ao Craton Kareliano de idade arqueana (Ramo et al., 1999). São definidos 4 grupos de rochas graníticas, segundo Eklund et al., (1998): granitóides sincinemáticos $(1,89-1,88 \mathrm{Ga}$, a maior parte do plutons); pós-cinemáticos $(1,88-1,87 \mathrm{Ga})$; tardi-orogênicos (1,84-1,82 Ga); e os pós-orogênicos (1,81-1,79 Ga). Os dois primeiros são suites calcioalcalinas, o terceiro tem assinatura geoquímica de granitos tipo $\mathrm{S}$ e o quarto grupo são granitos alkalinos. Tal subdivisão não foi identificada no presente estudo.

Em geral a composição isotópica de Nd para as rochas granítóides no Escudo Báltico são uniformes com valores de $\varepsilon_{\mathrm{Nd}(\mathrm{t} m 1,88 \mathrm{Ga})}$ e idades $\mathrm{T}_{\mathrm{DM}}$ variando entre $-1,1$ a $+0,5 \mathrm{e}$ 2,10 e 2,29 Ga, respectivamente (Huhma, 1986; Patchett e Kuovo, 1986, Lahtinen e Huma, 1997; Ramo et al., 1998). Estes valores sugerem a participação de material mais antigo na formação dos magmas destas rochas, apesar de que mesmo com os trabalhos de mapeamento de detalhe da Finlândia, ainda não foi identificada uma crosta mais antiga no Terreno Svecofiniano. No caso do Terreno Jauru, a crosta mais antiga que possivelmente contribuiu para a geração dos corpos plutônicos do arco Cachoeirinha é exemplificada pelas rochas paleoproterozóicas do greenstone belt Alto Jauru, com idades entre 1,79 e 1,75 Ga.

\section{O Terreno Pontes e Lacerda}

As rochas da Suite Santa Helena (1450 a $1430 \mathrm{Ma}$ ) correlacionam-se temporalmente às rochas da Província Rondoniano/San Ignácio (e.g. Tassinari e Teixeira, 1984). Em Rondônia neste período de tempo ocorrem rochas graníticas rapakivi intrudidas nas rochas da Província Rio Negro-Juruena, e são interpretadas como suítes intrusivas anorogênicas. Bettencourt et. al., (1989) definem a geração desta unidade entre 1,6 e 1,0 Ga (idades $\mathrm{Rb} / \mathrm{Sr}$ ), porém em trabalho mais recente Bettencourt et. al., (1999) definem o Rondoniano 
com idades U/Pb entre 1606 e $980 \mathrm{Ma}$. A correlação temporal (idades U/Pb) destas rochas de Rondônia com as rochas da Suíte Santa Helena permite sugerir que parte das rochas anorogênicas descritas em Rondônia (Suíte Intrusiva Santo Antônio, de idade U/Pb de 1406 $\pm 32 \mathrm{Ma}$ ), pode ser reflexos intracratônico do processo de subducção responsável pela geração do arco magmático que originou as rochas calcioalcalinas da Suite Santa Helena.

A comparação das rochas do Terreno Pontes e Lacerda, por sua vez com os granitóides de áreas a leste (na Bolivia) é prejudicada pelo fato das datações disponíveis naquele país se limitarem ao método $\mathrm{Rb} / \mathrm{Sr}$ e $\mathrm{K} / \mathrm{Ar}$.

A correlação desta unidades no Estado de Mato Grosso e em Rondônia permite ainda sugerir que o limite oeste (atual) do proto-cráton Amazônico o final do Paleoproterozóico seria representado pelos limites setentrionais destas unidades, cuja configuração atual em mapa pode ser observado na Figura 9.1, representado pelo limite do Terreno Pontes e Lacerda no Mato Grosso e da Província Estanífera em Rondônia.

Complexos acrescionários constituídos por rochas geradas em arcos magmáticos de idades e características equivalentes aos aqui apresentados são tradicionalmente descritos no Escudo Báltico e na América do Norte (e.g. Reed et al., 1993, Eklund et al., 1998). O arco magmático Santa Helena apresenta, por sua vez, algumas características semelhantes e outras diferentes aos exemplos previamente utilizados Penokeano e Svecofeniano). Em relação ao complexo acrescionário Penokeano, as semelhanças são as variações composicionais dos corpos plutônicos e suas composições químicas. Outra semelhança interessante entre as rochas do Penokeano e as rochas do arco Santa Helena é a assinatura de isótopos de $\mathrm{Nd}$, com valores de $\varepsilon_{\mathrm{Nd}(t)}$ positivos em ambos os casos. Em relação ao Escudo Báltico, as semelhanças com o arco Santa Helena são em relação aos litotipos e respectivos químismos, e também ao tipo de placas envolvidas na colisão. Porém as assinaturas isotópicas de $\mathrm{Nd}$ são distintos: no Báltico os $\mathrm{T}_{\mathrm{DM}}$ e os valores de $\varepsilon_{\mathrm{Nd}(\mathfrak{l})}$ sugerem uma importante participação de uma crosta mais antiga durante a geração dos magmas das rochas plutônicas, contrariamente ao observado nas rochas do batólito Santa Helena. 


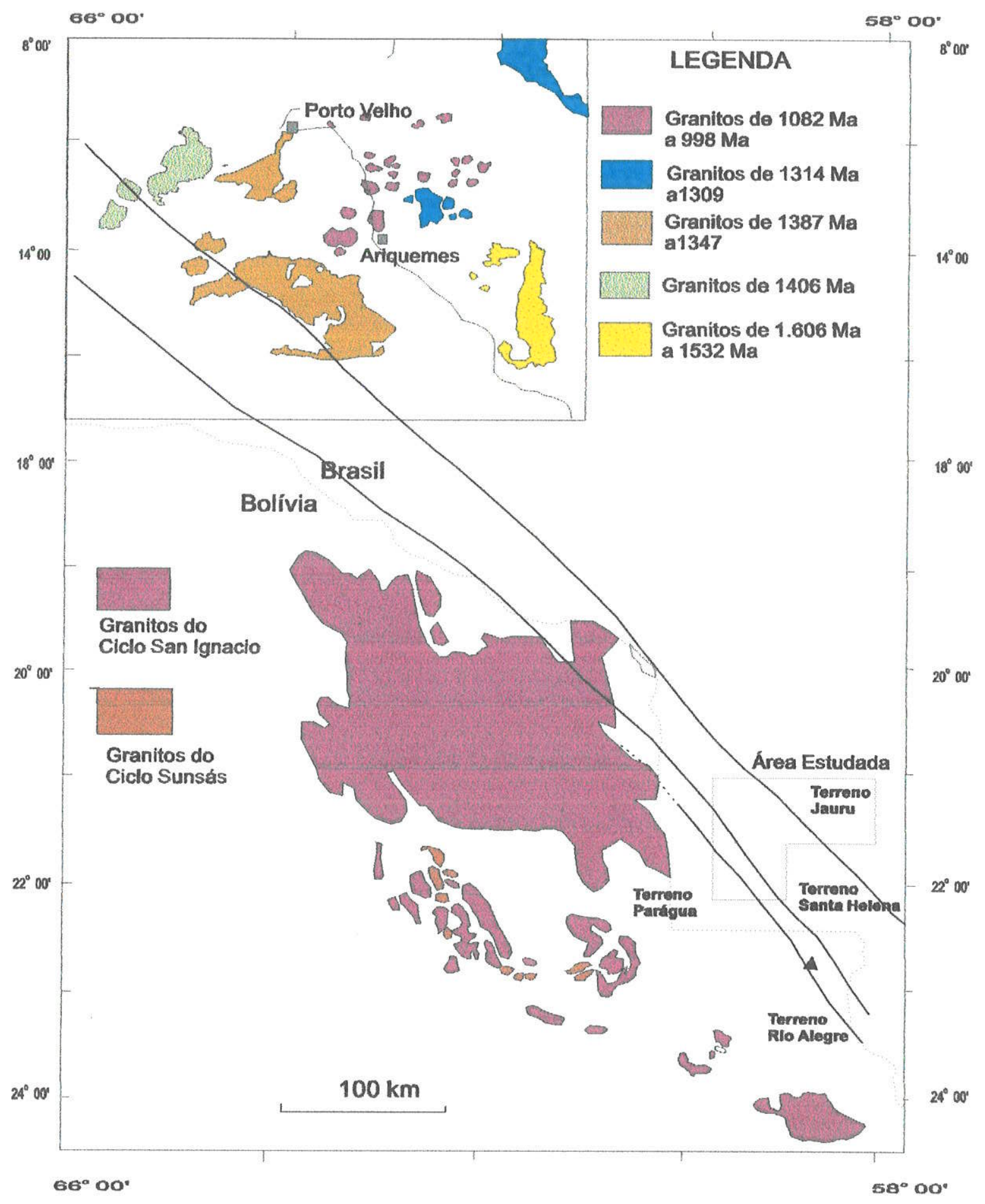

Figura 9.1. Mapa com localização dos granitóides Mesoproterozóicos das regiões de Rondônia, Bolívia e Mato Grosso. Na Bolívia os dados são de Litherland et. al., (1989) e em Rondônia os dados são de Bettencourt et. al., (1999). As idades apresentadas na área na Bolívia foram obtidas pelo método $\mathrm{Rb} / \mathrm{Sr}$. 
Conseqüentemente as rochas do arco Santa Helena apresentam associação de rochas com quimismo e assinaturas isotópicas que definem seu caráter juvenil (como no evento Penokeano na América do Norte), porém controles geológicos regionais (rochas contemporâneas intrudidas na crosta mais antiga representada pelo Terreno Jauru), indicam o desenvolvimento deste arco em margem continental ativa (como no caso do Escudo Báltico). A partir destas características, propõem-se que o ambiente de formação para o arco magmático Santa Helena seja distal em relação a crosta pré-existente, ou seja, apresente uma proximidade porém uma participação secundária desta crosta mais antigas na geração dos magmas que deram origem as rochas granitóides aqui apresentados.

\section{O Terreno Rio Alegre}

As rochas da Sequência Metavulcanossedimentar do Rio Alegre não apresentam unidades correspondentes no estado de Rondônia e na Bolívia. Como foi descrito nos capítulos anteriores, esta associação vulcanossedimentar se originou provavelmente durante a geração de crosta oceânicas em cadeia mesomoceânica. $O$ terreno gerado por este evento é mais antigos (1,50 Ga) do que o arco de Suíte Santa Helena (1,45-1,43 Ga), tendo sido amalgamado ao protocraton Amazônico possivelmente entre 1,38 Ga (idade de estabilização do Arco Santa Helena) e 1,30 Ga (possível idade de início de deposição do Grupo Aguapeí). Idades $\mathrm{U} / \mathrm{Pb}$ de 1,34 Ga em granulitos em Rondônia (Tassinari et. al., 1999) sugerem um evento colisional importante que pode estar correlacionado com a colagem do Terreno Rio Alegre ao Terreno Santa Helena.

Geograficamente a continuidade deste terreno deveria seguir a direção NW (direção da estruturação desta unidade) e adentrar no território da Bolívia, porém esta hipótese ainda carece de confirmação. 
Domínio Fazenda Reunidas

O Domínio Fazenda Reunidas tem limites geocronológicos mal definidos, porém sugere ter uma história geológica policíclica em função dos resultados analíticos $\mathrm{U} / \mathrm{Pb}$ em zircões indicarem idades variando entre 1,60 a 1,30 Ga. A localização deste domínio no extremo oeste do Terreno Rio Alegre sugere sua continuidade e possível correlação com o Cráton Parágua descrito por Litherland et. al. (1989), englobando rochas do Complexo Pensamiento, geradas durante a Orogênese San Ignácio.

O Complexo Pensamiento, por sua vez, é composto por rochas graníticas de composição calcioalcalina de idade $\mathrm{Rb} / \mathrm{Sr}$ entre 1400 e $1280 \mathrm{Ma}$. Os diversos corpos graníticos desta unidade são de sin a tardi tectônicos (granitos Poerto Alegre, Florida e Guarayos), tardi a pós tectônicos (granitos Bella Vista, Padre Eterno, Três Picos, Diamantina e Orobaya) e sin a pós tectônicos (granitos Piso Firme, Suíte Sierro Grande e Complexo Alcalino El Tigre). Petrologicamente, os dados dos granitos bolivianos sugerem uma variação de sienogranitos a monzogranitos, com misturas tardias de granitóides de composição granodiorítica, o que levou Saes e Fragoso Cesar, (1996) a reinterpretá-los como uma suíte calcioalcalina formada em ambiente de arco magmático

Os granitos Serra da Providência (Rondônia) foram correlacionados com base nos dados $\mathrm{Rb} / \mathrm{Sr}$ aos granitos do Complexo Pensamiento por Teixeira e Tassinari (1984), Litherland et. al., (1986), Bettencourt et. al., (1987) e Teixeira et. al., (1989). Desta forma estes autores sugerem o elo entre os Cinturões San Ignacio e Rondoniano. Esta correlação é embasada pela proximidade e continuidade destas áreas, mas somente estudos de maior detalhe (principalmente de datação $\mathrm{U} / \mathrm{Pb}$ ) na região de fronteira entre Brasil e Bolívia confirmarão tal hipótese. Bettencourt et al., (1999) apresentaram a idade U/Pb de $1606 \mathrm{Ma}$ para a Suíte Intrusiva Serra da Providência, o que nos leva a crer que os eventos Rondoniano-San Ignacio provavelmente não são correlacionáveis. 


\section{A Deformação Sunsás/Aguapeí}

Na região sul de Rondônia são descritas associações de rochas compostas por paragnaisses (derivados de metaturbiditos), rochas básicas e graníticas metamorfisadas na fácies anfibolito e granitos anatéxicos (Rizzoto et. al., 1999a). As rochas graníticas e básicas apresentam idade $\mathrm{U} / \mathrm{Pb}$ de $1,1 \mathrm{Ga}$ e os granitos anatéxicos de 1,08 $\mathrm{Ga}$ (Rizzoto et. al., 1999b). Esta associação é interpretada como originada durante um processo de rifteamento (com magmatismo bimodal representado pelas rochas básicas e os granitos), deposição de sedimentos em ambiente marinho, subducção da crosta oceânica pré-formada e colisão com metamorfismo e fusão parcial dos metassedimentos (Rizzoto et. al., 1999c).

Estes movimentos crustais podem ter tido continuidade ao sul, de forma a ser representado pelo aulacógeno Aguapeí, com um maior avanço no processo de abertura oceânica durante o período rift a norte, e menos intenso a sul, representado (no Mato Grosso) pela deposição do Grupo Aguapeí em ambiente intracratônico. A inversão da abertura oceânica, colisão com metamorfísmo atingindo a fácies xisto verde baixa ao sul é marcado pelas idades $\mathrm{K} / \mathrm{Ar}$ em sericita com idades entre 1000 e $900 \mathrm{Ma}$ (idades de resfriamento). Ao norte este mesmo evento atingiu a fácies anfibolito alto e a anatexia de metassedimentos, marcados pelas idades $\mathrm{U} / \mathrm{Pb}$ de $1,1 \mathrm{Ga}$.

$\mathrm{O}$ último evento magmático na região $\mathrm{SW}$ do cráton Amazônico tem idade $\mathrm{U} / \mathrm{Pb}$ entre 939 e $916 \mathrm{Ma}$ e gerou rochas que apresentam características composicionais indicativas de terem sido formadas em ambiente intracratônico posteriormente a deposição dos sedimentos do Grupo Aguapeí e do Grupo Sunsás, possivelmente em uma bacia sedimentar conectada (Saes, 1999). A idade de geração das rochas plutônicas aqui descritas apresentam equivalência no tempo com as idade $\mathrm{K} / \mathrm{Ar}$ que por sua vez indicam a idade da deformação Aguapeí entre 970 e $840 \mathrm{Ma}$. Neste mesmo período de tempo são descritos granitos gerados durante a Orogênese Sunsás (Litherland et. al., 1989) na Bolívia. Neste país este evento gerador de rochas graníticas é definido por idade $\mathrm{Rb} / \mathrm{Sr}$ entre 1280 e 950 Ma e idades K/Ar entre 1078 e 795 Ma sendo interpretado (Saes, 1999) como resultado de subducção com direção de oeste para leste que finalizou com a colisão do Terreno San 
Pablo (a oeste da Bolívia) com o Complexo Pensamiento, já estabilizado e denominado de Cráton Parágua por Litherland et. al., (1989). Esta possível colisão entre o Terreno Pablo e - Cráton Parágua teve como conseqüência o encurtamento crustal que resultou na Orogênese Sunsás na Bolívia e na deformação do Grupo Aguapeí no Brasil.

\subsection{Implicações Tectônicas}

Os resultados aqui reportados podem contribuir para estudos de reconstrução paleogeográfica, uma vez que na reconstrução do supercontinente Rodínia foi proposta a Amazônia justaposta com a Laurentia e Báltica como resultado da fusão entre 1,1 e 1,0 Ga (Hoffman, 1989; Dalziel, 1992). Sadowski e Bettencourt (1996) sugerem que a Amazônia também estava justaposta com a Laurentia e a Báltica a $1,6 \mathrm{Ga}$ e separaram-se durante um rifteamento Mesoproterozóico que iniciou um novo Ciclo de Wilson que encerrou com a formação do Rodínia.

A definição do Cráton Parágua por Litherland (1989), por sua vez, foi criticado por Sadowiski e Bettencourt (1996) uma vez que, segundo estes autores, o Cráton Amazônico teria a sua extensão até o território Boliviano. Porém não se descarta a hipótese de que o Terreno Parágua tenha se comportado como um bloco independente, configurando uma área estável cratonizada no período anterior a sua colagem ao Cráton Amazônico.

Em suma, propõe-se que a borda oeste do protocráton Amazônico neste período de tempo $(\sim 1,3 \mathrm{Ga})$, era constituída por uma sequência de acresções laterais correspondente aos Terrenos Jauru, Pontes e Lacerda e Rio Alegre (incluindo o Domínio Fazenda Reunidas) e Terreno Parágua. Uma proposta equivalente foi sugerida por Litherland et al. (1989), de forma que o SW do Cráton Amazônico apresentaria uma sequência de 5 orógenos a partir do núcleo Arqueano (Cinturão Maroni-Itacaiúnas, Cinturão Ventuari-Tapajós, Cinturão Rondoniano, Cinturão San Ignácio, Cinturão Sunsás) com idades decrescentes paleoproterozóicas a mesoproterozóicas. 
Os resultados aqui reportados permitem duas hipóteses para a correlação geológica na região estudada e a região da Bolívia. A primeira seria que as rochas policíclicas são continuidade do Cráton Parágua, o que por sua vez indica que as idades $\mathrm{Rb} / \mathrm{Sr}$ e $\mathrm{K} / \mathrm{Ar}$ descritas na Bolívia para os Complexo Pensamiento são resultado de processo de rehomogeneização isotópica e não são idades de cristalização, como originalmente interpretadas (Litherland et al., 1986). A segunda hipótese, mais convincente, seria que o Domínio Fazenda Reunidas não representa a continuidade do Cráton Parágua, o que nos leva a propor que entre o Terreno Rio Alegre e o Cráton Parágua teria ocorrido a acresção de um terreno suspeito (no conceito de Howell, 1995) com história geológica distinta e não correlacionada com os seus vizinhos e que, consequentemente, não nos permite, por falta de informações, caracterizar com precisão a evolução geológica completa do SW do Cráton Amazônico.

Os resultados apresentados na literatura (e.g. Dalziel, 1992, Dalziel et al., 1994; Unrug, 1997) suportam o modelo tectônico de que no período Mesoproterozóico existiram grandes massas continentais estáveis e a deposição de sedimentos cratogênicos sucedeu a grande amalgamação que deu origem ao supercontinente Rodínia. Um ponto de dúvida que ainda permanece é a paleogeografia deste supercontinente. Os principais modelos paleogeográficos existentes para o Rodínia são de Danziel (op. cit) e Unrug (op. cit.) nos quais os autores sugerem justaposição do leste do Laurentia (hoje representado pela América do Norte, Groelândia e Escócia) e do Gondwana (répresentado hoje pela América do Sul, África, Austrália e Índia). Desta forma pode-se sugerir que a evolução do Cinturão Grenvilliano no continente Americano apresentou uma paleogeografia composta de uma grande massa continental onde ocorreram sedimentações em diferentes latitudes.

O modelo de reconstituição paleogeográfica que considera a existência de uma grande massa continental é ainda referenciado no trabalho de Tosdal (1996), no qual o autor utiliza dados de isótopos de chumbo de área do norte da Argentina, norte do Chile, sul do Peru e da Bolívia e compara-os com dados da Província Grenville (Canadá) e da Escócia. O resultado desta análise é que o norte da Argentina apresenta assinatura isotópica semelhante ao da Escócia e do Canadá. Os dados do norte do Chile, sul do Peru e da Bolívia são 
equivalentes e se assemelham com as assinaturas isotópicas do Cráton Amazônico. $\mathrm{O}$ autor conclui que as unidades estudadas constituíam parte do supercontinente Rodínia porém no período da sua fragmentação parte da crosta correlacionável ao Laurentia permaneceu colada ao Cráton Amazônico e hoje encontra-se inserida na Cadeia Andina.

As investigações geocronológicas, por diferentes métodos, destes terrenos permitiu delinear uma grande Faixa Móvel continental de largura variável, com registros radiométricos desde a Argentina até o Canadá. A existência deste grande cinturão Mesoproterozóico (Grenville) tem sido referida nos seguintes países: Cuba (Renne et al., 1989; Ballard e Van der Voo, 1989; e Patchett e Ruiz, 1987); Honduras e sul da Guatemala (Horne et. al., 1976); na Colômbia (Kroonemberg, 1982; Priem et. al., 1989; e Suarez, 1990); na Bolívia (Litherland et. al., 1985; Litherland et. al., 1989; e Lehmann, 1979); na Argentina inúmeros trabalhos têm sido publicados sobre terrenos de idade mesoproterozóica: Mon e Hongn (1996), Ramos (1989), Dalla Salda et. al. (1993) e Dalla Salda et. al. (1994); no Chile (Pacci et. al., 1980; e Damm et. al., 1990); no Peru (Shackleton et. al., 1979; Wasteneys et. al., 1995; Cordani et. al., 1985, e Tosdal, 1995).

Hoffman (1991) sugeriu uma reconstituição de um paleocontinente fragmentado no Paleoproterozóico e reagrupado por colagem no Neoproterozóico de forma que áreas intracontinentais evoluíram para zonas de rifts e para margem continentais. Antigos ambientes de margens continentais evoluíram para zonas de colisão e para zonas de sutura intracontinentais. Por este modelo o Cinturão Rondoniano/Sunsás teve sua formação em área contígua ao Cinturão Grenville. Hoffman (1989) sugeriu ainda que o Cráton Amazônico fez parte do Rodínia e a conveç̧ão desenvolvida abaixo deste supercontinente estacionário (resultado do efeito " tampão") é comprovado pela associação de riolitos, sienogranitos, anortositos, gabros, enxames de diques e rifts.

No Terreno Grenville são descritos (Gower e Tucker, 1994) eventos acrescionários (Elzeveriano, entre $\sim 1,58 \mathrm{Ga}$ ) extensivos (Penowriano, $\sim 1,47 \mathrm{Ga}$ ) e metamórficos (Elsoniano entre 1,4-1,3 Ga). O segundo evento é contemporâneo ao desenvolvimento de um processo de colisão de placas litosféricas no Cráton Amazônico (arco Santa Helena) que foi seguido, a partir de 1,35 Ga por um processo extensional com geração de uma margem 
foi seguido, a partir de 1,35 Ga por um processo extensional com geração de uma margem continental passiva (Grupo Sunsás) e um rift intracontinental (Grupo Aguapeí o Mato Grosso e Nova Brasilândia em Rondônia). O ciclo de Wilson teria sido completado pela cicatrização dos oceanos gerados pelos processos extensivos precedentes.

Por enquanto não existem dados paleomagnéticos na Amazônia que corroborem com a hipótese destas acresções representarem uma colagem que resultou em uma grande massa continental pré-Rodínia, apesar disto ter sido sugerido por Rogers (1996), que postulou a formação do supercontinente Ártica no período de tempo entre 1,8 e 1,7 Ga. Seguindo ainda este raciocínio, a fragmentação deste supercontinente teria como conseqüência o estabelecimento de uma massa continental independente representada pelo proto-cráton Amazônico que apresentou dois eventos de acresção após a fissão do Ártica: o arco Cachoeirinha $(1,57-1,53 \mathrm{Ga})$ e o arco Santa Helena $(1,48-1,42 \mathrm{Ga})$. 


\section{CAPÍTULO 10 \\ Referências Bibliográficas}

AGRINIER, P.; JAVOY, M.; SMITH, D.C. e PINEAU, F. (1985). Carbon and oxigen isotopes in eclogites, amphibolites, veins and marbles from the western gneiss region, Norway. Chemical Geology, 52:145-162.

AMARAL, G.; CORDANI, G.; KAWASHITA, K.; REYNOLDS, J.H. (1966). Potassiumargom dates of basaltic rocks from southern Brazil. Geochimica et Cosmochimica Acta. 30: 159-181.

AMARAL, G. (1974). Geologia Pré-Cambriana da Região Amazônica. São Paulo. IG.USP. Tese de Livre Docência.. 212p.

AMORIM, J.L., RIZZOTO, G.J. e SCANDOLARA, J.E. (1999a). Complexo Jamari, sudoeste do Cráton Amazônico: reavaliação do contexto geotectônico. VII Simpósio Nacional de Estudos Tecônicos. (SNET). p.28-30.

AMORIM, J.L., RIZZOTO, G.J. e SCANDOLARA, J.E. (1999b). Terreno Jamari, região central de Rondônia: evidências de processos trafogenéticos que precedem a convergência do início do Mesoproterozóico no segmento sudoeste do Cráton Amazônico. VI Simpósio da Geologia da Amazônia, Manaus. Anais. p. 270-273

APOITIA. L.F.M. e PINHO, M.A. de D.B. (1995). Contribuição ao conhecimento petrográfico e geoquímico do Granito Alvorada-Faixa Cabaçal (Araputamga, MT). In: Simp. de Geol. do Centro Oeste. Anais. p. 127-130.

BALLARD, M.M. e VAN DER VOO, R. (1989). Paleomagnetic results from Grenvillianaged rocks fron Oaxaca, Mexico: Evidence for a displaced terrane. Precambrian Research, 42:343-352.

BASU, A.R.; SHARMA, M. e DECELES, P.G. (1990). Nd, Sr-isotopic provenance and trace element geochemistry of Amazonian foreland basin fluvial sands, Bolivia and 
Peru: implications for ensialic Andean orogeny. Earth and Planetary Science Letters. 100:1-17.

BAROVICH, K.M., PATCHETT, J.P., PETERMAN, Z.E, SIMS, P.K. (1989). Nd isotopes and the origin of a 1,9-1,7 Ga Penokean continental crust of the Lake Superior region. Geological Society of America Buletim, 101:333-338.

BARROS, A.M; SILVA, R.H. da; CARDOSO, O.R.F.A.; FREIRE, F.A; SOUZA JUNIOR, J.J. da; RIVETTI, M.; LUZ, D.S. da PALMEIRA, R.C. de B.; TASSINARI, C.C.G. (1982). Projeto RadamBrasil. Folha SD-21 (Cuiabá). 192p.

BETTENCOURT, J.S.; DALL'AGNOL, R.; YOKOI, O.Y.; VIGLIO, O.P.; DE PINHO, O.G.; SILVA, R.F. E CARNEIRO FILHO, L. (1987). The Rondonian tin-bearing granites and associated mineralization. Intern. Symp. on Granites and Associated Mineralization. Salvador-Brazil. Excursion Guide. p. 49-87.

BETTENCOURT, J.S.; ONSTOTT, T.C.; DE JESUS, T. e TEIXEIRA,W. (1996). Tectonic interpretation of ${ }^{40} \mathrm{Ar} /{ }^{39} \mathrm{Ar}$ ages on country rocks from the central sector of Rio NegroJuruena Province, SW Amazonian craton. Internationa Geology Review.23:124-135.

BETTENCOURT, J.S. TOSDAL, R.M.; LEITE, Jr. W.R. e PAYOLLA, B.L.. (1999). Mesoproterozoic rapakivi granites of Rondonia Tin Province, southwestern border of Amazonian craton, Brazil- I. Reconnaissance $\mathrm{U}-\mathrm{Pb}$ geochronology and regional implications. Precambrian Research 95:41-67.

BEZERRA, J.R L. (1993). Geofísica. In: Folha Pontes e Lacerda 1:100.000. Carta Geológica e Texto Explicativo. MENEZES, R. G. de; LOPES, I. e BEZERRA, J.R.L. (1993) Programa de Levantamentos Básicos. CPRM-DNPM. 176p.

BURT, D.M. (1989). Compositional and phase relations among rare earth elements minerals. In: B.R Lipin. e G.A, McKay, (eds). Geochemistry and Mineralogy of Rare Earth Elements. Review in Mineralogy. 21: 258-307..

CARNEIRO, M.A. (1985). Contribuição à Geologia da Região de São José dos Quatro Marcos-MT. São Paulo. IG-USP. Dissertação de Mestrado. 156p.

CARNEIRO, M.A.; ULBRICH, H.H.G.J. e KAWASHITA, K. (1989). Petrologia e geocronologia dos granitóides de São José dos Quatro Marcos, sudeste de Mato Grosso. Rev. Bras. de Geoc. 19:132-140.

CARNEIRO, M.A.; ULBRICH, H.H.G.J. e KAWASHITA, K. (1992). Proterozic crustal evolution at the southern margin of the Amazonian Craton in the State Mato Grosso, Brazil: evidence from $\mathrm{Rb} / \mathrm{Sr}$ and $\mathrm{K} / \mathrm{Ar}$ data. Precambrian Research 59: 263-282.

CLARK, A.M., (1984). Mineralogy of the rare earth element. In: P. Henderson (ed.), Rare Earth Element Geochemistry, Developments in Geochemistry 2, Elsevier, Amsterdam, p. 33-61. 
CONDIE K. e MELIS, E.A. (1998) Filling the Age gaps: A search for lost arcs. International Correlation Program 423. Wiyoming Craton Field Conference. Field Trip Guide with Abstracts. p. 106-107.

CORDANI, U.G.;TASSINARI, C.C.G.;TEIXEIRA,W.; BASEI, M.A.S.; e KAWASHITA, K. (1978). Evolução tectônica da Amazônia com base nos dados geocronologicos.

Segundo Congresso Geológico Chileno. Arica, Chile. Anais. p.137-148.

CORDANI, U.G. e BRITO NEVES, B.B. de (1982). The geology evolution of South America during the Archean and Early Proterozoic. Revista Brasileira de Geociências $12(1-3): 78-88$.

CORDANI, U.; KAWASHITA, K. SIEGL, G.G. e VICENTE, J.C. (1985). Geocronologia del extremo sureste del macizo de Arequipa. Comunicaciones, 35: 45-51.

COSTA NETO, M.C. (1996). Estudo da Interação Fluído-Rocha no Distrito Aurífero de Pontes e Lacerda, MT. Em preparação. Dissert. de Mestrado. IG-UNICAMP.

D'AGRELlA, M.S, PACCA, I.G., TEIXEIRA, W., BETTENCOURT, J.S. (2000). Preliminary paleomagnetic results of mesoproterozoic rocks from SW Mato Grosso state, Brazil. To be presented at $31^{\text {st }}$ International Geologic Congress, Rio de Janeiro, Brazil.

DALLA SALDA, L. LINGOLANI, C. e VARELA, R. (1993). A pre-Carbonifeous tectonic model in evolution of soutern South America. Comunicat. Renuvie. 1: 371-384.

DALlA SALDA, L.; VARELA, R. e CINGOLANI, C. (1994). Sobre la colision de Laurentia-Sudamerica y el Orogeno Famatiano. In: XII Congr. Geol. Argent. y II Congressso de Exploraciones de Hidrocarbonos. Atas III. p. 358-366.

DAMM, K.W.; PICHOWIAL,S.; HARMON, R.S.; TODT, W.; KELLY, S.; OMARINI, R. e NIEMEYER, H. (1990). Pre-Mesozoic evolution of the Central Andes; The basement revisited. In Plutonism from Antarctica to Alaska: Boulder, Colorado. Geological Society of America Special Paper 241 (Kay, S.M. E Rapela, C.W., eds) p. 101-125.

DANZIEL, I.W.D. (1992). On the organization of americam plates in the Neoproterozoic and the breakout of Laurentia. GSA Today, 2:237-241.

DANZIEL, I.W.D.; DALLA SALDA,L.H. e GAHAGAN, L.M. (1994) Paleozoic Laurentia-Gondwana interaction and the origin of the Appalachian-andean montain system. Geol. Soc. Am. Boll., 106:243-252.

De PAOLO, D.J. (1988a). Neodymiun Isotope Geochemistry. Springer-Verlag. Mineral and Rocks 20:181p. 
De PAOLO, D.J. (1988b). Age dependence of the composition of continental crust: evidence from $\mathrm{Nd}$ isotopic variation in granitic rocks. Earth and Planetery Sciences Lettres, 90:263-271.

DICKINSON, W.R. (1970). Relations of andesites, granites and derivative sandstones to arc-trench tectonics. Reviews of Geophysics and Space Physics. 8:813-860.

DICKINSON, W.R. (1974). Sedimentation within and besides ancient and modern magmatisc arcs. Sp. Publ. Soc. Econ. Paleont. Mine.. 19:230-239.

DICKINSON, W.R. (1982). Compositions of sandstones in Circum-Pacific Sudbduction Complexes and Fore-Arc Basins. The American Association of Petroleum Geologists Publication. 66:121-137

FAURE, G. (1986). Principles of Isotope Geology. John Wiley \& Sons. New York. 589p.

FERREIRA FILHO, C.F. E BIZZI, L.A. (1985). Caracterização dos cumulatos máficos granulitizados do Rio Alegre, M.T. II Simp. de Geol. do Centro Oeste. Goiânia. p. 239-246.

FIGUEIREDO, A.J.; RODRIGUES, A.P.; PIMENTEL, G. de B.; REISCHL, J.L.; REZENDE FILHO, S.T. de; RIBEIRO FILHO, W. (1974). Projeto Alto Guaporé. Goiania. DNPM/CPRM. Relatório Final. vol. IV: $35 p$.

GERALDES, M. C. (1996). Estudos geoquímicos e isotópicos das mineralizações auríferas da região de Pontes e Lacerda, MT. Dissertação de mestrado. UNICAMP. 104 p.

GILL, J.B. (1983). Montain Building and Volcanism. In. Montain Building Processes. NY, A. Press., p. 145-165.

GOWER, C.F. and TUCKER, R.D., (1994). Distribuition of pre-1400 Ma crust in the Grenville province: Implications for rifting in Laurentia-Baltica during geon 14. Geology 22:827-830.

HAMILTON, W. (1966). Origin of the volcanic rocks of eugeossinclines and island arcs. In Continental Margins and Island Arcs. GeologicalSurvey of Canada Papper, 66-15:517533.

HASUI, Y e ALMEIDA, F.F.M. de, (1970). Geocronologia do Centro-Oeste Brasileiro. Boletim da Sociedade Brasileira de Geologia 19: 5-26.

HATERTON, T. e DICKINSON, W.R. (1969). The relationship between Andesitic Volcanism and Seismicity in Indonesia, the lesser Antilles and the other Island Arc. Journal of Geophysics Research. 74:5301-5310. 
HENDERSON, P. (1984). Rare Earth Element Geochemistry, Developments in Geochemistry 2, Elsevier, Amsterdam, 510p.

HOFFMAN, P.F. (1989). Speculation on Laurentia's first gigayear (2,0 to 1,0 Ga) Geology 17: $135-138$.

HOFFMAN, P.F. (1991). Did the breakout of Laurentia turn Gondwanaland inside-out? Science 252: 1409-1412.

HORNE, G.S.; CALRK, G.S. e PUSHKAR, P. (1976). Pre-Cretaceous rocks of northwestern Honduras: Basement terrane in Sierra de Omoa. The Amerivan Association of Petroleoum Geologists Bulletin, 60:566 583 .

HOWELL, D.G. (1995). Tectonics of Suspect Terranes. Chapman and Hall. 245p.

HUMA, $\mathrm{H}$. (1986). $\mathrm{Sm} / \mathrm{Nd} \mathrm{U/Pb}$ and $\mathrm{Pb} / \mathrm{Pb}$ isotopic evidence for the origin of the Early Proterozoic Svecokarelian crust in Finland. Geological Survey of Finland Bulltetin 337:48p.

HUMPHRIS, S.E. (1984). The mobility of the rare earth elements in the crust. In: $P$ Henderson (ed.), Rare Earth Element Geochemistry, Developments in Geochemistry 2, Elsevier, Amsterdam, p. 33-61.

JANASI, V.A., ANDRADE, S. e ULBRICH, H.H.G.J. (1996). A correção do drift instrumental do ICP-AS com espectrometria sequencial e a análise de elementos maiores, menores, e traços em rochas. Boletim do I.G., série Científica, 26:45-58.

KROUGH, T.E.. (1973). A low contamination method for hydrothermal decomposition of zircons and extraction of $\mathrm{U}$ and $\mathrm{Pb}$ for isotopic age determinations. Geochimica and Cosmochimica Acta. 37:485-494.

KROUGH, T.E.. (1982a). Improves accuracy of U-Pb zircon dating by selection of more concordant fraction using a high gradient magnetic separation technique. Geochimica and Cosmochimica Acta. 46:631-635.

KROUGH, T.E.. (1982b). Improves accuracy of U-Pb zircon dating by the creation of more concordant systems using na air abrasion technique. Geochimica and Cosmochimica Acta. 46:637-649.

KROONEMBERG, S.B. (1982). A grenvillian granulite belt in the Colombian Andes and its relation to the Guiana Shield. Geologie en Mijnbouw 61: 325-333.

KUNO, H. (1966). Lateral variation of basalts magma across Continental Margins and Island Arcs. In: Continental margins and Island Arcs, Geological Survey of Canada Papper, 66(15):517-533. 
LAHTINEN, R. e HUHMA, H. (1997). Isotopic and geochemical constrains on the evolution of the 1,93-1,79 Ga Svecofennian crust and mantle in Finland. Precambrian Research 82:13-34.

LEITE, J.A.D. (1989). Contexto geológico e geoquímica das lavas máficas da Sequência Vulcano-Sedimentar Quatro Meninas, Município de Indiavaí, MT. Porto Alegre. UFRGS. Dissertação de Mestrado. 82p.

LEITE, J.A.D.; SAES, G.S.; RUIZ, S. (1986). Anatomia e Interpretação das Lavas Basálticas subaquosas da Sequência Vulcano-Sedimentar Quatro Meninas, Araputanga, M.T. In: 34 Cong. Bras. de Geol.; Bol. de Res. e Brev. Com. p. 99.

LEHMANN, B. (1979). A Precambriamn core sample from the altiplano/Bolivia. Geolog. Rundsch., 67:270-278.

LITHERLAND, M; KLINK, B.A.; OÇONNORS, E.A. E PITFIELD, P.E.J. (1985). Andean trending mobile belt in Brazilian Shield. Nature, 314: 345-348.

LITHERLAND, M.; ANNELS, R.N.; APPLETON, J.D.; BERRANGE, J.P.; BLOOMFIELD, K.; BURTON, C.C.J.; DARBYSHIRE, D.P.F.; FLETCHER, C.J.N.; HAWKINS, M.P.; KLINK, B.A.; LLANOS, A.; MITCHEL, W.I.; OCONNORS, E.A.; PITFIELD, P.E.J.; POWER, G e WERB, B.C. (1986). THE Geology and Mineral Resources of the Bolivian Precambrian Shield. British geological Survey. Overseas Memoir 9. London, Her Majesty's Stationery Office. 140 p.

LITHERLAND, M; ANNELS, R.N.; DARBYSHIRE, D.P.F.; FLETCHER, C.J.N.; HAWKINS, M.P.; KLINK, B.A.; MITCHEL, W.I.; OÇONNORS, E.A; PITFIELD, P.E.J.; POWER, G e WERB, B.C. (1989). The Proterozoic eastern Bolivia and its relationship to the Andean mobile belt. Prec. Res. 43: 157-174.

LOPES JR., I; PIZZATO, L.G; MENEZES, R.G. E SILVA, L.C. (1992). Geoquímica do Granito Santa Helena na Folha Pontes e Lacerda M.T. Anais do 37 Congresso Brasileiro de Geologia. p.52-65.

LUDWIG, K. R. (1990). A plotting and Regression Program for Radiogenic-Isotope Data for IBM-PC Compatible Computers. US Geological Survey. Report 88-557. 33p

LUDWIG, K.R. (1998). Using Isoplot/Ex (Version 1.00b) A Geochronological Toolkit for Microsoft Excel. Berkley Geochronology Center, Special Publication No 1. 44p.

MANIAR, P.D. e PICCOLI, P.M. (1989). Tectonic discrimination of granitoids. Geological Society of America Bulletin 101: 635-643.

MATOS, J.B. (1994). Contribuição à geologia da parte meridional do Cráton Amazônico: Região do Rio Alegre, M.T. Dissertação de Mestrado. IG-USP. 108 p. 
MATOS, J.B. E RUIZ, A.S. (1991). Contribuição à geologia da Folha Santa Rita. Mato Grosso. Anais do III Simp. de Geol. do Centro Oeste. p. 122-130.

MATOS, J.B.; SOUSA, M. Z. A.; RUIZ, A. S.; SILVA, C. H.; e SOUSA, F. J. (1986). Caracterização preliminar do Granodiorito Água Clara do Distrito de Farinópolis (Araputanga-MT). XXXIX Congresso Brasileiro de Geologia. Anais, volume 2, p.6264.

MATOS , J.B. e SCHORSCHER J.H.D. (1997a). Tendências geoquímicas da Sequência Vulcano-sediemntar do Rio Alegre-MT. Anais do VI Simpósio de Geologia do Centro Oeste. Cuiabá, Outubro de 1997. P.26-28.

MATOS , J.B. e SCHORSCHER J.H.D. (1997b). Geologia da região do Rio Alegre-MT. Anais do VI Simpósio de Geologia do Centro Oeste. Cuiabá, Outubro de 1997. P.85-87.

MENEZES, R. G. de; LOPES, I. e BEZERRA, J.R.L. (1993). Folha Pontes e Lacerda 1:100.000. Carta Geológica e Texto Explicativo. Programa de Levantamentos Básicos. CPRM-DNPM. 176p.

MIYASHIRO, A. (1975). Volcanic rocks series and tectonic settings. Annual review of Earth and Planetary Sciences. 3:251-269.

MON, R. e HONGN, D. (1996) Estrutura del basamento Proterozoico y Paleozoico inferior del norte Argentino. Revista de la Associacion Geologica Argentina, 51:3-14.

MONTEIRO, H.; MACEDO, P.M. de; SILVA, M.D. da; MORAES, A.A. de; MARCHETO, C.M.L. (1986). O greenstone belt do Alto Jauru. In: 34 Congr. Bras. de Geol. Goiânia. vol. 2: p. 630-646.

OLIVA, L.A. (1979). Ocorrências Minerais na Folha Cuiabá (SD.21) Relatório de Viagem. Goiânia, DNPM. 18p.

O'NEIL, J.R. e TAYLOR, H.P. (1967). The oxigen isotope and caution exchange chemistry of feldspars. The American Minetalogist. 52:1414-1437.

PACCI, D, HERVE, F.; MUNIZAGA,F.; KAWASHITA e CORDANI,U. (1980). Acerca de la edad $\mathrm{Rb} / \mathrm{Sr}$ precambrica de rocas de la formacion esquistos de Belen, departamento de Parinacota, Chile. Revista Geologica de Chile, 11:43-50.

PAYOLLA, B.L., KOZUCH, M., LEITE, W.B. JR., FETTER, A., BETTENCOURT, J.S AND VAN SCHMUS, W.R. (1998). Proterozoic geological evolution of the centraleastern part of the Rondônia Tin Province (Brazil), infered from U/Pb and $\mathrm{Sm} / \mathrm{Nd}$ isotopic data. University of Wisconsin. Open File Report 1998-10, pp. 165.

PARRISH, R.R. (1987). An improced micro-capsule for zircon dissolution in U-Pb geochronology. Isotope Geoscience. 66:99-102. 
PATCHETT, J. e KOUVO, O., (1986). Origin of continental crust of 1,9-1,7 Ga age Nd isotopes and $\mathrm{U} / \mathrm{Pb}$ zircon ages in the Svecokarelian terrain of South Finland. Contribuition to Mineralogy and Petrology 92:1-12.

PATCHETT, P.J. e RUIZ, J. (1987). Nd isotopic ages of crust formation and mettamorphism in the Precambrian eastern and souther Mexico. Contribuition to Mineralogy and Petrology. 96:523-528.

PEACOCK, M.A. (1931). Classification of igneous rock series. Journal of Geology. 39:65-77.

PEARCE, J. A.; HARRIS, N.B.W. e TINDLE, A.G. (1984). Trace element discrimination diagrams for the tectonic interpretation of granitic rocks. Journal of Petrolology 25: 956983.

PEARCE, J.A. e NORRY, (1979). Petrogenetic implications of Ti, Zr, Y and $\mathrm{Nb}$ variations in volcanic rocks. Contributions to Mineralogy and Petrology, 69:33-47.

PINHO, M.A. de S.B. (1990). Geologia, Petrologia, e Geoquímica das Rochas Ocorrentes ao Longo do Rio Aguapeí- Sudoeste do Cráton Amazônico-Pontes e Lacerda-MT. Porto Alegre. URGS. Dissertação de mestrado. 199p.

PINHO, F.E.C. (1996). The origin of the Cabaçãl Cu-Au deposit, Alto Jauru Greenstone Belt, Brazil. Doctored Dissertation. The University of Western Ontario, London, Ontario, Canada.. $211 \mathrm{p}$.

PINHO, M.B. E FYFE, W.S. (1994). A evolução do conhecimento geoquímico das vulcânicas máficas-ultramáficas tholeí́ticas da formação Mata Preta, greenston belt do Alto Jauru- Mato Grosso. In: 38 Congresso Brasileiro de Geologia vol. 3: p. 141-143.

PINHO, F.E.C., FYFE, W.S. e PINHO, M.A.S.B. (1997). Early Proterozoic evolution of the Alto Jauru greenstone belt, southern Amazonian craton, Brazil. International Geology Review, 39:220-229.

PITCHER, W. (1982). Granite type and tectonic environment. In : HSU, K. (ed.) Moutain Building Processes. Academic Press. p. 19m40.

PRIEM, H.N.A.; KROONEMBERG, S.B.; BORLRIJT, N.A.M. e HEBEDA, E.H. (1989). $\mathrm{Rb} / \mathrm{Sr}$ and $\mathrm{K} / \mathrm{Ar}$ evidence for the presence of a 1,6 Ga basement underlying the 1,2 $\mathrm{Ga}$ Garzón-Santa Marta granulite belt in the Colombian Andes. Precambrian Research 42: 315-324.

PRIEM, H.N.; BON, E.H.; VERDUMEN, E.A.I. e BETTENCOURT, J.S. (1989). Rb/Sr chronology of Precambrian crustal evolution in Rondonia (western margin of Amazonian Craton), Brazil. Journal of South America Earth Sciencies 2: 163-170. 
RÄMÖ, O.T. (1991). Petrogenesis of the Proterozoic rapakivi granites and related basic rocks of southeastern Fennoscandia: $\mathrm{Nd}$ and $\mathrm{Pb}$ isotopic and general geochemical constraints, Geological Survey of. Finland Bulletim. 355, 161p.

RÄMÖ, O.T., NIRONEN, M. e PAKARINEN, J. (1995). The 1,87 Ga potassim granitegabro complex at Honkajoki, western Finland: Much more in common with the classic 1,65-1,54 Ga Finish rapakivi granites! In: Dall'Agnol, M.J.B. Macambira, and H.T. Costi (eds) Symposium on Raakivi Ganites and Related rocks. Belem, Brazil. Abstract Volume. University Federal of Para, Center for Geociences. P.66.

RÄMÖ, O.T., NIRONEN, M. e ELLIOTT, B.A.. (1998). Nd and Pb isotopic composition of post-kinematic and rapakivi granitoids in the Finnish Svecofennian: Evidence for two microcontinents. In: W.R. Van Schmus, B.A., Brown, e M.G. Mudrey, Jr. (eds) International Geological Correlation Project 426: Proterozoic Granite Systems and Proterozoic Lithosferic Process, 1998 International Field Trip Conference: Proterozoic Granite Systems of the Penokean Terrane in Wisconsin, Field Guide and Proceedings Volume, p. 170-171.

RAMOS, V. (1989). The birth of Southern South America. American Scientist 77: 444450.

REED, J.C., Jr., BICKFORD, M.E., e TWETO, O. (1993). Proterozoic accretionary terranes of Colorado and southern Wyoming, In: Reed, J.C. Bickford, M.e., Houston, r.s., Link, P.K., Rankin, D.W., Sims, P.K. and Van Schmus, W.R., eds, Precambrian: Conterminous U.S. Boulder, Colorado, Geological Society of America, The Geology of North America, v. C-2, p. 239-259.

RENNE, P.R.; MATTINSON, J.M.; HATTEN, C.W.; SOMIN, M.; ONSTOTT, T.C.; MILTON, G. E LINARES, E. (1989). ${ }^{40} \mathrm{Ar} /{ }^{39} \mathrm{Ar}$ and $\mathrm{U} / \mathrm{Pb}$ evidence for Late Proterozoic (Grenville age) continental crust in north-central Cuba and regional tectonic implications. Precambrian Research 42: 325-341.

RIZZOTO, G.J. (1999). Petrologia e Ambiente Tectônico do Grupo Nova Brasilândia-RO. Master Thesis. UFRS. $136 \mathrm{p}$.

RIZZOTO, G.J.; LIMA, E.F.; CHEMALE Jr., F.; e LUFT, J.L. (1999a). Caracterização do Cinturão transpressivo Rio Branco do sudoeste de Rondônia. VI Simpósio da Geologia da Amazônia, Manaus. Anais. p. 315-318.

RIZZOTO, G.J.; LIMA, E.F.; CHEMALE Jr., F.; e LUFT, J.L. (1999b). Acreşã̃o continental do Esteniano no sudeste de Rondônia: Implicações tectônicas. VI Simpósio da Geologia da Amazônia, Manaus. Anais. p. 319-322

RIZZOTO, G.J.; LIMA, E.F.; CHEMALE Jr., F.; e LUFT, J.L.; VAN SCHMUS, W.R.; e FETTER, A. (1999c). Dados isotópicos $\mathrm{Sm} / \mathrm{Nd}$ e U/Pb das rochas da Sequência Metaplutonossedimentar Nova Brasilandia (SMNB) RO. VI Simpósio da Geologia da Amazônia, Manaus. Anais. p. 490-493 
ROBERTSON, J.M., GRAMBLING, J.A., MAWER, C.K., BOWRING, S. , WILLIANS, M.L., BAUER, P.W., e SILVER, L.T. (1993). Precambriam Geology of New Mexico. In: Reed, J.C. Bickford, M.e., Houston, r.s., Link, P.K., Rankin, D.W., Sims, P.K. and Van Schmus, W.R., eds, Precambrian: Conterminous U.S. Boulder, Colorado, Geological Society of America, The Geology of North America, v. C-2, p. 239-259.

ROGERS, J.W. (1996). A history of continents in the past three billions years. The Journal of Geology. 104:91-107.

ROLLINSON, H. (1993). Using Geochemical Data: Evaluation, Presentation, Interpretation. Longman Scientific e Technical. England. 352 p..

RYAN, B. (1981). Volcanism, sedimentation, plutonisn and grenvilian deformation in the Helikian basins of central Labrador. In: Proterozoics Basins of Canada. (F.H.A. Campbell, ed.) Geological Survey of Canada. paper 81:361-378.

RUIZ A.S. (1992). Contribuição à Geologia do Distrito da Cachoeirinha, MT. São Paulo. IG-USP. Dissertação de Mestrado. 98p.

SADOWSKY, G.R. e BETTENCOURT, J.S. (1996). Mesoproterozoic tectonic correlations between east Laurentia and the western border of the Amazon Craton. Precambrian Research 76: 213-227.

SAES, G.S. (1999). Evolução Tectônica e Paleogeográfica do Aulacógeno Aguapeí (1.2$1.0 \mathrm{Ga}$ ) e dos Terrenos do seu Embasamento na Porção Sul do Cráton Amazônico. Doctored Dissertation. USP. São Paulo. pp. 135

SAES, G.S.; LEITE J.A.D.; e WESCA, R.K. (1984) Geologia da Folha Jauru (SD-21-Y-CIII): Uma Síntese dos Conhecimentos. In: 33 Congr. Bras. de Geol. Rio de Janeiro. vol. 5: p. 2193-2204.

SAES, G.S. e LEITE, J. (1992) Evolução tectono-sedimentar do Grupo Aguapeí, Proterozóico Médio na porção meridional do Cráton Amazônico: Mato Grosso e oriente Boliviano. Revista Brasileira de Geociências. 23:31-37.

SAES, G.S.; FRAGOSO CESAR, A. R. S. (1996) Acresção de terrenos mesoproterozóicos no SW da Amazônia. In: 39 Congresso Brasileiro de Geologia p.348.

SANTOS, J.O.S.; RIZZOTO, G.J.; HARTMANN, L.; McNAUGHTON, N.; e FLETCHER, I.R. (1999) Duas orogêneses principais no sudoeste do cráton Amazônico: Evidências através de datações U/Pb em zircão (shrimp). VI Simpósio da Geologia da Amazônia, Manaus. Anais. p.506-509.

SATO, K. TASSINARI, C.G.; KAWASHITA, K. e PETRONILHO, L. (1995). O método Geocronológico Sm-Nd no IG/USP e suas aplicações. Anais Academia Brasileira Ciências 67 (3): 314-336. 
SATO, K. e TASSINARI, C.C.G. (1998) Principais eventos de acreção continental no Cráton Amazônico baseados em idade modelo $\mathrm{Sm} / \mathrm{Nd}$, calculada em evoluções de estágio único e estágio duplo. In: Contribuições à Geologia da Amazônia. Publicado pela SBG-Núcleo Norte. p.91-138.

SCANDOLARA, J. (1999) A evolução proterozóica de Rondônia, principais eventos e cronologia dos movimentos tectônicos. VI Simpósio da Geologia da Amazônia, Manaus. Anais. p. 255-258.

SCANDOLARA, AMORIM, J.L J. (1999) A Faixa Móvel Guaporé, sua definição e inserção no contexto geotectônico do SW do Cráton Amazônico. VI Simpósio da Geologia da Amazônia, Manaus. Anais. p. 278-281.

SCANDOLARA, J. . RIZZOTO, G.J., AMORIM, J.L (1999a) Mapa Tectônico do estado de Rondônia. Inédito.

SCANDOLARA, J. RIZZOTO, G.J., AMORIM, J.L. (1999b) Evolução Proterozóica de Rondônia: Cronologia dos eventos tectônicos. VII Simposium Nacional de Estudos Tectônicos (SNET). p. 24-27.

SCANDOLARA, AMORIM, J.L J. RIZZOTO, G.J.; QUADROS, M.L.E.S.; e BAHIA, R.B.C. (1999c) Compartimentação tectônica-estratigráfica pré-Cambriana de Rondônia: Subsídios para modelos evolutivos. VI Simpósio da Geologia da Amazônia, Manaus. Anais. p. 282-285.

SCHOBBENHAUS, C., CAMPOS, D.A., DERZE, G.R., AND ASMUS, H.E., (1974). Geological map pf Brazil, scale 1:2,500,000: Brasília, Ministério de Minas e Energia/Departamento Nacional de Produção Mineral.

SHACKLETON, R.M.; RIES, A.C.; COWARD, M.P. e COBBOLD, P.R. (1979) Structure, metamorphism and geochronology of the Arequipa Massif of coastal Peru. Journal of Geological Society of London, 136:195-214.

SIAL, A.N. e FERREIRA, V.P (1990) Granitoids in northeastern Brazil: Oxygen and sulfur isotopes compositions and depths of emplacement. Journal of South america Earth Sciences, $3(2 / 3): 103-112$.

SIAL, A.N.; TOSELLI, A.J.; FERREIRA, V.P.; ROSSI de TOSELLI e FALLICK, A.E. (1996) Granitóides com epidoto magmático da Província de Borborema, NE do Brasil e das Serras Pampeanas, NW da Argentina. Boletim do Instituto de Geociências. 5:51-53.

SILVA, C.G.; LIMA, M.I. de; ANDRADE, A.R.F. de; ISSLER, R.S.; GUIMARÃES, G.;LEAL, J.F.V.; BASEI, M.A.S.; DA'LAGNOL, R.; TEIXEIRA, J.B.G;; MONTALVÃO, R.M.G. de; (1974) Folha SB-22 (Araguaia) e parte da Folha SC-22 (Tocantins). Projeto RADAMBRASIL. 143p. 
SIMS, P.K. (1989) Geology and geochemistry of Early Proterozoic rocks in the Dunbar area, northeastern Wisconsin. U.S. Geological Survey Professional Paper 1517, 65p.

SIMS, P.K, VAN SCHMUS, W.R., SCHULZ, K.J. e PETERMAN, Z.E. (1989) Tectonostratigraphic evolution of the Early Proterozoic Wisconsin magmatic terranes of the Penokean orogen. CanadianJournal of Earth Sciences, v. 26:2145-2158.

SOUZA, E. P. e HILDRED, P.R. (1980) Contribuição ao estudo da geologia do Grupo Aguapeí, Mato Grosso. In: 31 Congr. Bras. de Geol.. vol. 2: p. 587-598.

STACEY, J.S. e KRAMERS, J.D. 1975 Aproximation of Terrestrial Lead Isotope Evolution by a Two-Stage Model. Earth and Planetary Science Letters. 26: 207-221. 1975.

STEIGER, R. H. e JAEGER 1977 Subcommission on geochronology: convention on the use of decay constants in geo- and cosmochronology. Earth and Planetary Sciences Letters 36: 359-362.

STREICKEISER, A. (1976) To each plutonic rock its proper name. Earth Science Review. 12:1-33.

SUAREZ, G.; MOLNAR, P. e BURCHFIELD, B.C. (1983) Seismicity, fault plane solution, depth of faulting, and active tectonics of Andes of Peru, Ecuador, and southern Colombia. Jour. of Geoph. Res. 88: 10.403-10.428.

SUN, S.S. e McDONOUGHT, W.F. (1989) Chemical and isotope systematics of oceanic basalts: implications for mantle composition and process. In Magmatism in the ocean basins. Geological Society, Special Publication, 42:313-345.

TASSINARI, C.C.G. (1981) Evolução Geotectônica da Província Rio Negro-Juruena na Região Amazônica. Dissertação de Mestrado. IG-USP. São Paulo. 99p.

TASSINARI, C.C.G., CORDANI, U.G., NUTMAN, A., W.R. VAN SCHMUS, BETTEENCOURT, J.S. e TAYLOR, P.N. (1997) Geochronological systematics on basement rocks from the Rio Negro-Juruena Province (Amazon Craton), and tectonic implications. International Geology Review, 35:263-277.

TASSINARI, C.C.G., CORDANI, U.G., CORREIA, C.T., NUTMAN, A.P., KINNY, P., DIAS NETO, C. (1999) Dating of granulites by shrimp U-Pb systematics in Brazil: constraints for the age of the metamorphism of Proterozoic Orogenies. Anais do II South American Symposium on Isotope Geology. p.234-238.

TAYLOR, Jr. H.P. 1974. The application of Oxygen and Hydrogen isotopes studies to problems of hydrothermal alteration and ore deposition. Economic Geology 69:843883. 
TAYLOR, H.P. (1988). Oxygen, hydrogen, and strontium isotope constrains on the origin of granites. Transsactions of the Royal Society of Edinburg: Earth Sciences, 79:317338 .

TEIXEIRA, W. e TASSINARI, C.C.G., (1984). Caracterização geocronológica da Província Rondoniana e suas implicações geotectônicas. Congresso Brasileiro de Geologia vol. 3 p.87-100.

TEIXEIRA, W.; TASSINARI, C.C.G.; CORDANI,U.G.; KAWASHITA, K. (1989). A Review of the Geochronology of the Amazonian Craton: Tectonic Implications. Precambrian Research 42:213-227.

TOLEDO, F.H. (1997). Mineralização e alteração hidrotermal do depósito de ouro do Cabaçal, Mato Grosso. Dissertação de Mestrado. UNICAMP. Campinas (SP). 86p.

TOSDAL, R.M. (1996). The Amazonian-Laurentian connection as viewed from the Middle Proterozoic rocks in central Andes, wester Bolivia and northern Chile. Tectonics 65:239-253.

VAN SCHMUS, W.R. BROWN, B.A., MUDREY, Jr., MICHAEL G. (1998). International Geological Correlation Projet 426: Granite Systems and Proterozoic Lithospheric Process. 1998 International Field Conference: Proterozoic Granite Systems of the Penokean Terrane in Wisconsin. Field Guide and Proceedings Volume, p. 148-149.

VAN WICK, N. e JOHNSON, C.M. (1997). Common lead, Sm/Nd and U/Pb constrains on petrogenesis, crustal architeture, and tectonic setting of the Penokean orogeny (Paleoproterozoic) in Wisconsin. Geological Society of America Bulletin 109:799-808.

UNRUG, R. (1997). The assembly of Gondwanaland: Episodes, v. 19, p. 11-20.

ZINDLER, R.E. e HART, S.R. (1986) Chemical geodynamics. Annual Review-Earth Planetary Sciences Letters 14: 493-571.

WASTENEYS, H.A; CLARK, A.H.; FARRAR, E. E LANGRIDGE, R.J. (1995). Grenvillian granulite-facies metamorphism in the Arequipa Massif, Peru: a LaurentiaGondwana link. Earth and Planetary Science Letters 132:63-73. 


\section{ANEXO 1}

\section{Resultados $\mathrm{U} / \mathrm{Pb}$}

Notas para as Tabelas 1 a 5 :

*: M, NM referece a frações magnéticas separadas no Franz (a 5 amp). Em parêntesis $[\mathrm{m}]=$ multigrão; $[1]=$ monocristal .

\#: Não corrigido pelo branco analítico ou $\mathrm{Pb}$ comum (não radiogênico) original.

$\dagger$ : Corrigido pelo branco analítico e pelo $\mathrm{Pb}$ comum (não radiogênico) original.

*: Baseado nas constantes de decaimento de Steiger and Jäger (1977). 


\begin{tabular}{|c|c|c|c|c|c|c|c|c|c|c|c|c|c|c|c|c|c|}
\hline TABELA 1 & & & & & & & & & & & & & & & & & \\
\hline & & & & & & & & & & & & & & & & & \\
\hline \multicolumn{18}{|c|}{ Dados U/Pb para as rochas do Terreno Jauru } \\
\hline & & & & & & & & & & & & & & & & & \\
\hline & & & & & & \multicolumn{3}{|c|}{ dados isotópicos } & & & & & & \multicolumn{3}{|c|}{ Idades calculadas } & \\
\hline Amostra & & & & $\mathrm{Pb} 206$ & $\mathrm{~Pb} 207 *$ & \pm & $\mathrm{Pb206*}$ & \pm & $\mathrm{Pb} 207 *$ & \pm & Correl. & $\mathrm{Pb} 206^{*}$ & \pm & $\mathrm{Pb207*}$ & \pm & $\mathrm{Pb} 207^{*}$ & \pm \\
\hline \multirow[t]{2}{*}{ Fração } & Peso & $\mathrm{U}$ & $\mathrm{Pb}$ & $\mathrm{Pb} 204$ & U235 & $2 \sigma$ & U238 & $2 \sigma$ & $\mathrm{Pb} 206^{*}$ & $2 \sigma$ & Coef. & $\mathrm{U} 238$ & $2 \sigma$ & $\mathrm{U} 235$ & $2 \sigma$ & $\mathrm{Pb} 206^{*}$ & $2 \sigma$ \\
\hline & $(\mathrm{mg})$ & ppm & $\mathrm{ppma}$ & (obs.) & & $(\mathrm{pct})$ & & (pct) & & $(\mathrm{pct})$ & (rho) & Idade & (Ma) & Age & (Ma) & Idade & (Ma) \\
\hline & & & & & & & & & & & & & & & & & \\
\hline \multicolumn{18}{|c|}{ MT97-131 Tufo Vulcânico } \\
\hline $\mathrm{M}(0)[1]$ & 0.001 & 1313 & 439 & 2209 & 444674 & 0.52 & 0.300640 & 0.51 & 0.107274 & 0.08 & 0.989 & 1721 & \pm 09 & 1695 & \pm 08 & 1754 & \pm 1.4 \\
\hline $\mathrm{M}(1)[1]$ & 0.005 & 725 & 212 & 3437 & 390623 & 0.51 & 0.26613 & 0.50 & 0.106454 & 0.08 & 0.988 & 1615 & \pm 08 & 1521 & \pm 08 & 1740 & \pm 1.4 \\
\hline$M(2)[1]$ & 0.005 & 887 & 222 & 3496 & 330036 & 0.64 & 0.229659 & 0.64 & 0.104226 & 0.08 & 0.991 & 1481 & \pm 09 & 1333 & \pm 08 & 1701 & \pm 1.6 \\
\hline $\mathrm{M}(3)[1]$ & 0.006 & 855 & 246 & 4369 & 385387 & 0.50 & 0.26215 & 0.50 & 0.106622 & 0.07 & 0.990 & 1604 & \pm 08 & 1501 & \pm 08 & 1743 & \pm 1.3 \\
\hline$M(4)[1]$ & 0.008 & 883 & 244 & 3082 & 362884 & 0.59 & 0.24846 & 0.57 & 0.105929 & 0.14 & 0.972 & 1556 & \pm 09 & 1431 & \pm 08 & 1731 & \pm 2.6 \\
\hline & & & & & & & & & & & & & & & & & \\
\hline \multicolumn{18}{|c|}{ MT97-147 Gneisse Aliança } \\
\hline $\mathrm{M}(3)[1]$ & 0.002 & 1321 & 472 & 1100 & 261222 & 0.69 & 0.192789 & 0.67 & 0.0982715 & 0.16 & 0.973 & 1304 & \pm 09 & 1137 & \pm 07 & 1592 & \pm 03 \\
\hline $\mathrm{M}(2) \mathrm{L}[1]$ & 0.001 & 3411 & 575 & 1027 & 218402 & 1.51 & 0.162097 & 1.43 & 0.0977194 & 0.47 & 0.950 & 1176 & \pm 17 & 968 & \pm 13 & 1581 & \pm 8.9 \\
\hline $\mathrm{M}(2) \mathrm{H}[2]$ & 0.005 & 3880 & 1027 & 1889 & 321945 & 0.59 & 0.232544 & 0.58 & 0.10041 & 0.09 & 0.986 & 1462 & \pm 08 & 1348 & \pm 08 & 1631 & \pm 1.8 \\
\hline $\mathrm{M}(2) \mathrm{K}[1]$ & 0.001 & 873 & 251 & 113 & 254517 & 1.03 & 0.175805 & 0.98 & 0.104999 & 0.28 & 0.961 & 1285 & \pm 13 & 1044 & \pm 10 & 1714 & \pm 5.2 \\
\hline $\mathrm{M}(0)[1]$ & 0.004 & 1198 & 264 & 740 & 273974 & 1.84 & 0.21367 & 1.79 & 0.0929959 & 0.36 & 0.980 & 1339 & \pm 24 & 1248 & \pm 21 & 1488 & \pm 07 \\
\hline & & & & & & & & & & & & & & & & & \\
\hline \multicolumn{18}{|c|}{ MT97-133 Gnaisse Rosa } \\
\hline $\mathrm{NM}(0)[1]$ & 0.002 & 512 & 145 & 480 & 379852 & 1.94 & 0.25800 & 1.90 & 0.106781 & 0.39 & 0.980 & 1592 & \pm 30 & 1480 & \pm 28 & 1745 & \pm 7.1 \\
\hline $\mathrm{NM}(1)[4]$ & 0.006 & 439 & 107 & 641 & 299124 & 0.49 & 0.20946 & 0.47 & 0.103576 & 0.11 & 0.973 & 1405 & \pm 07 & 1226 & \pm 06 & 1689 & \pm 2.1 \\
\hline $\mathrm{NM}(0)[3]$ & 0.003 & 845 & 225 & 890 & 342581 & 0.64 & 0.23538 & 0.61 & 0.105556 & 0.16 & 0.967 & 1510 & \pm 10 & 1363 & \pm 08 & 1724 & \pm 03 \\
\hline \multicolumn{18}{|c|}{ MT-97-129 Granito Alvorada } \\
\hline $\mathrm{NM}(3)[1]$ & 0.003 & 866 & 240 & 431 & 293909 & 0.70 & 0.24140 & 0.68 & 0.0883022 & 0.15 & 0.976 & 1393 & \pm 10 & 1394 & \pm 09 & 1389 & \pm 2.9 \\
\hline $\mathrm{M}(3)[1] \mathrm{a}$ & 0.005 & 2860 & 403 & 1355 & 152602 & 0.50 & 0.13619 & 0.49 & 0.0812559 & 0.09 & 0.985 & 941 & \pm 05 & 823 & \pm 04 & 1228 & \pm 1.7 \\
\hline $\mathrm{M}(4)[1]$ & 0.004 & 2219 & 267 & 1111 & 127879 & 0.56 & 0.11257 & 0.54 & 0.0823919 & 0.11 & 0.981 & 836 & \pm 05 & 688 & \pm 03 & 1255 & \pm 2.1 \\
\hline $\mathrm{NM}(3) \mathrm{b}$ & 0.002 & 1356 & 261 & 624 & 216566 & 0.77 & 0.177807 & 0.74 & 0.0883361 & 0.20 & 0.965 & 1170 & \pm 09 & 1055 & \pm 07 & 1390 & \pm 3.8 \\
\hline $\mathrm{NM}(3) \mathrm{b}$ & 0.002 & 594 & 148 & 194 & 2246445 & 1.42 & 0.186568 & 1.29 & 0.087329 & 0.56 & 0.917 & 1196 & \pm 16 & 1103 & \pm 13 & 1368 & \pm 11 \\
\hline \multicolumn{18}{|c|}{ MT97-132 Granito Alvorada } \\
\hline $\mathrm{NM}(5)[1]$ & 0.001 & 1327 & 239 & 602 & 192455 & 0.88 & 0.16038 & 0.86 & 0.087030 & 0.17 & 0.982 & 1090 & \pm 10 & 959 & \pm 10 & 1361 & \pm 3.2 \\
\hline $\mathrm{NM}(5)$ "O" & 0.002 & 1348 & 323 & 3873 & 324699 & 0.80 & 0.248426 & 0.80 & 0.0947944 & 0.14 & 0.985 & 1469 & \pm 12 & 1430 & \pm 11 & 1524 & \pm 2.6 \\
\hline $\mathrm{M}(6)[1]$ & 0.002 & 1553 & 318 & 1516 & 238753 & 0.73 & 0.19195 & 0.72 & 0.0902092 & 0.13 & 0.984 & 1239 & \pm 09 & 1132 & \pm 08 & 1430 & \pm 2.5 \\
\hline
\end{tabular}




\begin{tabular}{|c|c|c|c|c|c|c|c|c|c|c|c|c|c|c|c|c|c|}
\hline & & & & & & & & & & & & & & & & & \\
\hline \multicolumn{18}{|c|}{ MT97-134 Gnaisse Cinza } \\
\hline $\mathrm{NM}(-1)[1]$ & 0.007 & 1013 & 256 & 3749 & 309600 & 0.49 & 0.23424 & 0.49 & 0.0958603 & 0.06 & 0.992 & 1432 & \pm 07 & 1357 & \pm 07 & 1545 & \pm 12 \\
\hline$M(1)[1]$ & 0.006 & 802 & 184 & 2667 & 280773 & 0.55 & 0.21244 & 0.55 & 0.0958557 & 0.07 & 0.991 & 1358 & \pm 07 & 1242 & \pm 07 & 1545 & \pm 1.4 \\
\hline$M(-1)[1]$ & 0.009 & 977 & 276 & 3601 & 344264 & 0.52 & 0.26153 & 0.52 & 0.0954699 & 0.59 & 0.993 & 1514 & \pm 08 & 1498 & \pm 08 & 1537 & \pm 1.1 \\
\hline $\mathrm{M}(0)[1]$ & 0.002 & 688 & 148 & 1595 & 261705 & 0.50 & 0.197009 & 0.50 & 0.0963440 & 0.07 & 0.991 & 1305 & \pm 07 & 1159 & \pm 06 & 1555 & \pm 1.2 \\
\hline \multicolumn{18}{|c|}{ MT97-136 Granodiorito Agua Clara } \\
\hline $\mathrm{NM}(0)[1]$ & 0.007 & 632 & 139 & 1099 & 273623 & 0.48 & 0.211527 & 0.47 & 0.093818 & 0.10 & 0.979 & 1338 & \pm 07 & 1237 & \pm 06 & 1505 & \pm 1.8 \\
\hline $\mathrm{M}(0)[1]$ & 0.004 & 395 & 85 & 1824 & 300620 & 1.38 & 0.21321 & 0.54 & 0.096798 & 0.15 & 0.965 & 1368 & \pm 08 & 1246 & \pm 07 & 1563 & \pm 2.7 \\
\hline$M(1)[1]$ & 0.007 & 479 & 83 & 3144 & 229866 & 0.59 & 0.17573 & 0.56 & 0.0948712 & 0.16 & 0.962 & 1212 & \pm 07 & 1044 & \pm 06 & 1526 & \pm 3.0 \\
\hline $\mathrm{NM}(0)$ & 0.004 & 799 & 192 & 674 & 295776 & 0.87 & 0.30399 & 0.83 & 0.09331066 & 0.26 & 0.953 & 1396 & \pm 12 ? & 1337 & \pm 11 & 1490 & \pm 5 \\
\hline NM $(0)$ & 0.004 & 62 & 22 & 106 & 306905 & 4.08 & 0.242033 & 3.92 & 0.091966 & 1.02 & 0.969 & 1425 & \pm 57 & 1397 & \pm 54 & 1467 & \pm 19 \\
\hline \multicolumn{18}{|c|}{ MT97-138 Granito Cachoeirinha } \\
\hline $\mathrm{NM}(0)[2]$ & 0.008 & 161 & 51 & 411 & 350167 & 0.87 & 0.266267 & 0.87 & 0.0953797 & 0.09 & 0.970 & 1528 & \pm 13 & 1522 & \pm 13 & 1536 & \pm 3.9 \\
\hline $\mathrm{M}(0)[2]$ & 0.011 & 668 & 150 & 702 & 201803 & 0.52 & 0.17121 & 0.50 & 0.0854868 & 0.14 & 0.961 & 1121 & \pm 06 & 1019 & \pm 08 & 1327 & \pm 2.8 \\
\hline $\mathrm{M}(1)[2]$ & 0.004 & 1156 & 284 & 1316 & 290693 & 0.54 & 0.223596 & 0.52 & 0.0942908 & 0.16 & 0.956 & 1384 & \pm 07 & 1301 & \pm 07 & 1514 & \pm 03 \\
\hline $\mathrm{M}(2)[2]$ & 0.004 & 2103 & 430 & 1191 & 227294 & 1.32 & 0.182087 & $(1.14$ & 0.0905331 & 0.66 & 0.865 & 1204 & \pm 12 & 1078 & \pm 12 & 1437 & \pm 13 \\
\hline \multicolumn{18}{|c|}{ MT97-139 Granito Alvorada } \\
\hline $\mathrm{NM}(5) " \mathrm{M}^{\prime}[1]$ & 0.002 & 139 & 39 & 294 & 310414 & 2.00 & 0.23967 & 1.96 & 0.0939343 & 0.30 & 0.989 & 1434 & \pm 28 & 1385 & \pm 27 & 1507 & \pm 5.6 \\
\hline $\mathrm{NM}(5)$ "N" [1] & 0.006 & 2118 & 504 & 417 & 243338 & 0.51 & 0.198040 & 0.49 & 0.0891161 & 0.13 & 0.969 & 1253 & \pm 06 & 1165 & \pm 06 & 1407 & \pm 2.4 \\
\hline $\mathrm{NM}(5)$ "O" [1] & 0.005 & 1035 & 283 & 514 & 293237 & 0.80 & 0.23548 & 0.77 & 0.0903152 & 0.19 & 0.970 & 1390 & \pm 11 & 1363 & \pm 10 & 1432 & \pm 3.7 \\
\hline NM (5) "F" & 0.010 & 7664 & 1655 & 1945 & 283983 & 0.54 & 0.215087 & 0.54 & 0.0957587 & 0.07 & 0.991 & 1366 & \pm 07 & 1256 & \pm 07 & 1543 & \pm 1.4 \\
\hline \multicolumn{18}{|c|}{ MT97-145 Gneisse Santa Cruz } \\
\hline$M(-1)[1]$ & 0.004 & 1262 & 329 & 322 & 283861 & 1.10 & 0.21308 & 0.94 & 0.096619 & 0.54 & 0.869 & 1366 & \pm 15 & 1245 & \pm 12 & 1560 & \pm 10 \\
\hline $\mathrm{M}(1)[1]$ & 0.013 & 262 & 74 & 956 & 344136 & 0.89 & 0.25935 & 0.88 & 0.0962361 & 0.12 & 0.991 & 1514 & \pm 13 & 1487 & \pm 13 & 1552 & \pm 2.3 \\
\hline $\mathrm{M}(2)[1]$ & 0.004 & 807 & 180 & 855 & 274331 & 1.02 & 0.208863 & 1.00 & 0.0952602 & 0.18 & 0.984 & 1340 & \pm 14 & 1223 & \pm 12 & 1533 & \pm 3.4 \\
\hline \multicolumn{18}{|c|}{ MT97-148 Gneisse Quatro Meninas } \\
\hline $\mathrm{NM}(-1) \mathrm{E}[1]$ & 0.018 & 1239 & 318 & 5879 & 357187 & 0.50 & 0.263509 & 0.50 & 0.0983093 & 0.06 & 0.994 & 1543 & \pm 09 & 1507 & \pm 09 & 1592 & \pm 1.2 \\
\hline $\mathrm{M}(-1)[1]$ & 0.025 & 1472 & 389 & 580 & 332806 & 0.71 & 0.24340 & 0.70 & 0.0991672 & 0.16 & 0.974 & 1488 & \pm 11 & 1404 & \pm 10 & 1609 & \pm 3.0 \\
\hline $\mathrm{M}(0)[1]$ & 0.016 & 1687 & 444 & 3287 & 346837 & 0.48 & 0.260473 & 0.47 & 0.096574 & 0.11 & 0.974 & 1520 & \pm 07 & 1492 & \pm 07 & 1559 & \pm 02 \\
\hline $\operatorname{NM}(-1)[1]$ & 0.006 & 1865 & 431 & 263 & 311016 & 0.70 & 0.236891 & 0.64 & 0.0952213 & 0.26 & 0.928 & 1435 & \pm 10 & 1370 & \pm 08 & 1533 & \pm 05 \\
\hline $\mathrm{NM}(-1) \mathrm{H}$ [1] & 0.003 & 6340 & 1665 & 1261 & 354954 & 0.68 & 0.257188 & 0.67 & 0.100097 & 0.14 & 0.977 & 1538 & \pm 10 & 1475 & \pm 10 & 1626 & \pm 2.7 \\
\hline $\mathrm{NM}(-1) \mathrm{I}[1]$ & 0.001 & 2696 & 6769 & 3966 & 337815 & 0.79 & 0.260243 & 0.79 & 0.0941453 & 0.06 & 0.997 & 1499 & \pm 11 & 1491 & \pm 12 & 1511 & \pm 1.1 \\
\hline & & & & & & & & & & & & & & & & & \\
\hline
\end{tabular}




\begin{tabular}{|c|c|c|c|c|c|c|c|c|c|c|c|c|c|c|c|c|c|}
\hline \multicolumn{18}{|c|}{ MT97-149 Gnaisse São Domingos } \\
\hline $\mathrm{NM}(-1)[4]$ & 0.006 & 557 & 164 & 544 & 369373 & 1.85 & 0.255916 & 1.79 & 0.104681 & 0.45 & 0.970 & 1570 & \pm 29 & 1469 & \pm 26 & 1709 & \pm 8.3 \\
\hline $\mathrm{M}(-1)[4]$ & 0.009 & 469 & 151 & 807 & 417118 & 1.22 & 0.285457 & 1.12 & 0.105978 & 0.47 & 0.922 & 1668 & \pm 20 & 1619 & \pm 18 & 1731 & \pm 8.6 \\
\hline $\mathrm{M}(1)[4]$ & 0.008 & 740 & 249 & 439 & 407927 & 0.63 & 0.284293 & 0.57 & 0.104067 & 0.28 & 0.903 & 1650 & \pm 10 & 1613 & \pm 08 & 1698 & \pm 5.1 \\
\hline $\mathrm{M}(0)[3]$ & 0.003 & 2134 & 540 & 767 & 29358 & 0.82 & 0.223395 & 0.77 & 0.0953128 & 0.28 & 0.941 & 1391 & \pm 11 & 1300 & \pm 10 & 1534 & \pm 5.3 \\
\hline $\mathrm{NM}(-1) \mathrm{J}[1]$ & 0.001 & 982 & 130 & 354 & 0.881317 & 1.58 & 0.104964 & 1.51 & 0.0608961 & 0.33 & 0.978 & 642 & \pm 09 & 643 & \pm 10 & 636 & \pm 7.2 \\
\hline $\mathrm{NM}(-1)$ "K" & 0.001 & 268 & 81 & 337 & 381267 & 1.83 & 0.271294 & 1.75 & 0.101927 & 0.48 & 0.964 & 1595 & \pm 28 & 1547 & \pm 27 & 1660 & \pm 09 \\
\hline NM(-1) "L" [1 & 0.001 & 298 & 83 & 510 & 368764 & 1.65 & 0.260997 & 1.63 & 0.102474 & 0.23 & 0.990 & 1569 & \pm 25 & 1495 & \pm 23 & 1669 & \pm 4.3 \\
\hline $\mathrm{NM}(-1)$ "M " & 0.001 & 339 & 94 & 466 & 355433 & 1.89 & 0.256389 & 1.66 & 0.100232 & 0.83 & 0.899 & 1536 & \pm 29 & 1471 & \pm 24 & 1628 & \pm 15 \\
\hline$N M(-1)$ "N" [ & 0.001 & 244 & 87 & 234 & 428069 & 2.08 & 0.295897 & 2.07 & 0.104923 & 0.26 & 0.992 & 1690 & \pm 33 & 1671 & \pm 33 & 1713 & \pm 4.8 \\
\hline 0 & & & & & & & & & & & & & & & & & \\
\hline \multicolumn{18}{|c|}{ MT97-159 Tonalito Cachoeirinha } \\
\hline $\mathrm{M}(-1)[1]$ & 0.004 & 223 & 76 & 195 & 351349 & 1.41 & 0.265629 & 1.24 & 0.0959316 & 0.63 & 0.894 & 1530 & \pm 21 & 1519 & \pm 18 & 1546 & \pm 12 \\
\hline$M(0)[1]$ & 0.002 & 244 & 73 & 262 & 346200 & 1.74 & 0.261295 & 1.70 & 09609370.33 & 0.981 & 0.981 & 1515 & \pm 25 & 1497 & \pm 256 & 1550 & \pm 6.3 \\
\hline $\mathrm{M}(1)[1]$ & 0.001 & 1312 & 380 & 618 & 337969 & 0.87 & 0.253957 & 0.85 & .09651980 .2 & 0.968 & 0.968 & 1550 & \pm 12 & 1459 & \pm 12 & 1558 & \pm 4.1 \\
\hline $\mathrm{M}(0)$ "b" [1] & 0.002 & 592 & 168 & 1247 & 348712 & 0.82 & 0.264017 & 0.82 & 09579280.09 & 0.993 & 0.993 & 1524 & \pm 12 & 1510 & \pm 12 & 1544 & \pm 1.8 \\
\hline
\end{tabular}




\begin{tabular}{|c|c|c|c|c|c|c|c|c|c|c|c|c|c|c|c|c|c|}
\hline TABELA 2 & & & & & & & & & & & & & & & & & \\
\hline & & & & & & & & & & & & & & & & & \\
\hline \multicolumn{18}{|c|}{ Dados U/Pb para a Suite Santa Helena } \\
\hline & & & & & & & & & & & & & & & & & \\
\hline & & & & & & \multicolumn{3}{|c|}{ dados isotópicos } & & & & & & \multicolumn{2}{|c|}{ Idades calculadas } & & \\
\hline Amostra & & & & $\mathrm{Pb} 206$ & $\mathrm{~Pb} 207^{*}$ & \pm & $\mathrm{Pb} 206^{*}$ & \pm & $\mathrm{Pb} 207^{*}$ & \pm & Correl. & $\mathrm{Pb206*}$ & \pm & $\mathrm{Pb207*}$ & \pm & $\mathrm{Pb} 207^{*}$ & \pm \\
\hline \multirow[t]{2}{*}{ Fração } & Peso & U & $\mathrm{Pb}$ & $\mathrm{Pb} 204$ & $\mathrm{U} 235$ & $2 \sigma$ & $\mathrm{U} 238$ & $2 \sigma$ & $\mathrm{Pb} 206^{*}$ & $2 \sigma$ & Coef. & $\mathrm{U} 238$ & $2 \sigma$ & $\mathrm{U} 235$ & $2 \sigma$ & $\mathrm{Pb} 206^{*}$ & $2 \sigma$ \\
\hline & $(\mathrm{mg})$ & ppm & ppm & (obs.) & & & & & & & (rho) & Idade & (Ma) & Idade & (Ma) & Idade & $(\mathrm{Ma})$ \\
\hline & & & & & & & & & & & & & & & & & \\
\hline \multicolumn{18}{|c|}{ MT97-102: Augen gnaisse Alto Guaporé } \\
\hline $\mathrm{M}(-1)[1]$ & 0,006 & 1188 & 298 & 5057 & 3,0756 & 0,48 & 0,24557 & 0,47 & 0,09088 & 0,07 & 0,988 & 1416 & \pm 07 & 1427 & \pm 07 & 1443 & \pm 01 \\
\hline $\mathrm{M}(0)[1]$ & 0,008 & 901 & 219 & 6829 & 2,9766 & 0,47 & 0,23780 & 0,47 & 0,09079 & 0,07 & 0,990 & 1375 & \pm 07 & 1402 & \pm 07 & 1442 & \pm 01 \\
\hline $\mathrm{M}(1)[1]$ & 0,005 & 1974 & 495 & 2370 & 3,0096 & 0,51 & 0,24066 & 0,50 & 0,09070 & 0,07 & 0,990 & 1390 & \pm 07 & 1410 & \pm 07 & 1440 & \pm 01 \\
\hline \multicolumn{18}{|c|}{ MT97-105: Granodiorito Alto Guaporé } \\
\hline $\mathrm{M}(0) \mathrm{A}[1]$ & 0,007 & 1865 & 432 & 3550 & 2,8723 & 0,49 & 0,23288 & 0,49 & 0,08945 & 0,05 & 0,992 & 1350 & \pm 07 & 1375 & \pm 07 & 1414 & \pm 01 \\
\hline $\mathrm{M}(0) \mathrm{B}[1]$ & 0,007 & 2119 & 470 & 4797 & 2,7773 & 0,47 & 0,22492 & 0,47 & 0,08955 & 0,05 & 0,993 & 1308 & \pm 06 & 1349 & \pm 06 & 1416 & \pm 01 \\
\hline $\mathrm{M}(0) \mathrm{C}[1]$ & 0,004 & 1591 & 378 & 2384 & 2,9686 & 0,51 & 0,23951 & 0,51 & 0,08990 & 0,06 & 0,992 & 1384 & \pm 07 & 1400 & \pm 07 & 1423 & \pm 01 \\
\hline $\mathrm{M}(0) \mathrm{D}[1]$ & 0,003 & 1338 & 355 & 1939 & 3,0295 & 0,53 & 0,24486 & 0,52 & 0,09988 & 0,09 & 0,983 & 1312 & \pm 07 & 1415 & \pm 07 & 1420 & \pm 02 \\
\hline $\mathrm{M}(0) \mathrm{B}[1]$ & 0,003 & 4520 & 933 & 3814 & 2,5466 & 0,93 & 0,20827 & 0,93 & 0,08868 & 0,10 & 0,994 & 1220 & \pm 11 & 1286 & \pm 11 & 1397 & \pm 02 \\
\hline & & & & & & & & & & & & & & & & & \\
\hline \multicolumn{18}{|c|}{ MT97-106: Granodiorito Alto Guaporé (encaixante). } \\
\hline $\mathrm{M}(0) \mathrm{A}[1]$ & 0,004 & 198 & 57 . & 240 & 2,9864 & 1,32 & 0,24193 & 1,29 & 0,08953 & 0,23 & 0,985 & 1398 & \pm 18 & 1404 & \pm 18 & 1416 & \pm 04 \\
\hline $\mathrm{M}(0) \mathrm{C}[1]$ & 0,004 & 84 & 72 & 41 & 3,2121 & 2,19 & 0,25815 & 1,93 & 0,09024 & 0,96 & 0,900 & 1480 & \pm 28 & 1460 & \pm 30 & 1431 & \pm 18 \\
\hline $\mathrm{M}(0) \mathrm{D}[1]$ & 0,004 & 305 & 74 & 1061 & 3,0152 & 0,95 & 0,24304 & 0,94 & 0,08998 & 0,14 & 0,989 & 1403 & \pm 13 & 1412 & \pm 13 & 1425 & \pm 03 \\
\hline \multicolumn{18}{|c|}{ MT97-108: Granodiorito Alto Guaporé } \\
\hline$M(-1)[6]$ & 0,045 & 293 & 63 & 5167 & 2,6111 & 0,50 & 0,21176 & 0,49 & 0,08943 & 0,08 & 0,986 & 1238 & \pm 07 & 1303 & \pm 07 & 1413 & \pm 02 \\
\hline $\mathrm{M}(1)[10]$ & 0,008 & 214 & 46 & 6008 & 2,5329 & 0,49 & 0,20465 & 0,48 & 0,08977 & 0,08 & 0,983 & 1200 & \pm 06 & 1282 & \pm 06 & 1420 & \pm 02 \\
\hline $\mathrm{M}(1)[2]$ & 0,030 & 42 & 10 & 6170 & 2,7974 & 0,48 & 0,22445 & 0,48 & 0,09040 & 0,09 & 0,980 & 1305 & \pm 07 & 1355 & \pm 07 & 1434 & \pm 02 \\
\hline & & & & & & & & & & & & & & & & & \\
\hline \multicolumn{18}{|c|}{ MT97-113: Tonalito Lavrinha } \\
\hline $\mathrm{NM}(-3)[4]$ & 0,025 & 296 & 16 & 992 & 0,6415 & 0,84 & 0,05045 & 0,80 & 0,09222 & 0,23 & 0,961 & 317 & \pm 04 & 503 & \pm 04 & 1471 & \pm 04 \\
\hline $\mathrm{NM}(-3)[4]$ & 0.015 & 46 & 12 & 590 & 3,1748 & 1,02 & 0,25090 & 0,10 & 0,09177 & 0,20 & 0,980 & 1443 & \pm 15 & 1451 & \pm 15 & 1463 & \pm 04 \\
\hline $\mathrm{M}(-2)[4]$ & 0,017 & 45 & 12 & 482 & 3,1550 & 1,70 & 0,24885 & 1,51 & 0,09195 & 0,72 & 0,905 & 1433 & \pm 22 & 1446 & \pm 25 & 1466 & \pm 14 \\
\hline $\mathrm{M}(3)[7]$ & 0,016 & 159 & 33 & 3855 & 2,5081 & 0,52 & 0,20070 & 0,50 & 0,09063 & 0,14 & 0,966 & 1179 & \pm 76 & 1274 & \pm 07 & 1439 & \pm 03 \\
\hline$M(3)[3]$ & 0,009 & 129 & 31 & 3002 & 3,0484 & 2,08 & 0,23874 & 1,98 & 0,09261 & 0,62 & 0,954 & 1380 & \pm 28 & 1420 & \pm 28 & 1480 & \pm 12 \\
\hline MT97-115: & ranito $\mathbf{G}$ & naisse Sa & ta Helen & & & & & & & & & & & & & & \\
\hline
\end{tabular}




\begin{tabular}{|c|c|c|c|c|c|c|c|c|c|c|c|c|c|c|c|c|c|}
\hline $\mathrm{NM}(1)[1]$ & 0,001 & 236 & 35 & 682 & 1,4522 & \begin{tabular}{l|l}
1,43 \\
\end{tabular} & 0,13843 & 1,35 & 0,076 & 0,44 & 0,951 & 836 & \pm 11 & 911 & \pm 13 & 1097 & \pm 09 \\
\hline $\mathrm{NM}(1)[1]$ & 0,007 & 298 & 152 & 590 & 11,3381 & 0,62 & 0,41108 & 0,61 & 0,200 & 0,96 & 0,988 & 2220 & \pm 14 & 2551 & \pm 16 & 2827 & \pm 02 \\
\hline $\mathrm{M}(0)[4]$ & 0,008 & 43 & 9 & 1860 & 2,5884 & 0,65 & 0,20962 & 0,64 & 0,210 & 0,64 & 0,978 & 1227 & \pm 08 & 1297 & \pm 08 & 1416 & \pm 03 \\
\hline $\mathrm{M}(1)[1]$ & 0,002 & 894 & 152 & 538 & 2,0096 & 1,52 & 0,16448 & 1,50 & 0,089 & 0,23 & 0,988 & 982 & \pm 14 & 1119 & \pm 17 & 1396 & \pm 05 \\
\hline $\mathrm{M}(3)[1]$ & 0,017 & 170 & 30 & 1344 & 2,0381 & 0,58 & 0,16734 & 0,57 & 0,088 & 0,11 & 0,982 & 997 & \pm 06 & 1128 & \pm 07 & 1390 & \pm 02 \\
\hline $\mathrm{M}(3)[1]$ & 0,009 & 39 & 9 & 465 & 2,5647 & 1,17 & 0,20739 & 1,14 & 0,090 & 0,23 & 0,980 & 1215 & \pm 14 & 1291 & \pm 15 & 1419 & \pm 04 \\
\hline \multirow{2}{*}{\multicolumn{17}{|c|}{ MT97-120 W Magnetita-Granito Cardoso. }} & \\
\hline NM(-1) a & & & & & 2,9946 & & & & 0.090 & & & & & & & & \\
\hline $\mathrm{NM}(-1) \mathrm{b}$ & 0,013 & 732 & 169 & 3179 & 2,7541 & 0,48 & 0,22174 & 0,47 & 0,090 & 0,10 & 0,977 & 1291 & \pm 05 & 1343 & \pm 06 & 1427 & \pm 02 \\
\hline $\mathrm{NM}(-1) \mathrm{c}$ & 0,003 & 690 & 160 & 2207 & 2,8041 & 0,57 & 0,22642 & 0,56 & 0,090 & 0,11 & 0,982 & 1316 & \pm 08 & 1357 & \pm 08 & 1422 & \pm 02 \\
\hline $\mathrm{NM}(-1) \mathrm{d}$ & 0,005 & 646 & 134 & 1540 & 2,3825 & 0,85 & 0,19469 & 0,72 & 0,089 & 0,42 & 0,870 & 1147 & \pm 09 & 1237 & \pm 11 & 1399 & \pm 08 \\
\hline & & & & & & & & & & & & & & & & & \\
\hline \multicolumn{18}{|c|}{ MT97-120 E Augen-Gnaisse Cardoso. } \\
\hline $\mathrm{NM}(-1) \mathrm{L}[1]$ & 0,010 & 345 & 95 & 4640 & 2,9933 & 0,64 & 0,24113 & 0,58 & 0,090 & 0,24 & 0,926 & 1393 & \pm 13 & 1406 & \pm 13 & 1426 & \pm 05 \\
\hline $\mathrm{M}(-1) \mathrm{M}[1]$ & 0,015 & 5505 & 1374 & 4105 & 3,0146 & 0,51 & 0,24321 & 0,51 & 0,090 & 0,10 & 0,981 & 1403 & \pm 07 & 1411 & \pm 14 & 1423 & \pm 02 \\
\hline $\mathrm{M}(-1) \mathrm{A}[1]$ & 0,006 & 554 & 144 & 646 & 2,9157 & 0,58 & 0,23506 & 0,58 & 0,090 & 0,10 & 0,987 & 1361 & \pm 08 & 1386 & \pm 0.8 & 1425 & \pm 02 \\
\hline $\mathrm{M}(-1) \mathrm{B}[1]$ & 0,002 & 1301 & 333 & 787 & 2,9595 & 0,61 & 0,23888 & 0,61 & 0,090 & 0,10 & 0,988 & 1380 & \pm 08 & 1397 & \pm 08 & 1422 & \pm 02 \\
\hline$M(-1) C[1]$ & 0,003 & 326 & 80 & 263 & 2,9215 & 0,70 & 0,23522 & 0,69 & 0,090 & 0,08 & 0,993 & 1362 & \pm 09 & 1388 & \pm 10 & 1427 & \pm 02 \\
\hline $\mathrm{M}(-1) \mathrm{D}[1]$ & 0,016 & 728 & 189 & 822 & 3,0504 & 0,59 & 0,24614 & 0,59 & 0,090 & 0,09 & 0,988 & 1419 & \pm 08 & 1420 & \pm 08 & 1423 & \pm 02 \\
\hline \multicolumn{18}{|c|}{ MT97-120 P Veio no Augen-Gnaisse Cardoso. } \\
\hline $\mathrm{NM}(-1]$ "D" & 0,008 & 163 & 39 & 497 & 2,7700 & 1,40 & 0,22548 & 1,39 & 0,089 & 0,18 & 0,991 & 1311 & \pm 18 & 1347 & \pm 18 & 1406 & \pm 04 \\
\hline $\mathrm{NM}(-1)$ "F" & 0,004 & 296 & 64 & 555 & 2,5467 & 1,67 & 0,20584 & 1,66 & 0,090 & 0,18 & 0,994 & 1206 & \pm 19 & 1285 & \pm 20 & 1420 & \pm 03 \\
\hline $\mathrm{NM}(-1)$ "K" & 0,006 & 42 & 12 & 217 & 2,9976 & 2,72 & 0,24258 & 2,66 & 0,089 & 0,51 & 0,982 & 1400 & \pm 36 & 1401 & \pm 37 & 1403 & \pm 10 \\
\hline $\mathrm{NM}(-1) \mathrm{O}$ & 0,012 & 1425 & 272 & 394 & 1,9602 & 2,98 & 0,16648 & 2,85 & 0,086 & 0,83 & 0,960 & 983 & \pm 27 & 1102 & \pm 31 & 1344 & \pm 16 \\
\hline NM(-1)"L" & 0,009 & 300 & 79 & 603 & 2,8940 & 0,85 & 0,23956 & 0,73 & 0,088 & 0,41 & 0,876 & 1384 & \pm 10 & 1380 & \pm 11 & 1374 & \pm 08 \\
\hline $\mathrm{NM}(-1) \mathrm{N}$ & 0,002 & 1093 & 240 & 4227 & 2,6447 & 1,07 & 0,21401 & 0,81 & 0,090 & 0,69 & 0,763 & 1250 & \pm 10 & 1318 & \pm 13 & 1419 & \pm 13 \\
\hline $\mathrm{NM}(-1) \mathrm{M}$ & 0,002 & 248 & 66 & 440 & 3,0183 & 1,48 & 0,24319 & 1,46 & 0,090 & 0,23 & 0,987 & 1403 & \pm 20 & 1412 & \pm 21 & 1426 & \pm 05 \\
\hline $\mathrm{NM}(-1) \mathrm{E}$ & 0,003 & 710 & 28 & 139 & 0,3512 & 1,91 & 0,02846 & 1,86 & 0,090 & 0,41 & 0,977 & 181 & \pm 33 & 306 & \pm 58 & 1415 & \pm 08 \\
\hline & & & & & & & & & & & & & & & & & \\
\hline \multicolumn{18}{|c|}{ MT97-123 Granito Carrapato } \\
\hline NM(-1) D [1] & 0,007 & 1371 & 261 & 1779 & 2,2334 & 0,54 & 0,18009 & 0,53 & 0,090 & 0,14 & 0,968 & 1068 & \pm 06 & 1192 & \pm 06 & 1424 & \pm 03 \\
\hline $\mathrm{NM}(-1)$ A $[1]$ & 0,005 & 254 & 66 & 1017 & 3,8549 & 0,95 & 0,23256 & 0,94 & 0,120 & 0,16 & 0,986 & 1348 & \pm 12 & 1604 & \pm 15 & 1960 & \pm 03 \\
\hline $\mathrm{NM}(-1) \mathrm{D}[1$ & 0,003 & 1355 & 144 & 503 & 1,9118 & 0,69 & 0,16015 & 0,63 & 0,087 & 0,29 & 0,908 & 958 & \pm 06 & 1085 & \pm 07 & 1351 & \pm 06 \\
\hline $\mathrm{NM}(-1) \mathrm{C}[1]$ & 0,003 & 1204 & 242 & 728 & 2,3241 & 0,62 & 0,18459 & 0,61 & 0,091 & 0,09 & 0,988 & 1092 & \pm 07 & 1220 & \pm 07 & 1453 & \pm 02 \\
\hline $\mathrm{NM}(1)$ [1] & 0,003 & 460 & 76 & 452 & 1,7309 & 1,16 & 0,15312 & 1,15 & 0,082 & 0,16 & 0,991 & 918 & \pm 11 & 1020 & \pm 12 & 1245 & \pm 03 \\
\hline MT97-135: G & anito $\mathrm{S}$ & Elina & & & & & & & & & & & & & & & \\
\hline
\end{tabular}




\begin{tabular}{|c|c|c|c|c|c|c|c|c|c|c|c|c|c|c|c|c|c|}
\hline $\mathrm{M}(0)[1]$ & 0,005 & 1657 & 389 & 1310 & 2,8145 & 0,85 & 0,22643 & 0,85 & 0,090 & 0,08 & 0,996 & 1315 & \pm 12 & 1359 & \pm 12 & 1429 & \pm 02 \\
\hline $\mathrm{M}(1)[1]$ & 0,007 & 2584 & 591 & 2529 & 2,7710 & 0,47 & 0,22366 & 0,46 & 0,090 & 0,06 & 0,990 & 1301 & \pm 06 & 1348 & \pm 06 & 1423 & \pm 01 \\
\hline $\mathrm{M}(2)[1]$ & 0,011 & 1312 & 317 & 2272 & 2,9744 & 0,70 & 0,23853 & 0,70 & 0,090 & 0,10 & 0,990 & 1379 & \pm 10 & 1401 & \pm 10 & 1435 & \pm 02 \\
\hline $\mathrm{M}(1) \mathrm{sm}$ & 0,001 & 720 & 293 & 89 & 2,8456 & 1,50 & 0,22861 & 1,34 & 0,090 & 0,61 & 0,913 & 1327 & \pm 30 & 1368 & \pm 33 & 1431 & \pm 12 \\
\hline \multicolumn{17}{|c|}{ MT97-140 Tonalito Pau-a-Pique } & \\
\hline $\mathrm{M}(0)[1] \mathrm{B}$ & 0,007 & 633 & 160 & 892 & 2,7974 & 0,55 & 0,22621 & 0,78 & 0,090 & 0,13 & 0,973 & 1315 & \pm 07 & 1355 & \pm 07 & 1419 & \pm 02 \\
\hline $\mathrm{M}(1)[1] \mathrm{C}$ & 0,003 & 710 & 183 & 685 & 2,8586 & 0,66 & 0,22890 & 0,59 & 0,091 & 0,28 & 0,902 & 1329 & \pm 08 & 1371 & \pm 09 & 1438 & \pm 05 \\
\hline $\mathrm{M}(2)[1]$ & 0,003 & 1111 & 258 & 1219 & 2,6564 & 0,90 & 0,21679 & 0,90 & 0,089 & 0,11 & 0,992 & 1265 & \pm 11 & 1316 & \pm 12 & 1401 & \pm 02 \\
\hline $\mathrm{M}(-1)^{" 1 \mathrm{~J}}$ & 0,002 & 385 & 126 & 121 & 2,5291 & 2,16 & 0,21525 & 1,88 & 0,085 & 0,97 & 0,894 & 1257 & \pm 23 & 1280 & \pm 27 & 1320 & \pm 19 \\
\hline $\mathrm{M}(-1)^{\prime \prime} \mathrm{I}^{\prime \prime}$ & 0,002 & 313. & 88 & 294 & 2,9913 & 1,18 & 0,23862 & 1,14 & 0,091 & 0,27 & 0,973 & 1380 & \pm 16 & 1405 & \pm 17 & 1445 & \pm 05 \\
\hline \multirow{2}{*}{\multicolumn{17}{|c|}{ MT97-141 Granito Maraboa }} & \\
\hline $\mathrm{M}(2)[1]$ & 0,005 & 295 & 106 & 122 & 2,7553 & 0,68 & 0,22284 & 0,52 & 0,090 & 0,42 & 0,792 & 1297 & \pm 07 & 1342 & \pm 09 & & \pm 08 \\
\hline $\mathrm{M}(3)[3]$ & 0,006 & 297 & 72 & 215 & 2,2306 & 0,55 & 0,18563 & 0,52 & 0,087 & 0,19 & 0,938 & 1098 & \pm 06 & 1191 & \pm 07 & 1364 & \pm 04 \\
\hline $\mathrm{M}(5)[1]$ & 0,006 & 1949 & 272 & 541 & 1,2809 & 1,34 & 0,12361 & 1,31 & 0,075 & 0,29 & 0,977 & 751 & \pm 10 & 837 & \pm 11 & 1073 & \pm 06 \\
\hline $\mathrm{M}(2)[1]$ & 0,006 & 1432 & 295 & 144 & 1,5902 & 0,61 & 0,14017 & 0,56 & 0,082 & 0,24 & 0,920 & 846 & \pm 07 & 966 & \pm 09 & 1252 & \pm 05 \\
\hline \multirow[t]{2}{*}{$\mathrm{M}(3)[3]$} & 0,003 & 835 & 152 & 263. & 1,5754 & 1,10 & 0,14366 & 0,78 & 0,080 & 0,76 & 0,719 & 865 & \pm 07 & 961 & \pm 07 & 1186 & \pm 15 \\
\hline & & & & & 0,0010 & 0,00 & 0,00100 & 0,00 & & & 0,999 & & & & & & \\
\hline \multicolumn{18}{|c|}{ MT97-168 Granito Fazenda Ellus } \\
\hline $\mathrm{NM}(2)[1]$ & 0,005 & 388 & 90 & 388 & 2,4538 & 0,62 & 0,19853 & 0,60 & 0,090 & 0,15 & 0,971 & 1167 & \pm 07 & 1259 & \pm 08 & 1418 & \pm 03 \\
\hline $\mathrm{M}(1)[1]$ & 0,001 & 1019 & 277 & 323 & 2,8948 & 0,86 & 0,23331 & 0,82 & 0,090 & 0,24 & 0,961 & 1351 & \pm 11 & 1381 & \pm 11 & 1425 & \pm 05 \\
\hline $\mathrm{M}(2)[1]$ & 0,003 & 351 & 81 & 297 & 2,3980 & 1,24 & 0,19271 & 1,14 & 0,090 & 0,46 & 0,928 & 1136 & \pm 13 & 1242 & \pm 15 & 1431 & \pm 09 \\
\hline $\mathrm{M}(2)$ "I" & 0,002 & 301 & 86 & 112 & 2,2289 & 1,42 & 0,18152 & 1,35 & 0,089 & 0,43 & 0,954 & 1075 & \pm 14 & 1190 & \pm 16 & 1404 & \pm 08 \\
\hline $\mathrm{M}(2)$ "J" & 0,005 & 292 & 77 & 168 & 2,3132 & 0,79 & 0,18775 & 0,74 & 0,089 & 0,27 & 0,939 & 1109 & \pm 06 & 1216 & \pm 011 & 1412 & \pm 05 \\
\hline \multicolumn{18}{|c|}{ MT97-169 Granito Garimpo Ellus } \\
\hline $\mathrm{NM}(1)$ I [3] & 0,002 & 787 & 205 & 228 & 2,5589 & 1,43 & 0,20635 & 1,24 & 0,090 & 0,69 & 0,874 & 1209 & \pm 15 & 1289 & \pm 18 & 1424 & \pm 13 \\
\hline $\mathrm{M}(1)[4]$ & 0,013 & 659 & 165 & 159 & 2,1174 & 1,00 & 0,17404 & 0,91 & 0,088 & 0,42 & 0,909 & 1034 & \pm 09 & 1155 & \pm 12 & 1388 & \pm 08 \\
\hline $\mathrm{M}(2)[4]$ & 0,015 & 212 & 44 & 119 & 1,5468 & 1,66 & 0,13337 & 1,21 & 0,084 & 1,07 & 0,766 & 806 & \pm 10 & 949 & \pm 15 & 1295 & \pm 21 \\
\hline $\mathrm{NM}(1)$ "F" & 0,003 & 184 & 50 & 132 & 2,2305 & 2,02 & 0,18371 & 1,84 & 0,088 & 0,77 & 0,926 & 1087 & \pm 20 & 1191 & \pm 23 & 1384 & \pm 15 \\
\hline $\mathrm{NM}(1)$ "E" & 0,003 & 141 & 41 & 226 & 2,9061 & 1,66 & 0,23391 & 1,56 & 0,090 & 0,54 & 0,946 & 1355 & \pm 20 & 1383 & \pm 23 & 1428 & \pm 10 \\
\hline $\mathrm{NM}(1)$ "H" & 0,003 & 84 & 25 & 143 & 2,7118 & 2,68 & 0,21959 & 2,60 & 0,090 & 0,60 & 0,975 & 1280 & \pm 33 & 1331 & \pm 34 & 1416 & \pm 11 \\
\hline
\end{tabular}




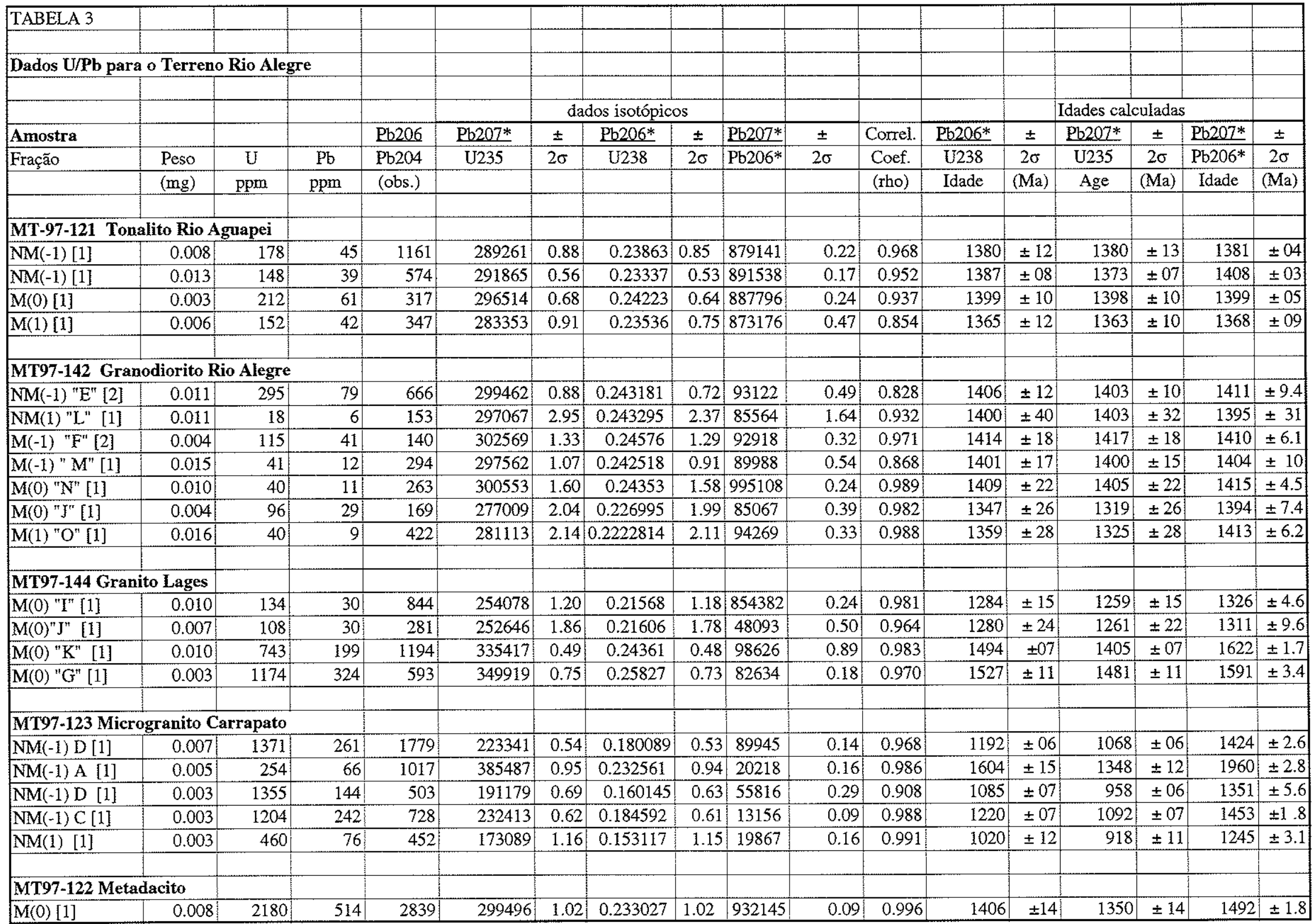




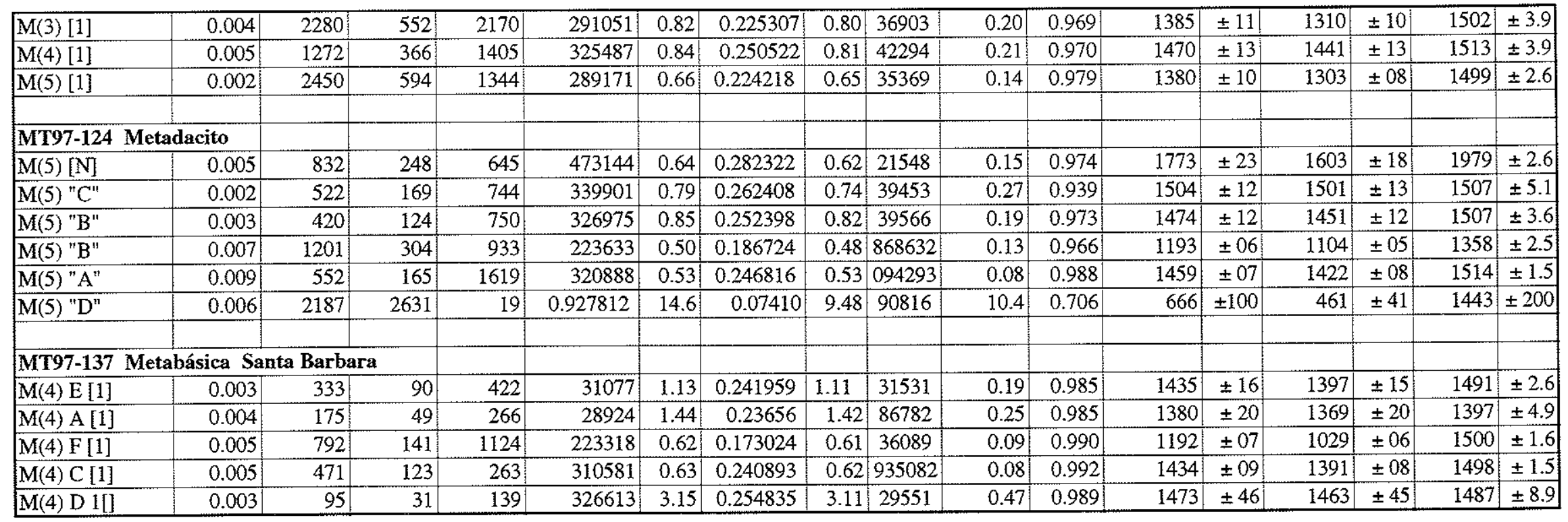




\begin{tabular}{|c|c|c|c|c|c|c|c|c|c|c|c|c|c|c|c|c|c|}
\hline TABELA 4 & & & & & & & & & & & & & & & & & \\
\hline & & & & & & & & & & & & & & & & & \\
\hline \multicolumn{18}{|c|}{ Dados U/Pb para a Suite Rio Branco } \\
\hline & & & & & & & & & & & & & & & & & \\
\hline & & & & & & \multicolumn{3}{|c|}{ dados isotópicos } & & & & & & \multicolumn{3}{|c|}{ Idades calculadas } & \\
\hline Amostra & & & & $\mathrm{Pb} 206$ & $\mathrm{~Pb} 207^{*}$ & \pm & $\mathrm{Pb206*}$ & \pm & $\mathrm{Pb} 207^{*}$ & \pm & Correl. & $\mathrm{Pb} 206^{*}$ & \pm & $\mathrm{Pb207*}$ & \pm & $\mathrm{Pb} 207^{*}$ & \pm \\
\hline \multirow[t]{2}{*}{ Fração } & Peso & $\mathrm{U}$ & $\mathrm{Pb}$ & $\mathrm{Pb} 204$ & U235 & $2 \sigma$ & $\mathrm{U} 238$ & $2 \sigma$ & $\mathrm{Pb} 206^{*}$ & $2 \sigma$ & Coef. & U238 & $2 \sigma$ & $\mathrm{U} 235$ & $2 \sigma$ & $\mathrm{Pb} 206^{*}$ & $2 \sigma$ \\
\hline & (mg) & $\mathrm{ppm}$ & $\mathrm{ppm}$ & & & & & & & & (rho) & Idade & $(\mathrm{Ma})$ & Age & (Ma) & Idade & (Ma) \\
\hline & & & & & & & & & & & & & & & & & \\
\hline \multicolumn{18}{|c|}{ Rb-04 Gabro Rio Branco } \\
\hline $\mathrm{M}(5) ") "[2]$ & 0.005 & 440 & 92 & 886 & 254360 & 1.21 & 0.200645 & 1.14 & 0.0919431 & 0.40 & 0.943 & 1285 & \pm 16 & 1179 & \pm 13 & 1466 & \pm 7.6 \\
\hline $\mathrm{M}(5){ }^{\prime \prime} \mathrm{L}^{\prime}[1]$ & 0.003 & 497 & 137 & 616 & 248892 & 0.64 & 0.204268 & 0.62 & 0.088371 & 0.15 & 0.970 & 1269 & \pm 08 & 1198 & \pm 07 & 1391 & \pm 03 \\
\hline $\mathrm{M}(5)^{\prime \prime} \mathrm{M}^{\prime}[1]$ & 0.002 & 517 & 108 & 569 & 175669 & 0.75 & 0.154678 & 0.73 & 0.0823696 & 0.18 & 0.969 & 1030 & \pm 07 & 927 & \pm 06 & 1254 & \pm 3.6 \\
\hline$M(5) " A "$ & 0.004 & 788 & 207 & 998 & 220494 & 0.53 & 0.187308 & 0.52 & 0.0853766 & 0.11 & 0.980 & 1183 & \pm 06 & 1107 & \pm 06 & 1324 & \pm 2.1 \\
\hline$M(5)$ "E" & 0.002 & 193 & 59 & 494 & 324695 & 1.64 & 0.255522 & 1.28 & 0.0921608 & 0.97 & 0.805 & 1468 & \pm 23 & 1467 & \pm 18 & 1471 & \pm 18 \\
\hline & & & & & & & & & & & & & & & & & \\
\hline \multicolumn{18}{|c|}{ Rb-10 Granófiro Rio Branco } \\
\hline $\mathrm{NM}(0)[1]$ & 0.002 & 133 & 38 & 520 & 302076 & 1.20 & 0.24357 & 1.17 & 0.0899476 & 0.24 & 0.980 & 1413 & \pm 17 & 1405 & \pm 16 & 1424 & \pm 4.5 \\
\hline $\mathrm{M}(0)[1]$ & 0.002 & 293 & 90 & 1004 & 360336 & 0.79 & 0.26520 & 0.77 & 0.0985452 & 0.18 & 0.974 & 1550 & \pm 12 & 1516 & \pm 12 & 1597 & \pm 3.3 \\
\hline $\mathrm{M}(1)[1]$ & 0.003 & 299 & 78 & 1525 & 294396 & 0.70 & 0.23779 & 0.68 & 0.0897924 & 0.17 & 0.969 & 1393 & \pm 10 & 1375 & \pm 09 & 1421 & \pm 3.3 \\
\hline $\mathrm{M}(2)[1]$ & 0.002 & 280 & 77 & 686 & 296879 & 0.82 & 0.23951 & 0.80 & 0.0899009 & 0.18 & 0.976 & 1400 & \pm 11 & 1384 & \pm 119 & 1423 & \pm 3.4 \\
\hline
\end{tabular}




\begin{tabular}{|c|c|c|c|c|c|c|c|c|c|c|c|c|c|c|c|c|c|}
\hline TABELA 5 & & & & & & & & & & & & & & & & & \\
\hline & & & & & & & & & & & & & & & & & \\
\hline \multicolumn{18}{|c|}{ Dados U/Pb para a Suite São Domingos } \\
\hline & & & & & & & & & & & & & & & & & \\
\hline & & & & & & \multicolumn{3}{|c|}{ dados isotópicos } & & & & & & \multicolumn{3}{|c|}{ Idades calculadas } & \\
\hline Amostra & & & & $\mathrm{PB} 206$ & $\mathrm{~Pb} 207^{*}$ & \pm & $\mathrm{Pb} 206^{*}$ & \pm & $\mathrm{Pb} 207^{*}$ & \pm & Correl. & $\mathrm{Pb} 206^{*}$ & \pm & $\mathrm{Pb} 207^{*}$ & \pm & $\mathrm{Pb} 207^{*}$ & \pm \\
\hline \multirow[t]{2}{*}{ Fração } & Peso & $\mathrm{U}$ & $\mathrm{Pb}$ & $\mathrm{Pb} 204$ & $\mathrm{U} 235$ & $2 \sigma$ & $\mathrm{U} 238$ & $2 \sigma$ & $\mathrm{Pb} 206^{*}$ & $2 \sigma$ & Coef. & $\mathrm{U} 238$ & $2 \sigma$ & $\mathrm{U} 235$ & $2 \sigma$ & $\mathrm{Pb} 206 *$ & $2 \sigma$ \\
\hline & $(\mathrm{mg})$ & ppm & $\mathrm{ppm}$ & (obs.) & & & & & & & (rho) & Idade & $(\mathrm{Ma})$ & Age & (Ma) & Idade & (Ma) \\
\hline & & & & & & & & & & & & & & & & & \\
\hline \multicolumn{18}{|c|}{ MT97-118a Granito Sao Domingos (Granada) } \\
\hline $\mathrm{M}(5) \mathrm{C}[1]$ & 0.005 & 783 & 126 & 301 & 132927 & 0.75 & 0.138301 & 0.70 & 0.0697085 & 0.27 & 0.932 & 859 & \pm 06 & 835 & \pm 06 & 920 & \pm 5.6 \\
\hline $\mathrm{M}(5) \mathrm{B}[1]$ & 0.004 & 550 & 85 & 400 & 139313 & 0.93 & 0.144545 & 0.91 & 0.00699016 & 0.20 & 0.976 & 886 & \pm 08 & 870 & \pm 08 & 925 & \pm 4.2 \\
\hline $\mathrm{M}(5) \mathrm{A}[1]$ & 0.005 & 523 & 71 & 327 & 115406 & 0.95 & 0.121182 & 0.88 & 0.0690698 & 0.33 & 0.936 & 779 & \pm 07 & 737 & \pm 06 & 901 & \pm 6.9 \\
\hline $\mathrm{NM}(0) \mathrm{C} 2$ [1] & 0.003 & 1804 & 294 & 198 & 121994 & 0.70 & 0.128488 & 0.67 & 0.0688615 & 0.23 & 0.943 & 810 & \pm 06 & 779 & \pm 05 & 895 & \pm 4.8 \\
\hline $\mathrm{M}(5) \mathrm{D}[1]$ & 0.011 & 649 & 134 & 1140 & 195943 & 0.53 & 0.20308 & 0.52 & 0.0699778 & 0.09 & 0.985 & 1102 & \pm 05 & 1192 & \pm 06 & 928 & \pm 1.9 \\
\hline $\mathrm{M}(5)) \mathrm{B} 2[1]$ & 0.005 & 754 & 188 & 411 & 218919 & 0.64 & 0.226731 & 0.60 & 0.0700279 & 0.22 & 0.939 & 1177 & \pm 07 & 1317 & \pm 08 & 929 & \pm 4.6 \\
\hline $\mathrm{M}(5) \mathrm{C} 2[1]$ & 0.005 & 75 & 18 & 418 & 222387 & 1.36 & 0.2330144 & 1.34 & 0.0700822 & 0.18 & 0.991 & 1189 & \pm 15 & 1335 & \pm 17 & 931 & \pm 3.7 \\
\hline $\mathrm{M}(5)) \mathrm{A} 2[1]$ & 0.006 & 311 & 72 & 282 & 187157 & 0.78 & 0.195166 & 0.76 & 0.0695506 & 0.17 & 0.976 & 1071 & \pm 08 & 1149 & \pm 09 & 915 & \pm 3.5 \\
\hline & & & & & & & & & & & & & & & & & \\
\hline \multicolumn{18}{|c|}{ MT97-118b Granito Sao Domingos } \\
\hline $\mathrm{NM}(0)$ "F" [1] & 0.005 & 1069 & 193 & 242 & 141232 & 0.54 & 0.14596 & 0.61 & 0.0701755 & 0.18 & 0.958 & 894 & \pm 06 & 878 & \pm 05 & 934 & \pm 3.7 \\
\hline $\mathrm{NM}(0)^{\prime \prime} \mathrm{A}^{\prime \prime}[1]$ & 0.003 & 1153 & 167 & 584 & 136693 & 1.56 & 0.13881 & 1.44 & 0.0714203 & 0.57 & 0.931 & 875 & \pm 14 & 874 & \pm 12 & 970 & \pm 12 \\
\hline $\mathrm{M}(0))^{\prime \prime} \mathrm{G}^{\prime}[1]$ & 0.005 & 1423 & 236 & 336 & 139908 & 0.80 & 0.14462 & 0.77 & 0.070160 & 0.23 & 0.959 & 889 & \pm 07 & 871 & \pm 07 & 933 & \pm 4.6 \\
\hline $\mathrm{M}(1) " \mathrm{H}^{\prime}$ [1] & 0.009 & 869 & 138 & 148 & 1055529 & 0.71 & 0.10919 & 0.65 & 0.0699363 & 0.27 & 0.926 & 730 & \pm 05 & 668 & \pm 04 & 927 & \pm 5.5 \\
\hline NM()) "B" [1] & 0.003 & 782 & 96 & 649 & 117424 & 0.92 & 0.120757 & 0.91 & 0.070525 & 0.15 & 0.986 & 788 & \pm 07 & 735 & \pm 07 & 944 & \pm 3.2 \\
\hline $\mathrm{NM}())$ "M"[1] & 0.005 & 769 & 127 & 266 & 13306 & 0.65 & 0.138272 & 0.62 & 0.0697934 & 0.17 & 0.965 & 859 & \pm 06 & 835 & \pm 05 & 922 & \pm 3.5 \\
\hline
\end{tabular}


ANEXO 2

Resultados geoquímicos 
Rochas Intrusivas do Greenstone Belt Alto Jauru

\begin{tabular}{|c|c|c|}
\hline $\begin{array}{l}\text { Amostra } \\
\mathrm{SiO} 2 \\
\mathrm{Al} 2 \mathrm{O} 3 \\
\mathrm{Fe} 2 \mathrm{O} 3 \\
\mathrm{MnO} \\
\mathrm{MgO} \\
\mathrm{CaO} \\
\mathrm{Na} 2 \mathrm{O} \\
\mathrm{K} 2 \mathrm{O} \\
\mathrm{TiO} 2 \\
\mathrm{P} 2 \mathrm{O} 5 \\
\mathrm{P} . \mathrm{F} \\
\text { Total }\end{array}$ & $\begin{array}{r}97-133 \\
73,42 \\
13,46 \\
3,21 \\
0,06 \\
0,48 \\
1,19 \\
3,92 \\
4,07 \\
0,28 \\
0,07 \\
0,47 \\
100,63\end{array}$ & $\begin{array}{r}97-147 \\
69,87 \\
13,52 \\
6,05 \\
0,17 \\
1,03 \\
1,37 \\
3,48 \\
4,25 \\
0,51 \\
0,14 \\
0,39 \\
100,78\end{array}$ \\
\hline $\mathrm{Be}$ & 2 & 2 \\
\hline $\mathrm{V}$ & -5 & -5 \\
\hline $\mathrm{Cr}$ & 0 & 0 \\
\hline Co & 3,2 & 3,1 \\
\hline $\mathrm{Ni}$ & 11 & -10 \\
\hline $\mathrm{Cu}$ & -10 & 14 \\
\hline $\mathrm{Zn}$ & 43 & 158 \\
\hline $\mathrm{Ga}$ & 15 & 16 \\
\hline $\mathrm{Ge}$ & 1,3 & 1,3 \\
\hline As & 0 & 0 \\
\hline $\mathrm{Rb}$ & 70 & 106 \\
\hline $\mathrm{sr}$ & 212 & 301 \\
\hline $\mathrm{Y}$ & 27 & 35 \\
\hline $\mathrm{Zr}$ & 148 & 139 \\
\hline$\widehat{N b}$ & 8,3 & 7,8 \\
\hline Mo & 1,4 & 0,8 \\
\hline $\mathrm{Ag}$ & $-0,5$ & $-0,5$ \\
\hline In & 0 & 0,1 \\
\hline $\mathrm{Sn}$ & 1 & 2,2 \\
\hline $\mathrm{sb}$ & 0,13 & 0,07 \\
\hline Cs & 0,4 & 0,6 \\
\hline $\mathrm{Ba}$ & 1328 & 1199 \\
\hline $\mathrm{Hf}$ & 4,3 & 3,9 \\
\hline $\mathrm{Ta}$ & 0,49 & 0,22 \\
\hline$w$ & 1,2 & 0,4 \\
\hline $\mathrm{TI}$ & 0,28 & 0,52 \\
\hline $\mathrm{Pb}$ & 11 & 18 \\
\hline $\mathrm{Bi}$ & 0,07 & $-0,05$ \\
\hline Th & 7,18 & 6,37 \\
\hline $\mathrm{U}$ & 2,79 & 1,6 \\
\hline $\mathrm{La}$ & 26 & 35,8 \\
\hline $\mathrm{Ce}$ & 52,7 & 68,6 \\
\hline $\mathrm{Pr}$ & 6,184 & 8,863 \\
\hline $\mathrm{Nd}$ & 24,3 & 36,3 \\
\hline $\mathrm{Sm}$ & 5,05 & 7,66 \\
\hline Eu & 0,936 & 1,771 \\
\hline$G d$ & 3,84 & 6,31 \\
\hline $\mathrm{Tb}$ & 0,65 & 0,95 \\
\hline Dy & 3,84 & 5,44 \\
\hline Ho & 0,82 & 1,1 \\
\hline $\mathrm{Er}$ & 2,67 & 3,33 \\
\hline $\mathrm{Tm}$ & 0,418 & 0,519 \\
\hline $\mathrm{Yb}$ & 2,88 & 3,43 \\
\hline $\mathrm{Lu}$ & 0,435 & 0,537 \\
\hline
\end{tabular}


Rochas plutônicas Intrusivas do Terreno Jauru

\begin{tabular}{|c|c|c|c|c|c|c|c|c|c|c|}
\hline $\begin{array}{l}\text { Amostra } \\
\mathrm{SiO} 2 \\
\mathrm{Al} 2 \mathrm{O} 3 \\
\mathrm{Fe} 2 \mathrm{O} 3 \\
\mathrm{MnO} \\
\mathrm{MgO} \\
\mathrm{CaO} \\
\mathrm{Na} 2 \mathrm{O} \\
\mathrm{K} 2 \mathrm{O} \\
\mathrm{TiO} 2 \\
\mathrm{P} 2 \mathrm{O} 5 \\
\mathrm{P} . \mathrm{F} \\
\text { Total }\end{array}$ & $\begin{array}{r}97-1 \\
73,38 \\
14,05 \\
1,94 \\
0,05 \\
0,32 \\
1,37 \\
3,7 \\
4,66 \\
0,21 \\
0,08 \\
0,58 \\
100,34\end{array}$ & $\begin{array}{r}97-1 \\
44,07 \\
16,63 \\
16,98 \\
0,19 \\
7,17 \\
8,29 \\
2,86 \\
0,83 \\
2,26 \\
0,3 \\
0,39 \\
99,97\end{array}$ & $\begin{array}{r}97-1 \\
73,26 \\
14,21 \\
2,06 \\
0,05 \\
0,47 \\
1,89 \\
3,62 \\
4,09 \\
0,23 \\
0,08 \\
0,27 \\
100,23\end{array}$ & $\begin{array}{r}97-1 \\
70,74 \\
15,55 \\
2,61 \\
0,04 \\
0,78 \\
2,92 \\
4,34 \\
2,72 \\
0,33 \\
0,11 \\
0,59 \\
100,73\end{array}$ & $\begin{array}{r}97-1 \\
73,37 \\
14,04 \\
2,05 \\
0,03 \\
0,4 \\
1,3 \\
3,48 \\
5,14 \\
0,22 \\
0,09 \\
0,68 \\
100,8\end{array}$ & $\begin{array}{r}97.1 \\
70,77 \\
15,34 \\
2,93 \\
0,05 \\
0,83 \\
2,99 \\
4,19 \\
2,62 \\
0,33 \\
0,11 \\
0,76 \\
100,92\end{array}$ & $\begin{array}{r}97-1 \\
68,26 \\
15,73 \\
3,94 \\
0,05 \\
1,02 \\
2,62 \\
4,61 \\
2,79 \\
0,52 \\
0,21 \\
0,46 \\
100,21\end{array}$ & $\begin{array}{r}97-1 \\
67,74 \\
16,24 \\
3,82 \\
0,05 \\
1,29 \\
3,22 \\
3,96 \\
3,15 \\
0,49 \\
0,19 \\
0,75 \\
100,9\end{array}$ & $\begin{array}{r}97-1 \\
71,12 \\
14,77 \\
3,84 \\
0,08 \\
0,91 \\
3,19 \\
4,21 \\
1,77 \\
0,28 \\
0,12 \\
0,63 \\
100,92\end{array}$ & $\begin{array}{r}97-1 \\
55,38 \\
16,21 \\
9,06 \\
0,14 \\
4,76 \\
7,04 \\
3,39 \\
1,91 \\
1,1 \\
0,48 \\
0,5 \\
99,97\end{array}$ \\
\hline $\mathrm{Be}$ & 3 & 2 & 2 & 2 & 1 & 2 & 1 & 2 & 2 & \\
\hline$V$ & 17 & 358 & 9 & 32 & 8 & 26 & 52 & 31 & 33 & 169 \\
\hline $\mathrm{Cr}$ & 0 & 59 & 0 & 0 & 0 & 0 & 0 & 25 & 0 & 89 \\
\hline Co & 1,9 & 76 & 2,6 & 5,4 & 2,5 & 5 & 6,8 & 7,5 & 6,6 & 27 \\
\hline $\mathrm{Ni}$ & 0 & 147 & 24 & 0 & 0 & 0 & 0 & 0 & 0 & 44 \\
\hline $\mathrm{Cu}$ & 0 & 42 & 0 & 0 & 0 & 0 & 0 & 14 & 0 & 42 \\
\hline $\mathrm{Zn}$ & 40 & 138 & 46 & 65 & 37 & 68 & 60 & 79 & 51 & 102 \\
\hline Ga & 18 & 24 & 17 & 19 & 14 & 19 & 16 & 21 & 14 & 20 \\
\hline $\mathrm{Ge}$ & 1,3 & 1,5 & 1,2 & 1 & 1,1 & 1 & 0,8 & 1,2 & 1,3 & 1,3 \\
\hline As & 0 & 0 & 0 & 0 & 0 & 0 & 0 & 7 & 0 & 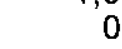 \\
\hline $\mathrm{Rb}$ & 154 & 13 & 123 & 76 & 74 & 71 & 46 & 93 & 39 & 40 \\
\hline $\mathrm{Sr}$ & 270 & 532 & 350 & 628 & 282 & 429 & 552 & 585 & 459 & 763 \\
\hline$Y$ & 30 & 26 & 23 & 22 & 14 & 16 & 19 & 18 & 17 & 30 \\
\hline $\mathrm{Zr}$ & 175 & 137 & 163 & 122 & 187 & 172 & 236 & 165 & 90 & 133 \\
\hline $\mathrm{Nb}$ & 17 & 7,4 & 9,2 & 4,3 & 2,6 & 7,5 & 3 & 8 & 6 & 6,7 \\
\hline Mo & 0,4 & 0,8 & 0,3 & 0,7 & 0,4 & 0,7 & 0,6 & 0,3 & 0,7 & 0,7 \\
\hline $\mathrm{Ag}$ & 0 & 0 & 0 & 0 & 0 & 0 & 0 & 0 & 0 & \\
\hline In & 0 & 0 & 0 & 0 & 0 & 0 & U & 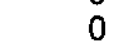 & 0 & \\
\hline Sn & 1,5 & 1,6 & 1,5 & 1,9 & 0,7 & 1,5 & 0,7 & 2,6 & 0,6 & 1,2 \\
\hline $\mathrm{Sb}$ & 0,13 & 0,09 & 0,18 & 0,07 & 0,21 & 0,1 & 0,09 & 0,14 & 0,07 & 0,09 \\
\hline Cs & 1 & 0,4 & 0,9 & 2,3 & 0,4 & 0,6 & 0,4 & 1,9 & 0,4 & 0,5 \\
\hline $\mathrm{Ba}$ & 1160 & 432 & 1505 & 999 & 2376 & 1210 & 2134 & 1057 & 84 & 1002 \\
\hline $\mathrm{Hf}$ & 5,3 & 3,5 & 4,8 & 3,2 & 4,7 & 4,6 & 5,8 & 4,5 & 2 , & 3,7 \\
\hline $\mathrm{Ta}$ & 1,18 & 0,39 & 0,61 & 0,29 & 0,22 & 0,52 & 0,17 & 0,43 & 0,52 & 0,22 \\
\hline W & 0,6 & 1 & 0 & 0,4 & 3 & 0 & 0,2 & 1,9 & 0,3 & 0,5 \\
\hline $\mathrm{TI}$ & 0,92 & 0 & 0,95 & 0,86 & 0,4 & 0,71 & 0,26 & 0,74 & 0,19 & 0,32 \\
\hline $\mathrm{Pb}$ & 35 & 7 & 38 & 14 & 32 & 28 & 19 & 31 & 11 & 12 \\
\hline $\mathrm{Bi}$ & 0 & 0 & 0 & 0 & 0 & 0 & & 0 & 0 & 0,08 \\
\hline Th & 24,1 & 1,52 & 23,4 & 3,67 & 16,3 & 19,6 & 5,75 & 14,6 & 5,14 & 3,7 \\
\hline$U$ & 8,64 & 0,32 & 3,33 & 1,13 & 2,07 & 3,0 & 1,11 & 1,14 & 1,11 & 0,75 \\
\hline La & 50,3 & 20 & 61,9 & 29,7 & 104 & 57,8 & 50,9 & 55,2 & 26,2 & 31 \\
\hline $\mathrm{Ce}$ & 94,3 & 43,4 & 115 & 45,7 & 200 & 105 & 95,6 & 106 & 50,1 & 65, \\
\hline $\mathrm{Pr}$ & 10,77 & 5,566 & 11,83 & 5,511 & 20,79 & 10,39 & 10,93 & 11,27 & 5,595 & 8,027 \\
\hline $\mathrm{Nd}$ & 37,9 & 24,1 & 39,7 & 20,2 & 75 & 36,1 & 41,7 & 41,4 & 20,5 & 34, \\
\hline $\mathrm{Sm}$ & 6,86 & 5,42 & 6,5 & 3,43 & 10,2 & 5,46 & 6,67 & 7,11 & 3,8 & $6,9 t$ \\
\hline Eu & 0,977 & 1,941 & 0,862 & 0,889 & 1,948 & 0,934 & 2,12 & 1,132 & 0,837 & 1,845 \\
\hline $\mathrm{Gd}$ & & 4,9 & 3,97 & 2,8 & 4,8 & 3,35 & 4,01 & 4,88 & 2,63 & \\
\hline $\mathrm{Tb}$ & 0,85 & 0,81 & 0,63 & 0,42 & 0,53 & 0,46 & 0,53 & 0,65 & 0,42 & \\
\hline Dy & 4,67 & 4,53 & 3,52 & 2,45 & 2,54 & 2,5 & 2,7 & 3,25 & 2,49 & 4,87 \\
\hline $\mathrm{Ho}$ & 0, & 0,9 & 0,71 & 0,53 & 0,45 & 0,51 & 0,58 & 0,58 & 0,51 & \\
\hline Er & 2,8 & 2,58 & 2,26 & 1,64 & 1,43 & 1,57 & 1,78 & 1,52 & 1,64 & 2,88 \\
\hline $\mathrm{Tn}$ & 0,433 & 0,358 & 0,344 & 0,224 & 0,155 & 0,242 & 0,219 & 0,18 & 0.25 & 0,433 \\
\hline $\mathrm{Yb}$ & 2,82 & 2,3 & 2,26 & 1,24 & 0,89 & 1,51 & 1,33 & 0,89 & 1,63 & 2,75 \\
\hline $\mathrm{Lu}$ & 0,418 & 0,351 & 0,378 & 0,215 & 0,157 & 0,272 & 0,221 & 0,134 & 0,278 & 0,415 \\
\hline
\end{tabular}


Suite Santa Helena

amostra

97-116fi 97-116co 97-102a

$97-113 \quad 97-140$

$97-141 \quad 97-115$

$97-120$

\begin{tabular}{|c|c|c|c|c|c|c|c|c|}
\hline $\begin{array}{l}\mathrm{SiO} 2 \\
\mathrm{Al} 2 \mathrm{O} 3 \\
\mathrm{FeO} \\
\mathrm{Fe} 2 \mathrm{O} 3 \\
\mathrm{MgO} \\
\mathrm{CaO} \\
\mathrm{Na} 2 \mathrm{O} \\
\mathrm{K} 2 \mathrm{O} \\
\mathrm{TiO} 2 \\
\mathrm{P} 2 \mathrm{O} 5 \\
\mathrm{MnO}\end{array}$ & $\begin{array}{r}73,38 \\
13,25 \\
1,92 \\
0,01 \\
0,025 \\
0,94 \\
3,3 \\
5,49 \\
0,28 \\
0,05 \\
0,04\end{array}$ & $\begin{array}{r}76,17 \\
12,6 \\
0,53 \\
0,34 \\
0,04 \\
0,68 \\
3,02 \\
5,74 \\
0,05 \\
0,04 \\
0,01\end{array}$ & $\begin{array}{r}66,62 \\
15,37 \\
2,9 \\
0,75 \\
1,59 \\
3,12 \\
3,28 \\
3,48 \\
0,58 \\
0,08 \\
0,05\end{array}$ & $\begin{array}{r}55,99 \\
16,15 \\
4,81 \\
1,77 \\
5,14 \\
6,87 \\
3,07 \\
1,2 \\
0,35 \\
0,09 \\
0,12\end{array}$ & $\begin{array}{r}50,02 \\
16,37 \\
5,69 \\
5,44 \\
3,97 \\
8,97 \\
1,78 \\
1,84 \\
1,78 \\
0,09 \\
0,15\end{array}$ & $\begin{array}{r}50,43 \\
12,46 \\
6,25 \\
1,56 \\
11,44 \\
10,92 \\
1,76 \\
0,45 \\
0,6 \\
0,08 \\
0,16\end{array}$ & $\begin{array}{r}77,46 \\
11,47 \\
0,31 \\
1,26 \\
0,06 \\
0,27 \\
2,91 \\
5,27 \\
0,15 \\
0,04 \\
0,02\end{array}$ & $\begin{array}{r}75,51 \\
12,5 \\
1,2 \\
0,56 \\
0,28 \\
1,01 \\
3,66 \\
4 \\
0,23 \\
0,06 \\
0,05\end{array}$ \\
\hline P.F. & 1,26 & 0,91 & 1,97 & 2,76 & 2,75 & 2,89 & 0,96 & 1,13 \\
\hline Total & 99,945 & 100,13 & 99,79 & 98,32 & 98,85 & 99 & 100,18 & 100,19 \\
\hline $\mathrm{Be}$ & 5 & 4 & 2 & 1 & 1 & 1 & 2 & \\
\hline Sc & 10 & 10 & 10 & 17 & 25 & 40 & 10 & 10 \\
\hline V & -5 & -5 & 53 & 89 & 470 & 186 & -5 & -5 \\
\hline $\mathrm{Cr}$ & 17 & 24 & 48 & 162 & 34 & 863 & 16 & 24 \\
\hline Co & 2,1 & 30 & 11 & 40 & 35 & 53 & 38 & \\
\hline $\mathrm{Ni}$ & 0 & 0 & 26 & 85 & 36 & 247 & 0 & \\
\hline $\mathrm{Cu}$ & 0 & 11 & 0 & 114 & 49 & 69 & 0 & 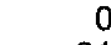 \\
\hline $\mathrm{Zn}$ & 38 & 20 & 73 & 114 & 97 & 73 & 50 & 81 \\
\hline $\mathrm{Ga}$ & 20 & 20 & 21 & 19 & 21 & 14 & 19 & 17 \\
\hline $\mathrm{Ge}$ & 1,7 & 1,6 & 1,4 & 1,5 & 1,6 & 1,8 & 1,9 & 1,7 \\
\hline As & 0 & 0 & 0 & 0 & 0 & 0 & 0 & \\
\hline $\mathrm{Rb}$ & 235 & 228 & 94 & 25 & 62 & 14 & 186 & 134 \\
\hline $\mathrm{Sr}$ & 57 & 48 & 441 & 666 & 626 & 284 & 29 & 101 \\
\hline$Y$ & 74 & 50 & 20 & 7,6 & 12 & 14 & 73 & 50 \\
\hline $\mathrm{Zr}$ & 211 & 47 & 222 & 81 & 50 & 51 & 185 & 137 \\
\hline$\overline{N b}$ & 23 & 19 & 6,5 & 4,9 & 2,3 & 1,9 & 18 & 6,4 \\
\hline Mo & 2,8 & 30 & 0,9 & 6,6 & 1,6 & 1,5 & 1,2 & 2,9 \\
\hline $\mathrm{Ag}$ & 0 & 0 & 0 & 0 & 0 & 0 & 0 & \\
\hline In & 0 & 0 & 0 & 0 & 0 & 0 & 0 & 0 \\
\hline Sn & 8,1 & 1,7 & 3,5 & 1,2 & 1 & 43 & 8,8 & 14 \\
\hline $\mathrm{Sb}$ & 0,11 & 0,13 & 0,43 & 0,27 & 0,6 & 0,28 & 0,14 & 0,22 \\
\hline Cs & 4,4 & 2,4 & 4,5 & 0,5 & 5,4 & 0,2 & 2,1 & 0,9 \\
\hline $\mathrm{Ba}$ & 306 & 216 & 1601 & 428 & 784 & 137 & 326 & 402 \\
\hline $\mathrm{Hf}$ & 8,2 & 2,4 & 6,3 & 1,9 & 1,3 & 1,2 & 6,9 & 4,3 \\
\hline Ta & 2,77 & 7,24 & 0,55 & 0,51 & 0,4 & 0,5 & 4,6 & 0,75 \\
\hline$W$ & 1,3 & 167 & 2,3 & 26 & 30 & 29 & 214 & 1,7 \\
\hline $\mathrm{TI}$ & 2,47 & 2,35 & 0,95 & 0,26 & 0,47 & 0,06 & 2,36 & 1,01 \\
\hline $\mathrm{Pb}$ & 60 & 63 & 32 & 10 & 19 & 15 & 60 & 37 \\
\hline $\mathrm{Bi}$ & 0,57 & 0,38 & 1,66 & 0,21 & 0,69 & 0,47 & 2,74 & 0,66 \\
\hline Th & 23,1 & 22,6 & 4,71 & 1,16 & 1,28 & 0,42 & 13,9 & 15,5 \\
\hline$U$ & 9,82 & 19,1 & 1,63 & 0,7 & 0,52 & 0,15 & 4,22 & 3,87 \\
\hline La & 54,6 & 47,7 & 62,7 & 17,4 & 7,19 & 4,6 & 63,1 & 37, \\
\hline $\mathrm{Ce}$ & 82,6 & 77 & 84,4 & 28,5 & 15,6 & 12 & 91,1 & 53,5 \\
\hline $\mathrm{Pr}$ & 10,78 & 9,151 & 9,968 & 2,949 & 1,871 & 1,738 & 13,78 & 7,173 \\
\hline $\mathrm{Nd}$ & 39,9 & 27,2 & 36,2 & 12 & 9,12 & 8,48 & 56,8 & 28,7 \\
\hline $\mathrm{Sm}$ & 8,43 & 6,11 & 5,65 & 2,13 & 2,18 & 2,1 & 13,2 & 6,5 \\
\hline $\mathrm{Eu}$ & 0,381 & 0,11 & 1,658 & 0,784 & 1,093 & 0,829 & 0,624 & 0,662 \\
\hline $\mathrm{Gd}$ & 8,05 & 5,55 & 4,33 & 1,53 & 2,22 & 2,45 & 12,2 & 6,75 \\
\hline $\mathrm{Tb}$ & 1,65 & 1,32 & 0,71 & 0,27 & 0,36 & 0,44 & 2,36 & 1,27 \\
\hline Dy & 10,6 & 8,37 & 3,56 & 1,27 & 2,01 & 2,32 & 13,5 & 7,4 \\
\hline Ho & 2,46 & 1,78 & 0,69 & 0,24 & 0,4 & 0,5 & 2,85 & 1,5 \\
\hline Er & 8,22 & 5,67 & 1,93 & 0,65 & 1,19 & 1,42 & 8,82 & 5,06 \\
\hline $\mathrm{Tm}$ & 1,485 & 1,066 & 0,255 & 0,091 & 0,184 & 0,187 & 1,404 & 0,861 \\
\hline $\mathrm{Yb}$ & 10,6 & 7,17 & 1,54 & 0,58 & 1,14 & 1,18 & 8,82 & 5,8 \\
\hline Lu & 1,647 & 1,143 & 0,251 & 0,095 & 0,175 & 0,188 & 1,328 & 0,943 \\
\hline
\end{tabular}


Suite Santa Helena (continuação)

$97-108 \quad 97-102 \quad 97-105 \quad 97-127$ TF $97-168 \quad 97-169 \quad 97-106$

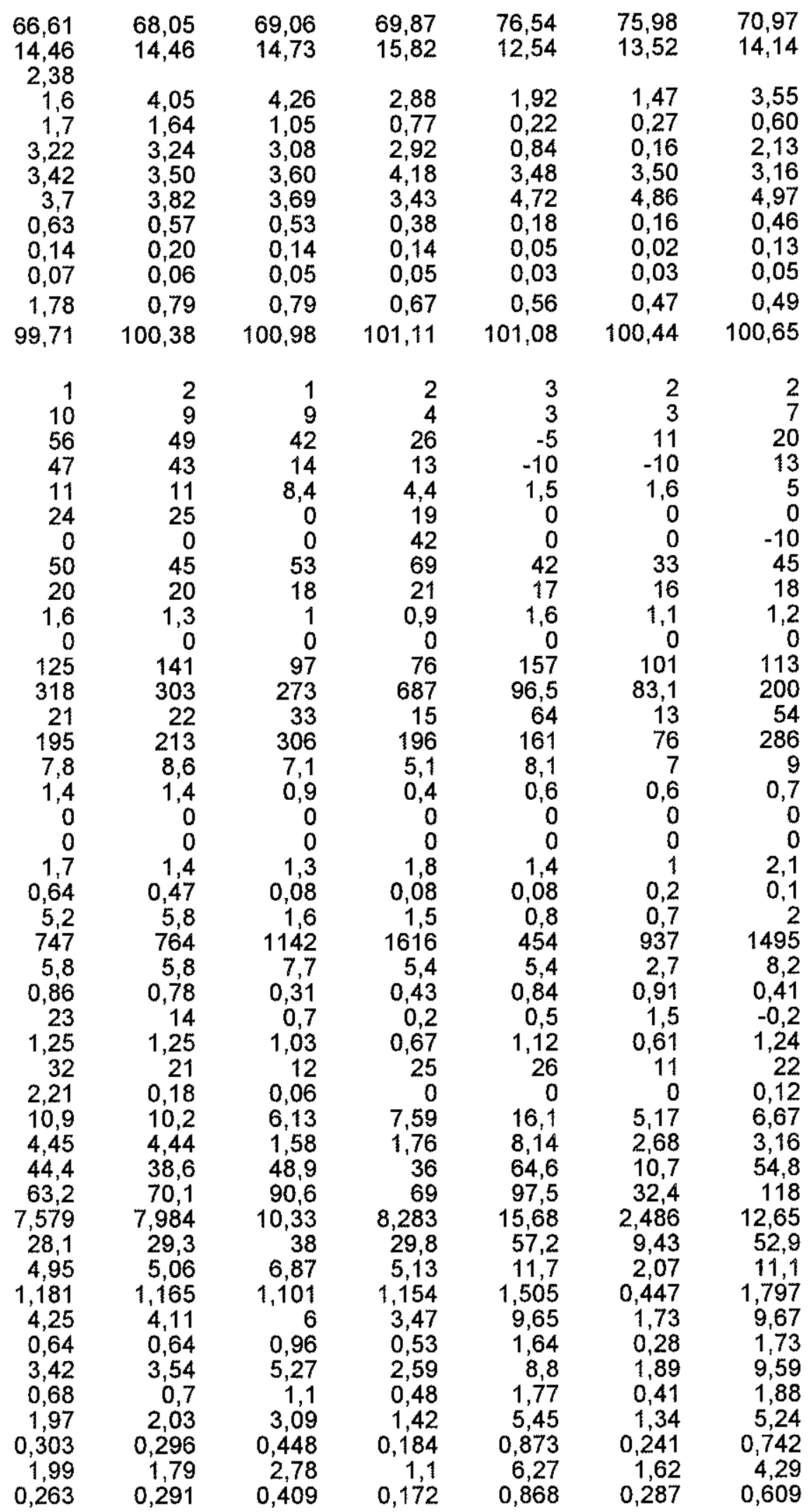


Suite Intrusiva Rio Branco

Amostra RB-01 RB-02 RB-03 RB-04 RB-05 RB-06 RB-07 RB-08

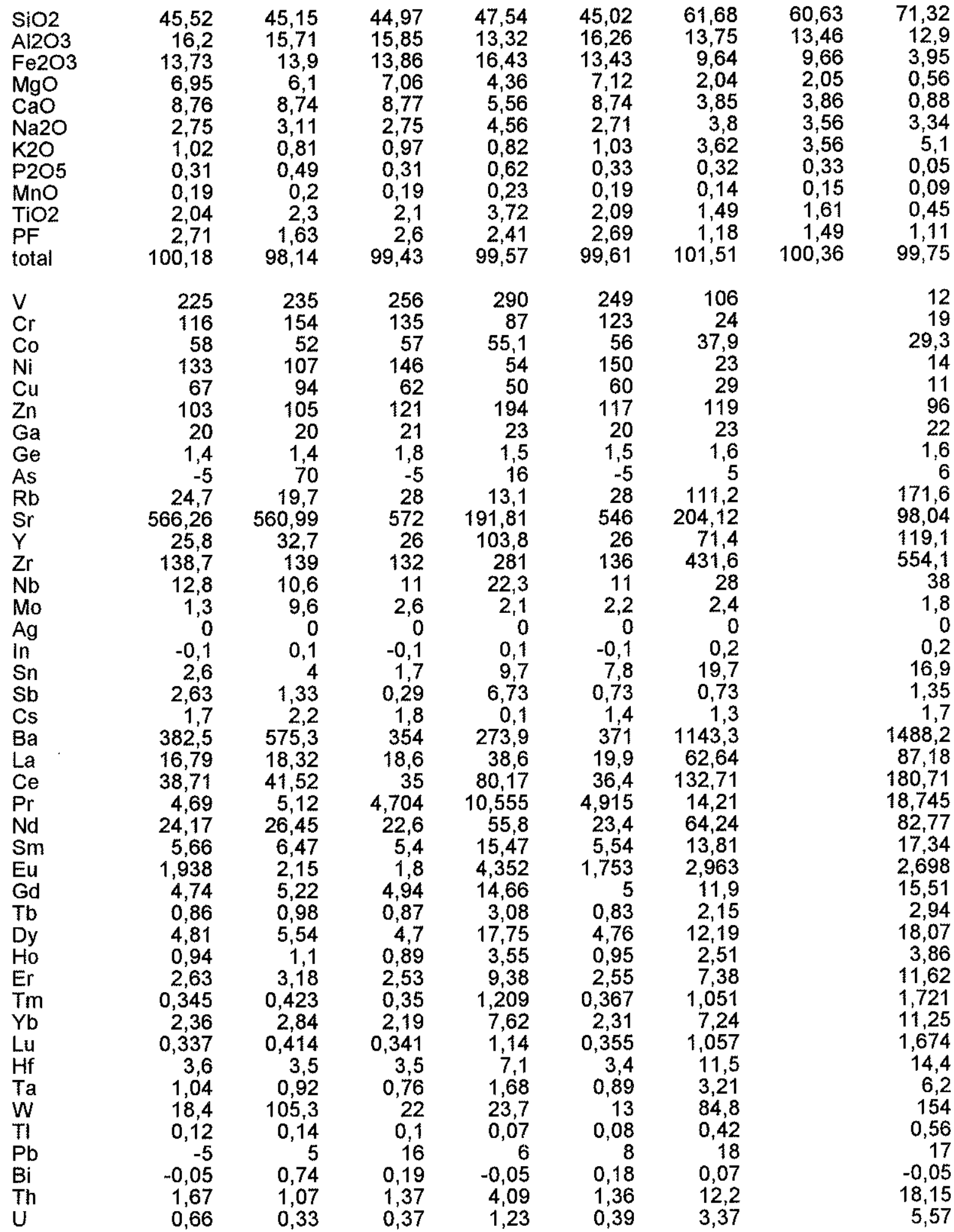


Suíte Intrusiva Rio Branco (continuação)

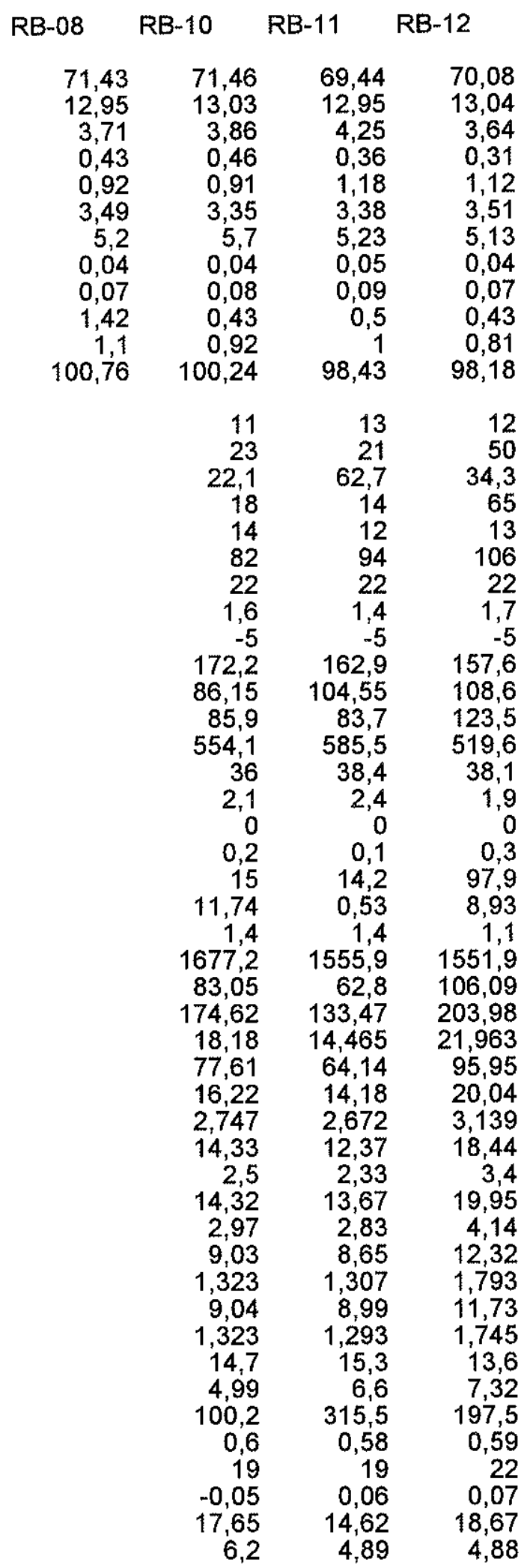


Suítes Guapé e São Domingos

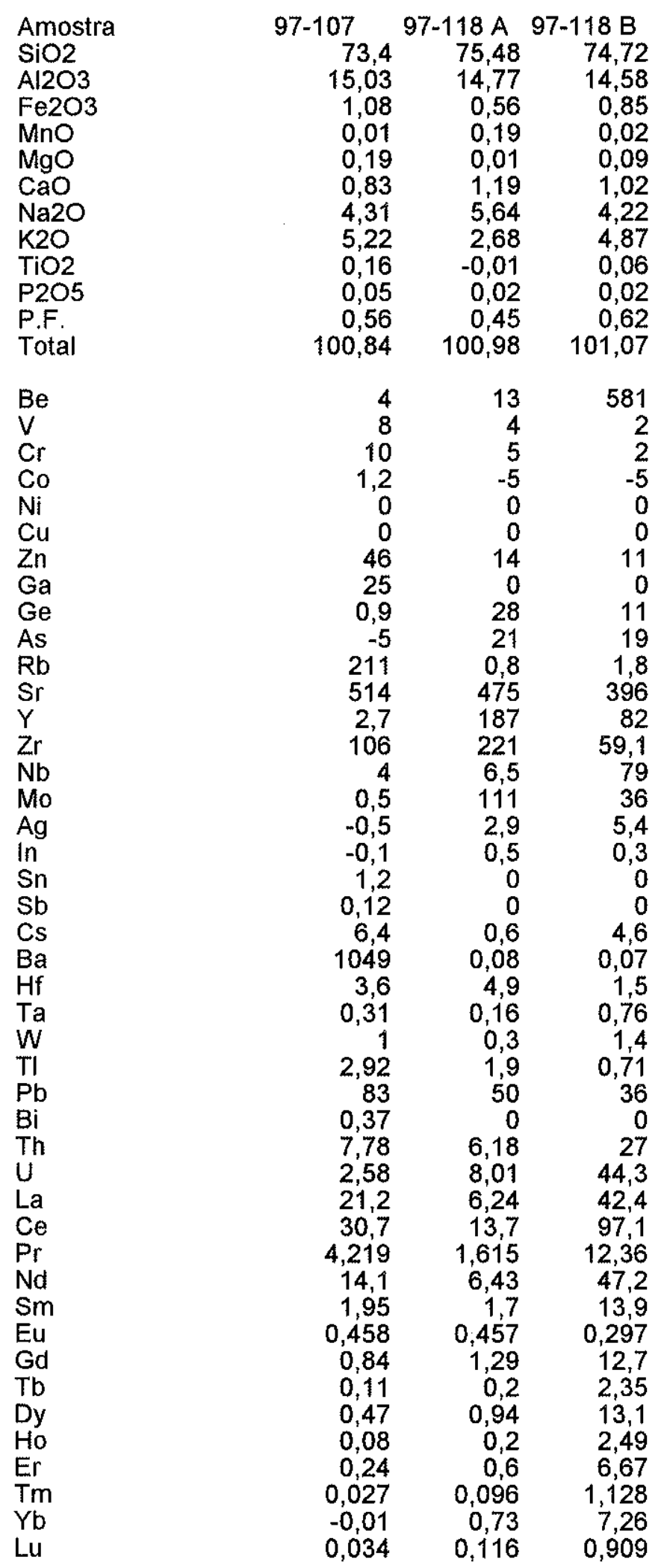


ANEXO 3

\section{Resultados Sm/Nd}


Resultados Sm/Nd para rochas do Terreno Jauru

\begin{tabular}{|c|c|c|c|c|c|c|c|c|c|c|c|}
\hline amostra & localidade & rocha & $\begin{array}{l}\text { idade } \\
\text { U/Pb }\end{array}$ & $\begin{array}{c}\mathrm{Nd} \\
(\mathrm{ppm})\end{array}$ & $\begin{array}{l}\mathrm{Sm} \\
(\mathrm{ppm})\end{array}$ & $\begin{array}{l}147 \mathrm{Sm} / \\
144 \mathrm{Nd}\end{array}$ & $\begin{array}{l}143 \mathrm{Nd} / \\
144 \mathrm{Nd}\end{array}$ & $\begin{array}{c}E(N d) \\
t=0\end{array}$ & $\begin{array}{c}E(\mathrm{Nd}) \\
\mathrm{t}(\mathrm{U} / \mathrm{Pb})\end{array}$ & $\begin{array}{c}\mathrm{T}(\mathrm{DM}) \\
\mathrm{Ma}\end{array}$ & $\mathrm{f}$ \\
\hline $97-129$ & Faz. Alvorada & granito & 1394 & 64,21 & 9,55 & 0,08993 & 0,511595 & $-20,34$ & $-1,27$ & 1773 & $-0,54$ \\
\hline $97-130$ & Araputanga & gabro & 1550 & 23,07 & 4,85 & 0,12716 & 0,512029 & $-11,87$ & 3,94 & 1773 & $-0,35$ \\
\hline $97-131$ & Araputanga & tufo & 1747 & 22,04 & 3,90 & 0,1072 & 0,51174 & $-17,70$ & 2,56 & 1853 & $-0,46$ \\
\hline $97-132$ & S.J.Q.M. & granito & 1546 & 38,65 & 5,96 & 0,09336 & 0,511632 & $-19,62$ & 0,87 & 1777 & $-0,53$ \\
\hline $97-133$ & S.J.Q.M. & gnaisse & 1795 & 34,40 & 6,20 & 0,10889 & 0,511711 & $-18,07$ & 2,16 & 1926 & $-0,45$ \\
\hline $97-134$ & Cachoeirinha & tonalito & 1536 & 25,88 & 5,24 & 0,12247 & 0,511913 & $-14,14$ & 0,48 & 1876 & $-0,38$ \\
\hline $97-136$ & Cachoeirinha & granodiorito & 1468 & 21,61 & 3,48 & 0,09751 & 0,511758 & $-17,16$ & 1,73 & 1675 & $-0,50$ \\
\hline $97-138$ & Cachoeirinha & granito & 1521 & 67,67 & 9,01 & 0,0805 & 0,511501 & $-22,17$ & 0,49 & 1754 & $-0,60$ \\
\hline $97-139$ & Cachoeirinha & granito & 1440 & 35,82 & 5,23 & 0,08834 & 0,511602 & $-20,21$ & $-0,21$ & 1743 & $-0,56$ \\
\hline $97-145$ & Cachoeirinha & granito & 1562 & 38,91 & 5,89 & 0,09165 & 0,511605 & $-20,16$ & 0,89 & 1786 & $-0,53$ \\
\hline $97-147$ & Cachoeirinha & gnaisse & 1587 & 23,70 & 5,97 & 0,12673 & 0,511869 & $-15,01$ & $-0,77$ & 2047 & $-0,36$ \\
\hline $97-148$ & Cachoeirinha & gnaisse & 1586 & 40,40 & 6,72 & 0,10064 & 0,511639 & $-19,48$ & 0,06 & 1882 & $-0,49$ \\
\hline $97-149$ & Cachoeirinha & granito & 1744 & 15,74 & 2,75 & 0,10557 & 0,511712 & $-18,05$ & 2,35 & 1865 & $-0,46$ \\
\hline $97-150$ & Cachoeirinha & tonalito & 1549 & 28,41 & 5,53 & 0,11774 & 0,511884 & $-14,70$ & 0,98 & 1829 & $-0,40$ \\
\hline
\end{tabular}


Resultados Sm/Nd para rochas do Terreno Pontes e Lacerda

\begin{tabular}{|c|c|c|c|c|c|c|c|c|c|c|c|}
\hline amostra & localidade & rocha & $\begin{array}{l}\text { idade } \\
\mathrm{U} / \mathrm{Pb}\end{array}$ & $\begin{array}{c}\mathrm{Nd} \\
(\mathrm{ppm})\end{array}$ & $\begin{array}{l}S m \\
(\mathrm{ppm})\end{array}$ & $\begin{array}{l}147 \mathrm{Sm} / \\
144 \mathrm{Nd}\end{array}$ & $\begin{array}{l}143 \mathrm{Nd} / \\
144 \mathrm{Nd}\end{array}$ & $\begin{array}{c}E(\mathrm{Nd}) \\
t=0\end{array}$ & $\begin{array}{c}E(N d) \\
t(U / P b)\end{array}$ & $\begin{array}{c}\text { T(DM) } \\
\mathrm{Ma}\end{array}$ & $f$ \\
\hline $97-101$ & Rio Sarare & granito & nd & 13,82 & 2,73 & 0,11961 & 0,512131 & $-9,90$ & nd & 1469 & $-0,39$ \\
\hline $97-102$ & F. Trian. & granito & 1445 & 37,14 & 5,97 & 0,09719 & 0,511841 & $-15,54$ & 2,90 & 1563 & $-0,51$ \\
\hline $97-105$ & F. Trian. & gnaisse & 1424 & 37,86 & 6,96 & 0,1111 & 0,511981 & $-12,81$ & 2,83 & 1567 & $-0,44$ \\
\hline $97-106$ & F. Trian. & gnaisse & 1424 & 47,10 & 9,93 & 0,12751 & 0,512194 & $-8,66$ & 3,98 & 1491 & $-0,35$ \\
\hline $97-107$ & F. Guapé & granito & $(\mathrm{Rb} / \mathrm{Sr}) 950$ & 16,81 & 2,34 & 0,08447 & 0,511894 & $-14,52$ & $-0,16$ & nd & $-0,57$ \\
\hline $97-108$ & F. Guapé & gnaisse & 1435 & 16,08 & 3,04 & 0,11445 & 0,512036 & $-11,75$ & 3,39 & 1537 & $-0,42$ \\
\hline $97-113$ & Lavrinha & tonalito & 1464 & 11,97 & 2,11 & 0,10658 & 0,511965 & $-13,12$ & 3,76 & 1532 & $-0,45$ \\
\hline $97-115$ & Rod 374 & granito & 1433 & 47,54 & 10,45 & 0,13289 & 0,512183 & $-8,88$ & 3,08 & 1618 & $-0,32$ \\
\hline $97-118 a$ & S. Domingos & granito & 939 & 4,01 & 1,11 & 0,16712 & 0,512363 & $-5,36$ & 3,08 & 2215 & $-0,15$ \\
\hline $97-118 b$ & S. Domingos & granito & 914 & 4,42 & 1,22 & 0,16711 & 0,512335 & $-5,91$ & 2,90 & 1313 & $-0,15$ \\
\hline $97-120 \mathrm{E}$ & Cardoso & granito & 1423 & 50,20 & 9,41 & 0,11337 & 0,512039 & $-11,69$ & 3,55 & 1516 & $-0,33$ \\
\hline $07-120 \mathrm{~W}$ & Cardoso & granito & 1423 & 18,47 & 3,11 & 0,10194 & 0,51195 & $-13,41$ & 3,88 & 1482 & $-0,42$ \\
\hline $97-120 \mathrm{P}$ & Cardoso & granito & 1411 & 20,76 & 5,25 & 0,15286 & 0,512387 & $-4,89$ & 3,05 & 1628 & $-0,22$ \\
\hline $97-135$ & S.Elina & granito & 1436 & 16,99 & 3,45 & 0,12289 & 0,512114 & $-10,22$ & 2,71 & 1549 & $-0,38$ \\
\hline $97-140$ & Pau-a-Pique & tonalito & 1434 & 9,11 & 2,22 & 0,14737 & 0,512385 & $-4,94$ & 4,14 & 1500 & $-0,25$ \\
\hline $97-141$ & Maraboa & granito & 1449 & 139,35 & 33,39 & 0,14485 & 0,512274 & $-7,11$ & 2,61 & 1698 & $-0,26$ \\
\hline $97-168$ & Faz. Ellus & granito & 1437 & 58,23 & 11,21 & 0,11636 & 0,512068 & $-11,13$ & 3,69 & 1518 & $-0,40$ \\
\hline $97-169$ & Garimpo Ellu & granito & 1444 & 10,05 & 1,99 & 0,11946 & 0,512084 & $-10,80$ & 3,51 & 1514 & $-0,39$ \\
\hline
\end{tabular}


Resultados Sm/Nd para rochas da Súte Intrusiva Rio Branco

\begin{tabular}{|c|c|c|c|c|c|c|c|c|c|c|c|}
\hline amostra & localidade & rocha & $\begin{array}{l}\text { idade } \\
\text { U/Pb }\end{array}$ & $\begin{array}{c}\mathrm{Nd} \\
(\mathrm{ppm})\end{array}$ & $\begin{array}{l}\mathrm{Sm} \\
(\mathrm{ppm})\end{array}$ & $\begin{array}{l}147 \mathrm{Sm} / \\
144 \mathrm{Nd}\end{array}$ & $\begin{array}{l}143 \mathrm{Nd} / \\
144 \mathrm{Nd}\end{array}$ & $\begin{array}{c}E(\mathrm{Nd}) \\
t=0\end{array}$ & $\begin{array}{c}E(\mathrm{Nd}) \\
\mathrm{t}(\mathrm{U} / \mathrm{Pb})\end{array}$ & $\begin{array}{c}\mathrm{T}(\mathrm{DM}) \\
\mathrm{Ma}\end{array}$ & $f$ \\
\hline $\mathrm{Rb}-01$ & S. do Céu & gabro & 1469 & 25,02 & 5,59 & 0,13511 & 0,511595 & $-0,78$ & 1,85 & 1745 & $-0,31$ \\
\hline $\mathrm{Rb}-02$ & S. do Céu & gabro & 1469 & 25,17 & 5,62 & 0,13497 & 0,512029 & $-10,41$ & 1,24 & 1804 & $-0,31$ \\
\hline $\mathrm{Rb}-03$ & S. do Céu & gabro & 1469 & 21,35 & 4,72 & 0,13380 & 0,511740 & $-9,96$ & 1,91 & 1734 & $-0,32$ \\
\hline $\mathrm{Rb}-04$ & S. do Céu & gabro pórfiro & 1469 & 89,82 & 11,29 & 0,07606 & 0,511632 & $-25,10$ & $-2,33$ & 1864 & $-0,61$ \\
\hline $\mathrm{Rb}-05$ & S. do Céu & monzosienito & 1469 & 20,62 & 4,73 & 0,13867 & 0,511711 & $-9,37$ & 1,59 & 1785 & $-0,30$ \\
\hline $\mathrm{Rb}-06$ & S. do Céu & monzosienito & 1423 & 64,33 & 12,69 & 0,11930 & 0,511913 & $-14,12$ & 0,00 & 1811 & $-0,39$ \\
\hline $\mathrm{Rb}-07$ & S. do Céu & monzosienito & 1423 & 58,69 & 12,04 & 0,12410 & 0,511758 & $-13,08$ & 0,16 & 1818 & $-0,37$ \\
\hline Rb-08 & S. do Céu & granófiro & 1423 & 81,12 & 16,08 & 0,11987 & 0,511501 & $-14,34$ & $-0,33$ & 1841 & $-0,39$ \\
\hline $\mathrm{Rb}-09$ & S. do Céu & granófiro & 1423 & 74,28 & 14,49 & 0,11793 & 0,511602 & $-14,85$ & $-0,49$ & 1845 & $-0,40$ \\
\hline$R b-10$ & S. do Céu & granófiro & 1423 & 69,55 & 13,40 & 0,11650 & 0,511605 & $-14,83$ & $-0,20$ & 1816 & $-0,41$ \\
\hline $\mathrm{Rb}-11$ & S. do Céu & granófiro & 1423 & 58,09 & 11,91 & 0,12392 & 0,511869 & $-13,40$ & $-0,13$ & 1842 & $-0,37$ \\
\hline Rb-12 & S. do Céu & granófiro & 1423 & 92,76 & 18,17 & 0,11853 & 0,511639 & $-15,21$ & $-0,96$ & 1886 & $-0,40$ \\
\hline
\end{tabular}


Resultados Sm/Nd para rochas do Terreno Rio Alegre

\begin{tabular}{|c|c|c|c|c|c|c|c|c|c|c|}
\hline amostra & localidade rocha & $\begin{array}{l}\text { idade } \\
\text { U/Pb }\end{array}$ & $\begin{array}{l}\mathrm{Nd} \\
(\mathrm{ppm})\end{array}$ & $\begin{array}{c}\mathrm{Sm} \\
(\mathrm{ppm})\end{array}$ & $\begin{array}{l}147 \mathrm{Sm} / \\
144 \mathrm{Nd}\end{array}$ & $\begin{array}{l}143 \mathrm{Nd} / \\
144 \mathrm{Nd}\end{array}$ & $\begin{array}{c}E(N d) \\
t=0\end{array}$ & $\begin{array}{c}E(\mathrm{Nd}) \\
\mathrm{t}(\mathrm{U} / \mathrm{Pb})\end{array}$ & $\begin{array}{c}\mathrm{T}(\mathrm{DM}) \\
\mathrm{Ma}\end{array}$ & $f$ \\
\hline \multicolumn{11}{|c|}{ Sequência Vulcanossedimentar Rio Alegre } \\
\hline $97-122$ & F. Minour metadac. & 1503 & 9,29 & 2,46 & 0,16007 & 0,512497 & $-2,75$ & 4,32 & 1536 & $-0,19$ \\
\hline $97-124$ & F. Minour metadir. & 1510 & 4,68 & 1,23 & 0,15967 & 0,512412 & $-2,46$ & 4,73 & 1484 & $-0,19$ \\
\hline $97-137$ & Rio Alegre amfibolito & 1494 & 25,12 & 5,19 & 0,12501 & 0,512061 & $-11,26$ & 2,48 & 1677 & $-0,36$ \\
\hline \multicolumn{11}{|c|}{ Domínio Fazenda Reunidas } \\
\hline $97-121$ & R. Aguape tonalito & 1383 & 29,33 & 7,26 & 0,14968 & 0,512397 & $-4,7$ & 3,65 & 1524 & $-0,24$ \\
\hline $97-123$ & F. Minour granito & 1540 & 40,45 & 7,63 & 0,11409 & 0,512063 & $-11,21$ & 4,16 & 1490 & -1042 \\
\hline $97-142$ & Rio Alegre granod. & 1412 & 40,42 & 10,01 & 0,14976 & 0,512375 & $-5,13$ & 3,61 & 1578 & $-0,24$ \\
\hline $97-144$ & Lages granito & 1326 & 49,97 & 9,03 & 0,1093 & 0,511877 & $-14,84$ & 0,01 & 1691 & $-0,44$ \\
\hline $97-144$ & granito & 1578 & 49,97 & 9,90 & 0,1093 & 0,511877 & $-14,84$ & 3,38 & 1691 & $-0,44$ \\
\hline
\end{tabular}




\title{
ANEXO 4
}

\author{
PUBLICAÇÕES VINCULADAS AO TEMA DA TESE
}

GERALDES, M.C., KOZUCH, M., TEIXEIRA, W. e VAN SCHMUS, W.R. (1997a) $\mathrm{U} / \mathrm{Pb}$ constraints on the origin of mesoproterozoic granites of Pontes e Lacerda region, SW Amazonian Craton. South-American Symposium on Isotope Geology. Campos do Jordão-SP. Resumos expandidos, p. 126-128.

GERALDES, M.C., MATOS, J.B. e TEIXEIRA, W. (1997b) A diferenciação magmática da Suíte Intrusiva Rio Branco: Aspectos petrológicos e Geoquímicos. Anais do VI Simpósio de Geologia do Centro-Oeste. Cuiabá-MT. p. 15-17.

GERALDES, M.C., VAN SCHMUS, W.R., KOZUCH, M., FETTER, A.H., TASSINARI, C.C.G., e TEIXEIRA, W. (1998a) Proterozoic granitoids in SW Mato Grosso, Brazil: evidence for a parallel magmatic arcs in SW Amazonia. International Geological Correlation Projet 426: Granite Systems and Proterozoic Lithospheric Process. 1998 International Field Conference: Proterozoic Granite Systems of the Penokean Terrane in Wisconsin. Field Guide and Proceedings Volume, p. 148-149.

GERALDES, M.C., VAN SCHMUS, e W.R TEIXEIRA, W.. (1998b) Age of Proterozoic crust in SW Mato Grosso, Brazil: Evidence for a 1450 Ma magmatic arc in SW Amazonia. The Geological Society of America 1998 Annual Meeting. TorontoCanadá. Abstract with Programs. p. 96-97.

GERALDES, M.C., VAN SCHMUS, W.R. e TEIXEIRA, W. (1998c) Geochronology and geochemistry s tudies of a mesoproterozoic Arc in SW Amazon Craton. American Geophysical Uniuon 1998 Fall Meeting. Eos, Transactions, AGU Volume 79, Número 45,1998 , p. 932.

VAN SCHMUS, W.R GERALDES, M.C., KOZUCH, M., FETTER, A.H., TASSINARI, C.C.G. e TEIXEIRA, W. (1998) U/Pb and $\mathrm{Sm} / \mathrm{Nd}$ constraints on the age and origin of proterozoic crust in southwestern Mato Grosso, Brazil: Evidence for a 1450 Ma magmatic arc in SW Amazonia. Internation Symposium on Tectonics. Ouro Preto-MG. Abstract Volume, p. 121-125.

VAN SCHMUS, W.R, GERALDES, M.C., FETTER, A.H., KOZUCH, M., TASSINARI, C.C.G. e TEIXEIRA, W. (1999) Jauru Terrane: A late Paleoproterozoic orogen in SW Amazon craton, Mato grosso State, Brazil. European Union Geology bianual Meeting. Streisburg, France. Abstract Volume, p.

GERALDES, M.C., VAN SCHMUS, W.R, FETTER, A.H., KOZUCH, M., RUIZ, A., MATOS, J.B., TASSINARI, C.C.G. e TEIXEIRA, W. (1999a) Pre-Rodinia proterozoic magmatic arcs in SW Amazonia craton, Brazil. European Union Geology bianual Meeting, Streisburg, France. Abstract Volume, p. 
GERALDES, M.C., MATOS, J.B., RUIZ, A., FETTER, A.H., KOZUCH, M., VAN SCHMUS, W.R, TASSINARI, C.C.G. e TEIXEIRA, W. (1999b) U/Pb constraints on Proterozoic magmatic arcs in SW Amazonia craton, Brazil. Actas II South American Symposium on Isotope Geology. Cordoba-Argentina, 1999. p. 68-71.

GERALDES, M.C., BETTENCOURT, J.S., VAN SCHMUS, TEIXEIRA, W., e MATOS, J.B. (1999c) The Mesoproterozoic Rio Branco suite, SW Amazon Craton, Brazil: A reconnaissance isotope study on a bimodal magmatic complex. In The origin of Granites and Related Rocks. B. Barbarin (ed.). Abstracts of Forth Hutton Symposium: p. 149.

GERALDES, M.C., BETTENCOURT, J.S., VAN SCHMUS, TEIXEIRA, W. e MATOS, J.B. (1999d) Estudos isotópicos (U/Pb e $\mathrm{Sm} / \mathrm{Nd}$ ) da suíte bimodal anorogênica Rio Branco, SW do Cráton Amazônico. VII Congresso Brasileiro de Geoquímica. Anais, p. 327-329.

GERALDES, M.C., RUIZ, A., MATOS, J.B., e TEIXEIRA, W., (1999e) Geoquímica dos granitóides do Terreno JaurumMato Grosso. Anais do VII Simpósio de Geologia do Centro-Oeste. Brasília-DF, p.67.

BELL, S., CONDIE, K. e GERALDES, M.C. (1999) Origin of arc-related granitoids from the SW Amazon craton: Juvenile crustal additions at 1550-1450 Ma. The Geological Society of America 1999 Annual Meeting. Denver-CO. Abstract with Programs. p. 205.

Trabalhos submetidos

GERALDES, M.C., TEIXEIRA, W. e VAN SCHMUS, W.R. The Rio Alegre Terrane in SW Amazonian craton: a suture zone recording a mesoproterozoic collision. GSA Mettenig, Charlleston, SC. (Março de 2000).

GERALDES, M.C., TEIXEIRA, W. e VAN SCHMUS, W.R. Geologic evolution of the SW Mato Grosso State (SW Amazonian craton): A Review. Precambrian Research.

GERALDES, M.C., MATOS, J.B., RUIZ, A., FETTER, A.H., KOZUCH, M., VAN SCHMUS, W.R, e TEIXEIRA, W., E TASSINARI, C.C.G.. What was happening in SW Amazonian craton during geon 14 ? Geology.

TASSINARI, C.C.G., BETTENCOURT, J.S., GERALDES, M.C., MACAMBIRA, J.B. (2000) The Amazonian Craton. In: The Geologic Evolution of South America (U. Cordani, ed.).

GERALDES, M.C., TEIXEIRA, W. e VAN SCHMUS, W.R. Three Parallel Crustal Accretionary Arcs (1.79-1.43 Ga) in the SW Amazon Craton, State of Mato Grosso, Brazil. Revista Brasileira de Geociências. 
ANEXO 5

Mapa Geológico Regional 
